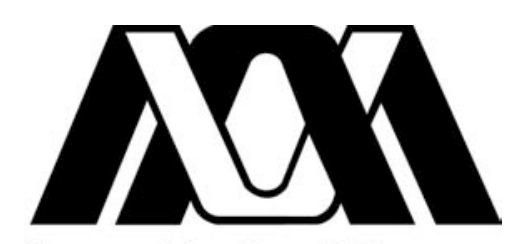

Casa abierta al tiempo

\author{
UNIVERSIDAD AUTÓNOMA METROPOLITANA - UNIDAD IZTAPALAPA \\ DIVISIÓN DE CIENCIAS SOCIALES Y HUMANIDADES \\ POSGRADO EN CIENCIAS ANTROPOLÓGICAS
}

\title{
LA CONSTRUCCIÓN DEL HABITAR \\ Redes interculturales en la edificación de vivienda en la Ciudad de México a principios del siglo XXI
}

Tesis de Doctorado en Ciencias Antropológicas

Miguel Antonio Zirión Pérez

\author{
Director: \\ Dr. Néstor García Canclini
}

Asesores:

Dra. Ángela Giglia Ciotta

Dr. Ricardo Pérez Montfort

México, D.F.

Julio, 2010 



\section{Índice}

Agradecimientos

INTRODUCCIÓN

La construcción social de la construcción y la cuestión del habitar

\section{Capítulo I: ETNOGRAFÍA REFLEXIVA, EXPERIENCIA ESTÉTICA Y MEDIOS AUDIOVISUALES \\ Cimientos teórico-metodológicos}

1. Teoría antropológica y práctica etnográfica

- Bruno Latour y la teoría del actor-red

- La recomposición de lo social

- Antropología de las asociaciones

- Etnografía y documentalismo

- Documentalismo subjetivo

- Mirada multifocal

2. Reflexividad

- El desarrollo del pensamiento reflexivo

- Etnografía reflexiva

- Historia y carácter del vínculo con los trabajadores

- Explicaciones y redefiniciones del proyecto a partir del trabajo de campo

- Reflexiones generales sobre la práctica etnográfica

3. Los lenguajes de la antropología

- La descripción verbal y la crónica etnográfica

- Representación visual de la experiencia etnográfica

- Hilando imágenes y textos en la narrativa etnográfica

- Etnografía visual y reflexividad

4. Estética

- Sobre la noción de estética

- Estética urbana

- Estética y antropología de los sentidos

- Etnografía sensorial y experiencia estética en la obra 
Capítulo II: TRANSFORMACIÓN DEL ESPACIO

Un caso de metamorfosis urbana

5. El cambiante rostro de nuestra ciudad

6. Pensar el espacio desde la antropología

- Breve historia del espacio

- Teorías del espacio

- El espacio en construcción

7. Desarrollo urbano y cuestión habitacional

- El concepto de vivienda

- El problema habitacional

- Políticas y lógicas de producción de vivienda

- Breve historia habitacional de la Ciudad de México

- El desarrollo habitacional en las últimas dos décadas (1990-2010)

- El abandono de la ciudad central

- Repoblamiento y boom constructivo en la ciudad central

- Los efectos del Bando dos

8. La Colonia Roma, breve historia de su desarrollo urbano

- De la época prehispánica hasta su fundación

- Inicios del siglo XX

- Porfiriato y arquitectura de influencia europea

- La Roma postrevolucionaria

- Modernidad estilo americano

- 19 de septiembre de 1985

- El valor patrimonial de la Roma

- Imaginario y representaciones de la Roma

- Los habitantes de la Roma, ayer y hoy

- La Roma en la actualidad

- Fotografía aérea y análisis de las transformaciones de la ciudad

- Mapas de obras en el cuadrante estudiado

- Vistas panorámicas de la Roma

9. Presentación general de los casos estudiados

- La obra de Córdoba

- La obra de Puebla

- Trayectoria de "DAKAB Grupo Inmobiliario" 
10. Comercialización del espacio

- Ataque al imaginario

- Estrategias de mercado

- Los agentes de ventas

- Albañiles, comercialización del espacio y reproducción de la desigualdad

11. El proceso constructivo en las obras de Córdoba y Puebla

- El proceso constructivo en la obra de Córdoba

- El proceso constructivo en la obra de Puebla

- Comparación entre las dos obras

- Agua y lodo sin fin: las condiciones del subsuelo

- Racionalidad e informalidad en la obra

- Interacción obra / entorno

- El caso de un árbol

- Epílogo: el final es un nuevo comienzo

12. Transformación del espacio: economía, política y cultura

- El poder y la lógica detrás del cambio urbano

- Gentrificación

- Producción inmobiliaria en tiempos de globalización

- Nuevas configuraciones espaciales, segregación social y cultura urbana

- La importancia de los objetos

14. Materia prima

- Las propiedades de la materia

- Los materiales como parte del paisaje

15. Instrumentos de trabajo

- Infraestructura laboral

- Maquinaria y grandes herramientas mecánicas

- Instrumentos manuales

- Herramientas autofabricadas y objetos multiusos 
16. La vida social de los objetos

- El valor simbólico de las cosas en la obra

- Herramienta, conocimiento técnico y jerarquía social

17. Redes, metáforas y alegorías

Capítulo IV: MANO DE OBRA

Albañiles y trabajadores de la construcción

18. Los sujetos de esta investigación

- Actores en el mundo de la construcción

- Formación y desintegración de grupos

19. Cultura urbana y orden laboral

- La noción de trabajo, una definición antropológica

- La dimensión simbólica del trabajo y el imaginario urbano

- Orden laboral y experiencias urbanas

20. Edificación de vivienda y trabajadores de la construcción

- Investigaciones en torno a la construcción habitacional

- La industria de la construcción en México

- Economía e industria de la construcción

- La edificación habitacional frente a otros tipos de construcción

- Modernización tecnológica vs. sobreoferta de mano de obra (barata)

- Composición de la mano de obra

- Balance de los estudios sobre la construcción en México

- Vocación etnográfica

- Los albañiles en el cine y la literatura

21. Oficios, perfiles de vida y relaciones laborales

- La red de actores involucrados

- Las empresas constructoras privadas

- Altos mandos

- Rango intermedio

- Los oficios más bajos

- Observaciones sobre distintos oficios

- Aprendizaje sobre la marcha

- Oficio, cultura material y trabajo artesanal

- Organización del trabajo e interacciones entre rangos y oficios 
22. Acciones y técnicas

- ¿Qué cuenta como una acción?

- Acciones individuales

- Acciones colectivas

- Cadenas humanas

23. Condiciones laborales

- Reclutamiento de la mano de obra

- Contrato laboral

- Trato personal

- Horario de trabajo

- Calendario laboral

- Salarios

- El pago de la raya

- Trabajo infantil

- Medidas de seguridad

- Salud y Seguro Social

- Sindicato

24. Movilidad

- Actores en movimiento

- Demanda variable de mano de obra

- Migración

- Tránsito entre obras

- Otras chambas

- Transformaciones y desigualdades en el mercado laboral urbano

25. Usos y costumbres: ¿cultura albañil?

- Vestimenta

- Juegos y actividades recreativas

- Tecnología y medios de comunicación

- Comida y hábitos alimenticios

- Momentos muertos y tiempo de descanso

- Usos del lenguaje

- Prácticas e imaginarios sexuales

- Estampas de la cultura albañil

- Fin de la jornada laboral 
Capítulo V: HABITAR LA OBRA

Culturas del habitar en el mundo de la construcción

27. La interacción sujeto-espacio

- La observación etnográfica del habitar

28. Los albañiles y el espacio en construcción

- Vivir y trabajar en la obra

- Precariedad e ingenio popular

29. Imágenes y modalidades del habitar

- Atrapados (asignación)

- Integrados (apropiación)

- Tránsito

- Pertenencias, huellas y marcas

- Nuevo mobiliario y desplazamiento hacia afuera de la obra

30. Hacia una antropología del habitar

- Aproximaciones a la cultura del habitar

- Culturas del habitar en el contexto de la Ciudad de México

La construcción del habitar y el habitar en construcción 


\section{Agradecimientos}

Quisiera expresar mi sincero agradecimiento a todas las personas que de una u otra manera intervinieron en este proceso de investigación, especialmente a aquellos que me acompañaron a lo largo del camino.

En primer lugar, a Néstor García Canclini por creer en este proyecto, por abrirme horizontes y señalarme los problemas y enfoques que dieron rumbo a esta investigación y por compartir su sabiduría, su aguda inteligencia y su visión panorámica de los autores y las corrientes más importantes del pensamiento actual. Me ha brindado su orientación como en la mejor relación posible entre maestro y aprendiz en el contexto de una obra.

A Ángela Giglia, cuyas ideas tienen tanta afinidad con mis intereses de investigación, que inevitablemente me las he ido apropiando. Muchas veces he sentido una sana frustración cuando lo que dice hubiera querido decirlo yo, pero no lo habría podido decir tan bien como ella. Su ejemplo ha sido motivo de inspiración en todo momento.

A Ricardo Pérez Montfort por su entusiasta y cálido apoyo; por su gran sensibilidad en el trabajo con imágenes y su pasión por la cultura popular, de las que sin duda se nutrió este trabajo. Sus observaciones me permitieron reconectarme con el lado creativo y afectivo de esta investigación.

A Isabel Cabrera por su paciente y sabio apoyo en la selección, edición y análisis de las imágenes que forman parte de esta investigación; su mirada crítica, su generosidad y su cariño me acompañaron a lo largo de este proceso.

A Lourdes Roca por su valiosa asesoría en las primeras etapas de esta investigación, sobre todo en cuanto a la interpretación de las fotografías aéreas, el tratamiento de las imágenes y en temas como la historia oral y la memoria colectiva de nuestra ciudad.

A Antonio Zirión Quijano, Claudia Martínez y Abeyamí Ortega por la cuidadosa lectura y corrección de estilo de las que se ha visto beneficiado este escrito.

AI CONACYT por la beca otorgada para la realización de este trabajo.

Al Posgrado en Antropología de la UAM-I por la formación, el apoyo y la libertad que me brindaron durante casi cinco años. Particularmente a los investigadores Scott Robinson, Eduardo Nivón, María Ana Portal, Raúl Nieto, Rodrigo Díaz, Luis Reygadas, María Eugenia Olavarría, Federico Besserer, por interesarse en este proyecto y hacerme enriquecedores comentarios. A Socorro Flores y María Eugenia Rojas por su apoyo logístico, así como a José Manuel Escalante y Armando Huerta del Laboratorio de Antropología Visual, por su apoyo técnico. A mis compañeros de distintas generaciones con quienes discutí los avances de este proyecto en varios seminarios y coloquios: André Dorcé, Alfredo Nateras, Gustavo Rojas, Yerko Castro, Jorge Linares, Mariana Orozco, Hugo Soto, Adrián Bautista, Amanda de la Garza, Carla Pinochet, Mariana Delgado y varios más.

A muchos maestros y colegas de distintas disciplinas e instituciones, de quienes he recibido buenos consejos y valiosa retroalimentación: Carmen Bueno, Emilio Pradilla, Francisco Mata, Claudia Zamorano, Ernesto Cabrera, Abeyamí Ortega, Carlos Flores, David Wood, etc.

A mis amigos de toda la vida, Débora y Juan Carlos, por su respaldo incondicional. A Paula por sumarse a esta exploración, suscitando nuevas modalidades de encuentro intercultural con los albañiles. A mis compañeros de Etnoscopio, Jornadas de Antropología Visual, DocsDFy Homovidens, por muchos proyectos juntos en el futuro. A Marcela por su invaluable ayuda en el diseño de esta tesis, y sobre todo por su paciencia, cariño y compañía durante la cuesta más empinada de este proceso.

Dedico este esfuerzo a Ana Rosa Pérez Ransanz y Antonio Zirión Quijano, quienes además de ser padres maravillosos, han sido mis más grandes maestros, así como a mis hermanas Ana, María, Sofía y Claudia, y a mis sobrinos Soren y Anita, porque llenan mi vida de cariño.

Finalmente, quiero agradecer al Arquitecto Canela y al personal de la compañía constructora DAKAB por abrirme las puertas de sus obras, permitiéndome indagar en el mundo de la construcción; y de manera muy especial, a todos los personajes que compartieron sus historias y sus vidas para hacer posible esta investigación. Espero que este trabajo sirva como homenaje a todos los albañiles y trabajadores de la construcción, héroes anónimos sin cuyo esfuerzo sería imposible habitar la ciudad. 



\section{INTRODUCCIÓN \\ La construcción social de la construcción y la cuestión del habitar}

\section{Presentación del problema de investigación}

Para comenzar a definir la problemática que aborda esta investigación, conviene aclarar que el título "La construcción del habitar" tiene un doble sentido: literal y metafórico. Por un lado, hace alusión a la edificación material de nuevas viviendas, particularmente edificios de departamentos en la zona central de la Ciudad de México, y por el otro, implica que el habitar, entendido ampliamente como la relación sujeto-entorno, no es algo dado, sino que se construye socialmente: es un producto cultural; por eso es que podemos hablar de diversas culturas del habitar en el seno de la megalópolis como un fértil campo de estudio para la antropología. Así, esta reflexión se moverá entre los planos material y simbólico al estudiar la producción y reproducción del espacio urbano contemporáneo.

También podríamos invertir los términos del título y hablar del acto de "habitar la construcción", haciendo referencia a que muchos albañiles -los actores principales de esta investigación - viven la mayor parte del tiempo en la obra donde trabajan; ahí mismo duermen, comen, se bañan, socializan, etc. En otro sentido, el "habitar en construcción" tiene la connotación más profunda de que los seres humanos habitamos siempre, todo el tiempo, en un estado provisional. Nuestra forma de apropiarnos el espacio e interactuar con él se caracteriza por estar siempre en proceso, en constante devenir; nunca es un hecho definitivo. Así, continuamente surgen diversas formas de adaptación y nuevas relaciones con el entorno urbano, que dan lugar a distintas culturas del habitar.

El presente estudio se ubica en la intersección de diferentes campos de investigación dentro de la antropología. En cuanto a su enfoque teóricometodológico, podría caracterizarse como una antropología de las asociaciones, cercana a la teoría del actor-red (TAR), aunque también puede entenderse como la puesta en práctica de una antropología reflexiva. Por el terreno que aborda -la colonia Roma en la zona central de la Ciudad de México-, podría considerarse, sin duda, una investigación de antropología urbana, preocupada por las cuestiones interculturales en el desarrollo de la ciudad. Por lo que se refiere a los sujetos estudiados - los trabajadores de la construcción— podríamos considerarla dentro de 
la antropología del trabajo, dado su interés en la organización laboral en la obra como un caso representativo de subempleo o trabajo semiinformal; o bien, podemos comprenderla como una antropología de los sectores populares y marginales de la sociedad. Ahora bien, desde el punto de vista de su metodología y su forma de aproximarse a la realidad, esta investigación puede entenderse como un trabajo de antropología visual, que recurre a la imagen como punto de encuentro y vehículo de conocimiento intercultural, también interesada por la estética y la dimensión sensible de la experiencia etnográfica. Finalmente, en cuanto a su interés temático y su propuesta conceptual, que se centra en la forma en que los albañiles habitan la obra, podemos catalogarla como una antropología del espacio, una antropología de la construcción, y más precisamente, como una antropología del habitar.

Hay que reconocer que la Ciudad de México es una de las más estudiadas y quizás menos comprendidas del mundo. Dentro de los diversas líneas de estudios urbanos, hay incontables investigaciones sobre nuestra ciudad que han explorado sus distintos aspectos desde múltiples perspectivas'. Este trabajo se coloca en el cruce de varias de estas vertientes de investigación sobre la ciudad, de las cuales mencionaré algunas que abordaré posteriormente: retomaré algunos planteamientos en torno a la estética urbana (Krieger, Medina); discutiré algunas representaciones de la ciudad y sus personajes, principalmente desde el cine y la literatura (Pacheco, Leñero, Fons, Rulfo). Recuperaré algunas nociones fundamentales sobre el espacio (Foucault), sobre todo desde la perspectiva de la geografía urbana (Soja, Harvey). Estudiaré algunos aspectos de la historia de la ciudad y sus barrios, en este caso de la colonia Roma (Tavares, Tovar y de Teresa, Perló, Lozada, Coulomb, Legorreta). Revisaré la historia y la situación actual del desarrollo urbano, en relación con la problemática de la vivienda (Schteingart, Villavicencio, Garza, Michel, Benlliure). Reflexionaré sobre la comercialización del espacio y los imaginarios de la globalización (Moreno, Pérez Negrete); sobre la cultura obrera y laboral, y su relación con el orden urbano (Nieto, Sennett); sobre la edificación de vivienda, las condiciones laborales de los trabajadores de la construcción y su cultura particular (Bueno, Connolly, Germidis, Liguori), sobre la cultura material y el trabajo artesanal en el contexto de la construcción (Sennett, Latour); así como sobre el habitar y las

\footnotetext{
${ }^{1}$ Muestra de ello es el impresionante compendio de Bibliografía de la Ciudad de México, siglos XIX y XX (1991) a cargo de Hira de Gortari, Regina Hernández y Alicia Ziccardi, editado por el Instituto Mora, la UNAM y el D.D.F.
} 
lógicas contradictorias que se mezclan en el espacio urbano (Giglia, Duhau, Signorelli). Estos son algunos de los temas y los autores con los que dialogaré a lo largo de este trabajo, marcando las coincidencias y diferencias con la presente investigación.

Quisiera ahora narrar brevemente la historia del presente proyecto de investigación, sus antecedentes, los primeros intereses y motivaciones, así como la evolución y el desarrollo de las ideas que me llevaron a explorar los temas de la construcción y el habitar en el ámbito urbano. Al regresar a la Ciudad de México, después de dos años de vivir fuera, me llamó mucho la atención no tanto el cambio que había sufrido la ciudad, sino el hecho de que se encontrara en pleno proceso de transformación. En cuanto recorrí las calles me encontré con lo que ahora entiendo como uno de los elementos más característicos de nuestro paisaje urbano: la omnipresencia de la construcción. Desde la monumental obra del Segundo Piso del Periférico hasta la insignificante reparación de un bache; desde la humilde casa de tabique con castillos de varilla saliendo del techo, hasta la edificación de un enorme complejo comercial, el panorama urbano contemporáneo está perpetuamente en construcción.

Así, pude darme cuenta de la enorme importancia que tiene actualmente el fenómeno de la construcción para entender la configuración y la dinámica de la ciudad y la cultura urbana. Con esta inquietud en mente, sin mayor claridad ni definición teórica, pero ávido por comenzar la investigación etnográfica, incursioné en la construcción del Segundo Piso del Periférico. Durante varias noches, en 2006, asistí a esta gran obra pública, cuya dimensión me pareció abrumadora y muy difícil de abordar; de esta experiencia son rescatables una serie de fotos y la sensación de asombro, entre vértigo y fascinación, frente a la complejidad del tema. Más adelante, en ese mismo año, abordé otro caso de construcción, o más bien, de destrucción; documenté el proceso de la demolición de un inmueble, una casa habitación que perteneció a mi familia, al sur de la ciudad ${ }^{2}$. Lo importante de estas dos breves inmersiones etnográficas es que, a pesar de la enorme disparidad entre estas dos obras, pude darme cuenta de que aquello que tenían en común era

\footnotetext{
${ }^{2}$ Los resultados de esta investigación fueron presentados en mi tesina de maestría en Ciencias Antropológicas titulada: La construcción social de la construcción: el caso de Rafael Checa \#18 (UAM-I, 2006), que constituye un antecedente importante de la presente investigación.
} 
precisamente lo que me interesaba investigar: ambas implicaban la cuestión de la transformación del espacio urbano.

La preocupación por el tema de la construcción está íntimamente ligada a un interés más profundo por la noción de cambio urbano. Hablar de obras y construcciones nos obliga a hablar de la intensa transformación de la ciudad, que en su conjunto está sometida actualmente a una especie de cirugía plástica, que en muchas ocasiones me parece superficial e innecesaria, e incluso a veces nociva o perjudicial. Si nos situamos en la intersección entre el tema de la construcción y la problemática de la transformación urbana, surge el problema de cómo se construye y se destruye nuestra ciudad, cómo se transforma material y simbólicamente hablando. ¿Cómo y por qué ocurren exactamente estas transfiguraciones del espacio urbano?

Pero la ciudad no es solamente un espacio físico, sino un espacio habitado, vivido y con significado; la vida de la ciudad es vida humana. El fenómeno de la construcción trasciende la transformación material de la ciudad, y se traduce - de diferentes maneras - en condiciones y formas de vida para la gente. Tomando esto en cuenta, comencé a interesarme por los procesos sociales necesarios para que sea posible cualquier transformación del espacio urbano, lo que llamé la construcción social de la construcción. Así, pretendo reflexionar sobre la actual transformación urbana a partir del fenómeno de la construcción, desde una perspectiva antropológica, analizando sobre todo su significado social y cultural. ¿Cómo se llevan a cabo estos cambios en el paisaje urbano? ¿Quiénes son los agentes u operadores de estos cambios? ¿Qué redes de interacción social se forman alrededor de un proceso constructivo?

Me interesa particularmente la cultura que se genera en estos procesos de transformación urbana, la cultura de los trabajadores de la construcción, los usos y costumbres de los albañiles, sus comportamientos e interacciones. Los albañiles son los actores principales que animan las obras de construcción, por tanto pretendo analizar sus prácticas más comunes, describir los rasgos más significativos de su vida cotidiana y observar las relaciones sociales que se tejen entre ellos. Para conocer de cerca a estos actores sociales, decidí abordar otro entorno constructivo más accesible, de una escala intermedia entre el Segundo Piso y la demolición de una casa habitación; decidí incursionar en la edificación de vivienda en el área central de 
Ciudad de México, la construcción de un edificio de departamentos en la calle de Córdoba en la colonia Roma, caso del que hablaremos extensamente más adelante.

Esta investigación se ubica justo en el punto de encuentro de estos dos ejes de análisis. Por un lado, está la transformación del espacio urbano, la pregunta por cómo se produce y reproduce la ciudad, una preocupación por el sentido y las consecuencias de dicho cambio, en el contexto de la Ciudad de México. Por el otro lado, hay un interés por conocer directamente a los actores involucrados en estos procesos de cambio, principalmente a la mano de obra, los albañiles y los trabajadores de la construcción. ¿Cómo combinar las dos preocupaciones centrales del trabajo? ¿Cómo articular el recuento de los cambios en el espacio con una aproximación a la perspectiva de los sujetos? ¿Cómo abordar estas dos preocupaciones paralela y complementariamente sin que ninguna se diluya en la otra?

Poco a poco descubrí que lo que más me llamaba la atención era la interacción de los trabajadores de la construcción con el espacio que construyen, la relación compleja y polisémica del albañil con la obra. Así se fueron definiendo mejor mis intereses teóricos hasta llegar a la noción del habitar, entendida por ahora como la interacción entre sujetos y lugares. Las relaciones que se entablan entre las personas y el espacio están mediadas por la cultura, el habitar es una experiencia que se presenta en una enorme diversidad de formas y adquiere numerosos significados a lo largo de la historia y a lo ancho del mundo. Esta relación entre el hombre y el espacio, que se manifiesta por ejemplo en la manera en que los obreros se dedican a la construcción de un edificio, es una actividad cultural primordial, acaso la expresión más elemental de la cultura, y como tal merece el cuidadoso escrutinio de una mirada antropológica.

Para ilustrar la noción de habitar, me parece apropiado traer a colación la metáfora de un colocador de piso que actúa e interviene sobre el espacio, transformándolo. Pero conforme avanza en la colocación del piso, va retrocediendo y cediendo terreno, hasta quedar arrinconado e inmóvil (porque no debe pisar el piso recién colocado); de manera que deberá ingeniárselas para no terminar atrapado. Este es un caso ilustrativo de cómo el espacio impone condiciones en la vida de las personas y de cómo los trabajadores de la construcción intervienen, 
transforman y usan el espacio, pero éste, a su vez, los constriñe a actuar de cierta manera.

El habitar puede entenderse como una respuesta adaptativa recíproca, como un diálogo o una retroalimentación entre el hombre y su entorno; el habitar implica una plasticidad mutua. Es decir, la relación entre hombre y espacio es bilateral; puede entenderse como un ir y venir, un constante vaivén de influencias, condicionantes y determinantes. El hombre hace al espacio pero el espacio también hace al hombre. Los seres humanos construyen sus casas y sus ciudades, pero éstas al mismo tiempo marcan significativamente nuestras vidas. Nos afecta la ciudad, nos impacta, tanto como nosotros la afectamos y la impactamos a ella. Estas son algunas de las cuestiones a las que nos remite en un primer momento la noción del habitar.

Podemos plantear la pregunta central de esta investigación en un plano abstracto: ¿cuáles son las causas, el sentido y las consecuencias de la intensa transformación que atraviesa la Ciudad de México en los primeros años del siglo XXI? En un nivel más concreto, la pregunta complementaria sería: ¿cómo se llevan a cabo estos cambios urbanos en el plano más material y cotidiano, vistos sobre todo desde la perspectiva de los trabajadores de la construcción? Otra cuestión que vale la pena plantear desde el principio es: ¿qué tipo de espacio es una obra? No es fácil determinar, por ejemplo, si la obra es un espacio público o privado, si es un sitio laboral o habitacional, si es un proyecto a futuro o una realidad presente. Comparte características de diferentes clases de lugares, pero no encaja claramente en ninguna categoría. La obra, que intentaré caracterizar como "espacio en construcción", posee características muy particulares, es un lugar sui generis que en algún sentido puede ayudarnos a entender ciertos rasgos de nuestro espacio urbano contemporáneo.

Así, en la siguiente investigación nos enfocamos en un grupo social que tiene formas muy particulares de habitar la obra. Los modos en que los albañiles utilizan y se apropian provisionalmente del espacio están marcados por la precariedad, la improvisación y el ingenio. Dada la movilidad, inestabilidad e informalidad que imperan en este medio laboral, su experiencia del habitar se caracteriza por ser siempre temporal y desapegada, lo cual nos obliga a repensar la relación entre las nociones de arraigo y espacio habitable. El estudio de las formas en que los albañiles habitan el espacio en construcción puede proporcionarnos ciertas pistas para 
comprender mejor las culturas del habitar en una ciudad como la nuestra, y nos ayuda a entender nuestras propias estrategias de adaptación y la interacción que establecemos con el entorno urbano.

\section{Motivos y justificación}

La aproximación teórica a la problemática de la construcción, el desarrollo y la transformación de la ciudad ha venido generalmente de la ingeniería, la urbanística y la arquitectura, o bien desde el análisis económico y de las políticas públicas. En contraste, existen relativamente pocos estudios antropológicos acerca del mundo de la construcción. Hace falta explorar a fondo estos aspectos y dimensiones de la urbe, así como las nuevas formas que adopta este proceso de urbanización, que evolucionan y se hacen más complejas cada día.

Considero que el estudio que aquí emprendo es relevante debido a que el mundo de la construcción tiene la peculiaridad de ser una caja de resonancia en la que se condensan y se manifiestan nítidamente varios de los aspectos más significativos de la cultura urbana contemporánea. Las desigualdades sociales y económicas, las hibridaciones culturales, los conflictos y tensiones, los choques e imposiciones, los prejuicios y estereotipos sobre los otros, las contradicciones entre órdenes superpuestos en un mismo espacio, son circunstancias que se presentan claramente en la obra. Una problemática igualmente importante en la que sin embargo no profundizaré, es la depredación del medio ambiente natural que implica casi cualquier proceso constructivo o de urbanización. Asimismo, abordar el espacio en construcción significa lidiar con rasgos característicos de la idiosincrasia de los mexicanos y enfrentarse con algunos de los problemas más apremiantes de las metrópolis modernas.

Por otro lado, ante mi propia torpeza e inutilidad en términos prácticos, una motivación para emprender esta investigación fue el asombro que me causa el hecho de que haya gente realmente hábil e ingeniosa, como los albañiles, que producen cosas y crean objetos materiales, construyen inmuebles, utilizando instrumentos como si fueran extensiones de su cuerpo. Este tipo de destrezas y habilidades son cada vez menos comunes en el mundo contemporáneo, el hombre moderno parece estar perdiendo al aprecio por la cultura material, la práctica artesanal o las labores manuales. En este sentido, a mi parecer el trabajo de los 
albañiles en muchos casos está más cerca del trabajo artesanal que del obrero fabril que desempeña un trabajo rutinario y mecanizado. El oficio de albañil implica cierta creatividad y mucho ingenio, nos remite a una gran tradición y sabiduría popular. Por esto quise acercarme y conocer a estos personajes responsables de crear el mundo concreto, los espacios por los que transitamos y los inmuebles que habitamos. Esta investigación surge de un profundo respeto y admiración por esta gente, y pretende ser una especie de homenaje a todos ellos.

En un plano más filosófico, esta investigación nace de un profundo interés por la construcción simbólica del mundo, que tiene que ver con el principio de nunca dar las cosas por sentado, nunca conformarse con la idea de que las cosas están dadas de antemano tal como las vemos. Esta inquietud me ha llevado a mantener una constante interrogación por el mundo y cada uno de sus elementos, por su origen y evolución, sus transformaciones, sus lógicas y sus dinámicas. Así, en torno a la ciudad, sus espacios e inmuebles, intento hacer el ejercicio de preguntarme cómo llegaron a ser así, gracias a qué acciones, a qué actores, con qué materiales, técnicas y herramientas, quién lo diseñó, con qué propósito, bajo qué presupuestos, con qué valores e ideas, qué constricciones impuso el terreno, qué consecuencias tendrá esta construcción para el entorno más amplio, quiénes se benefician y quiénes serán perjudicados.

\section{Los estudios de caso en la colonia Roma}

Ante la imposibilidad de resolver todas estas cuestiones con respecto a la ciudad en su conjunto, debemos proceder por partes y plantearnos estas interrogantes en torno a un lugar particular. Así, abordaremos un estudio de caso, partiendo de lo micro para luego reflexionar sobre el conjunto. Estudiaremos la construcción material, social y simbólica de un espacio determinado, con la intención de atestiguar y documentar el surgimiento de un inmueble, un edificio de departamentos, como si se viera por primera vez, como si fuera un caso extraordinario.

Con esto en mente, adopté como terreno de investigación principal la obra de construcción de un edificio de departamentos en la calle de Córdoba, en la colonia Roma, en la zona central de la Ciudad de México. En este caso cubrí de principio a fin el ciclo constructivo, desde antes de que empezaran las labores y hasta el día en que 
ya vivían ahí los primeros habitantes. Por otra parte, más adelante abordé parcialmente otro caso complementario, también en la colonia Roma, a cargo de la misma compañía constructora, esta vez en la calle de Puebla, esquina con Córdoba, a pocas cuadras de distancia del primer sitio. El trabajo de campo en estas obras fue realizado a lo largo de 16 meses, de noviembre de 2006 a febrero de 2008.

En primer lugar, los estudios de caso seleccionados resultan significativos y reveladores porque permiten observar la intersección entre los dos grandes intereses de esta investigación. Por un lado, son casos representativos de las transformaciones del espacio urbano en el centro de la Ciudad de México en los últimos años, y por otro, presentan claramente la situación de los obreros de la construcción, su cultura particular, sus estrategias de adaptación y supervivencia en el mercado laboral urbano.

Pero cabe preguntarnos: ¿por qué la colonia Roma y no otro barrio? Ante la palpable proliferación de construcciones en la ciudad central, me parece que este tipo de obras son un ejemplo representativo de la dinámica de transformación general del espacio urbano, bajo una intensa oleada constructiva como la que presenciamos actualmente. En otras palabras, con estos estudios de caso pretendo explorar una instancia paradigmática de la transformación del espacio y las formas de habitar, en el contexto de las nuevas acciones de urbanización en el centro de la ciudad. Se trata de casos que reflejan claramente los cambios y las problemáticas que enfrenta la colonia Roma en relación con el fenómeno de la construcción, que a su vez son circunstancias bastante típicas que ocurren también en otras partes de la ciudad central. Es decir, esta tendencia constructiva no es exclusiva de la colonia Roma, pero considero que ahí se manifiesta con especial claridad.

Por otro lado, debo reconocer que la elección de estos terrenos de investigación respondió también a intereses y preferencias personales. Durante los años en que transcurrió la investigación, residí en la colonia Roma, a pocas cuadras de las obras estudiadas. Esta circunstancia me facilitaba, por un lado, estar presente cotidianamente en la obra, y por otro lado, respondía a mi interés personal por entender mejor el barrio y el entorno inmediato en el que estaba inserto. Desde luego, los temas y las instancias que elegimos investigar hablan mucho de quiénes somos y qué buscamos como investigadores y como personas humanas que somos. 
Ahora bien, ¿no resulta pretencioso hablar de la construcción social de la construcción o de la construcción del habitar en la Ciudad de México, cuando hemos abordado únicamente un par de estudios de caso? ¿Qué tan válido es reflexionar en términos generales sobre lo que sucede en la urbe a partir de dos casos particulares en la colonia Roma? Sin duda, podemos correr el riesgo de extrapolar o generalizar equivocadamente los hallazgos de un microestudio a una escala mayor. Pero me parece evidente, en primer lugar, que no existe ningún caso particular que pudiera dar cuenta de una problemática tan compleja como la construcción. Además, resulta imposible abordar de lleno, de manera abstracta o integral, el mundo de la construcción, que es sumamente amplio y diverso; por lo tanto, metodológica y epistemológicamente, considero que la mejor opción es abordar esta problemática por parcelas, partiendo de casos concretos.

No obstante, cualquier caso está inserto en un contexto y una circunstancia. Más que generalizar con base en un caso tan particular, he intentado interpretar este caso concreto como expresión de una tendencia más amplia y general, como parte de una dinámica macrosocial urbana palpable en otras partes de la Ciudad de México. La estrategia ha sido leer lo concreto a la luz del marco más amplio en el que se inserta. Pero me parece que no podría haber un estudio de caso sin un marco teórico, así como no podría haber un marco teórico sin aplicación y retroalimentación frente a alguna realidad concreta. A lo largo de esta investigación ha habido un constante ir y venir entre el caso y la teoría, reinterpretando el caso a la luz de nuevas ideas y modificando el marco teórico según lo fue exigiendo esta realidad particular.

\section{Retos y objetivos}

Un objetivo de esta investigación es reflexionar acerca de la construcción de nuevas viviendas, intentando echar luz sobre algunos problemas sociales de las grandes urbes contemporáneas. Este proyecto busca contribuir conceptual y etnográficamente a la elaboración de una antropología de la construcción en y de la Ciudad de México. Emplearemos la noción de construcción en diversos sentidos, para referirnos a la construcción material de inmuebles, a la construcción social y simbólica de la ciudad, a la construcción de la identidad de los sujetos a partir de su relación con el espacio, así como a la construcción de un discurso antropológico 
acerca de la realidad. Quisiera plantear la importancia que tiene el fenómeno de la construcción para comprender las dinámicas y procesos de las grandes ciudades como México.

Me dispongo a mirar de manera antropológica la transformación de un terreno de la ciudad, pero a la vez intento explorar el mundo de los trabajadores de la construcción. Es decir, pretendo dar cuenta de la construcción del espacio urbano a partir de los encuentros y desencuentros entre distintos actores, poniendo atención en los choques, sintonías o hibridaciones interculturales que se generan en este campo. Todo esto con la finalidad de dar cuenta de los aspectos más reveladores de la cultura urbana y las formas de habitar la ciudad que se generan y reproducen al interior y alrededor de una obra de construcción.

Uno de los retos más grandes de este proyecto de investigación es lograr una verdadera antropología de la obra y no tan solo hacer antropología en la obra. Lo anterior se plantea retomando la distinción que hace García Canclini (1994) entre una antropología urbana que se limita a hacer antropología en la ciudad, a elaborar etnografías de los distintos espacios urbanos desarticuladamente, y aquella que construye una reflexión antropológica general sobre la urbe, una verdadera antropología de la ciudad, poniéndola en contexto, pensándola en su conjunto, en términos relacionales, atendiendo tanto a cuestiones estructurales como a eventos fortuitos y rasgos azarosos.

¿Por qué vamos a condenarnos a hablar del barrio y callar sobre la ciudad, a repetir en las grandes ciudades una concepción aldeana de la estructura social?... Al estrechar tanto el horizonte de la antropología... se escapa algo decisivo de la formación y la vida de la ciudad si no se puede mostrar en qué grado las relaciones cortas de las cuales hablan los estudios de caso están condicionadas por las estructuras amplias de la sociedad (García Canclini, 1994: 16).

Definitivamente, en esta investigación hay principalmente un trabajo de antropología en la obra, una minuciosa investigación etnográfica en un contexto constructivo determinado. Pero también se ensaya una antropología de la obra, una representación global y una reflexión analítica general, considerando su contexto y coyuntura actual, además de otros factores económicos, jurídicos, políticos e históricos importantes para comprenderla. Con esta convicción, la presente investigación intenta articular una fuerte vocación etnográfica con una reflexión 
sobre las conexiones de la obra con el resto del entorno urbano. Por un lado, se busca estar lo más cerca y comprometido posible de la obra y los actores, pero a la vez trataremos de tomar distancia para mirarla globalmente y entender su importancia dentro del contexto más amplio de la ciudad, y para abstraer las nuevas formas de apropiarse, significar, usar y transitar por la metrópoli, que definen diversas culturas del habitar en la ciudad del siglo XXI.

En mi opinión, la antropología en y de la obra (o en y de la ciudad), no podrían existir una sin la otra, se refieren más bien a etapas diferentes de la investigación, aunque no necesariamente se presenten sucesivamente, sino a veces de manera simultánea, en un ir y venir constante entre estos dos polos, como ha sucedido en el caso del presente trabajo. He intentado mantener una mirada multifocal sobre el problema de investigación, yendo constantemente de lo micro a lo meso y a lo macro, o al revés. En estas reflexiones me muevo constantemente entre lo concreto y lo abstracto, lo particular y lo general, entre el dato y el modelo, experimentando con varias metodologías y explorando diversas dimensiones para elaborar un discurso polifónico.

\section{Metodología}

Una primera cuestión teórico-metodológica importante es la lejanía que guarda esta investigación con respecto a los objetos de estudio clásicos de la antropología, comúnmente interesada en las tradiciones y costumbres ancestrales, en preservar el patrimonio, conservar la memoria, la historia oral, marcada por la preocupación por la "desaparición" de las culturas, etc. En el caso que nos ocupa encontramos una situación radicalmente distinta e incluso opuesta, en la que impera la sensación de que la realidad todo el tiempo nos está dejando atrás. Para abordar el tema de la construcción en la ciudad, partimos de la transformación constante como presupuesto principal; es necesario asumir que el cambio es la regla y no la excepción. Ante un panorama como el que vamos a estudiar, se requiere una antropología diferente, mucho más basada en la idea de que el mundo cambia inevitablemente. ¿Cómo tiene que reinventarse la antropología para abordar este tipo de realidades? ¿Cómo debe cambiar la práctica etnográfica para adaptarse a los nuevos escenarios móviles, efímeros e inestables? 
En relación con lo anterior, un aspecto importante de carácter prácticometodológico tiene que ver con la manera de aproximarme a los sujetos y al problema de la investigación. En general, mi intención ha sido ensayar formas no tan convencionales de hacer antropología, mirar la obra y a los albañiles desde un punto de vista alejado de los dogmas y métodos clásicos de la práctica etnográfica. Aunque pueda parecer obvio, es necesario aclarar que se trata aquí de un análisis cualitativo de la cultura y el mundo de la construcción; no de un estudio cuantitativo lleno de datos, cifras, estadísticas o gráficas comparativas. En este sentido, también cabe mencionar que adopto la perspectiva de la antropología visual, basada en la práctica fotográfica, con una inclinación hacia la estética y la parte sensorial y afectiva de la experiencia etnográfica. Espero que de estos ejercicios pueda rescatarse alguna noción o procedimiento útil para el desarrollo de una antropología más libre y abierta.

Quisiera insistir en que esta investigación tiene primordialmente un carácter etnográfico. La mayor parte de la información que presento es fruto del trabajo de campo, está construida alrededor de mi propia experiencia en la obra. A pesar de que a lo largo del camino consulté varios libros y me empapé de ideas y teorías de distintos autores, esta investigación no es meramente teórica ni se basa en una revisión bibliográfica extensa sobre el tema; no es producto de una antropología de gabinete, sino que se plantea sobre todo como un conjunto de reflexiones antropológicas a partir del encuentro intercultural y la experiencia etnográfica que suscita.

En el tiempo que duró este trabajo de campo logré involucrarme y convivir de cerca con los albañiles y otros actores que animan este enclave urbano tan común como extraordinario. Gracias a esta labor etnográfica he logrado sumergirme en la cultura de los trabajadores de la construcción, intentando ponerme en sus zapatos para reflexionar acerca del mundo de la construcción y la transformación del espacio, tomando en cuenta su perspectiva. Las observaciones personales que aparecen en esta investigación no provienen de una mirada distante o ajena, sino de una mirada cercana, involucrada y cómplice. Mantengo la convicción de que conocer a los actores directamente, de primera mano, escucharlos, dialogar con ellos y comunicar sus voces, es un primer paso importante para resolver las problemáticas 
de las condiciones laborales de los albañiles, así como para repensar algunas cuestiones relacionadas con el desarrollo urbano de nuestra ciudad.

Para llevar a cabo esta investigación fue necesario utilizar algunas herramientas etnográficas que me permitieron recolectar, registrar y transmitir los detalles de la vida cotidiana de los trabajadores en la obra y su rica cultura laboral. Buscando el efecto de transportar al lector al interior de la obra y familiarizarlo con sus colores, olores, texturas, sonidos y demás elementos característicos, recurro a métodos como la observación participante, la conversación dirigida con los personajes y el registro fotográfico, para elaborar descripciones detalladas, presentar testimonios de los trabajadores y esbozar algunas de sus trayectorias laborales y perfiles de vida. Más allá de las entrevistas formales, los cuestionarios y las encuestas, pienso que las conversaciones informales y cotidianas con los diferentes personajes poseen un valor particularmente elevado para la investigación antropológica. Así, espero dar cuenta de rasgos culturales muy significativos pero difíciles de aprehender: gestos, voces, rostros, hábitos, formas de vestir, comer y hablar, etc. En este sentido, cabe destacar la gran importancia de la empatía y el rapport en el trabajo de campo. Los principales conductos para llevar a cabo esta investigación fueron las relaciones amistosas que establecí con muchos trabajadores y otras personas en la obra.

También es importante aclarar desde el principio que buena parte de este trabajo de campo se realizó como una investigación basada en imágenes (image-based research). La observación directa fue complementada con la creación de imágenes y un ejercicio de representación visual, que permitió además el posterior análisis de estas imágenes, que fueron fuentes de información fundamentales para la investigación. Pero la fotografía etnográfica funcionó en varios niveles, desde la captura de imágenes como registro, como memoria o documentación, hasta la construcción de una narrativa sobre el habitar en la obra, sustentada en dichas imágenes. El uso de la cámara en el trabajo de campo puede jugar un papel importante en la relación entre el investigador y los sujetos; en casos como el nuestro fue determinante en la interacción que establecí con los personajes.

El registro en imágenes ocupa un lugar especial en esta investigación, a pesar de que en esta versión escrita no aparezca extensamente. Quisiera aclarar que debido al carácter académico de esta tesis y a limitaciones de espacio, en esta entrega únicamente presento una serie de ocho collages que más o menos corresponden a 
los temas abordados en cada uno de los capítulos, como una muestra de este material etnográfico. El resto de este acervo visual formará parte de otros desarrollos posteriores de esta investigación, que podría cobrar distintas formas o recibir diferentes tratamientos: como series de fotografías, como un video documental o como un trabajo multimedia, por ejemplo.

Vale la pena advertir al lector sobre ciertos usos del lenguaje en esta tesis. En la literatura antropológica tradicional se acostumbra que siempre haya una distinción clara entre el lenguaje del autor y el de los personajes a los que se aproxima. A contracorriente de este formalismo, en mi tesis hay varios pasajes en que esos lenguajes se mezclan e incluso se confunden. En algunas descripciones suelo imitar el lenguaje de los personajes, especialmente cuando reproduzco fragmentos de $\mathrm{mi}$ diario de campo o cuando pretendo que el texto sea de naturaleza más o menos literaria. Lejos de ser accidental, quisiera justificar esta circunstancia adoptándola deliberadamente como un estilo de escritura etnográfica.

Asimismo, quisiera anunciar una importante distinción marcada entre los dos tipos de registro escrito que conforman esta tesis. He decidido diferenciar con letra cursiva la narrativa etnográfica que provienen directamente del diario de campo y dejar como texto normal el discurso general, la parte teórica, académica, contextual y autorreflexiva de esta investigación.

\section{Esquema de la exposición}

Esta investigación consta de cinco capítulos, además de la introducción y las reflexiones finales; dentro de estos capítulos hay varias secciones numeradas en una única secuencia a lo largo de toda la tesis; a su vez, cada sección comprende una serie de apartados. Para presentar la estructura general de esta tesis voy a recurrir a una metáfora extraída de mi propia experiencia etnográfica. Podemos pensar en la estructura de este reporte de investigación como si fuera la estructura de un edificio como los que estudiamos, ya terminado. De acuerdo con la analogía, esta Introducción sería equivalente a la fachada del edificio, o quizás más bien al lobby o la recepción, donde se explica en términos generales cuál es el problema de investigación, se presenta el terreno y las características del estudio de caso, se justifica su relevancia, se explicitan los motivos, se plantean los retos y objetivos, y se describen las formas de abordar el problema. 
El capítulo I: Etnografía reflexiva, experiencia estética y medios audiovisuales sería equiparable a los cimientos del edificio; representa los fundamentos teóricometodológicos sobre los que se construyó esta investigación. En este primer capitulo se define la orientación teórica dentro del pensamiento antropológico, que podría denominarse como una antropología de las asociaciones, acorde con la propuesta de la teoría del actor-red. Se declara la inclinación etnográfica que ha guiado esta investigación, en relación con el documentalismo, la subjetividad y el problema de las distintas escalas de la realidad que se abordan. Se introduce el tema de la reflexividad, se exponen sus antecedentes y principales problemas, y se muestra cómo ponerlo en práctica en el trabajo etnográfico. Se trata la cuestión de los diferentes lenguajes de los que puede valerse la antropología, siendo la imagen y la palabra sus principales vehículos, que se pueden articular de distintos modos. Un campo fundamental que se abre en esta declaración de principios y presupuestos, es el de la estética y la experiencia sensorial y afectiva del mundo, interés que puede conducir a la etnografía por nuevos caminos.

El capítulo II: Transformación del espacio equivaldría al primer piso del edificio, una planta o plataforma por la que hay que atravesar forzosamente para ingresar a otras áreas del inmueble. Este capítulo parte de una reflexión teórica e histórica sobre la noción de espacio y luego plantea el problema de qué tipo de espacio es una obra. Se desarrolla la cuestión de la vivienda en la Ciudad de México en relación con el tema del desarrollo urbano, en una perspectiva histórica, a lo largo del siglo XX, pero aterrizando en la situación y los problemas actuales. Se adentra en la historia de la colonia Roma, el contexto en el que se circunscribe nuestro estudio de campo, particularizando su desarrollo urbano, su tipo de arquitectura, la cuestión del patrimonio, hitos históricos como el terremoto de 1985, así como algunas representaciones de esta colonia desde la literatura. Se analizan sus transformaciones recientes por medio de la interpretación de fotos aéreas y otros mapas que muestran el incremento de obras y construcciones en esta zona en años recientes. En este mismo capítulo entramos de lleno en los casos estudiados, se presentan detalladamente las obras, así como el perfil de la compañía constructora, sus estrategias y prácticas de mercado para la comercialización del espacio. Se documenta paso por paso el proceso constructivo, comparando los puntos en común y las diferencias entre ambas obras, observando su interacción con el entorno y la 
particular manera en que se mezclan la informalidad y la racionalidad. Hacia el final de este capítulo hay una reflexión acerca del rol de la economía, la política y la cultura en la transformación del espacio urbano, así como, finalmente, acerca de las consecuencias sociales que parecen emerger y algunos escenarios posibles por venir.

El capítulo III: Materiales y herramientas está dedicado a analizar la vida social que tienen los objetos en la obra y la importancia de la cultura material en un entorno como éste. En primer lugar, se aborda la importancia de la materia prima y las propiedades de los materiales de construcción. Después de describen los diferentes tipos de instrumentos con los que los trabajadores manipulan e intervienen el espacio, desde las grandes máquinas hasta las herramientas manuales de fabricación casera u objetos a los que se les dan múltiples usos. Esta reflexión pretende resaltar el valor simbólico de las cosas y los materiales, reconocerlos como actores que forman parte de las redes sociales, que reflejan distintos tipos de conocimientos y marcan diferencias en términos de jerarquías sociales. Por su posición estratégica como un componente esencial en el acto de habitar, este capítulo, más breve que los demás, se plantea como un puente o una rampa que conecta los dos pisos principales, que son los dos capítulos centrales de la tesis. Así, los materiales y herramientas son el enlace indispensable entre la transformación del espacio y la mano de obra.

El siguiente piso, la segunda plataforma fundamental en esta investigación, estaría conformada por el capítulo IV: Mano de obra, que trata a profundidad el tema de los albañiles y trabajadores de la construcción. En él se discuten algunos principios básicos de la cultura y la organización laboral de los obreros y su relación con el orden urbano. Se hace un recuento de algunas investigaciones enfocadas en la industria de la construcción y los trabajadores que forman parte de ella. Se examinan algunas representaciones de los albañiles desde el cine y la literatura. Se analizan los diferentes oficios de la construcción, las jerarquías y la división del trabajo, así como las interacciones entre los distintos tipos de trabajadores. Se hace un relato de las acciones y técnicas, individuales y colectivas, que llevan a cabo para transformar el espacio. Se reflexiona sobre sus condiciones laborales, en términos de su horario y calendario laboral, del reclutamiento y el contrato informal que establecen, el sueldo que reciben, las medidas de seguridad y de protección social, etc. Un factor de especial importancia que sale a relucir en este capítulo es la 
movilidad que presentan estos actores, ya sea en forma de migración temporal del campo a la ciudad o como una transitoriedad entre varias obras, oficios y empleos. Por último, se elabora un recuento pormenorizado de los usos y costumbres de estos trabajadores de la construcción, incluyendo su vestimenta, hábitos alimenticios, juegos, formas de hablar, prácticas e imaginarios relacionados con la sexualidad, etc.

Por último, el capítulo V: Habitar la obra analiza detalladamente las formas en que los albañiles y trabajadores de la construcción interactúan con el espacio de la obra; se observa cuidadosamente cómo lo transforman y al hacer esto se apropian de él, lo habitan, lo dotan de significado. Un rasgo característico de esta forma de habitar es que el ingenio es la herramienta principal para sobreponerse a la precariedad inherente al espacio en construcción. También recupero aquí algunas nociones teóricas de varios autores que han abordado la interacción sujeto-espacio desde la antropología. A través del análisis de mis fotografías etnográficas, en diálogo con las ideas de estos autores, planteo un esquema para interpretar visualmente las diversas modalidades de habitar en la obra. Finalmente, este capítulo apunta hacia la necesidad de una antropología del habitar que se dedique a las nuevas formas y culturas del habitar que surgen en entornos urbanos tan complejos como el de la Ciudad de México. Esta capítulo se plantea como el último piso o penthouse que culmina el edificio, que se sostiene firmemente sobre todos los anteriores.

Las Reflexiones finales se podrían plantear como la azotea o roof garden del edificio; desde ahí será posible comprender todo el andamiaje en su conjunto; constituyen un mirador desde el que se abren nuevas perspectivas y se vislumbran problemas para futuras investigaciones. 
ESTRUCTURA GENERAL $D E L ~ E D I F I C I O$ DE LA TESIS

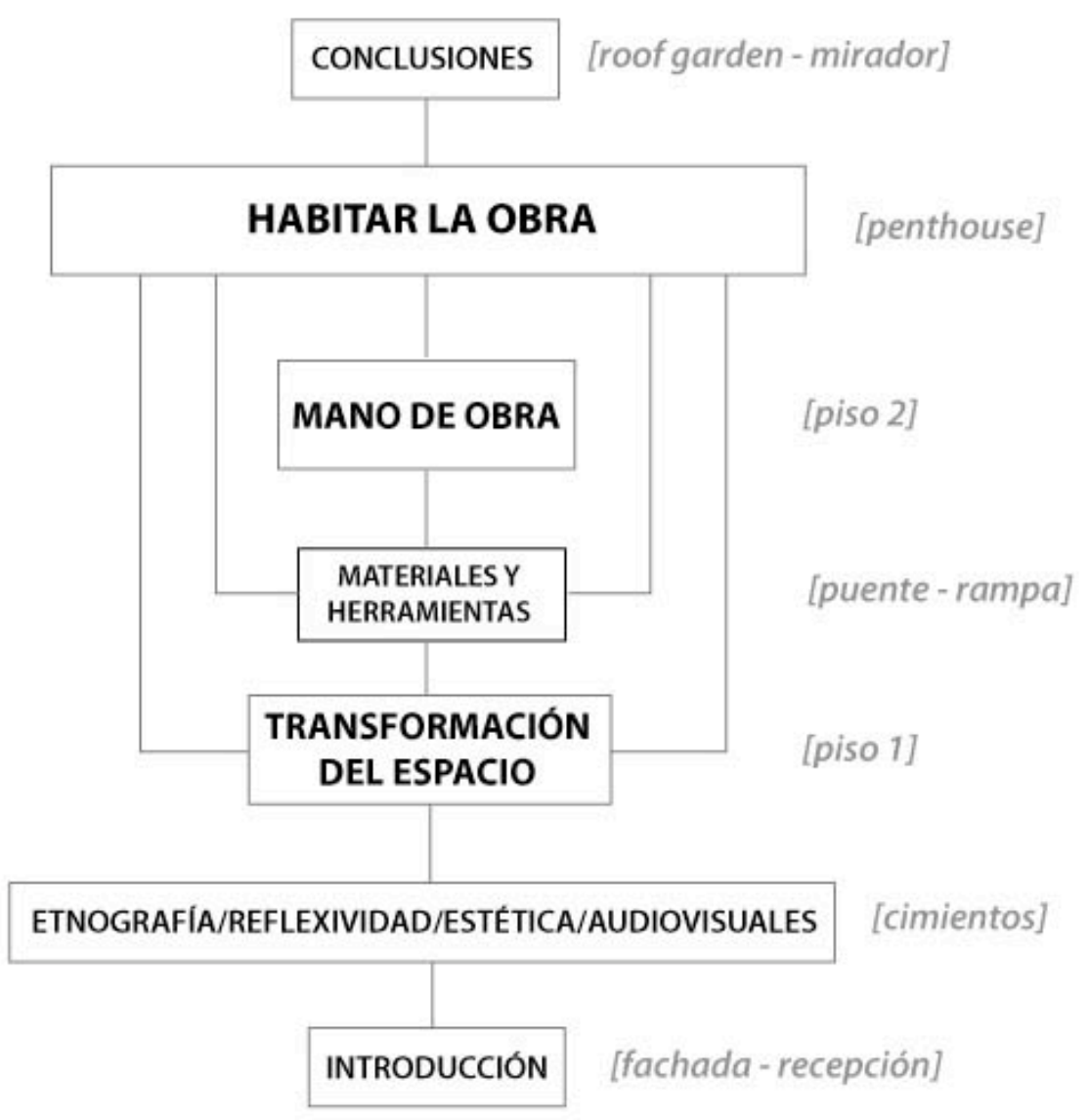





\section{Capítulo I \\ ETNOGRAFÍA REFLEXIVA, EXPERIENCIA ESTÉTICA \\ Y MEDIOS AUDIOVISUALES \\ Cimientos teórico-metodológicos}

\section{Teoría antropológica y práctica etnográfica}

Este primer capítulo se plantea como los cimientos teórico-metodológicos indispensables sobre los que se construye la presente investigación. Presentaré los presupuestos fundamentales desde donde se mira y se aborda la temática de la construcción del habitar, y a la par reflexionaré sobre las estrategias y técnicas empleadas en el proceso de observación, documentación, interpretación y representación de este problema de investigación. Haré un recuento de los autores, escuelas, corrientes, modelos y conceptos que utilizaré para pensar e intentar desentrañar la compleja realidad de la transformación del espacio urbano y conocer de cerca el mundo de los trabajadores de la construcción en el contexto de una obra. Las siguientes reflexiones permitirán ubicar este estudio de caso particular dentro de una concepción de la antropología que va más allá de su investidura científica, que la entiende como un cuestionamiento filosófico profundo, como una forma de conocimiento integral sobre el hombre y la cultura, como un vehículo para la comunicación intercultural y la acción social, que a su vez se nutre de otras disciplinas para lograr su cometido y enriquecer su labor.

Es importante destacar desde un inicio que teoría y práctica están siempre fundidas en un mismo modus operandi. Los marcos teóricos condicionan nuestras prácticas y procedimientos, así como nuestros caminos y experiencias van modificando nuestras teorías, interpretaciones y representaciones del mundo. No hay práctica libre de teoría, así como tampoco hay teoría que no tenga implicaciones prácticas. De esta manera, hay una retroalimentación constante entre nuestra forma de entender el mundo y nuestras formas de proceder en él. A lo largo de este proyecto, teoría y práctica se fueron moldeando una a la otra; no se estableció de inicio un punto de vista fijo y único, sino que intenté mantener siempre cierta flexibilidad para moverme entre diferentes marcos de referencia. 


\section{Bruno Latour y la teoría del actor-red}

A pesar de que esta tesis no se apega totalmente a ninguna corriente teórica 0 escuela de pensamiento (al menos no concientemente), debo reconocer que la llamada teoría del actor-red (TAR), tal como la expone Bruno Latour (2005) en su libro: Reassembling the Social. An Introduction to Actor-Network Theory ${ }^{3}$, ha ejercido bastante influencia en mi manera de ver el mundo y de entender la labor del antropólogo. Si hay algo que se acerque a un marco teórico dentro del cual ubicar esta tesis, quizás sería la teoría del actor-red o la antropología de las asociaciones. En esta sección me dispongo a exponer en líneas generales las bases fundamentales de la TAR, según Latour. Después, a lo largo de los siguientes capítulos, seguirán apareciendo algunas ideas de Latour en torno a esta concepción alternativa de las ciencias sociales, según sea relevante en cada apartado.

Bruno Latour es uno de los autores franceses contemporáneos más importantes, que continúa con una larga tradición de grandes pensadores de este país cuya obra refleja una concepción integral del mundo, como por ejemplo Bourdieu, Derrida o Foucault. Las principales áreas por las que transitan las ideas de Latour son la filosofía y la historia de la ciencia, así como la sociología y la antropología ${ }^{4}$. La obra que ahora ocupará nuestra atención, Reassembling the Social (2005), tiene el propósito de elaborar una introducción clara y sistemática a la TAR, concebida como un nuevo paradigma de pensamiento en las ciencias sociales. Latour parte de una crítica radical al pensamiento sociológico del último siglo y medio, desde Durkheim hasta nuestros días, y lo hace con un estilo particularmente irónico y provocador, en un tono a veces arrogante, pero siempre erudito, lúdico y muy lúcido, aunque a veces un tanto reiterativo.

\section{La recomposición de lo social}

El agudo cuestionamiento y replanteamiento de las ciencias sociales que realiza Latour, comienza con la contundente y temeraria afirmación de que "lo social" no

\footnotetext{
${ }^{3}$ Aunque existe la traducción al español de este libro: Reensamblar lo social. Una introducción a la teoría del actor-red, publicada por Editorial Manantial, Argentina, 2008, quiero aclarar que las notas y citas que presento fueron retomadas de la edición en inglés referenciada en la bibliografía, y la traducción corrió por mi cuenta. Cabe mencionar que "La recomposición de lo social" me hubiera parecido una mejor traducción del título de esta obra.

${ }^{4}$ Entre sus varios libros, además del que comentaremos más a fondo en esta tesis, me gustaría mencionar otro: We have never been modern (1993), que en mi opinión contiene importantes aportaciones críticas para el pensamiento antropológico contemporáneo.
} 
existe. Argumenta que lo social no es un tipo de material, ni un dominio de la realidad, sino es más bien un concepto comodín, un atajo o una muletilla utilizada irreflexivamente por todos los científicos sociales. "Lo social parece haberse diluido por todas partes y a la vez no se encuentra en ningún lugar en particular" (Latour, 2005: 2). Latour nos sugiere realizar el ejercicio mental de "suspender la hipótesis de sentido común de que existe un reino de lo social; abandonar por un momento la noción de una sustancia social" (Latour, 2005: 12). Ésa debería la actitud escéptica que tendrían que adoptar los científicos sociales en la base de todas sus investigaciones.

Latour pretende redefinir la noción de lo social recuperando su sentido original. Si nos remontamos a la etimología de la palabra, lo social se refiere a un movimiento que genera una conexión, designa la huella o rastro de las asociaciones entre elementos heterogéneos. En esta acepción, el adjetivo social no designa una cosa entre otras cosas, no se entiende como un dominio especial, un reino específico o un tipo particular de cosa; ahora lo social se refiere a un tipo de conexión entre cosas que no necesariamente son sociales en sí mismas. Así, lo social puede interpretarse como un movimiento peculiar de reensamble o rearmado, un desplazamiento, una transformación o una traducción (cf. Latour, 2005: 6-7).

Lo social es un movimiento que solamente puede asirse indirectamente cuando hay un ligero cambio en una asociación previa que muta para formar una conexión ligeramente nueva o diferente. Lejos de ser algo estable y seguro, no es más que un chispazo ocasional generado por un cambio (Latour, 2005: 36).

Entonces, 'social' es todo lo que va junto. Lo crucial es la forma en que las cosas están unidas o amarradas juntas, y no tanto el tipo de elementos en cuestión. Argumenta Latour que hay que evitar a toda costa recurrir a las explicaciones basadas en la existencia de una misteriosa fuerza social que nos hace actuar: "no hay que inventar un instinto social escondido, inconciente, ni plantear que nos movemos en una especie de ether de lo social" (Latour, 2005: 47).

\section{Antropología de las asociaciones}

Si tomamos en serio estos planteamientos, tenemos que redefinir también la misión tradicional de la sociología, entendiéndola ahora como la ciencia que se ocupa del seguimiento o el rastreo de todas las asociaciones y conexiones que conforman y 
hacen posible lo social. En este sentido, Latour (2005) distingue entre dos aproximaciones diferentes frente a la pregunta por lo social: la sociología tradicional o "sociología de lo social", que se ha convertido en sentido común, y la nueva sociología alternativa que propone, que llama "sociología de las asociaciones", derivada de la TAR. Me parece que esta caracterización propuesta por Latour podría aplicarse también al resto de las ciencias sociales, de tal forma que sería posible pensar en hacer y practicar una antropología de las asociaciones.

La sociología tradicional, dice Latour, ha postulado la existencia de una clase específica de fenómenos que ha llamado 'sociedad', 'orden social', 'dimensión social' o 'estructura social'. Se ha esforzado por distinguir este dominio específico de la realidad de otros dominios, como el económico, biológico, psicológico, etc. En cambio, la nueva aproximación no da por sentado este dogma. Proclama que no hay nada específico que pertenezca al orden social, que no hay dimensión social, ni contexto social, no hay ninguna 'fuerza social' disponible para explicar las acciones de los actores, ni un dominio distinto de la realidad al que se le pueda atribuir la etiqueta de 'social' o 'sociedad'. Para Latour, la sociedad, lejos de ser el telón de fondo preestablecido en el que todo está enmarcado, es precisamente aquello que tiene que ser explicado, interpretado y construido constantemente. La TAR considera como el mayor enigma aquello que la concepción tradicional postula como solución, es decir, la existencia misma de vínculos sociales (cf. Latour, 2005: 4-5).

La antropología de las asociaciones sería aquella que, como la TAR, invierte la dirección de la explicación del sentido común, y no considera lo social como premisa sino como aquello a lo que habría que llegar como conclusión. Lo social nunca permanece como una variable estable, no puede usarse para explicar un estado de la cuestión; por eso es necesario siempre dar cuenta de cómo están conectadas las cosas y cómo estos lazos se modifican constantemente, y esta sería precisamente la tarea de la antropología de las asociaciones. Así entendida, la labor etnográfica consistiría en 'seguir a los actores mismos' para dar cuenta de las nuevas asociaciones que establecen. La antropología de las asociaciones, en sintonía con la TAR, se caracterizaría por mantener una perspectiva relativista, empírica, descriptiva y objetivista (cf. Latour, 2005: 11-12). 


\section{Etnografía y documentalismo}

La inquietud filosófica-antropológica (asombro, curiosidad, interés) que da origen a este trabajo es desentrañar el proceso por el que las cosas, en este caso los inmuebles urbanos, cobran existencia o dejan de existir, tanto material como simbólicamente hablando. Esta investigación de campo nace de un deseo por atestiguar y registrar el momento mismo de la creación y destrucción de la ciudad, del impulso por dar fe del momento en el que las cosas empiezan a ser o dejan de ser de cierta manera. Para esto, fue necesario buscar la ocasión adecuada y la oportunidad de estar ahí cuando una cosa se transfigura en otra, cuando algo deviene algo diferente.

Muchas veces damos por sentada la infraestructura urbana, actuamos como si fuera algo natural, como si hubiera existido siempre. Nos olvidamos que fue necesaria una compleja serie de acciones para que las cosas empezaran a ser de esta manera o dejaran de ser como eran antes. El espíritu que anima este trabajo puede identificarse con lo que el cineasta etnográfico Robert Gardner (2006) ha llamado el impulso de preservar, o la misión de documentar y dar fe de algún momento en la historia, de una forma de vida particular o de un proceso de transformación. En este sentido, este trabajo responde a la intención de presenciar y preservar ciertos momentos clave o fragmentos importantes de la formación y transformación actual del paisaje urbano de la Ciudad de México.

Tuve la suerte de encontrar las obras que estudié en la colonia Roma y elegirlas como terrenos de investigación desde sus primeros inicios, incluso antes de que comenzara la construcción. De esta manera pude seguir de cerca todo el proceso constructivo, documentando cada etapa de su desarrollo, adentrándome en el ambiente y las relaciones sociales que se generan en torno a él. Intenté dar cuenta de detalles aparentemente insignificantes, ser testigo directo, un tanto ingenuo y ajeno, pero con toda la disposición de observar y aprender sobre las formas en que se construye hoy día en la zona central de la Ciudad de México.

Según la TAR, al iniciar cualquier proceso de investigación, hay que dejarnos llevar, permitirnos ser puestos en movimiento por los demás actores, para rastrear las conexiones y elaborar mapas de las redes que se entretejen con las interacciones entre sujetos (cf. Latour, 2005: 49). En este sentido, en un principio registré prácticamente todo lo que me fue posible en estas obras, tanto verbal como 
visualmente, dejándome llevar por los actores que me interesaban, siguiendo a los objetos que me llamaban la atención. Más adelante, poco a poco se fueron definiendo mejor mis intereses y puntos de enfoque; orientado por algunas lecturas y autores que más adelante discutiremos, me planteé guías de observación y fui haciendo un registro etnográfico-documental más selectivo, dirigido e intencionado.

\section{Documentalismo subjetivo}

Por otra parte, es importante señalar que este recuento o testimonio de la construcción del habitar se realiza inevitablemente desde una perspectiva subjetiva, desde mi propia experiencia. No hablaré de la realidad en general, hablaré de mi experiencia de la realidad. No pretendo hablar de cómo son las obras siempre, sólo puedo hablar de lo que me tocó ver en estas obras, de cómo sucedieron las cosas para mí, de cómo las percibí desde mi punto de vista particular. En este trabajo se trata de dar fe, describir y comentar, ser testigo, interpretar y representar la realidad. Es una suerte de reconstrucción de la construcción, la recomposición del mundo de la construcción. Coincido plenamente con la postura que algunos autores han denominado "documentalismo subjetivo" (cf. Fontcuberta, 1997), que mantiene compromiso de apego a la realidad atestiguada, pero al mismo tiempo es conciente de su operación interpretativa y asume sin remordimiento su libertad creativa.

Ahora bien, asumir de inicio la inevitable subjetividad es un buen primer paso; no obstante, el verdadero problema de fondo es cómo controlar la subjetividad para construir un conocimiento colectivo confiable. ¿Cómo apuntar hacia una subjetividad controlada? En primer lugar, hay consideraciones de corte ético que hay que tomar en cuenta, compromisos con los sujetos, con los posibles lectores o interlocutores y con nosotros mismos. Todas estas consideraciones han llevado a establecer parámetros de verificación y criterios de control de la información en el trabajo etnográfico, que es importante contemplar.

Definitivamente, el problema de la verdad y la subjetividad no es el mismo para el arte (llámese literatura, cine, foto, etc.) que para la antropología. Hay que tener claras las diferencias esenciales en sus compromisos y formas de procedimiento. Debe distinguirse claramente entre los materiales empíricos de una investigación etnográfica y los contenidos que provengan de la ficción y el imaginario del autor. En mi opinión, lo que diferencia un discurso de otro es sobre todo epistemológica, tiene 
que ver con principios de veracidad, verosimilitud y evidencia controlable. En el mundo de la ficción todo se vale, mientras que en la investigación empírica hay cierto compromiso con la realidad, tal como se presenta en nuestra experiencia. No se trata de buscar ingenuamente la objetividad, sino de tenerla presente como horizonte. Quizás la noción de intersubjetividad sirva mejor para guiar la práctica etnográfica-documental.

\section{Mirada multifocal}

La antropología urbana se ha debatido si debe proceder mediante microestudios de caso en la ciudad - lo que se ha llamado antropología en la ciudad- o hacer macroestudios de la ciudad como un todo - lo que se denominó antropología de la ciudad. Este debate puede resolverse realizando estudios que no se enfoquen exclusivamente en una escala micro pero tampoco en una macro, sino que más bien se concentren en los lazos y conexiones entre estos niveles, esto es, que se fijen en las redes culturales, relaciones económicas y juegos de poder que atan la casa, la vecindad, la colonia con el resto de la ciudad, la región, el país o incluso más allá, con el panorama global.

Ésta es precisamente una de las intenciones y uno de los retos de esta investigación: no enfocarse solamente en el caso concreto de las obras estudiadas, ni abordar el mundo de la industria de la construcción en términos generales y abstractos. Lo que se busca es mantener una mirada multifocal que nos permita ajustar la observación a distintas escalas: micro, meso y macro. A lo largo de esta investigación nos interesa estudiar desde la escala de la obra particular, la cuadra, la colonia Roma, la Delegación Cuauhtémoc, la ciudad central, el Distrito Federal, la Zona Metropolitana de la Ciudad de México, hasta contemplar incluso el contexto nacional y mundial. Es decir, se busca partir de una antropología en la ciudad, en una colonia determinada, en una obra particular, para después ir y venir constantemente desde y hacia una antropología de la ciudad, la colonia y la obra.

En este sentido, para justificar la elección de un estudio de caso tan micro y tan particular (sobre todo para acabar hablando de una noción tan abstracta como es la construcción del habitar), quisiera retomar algunas ideas de Gabriel Tarde, presentadas por Bruno Latour (2005). Tarde es un autor relativamente desconocido en estas latitudes y en estos tiempos; Latour lo considera un importante precursor 
de la teoría del actor-red, ya que concebía lo social como un principio de conexiones, como un flujo circulatorio; pensaba que no había razón para separar lo social de otro tipo de asociaciones. Pero lo que aquí nos interesa recuperar de Gabriel Tarde es que invierte la dirección convencional del vínculo entre micro y macro, en contra del razonamiento común que siguió la tradición sociológica, establecido por Durkheim. Tarde consideraba un error creer que para ver regularidades, orden y lógica en los fenómenos sociales hay que olvidarnos de los detalles y obtener una vista panorámica de lo general. De acuerdo con su pensamiento, lo más grande sólo se comprende por lo más pequeño y el todo solamente se puede explicar mediante sus partes (cf. Latour, 2005: 13-15). En este mismo sentido, de acuerdo con Ángela Giglia (2007), Marcel Mauss decía que un solo caso bien estudiado dice más que muchos casos abordados superficialmente.

\section{Reflexividad}

En este apartado presento y pongo en juego los principios y estrategias de la llamada reflexividad dentro del pensamiento antropológico y la práctica etnográfica. En líneas generales, la idea de la reflexividad se refiere a la capacidad de un sujeto para pensarse a sí mismo y ser conciente del impacto que tiene su presencia en determinado entorno. Para la investigación antropológica, adoptar el principio de la reflexividad implica varias cosas. Primero, ser concientes de nuestra posición, tanto física como social, dentro del universo que pretendemos comprender, y de cómo nuestra presencia interviene -e incluso a veces interfiere- en las dinámicas que ahí se generan. Cuando pretendemos acercarnos, conocer y tratar de entender a otros seres humanos, también hay que hacer un análisis serio de nuestra relación con estos sujetos. Ser autorreflexivos también significa reconocer la objetividad como horizonte, asumir la inevitable subjetividad y ubicarnos en el terreno de la intersubjetividad.

Una antropología reflexiva, de acuerdo con las ideas de Pierre Bourdieu (2002, 1995), es aquella que reconoce su propio sesgo, su propia subjetividad, es aquella consciente del lugar desde el que mira y del efecto que su misma mirada tiene en el universo que estudia; una antropología reflexiva es aquella capaz de pensarse a sí misma. Se trata, como dice Löic Wacquant, de ejercer un constante autoexamen, de 
"someter la posición del observador a un análisis crítico" (Wacquant-Bourdieu, 1995: 34). Un verdadero ejercicio reflexivo implica para el investigador llevar a cabo un cuestionamiento radical de sus propias construcciones mentales e interpretaciones del mundo. Asumir el principio de reflexividad en una investigación produce un cambio en la mirada y una ruptura epistemológica.

Dice Pierre Bourdieu que hay que ser concientes, lúcidos y no engañarnos con respecto a las perspectivas y coordenadas donde estamos ubicados cuando hacemos trabajo etnográfico. Es necesario considerar críticamente nuestro punto de vista en términos culturales, sociales y en sentido amplio, ya que la realidad cambia según el punto de vista desde el que se mira. No hay que ocultar ni ignorar estos condicionantes, es mejor utilizarlos como una herramienta para hacer una mejor etnografía. Si no somos reflexivos, estos condicionantes son vistos como un estorbo, pero si somos reflexivos, las condiciones de la investigación se tornan datos interesantes que hay que tomar en cuenta y analizar. Un método rigurosamente reflexivo es aquel que explicita y hace transparentes sus propios procedimientos. Siguiendo a Giglia, si lleváramos este planteamiento al extremo, como sugería Gerard Althabe, lo único que podemos estudiar es la propia investigación, la lógica que la orienta y las reacciones de los sujetos ante ella. Desde un punto de vista reflexivo, es recomendable siempre hacer partícipe al lector de nuestro nivel de conciencia, de nuestros nudos psicológicos. Ser reflexivo ayuda a resolver y desenredar estos nudos, ayuda a no perder el hilo durante el trabajo de campo (cf. Giglia, 2007).

Ahora bien, la reflexividad no es una fórmula mágica que anule automáticamente las condiciones sociales del investigador, ni un antídoto contra prejuicios e ideas preconstruidas; sin embargo, la toma de conciencia que induce la reflexividad le brinda al investigador la oportunidad de reducir o compensar los inevitables efectos de su posición en la estructura social frente a los otros sujetos que estudia.

La diferencia no es entre la ciencia que efectúa una construcción y la ciencia que no lo hace, sino entre la que lo hace sin saberlo y la que, sabiéndolo, se esfuerza por conocer y dominar lo mas completamente posible sus actos, inevitables, de construcción y los efectos que, de manera igualmente inevitable, estos producen (Bourdieu, 2002: 528). 


\section{El desarrollo del pensamiento reflexivo}

En el siguiente apartado presento un conjunto de notas y reflexiones surgidas a partir del curso "Metodología, conocimiento antropológico y reflexividad" dictado por la Dra. Ángela Giglia Ciotta en la UAM-I, en abril de 2007. En buena medida, retomaré ideas planteadas casi literalmente por Giglia durante este curso, pero estarán entremezcladas con aportaciones propias, intervenciones de otros compañeros y discusiones grupales dentro del curso. Dada la naturaleza verbal del curso y las limitaciones de las notas para registrar todo lo dicho, sería difícil citar con precisión y distinguir qué parte dijo cada quién. Por tanto, de entada prefiero atribuir a Giglia cualquier acierto y adjudicar cualquier torpeza a mi mala interpretación.

La antropología reflexiva puede considerarse una tendencia al interior de la teoría antropológica que ha cobrado fuerza en los últimos veinte años, ligada a la antropología posmoderna y particularmente a la corriente interpretativa y dialógica de Clifford Geertz. El debate comienza con las ideas acerca de la antropología interpretativa como parte de las humanidades, distinta al análisis objetivo de otras escuelas dentro de las ciencias sociales. La "interpretación" que plantea Geertz en el centro de la labor antropológica implica necesariamente la adopción de un "punto de vista". Los textos e imágenes son susceptibles de múltiples lecturas. Leemos la realidad de acuerdo con las categorías conceptuales con las que contamos. Por tanto, es necesario examinar las categorías que usamos los antropólogos para leer la realidad. Más que con datos duros, trabajamos con materiales de investigación, que no están dados, sino que los vamos armando y construyendo; son piezas que ensamblamos a lo largo del camino (cf. Giglia, 2007).

Estas ideas originaron un intenso debate acerca de la legitimidad de la labor etnográfica: ¿qué derecho o autoridad tenemos los antropólogos para hablar del otro, para representarlo? ¿Por qué no mejor dejar que ellos hablen de sí mismos, por sí mismos? Algunos autores adoptaron una postura dialógica, según la cual en los relatos etnográficos debemos establecer conversaciones con los sujetos y no solamente hablar los antropólogos. Pero si se trata de entablar diálogos, ¿qué sucede con la noción de autoría?, ¿seguimos siendo autores de nuestras etnografías o deberíamos compartir el crédito con nuestros "informantes", ahora convertidos en "interlocutores" ? Sin duda, el estatus epistemológico y político que le otorgamos 
a nuestros sujetos de estudio influye en nuestra labor etnográfica. Cabe preguntarnos entonces si esta postura dialógica significa necesariamente el fin de la observación participante tradicional (cf. Giglia, 2007).

Estas inquietudes cobraron fuerza en los años 80, principalmente en Estados Unidos, pero repercutieron en otros países, como Francia y México. Las cuestiones interpretativas, dialógicas y reflexivas que la antropología posmoderna puso de relieve tuvieron un gran impacto e hicieron temblar el paradigma teórico de la antropología científica y académica. Pero en realidad, tampoco se trataba de algo nuevo, sino que estas cuestiones ya habían surgido antes dentro de otras tradiciones antropológicas menos visibles. En realidad, lo que hicieron Geertz y sus discípulos fue dar relevancia a temas que ya habían sido planteados por otros autores, en otros países y otras épocas. Quisiera mencionar brevemente tres antecedentes fundamentales del pensamiento reflexivo previo al pensamiento posmoderno norteamericano: Pierre Bourdieu, quien había hecho un análisis crítico de las condiciones de posibilidad de la antropología; anteriormente, otro francés, Gerard Althabe, había planteado una antropología de lo cercano y discutido la legitimidad de la mirada etnográfica ante situaciones de proximidad o familiaridad cultural; y finalmente Ernesto de Martino, filósofo, antropólogo y psiquiatra italiano, desde los años 50 y 60 señalaba la necesidad de una reflexividad entre distintos campos del conocimiento, planteando visionariamente la posibilidad de la transdisciplinariedad (cf. Giglia, 2007).

\section{Etnografía reflexiva}

A la luz de las premisas de la reflexividad es posible lanzar una mirada crítica sobre la labor etnográfica y repensar las implicaciones que tiene en la forma de conducirnos en el trabajo de campo. En primer lugar, la reflexividad implica un cuestionamiento de lo empírico del dato etnográfico; si no hay verdad, ni neutralidad ni objetividad, hay que pasar del supuesto de la observación objetiva a la noción de experiencia y conocimiento intersubjetivo; hay que abandonar la pretensión de ofrecer explicaciones de la realidad y asumir la tarea de interpretación cultural. El pensamiento reflexivo suscita un cuestionamiento profundo, pone en tela de juicio los fundamentos mismos de la etnografía, se interroga por la propia perspectiva. Sin duda, los siguientes relatos sobre la 
transformación del espacio y la vida de los albañiles estarán irremediablemente filtrados por mi propia mirada y vivencia del vínculo con ellos. Mi experiencia personal será el vehículo inevitable para aproximarnos e intentar comprender y representar el mundo de la obra y los trabajadores de la construcción. Por ello, desde el principio del trabajo de campo me propuse llevar a cabo una etnografía reflexiva.

Una etnografía reflexiva es aquella que da cuenta de las condiciones en las que se lleva a cabo la investigación, sobre qué fundamentos se plantea, bajo qué presupuestos opera, en qué términos se realiza, revelando tanto los aciertos como las fallas. Todo lo que acontece alrededor de una investigación puede ser información relevante, por insignificante que pueda parecer, toda información constituye material útil, aunque sea para el análisis de los métodos, procedimientos, estrategias y técnicas de investigación de campo. Un relato etnográfico reflexivo permite dar cuenta de cómo se insertó el antropólogo en el campo, brinda transparencia y honestidad al proceso de construcción del conocimiento. Por otra parte, inevitablemente, la observación participante coloca al etnógrafo como parte de la escena que estudia, su presencia tiene un efecto directo en las personas que pretende entender. Pero a su vez, estas personas también tratan de entender la labor del etnógrafo, lo interrogan, hacen sus propios juicios e interpretaciones, sacan conclusiones sobre nosotros y actúan en consecuencia. Es decir, la reflexividad tiene que ver también con la capacidad de escuchar atentamente las percepciones e ideas que se forman los sujetos que estudiamos sobre nosotros y nuestro proyecto.

\section{Historia y carácter del vínculo con los trabajadores}

Tomando en cuenta lo anterior, lo que sigue es un relato de algunos pormenores de mi relación con los trabajadores a lo largo del periodo de campo en la obra, desde los primeros encuentros, cómo fue creciendo la confianza, hasta que nos dejamos de ver. Quisiera expresar sobre todo el tipo o el carácter amistoso, relajado e informal, que tuvo este vínculo, como parte importante de mi estrategia de aproximación.

El primer contacto que tuve con alguna persona relacionada con la obra de Córdoba fue cuando me acerqué a la agente de ventas para explicarle mis intenciones de investigación. Ella me remite con el Ing. Canela; me dice que lo vaya a buscar después. Platico con Antonio Bobadilla, el encargado de la obra; me 
presento con él y le explico mis intereses. Él a su vez me presenta a quienes serán el maestro de obras, Nicolás, y el segundo, Silvano. Me ofrece poner al tanto al Ing. Canela sobre mí y mis intenciones de hacer trabajo de campo en esa obra, entonces le escribo en un papel mi nombre, teléfono y otros datos.

Al día siguiente, la puerta del terreno está cerrada pero hay algunos trabajadores afuera del terreno. "¿Ya van a empezar?", pregunto. "Sí, ya estamos aquí haciendo ruido", me contesta Silvano, quien desde estas primeras veces me reconoce y me saluda amablemente. Le pido permiso para sacar fotos del terreno y me dice que sí. Al fondo hay dos trabajadores, uno removiendo cerros de tierra con una pala y el otro clavando y midiendo tablas. El que la hace de carpintero me saluda muy amablemente. Su nombre es Patricio, nos damos la mano. El otro trabajador, mucho más hosco, me mira desconfiado.

Después de esperarla un buen rato, por fin llegó la señora agente de ventas. Me presento con ella, le pido su nombre y le explico que es para poder dirigirle una carta oficial de presentación por parte de la UAM, solicitando que se me permita el acceso a la obra, para hacer trabajo de campo. Pero ella no me quiere dar su nombre. Me dice que la carta tendría que ir dirigida al Arquitecto Canela, pero según ella no se acuerda de su nombre completo. Es evidente su desconfianza hacia mí. En cambio, el maestro Nicolás me da amplio permiso para que pase por todas partes de la obra y le saque fotos a todo, sin ningún reparo. Yo le pregunto si cree que el ingeniero tendrá inconveniente en darme autorización... "Quién sabe, güero, no sabría qué decirte, eso depende de mi patrón, la verdad tampoco lo conozco muy bien y uno nunca se sabe cómo va a reaccionar", responde. Por su parte, Antonio Bobadilla me informa que ya le comentó al "arqui" sobre mí y que no cree que haya mayor problema. Me despido de los presentes, le doy la mano a Bobadilla, a Nicolás y a Silvano; de paso me despido también de la señora de ventas.

Voy con la Sra. de ventas para dejarle la carta de presentación por parte de la UAM, para que ella se la entregue al Arquitecto Canela. Pero ella me dice que a pesar de que sí suele ver al Arqui, prefiere no recibirme la carta porque ella no tiene ninguna autoridad en relación con la obra. Pero le insisto que me haga el favor, entonces acepta y me firma de recibido. Me pregunta por mi investigación y conversamos brevemente, ya mostrando un poco más de familiaridad y confianza que en ocasiones anteriores. 
Luego saludo a Antonio Bobadilla y le menciono que ya entregué la carta en la oficina de ventas; me responde enérgicamente que hice mal, porque allá nada tienen que ver con la obra, "allá es ventas y el manejo de la obra es otra cosa aparte". Me aclara que él prefiere no mezclar las cosas para no tener problemas. Entonces voy de nuevo por la carta para entregársela a él; me asegura que se la hará llegar al arquitecto lo antes posible.

Un señor mayor, regordete, de bigote canoso, me saluda amable al pasar junto a mí. Después lo identificaría como Raúl. Saludo a dos peones jóvenes ya conocidos con un "quihubo carnales" y me meto al terreno. Entre los peones chavos que veo adentro hay caras conocidas que también me reconocen de otras veces. Me alegra ese sentimiento de familiaridad. Uno a uno los trabajadores me van reconociendo y nos saludamos más afectuosamente cada vez.

Entre las consideraciones éticas relacionadas con esta labor etnográfica, cabe señalar que opté por decirle 'mai' a todos para siempre tener una presencia humilde ante todos los trabajadores, sin distinción alguna. Sean o no sean maestros, de entrada decirles "mai", abreviatura familiar de "maestro", me parece que demuestra cierto aprecio, intentando cancelar de entrada una posición de autoridad de mi parte.

La primera vez que saludo al Arquiteco Canela, él me dice a rajatabla:

— ¿Sabes qué te va a costar estar viniendo?, ¿cada cuánto tienes que entregar informes o reportes en tu universidad?

-Trimestralmente-, le contesto.

-Entonces cada tres meses quiero copia de ese reporte, antes de entregarlo le sacas copia a todo y me lo traes, si no, no tienes acceso; para comprobar que estás haciendo algo aquí, no vaya a ser que nomás vengas a hacerte güey, porque pues nunca se sabe, luego hay casos como hace poco el cabrón que se metió a la bóveda de seguridad de Banamex por el sótano de la casa de junto, ese cabrón conocía bien los planos.

—No'mbre, si yo no entiendo nada de lo que sucede aquí, por eso apenas quiero aprender-.

-Bueno, ya sabes, si en tres meses no tengo un informe tuyo, ya nunca vuelves a entrar.

Me dice esto con cierto tono de broma, entre amistosa y amenazante. Después el arquitecto se da la vuelta y se va sin despedirse a atender algún asunto de la obra con Silvano. Luego pasa a retirarse a bordo de su coche negro que estaba 
estacionado afuera en la puerta de la obra. Resulta interesante preguntarnos si esta reacción de desconfianza del arquitecto Canela hacia mi presencia en la obra, hubiera sido tal hace 10 años, por ejemplo. Me parece que esta actitud puede leerse como un síntoma de la situación que atraviesa la construcción en nuestros tiempos, a diferencia de otras épocas. Se trata de una urbanización más agresiva y voraz que comienza a ser seriamente cuestionada por la opinión publica, situación ante la cual los actores involucrados adoptan de entrada una actitud defensiva. Aunque también hay que considerar que la reacción del arquitecto responde en buena medida a la creciente inseguridad en la ciudad, ante la cual deben tomarse precauciones extras.

Saludo al señor llenito y amable, Raúl, y a Patricio, que junto con un trabajador más joven que me pareció muy listo, a quien llaman Paul, estaban armando estribos en la mesa de trabajo de madera en el fondo del terreno. Por ahí veo al maestro Nicolás, a quien hace tiempo no veía, acompañado por otro señor que ya había visto antes... Una tarde, después del final de la jornada laboral, platico con varios trabajadores, sobre todo con un chavo grandote, simpático, de bigote y pelo largo recogido en una cola de caballo, con chaleco rojo y gorra hacia atrás; se llama Édgar, alias El Gordo... En el hoyo, en sus puestos de trabajo, están Leonel, Raúl, Pato, El Gordo y otros trabajadores más que reconozco de otras veces. Me saludan con la mano, con un grito, un silbido o con la mirada y un guiño.

Le anuncio a Silvano que me ausentaré de la obra por dos semanas. Le comento que temo que avancen mucho durante mi ausencia, porque me lo voy a perder. ¿Qué tanto avanzarán en una docena de jornadas laborales? De los trabjadores que he conocido, ¿quiénes seguirán ahí y quiénes no?, probablemente a algunos jamás los volveré a ver... "Pero yo pienso que hasta ahorita vas bien con el ritmo que Ilevas, con lo de las fotos, ¿o no güero?", me dice Silvano. Es interesante que, por su parte, los sujetos que estudiamos, nuestros personajes, también evalúan nuestro desempeño como etnógrafos o documentalistas.

De regreso a la obra, identifico rápidamente al Pato y a Édgar, El Gordo. Al saludarlos, El Gordo me dice: "Yo te hacía todavía en Acapulco, güero", y se ríe. Les pregunto cómo les ha ido y Édgar me contesta: "aquí estuvimos como en Acapulco pero en la azotea, con todo y alberca... mira nomás", señalando el charco de agua estancada que persiste en el fondo del terreno. 
Un día, al pasar caminando frente de la obra de Córdoba alguien me grita fuerte como para espantarme, y lo logra; cuando me asomo por la puerta semiabierta, veo que fue Rufino, quien me recibe bromeando: "¿se le perdió algo?"... Me anuncia Silvano que el próximo miércoles se va a hacer el colado de la segunda losa, que no me lo vaya a perder porque va a estar bueno, parece que va a ser una intensa la jornada de chamba y transformación en la obra... Mientras grababa una acción colectiva, trataba de no estorbar, pero como el espacio era muy reducido, tenía que quitarme y arrinconarme a cada rato. Incluso intervine pasándoles herramienta y material, como un eslabón más en la cadena. En un momento dado llegué a sentir que mi presencia con la cámara no afectaba la dinámica en absoluto, como si a los trabajadores ya les resultara familiar verme entre ellos, no como si fuera invisible, sino como si fuera uno más de ellos.

Me quedo con Silvano platicando un muy buen rato, a la orilla de la primera planta, mirando el panorama en construcción debajo de nosotros, y él explicándome detalladamente muchas de las cosas que suceden ahí abajo. Esta situación me hace sentir como alguien importante en la obra, alguien con quien el maestro se toma el tiempo de platicar con toda paciencia.

Le regalo a Pato una chamarra que conseguí para él, pensando que le serviría para el frío que hace por su casa en estas épocas; en respuesta, se lanza agradecido a darme un abrazo... Le digo a Pato que traigo un juego de naipes que les quiero regalar, si es que les gusta jugar cartas. Pato me señala a Paul, que está ahí cerca trabajando, y me dice: "yo sí juego, pero él es mucho más jugador que yo". Entonces le doy las cartas a Paul, quien las mira y las acepta gustoso. Le advierto que la única condición es que me enseñe a jugar; "mañana mismo a la hora de la comida, ya es un trato hecho", se apresura a decir... Le regalo a Ángel una cartera que me sobra, habiéndome fijado en días anteriores que él no tenía nada para guardar su poco dinero. Pensé que darle una cartera era importante simbólicamente, ya que le permitiría guardar y ahorrar mejor el dinero.

Raúl, trabajador mayor, bromea conmigo sobre mis botas de hule llenas de lodo que llevo en una bolsa... "¿Ahora no trajo sus botas?", me pregunta Raúl al verme salir. "No, ahora no, a veces sí y a veces no", le respondo. Me lo dice con una gran sonrisa en un tono burlón que denota, me parece, que le llama mucho la atención que a veces lleve mis boras para meterme al hoyo con ellos... Raúl me pregunta una 
vez más por mis botas, en tono burlón y confianzudo. Le digo que ahora no hacen falta, "cómo no, para que se meta bien allá abajo, con los pies en lodo", insiste.

Al verme, Pato me saluda y me pregunta si ya vengo a estudiarlos, le digo que sí, eso mero... Para saludarme de mano, Ángel se quita los guantes con los que estaba trabajando el fierro. Me despido dándole la mano a cada uno de los presentes; Rufino, como tiene las manos muy sucias me ofrece el antebrazo... Al saludarnos y despedirnos todos me dan siempre la mano o el antebrazo si su mano está muy sucia, aunque yo casi siempre procuro darles la mano de cualquier modo, aunque me ensucie.

Le pregunto algo a Nicolás pero no me oye bien y me contesta de mala gana, como desconfiando y molesto. Me doy cuenta de que no es un buen momento para socializar con él, entonces mejor me voy... El maestro Nicolás se ha tornado un tanto seco y cortante conmigo, al igual que Antonio Bobadilla, aunque no tanto como éste. Pero sí hay una gran diferencia entre cómo me tratan estos dos, y cómo es mi trato con Silvano, Patricio y El Gato.

En una ocasión, no había nadie que le ayudara a cortar unas varillas al Pelón, quien estaba batallando para hacerlo él solo, mientras yo lo retrataba. Decidí ofrecerle una mano y traté de ayudarlo haciendo palanca y doblando la varilla lo más posible para que se rompiera, pero nunca logré quebrar la varilla con una mano, sosteniendo la cámara con la otra. Hasta que vino a relevarme otro trabajador que pasaba por ahí, quien logró hacerlo sin esfuerzo en un santiamén. Es impresionante lo torpe y débil que uno se puede llegar a sentir entre esta gente tan hábil, fuerte e ingeniosa.

Me preguntan Chucho y Ángel si soy mexicano, porque habían comentado entre ellos que les parezco extranjero, pero quién sabe de dónde. Me preguntan por la universidad en la que hago mis estudios; les cuento con toda calma y detalle sobre mí y mi circunstancia, para corresponder con su apertura. Me preguntan dónde vivo y les digo que muy cerca en la Roma, lo cual nos hace prácticamente vecinos, ellos viven en un edificio en la calle de Guanajuato, a unas cuadras de la obra, entonces al confirmar algunas referencias territoriales en común, se crea un lazo más estrecho entre nosotros, gracias a que compartimos un mismo mapa mental.

Tuve una larga conversación con Chucho junto a una casita improvisada con tablas y plásticos. Yo me senté en una cubeta y él, que supuestamente debía seguir 
trabajando, se mantuvo de pie, haciendo la finta de que removía tierra de vez en cuando, por si Silvano volteaba a verlo. Chucho sonriente aprovecha para descansar del sol y por lo visto le gusta mucho platicar, cuando alguien le presta un oído atento. Más rica que una entrevista formal, ésta fue una plática espontánea y sincera, a través de la cual dos personas originalmente extrañas se conocen y se hacen amigos; una conversación en la que más allá de la información, se intercambian experiencias, se comparten historias y se crean vínculos, o como diría Latour, se construye lo social.

La noche de año nuevo me conmueve recibir una llamada de Ángel, El Pelón, quien me llama para desearme feliz año y anunciarme que luego me quiere contar algo personal.

Después de ausentarme durante varios días de la obra, encuentro cambios drásticos tanto en el personal como en la apariencia general del espacio. Me siento "desencanchado" una vez más, otra vez desconozco y me desconocen varios trabajadores nuevos y casi no reconozco el espacio. Me acerco con la cámara y otra vez soy como un extraño que tiene que comenzar desde cero a ganarse la confianza de los sujetos, por la acelerada y violenta metamorfosis de los espacios, por la presencia fugaz de muchos actores que confluyen en la obra y la fragilidad e inestabilidad de los lazos que ahí se forman.

El Gato me pregunta si trabajo para DAKAB; insinúa de broma que el "arqui" me contrató como espía para sacarles fotos y vigilar a los trabajadores. Me río con él y le contesto que ojala me pagara la compañía por este trabajo, si apenas me dejan entrar. Con esta conversación se definieron lealtades, le quedó claro al Gato que yo no tenía ningún lazo laboral con la compañía y que mi interés eran sobre todo ellos, los trabajadores. A partir de entonces la confianza creció con El Gato e incluso en ocasiones aprovechó para denunciar o desahogar algunas inconformidades que tenía hacia la compañía.

En la obra de Puebla entrego un paquete de $14 C D$ con todo el registro visual de la obra de Córdoba y una carta dirigida al arquitecto Canela, pidiéndole autorización para registrar también la obra de Puebla. Días después, el arquitecto me confirma que ya le entregaron los CD y la carta; me informa que me concede el permiso para hacer trabajo de campo en la obra de Puebla, siempre y cuando me 
comprometa a entregarle también copia del material visual que genere en esta nueva obra.

Cuando estoy tomando fotos en la entrada del edificio se me acerca un joven bien vestido y muy peinado, de tez blanca y ojos claros. Ya lo había visto de reojo minutos antes, supervisando los acabados del departamento de muestra. Me pregunta de qué estoy tomando fotos, en un tono un tanto prepotente, entonces respondo literalmente a su pregunta, "saco fotos de la entrada, del andamio y del trabajador". "No, pero... ¿para qué o con qué fin?", me dice contrariado. "Con el permiso del arquitecto he venido registrando todas las etapas de esta construcción, desde el comienzo de la obra", contesto. "De acuerdo", me dice y se retira. Más adelante me enteraría de que, al parecer, se trataba del hijo del arquitecto Canela.

Calderón, el maestro carpintero, ya por fin me tiene más confianza. Me lo encuentro y nos saludamos con una sonrisa, me pregunta por qué no había ido. Platicamos y lo sigo hasta un hueco, donde va a desclavar unas tablas, trepado en una escalera improvisada. Me permite retratarlo y me comenta algunos pormenores técnicos de la obra.

A principios de noviembre, a un año de que comenzara la construcción, recibo el primer aviso del fin de mi permiso para tener acceso a la obra. Tan pronto me ve en la obra con mi cámara, el arquitecto Canela se dirige hacia mí diciendo: "Toma todas las fotos que quieras ahorita, porque la semana que entra ya no vas a poder entrar, ya no te van a dejar pasar; es más, hoy es el último día que entras, porque ya mero entregamos los primeros departamentos y no quiero que los condóminos sepan que existen fotos de todo esto, por razones de seguridad". Me dice esto en un tono amenazante y lapidario, con una actitud un tanto prepotente. Pienso que tal vez así es como empieza a cerrarse naturalmente el ciclo de mi trabajo de campo.

Le pregunto al arquitecto si un día de estos me concedería una entrevista para mi tesis. "¿Entrevista de qué o para qué?", me devuelve la pregunta en un tono seco y áspero. "Pues acerca de cómo surgió este proyecto, su trayectoria, los nuevos planes de la compañía, etc." le contesto. "Pues me debes mis discos con las últimas fotos, ¿estás yendo también a Puebla, verdad? Cuando me entregues todos esos discos vemos lo de la entrevista", sentencia. 
Llego a la obra de Córdoba temeroso de encontrarme al arquitecto Canela, quien ya me advirtió que mi acceso al edificio terminaba la semana pasada. Le pregunto a uno de los trabajadores que están afuera si anda por ahí el arquitecto y me informa que fue en la mañana pero que ya se retiró; entonces entro más confiado, aunque ahora ya de contrabando. Más arriba me asomo a la calle por la ventana de un departamento del segundo piso y veo llegar al arquitecto Canela; me preocupa que tendré que esconderme para que no me vea al bajar ni al salir del edificio. Tendré que medio esconderme y esperar a que se vaya para entonces poder salir de la obra.

Al enterarme de la noticia del asalto a la obra de Puebla la noche de año nuevo, lo primero que temo es que Antonio Bobadilla o el arquitecto puedan sospechar de mí, por aquello del chiste o advertencia que meses atrás me hizo el arquitecto, en el sentido de que yo podría usar las fotos y la información para planear un robo a la obra o al edificio una vez terminado. Por suerte no desconfiaron de mí. Pero a raíz del asalto a la obra, en la obra de Puebla un guardia de seguridad uniformado vigila la entrada y merodea los alrededores. Al verme entrar me llama y me pide mis referencias. Dudoso al principio, renuente a dejarme entrar, finalmente lo convenzo de que tengo permiso del arquitecto Canela y le digo que de todos modos anote mi nombre.

A mediados de febrero de 2008, transcurren los últimos días de trabajo de campo en los edificios de departamentos que construye $D A K A B$ en la Roma. Continué pasando ocasionalmente por estos sitios, entrando siempre que era posible, hasta que un policía uniformado me impidió pasar al edificio. El permiso del arquitecto llegaba hasta que el edificio se terminara de construir. Más allá de esto, con los nuevos dueños o inquilinos, habitantes de los departamentos, hubiera tenido que hacer otro tipo de trámite para solicitar su permiso... Desde entonces, a los trabajadores de la construcción que conocí no los he vuelto a ver. Ya sea que se hayan quedado trabajando con DAKAB alguna de sus obras, que se hayan mudado a cualquier obra de otra compañía, o incluso que se hayan cambiado de oficio en un intento por ganarse la vida, dudo que nos volvamos a encontrar.

A los trabajadores que conocí durante este trabajo de campo, sobre todo a aquellos con los que establecí lazos amistosos, los busco en cada obra que me encuentro por la Roma; siempre que veo un grupo de albañiles me parece reconocer a alguno de mis amigos, pero al final me percato de que no son; su 
apariencia y sus rasgos particulares no son tan particulares, en realidad se parecen mucho entre ellos. Con el paso del tiempo, echo de menos a algunos a estos personajes, en varias ocasiones incluso he soñado con los sujetos de esta investigación etnográfica.

\section{Explicaciones y redefiniciones del proyecto a partir del trabajo de campo}

Muchas veces, las aclaraciones que les daba a los trabajadores cuando me preguntaban sobre mi proyecto, justo cuando trataba de explicarlo en los términos más sencillos y accesibles, me ayudaron posteriormente a entender el sentido que iría adquiriendo esta investigación.

Uno de los primeros días de mi presencia en la obra, Patricio me pregunta: "¿algún plan de estudio?". Me presento y le cuento un poco sobre mi proyecto de investigación. Así también, el segundo de la obra, Silvano, se muestra amistoso y me pregunta sobre mi estudio y la universidad de la que vengo.

Muy al principio de la temporada de campo, a las pocas semanas de estar yendo a la obra, un día me pregunta Patricio si ya voy a terminar con mi trabajo que estoy haciendo; le digo que no, que apenas voy comenzando. Le explico que en principio quiero permanecer y seguir yendo desde el principio hasta el final de la obra, todo el tiempo, lo que dure.

Uno de los presuntos inversionistas, al verme con la cámara, me pregunta por qué estoy registrando la obra, si soy pasante de ingeniero o estudiante de arquitectura o qué estoy haciendo ahí en la obra... Cuando me presento con el nuevo encargado de la obra de Puebla, el maestro Javier, le explico que he estado trabajando en la obra de Córdoba y que tal vez también empiece a venir aquí para sacar fotos y observar. "¿Trabajando en qué sentido?", me pregunta. Respondo que es un estudio para la universidad y que el arquitecto Canela ya me dio permiso. "Ah, ¿eres estudiante de ingeniería o arquitectura?". Le digo que de antropología urbana y le explico en resumidas cuentas que se trata del estudio de la sociedad y la cultura en las ciudades. No sé si me haya entendido, pero me ofrece amablemente su ayuda en lo que necesite.

Furcio me pregunta en qué consiste mi chamba. Le cuento sobre mi investigación para la universidad, pero no parece entender bien. "Está buena tu chamba, está tranquila, no hay que trabajar fuerte, sólo hay que saber tomar fotos y lo mejor es 
que vas de un lado a otro conociendo gente", me dice simple y sabiamente Furcio, tachado por todos como el más tonto de la obra, quien según yo no entendía nada de lo que intentaba explicarle.

Nicolás me pregunta nuevamente por mi investigación; le cuento de la UAM, de la antropología urbana, de la transformación de la colonia, de las construcciones en la zona central de la ciudad, de la cultura de los albañiles, de sus formas de habitar la obra, etc. Es todo un reto intentar hacer entender a los trabajadores el objetivo de mi investigación y el por qué de mi presencia entre ellos, casi siempre apuntándoles con la cámara. Ha sido un buen ejercicio para darme cuenta de que ni yo mismo lo tengo bien claro. Sin embargo, otras veces me sorprendo explicándolo en términos tan simples, que me hacen reencontrarme con el sentido atropológico primordial de lo que estoy haciendo.

Al inicio de la construcción de la obra de Puebla me encontré en una encrucijada que resultó significativa y reveladora para el desarrollo de mi investigación, que me obligó a repensar mis motivos y objetivos principales de investigación. ¿Se trataba de documentar todo el proceso de una obra de principio a fin, o se trataba de seguir a los trabajadores que iba conociendo en el camino? Esta duda me causó cierta parálisis en un momento dado, no sabía si seguir a los albañiles que ya conocía relativamente bien a donde quiera que se movieran, o si debía mantenerme fiel a un espacio y completar el seguimiento del desarrollo de una sola obra. ¿No sería posible hacer las dos cosas? Le cuento a Silvano que no sé que hacer con esto de las dos obras simultáneas. Se ríe de mí diciendo: "Pues ora sí que como puedas y te convenga, güero". Finalmente, en efecto, me propuse hacer ambas cosas: seguir a los trabajadores en su tránsito por estas dos obras, la de Córdoba y la de Puebla, pero al mismo tiempo mantuve el propósito de documentar toda la obra de Córdoba como referencia de un proceso constructivo completo.

Javier y yo conversamos un buen rato en confianza. Me interroga: " $¿$ Tienes otra chamba?"... "¿Ya vas a terminar la carrera?"... "¿Luego a chambear, o qué?"... "¿De fotógrafo o de profesor universitario?"... "Ni modo, a buscarle"... "No está fácil"...

Se me acerca el maestro que se ha encargado de pintar todo el sótano y me pregunta qué es lo que hago; le explico en términos sencillos que he registrado toda la obra desde el principio, interesado en cómo se construyen los nuevos edificios en esta ciudad hoy en día, documentando todos los procesos, materiales, 
técnicas, las etapas, los oficios y los personajes implicados. Parece que lo entiende bastante bien. De pronto a mí mismo me suena todo muy fácil y claro, cuando en otros momentos me ha parecido complicadísimo y sumamente confuso.

Les comento al Gato y a Javier que estudio antropología y trato de explicarles lo que eso significa, remitiéndome a la evolución del ser humano y sus formas primitivas de construir su morada, hasta la vida moderna en las ciudades, el desarrollo de la arquitectura y distintas modalidades de construir y habitar el espacio. Suena claro y simple, siento que me entienden. "O sea que en diez años tu nieto te va a ver en el museo en una foto del güero", le comenta Javier al Gato, siempre ocurrente y chistoso. Pero además, la noción de patrimonio y memoria detrás del comentario de Javier, reafirma el valor de la documentación en un estudio de caso como éste.

Al explicárselo a ellos, al tratar de ponerlo en los términos más básicos y elementales, me doy cuenta de una potencial arista evolutiva en el fondo de mi proyecto de investigación, así como de la posibilidad de la comparación geográfica. ¿Qué lugar ocupan estas construcciones en el desarrollo de la civilización y en la evolución de la humanidad? ¿Cómo se construyen y se habitan las viviendas en otras ciudades del mundo? ¿En qué se parecen, qué elementos tienen en común y en qué se diferencian de otras construcciones de la capital mexicana?

Uno de los plomeros me pregunta si hago fotos para los catálogos promocionales de las compañías constructoras, le digo que no, que hago un estudio para la universidad sobre cómo han ido cambiando las formas de construir los edificios en las ciudades a lo largo del tiempo y cómo se construyen edificios en nuestra ciudad actualmente. Me pregunta si ya fui a Monte Albán, Oaxaca, de donde es él, porque ahí le dijeron que las construcciones de pirámides y casas se hacían con baba de nopal.

\section{Reflexiones generales sobre la práctica etnográfica}

Casi siempre la experiencia etnográfica se presenta como un todo indistinto. Después, a través de la reflexión antropológica, poco a poco vamos desentrañando, fragmentando y ordenando esta información, surgen así categorías analíticas de acuerdo con las que se clasifica el material empírico que forma el corpus etnográfico. Pero a final de cuentas, siempre habrá cruces y traslapes que nos recuerdan que la 
experiencia de la realidad es más compleja y ambigua de lo que parece comúnmente en los reportes etnográficos.

Raúl me explica más o menos el procedimiento de construcción que se seguirá a partir de entonces, pero por los términos técnicos que usa no alcanzo a comprender casi nada. Trato de visualizar el proceso según lo que me dice Raúl, pero me doy cuenta de que es inútil tratar de adelantarme con la imaginación. Me es imposible anticipar lo que sucederá porque no conozco este mundo, así que mejor voy observando y registrando día a día pacientemente.

Sostengo una larga y agradable plática con Silvano; conversamos un buen rato sobre varios temas: la empresa inmobiliaria, los salarios, el reclutamiento de trabajadores, el trato que se les da, el sindicato, la demanda de empleo, el rendimiento de los trabajadores, los abusos y tranzas que puede haber en una obra, sobre su responsabilidad, etc. Platicamos sobre todo esto y muchas cosas más que se me pueden estar olvidando, que si hubieran quedado grabadas seguramente resultarían valiosas. Fue una conversación muy interesante y agradable, que lamentablemente no grabé ni pude tomar notas de ella en ese momento; pero también por eso mismo - sospecho- fue una conversación tan interesante y agradable; probablemente, si la conversación hubiera sido grabada, no hubieran fluido de forma tan natural y espontánea.

Permanecí una hora más observando asombrado, fijándome en cada detalle, contemplando la gran destreza y el ingenio de los trabajadores, inútilmente tratando de registrar todos los términos que usaban y cómo se comunicaban entre ellos... Siempre sucede más de lo que uno puede alcanzar a percibir y documentar, siempre alrededor de uno se desarrollan muchas cosas imposibles de ver, notar, grabar, escribir, filmar, recordar. Por supuesto, en la labor etnográfica siempre nos enfrentamos con la imposibilidad de captar, documentar y dar cuenta de todo lo que vivimos; es una ley a la que los etnógrafos nos tenemos que atener.

Muchas veces me sucedió que hubiera querido y podido permanecer más tiempo en la obra, pero ya estaba demasiado saturado de impresiones, vivencias, imágenes e información, que sentí que perdería si no las plasmaba cuanto antes en el diario de campo. Mientras tomo notas para no olvidar y fotos para volver a ver, se llena la memoria de almacenaje de la cámara y se satura mi propia memoria de impresiones y observaciones, así que mejor me retiro de la obra para vaciar lo recogido en el 
diario de campo, con ayuda de las imágenes, que en este caso, como veremos más adelante, actuaron también como disparadores de recuerdos.

Después de más de una semana de no haber ido a la obra me invadía cierta angustia, un sentimiento de estarme perdiendo momentos importantes. Me da miedo regresar $y$ ver que ha habido grandes cambios o que algunos de mis amigos trabajadores desparecieron sin poder despedirme de ellos, perdiendo todo contacto para siempre. Siento que a veces en la etnografía se genera una especie de adicción al objeto de estudio, sobre todo cuando uno se involucra genuinamente con su terreno y sus sujetos de investigación.

El trabajo de campo puede llegar a esclavizar al etnógrafo, puede producirle cierta angustia y ansiedad si deja de ir por unos días al terreno de estudio. A veces tengo la sensación de que la realidad me está dejando atrás, de que me pierdo detalles importantes del transcurso del tiempo en determinado lugar. Sobre todo cuando se trata de una obra, cuando el espacio cambia tan drástica, rápida e irreversiblemente, no hay marcha atrás, lo que te perdiste ya no lo volverás a ver. Se siente algo como un vértigo ante la transformación incesante, que conlleva una obsesión por el registro y un impulso de preservar hasta lo más insignificante.

Es extraño tener que convertir la experiencia en dato, desarticular el orden cronológico del diario de campo y acomodar los relatos según categorías temáticas o teóricas. A veces siento como si en este proceso se perdiera el alma de la vivencia relatada, para convertirse en información. ¿Cómo conservar el valor humano y vivencial de la experiencia etnográfica en el informe final de una investigación que a su vez pretende ser científica?

Curiosamente, las conversaciones más fluidas y llenas de significado son posibles sobre todo cuando no llevo la cámara y no estoy mirando a través del lente; entonces me doy la oportunidad de conversar con los trabajadores sin que nadie 'capture' a nadie de ninguna forma, de igual a igual. Así es más fácil poner atención en la gente, recordar sus frases, el contenido y el sentido de lo que dicen.

Ya me estoy hartando de hacer siempre lo mismo cuando voy a las obras. Me siento un tanto estancado. No veo cosas nuevas, no me surgen nuevas preguntas. Cultivé muy buenas relaciones y amistades pero no sé qué hacer con ellas, como que no las estoy aprovechando. Ya me cansé de tomar fotos de todo y de intentar describirlo todo y narrar las pláticas palabra por palabra. Siento que a pesar de mi 
persistencia, me quedo en la superficie y realmente no doy un salto más allá para acercarme a la vida de los trabajadores.

Me reúno con un grupo de trabajadores que apenas conozco, hablamos durante un buen rato, casi durante toda la hora de la comida, sentados en el piso de la azotea, al borde del edificio, recargados sobre un muro, bajo el pleno sol del mediodía. Tocamos muchos temas con toda confianza. Empecé contándoles sobre mí: mi estado civil, dónde vivo, qué estudio, mis perspectivas de vida, etc. Sólo entonces ellos también se abrieron ante mí y me contaron sobre sus vidas: de dónde son, cómo llegaron a trabajar ahí, dónde estaban antes, qué harán después, cuánto ganan, etc. Durante toda esa charla guardé mi cámara y dejé a un lado mi libreta de campo, para interactuar plenamente, sin mediaciones ni obstáculos. Paradójicamente, en los momentos en que uno se olvida de hacer etnografía es cuando la experiencia etnográfica es más valiosa y fructífera, sobre todo en cuanto a su lado estético y humano. Casi como si las propias pretensiones de ser un científico social, investigador, fueran una traba o freno para lograrlo cabalmente.

\section{Los lenguajes de la antropología}

A mi entender, así como no hay una única corriente o teoría antropológica, ni una única metodología o conjunto de técnicas de investigación, así tampoco hay un solo medio o lenguaje del que se pueda valer nuestra disciplina para expresar y comunicar las experiencias y el conocimiento generado. A grandes rasgos, encuentro que la palabra y la imagen son dos vías legítimas y fructíferas para desarrollar la antropología y la etnografía. En este proceso de investigación etnográfica, el recurso a la imagen y el recurso a la palabra han ido de la mano, retroalimentándose recíprocamente. En el siguiente apartado presentaré y discutiré las implicaciones que ha tenido para el presente trabajo el hecho de no haberme limitado a transitar exclusivamente por una de estas dos vías, sino más bien a alternar libremente entre ellas.

\section{La descripción verbal y la crónica etnográfica}

A lo largo de esta investigación etnográfica he llevado a cabo un minucioso registro escrito de todas las ocasiones que he visitado la obra. Desde un principio, he 
intentado que mis notas de campo sean crónicas etnográficas, narradas casi siempre en primera persona, que cuenten historias y relaten los pormenores de $\mathrm{mi}$ encuentro con los albañiles, que formen un registro ameno de mi inmersión en su mundo y su cultura. Esta serie de escritos conforman una representación narrativa de mi experiencia etnográfica. En ellos intento recordar anécdotas, frases, gestos, ambientes, circunstancias, impulsado por una cierta obsesión por no dejar escapar nada, por registrar hasta el más minúsculo detalle, aparentemente insignificante. Trato de que estas notas no sean un inventario de hechos observados, sino relatos con una intención narrativa, que permitan reconstruir y representar la experiencia etnográfica vivida y que conformen una buena fuente de material de análisis.

En esta tesis adopto algunas recomendaciones prácticas y metodológicas hechas por Bruno Latour (2005) a propósito de la teoría del actor-red (TAR) y la antropología de las asociaciones. Por ejemplo, retomo la convicción de que una buena descripción no necesita estar acompañada de una explicación, sino que se basta a sí misma. Una buena descripción debe ser autosuficiente y contener de alguna manera una interpretación de aquello que describe. Desde esta perspectiva, las ciencias sociales podrían consistir en una serie de relatos que den cuenta de la circulación y las conexiones entre distintos actores, elaborando narrativas etnográficas que podrían considerarse cercanas a un género literario como la crónica, lo cual implicaría considerar al etnógrafo como autor, además de interesantes cuestionamientos acerca de la representación de las culturas.

Quiero referirme brevemente al proceso de registro escrito en el diario de campo. Cuando voy a la obra trato de observar todo lo que sucede alrededor, platico con los trabajadores, recorro los distintos lugares del terreno. Voy tratando de recordar obsesivamente todo lo que miro y escucho, lo que conversamos, los chistes, las interacciones e intercambios. A veces hago anotaciones mientras platico con ellos, palabras clave que más adelante me remitirán a una idea más completa; me siento en un rincón del terreno y escribo dos o tres ideas, frases o citas que no quiero olvidar. Estas notas simples funcionan como un recurso de nemotecnia para desatar recuerdos que después transcribo en el diario de campo, como notas más desarrolladas y mejor elaboradas.

Con respecto a la narración verbal de la experiencia etnográfica, quisiera advertir que casi todo el material proviene de mis diarios de campo. En muchas ocasiones 
consideré más conveniente conservar su tono y forma originales. Así, en algunos puntos de esta narración puede haber tiempos y formas gramaticales distintas; muchas veces escribo en presente y en primera persona, pero otras veces se trata de un relato en tiempo pasado. Asimismo, utilizo en buena medida un lenguaje coloquial, intentando mimetizar mis palabras con la forma de hablar y el sociolecto particularmente rico de los albañiles.

En este punto, no está de más recordar que ésta es una de las principales recomendaciones de la teoría del actor-red para el trabajado etnográfico: respetar el lenguaje de los actores mismos. De acuerdo con Latour (2005), el lenguaje de las ciencias sociales gana en inventiva al aproximarse al lenguaje de los actores. El vocabulario empleado en los relatos y reportes etnográficos debería ser el vocabulario propio de los actores; no hay que intentar traducir sus palabras a otros términos más científicos. Hay que resistir la tentación de intercambiar las palabras variopintas que utilizan los actores por un repertorio de términos antropológicos que solamente entienden los especialistas. Cada entrevista, testimonio, narrativa o comentario de los sujetos, "sin importar su aparente trivialidad, proporciona al investigador una sorprendente variedad de entidades que dan cuenta de cómo y por qué se desarrolla cualquier línea de acción; por más barrocos, raros e idiosincrásicos que sean los términos y el vocabulario de los actores, no debemos ignorarlos" (Latour, 2005: 47).

Para justificar esta vena narrativa en el trabajo etnográfico, también retomo algunas ideas de tres investigadores invitados como conferencistas a la UAM-I: Renato Rosaldo, Gabriela Polit y Francisco Cruces, cuyas planteamientos provocaron una reflexión interesante acerca del papel de la palabra en la antropología y los lazos que conectan la antropología con la literatura.

Renato Rosaldo, en su conferencia: "La narrativa en la etnografía; verdades, mentiras y usos" (2007), sostuvo que la narrativa siempre ha existido en la etnografía, aunque de manera marginal. Pero argumentó que en las últimas décadas hemos pasado de un uso preconciente a un uso conciente e intencional de la narrativa en la antropología, y que hoy día incluso habría que considerar a la narrativa etnográfica como parte de la literatura llamada Creative Non-Fiction, género en el que los estudios de caso de distintas disciplinas han ocupado un lugar importante. La narrativa etnográfica puede entenderse como una descripción densa 
pero con prosa sencilla, en la que se relata la experiencia del trabajo de campo, la vivencia del contacto intercultural, siendo muchas veces el antropólogo uno de los protagonistas de la historia. Pero lo más importante es que esta narrativa etnográfica busque transmitir el ambiente social y la vida cotidiana del universo cultural al que el investigador se aproxima, hasta en sus detalles y matices más sutiles (cf. Rosaldo, 2007).

De acuerdo con Rosaldo, sería deseable que los etnógrafos pusieran más atención y cuidado en el proceso de escritura, que enriquecieran las formas de escribir etnografía adoptando recursos de la poesía y la narrativa, tales como las puestas en escenas, el uso del diálogo, la atención al punto de vista de distintos actores, recursos como la metáfora o la estructura de los cuentos, etc. Según Rosaldo, la etnografía, como la poesía, debe hablar de lo concreto sin mayor mediación de teorías, debe ser ligera pero profunda. Ambas disciplinas tienen en común el hecho de querer mostrar, no explicar, el mundo, en un esfuerzo por pensar a partir de lo específico y concreto de la vida cotidiana. En este sentido, podríamos considerar a la etnografía como una forma de ficción, no porque sea una mentira o una fantasía, pero definitivamente hay que asumir que es un discurso construido a partir de la experiencia subjetiva y particular de un autor (cf. Rosaldo, 2007).

Gabriela Polit, en su conferencia: "Antropología, literatura y narcotráfico" (2007), habló sobre el caso de una antropóloga que primero escribió su tesis de doctorado y luego una novela de ficción sobre el mismo tema, porque sintió que la novela era "un medio más propicio para la representación de la vida cotidiana, de la cultura menuda y la complejidad de las relaciones sociales" (Polit, 2007). Rosaldo afirma que muchas veces una novela nos acerca más a la realidad social, se aproxima más fácilmente a la experiencia vivida y al sentir de los sujetos, que una etnografía clásica. "En las etnografías los protagonistas no sudan, en las novelas sí" (cf. Rosaldo, 2007).

De acuerdo con Polit, entre antropología y literatura hay sobre todo una brecha ética. En el discurso antropológico el sujeto siempre permanece de un lado y el objeto del otro. En cambio, en la ficción el sujeto se identifica más con el objeto, lo que le permite presentar e interpretar al otro con mayor empatía, dejarlo hablar, expresarse por sí solo y cobrar vida propia. La flexibilidad de la ficción abre en la literatura una dimensión ética más rica e interesante, y según Polit esto es lo que 
marca la diferencia entre antropología y literatura. La narrativa permite muy bien, al parecer mejor que la etnografía, representar los juegos de miradas, los saltos de una perspectiva a otra, la rreconstrucción polifónica de un hecho, escuchar varias voces y recoger múltiples versiones (cf. Polit, 2007). Entonces, a mi parecer, se vuelve necesario repensar constantemente el lenguaje y los medios propios de la antropología, para no permanecer preso en sus límites epistémicos tradicionales.

¿Es realmente necesario abandonar las ciencias sociales y dar el brinco a la literatura de ficción para describir mejor la realidad cultural? ¿Qué aspectos de la humanidad no pueden ser descritos por la etnografía y sí transmitidos a través de la literatura? ¿Cuáles son las diferencias y similitudes entre la mirada del etnógrafo y la mirada del novelista? ¿Podemos crear productos híbridos que contengan ambas miradas?

Para concluir este apartado, retomo lo dicho por Francisco Cruces en su conferencia: "Trabajar con historias urbanas: de la entrevista a la etnografía" (2007), acerca de la importancia de la narrativa en la construcción de la vida social. Conocemos el mundo y nos relacionamos con los demás gracias a los relatos. Negociamos significados a través de historias. La historia, el relato y la crónica no sólo son un género literario sino una categoría epistemológica, una forma de aprehender el mundo e interactuar con otros sujetos (cf. Cruces, 2007). Definitivamente, la narrativa debe ser valorada como un medio de conocimiento para la antropología. No obstante, coincido plenamente con Renato Rosaldo, cuando afirma que desde el punto de vista antropológico la narrativa debe estar al servicio de un proyecto analítico, y no al revés; es decir, como investigadores sociales, no se trata de partir de un interés artístico y derivar luego en la teoría social, sino más bien al contrario; nuestro fin primordial debe ser el conocimiento intercultural, y sólo entonces la narrativa puede resultar una herramienta valiosa (cf. Rosaldo, 2007).

\section{Representación visual de la experiencia etnográfica}

El trabajo con imágenes ha ocupado una parte fundamental de esta investigación, tanto la producción como el análisis y la interpretación de las mismas. Para justificar este recurso quisiera argumentar muy brevemente a favor de la importancia de la imagen para la antropología. Considero que las imágenes visuales representan una fuente inagotable de conocimiento antropológico. Al igual que la palabra, pero de 
distintas maneras, la imagen describe, genera, encierra y transmite información, ideas, sensaciones y significados. Además de ser una excelente herramienta de registro en el trabajo de campo, las imágenes constituyen un lenguaje alterno para comunicar experiencias etnográficas y generar nuevo conocimiento antropológico.

La imagen fotográfica digital ha sido una herramienta fundamental en esta etnografía visual. He generado un acervo de imágenes que dan cuenta de diversos aspectos del proceso de construcción y la dinámica laboral en la obra: hay tomas generales del terreno que revelan el progreso de la obra, hice un registro sistemático de las labores que llevan a cabo los trabajadores, capturé detalles y texturas de los materiales, realicé varios retratos de los trabajadores, fotografié el paisaje urbano alrededor de la obra, etc. Este conjunto de fotos conforman una especie de bitácora visual de la obra, que incluso llegó a ser útil para el arquitecto y el encargado de la obra.

Las imágenes en esta investigación han servido de distintos modos. En primer lugar han sido herramienta de registro, no un registro objetivo de hechos, sino el testimonio de una experiencia de una circunstancia particular. Casi siempre las imágenes fueron captadas sin un plan ni un guión previo, simplemente me dejé llevar por lo que en su momento llamaba mi atención, confiando en los instintos que provienen de los sentidos y las sensaciones. Muchas veces fotografiaba algo sin saber bien por qué, disparaba espontáneamente, y después, al regresar a la imagen, entendía el sentido y lo que quería decir, o bien lo que yo buscaba en ella. Cabe señalar que las fotos, a través de un cuidadoso proceso de selección e interpretación, fueron las que me hicieron entender y darme cuenta de mi principal interés teórico en esta investigación. Analizando las imágenes recogidas en campo llegué a la noción del habitar como el concepto central de este trabajo. Así, en esta investigación la fotografía marcó en buena medida la pauta y la orientación, por lo que podría considerarse dentro de la categoría de estudios que se ha denominado image-based research.

La serie de imágenes captadas durante el trabajo de campo han sido un recurso sumamente útil, concretamente para redactar el diario de campo. Empecé a usar las fotos a manera de notas visuales que luego desarrollaba en el diario de campo y las integraba en una narración coherente. Las imágenes han servido como recordatorio, como auxiliares de la memoria y detonadores de ideas y reflexiones. Las fotos 
conforman un registro muy personal y subjetivo de vivencias, emociones, rostros, ambientes y otros aspectos fundamentales de la experiencia etnográfica. Así, independientemente de que las fotos formen un discurso en sí mismas o tengan algún valor estético, todas estas imágenes han servido como fuente para escribir las notas de campo sobre las cuales se construyó posteriormente esta tesis. En este sentido, encontramos una primera correlación importante entre palabra e imagen.

Pero la fotografía es mucho más que una herramienta de registro en el trabajo de campo; puede tener muchos usos y posibilidades diversas. La incorporación de cámaras en el trabajo etnográfico provoca una interacción distinta entre el investigador y las personas que estudia, es un elemento importante en la negociación de la presencia del etnógrafo en campo, que lo define y marca su inserción en el mundo al que se aproxima. La cámara fue un elemento esencial en cómo me percibían ellos a mí. Cuando voy sin la cámara me preguntaban dónde la dejé y por qué no la llevaba. Cabe mencionar que en la obra todos me llamaban "güero", pero para mayor precisión (porque no era el único al que llamaban güero), era conocido como "el güero de las fotos".

Las imágenes fotográficas pueden funcionar como un vehículo que facilita la reciprocidad entre el investigador y los demás actores. A lo largo del trabajo de campo les llevaba de regalo a los trabajadores las fotos impresas en las que aparecían. Siempre me lo agradecían mucho y esto generó lazos de confianza que permitieron un buen acercamiento con los sujetos de esta investigación. Siempre había una gran algarabía cuando llegaba a repartir las fotos. Como relataré más adelante, les gustaba mucho ver las fotos de todos, aunque ellos no salieran, sobre todo porque se burlaban gustosos de sus compañeros. En un ambiente tan inestable como la obra, la foto cobra un valor especial como prueba del vínculo social, sobre todo cuando éste es tan frágil y efímero.

La cámara en la práctica etnográfica funciona como un catalizador de reacciones culturales. Durante el periodo de investigación en la obra realicé numerosos retratos de los albañiles y en algunos casos me llamaron mucho la atención sus reacciones ante la cámara, desde la espontaneidad hasta la pose, y no era raro que llegaran a payasear frente a la cámara; la vergüenza de algunos contrastaba con la excitación de otros. Algunos eran muy fotogénicos y había los que nunca salen bien. Los 
albañiles pueden sobreactuar para la cámara o bien pueden rehuirle con inocultable timidez.

Hay que tener presente que el uso de cámaras en el trabajo de campo implica serias cuestiones éticas y epistemológicas a las que hay que prestar atención. Modifican tajantemente la interacción con la gente, por lo que es sumamente importante prestar atención al efecto que tienen en los sujetos. La reacción que provoca una cámara en la gente es muy diferente a la que genera la sola presencia del etnógrafo. Por consiguiente, se vuelve crucial retomar el tema de la reflexividad, aplicado especialmente al uso de los medios audiovisuales en la investigación etnográfica.

\section{Hilando imágenes y textos en la narrativa etnográfica}

A mi entender, palabra e imagen constituyen dos lenguajes independientes pero complementarios para la investigación antropológica. El recurso a la imagen en la antropología debe siempre usarse armónicamente junto con la antropología verbal. Más que usar estos dos lenguajes uno en función del otro (como imágenes que únicamente ilustran textos o como textos que sólo explican imágenes), lo deseable es que se refuercen e impulsen mutuamente. Lo visual y lo verbal no son simplemente formas distintas de comunicar lo mismo, son lenguajes que comunican diferente tipo de información, que bien articulados, pueden apuntar en un mismo sentido y reforzar, cada uno a su manera, la tesis central de una investigación.

Ahora bien, la retroalimentación entre palabra e imagen no siempre es fácil y armónica, también es posible encontrar discrepancias entre estos lenguajes, puede existir cierta tensión o contradicción entre lo que dicen las palabras y lo que muestran las fotos. Las imágenes pueden reproducir estereotipos y reforzar ideas preconcebidas, o bien pueden desmitificar y presentar más directamente ciertas realidades ante el espectador. Pero a fin de cuentas, independientemente del modo particular en el que interactúen lo visual y lo verbal, me parece que siempre pueden derivar en un enriquecimiento mutuo y de gran valor para el etnógrafo.

En esta incursión recurrí a distintos medios para capturar, organizar, interpretar y presentar el material empírico recogido en campo. Realicé básicamente dos tipos de registro distintos pero que, no obstante, dialogan y se complementan las más de las veces. Me refiero, por una parte, al registro fotográfico o la bitácora visual, y por 
otra, al registro escrito plasmado en el diario de campo. Ambos son fruto de una misma experiencia etnográfica y están correlacionados de distintos modos y en diferentes niveles.

Podemos pensar en diferentes formas de articular estos medios, textos y fotografías, para construir una narrativa que dé cuenta de manera integral de una experiencia etnográfica. Las relaciones entre imagen y palabra en esta investigación pueden tener diversos sentidos; a veces las imagenes generan una reflexión escrita, otras veces la información textual nos remite a alguna imagen en especial. A mi juicio, no hay ningún antagonismo entre palabra e imagen, sino todo lo contrario: son dos formas igualmente válidas de apelar a la inteligencia y a la sensibilidad humana, y como tales, deben ser aprovechadas por la antropología.

\section{Etnografía visual y reflexividad}

En muchos momentos durante esta investigación, el pensamiento reflexivo antes referido ha tenido que ver con el uso de los medios audiovisuales en el trabajo de campo; la reflexividad ha estado encaminada a detectar cómo las cámaras fotográficas o de video transforman la labor etnográfica, intentando practicar una etnografía visual reflexiva. En el siguiente relato pretendo dar cuenta de algunas anécdotas sucedidas detrás de las cámaras en esta investigación etnográfica.

Se podría decir que la imagen fotográfica es reflexiva en sí misma. Suele pensarse en la foto como un reflejo más o menos fiel y exacto de la realidad, pero se trata más bien de un reflejo bastante parcial, sesgado, distorsionado y fragmentario. Coincido con la propuesta de Jordi Grau (2005) de que hay que entender la imagen no tanto como un reflejo sino más bien como una refracción de la realidad, que se trastoca de acuerdo con nuestra experiencia de dicha realidad y los medios que empleamos para representarla. También me parece atinada la metáfora de la imagen como una cerradura que apenas nos permite asomarnos a cierta realidad, echar un vistazo a una escena determinada, nos permite conocerla de manera sumamente limitada y constreñida por una serie de condiciones de diversa índole.

Reacciones ante la cámara

En algunos casos, la práctica fotográfica o de filmación en el trabajo de campo puede desatar un montón de expectativas entre nuestros sujetos o interlocutores, 
que presentan diferentes tipos de actitudes y reacciones ante la cámara, como curiosidad, protagonismo, vergüenza, rechazo, hilaridad, etc. El trabajo de la etnografía visual genera un remolino de respuestas culturales en los sujetos retratados que resultan muy ricas para al análisis antropológico.

Las bromas más comunes entre los trabajadores, cuando ven que les estoy sacando fotos, son frases como: "se va a romper la cámara", "pero te peinas, compadre" o "que salga bien para que su mujer vea que de verdad trabaja", etc. $O$ cuando se trata de fotos grupales, inevitablemente intentan "ponerle cuernos" a alguien sin que se dé cuenta.

Cuando le comento al Arquitecto Canela que tengo pensado tomarle fotos a los trabajadores para después regalárselas, me contesta irónico: "No, pues eso allá tú, eso es otro cuento que a mí no me importa; pero además están re feos, no sé ni por qué quieres sacarles fotos a esos cabrones". Un día, al terminar de grabar me despido de todos; al pasar, voy a darle la mano y las gracias al maestro, le digo que si le preguntan los chavos por la filmación les avise que es sólo para un trabajo de la universidad, nada de tele ni noticias. "Si no luego se van a sentir actores", me dice riéndose.

Un grupo de trabajadores nuevos me miran con gran curiosidad y no dejan de observar la cámara. Entre estos carretilleros están algunos de los trabajadores más jóvenes, uno de ellos actúa como un payaso frente a la cámara. La vieja broma de "poner cuernos" al de junto genera risa colectiva... Saco fotos de un grupo de trabajadores que están en la planta de arriba, que se "chivean" al darse cuenta de que los estoy retratando; bromean nerviosos, se empujan, se esconden... Escucho con satisfacción que le dicen a un chavo nuevo que las fotos que les tomo sí salen bien chidas; entonces viene a preguntarme "de a cómo son las fotos"; cuando le digo que son de regalo, me lleva a que lo retrate frente a una estructura de varilla, ante las risas y burlas de los demás. Este chavo resultó ser el Tlacuache, a quien eventualmente conocería mejor.

Sigo tomándole fotos a los trabajadores, con más confianza algunos ya se muestran abiertamente, como haciendo un performance, me dirigen y me dicen cómo quieren que los retrate. Yo les sigo la corriente. Retrato a un trabajador joven que posa gustoso para la cámara, desinhibido, con chamarra roja y sin camiseta... El Apache me sugiere que le saque una foto a no sé quién, para después colgarla en la 
esquina del terreno y así espantar a los gatos que merodean la obra de noche, "de tan feo que está ese cabrón"... Cuando me acerco a una pareja formada por un oficial y un ayudante, me dicen: "ya es hora de que nos tomes una foto, güero, para que se note bien el avance de la obra y quede huella del buen equipo que armamos este pendejo y yo"; posan abrazándose con la construcción de fondo.

Unos trabajadores me piden que les tome una foto de grupo y posan cual equipo de fútbol, durante la toma bromean: "pero abrázalo, no me piques el culo, péinate, mejor cállate y sonríe"... Javier dice de broma que si le hubiera avisado que lo iba a retratar, se vestía bien y se peinaba. Posa un poco para la cámara y me pide por favor que luego le lleve las fotos. Me ofrece dinero por ello pero le digo que no es necesario... Un chavo posa con facilidad para la cámara, de hecho él es quien me pide que lo retrate y me dice dónde; mira de frente al lente con los brazos extendidos, haciendo un performance gestual sin duda previamente estudiado frente al espejo... He hecho varias fotografías así, por encargo, es curioso notar que ahora son ellos quienes me solicitan que los retrate e incluso me sugieren cómo hacer las tomas.

El Gato me pide que le saque unas fotos en las que aparezca chambeando, para enseñárselas a su mujer y que vea que trabaja duro toda la semana; quiere usar las fotos como prueba de lo que hace cuando está lejos de su casa y su familia. Le digo que si quiere de una vez se las tomo, entonces él monta una pequeña puesta de escena en la que medio actúa y medio trabaja, haciendo lo que hace todos los días, revisando unos planos en cuclillas y tomando medidas sobre el piso con una cinta métrica.

Me encuentro al señor de bigote que siempre tiene un cigarro en la boca, quien se molesta porque le tomo una foto. Me mira con ojos de pistola y me dice que a él no le gusta eso de las fotos. Le pido una disculpa y le prometo que no lo vuelvo a retratar... Otro día, el señor del cigarro en la boca trabaja doblando fierro en la mesa de trabajo de madera. Al verme con la cámara en la mano, me vuelve a pedir que a él no le tome fotos. Le digo: "no se preocupe, ya sé que a usted no le gustan las fotos... ¿pero qué hago con unas fotos suyas que ya tengo?", le pregunto; "ésas mejor sí tráemelas, güero, por favor", responde sin dudar, e incluso me pide que algún día le vaya a sacar un video y unas fotos a sus hijos y sus nietos allá en su 
casa... Otro de los trabajadores me pregunta si podría ser el fotógrafo en el bautizo de su hija el próximo 29 de marzo.

Una trabajadora de la limpieza es muy tímida, apenas accede a ser fotografiada con mucha vergüenza por estar toda fachosa, según ella... "Ah, mira", le dice la trabajadora de limpieza a su amiga, "él es el que te conté que le saca fotos a los hoyos en las paredes", y se ríen. Me preguntan sobre mi función en la obra, les explico a grandes rasgos y entonces acceden a que las retrate, pero sólo si luego les regalo la foto.

Me acerco a la reunión de tres hombres importantes en la obra: Gato, Nicolás y Javier, que están platicando sobre la necesidad de ir pidiendo más materiales. Al verme llegar, Javier conmina a los otros dos a que posen juntos para que les tomé "la foto del recuerdo" y automáticamente lo hacen. En la foto, El Gato se está comiendo una torta que le llevó Pato, Javier y Nico sonríen cada uno con una CocaCola en la mano.

Cuando Silvano me ve tomando fotos me pide que le saque una a él, parado junto al pedazo de terreno que tanto trabajo les costó excavar, según me dice,. Se baja descolgándose por las varillas, camina sorteando obstáculos y ahí se queda parado medio tieso. Me imagino que le interesa tener esa foto como prueba de que dominó un terreno difícil, como testimonio de cuando logró domesticar un espacio especialmente complicado, antes de que estuvieran listos los cimientos.

Fotos de regalo

Me dirijo al fondo del terreno, donde están los trabajadores que conozco, para darles el regalo que les traje: retratos suyos impresos. Les reparto las imágenes donde aparecen, una o dos a cada uno. Me lo agradecen mucho. Se divierten mucho al reconocerse unos a otros. "Yo pensé que se había acabado el rollo sólo conmigo", dice uno. "Yo salgo con mi cara de idiota, pero eso no puedo evitarlo", dice otro. También les doy sus fotos a Silvano y Nicolás. Gracias a las fotos que tomo $y$ después les regalo, logro un buen acercamiento y confianza con los trabajadores.

Nuevamente voy a imprimir varias fotos para regalárselas a los trabajadores que aparecen retratados. Le regalo a Ángel su foto en la que aparece detrás de un castillo de varillas, los otros la ven y se burlan: "pareces un criminal encerrado tras las rejas". Me piden ver el resto de los fotos y van reconociendo a los retratados, 
con gran excitación y algarabía. Los que no aparecieron en las fotos me piden que ahora sí los retrate, como por ejemplo Rufino, quien posa nervioso y muy tieso; otro chavo muy seguro de sí mismo posa cargando ladrillos. Eliseo, quien primero no quería salir en las fotos, luego ya se animó.

Algunas de las fotos que les llevé de regalo a los trabajadores son en blanco y negro, de lo cual se burlan diciendo: "Uy, güero, esas fotos parecen de los 70, ya no sirven, en cambio en las otras se miran mejor los colores", y se burlan de quienes recibieron su foto en blanco y negro. Quizás de ahora en adelante, por estas consideraciones de ellos mismos, deje de tomar fotos en blanco y negro y recurra únicamente al color, para así regalarles algo que ellos aprecien más.

Procedo a regalar fotos a los trabajadores, procurando observar el momento del autorreconocimiento y la reacción ante la propia imagen de algunos albañiles. Le doy a Silvano una foto suya en la que aparece sentado en cuclillas, supervisando la obra desde una esquina elevada; bromea sobre la posición en la que lo pesqué y se ríe a carcajadas. Me pide que si después le puedo tomar una foto donde aparezca él bien con la obra de fondo.

Nuevamente les llevé de regalo a los trabajadores sus fotografías, provocando como siempre gran curiosidad y alboroto... Cuando les entrego las fotos, muchas veces me preguntan cuánto es y me agradecen mucho cuando les digo que son de regalo, entonces otros trabajadores también se animan a que les saque fotos... Se burlan de la foto de un trabajador chaparrito que lee el periódico: "nomás se está haciendo güey, ni sabe leer ese cabrón". Luego se burlan de un trabajador de muy baja de estatura, tez morena y rasgos indígenas, al que todos llaman el "hormiga atómica".

Una vez más voy a repartir entre los trabajadores fotos impresas tomadas en ocasiones anteriores. Los trabajadores se reúnen ávidos de ver fotos suyas o de sus compañeros, más por curiosidad que por otro tipo de interés. La foto del Gato bañándose causa conmoción, al parecer la transgresión de la intimidad les provoca extrañamiento y risa nerviosa. La algarabía es contagiosa y en breve ya hay un grupo nutrido de albañiles a mi alrededor. Se forma un momento de descanso y relajamiento general, hasta que nos regaña Patricio, quien supervisaba todo desde la altura, parado sobre un muro: "ora cabrones, a trabajar, si todavía no es la una 
para que anden en el desmadre". A mí me dice: "ya estuvo bueno de tomar fotos, güero", espero que bromeando.

\section{Bitácora visual}

Al verme con una cámara, se me acerca al arquitecto y me pide que le lleve las fotos que estoy tomando, todas hasta las de este momento y de preferencia ordenadas por fecha, porque él anda sin cámara, se le perdió. Le digo que le voy a quemar un $C D$ con una selección... Otro día, el arquitecto le grita a Silvano pidiéndole que le muestre la bitácora de la obra. Al oír la palabra "bitácora" se me ocurre que así se podría denominar la labor que estoy desempeñando dentro de la obra; podría decirse que estoy haciendo una bitácora visual de la obra, además del recuento por escrito. La noción de bitácora tiene más o menos el mismo sentido que el diario de campo, en tanto registro, documentación y representación de una experiencia de investigación, pero tiene además matices interesantes que le agrega la idea de ser la memoria de un viaje (en sentido literal o figurado), lo cual le brinda de entrada una cierta estructura narrativa.

El arquitecto Canela y un inspector de la delegación se meten a la obra discutiendo. Al verme, el arquitecto me pregunta: "¿tú no tienes fotos del terreno cuando estaba todavía plano?". Le respondo que claro que sí y pienso que tal vez nunca llegó a sus manos el disco de fotos que le mandé a través de Bobadilla. "¿Las tienes aquí?". "No, pero puedo ir por ellas", le contesto ofreciéndome a hacerle el favor, a lo que me responde: "ándale, pero córrele, no te tardes", en un tono bastante déspota que me indigna, pero me aguanto el coraje y le hago el favor. Voy a mi casa a imprimir un par de fotos de cuando el terreno estaba plano, ni siquiera excavado, para que el arquitecto le demuestre algo al supervisor de la delegación... Finalmente vuelvo a encontrar al arquitecto y al supervisor. Le extiendo al "arqui" las fotos, que casi me arrebata de las manos sin decir ni gracias. Las ve y se las muestra una por una al supervisor para demostrarle algo, se detiene en una foto, sacude las hojas y le señala un punto en especial, recalcándolo con el dedo. Después me devuelve las fotos estirando la mano sin decir nada ni voltearme a ver. 
Video

Un día llevé la cámara de video y estuve registrando procesos laborales y algunas conversaciones con los trabajadores. Noto que la interacción no es tan fluida, natural y desenfadada cuando la videocámara está de por medio. No creo que esto se deba sólo a un cambio en su actitud, sino más bien se debe a mi torpeza para controlar la cámara a la vez que trato de convivir con ellos. Me hacen algunas preguntas sobre cómo se usa la cámara y para qué filmo, y me manifiestan su interés en tener una copia del video para poder verse y recordarse. Me comprometo a luego llevarles un disco con el video. Me pregunta Pato por el costo de la copia, le digo que se la regalaré. Algunos de los jóvenes que sacan agua del hoyo con cubetas hacen burlas y payasean frente a la cámara.

Tratamos de filmar el proceso del colado completo, etapa por etapa. Es difícil no estorbar las acciones siendo un equipo de dos personas paradas en un espacio tan reducido. Además hay múltiples desniveles, rampas, estructuras y varillas con las que hay que tener cuidado de no tropezarse. Cuando nos ve grabando, el chofer del camión revolvedora de CEMEX se acerca y nos pregunta para qué es la filmación y nos pide nuestros nombres para reportarlo a la empresa, por cuestión de seguridad. Después de mostrarle nuestras credenciales se torna gentil y hasta se disculpa con nosotros, pidiéndonos que comprendamos su deber y responsabilidad.

La mezcla es escupida violentamente por la manguera, brinca y salpica, llega hasta el lente de la cámara, que hay que limpiar inmediatamente. Con razón los trabajadores de CEMEX que vienen con la olla traen lentes de plástico para protegerse los ojos. Durante la intensa acción colectiva que implica el colado de una planta, todos estamos salpicados de mezcla por todos lados, con la cara llena de gotas secas y la ropa ni se diga. A la cámara también le cayeron gotas de mezcla y los cables de los audífonos prácticamente se sopearon en la mezcla. Estuvimos un par de horas ahí, filmando y conviviendo, con toda la ropa salpicada de gotas de mezcla ya seca, salpicados de ciudad.

El Gato me cuenta que ya vio el video de la obra junto con sus hijos. Cuando le pregunto qué le pareció, me contesta con una sincera y acertada crítica: "Pues más o menos, se ve que todavía le falta; como que necesita más entrevistas. Mis chavitos estaban bien emocionados porque creían que iba a salir su papá, pero yo les 
explicaba que todavía no trabajaba en este edificio". Acto seguido, El Gato se autopropone para ser personaje de una película sobre los albañiles que quiere que yo haga; dice que si me la aviento, él con mucho gusto me explica bien todo mientras que lo va haciendo, y que hasta me invita a su casa para que conozca cómo viven en su pueblo. Sólo quisiera luego tener copias del video para que en el futuro lo vean sus nietos y se acuerden de su abuelo y de cómo era la cosa antes.

La empleada de limpieza me saluda amablemente, "qué paso manito". Me pregunta si yo soy el que sacó el video de la obra que vio el otro día en un disco con Evaristo, el flaco, el que es su compañero. Dice que "sí está chido ese video". Definitivamente las dos copias del video que entregué a los trabajadores han circulado entre los trabajadores de las dos obras más allá de mi previsión.

Presencia femenina y medios audiovisuales Voy a la obra para filmar el colado junto con mi amiga Paula, quien me va a ayudar a grabar el sonido directo. Como era de esperarse, la presencia femenina atrae la atención de todos los trabajadores que reaccionaron de forma inusual ante la presencia de una cámara y sobre todo de una muchacha. A Paula le insisten mucho que vuelva a visitarlos en la obra, le dan la mano, se le arriman y no la sueltan por unos instantes, siempre en tono de juego, pero entre broma y broma...

Édgar con Israel, el velador, me piden que le tome foto a tres chicas que están jugando rayuela en la esquina, que ya tenían bien localizadas desde hace rato, incluso en comunicación con otros trabajadores en otros pisos del edificio. De pronto se escuchan silbidos y el velador me indica que voltee a ver y a retratar a otras chicas que pasaban por enfrente justo en ese momento. Más tarde, el velador y otro joven intercambian información de un piso a otro sobre la situación de las muchachas.

Me pregunta Édgar por la cámara, le cuento que ahora no la pude traer, "entonces de menos te hubieras traído a la ayudante", y se ríe... Luego me pide que le tome una fotografía a la vendedora de tamales y atole: "pero que salgan bien encuadradas sus nalgas, eh güero, y luego esa sí que me la traes de regalo", concluye y suelta una carcajada.

Grabar el pago de la raya 
Le pido permiso a Silvano para grabar con la cámara de video el pago de la raya, entendiendo que por haber dinero involucrado, puede ser delicado de filmar. Me dice que quién sabe, que va a ver si se puede, que por él no hay ninguna bronca, pero a lo mejor sus jefes no quieren; ahora bien, "si ellos no se dieran cuenta, pues entonces adelante", agrega. Habrá que esperar a la tarde, cuando le llevan la raya, porque algunas veces sólo le llevan el dinero y se van, pero otras veces se quedan con él durante el pago. Agradezco su ayuda y le digo que no se preocupe si no se puede... ya veremos.

Un trabajador me avisa que Silvano nos llama allá abajo. Era para decirnos que esta vez sí podríamos grabar el pago de la raya, cosa para la que le había pedido permiso la semana anterior, pero en aquella ocasión no se había podido. En efecto, esta vez Antonio Bobadilla no estaría presente, así que no habría ningún impedimento para grabar la escena. Pero cuando ya estábamos en el cuartito del sótano, a punto de filmar el pago de la raya, apareció inesperadamente Antonio Bobadilla y nos dijo que por favor eso no lo grabáramos. Pedí una disculpa y nos fuimos un rato hacia el fondo de terreno. Desaparecimos un buen rato hasta que constatamos que Bobadilla se retiró del terreno. Un rato después regresamos para pedirle perdón a Silvano si acaso le habíamos ocasionado un problema con su jefe; contesta que no pasó nada y que todavía nos dejaría grabar si queremos. Entonces Silvano procedió a pagarle a los trabajadores y nosotros a grabarlo.

\section{Otras anécdotas}

Raúl me vuelve a preguntar si hoy me voy a meter al hoyo con las botas y la cámara, "para que no se le escape ningún detalle", me dice imitando la postura de los camarógrafos... Me encuentro con Raúl y al verme sin cámara me pregunta: "¿ahora no trajo la que captura todos los detalles?"... Raúl siempre hace referencia a la presencia de la cámara: "que quede bien grabado todo, eh; quiero que salga grabado bien bonito"... Días después me pregunta Raúl cuándo va a estar lista "la peliculita" y le digo que ya pronto les voy a llevar el disco. "O sea que ya hay que ir preparando las palomitas", remata frotándose las manos... Entrando al terreno, Raúl desde lejos me pregunta a señas por la cámara, imitando el gesto del fotógrafo viendo a través de su instrumento; en cuanto se la enseño, me hace la señal de que está muy bien con el pulgar hacia arriba... 
Un trabajador que se llama Jacobo, pero a quien todos le dicen Furcio, se me acerca en cuanto saco la cámara y me pide que le saque una foto, pero cuando me dispongo a hacerlo se arrepiente. A su siguiente vuelta me dice que siempre sí quiere la foto, pero junto a la camioneta Suburban que está estacionada afuera. Entonces salimos para hacerle un retrato como lo pidió. Lamenta que su casco lo dejó allá abajo, así que mejor también se quita los guantes, "para no parecer obrero, aunque igual estoy todo mugroso". Confiesa que quiere la foto para presumir allá por su casa, para fingir e imaginarse dueño de una Suburban. Furcio me interroga con curiosidad por la cámara que traigo, me pregunta si está buena, si salen bien las fotos, que cuánto cuesta, que seguramente es muy cara, que ha oído que hay unas que cuestan hasta tres mil pesos, me dice. Finalmente, me pide que su foto se la dé solamente a él y a nadie más, porque si no luego se burlan de él. Se regresa con una sonrisa a seguir trabajando.

Ángel convive con nosotros a través de la cámara un rato, mientras corta una varilla en varios trozos. Le da duro a la segueta y se desenvuelve con confianza frente a la cámara, sin reservas ni mayor pendiente por estar siendo filmado. Seguimos hablando sobre varias cosas mientras él se cambiaba de ropa: cuenta sobre sus perspectivas de comprar una vivienda para su familia, sobre fútbol, sus otros oficios, su tiempo libre, etc. Se cambia de tenis y pantalones, anda frente a la cámara sin camiseta desenfadadamente, a la vez que sostenemos una conversación espontánea. Una vez que se termina de cambiar, Ángel toma de un cigarro de la cajetilla que está en la mesa, lo enciende y fumando se despide de nosotros, tras una entrevista-conversación imprevista e informal, pero muy abierta, sincera y natural.

Rufino me comenta que los calculistas han venido a sacar fotos de la obra; comento en tono de broma que ya me quieren bajar la chamba; "ya ve, por no llegar temprano", remata y nos reímos... Al final de la jornada laboral nos despedimos de Pato, Silvano, Édgar y otros más. Los grabo cuando se van caminando por la calle Córdoba, con telefoto, alejándose poco a poco, cual final de película.

\section{Estética}

\section{Sobre la noción de estética}

De acuerdo con su raíz etimológica, "estética" es un término derivado del adjetivo 
griego aisthétikós, que significa "susceptible de percepción sensorial", "susceptible de ser percibido por los sentidos". Aisthétikós proviene del nombre áisthesis, que se refiere a la sensibilidad o "facultad de percepción por medio de los sentidos". Aisthésis, a su vez, deriva del verbo griego aisthànomai, que significa percibir, pero también comprender; es decir, que la aesthesis no sólo se refiere a lo sensorial, sino también a una cierta capacidad intelectual. De acuerdo con su sentido original, lo estético sería aquello que es susceptible de percepción sensorial, aquello que cae en el dominio de la sensibilidad, lo que se da o se ofrece a una captación sensible. La estética, entonces, se refiere a nuestra relación con el mundo a través de los sentidos, a la experiencia sensorial, al conocimiento que se obtiene a través de la sensibilidad.

Hay que señalar que el término "estética", aplicado a la disciplina que estudia lo bello, lo artístico y la experiencia estética, fue introducido apenas en el siglo XVIII, por Alexander Baumgarten. Pero los orígenes de la reflexión estética se remontan al nacimiento mismo del pensamiento filosófico, en Grecia durante el siglo VI a.c. ${ }^{5}$ Lo que Baumgarten logró al acuñar el término, fue otorgarle a la estética una cierta autonomía e identidad propia como rama especializada en el campo de la filosofía. Recientemente el arte contemporáneo ha obligado a repensar todas estas categorías y nociones sobre el arte, lo bello y lo estético, ampliando los horizontes de la estética más allá de lo bello, abarcando otras cualidades de los objetos que también impactan la sensibilidad, como lo grotesco, lo absurdo, lo ridículo, lo trágico, etcétera, suscitando así nuevas concepciones de la estética.

¿Pero sobre qué versa la estética, qué es lo que estudia y desde qué punto de vista lo estudia? Hay que advertir que se puede hablar de estética en muy diversos sentidos. Es muy importante identificar dos vertientes de la estética dentro de la reflexión filosófica. Primero, la estética como disciplina filosófica que se dedica al estudio de lo bello, al papel de la belleza en el mundo, en el arte, a nociones como lo sublime, la apreciación o contemplación, el gusto o el juicio estético. La belleza como

\footnotetext{
${ }^{5}$ Para revisar la historia de la estética habría que por estudiar desde los poetas griegos presocráticos (Homero, Hesíodo, Safo o Píndaro), pasando por los grandes filósofos clásicos (Platón y Aristóteles), la estética escolástica de la Edad Media (Santo Tomás y San Agustín), autores del Renacimiento y el humanismo (Leonardo da Vinci), la filosofía moderna, tanto en su vertiente racionalista en Francia (Descartes), como en su vertiente empirista en Inglaterra (Hume y Bacon), la estética alemana del siglo XVIII (Baumgarten, Kant, Hegel, Schopenhauer y Nietzche), hasta llegar a autores más recientes (Umberto Eco) y seguir las líneas contemporáneas de la reflexión estética.
} 
foco de la estética ha marcado la concepción dominante en la historia del pensamiento filosófico. El problema que se plantea es: ¿Qué es la belleza, qué es lo que hace que un objeto sea bello, cómo se presenta esta belleza, qué rasgos la caracterizan, cuál es su esencia?

Pero el sentido que más me interesa rescatar es el más apegado a la definición original del término estética, y es el que sirve de enlace con la reflexión antropológica. La noción de estética como disciplina filosófica que se refiere a lo sensorial, en sentido más amplio, cae dentro de la teoría del conocimiento o epistemología. Se preocupa por la relación sensorial que tenemos con el mundo gracias a la percepción, los sentidos, las sensaciones y las emociones, y cómo hacen posible el conocimiento racional. ¿Cómo se integra lo sensorial con lo intelectual?

\section{Estética urbana}

Una de las dimensiones que más me interesa explorar es la estética urbana. ¿Por qué puede ser la ciudad un tema de estudio para la estética? Peter Krieger (2006) sostiene que "mediante la percepción de informaciones sensoriales se perfila la ciudad como objeto estético" (Krieger, 2006, pp. 15). La dimensión de la estética urbana aborda la ciudad partiendo de la experiencia sensible, se concentra en la representación, interpretación y reproducción de imágenes y significados urbanos.

Ante la proliferación de construcciones en la Ciudad de México, el problema estético no radica simplemente en la belleza relativa de éstas, sino en el impacto que tienen sobre la manera en que nos vinculamos con nuestra ciudad, su efecto en nuestra forma de habitar y encarnar el espacio urbano. ¿Cómo nos impactan estéticamente las obras urbanas? ¿Cómo determinan nuestras formas de experiencia? El problema estético radica en el impacto que tiene el espacio urbano sobre la cultura, en la manera en que nos vinculamos con la ciudad a través de nuestra percepción y sensibilidad, y tiene mucho que ver con nuestra aprehensión afectiva de la metrópolis. La reflexión estética sobre la ciudad busca entender cómo los habitantes adoptan, rechazan, revisan y reformulan las formas, las imágenes y las estructuras urbanas. Hay que tratar de comprender las funciones y las relaciones entre espacio urbano y formas de vida.

El impacto estético al que me refiero tiene que ver con los efectos que provoca el entorno urbano -constantemente en construcción - sobre nuestra percepción y 
sensibilidad, sobre nuestra aprehensión afectiva de la ciudad. Me interesa indagar el ámbito de las reacciones psicológicas y emocionales que nos provoca el medio urbano, las cuales determinan la actitud que adoptamos ante la ciudad y las interacciones cotidianas que establecemos con el resto de los habitantes. Estas respuestas sensoriales, emocionales y cognitivas - por ejemplo la confusión, la desesperación, el miedo o la violencia- están directamente vinculadas con otras esferas fundamentales de la cultura urbana, como el imaginario y la memoria colectiva, la participación o la exclusión social, por mencionar algunas. Podría decirse que el impacto estético que provoca el espacio urbano condiciona también nuestra manera de conocer y valorar la ciudad, ya que emotividad y cognición son procesos inseparables.

De acuerdo con los planteamientos de Ángela Giglia y Miguel Ángel Aguilar ${ }^{6}$ la estética urbana surge como resultado de la relación entre los sujetos y el espacio urbano; se refiere a la interrelación de las formas físicas y las formas sociales, que ejercen una influencia mutua y dan lugar a formas complejas de habitar y apropiarse de la ciudad. Más que una sola estética, en el ámbito de la ciudad coexisten diversas estéticas populares y colectivas, una trama de simbologías para descifrar y entender el espacio urbano, que conforman una dimensión semioéstética. La estética urbana es también una estética cotidiana, anclada en la experiencia de la gente común, y no sólo tiene que ver con las formas que responden a una voluntad o intención de significar algo, sino sobre todo con las formas anárquicas, populares, espontáneas, azarosas, sin intencionalidad significativa.

Krieger argumenta que los espacios urbanos son archivos inagotables de la memoria humana que resguardan múltiples significados. Es posible hacer una lectura de la ciudad, interpretar la imagen citadina como si se tratara de un texto; podemos leer las calles y otros espacios urbanos tomando cada elemento del panorama como un signo o una letra dentro de un libro abierto en permanente actualización, y sujeto a múltiples lecturas. Dice Siegfried Kracauer, citado por Krieger, que a la ciudad hay que "descifrarla como un jeroglífico de la realidad social" (Krieger, 2006: 18).

\footnotetext{
${ }^{6}$ Expresados en la mesa sobre Estéticas urbanas y calidad de vida, dentro del "Laboratorio de cultura urbana: conflictos culturales en el futuro de las ciudades", organizado por la UAM-I y el Instituto Italiano de Cultura, mayo de 2005.
} 
Ya no hay una imagen única comprensible de la ciudad. Nuestro panorama urbano está compuesto por una serie de fragmentos, tanto físicos como sociales y estéticos, que forman una totalidad compleja prácticamente inasible. En la morfología de la ciudad a principios del siglo XXI ya no hay límites aprehensibles. Según Krieger, la pérdida de contornos conlleva una cierta impotencia para ordenar simbólicamente el cosmos urbano y produce la sensación de estar desubicado en la trama social urbana (cf. Krieger, 2006: 48). Este paisaje en constante mutación tiende a generar una confusión cultural, un sentimiento de angustia y desconcierto ante la complejidad de la ciudad. Los ciudadanos recurren a un sinnúmero de estrategias e historias para lidiar y explicar esta condición de perplejidad ante el caos urbano, y esta es, sin duda, una rica materia de análisis para la estética urbana.

Krieger propone la imagen de la ciudad modernizada, hiperurbanizada, como un palimpsesto: un documento antiguo que se caracteriza por tener una superficie de la que se puede borrar lo inscrito para volver a escribirle encima, un lienzo que se borra intencionalmente para escribir sobre él nuevamente, pero que conserva en alguna medida las huellas de una escritura anterior. En otros términos, la urbe actual es una suerte de collage, una forma abierta, inconclusa, con un gran capital creativo y con una enorme energía de reproducción. La ciudad es como una obra de arte nunca terminada, en metamorfosis continua, con un potencial estético impresionante. Hay en nuestras vivencias de la urbe contemporánea una suerte de antagonismo entre el orden urbano impuesto y el caos autogenerado que emana de la vida colectiva cotidiana. Pero más allá de un antagonismo entre orden y caos, surge una interesante síntesis entre ambas fuerzas, dando como resultado una curiosa y singular configuración del espacio urbano (cf. Krieger, 2006).

No cabe duda de que con cada nueva construcción incrementa la complejidad espacial y estética de nuestra ciudad. Pero desde esta óptica no solamente importa la abundancia de construcciones, sino su calidad, el tipo de obras y la forma en que se realizan en la Ciudad de México. ¿Cuáles son los elementos característicos de nuestra estética urbana, ligados al fenómeno de la construcción?

En este sentido, me parece que los albañiles son responsables de muchas de las formas populares y espontáneas que abundan en la ciudad. Los albañiles son personajes protagónicos en la conformación de la estética urbana, especialmente en una época de auge constructivo. La manera en la que cuelgan sus pertenencias de 
las varillas que sobresalen de las obras, los andamios, las escaleras y los puentes improvisados de madera, los ladrillos, el cemento y otros materiales, así como las herramientas, la ropa de trabajo o las botellas de Coca-Cola de cabeza en la punta de una varilla, son algunos elementos recurrentes en la estética de las obras y en la composición del paisaje urbano contemporáneo. Sus huellas, sus pertenencias y herramientas, junto con las estructuras provisionales por las que se mueven y la basura que dejan tras de sí, forman esculturas improvisadas o instalaciones involuntarias y efímeras, sin ninguna intensión creativa, pero que sin embargo responden a cierta estética espontánea, anárquica, popular.

Otro tema interesante que se abordará posteriormente, en referencia a nuestro estudio de caso en la colonia Roma, es cómo coexisten en un mismo espacio estéticas propias de etapas constructivas diferentes. Anticipo la idea de que en la Roma, como en otras partes de la ciudad, se ha generado un peculiar collage arquitectónico. Sería interesante estudiar cómo las valoran los distintos sectores sociales, la relación entre los habitantes y el espacio habitado en términos de los gustos, tendencias, usos, paradigmas estéticos y configuraciones espaciales, que definen a las diversas culturas del habitar.

\section{Estética y antropología de los sentidos}

Quisiera expresar una inquietud en torno a la experiencia estética en relación con la práctica etnográfica. Podemos considerar a la etnografía como una construcción, como un producto cultural humano, y como tal puede tener un cierto valor estético por su carácter de representación —escrita o visual— de la experiencia etnográfica. ¿Pero ahí se agota o a eso se reduce su valor estético, o en dónde más reside éste? Considero que la dimensión estética en la práctica de la antropología va más allá de su semejanza con la narrativa literaria, con la poética, o va más allá de su belleza como representación visual. Lo estético se encuentra primordialmente en la experiencia misma de contacto con el otro, en la empatía, en el desdoblamiento del yo para intentar comprender otras perspectivas; ahí está el germen de la dimensión estética. Es decir, que hay algo estético inherente en la experiencia etnográfica. El conocimiento del otro, el encuentro intercultural es ya de por sí una experiencia estética. 
Sin embargo, en mi opinión, el punto de encuentro más claro entre antropología y estética tiene lugar en el terreno de la antropología visual y la práctica del cine etnográfico o la fotografía antropológica. Si una misión central de la antropología visual es transmitir la experiencia de estar ahí, en el campo, frente a la alteridad, dar cuenta de un encuentro intercultural, representar un diálogo entre personas provenientes de distintas culturas, entonces el ámbito de las imágenes permite representar de manera efectiva el encuentro intercultural, es capaz de resaltar la textura emocional de cada momento y de comunicar lo concreto, lo particular, la parte sensible, la dimensión estética de la experiencia etnográfica.

La antropología visual ha sido causa y efecto de un cambio de paradigma en la teoría antropológica, sobre todo después del surgimiento de la antropología posmoderna. Es parte importante de un movimiento de ruptura con la antropología clásica, cientificista y positivista, encerrada en el reino de la palabra y el logos, movimiento que apunta hacia la construcción de una antropología más libre y abierta, más preocupada por los sentidos y la dimensión estética, acaso más cercana a las humanidades y al arte.

En años recientes ha habido un giro hacia lo sensorial dentro de los estudios sociales y antropológicos, un renovado interés por el papel que juegan los sentidos y las sensaciones en la cultura y la sociedad. Este giro ha sido impulsado en buen medida desde la antropología visual. En mi opinión, los cuatro autores cuyas obras han sido fundamentales para consolidar esta nueva tendencia teórico-metodológica son: David Howes: The Empire of the Senses. The Sensual Culture Reader (2005); Catherine Rusell: Experimental Ethnography (1999); Laura U. Marks The Skin of the Film: Intercultural Cinema, Embodiment and the Senses (2000); y David MacDougall: The Corporeal Image: Film, Ethnography and the Senses (2006).

Siguiendo algunos planteamientos de estos autores podemos esbozar un panorama general y los antecedentes de este paradigma sensorial. A partir del giro lingüístico, con el Circulo de Viena, encabezado por Wittgenstein, se ha entendido a la cultura y al mundo en general como texto, como un discurso formado por signos. Esta concepción semiótica de que todo lo humano puede ser entendido como formas de lenguaje, ha sido dominante dentro de las humanidades y las ciencias sociales a lo largo del siglo XX. Esta corriente podría denominarse logocentrismo, identificando a la palabra con la razón (cf. Howes, 2005). 
Esta tendencia, que promueve una revolución sensorial en el pensamiento contemporáneo, intenta reivindicar la importancia los sentidos en la construcción del conocimiento y la cultura. Propone pasar del imperio de los signos al imperio de los sentidos. Los sentidos son el medio a través del cuál experimentamos y entramos en contacto con otras culturas. Desde esta perspectiva la labor del etnógrafo ya no consiste en leer e interpretar a las culturas sino de sentirlas y dar cuenta de esta experiencia intercultural (cf. Howes, 2005).

En vez de asociar simplemente los sentidos con la naturaleza y la biología humana, como se ha hecho tradicionalmente, se trata de entenderlos como un producto de la cultura; si bien la biología es el barro o la materia prima, la cultura sería el alfarero que les da forma. La percepción sensorial no sólo debe ser materia de la psicología, la biología y las ciencias naturales, sino que debe ser abordada por la antropología y las ciencias sociales en tanto construcciones culturales. La percepción es un fenómeno social; los sentidos están ordenados, regulados, jerarquizados, permeados por valores sociales. Por ejemplo, es claro el predominio del sentido de la vista en la cultura occidental contemporánea. También es importante destacar que los sentidos nunca se presentan aislados, sino que siempre están interconectados en una especie de nudo. Esto es lo que quiere decir la noción de sinestesia, nudos o conglomerados sensoriales que son diferentes en cada cultura (cf. Howes, 2005).

La antropología sensorial estudia la relación sensorial que establecemos con el entorno, la forma de interactuar con el mundo a través de los sentidos. A pesar de que pueda haber mundos sensoriales ampliamente compartidos, sería deseable que existieran más estudios culturales de los sentidos, investigaciones sobre las diferentes formas de sentir en diferentes culturas, desde la antropología, la geografía, la historia, etc. Como las formas sensoriales no son homogéneas al interior de una misma cultura, habría que investigar también las variaciones de los sentidos entre diferentes grupos o clases sociales, así como aquellas sensibilidades extraordinarias dentro de una cultura (cf. Howes, 2005).

Sin duda, es necesario el reconocimiento de otras formas de sensibilidad en otras culturas. Esto nos lleva a un concepto de fundamental importancia, la intersensorialidad, que se refiere a los encuentros y desencuentros, la interacción multidireccional entre diferentes configuraciones sensoriales o formas de sensibilidad. Esta interacción no siempre es armónica; la intersensorialidad a veces es 
conflictiva y comúnmente está sujeta a jerarquías sociales y juegos de poder. Ante la diversidad de órdenes sensoriales y sistemas de percepción, es importante nuevamente mantener cierto relativismo cultural y poner en práctica una antropología intersensorial (cf. Howes, 2005).

Pero también es importante considerar que no podría haber signos sin información proveniente de los sentidos, así como tampoco podríamos discernir entre diversas sensaciones del mundo externo si no nos comunicáramos a través de signos que transmiten significados e ideas racionales. Por lo tanto, habrá que buscar adoptar una posición intermedia que intente reunir ambas esferas - semiótica y sensorial— de la realidad social.

\section{Etnografía sensorial y experiencia estética en la obra}

En este apartado me referiré al conocimiento de los espacios de la obra y su transformación por medio de los sentidos. Recuperaré del diario de campo aquellos pasajes que podrían formar parte de una etnografía sensorial, que describen aspectos de la realidad que normalmente suelen quedar fuera de los recuentos antropológicos más tradicionales. Describiré algunos aspectos sensibles que se perciben en la obra, por ejemplo, los ambientes sonoros y olfativos, los gustos y sabores que se pueden apreciar, las temperaturas, la humedad, las texturas de materiales y objetos, y en cuanto a la visualidad.

Sin embargo, cabe señalar que estos registros sensoriales no se dan aislados o por separado, sino que la mayoría de las veces se presentan anudados, enredados unos con otros, en forma de paquetes multisensoriales, que producen sensaciones complejas, estados de ánimo, emociones, que también forman parte del conocimiento sensible del mundo, que genera la experiencia estética. En este recuento intento presentar algunos datos sensibles poniendo de relieve su naturaleza intrincada y carácter multisensorial.

\section{Visualidad}

Relataré algunas experiencias relacionadas con la estética visual de la obra, que abarca los juegos de luz, reflejos, sombras, puntos de fuga, líneas, proporciones, profundidades, vistas panorámicas y algunos elementos curiosos en el paisaje. 
Mencionaré aspectos como los cambios y matices de luz, formas y figuras, así como los juegos entre diversos elementos en el campo visual de la obra.

Acaba de dejar de llover, ya salió el sol y el cielo está despejado. En algunas partes de la obra, sobre todo entre los nuevos muros de ladrillo, se formaron algunos charcos en los que se reflejan invertidos los castillos de varilla de la obra... Atardece y hace calor, los rayos de sol caen directo sobre la obra, generando sombras muy precisas que se entrelazan con las varillas amontonadas en el suelo.

Con el cielo azul de fondo, los obreros suben y bajan cubetas hasta el nivel superior de la losa recién colada, en medio de varillas elevadas y mangueras de plástico naranja, transitan por puentes y pasillos elevados improvisados con madera, que conectan por fuera las distintas habitaciones de un departamento. Me parece un deleite ver este ir $y$ venir de los trabajadores, que por momentos parece un ballet perfectamente orquestado.

Las recientes lluvias tienen el piso cubierto de charcos que reflejan luz y formas raras. El cielo de un azul intenso es un buen fondo para retratar a contraluz a unos trabajadores trepados sobre castillos de varilla, como arañas en su telaraña... un enjambre de varillas forman una geometría visual privilegiada para la mirada fotográfica, una compleja retícula que comprende una multiplicidad de planos con incontables líneas que se cruzan y forman mil encuadres, ángulos, puntos de fuga, perspectivas, profundidades, puntos áureos, etc.

Ambientes sonoros y olfativos

En la punta de una de las cuatro columnas ya coladas, cuelga de una varilla el radio que llena de música la obra. Un trabajador reconoce una canción que comienza, y se anticipa a cantar el primer verso. El radio está conectado gracias a una muy larga extensión que cruza toda la obra y llega hasta la puerta de entrada... En la radio hay un concurso al que todos los obreros, fieles radioescuchas, permanecen atentos mientras trabajan, a lo largo de una hora más o menos. También se escuchan las voces de las estudiantes de la escuela secundaria que está junto a la obra, chismeando a la hora de la entrada... Adentro, todo transcurría con serenidad. Esta vez no suena el radio pero a lo lejos un albañil canta a todo pulmón "La barca", y su canto se mezcla con el martilleo de las piedras que golpea un albañil muy joven con gran determinación. 
El ruido de la pala al arrastrarse contra el piso para recoger la mezcla mantiene un ritmo más o menos constante. Se le suman los sonidos metálicos de las varillas que están siendo segueteadas, golpes de martillo clavando clavos en la madera, gritos, voces y silbidos de los trabajadores; a lo lejos se oyen motores, cláxones y otros sonidos de la calle, todo esto conforma el ambiente sonoro de la obra.

Un olor agrio impregna el aire, mezcla de cemento y tierra mojada, con el sudor de los trabajadores... El sótano huele a encerrado, a humedad, a agua estancada. En un departamento donde trabajan varios carpinteros hay un fuerte olor a thinner y aguarrás... En las esquinas del terreno huele a orines... A la salida, cuando se lavan los trabajadores, todo huele a jabón, crema y loción.

\section{Formas y texturas}

Me llaman la atención unas cajas llenas de clavos, el abigarramiento de objetos. Me gusta cómo se acomodan o apilan los materiales, por ejemplo las pilas de estribos, los cerros de grava, los montones de ladrillo que forman esculturas involuntarias, instalaciones espontáneas, azarosas, que no responden a una voluntad creativa, sino que simplemente son así.

Los escurrimientos de cemento sobre las paredes de la obra negra a veces forman figuras abstractas muy interesantes, que adornan temporalmente algunos muros durante la construcción de un inmueble. Los rastros de cemento seco sobre las paredes, trazan rutas y dibujan mapas accidentalmente. Estos son rincones cualesquiera de la obra, aparentemente insignificantes, que no obstante, por razones estéticas, creo que merecen ser apreciados o por lo menos mencionados... Esta mañana se coló una losa. Cuando la mezcla está recién pulida y todavía fresca, se forman en el suelo interesantes figuras abstractas que desaparecen muy pronto, formas efímeras que se desvanecen en pocas horas cuando la mezcla se seca completamente.

\section{Temperatura}

Pato se queja de que ha hecho mucho frío, tanto frío que incluso a esta hora, casi al mediodía, el sol todavía ni siquiera alcanza a calentarlos en la obra, sobre todo por culpa del edificio alto de junto, que les hace sombra toda la mañana... En otra época del año, el sol del mediodía pega muy duro sobre la obra, sin filtro ni 
interferencia de nube alguna en el cielo. El calor acumulado a lo largo de la mañana a veces se sigue sintiendo toda la tarde. Los rayos de sol rebotan sobre el concreto y hasta se siente cómo queman la piel. Los trabajadores que laboran al aire libre, en la edificación de una nueva planta, sudan a chorros por el calor y el esfuerzo físico. En estos días de sol suele haber muchas botellas de refresco por todos lados. Pero a pesar del intenso calor, veo muchos trabajadores que traen una sudadera puesta e incluso se ponen el gorrito de la sudadera bajo el casco, como guardando calor para la noche u otros momentos más fríos.

\section{Descripciones multisensoriales}

Bajamos al primer nivel del edificio, un sótano oscuro, un laberinto formado por vigas, cabezales y polines que detienen el techo o refuerzan el piso de arriba, recién colado. Es un lugar lleno de basura que huele a orines en ciertas esquinas, con una acústica o eco de alta resonancia y un olor muy particular, mezcla de madera, humedad, basura y sudor encerrado. El contraste entre la luminosidad de afuera y la oscuridad de abajo requiere un ajuste de la pupila que toma unos cuantos segundos.

En el piso de arriba hay un pelotón de albañiles, principalmente fierreros, trabajando bajo la intensa llovizna, armando estructuras de varilla horizontales sobre los cajones de madera de la cimbra. En el ambiente hay un olor a cemento mojado, se escuchan los chiflidos de los albañiles y el sonido de las varillas al deslizarse unas sobre otras, brincan astillas de la madera, el polvo rojizo del tabique cubre las superficies, Todo está medio mojado por la tormenta que cayó hace rato y porque no ha parado bien de llover desde entonces, a ratos arrecia y de pronto se calma, pero no cesa por completo. Con la lluvia, los olores de los materiales se acentúan, la madera y el cemento huelen más fuerte, como la tierra cuando está mojada. 


\section{Capítulo II \\ TRANSFORMACIÓN DEL ESPACIO \\ Un caso de metamorfosis urbana}

\section{El cambiante rostro de nuestra ciudad}

Dada la inmensidad de la Ciudad de México, la vida en ella y su funcionamiento elemental —ya no digamos óptimo— - serían imposibles sin una labor permanente de mantenimiento y renovación, de adaptación a las nuevas circunstancias, demandas y retos que le impone su cambiante y creciente población. Podemos evocar la metáfora del puente Golden Gate, en San Francisco, que requiere ser pintado continuamente para conservar vivo su característico color rojo. El equipo de pintores empieza su labor partiendo de un extremo, pero cuando ha llegado al otro lado, ya es necesario comenzar de nuevo. De la misma manera, el mantenimiento y la renovación de la Ciudad de México se han tornado una labor interminable, como una expresión actual del mito de Sísifo.

Casi a cualquier lado que dirijamos la mirada, encontraremos algún tipo de intervención sobre el entorno urbano, sea una obra pública o privada, residencial o industrial, de pequeña o gran escala. Ya sea por mantenimiento, renovación, remodelación, ampliación o por una nueva edificación, en la actualidad el espacio urbano de la Ciudad de México crece y se reinventa día a día. "Cuando pensamos en el urbanismo propio de México, pensamos en un entorno urbano que en su mayoría se encuentra constantemente en proceso de hacerse y rehacerse" (Giglia, 2005). En este punto resulta conveniente recuperar la propuesta de Georges-Hubert de Radkowski (2002), quien elabora una teoría general del habitar partiendo de una caracterización sui generis de lo urbano como "la forma de hábitat que se caracteriza por su desarrollo constante" (citado en Giglia, 2005).

Tengo la impresión de que el intenso cambio que sufre actualmente la Ciudad de México no es una transformación natural; no es solamente un paso en nuestra evolución urbana. Las operaciones actuales me recuerdan más bien a una cirugía plástica, a una operación artificial sobre su faz, una metamorfosis un tanto violenta y forzada que irónicamente responde a una lógica funcionalista y pragmática, así como a intereses económicos relacionados con el boom inmobiliario, que operan con una visión de corto plazo. Otro factor importante que hay que tomar en cuenta es el 
constante rehacerse de la ciudad como resultado de una expansión acelerada e improvisada, anárquica y sin plan, producto de una negociación muchas veces azarosa y dispareja entre múltiples voluntades. La planeación urbana "profesional" puesta en marcha por parte de las autoridades encargadas del desarrollo urbano sólo logra seguir tardíamente los procesos que ya están en curso.

Hay que considerar que muchas de estas decisiones e intervenciones sobre el espacio urbano no tienen marcha atrás: transfiguran la ciudad de una manera irreversible. Además, me parece que, irónicamente, una ciudad que se reconstruye constantemente es a la larga una ciudad que envejece aceleradamente. Cuando hay tantos cambios en las fachadas y las apariencias, el paso del tiempo se nota más claramente. Con cada "intervención quirúrgica" la ciudad se ve de momento más joven, pero en el fondo se desgasta y deteriora más. Sus habitantes estamos tan acostumbrados a verla cambiar constantemente, que cuando su apariencia permanece igual por más tiempo de lo habitual, en un contexto en el que todo lo demás cambia, entonces transmite la sensación de viejo, caduco, expirado, pasado de moda. La ciudad se torna esclava de la recreación constante de su propia imagen.

Los habitantes de la Ciudad de México nos hemos ido habituando a la construcción como estilo de vida. El hecho de vivir en construcción, en ajuste constante, tiene importantes repercusiones en la actitud, la mentalidad y el discurso de sus pobladores, constituyéndose como un elemento fundamental de nuestra cultura urbana. No obstante, la construcción es una práctica cultural que se vive y se asimila de diferentes maneras por los distintos habitantes de la ciudad; por eso, es importante contemplar los diferentes sentidos y valores que diversos ciudadanos, grupos o sectores confieren al fenómeno de la construcción, que a su vez se inscribe en una cadena de transformaciones profundas en la cultura urbana.

¿Qué ciudad queda tras todos estos cambios y los que vendrán en el futuro? Definitivamente, no es una ciudad llana: la superficie presenta fallas, intersticios, parches y profundas grietas que permiten entrever historias y significados enterrados, formando varias capas de sentido apiladas. Vivimos en una ciudad llena de cicatrices, a la que continuamente se le arrancan fragmentos que forman parte de su identidad, y en su lugar se construyen nuevos espacios y referentes materiales que dan lugar a nuevas formas de cultura urbana. 
En este capítulo daré cuenta detalladamente del cambio que sufrieron un par de espacios urbanos en particular; surge del afán por atestiguar, describir y reflexionar sobre todo lo acontecido, percibido y experimentado en la exploración etnográfica de estas obras de construcción. Así, las siguientes páginas tratan de describir paso a paso las etapas y los momentos más importantes en el proceso de construcción de los edificios de departamentos, según los registré a lo largo del trabajo de campo. La intención es dar testimonio del antes, durante y después de un proceso de transformación. Elaboraré una narración de cómo fue cambiando paulatinamente el espacio, cómo se fue transformando poco a poco. Así, busco rendir cuentas pormenorizadas del avance de la obra.

Evidentemente, para construir este discurso sobre la transformación del espacio de una manera completa, habrá que considerar la intervención de la mano del hombre, la interacción entre la mano de obra y el espacio físico, a través de las herramientas y la combinación de materiales. Pero es necesario aclarar que este apartado se enfoca únicamente en el espacio, poniendo entre paréntesis por ahora la dimensión humana y la perspectiva de los actores que intervienen en el proceso constructivo. El papel de los trabajadores de la construcción o albañiles que llevan a cabo dicha transformación será tratado detalladamente en el capítulo dedicado a la mano de obra.

Hay que subrayar que la transformación del espacio es gradual, acumulativa; que hay cambios más drásticos y súbitos que otros, pero muchas veces no es fácil determinar con exactitud en qué momento un espacio se transforma, cuándo deja de ser lo que era y deviene algo distinto. Nunca es sencillo determinar en qué momento o por medio de cuáles agencias un espacio se convirtió en un lugar; no es fácil identificar un momento preciso en el que un no-lugar deja de serlo para dar paso a un lugar, o viceversa (Augé, 1992). O por ejemplo, en el presente estudio de caso, resulta complicado reconocer el momento preciso en que el terreno se convirtió en obra, la obra en edificio, las losas en pisos; cuándo los muros y estructuras de la obra negra se hicieron baños o habitaciones de departamentos. Sin duda, éste es un proceso paulatino, relativo, multifactorial, que depende sobre todo de la perspectiva desde la que se mire.

Por otra parte, es interesante cobrar conciencia de que toda construcción implica necesariamente cierta destrucción. Tan importante es el advenimiento de algo 
nuevo como la desaparición de algo que deja de ser, de algo cuya existencia se ve trastocada esencialmente, algo que ya no es más lo que era antes. Al dar cuenta del proceso constructivo, al mismo tiempo va quedando constancia de lo que queda atrás, de aquello sobre lo que se edifica una nueva estructura. No solamente en cuanto a la dimensión material de un lugar, sino en cuanto a todo lo que significa, al sentido que alguna vez tuvo para la gente que se relacionó con ese lugar. Es por eso que en este recuento de la transformación de estos espacios de la colonia Roma, intento poner atención en lo que permanece y en lo que cambia, en las rupturas y continuidades, así como en los choques o articulaciones entre lo tradicional y lo moderno. Esta reflexión pone de manifiesto el valor del trabajo de documentación como una forma de ejercer la memoria y combatir el olvido del patrimonio urbano, arquitectónico y cultural.

\section{Pensar el espacio desde la antropología}

\section{Breve historia del espacio}

En el texto conocido en español como Los espacios otros ${ }^{7}$ (1984), Michel Foucault esboza una historia y una teoría general del espacio en el mundo occidental. Dice Foucault que "la gran obsesión del siglo XIX, su idea fija, fue la historia". En cambio, "nuestra época sería más bien la época del espacio... El mundo se experimenta menos como vida que se desarrolla a través del tiempo que como una red que comunica puntos... la inquietud actual se suscita fundamentalmente en relación con el espacio, mucho más que en relación con el tiempo" (Foucault, 1984: 1).

En este mismo sentido, David Harvey argumenta que en el pensamiento tradicional ha habido una predisposición a dar prioridad al tiempo y a la historia frente al espacio y la geografía, y agrega irónicamente que la pregunta por la dimensión espacial de los asuntos humanos "es demasiado importante como para dejársela solamente a los geógrafos" (Harvey, 1989: 4). Volviendo a Foucault, este autor bosqueja una historia del espacio destacando y caracterizando distintas etapas, empezando por "el espacio medieval", que define como un "espacio de

\footnotetext{
${ }^{7}$ Durante años este escrito permaneció inédito y jamás fue revisado para su publicación por el propio Foucault, por lo que no se considera dentro del cuerpo oficial de su obra. Sin embargo, el manuscrito se dio a conocer poco después de su muerte, fue publicado por una revista francesa en 1984, e inmediatamente se tradujo a varios idiomas y se difundió por varios medios, principalmente electrónicos, por los que hoy circula libremente.
} 
localización". En la Edad Media el espacio era un conjunto jerarquizado de lugares, ordenados de acuerdo con oposiciones binarias, formando dicotomías como sagrados y profanos, abiertos y resguardados, urbanos y rurales, celestes y terrenales, etcétera (Foucault, 1984: 1).

Siguiendo a Foucault, a partir de Galileo hubo un cambio revolucionario de paradigmas en cuanto a la concepción del espacio. La superación de la concepción medieval del espacio en términos de localización y oposición se dio gracias al planteamiento de que el espacio es infinito e infinitamente abierto. El énfasis se desplazó hacia el movimiento, el lugar de una cosa estaba determinado por su desplazamiento a través de la extensión del espacio. "Desde Galileo, desde el siglo XVIII, la extensión sustituye a la localización" (Foucault, 1984: 1).

“En la actualidad, la ubicación ha sustituido a la extensión... La ubicación se define por las relaciones de vecindad entre puntos o elementos". Podría decirse que esta concepción contemporánea del espacio a la que se refiere Foucault es de carácter relacional, erige un espacio apto para la circulación a través de redes que se hacen y deshacen continuamente: "vivimos en una época en la que el espacio se nos ofrece bajo la forma de relaciones de ubicación". Por otra parte, el espacio contemporáneo tiene arraigados vestigios de la jerarquía y división medieval, aunque su denominación y significado ha cambiado: ahora son espacios públicos y privados, familiares, sociales, culturales, laborales, de entretenimiento, de consumo, de tránsito, etcétera. (Foucault, 1984: 1).

\section{Teorías del espacio}

Foucault marca un distinción muy importante entre el espacio interior y el espacio exterior. Argumenta que la fenomenología ha abordado primordialmente el espacio interior, y a diferencia de esta corriente de pensamiento, a él le interesa específicamente el espacio exterior. Coincide con la fenomenología en que "no vivimos en una especie de vacío en cuyo seno podrían situarse las personas y las cosas", pero en vez de sostener que vivimos atrapados en un espacio subjetivo emocional, plantea que nos movemos siempre dentro de un conjunto de relaciones, que define como "ubicaciones". De esto se desprende que la tarea del antropólogo o del científico social sería "la descripción de estas distintas ubicaciones, investigando cuál es el conjunto de relaciones que permiten definirlas... describir el haz de 
relaciones, los conjuntos y las redes" que se forman con cada vínculo y se reinventan con cada nuevo movimiento (Foucault, 1984: 2).

Otro autor de fundamental importancia que ha colocado el tema de la espacialidad en el centro de la teoría social es Edward Soja, geógrafo urbano norteamericano. Este autor postula la centralidad del espacio en la constitución de la sociedad; argumenta que el espacio es un factor fundamental para entender los problemas del desarrollo y las bruscas transformaciones sociales y económicas que han marcado al mundo en las últimas décadas (Latham, 2004: 269). Según Soja, lo espacial es fundamentalmente constitutivo de la vida social, y en este sentido plantea que existe una "dialéctica socio-espacial". Sin embargo, denuncia que la dimensión de la espacialidad ha permanecido profundamente ignorada e inexplorada por la teoría social tradicional, que por mucho tiempo se enfocaba exclusivamente en las cuestiones del tiempo y la historicidad. Para esta corriente de pensamiento, el espacio aparecía como algo dado, fijo, inmóvil, como una categoría estable que no da mucho que pensar. Las ideas de Soja se hacen eco de otros autores como David Harvey, Anthony Giddens, Manuel Castells o Henri Lefebvre, que forman una corriente de pensamiento que busca contrarrestar el énfasis historicista de las ciencias sociales tradicionales y exponer la profunda espacialidad de la vida social (Latham, 2004: 269).

Una de las aportaciones teóricas de David Harvey que nos interesa rescatar es su planteamiento de que el espacio no está dado como un contenedor vacío. El espacio se construye no solo física y materialmente, sino sobre todo social y culturalmente. Para Harvey, la pregunta sobre qué es el espacio debería ser reemplazada por la pregunta sobre cómo es que distintas prácticas humanas crean y hacen uso de los distintos tipos de espacios. Según este autor, las prácticas y procesos sociales crean espacios y estos espacios, por su parte, constriñen, permiten o alteran aquellas prácticas y procesos sociales. Harvey afirma que el espacio es al mismo tiempo causa y efecto de la vida social (Castree, 2004: 182).

\section{El espacio en construcción}

Ante las tipologías que han definido las diferentes clases de espacios, generalmente separándolos por binomios: públicos/privados, rurales/urbanos, abiertos/cerrados, 
interiores/exteriores, individuales/colectivos, habitacionales/laborales, de producción o de consumo, cabe preguntarnos: ¿qué tipo de espacio es una obra?

Una de las primeras cuestiones que es necesario plantear es si el espacio en construcción es un lugar público o privado, si es un enclave urbano o rural, si se trata de un sitio regido por la racionalidad o la informalidad, si es un lugar material, virtual o imaginario. En este trabajo intentaré argumentar que una obra es un lugar híbrido, sui generis, que prácticamente escapa a cualquier tipo de clasificación. Un sitio en construcción posee características particulares; ciertamente es similar en algunos aspectos a otros sitios comúnmente clasificados, pero al mismo tiempo es único, singular y diferente a todos los demás.

Una obra es un lugar en proceso de ser, un espacio en constante devenir, un sitio que se crea y recrea, inventa y reinventa sin cesar. Cuando deja de hacerlo, ya no es una obra. Una construcción está marcada por la coexistencia simultánea de un nolugar y un lugar. Las condiciones materiales del espacio son efímeras, transitorias, temporales. La apariencia del lugar, sus propiedades físicas cambian día con día, y por lo tanto el efecto que produce en los sujetos que lo habitan está en continuo cambio. Es por esto que podemos considerar la obra como un excelente observatorio, una caja de resonancia, un laboratorio, un microuniverso para estudiar los procesos de desarrollo urbano y de transformación del mundo contemporáneo.

También considero pertinente mencionar que el espacio en construcción es por naturaleza ambivalente, ambiguo, polifacético, tiene múltiples usos y significados. A diferencia de los lugares más habitados y mejor definidos, una obra es más difícil de asir; es un sitio más complejo en el que prácticamente cualquier cosa puede suceder: al no ser nada en especial, se presta para variadísimos usos. Por ejemplo, la parte de atrás del terreno es a la vez bodega, tiradero de desechos, rincón donde un trabajador se echa una siesta y lugar de trabajo para los tres trabajadores que doblan y cortan fierro sobre una improvisada mesa de madera... sin mencionar que cuando termine la construcción este mismo lugar será el jardín trasero del edificio.

\section{La obra como heterotopía}

Para romper con la división estricta y terminante de los espacios, Foucault aborda aquellas ubicaciones "que tienen la curiosa propiedad de ponerse en relación con todas las demás ubicaciones". Son de dos tipos. Por un lado, están las utopías, 
"lugares sin un espacio real... espacios que son fundamental y esencialmente irreales... que entablan con el espacio real (únicamente) una relación general de analogía directa o inversa" (Foucault, 1984: 2). Por otro lado, están los tipos de espacio que Foucault denomina "heterotopías", en contraposición con las utopías. Estos son "espacios reales, espacios efectivos, espacios delineados por la sociedad misma, y que son una especie de contraespacios... espacios que están fuera de todos los espacios, aunque no obstante sea posible su localización" (Foucault, 1984: 2). Las heterotopías, siguiendo a Foucault, son aquellos lugares reales que no obstante son "reflejo y alusión" de otros espacios, espacios ambiguos que se constituyen como refracciones y reflexiones distorsionadas, invertidas y fragmentarias de otros lugares.

La obra, como espacio en construcción, puede entenderse como un espacio heterotópico, un contraespacio siempre entre el topos y el porvenir, siempre en tránsito hacia alguna forma nueva, en transformación. De esta manera, la obra se encuentra enraizada en un lugar fijo y delimitado, pero constantemente está en proceso de ser algo diferente, de acuerdo a un plan y un discurso ideales.

\section{La obra como "tercer espacio"}

Otra pista relevante para pensar la obra es el concepto de "tercer espacio" propuesto por Soja (1996). De acuerdo con su argumentación, el "primer espacio" es el mundo real y material; el "segundo espacio" es el mundo imaginario de las representaciones; y el "tercer espacio" es "el espacio en el que todo se reúne: la subjetividad y la objetividad, lo abstracto y lo concreto, lo real y lo imaginario... la estructura y la agencia" (Soja, 1996, citado por Latham, 2004: 272). No deja de ser tentador estudiar más a fondo esta noción y quizás retomarla para pensar en la obra de construcción como una suerte de "tercer espacio".

La obra, ¿lugar o no-lugar?

También resulta ilustrativo recordar la distinción que propone Marc Augé (1992) entre lugar y no-lugar. De acuerdo con Augé, a diferencia del espacio vacío o desnudo, un lugar se caracteriza porque pueden atribuírsele tres adjetivos: todo lugar es identitario, relacional e histórico. Esto es, los lugares generan procesos de 
identidad en los sujetos, propician distintos tipos de relaciones entre ellos y dan lugar a historias comunes que los sujetos almacenan en su memoria.

No cabe duda de que una obra de construcción es un lugar en el pleno sentido de la palabra: es un sitio de conformación y confrontación de identidades, un punto de encuentros, desencuentros y de construcción de relaciones interculturales, así como un referente en la memoria y la historia personal de los albañiles y otros actores que coinciden ahí. Sin embargo, también podríamos pensar en la obra como un no-lugar, pero no por su falta de atributos personales, relacionales, memorables; no porque no esté subjetivada o humanizada, sino porque su vínculo con los actores es efímero, frágil, ya que se trata de un lugar siempre cambiante, en continuo devenir, y por ello resulta difícil concebirla como un lugar terminado, definido, independientemente de su relación con los actores.

Cabe mencionar que desde que Augé planteó su concepción de lugar y no-lugar, han surgido interesantes críticas desde diversos flancos. Una de las más contundentes se refiere a la cuestión de la perspectiva de los sujetos involucrados; qué es un lugar y qué un no-lugar es un asunto relativo a la experiencia de los sujetos que entran en contacto con los diferentes tipos de espacios. La obra, para algunos albañiles, sobre todo para los que habitan en ella, es un lugar. Pero podemos pensar en otros actores para los que la obra sería un no-lugar, por ejemplo los trabajadores de CEMEX que diariamente distribuyen cemento en distintas obras. Si la obra puede pensarse como un lugar o un no lugar, dependerá del actor en cuestión.

Para darle otra vuelta de tuerca a las ideas de los lugares y no lugares de Augé, me gustaría señalar, siguiendo a Ángela Giglia, que Augé nunca quiso trazar una dicotomía rígida entre lugar y no lugar; al contrario, advierte que "el lugar y el no lugar son más bien polaridades falsas: el primero no queda nunca completamente borrado y el segundo no se cumple nunca totalmente, son palimpsestos donde se reinscribe sin cesar el juego de la identidad y la relación" (Augé, 1992: 84, citado por Giglia, 2009: 237). Tomando esto en cuenta, la obra podría haberle servido perfectamente a Augé para ejemplificar esta situación en la que un lugar y un nolugar son uno y el mismo, en una situación liminal entre uno y otro, en tránsito permanente, en el umbral, dependiendo de la perspectiva de los distintos actores que la miren. La obra es un lugar privilegiado para observar el tránsito del no-lugar 
al lugar, del terreno a la obra, al edificio, pasando por la morada provisional de quienes la construyen.

La obra como lugar híbrido

Amalia Signorelli (2008) señala que existe un nuevo tipo de lugares, que propone llamar lugares híbridos, muy propios de los mundos contemporáneos. Los lugares híbridos se caracterizan por tener una naturaleza compleja: comparten características de diferentes tipos o categorías de lugares, pueden ser al mismo tiempo materiales y virtuales, públicos y privados, reales e imaginarios, etc. En este sentido, las obras de construcción pueden entenderse como lugares híbridos que se ubican entre el ser y el devenir, entre lo público y lo privado, que existen en el terreno del imaginario, en tanto representación a través de las imágenes publicitarias, maquetas y planos arquitectónicos, y en la materialidad del presente. Son lugares en los que pueden detectarse los rastros de la macroeconomía en la realidad cotidiana y particular de los trabajadores de la construcción. Una obra es, en suma, un tipo sui generis de lugar - ya que el proceso de transformación de espacio en lugar está a la vista constantemente-, que cambia continuamente de sentido para los múltiples sujetos que en ella confluyen.

\section{Desarrollo urbano y cuestión habitacional}

\section{El concepto de vivienda}

De acuerdo con Trejo (1974: 10), "Gordon Childe dice que veinticinco mil millones de años antes de nuestra era ya existían construcciones calificables de vivienda". En el mismo sentido, volcado sobre el origen histórico de la vivienda, Rafael Catalán (1993: 13) apunta que "alimentarse, abrigarse y disponer de un lugar protegido y protector en donde vivir han sido siempre, y serán, necesidades y aspiraciones fundamentales de los seres humanos".

De entrada, podríamos partir de "una doble conceptualización de la vivienda, como necesidad social y como producto o mercancía" (Connolly, 1988: 186). La vivienda puede entenderse como un derecho universal, pero también como un bien de cambio, como el contenedor de la familia o como el espacio privado por excelencia. Algunos autores proponen concebir la vivienda como "resultado de 
procesos económicos y políticos más amplios y sobre todo, de un proceso en el que se articulan en diferentes planos y niveles, distintos intereses, demandas y una determinada forma de intervención del Estado, que se expresa a través de la política habitacional" (Michel, 1998: 7).

Desde la perspectiva de la antropología, es necesario buscar una noción de vivienda que se adapte a las diversas realidades contemporáneas y a las diferentes culturas del habitar. Claudia Zamorano hace una caracterización de este concepto que me parece bastante acertada y completa.

Vivienda: reflejo de la conformación de la cultura de las familias urbanas; objeto estructurado y estructurante de las prácticas familiares; recurso que se invierte en las estrategias de vida; producto y reflejo de las prácticas familiares, y no únicamente de las residenciales, sino también de las profesionales, matrimoniales y de solidaridad; reflejo, en fin, de las condiciones macroeconómicas que viven las familias (Zamorano, 2007: 173).

\section{El problema habitacional}

A continuación, quisiera retomar algunos estudios acerca de diferentes aspectos de la problemática habitacional en la Ciudad de México. Priscilla Connolly (1988) explica que en la década de los setenta hubo "una oleada de estudios críticos sobre el problema de la vivienda". Las investigaciones aquí comentadas forman parte de esta tendencia o sus desarrollos posteriores, pero comparten un interés por "las interrelaciones existentes entre estructura social, política urbana y vivienda" (Michel, 1998: 7).

En su artículo "Acción habitacional y vivienda popular", Judith Villavicencio afirma tajantemente que cuando se habla del problema de la vivienda debemos entender "la carencia de un lugar adecuado para habitar, que afecta a una parte importante de la población en México". Explica que el término déficit habitacional "hace referencia al número de viviendas que se requeriría producir para responder a las necesidades actuales", para satisfacer la demanda real de la población, que en el caso de la Ciudad de México en 1980 era de más de 400 mil viviendas. Cabe señalar que el déficit habitacional contempla no sólo la necesidad de nuevas viviendas para nuevos pobladores, sino sobre todo la sustitución o el mejoramiento de viviendas 
populares en condiciones precarias, ya sean casas autoconstruidas irregularmente o inmuebles antiguos y deteriorados (Villavicencio, 1991: 277).

Definitivamente, el déficit habitacional constituye un problema social de primera importancia en un país como el nuestro. Para Trejo, el problema de la vivienda tiene tres vertientes: "el rápido crecimiento demográfico, la inestabilidad económica y el atraso en las políticas" (Trejo, 1974: 7). De acuerdo con este autor, en la sociedad de hoy:

... el incremento de la población y el éxodo hacia las ciudades constituye una manifestación típica de la cultura moderna. Cada día son más numerosos los núcleos humanos que se instalan en las ciudades, con la consecuente demanda de servicios públicos y habitación... El crecimiento demográfico y la migración rural se traducen en presiones de demanda de vivienda muy por encima de la capacidad de oferta al respecto. En consecuencia, el déficit de vivienda crece año con año y una parte de la población permanece todavía al margen de las posibilidades reales de mejorar su morada... (Trejo, 1974: 10-11).

\section{Políticas y lógicas de producción de vivienda}

Revisaremos ahora un par de artículos de Martha Schteingart (1991) y Judith Villavicencio (1991) en los que elaboran un diagnóstico y una serie de recomendaciones para abordar, desde una perspectiva sociológica, el problema de la vivienda y la cuestión de la producción habitacional en la Ciudad de México.

No está de más enfatizar, siguiendo a Martha Schteingart, que han existido distintas formas de urbanización y producción de vivienda en la Ciudad de México. A partir de esta afirmación, la autora se dispone a presentar las características más destacadas de la producción habitacional en nuestra metrópoli. En sintonía con las ideas de otros autores (Giglia, Duhau, Coulomb, Benlliure), Schteingart separa la forma de producción autogestiva y anárquica de la forma de producción planificada y funcionalista; en sus propias palabras, distingue "la producción capitalista de vivienda terminada y la producción popular que se da fundamentalmente en los asentamientos irregulares periféricos de la ciudad" (Schteingart, 1991: 248). En estas formas de producción habitacional se involucran distintos agentes sociales con diferentes intereses económicos y políticos.

Esta autora estudia las interacciones entre los actores sociales que participan en la producción de vivienda, y agrega que es muy importante tener en cuenta la acción 
de las instancias gubernamentales, las políticas públicas de desarrollo urbano y los programas de vivienda del Estado en sus distintos niveles, desde las autoridades de la delegación, de la ciudad o del gobierno federal. Así, revisa la política desarrollada por el Estado mexicano para atacar el déficit de viviendas, realiza un minucioso estudio histórico de las políticas de vivienda y elabora un recuento de las acciones que el Estado mexicano ha emprendido en materia habitacional, haciendo hincapié en el marco jurídico en el que han estado insertas (Schteingart, 1991).

El estudio de Villavicencio también se centra en las acciones oficiales del gobierno para contrarrestar el déficit de vivienda en la Ciudad de México, que de acuerdo con su análisis han resultado por demás insuficientes: "Algunos estudios han señalado que el INFONAVYT logra dotar de vivienda, anualmente, a sólo $1.8 \%$ de su demanda (Connolly, 1987, citado por Villavicencio, 1991: 283). De esta manera, podría afirmarse que el aumento sostenido de la producción de vivienda popular autoconstruida en las últimas décadas ha sido una consecuencia colateral de la ineficacia de estos programas gubernamentales (Villavicencio, 1991: 287).

\section{Breve historia habitacional de la Ciudad de México}

En este apartado revisaré algunos artículos acerca del proceso de urbanización de la Ciudad de México, sobre todo durante el siglo XX, poniendo especial atención en la cuestión de la vivienda y las estrategias habitacionales de cada época.

En su estudio, Marco Antonio Michel (1998: 7) reflexiona sobre el proceso habitacional en la Ciudad de México; "hace una revisión global de la relación entre desarrollo económico-social, crecimiento urbano y política habitacional del Estado, a partir de la década de 1920". Por otra parte, en "La evolución de la Ciudad de México en el siglo XX" (1998), Gustavo Garza realiza un análisis del crecimiento, la urbanización y los procesos habitacionales en esta urbe. A partir de ello, reflexiona sobre su impresionante transformación: cómo pasó de ser una ciudad pequeña en 1900, a ser la megalópolis actual, en tan solo un siglo. El estudio de Garza (1998: 19) asume de inicio que "la investigación de la cuestión habitacional se debe inscribir en el marco general del proceso de metropolización de la urbe".

El primer dato que hay que tomar en cuenta es que la Ciudad de México tiene aproximadamente cinco siglos de haber sido fundada; sin embargo, su proceso de crecimiento y desarrollo urbano, que la ha llevado a ser una de las ciudades más 
grandes del mundo en la actualidad, se remonta solamente a los primeros años del siglo XX. "Entre los siglos XVI y XIX creció diez veces, pasando de tener $30 \mathrm{mil}$ habitantes en 1552 a 300 mil en 1884" (Michel, 1998: 11). No fue sino hasta la segunda mitad del siglo XX cuando ocurrió su mayor transformación.

En la historia del vertiginoso desarrollo urbano de la Ciudad de México a lo largo del siglo XX, Michel identifica cuatro grandes etapas de crecimiento de la ciudad; "en cada una de estas etapas ocurrieron determinados procesos habitacionales que, a su vez, dieron lugar al predominio de ciertos tipos de vivienda" (Michel, 1998: 12-13). Garza también propone una periodicidad que fundamentalmente coincide con las nociones centrales que sugiere Michel.

La primera etapa, de 1920 a 1930, es cuando "ha cesado la fase más violenta de la Revolución, se regulariza la actividad económica, se fundan las principales instituciones públicas". En términos de vivienda, "el área del centro de la Ciudad de México aumenta sensiblemente de población, llegando a poco más de un millón de habitantes" (Michel, 1998: 11). A la primera etapa Garza (1998) la denomina "crecimiento del núcleo central", debido a que básicamente se consolida lo que después se conocerá como la ciudad central.

La segunda etapa, de 1930 a 1950, ocurre en el contexto de la modernización del país, durante la fase de "industrialización sustitutiva", tras la privatización de varios recursos cruciales para el desarrollo económico de la nación. "Surgen nuevas colonias y barrios alrededor del centro de la ciudad y comienza la desconcentración del comercio, los servicios y la población" hacia unidades administrativas fuera del centro, pero aún dentro los límites del Distrito Federal. En términos poblacionales y habitacionales, la ciudad central pierde aceleradamente importancia respecto al resto del área urbana. La ciudad crece más bien por los bordes, y no tanto en términos de una densificación del centro. "La población total, al término de este periodo, era de 3.1 millones de habitantes" (Michel, 1998: 12). Garza se refiere a esta segunda etapa como "expansión periférica".

Estas primeras dos etapas se caracterizan por una "relativa estabilidad económica", aunada a una "abundante disponibilidad de tierras con facilidades de urbanización". En estas condiciones comenzó la expansión territorial y la urbanización. "Los espacios centrales acogieron a los estratos de bajos ingresos", a las clases más populares, así como a mucha de la población migrante, mientras que 
los sectores medios en auge poblaron las nuevas colonias aledañas al centro de la ciudad" (Michel, 1998: 12).

La tercera etapa, de 1950 a 1970, "se identifica por un elevado crecimiento sostenido, rápida industrialización y urbanización acelerada... Es entonces cuando se produce la expansión de la mancha urbana sobre el territorio de algunos municipios del Estado de México". Muchas de las nuevas industrias se instalan en los alrededores de la metrópoli. Algunos núcleos poblacionales que hasta entonces permanecían aislados, se integran plenamente a la red urbana. Más allá de la ciudad central y los límites el D.F., comienza a gestarse una dinámica metropolitana, por ejemplo, en cuanto a comunicaciones y transportes. La población ascendía a casi 9 millones y medio de habitantes, de los cuales más de dos millones ya se instalaba en las periferia de la ciudad, ocupando los municipios conurbados (Michel, 1998: 12). A esta tercera etapa Garza la denomina de "dinámica metropolitana".

A partir de los años cincuenta, el proceso habitacional en la Ciudad de México se caracteriza por la multiplicación a escala metropolitana de las colonias populares y los fraccionamientos de clase media, así como por el desarrollo de importantes conjuntos habitacionales promovidos por el Estado (Michel, 1998: 13).

La cuarta etapa, de 1970 hasta 1987, "ha estado signada por la terciarización del aparato productivo, el agravamiento de algunas deficiencias estructurales del modelo económico y por un contexto internacional extremadamente complejo y adverso". El crecimiento poblacional y urbano continúan, aunque a ritmo más lento que en las décadas anteriores. Hay una resuelta participación del Estado en la atención a las necesidades habitacionales. Se crearon programas y fondos para incentivar la producción de vivienda de interés social, a través de créditos, préstamos - hipotecas para construir viviendas para la población más necesitada; así surgieron organismos como el INFONAVIT y el FOVISSSTE. De acuerdo con Schteingart, entre 1960 y 1980 "observamos cambios importantes en cuanto al tipo de empresas que han dominado este sector y las diferentes combinaciones de sus prácticas con las políticas y acciones del Estado" (Schteingart, 1991: 245). Han ocurrido "cambios importantes, sobre todo a partir de la crisis económica de los años ochenta, en la participación tanto de agentes privados como públicos en la producción habitacional" (Schteingart, 1991: 248). 
En esta época, la ciudad se desborda francamente hacia afuera de los límites del Distrito Federal. Se eleva a 17 el número de municipios del Estado de México que pasan a formar parte del tejido de la ciudad. Michel reporta que hacia 1980 había 14 millones y medio de habitantes, cinco de los cuales estaban instalados en la zona conurbada (cf. Michel, 1998: 12-13). Vale la pena señalar que en esta cuarta etapa, a la que Garza denomina "megalópolis emergente", se da un proceso de suburbanización que trae consigo "la intensa integración de núcleos urbanos. Surgen así tejidos urbanos policéntricos... verdaderos subsistemas de ciudades altamente integrados. Se denomina megalópolis a este tipo de interrelaciones urbanas que surge de la unión o traslape de dos o más áreas metropolitanas" (Garza, 1998: 27).

Martha Schteingart señala que entre 1982 y 1987, debido al tamaño cada vez más reducido de los lotes para cada vivienda en la ciudad..., la expansión urbana se ha traducido en "un aumento en la densidad habitacional". En particular, esto se manifiesta en la construcción hacia las alturas; es decir, la vivienda individual es remplazada por la vivienda colectiva... la densidad habitacional aumenta de 33 a 73 viviendas por hectárea en los años ochenta" (Schteingart, 1991: 227). Esta tendencia al crecimiento vertical, es decir, la construcción de edificios de departamentos como los estudiados en esta investigación, que se incrementó en los ochenta, actualmente continúa siendo la opción más rentable y socorrida en cuanto a la edificación de vivienda en la ciudad central.

Sin duda, un parteaguas definitivo en la historia de la ciudad, sobre todo desde el punto de vista habitacional, fueron los sismos de septiembre de 1985. Los efectos devastadores del terremoto ocasionaron que se dejara de "privilegiar la atención de los procesos habitacionales en la periferia", y que "la atención prioritaria del gobierno del Distrito Federal" se enfocara en "los programas de reconstrucción" de las viviendas afectadas y en resolver "la problemática habitacional en el centro de la Ciudad de México" (Michel, 1998: 14). El tema del terremoto de 1985, un hito en la historia de la capital mexicana, será tratado más extensamente un poco más adelante, cuando revisemos el impacto que tuvo sobre la colonia Roma.

En los últimos años de la década de 1980 y durante los años noventa, la ciudad incrementó su población a un ritmo de medio millón por año, pero únicamente en los municipios periféricos, mientras que el centro del Distrito Federal se convirtió en una zona de expulsión de la población. La expansión urbana continuó hacia las zonas 
periféricas conurbadas, pero mientras las periferias crecían sin control, el núcleo de la ciudad se vaciaba y se despoblaba paulatinamente. De esta manera, se dio lo que algunos especialistas han llamado el "efecto dona". Dadas estas nuevas circunstancias, el gobierno y los especialistas comenzaron a "buscar la redensificación intraurbana y el aprovechamiento de la infraestructura subutilizada" (Michel, 1998: 16). Estos son los antecedentes que dieron pie al decreto del Bando dos a mediados de la década de los noventa, que discutiremos más adelante.

Un dato impresionante que nos permite establecer un corte histórico, es que el $80 \%$ del tamaño actual de la mancha urbana se ha construido tan solo en los últimos 50 años, es decir, de 1960 a la fecha. "De 1960 a 1990 la ciudad creció casi tres veces su tamaño original". Trejo (1974) estimaba en esos años que, como parte de este crecimiento urbano, "la vivienda es por mucho el principal uso de la tierra urbana: quizás el 50\% del total" (Trejo, 1974: 24). Me parece muy relevante actualizar este dato; de acuerdo con las investigaciones de Pablo Benlliure, la construcción de vivienda representa aproximadamente el $70 \%$ de la expansión metropolitana, en los primeros años del siglo XXI (cf. Benlliure, 2007: 63).

\section{El desarrollo habitacional en las últimas dos décadas (1990-2010)}

Para continuar con el recuento de la historia del desarrollo urbano y la problemática habitacional de la ciudad a partir de 1990, resulta ilustrativo recurrir a los estudios realizados por Pablo Benlliure (2007). A través de su investigación es posible estimar la magnitud del fenómeno de la construcción en nuestra ciudad, entender su complejidad y reconocer su dinámica en los últimos años, además de abrir la reflexión sobre sus razones y repercusiones. Para esto, resulta conveniente echar mano de algunos indicadores y datos que nos permiten medir, por ejemplo, los efectos recientes del decreto conocido como Bando dos, entre otras condiciones actuales relacionadas con la construcción de vivienda en la Ciudad de México, en los primeros años del siglo XXI.

\section{El abandono de la ciudad central}

Desde el punto de vista poblacional, entre 1970 y 2000 ocurrió en la Ciudad de México un fenómeno que se ha denominado "efecto dona". La urbe creció 
desmesuradamente porque sus periferias se extendieron y se fueron poblando, mientras que su centro se iba vaciando paulatinamente. Se calcula que más de un millón de pobladores abandonaron la zona centro de la ciudad en tal periodo. Una de las causas históricas que permite entender este éxodo habitacional del centro de la ciudad es el decreto que dictó, a finales de los años 60, el regente de la ciudad, Ernesto P. Uruchurtu (alias "el regente de hierro"), que "prohibía la construcción de fraccionamientos en el Distrito Federal, lo cual generó un crecimiento desmesurado de los territorios hoy conurbados del Estado de México" (Benlliure, 2007: 70). Sin duda, otro factor determinante para el abandono de la ciudad central fueron los sismos de septiembre de 1985, que provocaron un éxodo de centrícolas hacia otras áreas de la ciudad, en busca de viviendas más seguras y condiciones de vida menos vulnerables.

El proceso de vaciamiento del núcleo metropolitano se dio de manera paulatina desde 1970 hasta 2000. Este despoblamiento del centro afectó principalmente a las cuatro delegaciones centrales: Miguel Hidalgo, Venustiano Carranza, Cuauhtémoc y Benito Juárez. Por ejemplo, la delegación Cuauhtémoc, que comprende la colonia Roma, perdió cerca de 250 mil habitantes en las últimas tres décadas del siglo XX (cf. Benlliure, 2007: 69).

Tan solo entre 1990 y 1995, en estas cuatro delegaciones que conforman la ciudad central, cerca de 14 mil viviendas fueron sustituidas por algún otro tipo de uso de suelo. A partir de entonces llegaron a esta zona numerosas oficinas y comercios, para ocupar los espacios disponibles que dejaban las viviendas. Como un efecto secundario inmediato, el precio del suelo comenzó a incrementarse. "Paralelo al decrecimiento de la población, los precios del suelo aumentaron; las rentas crecen debido a los cambios de uso de suelo... el uso de suelo para la vivienda emigró y fue sustituido por usos no habitacionales" (Benlliure, 2007: 69). El abandono del centro representa un grave problema para la ciudad en su conjunto, ya que, como bien lo explica Benlliure, implica el lamentable desperdicio de toda la infraestructura y servicios urbanos con los que cuenta esta zona: metro y vialidades, hospitales, parques, escuelas, teatros, cines, etc.

\section{Repoblamiento y boom constructivo en la ciudad central}


Con esto en mente, en 1997 surgieron las primeras estrategias gubernamentales para revertir esta tendencia; se crearon y pusieron en marcha programas de desarrollo urbano y ordenamiento territorial para repoblar la ciudad central. EI decreto conocido como Bando dos, emitido y ejecutado por el Gobierno Distrito Federal (en aquel entonces encabezado por Cuauhtémoc Cárdenas), ordenaba que todos los grandes desarrollos habitacionales y comerciales debían orientarse exclusivamente hacia el centro de la ciudad.

En consecuencia, a partir de ese momento, entre 1997 y 2000, hubo un crecimiento constante en el número de viviendas construidas en las cuatro delegaciones centrales. La oferta de vivienda se concentró en el centro: entre 2000 y 2003 pasó de representar el $21 \%$ a representar el $85 \%$ del total de la oferta en la ciudad. En sólo un año, entre 2004 y 2005, la oferta de nuevas viviendas en el D.F. aumentó de 22 a 29 mil. En suma, en los últimos años la construcción de viviendas volvió a orientarse hacia la ciudad central y por consiguiente el número de obras incrementó significativamente. Entre 2001 y 2005 se edificaron alrededor de 37 mil viviendas en las cuatro delegaciones centrales del Distrito Federal, que en estos mismos años han albergado aproximadamente 135 mil nuevos habitantes (cf. Benlliure, 2007: 72, 88). Es en este contexto que podemos ubicar y entender el caso de las obras de DAKAB en la colonia Roma, que se estudia en esta investigación.

\section{Los efectos del Bando dos}

No obstante, siguiendo a Benlliure, una de las consecuencias inesperadas del Bando dos fue que "la poca disponibilidad de terrenos en el área central de la ciudad elevó el precio del suelo disponible" (Benlliure, 2007: 75). Esta situación propició un fuerte boom inmobiliario, un auge de transacciones de compraventa de propiedades, grandes especulaciones y comercialización del espacio urbano. El Bando dos contribuyó al encarecimiento del suelo, que en la zona central aumentó como mínimo entre $150 \%$ y $200 \%$, alcanzando en ciertos casos hasta un $205 \%$ (cf. Benlliure, 2007: 74).

Esto fue seguido evidentemente por un auge en la actividad de la construcción en la ciudad central. Varias empresas inmobiliarias y constructoras privadas han hecho de este tipo de construcciones de edificios de departamentos un gran negocio. Actualmente, "se estima que aproximadamente el $50 \%$ del crecimiento físico de la 
zona metropolitana es realizado por los desarrolladores inmobiliarios privados de vivienda" (Benlliure, 2007: 88). Otra consecuencia del alza exagerada en el precio del suelo es que "los desarrolladores inmobiliarios incrementaron la densidad de la construcción... construyeron más viviendas por hectárea, reduciendo el tamaño de las mismas... En general, se estima que en la mayoría del territorio de la ciudad se construyen viviendas de más o menos 50 metros cuadrados" (Benlliure, 2007: 78-79).

Casi todas las nuevas viviendas que se construyen en las colonias que forman el Bando dos están dirigidas al estrato socioeconómico medio-alto de la población capitalina. Se estima que en 2007 había una oferta de 20 mil viviendas para los sectores de mayores ingresos en las cuatro delegaciones centrales. Sin embargo, esto vino de la mano con una disminución en la producción de viviendas para los sectores de bajos ingresos por parte de INFONAVIT, que se ha visto obligado a reorientar su oferta de vivienda hacia los estratos medios. Se calcula que en la actualidad se está construyendo un número mayor de viviendas para sectores medios del que en realidad se necesita. Como resultado de la macroinversión en la producción y reconstrucción del espacio urbano en la ciudad, actualmente hay una sobreoferta de vivienda en las colonias centrales del D.F., lo cual podría tener consecuencias inesperadas en el mercado habitacional (cf. Pérez Negrete, 2009). Como expresión de las contradicciones inherentes al sistema neoliberal, por un lado, hay una sobreoferta de vivienda para las clases medias y altas, al grado que hay espacios habitacionales prácticamente desperdiciados, mientras que la población más pobre, quienes realmente necesitan una vivienda digna, siguen saliendo perjudicados.

Además, en los escasos terrenos disponibles que había en la ciudad central, por lo general existían edificaciones anteriores que estas compañías tuvieron que demoler antes de construir sus nuevos edificios de varios pisos, aprovechando al máximo el espacio, saturándolos de departamentos. La mayor parte de los espacios sobre los que construyen estas nuevas viviendas solían ser de uso industrial, pero en algunos casos también eran viviendas viejas, estacionamientos, bodegas o inmuebles abandonados, edificados entre 1940 y 1970 (cf. Benlliure, 1007: 73). En muchos de estos casos se lleva a cabo una demolición para la posterior sustitución total; es decir, se reemplaza todo lo que había antes por nuevas y modernas viviendas. Pero en otros casos, las obras que se llevan a cabo son construcciones de reciclamiento, es 
decir, se aprovecha en alguna medida la infraestructura anterior para la edificación de un nuevo inmueble, generalmente un edificio de departamentos o un conjunto habitacional. Estas viviendas pueden considerarse recicladas porque pasan por un proceso de reconstrucción más profundo que una mera remodelación. El proceso de reciclamiento urbano puede ser una opción muy viable de optimización del espacio de la ciudad, pero ha generado un interesante debate, ya que puede presentarse de muy distintas maneras, algunas veces incluso perjudiciales para el desarrollo urbano, como se discutirá más adelante en el caso de la colonia Roma.

La proliferación de construcciones de conjuntos habitacionales y edificios de departamentos revela, antes que nada, un crecimiento urbano intensivo y vertical en la ciudad central. Es cuestionable si esta tendencia está sustentada en la debida planificación urbana por parte de profesionales y autoridades, o si es resultado de un esquema de concesiones, clientelismo y producto de una lógica primordialmente económica. Las obras de este tipo pueden considerarse construcciones exprés por su relativamente corta duración; son diseñadas casi en serie, aplicando fórmulas y siguiendo patrones arquitectónicos y estéticos funcionales pero de mala calidad. Emplean materiales baratos y fáciles de manejar. Muchas veces sus acabados son toscos y poco refinados. El cemento crudo aporta el color gris y la textura rasposa predominantes en estas construcciones, que tienen apariencia de quedar casi como en obra negra (algo que ha sido denominado estilo brutalista), pero siempre con ciertos toques finos que nos recuerdan su pretensión de exclusividad. En cierta forma, parece como si estos inmuebles 'en bruto' estuvieran siempre en construcción; da la sensación de que su apariencia es provisional y está sujeta a cambios.

A pesar de los impactos negativos ya señalados, el Bando dos ha demostrado su eficacia para frenar y revertir el despoblamiento del centro de la ciudad. "De continuar dicha política, se espera un total redoblamiento de esas cuatro delegaciones en un periodo de diez a quince años" (Benlliure, 2007: 88). No obstante, cabe preguntarnos: ¿hasta cuándo se debe seguir repoblando la ciudad central? ¿De qué manera? ¿Cómo satisfacer las necesidades de vivienda? ¿Cómo hacerlo sin afectar la calidad de vida en la ciudad? ¿De qué manera encauzar el proceso de urbanización sin fomentar el crecimiento desmedido de la ciudad? Esta es la encrucijada que enfrenta el desarrollo urbano de nuestra ciudad en materia de 
vivienda y es parte importante del contexto en que podemos ubicar los edificios que conforman nuestro estudio, mismos que podríamos entender como una alternativa posible a la problemática habitacional de nuestra ciudad, y como tal, habría que reflexionar cuidadosamente sobre su efectividad y sus impactos negativos.

Así, a lo largo de esta tesis se entrecruzan temas como la destrucción, reconstrucción y transformación de los inmuebles que le dan rostro a la ciudad, la obsolescencia de la infraestructura urbana, la redensificación del espacio urbano en la ciudad central, las nuevas configuraciones habitacionales, las diversas modalidades que adquiere el habitar. Todo esto vinculado a un interés por las huellas del paso del tiempo sobre la ciudad y las transformaciones que acontecen en el espacio y la cultura urbana.

\section{La Colonia Roma, breve historia de su desarrollo urbano}

El trabajo de campo que sustenta esta investigación se realizó a lo largo de 18 meses en dos obras de construcción de edificios de departamentos, ambas localizadas sobre la calle de Córdoba, en la colonia Roma norte, Delegación Cuauhtémoc, Distrito Federal. La Roma, ubicada a pocos kilómetros al suroeste del Zócalo capitalino, es una colonia emblemática de la capital en la que se expresan claramente algunas de las tendencias y problemáticas propias de la ciudad central, en relación con la construcción habitacional y el desarrollo urbano.

De acuerdo con Manuel Perló Cohen (2009), la Roma no es un espacio genérico ni un barrio más de la ciudad: tiene algo único que la hace memorable, singular, una cierta personalidad o identidad, algo que tal vez podría llamarse "romanidad". Ha sido un lugar sumamente estudiado, documentado y celebrado, escenario de episodios importantes de la vida de la ciudad, epicentro de tragedias históricas, cuna de movimientos sociales y cambios culturales, referente y fuente de inspiración para diversas expresiones artísticas, sobre todo literarias (cf. Perló, 2009).

Cabe señalar que a principios del siglo XX la colonia Roma se limitaba a un trapecio formado por las avenidas que hoy conocemos como Insurgentes, Chapultepec, Álvaro Obregón y Cuauhtémoc. Este territorio original de la colonia (que más adelante se extendería bastante más, sobre todo hacia el sur) es precisamente la zona en la me enfoco en esta investigación. 


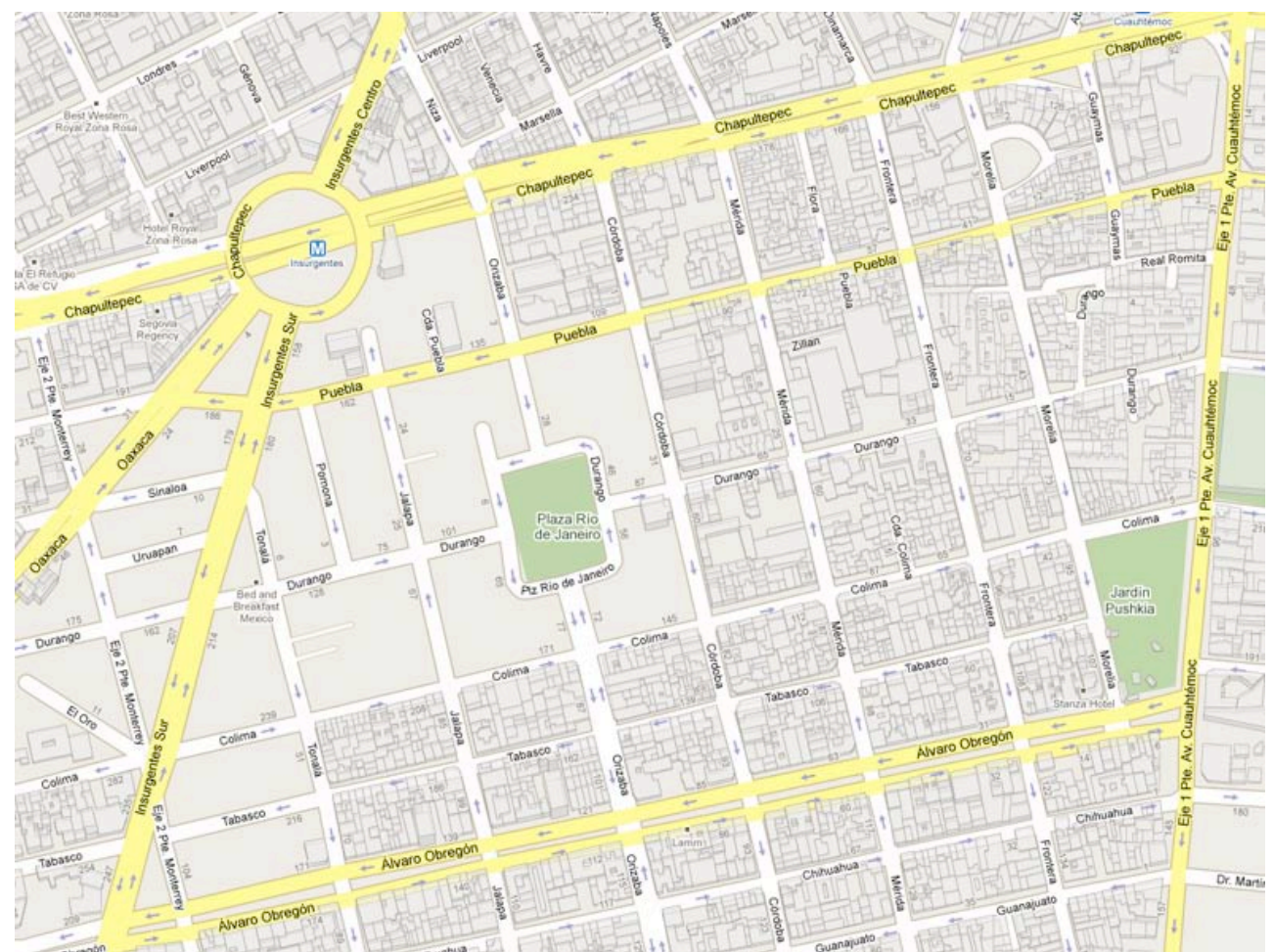

Mapa del cuadrante estudiado, dentro de la colonia Roma norte. Fuente: Google Maps, 2010.

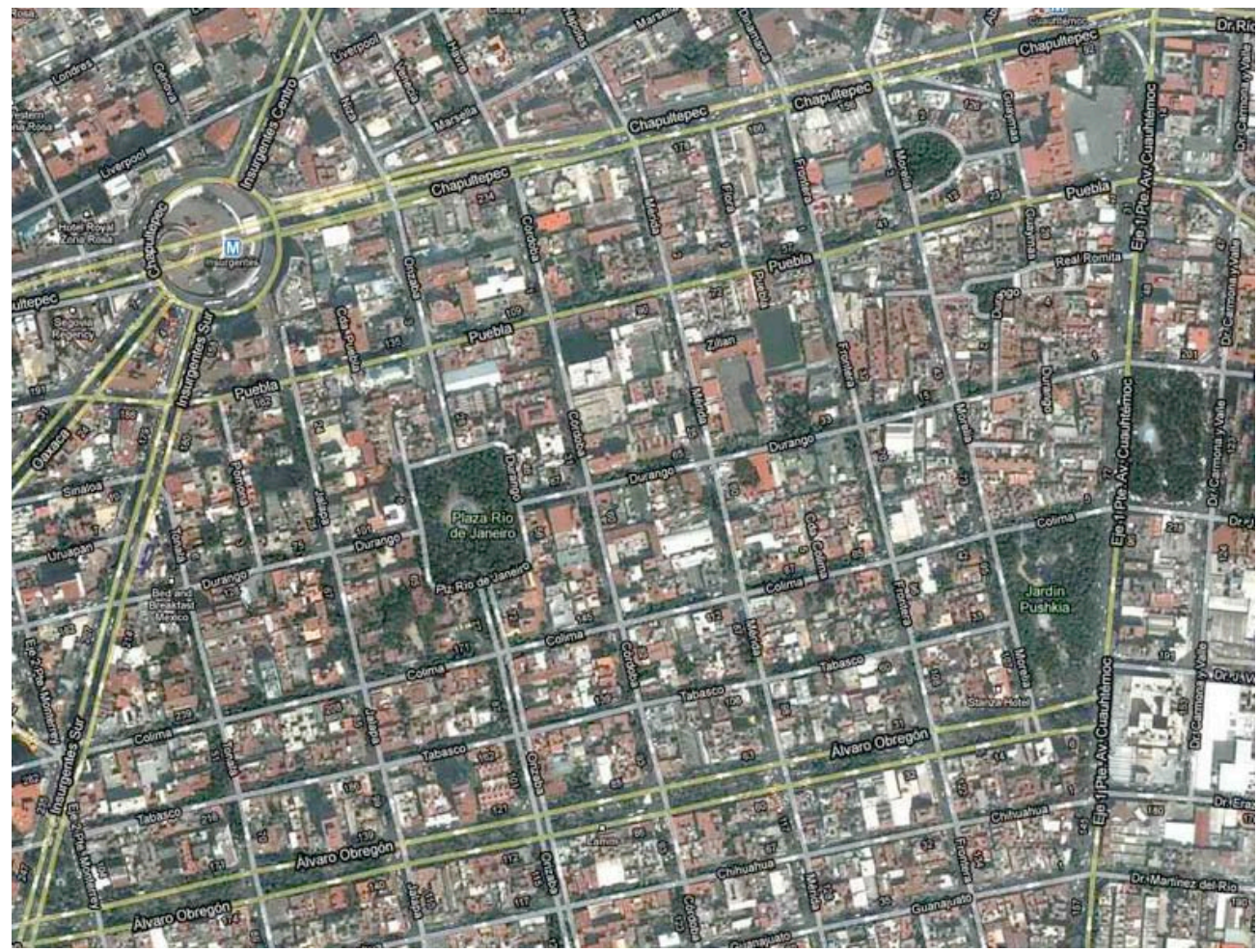

Mapa del cuadrante estudiado, dentro de la colonia Roma norte. Fuente: Google Maps, 2010. 
Como hemos visto, la situación de transformación intensiva del espacio urbano no es nada nueva. La ola de sobreconstrucción que se aprecia actualmente en las colonias centrales de la Ciudad de México forma parte de una serie de procesos históricos complejos. De acuerdo con Duhau y Giglia (2008), sería inadecuado pretender que todo lo que ocurre en las megaciudades modernas es resultado de la globalización, que todo ha cambiado en los últimos treinta años. En una metrópoli como la mexicana, la pobreza, la segregación, la fragmentación, la violencia, el desorden, la sobreexplotación del espacio... son fenómenos detrás de los cuales hay procesos de muy larga duración (cf. Duhau-Giglia, 2008: 16). Tomando esto en consideración, aunque en esta investigación me concentraré principalmente en la situación actual de esta zona de la ciudad, resulta imprescindible echar un vistazo a su pasado, en busca de claves que nos ayuden a comprender mejor su presente.

Reflexionaré sobre la historia, el contexto general y las coyunturas particulares que definen a la Roma y que nos permitirán entender los casos estudiados en el marco del largo proceso de transformación que ha atravesado esta colonia. Intentaré describir cómo creció la colonia a lo largo del siglo $X X$, cómo se ha modificado su traza, sus inmuebles y espacios públicos, cómo ha variado su densidad poblacional, recurriendo a algunos datos sobre su desarrollo urbano e historia arquitectónica.

Para elaborar este recuento panorámico sobre la colonia Roma fue necesario recurrir a diversas fuentes; revisé artículos especializados en revistas, consulté libros monográficos, documentales televisivos, además de diversas obras literarias, como Las batallas en el desierto y El vampiro de la colonia Roma, entre otras. A este conjunto de materiales se suman las notas elaboradas a partir de un coloquio académico dedicado a reflexionar desde distintas perspectivas sobre esta colonia y su significado para el resto de la ciudad. Este encuentro, titulado "Colonia Roma: orígenes, historia, identidad, perspectivas", fue organizado en 2009 por el Programa Universitario de Estudios sobre la Ciudad de la UNAM, en conjunto con otras instituciones y organizaciones civiles.

Por otra parte, presentaré un conjunto de fotos aéreas de esta zona correspondientes a las últimas cuatro décadas, en las que se pueden leer minuciosamente los cambios que ha sufrido la demarcación. Además, elaboré una 
serie mapas que muestran la cantidad de obras que había en esta área en un momento dado. Estas fotos y mapas nos ayudan a comprender, o por lo menos a imaginar mejor en términos visuales, el intenso proceso de transformación que atraviesa la colonia en años recientes. Buscaré que mi experiencia y el material etnográfico obtenido dialoguen con el material bibliográfico consultado sobre esta singular zona de nuestra ciudad.

Me parece que estudiar y analizar la evolución de la colonia Roma a través del siglo XX nos da elementos para entender, por un lado, la transformación particular de nuestros sitios estudiados, y a la vez permite comprender aspectos fundamentales de la evolución general de la Ciudad de México. Es decir, la colonia representa un nivel intermedio en el que es posible vincular el análisis macro con una perspectiva micro. Nos brinda una dimensión media en la que se funden las particularidades de un estudio de caso con las tendencias generales de la metrópoli en la actualidad.

\section{De la época prehispánica hasta su fundación}

En cuanto al pasado precolombino de la colonia Roma, hay muy pocos vestigios. Según el arqueólogo Salvador Guilliem (2009), los escasos datos que existen, sobre todo en antiguos mapas de la ciudad de Tenochtitlán, se refieren a esta zona como el barrio de Aztacalco. En el primer mapa de la ciudad, atribuido a Hernán Cortés, ya aparece Aztacalco, que significa "Lugar de las Garzas" o "Lugar de la blancura"; no obstante, es un nombre de difícil traducción, refiere el arqueólogo.

Existen escasas evidencias en torno al asentamiento que existía ahí antes de la llegada de los españoles. De acuerdo con Guilliem, los grandes historiadores y geógrafos de la Ciudad de México ubican a Aztacalco en las delimitaciones de la ciudad, cerca de la Ciudadela, al sur de la bajada de las aguas por el acueducto de Chapultepec. En ese lugar había un importante tianguis de frutas, legumbres y diversas vendimias provenientes de Xochimilco. Se sabe que en la capilla de esta demarcación, una de las más antiguas en México, fundada en 1530, se bautizó a los primeros indígenas en 1537 (cf. Tavares, 2005, 2009; Yubi, 2005; Porras, 2007).

En un plano de 1628 se ve claramente cómo con el sistema de pilotes se le va ganando terreno a las aguas del lago, formando islotes cada vez más extensos. Aztacalco se consolida como uno de estos islotes. En un mapa de 1735 que está en el 
Museo de Historia de la Ciudad, aparecen diferenciadas la Romita y Aztacalco. En el siglo XVIII se le bautizó Romita, por el hermoso paseo arbolado que conducía desde estos parajes hasta Chapultepec (actualmente Avenida Chapultepec), muy semejante al paseo Tívoli en Roma, pero en menor escala. Cuando más tarde se constituyó la colonia Roma, se apropió del nombre del antiguo barrio, pero eliminando el diminutivo (cf. Tavares, 2005; Porras, 2007).

Cabe mencionar que desde finales del siglo XVIII y principios deI XIX el viejo barrio de la Romita se convirtió en un barrio sumamente popular e incluso en un territorio marginal, de mala fama. Édgar Tavares nos remite a las leyendas acerca de los ahorcados de la Romita, presos provenientes de Tepito condenados a muerte, que eran ejecutados colgados de un árbol en esta zona. En la Romita se filmaron algunas escenas de la película Los Olvidados (1950) de Luis Buñuel, que retrata el grado de pobreza que aqueja a este barrio, y en la novela de José Emilio Pacheco, la Romita aparece como territorio del miedo, como los rumbos del "Robachicos", siniestro personaje que secuestraba niños, se los robaba en un saco y los esclavizaba (cf. Tavares, 2009). Hoy en día, las cuadras que rodean la iglesia de la Romita son quizás la parte donde vive la clase más baja de la colonia Roma; una zona de talleres mecánicos, a espaldas de un franja comercial en el cruce de las avenidas Cuauhtémoc y Chapultepec, cerca de la estación del metro Chapultepec. Aunque en los últimos dos siglos han cambiado mucho las formas de pobreza al interior de la ciudad, la condición marginal de la Romita ha sido una constante en la historia de esta zona.

Por su parte, la colonia Roma, propiamente dicha, no aparecería sino hasta los primeros años del siglo XX, y se desarrollaría alrededor del antiguo barrio de la Romita, extendiendo cada vez más su demarcación hacia el sur y el oeste. Curiosamente, su nacimiento oficial como colonia está ligado al circo. Su fundador, el empresario inglés Edward Walter Orrin, era propietario del famoso Circo Orrin. En las doce vecindades que antiguamente había en la Romita (que hoy son edificios multifamiliares), vivían principalmente los artistas y cirqueros que trabajaban en esta compañía. Por otra parte, José Alfonso Suárez del Real, vecino erudito de la colonia Roma, explica que las calles se nombraron en homenaje a los estados de la República Mexicana en los que tuvo éxito el Circo Orrin (Yubi, 2005).

El 24 de enero de 1902, el señor Orrin solicitó al ayuntamiento fraccionar la zona conocida como los potreros de la Condesa, alrededor del antiguo barrio de la Romita. 
Aunque en un principio se le negó el permiso, pocos meses después le sería otorgado. Así, el 30 de diciembre de 1902 se firmó el documento oficial, que convierte a este empresario extranjero en el fundador y primer desarrollador urbano de la naciente colonia Roma (cf. Tavares, 2005). A partir de este momento se puede decir que inicia la historia de la colonia que, por cierto, en 2010 cumplirá su 108 aniversario.

\section{Inicios del siglo $\mathrm{XX}$}

Édgar Tavares López (2009), arquitecto y urbanista interesado por la transformación de la vida cotidiana en los barrios de la Ciudad de México, ofrece un excelente recuento panorámico del desarrollo de la colonia Roma en el tiempo, de 1902 a 2009. Por su parte, Guadalupe Lozada León (2009), Coordinadora de Patrimonio Histórico, Artístico y Cultural del Gobierno del Distrito Federal, aborda también el problema de la transformación de la colonia Roma a lo largo del siglo XX y lo que va del XXI. En lo que sigue, retomo en buena medida la información expuesta por estos autores.

\section{Porfiriato y arquitectura de influencia europea}

"Para hablar de los orígenes de la colonia Roma hay que remontarnos a los inicios del siglo $\mathrm{XX}$, momento en el que el porfirismo prometía optimistas perspectivas de desarrollo, lujo y modernidad..." (Porras, 2007: 5). Durante el Porfiriato, la Ciudad de México atravesó por un gran ímpetu constructor; desde los primeros años del siglo pasado, los fértiles terrenos de esta zona serían fragmentadas por empresarios, en muchos casos extranjeros, que sin duda amasaron considerables fortunas. En 1903, Porfirio Díaz celebró en un discurso público este proceso de urbanización en las colonias Roma y Condesa, y señaló que la Ciudad de México continuaba extendiéndose notablemente gracias a contratos con empresas particulares y extranjeras (cf. Porras, 2007).

Los hermanos Lamm se encargaron del diseño urbanístico general y del fraccionamiento de la colonia. La Casa Lamm era precisamente la sede de las oficinas de su empresa fraccionadora. La entonces llamada Plaza Roma, hoy Plaza Río de Janeiro, es el centro estratégico en el trazo de la colonia. A su alrededor comenzaron a edificarse numerosas viviendas y edificios de lujo, mientras que las 
primeras casas fueron habitadas en 1906. El éxito vertiginoso de los primeros fraccionadores de la colonia hizo que ésta se poblara rápidamente. Ya para 1910, la Roma se consideraba orgullosamente "un pequeño rincón de París", con sus exuberantes y ostentosas mansiones. Para 1911, esta zona ya estaba plenamente integrada a la ciudad a través de amplias vialidades que la comunicaban directamente con el Zócalo y con Chapultepec (cf. Lozada, 2009).

De acuerdo con Héctor Mendoza Vargas, geógrafo de la UNAM, la colonia Roma se creó como un nuevo espacio urbano en los primeros años del siglo XX, que trajo consigo nuevas formas de habitar y de vivir en la ciudad. En su momento, la colonia Roma representó una forma de vida diferente, una nueva identidad y patrón de urbanismo novedoso. Las innovaciones urbanísticas y la calidad del trazo urbano pueden rastrearse, por ejemplo, en las calles anchas de dos vías, con camellón en el centro, algunas de ellas con palmeras.

La colonia Roma fue uno de los escenarios principales del movimiento arquitectónico mundial durante el Porfiriato, a finales del siglo XIX y principios del $X X$. La zona alberga algunas muestras singulares de arquitectura ecléctica de fin de siglo y algunos ejemplos únicos en la década de 1900-1910, mezcla de diferentes estéticas, entre el gótico y el neoclásico. En sus construcciones se expresan diferentes manifestaciones culturales, como el art nouveu y el estilo germánico mexicanizado, de "aires afrancesados, formas sinuosas y serpentinas en las fachadas, rejas de hierro forjado" (Porras, 2007). Todavía en la actualidad podemos apreciar algunos ejemplos notables de esta arquitectura extraordinaria de hace más o menos un siglo, edificios y casonas emblemáticas o llenas de historia. Basta mencionar tres inmuebles que son íconos de la colonia Roma: el edificio de las Brujas, de estilo ecléctico; la iglesia de la Sagrada Familia, también ecléctica con rasgos góticos y, en contraesquina, el edificio de la actual Casa Universitaria del Libro, en la esquina de Puebla y Orizaba, muestra del más puro estilo neocolonial (cf. Tavares, 2009).

Durante el Porfiriato, diferentes arquitectos extranjeros, sobre todo europeos, italianos y franceses, pero también algunos estadounidenses, fueron invitados a construir varios edificios. Esto representó para algunos jóvenes arquitectos mexicanos la gran oportunidad de incursionar en los nuevos estilos arquitectónicos europeos, principalmente de influencia francesa. Esta influencia se reflejó en numerosas casas, iglesias, monumentos y plazas, construidas aprovechando la 
opulencia y los beneficios de la economía porfirista (cf. Mendoza, 2009). Hugo Arciniega, especialista en historia de la arquitectura en México, rescata la figura de Manuel Gorozpe, arquitecto responsable en buena medida del perfil arquitectónico de la Roma, de su apariencia estética y su patrimonio edificado. Él es el arquitecto que construyó la iglesia de la Sagrada Familia, que requirió una innovadora tecnología y maquinaria constructiva para esa época (cf. Arciniega, 2009).

Después, hacia finales de los años 20 e inicios de los 30, paulatinamente comenzaron a llegar algunas tendencias arquitectónicas norteamericanas. Por primera vez se importaron materiales de otros países y, en sentido amplio, cambió la forma de construir (cf. Porras, 2007: 6). Es importante hacer hincapié en que ésta fue una etapa fundamental en la historia constructiva de la ciudad, y precisamente uno de sus centros neurálgicos fue la colonia Roma. Se trataba de una época de experimentación, en la que se probaban nuevas técnicas y estilos constructivos, que a su vez se mezclaban con prácticas tradicionales y saberes ancestrales.

\section{La Roma postrevolucionaria}

Después de la Revolución se generó un gran desprecio por todo lo porfiriano, incluida la arquitectura de influencia francesa. Desde aquel entonces se demolieron varios edificios, que se consideraban vejestorios anticuados. Es muy importante aclarar que el proceso de transformación, destrucción, renovación, sustitución y demolición no es para nada nuevo ni exclusivo del desarrollo inmobiliario de los últimos años, sino que data de la época revolucionaria; en este sentido, se trata de una problemática endémica, crónica de la colonia y la ciudad en general (cf. Lozada, 2009).

En los años 30 se introdujo el sistema de tranvías, cuyas rutas circundaban y atravesaban la colonia. A partir de entonces, la colonia se convirtió en un punto estratégico para la ciudad, en términos de comercio y servicios de transporte y comunicación. Incluso en la actualidad, la Roma es un lugar al que se puede llegar desde todos lados y desde donde se puede ir a todos lados porque, a final de cuentas, todos los caminos conducen a la Roma (cf. Lozada, 2009).

\section{Modernidad estilo americano}

En los años cuarenta se introdujeron servicios de todo tipo, escuelas, transporte y entró plenamente la modernidad según el modelo americano, que consideraba vieja 
y anticuada la traza de la colonia Roma, estilo francés. La modernidad se arraigó en la colonia Roma con la apertura de la tienda departamental SEARS, sobre la Avenida Insurgentes, en 1947, en cuyos aparadores puede encontrarse, por ejemplo, el germen del consumismo navideño importado de Estados Unidos (cf. Lozada, 2009).

También en este periodo aparecen los primeros desarrollos de vivienda en serie a gran escala del célebre arquitecto Mario Pani, quien construye el multifamiliar Juárez en los linderos de la colonia Roma, inaugurando un nuevo concepto arquitectónico, punta de lanza de la modernidad urbana. Pero, al parecer, este proyecto inmobiliario no contempló debidamente las condiciones del subsuelo pantanoso y unas décadas más adelante este megaconjunto habitacional moderno colapsaría durante el terremoto de 1985 (cf. Lozada, 2009).

Siguiendo a Tavares, en los años sesenta comenzó un proceso de cambio en el tipo de uso de suelo en la colonia Roma. Poco a poco ha dejado de ser una zona exclusivamente residencial, y se ha convertido en una zona de uso mixto, con muchas escuelas y oficinas, y cada vez más comercial (cf. Tavares, 2009). Antes de que existiera el metro, en 1966, era una colonia mucho más apacible. En 1969 se construye la glorieta y las estaciones del metro Insurgentes. Con la consigna de la modernidad bien arraigada se desata una ola de transformación radical del espacio. En los años setenta la colonia fue atravesada por el urbanismo moderno y por la construcción de los ejes viales, hoy llamados Monterrey, San Luis Potosí, Querétaro y Baja California (cf. Lozada, 2009).

\section{9 de septiembre de 1985}

Siguiendo a Tavares, lo que marca definitivamente la década de los ochenta en la colonia Roma son los sismos del 19 y 20 de septiembre de 1985, que representaron un terrible embate de la naturaleza contra los edificios de esta colonia y sus pobladores. Según Roberto Meli (2009), experto en ingeniería sísmica, quien tuvo la tarea de evaluar los daños tras el temblor, en la zona afectada hubo un total 13 mil edificios trastocados, seis mil con daños serios y quinientos colapsos.

En cuestión de segundos la historia de la ciudad cambió. La tierra de la gran chinampa que es la Ciudad de México comenzó a agitarse de tal forma que cuando al fin concluyó, la ciudad ya no era la misma. Un sismo, un brutal movimiento telúrico convirtió al 19 de septiembre de 1985 en un parteluz en la historia de la Ciudad de México. De pronto, pareció que la Naturaleza venció de nuevo al ser 
humano y a su sofisticada tecnología... nuestra identidad como habitantes de la Ciudad de México estaba en ruinas. Se reportaron daños y derrumbes en edificios de todas las épocas de nuestra historia constructiva (Fernández, 1990: 13).

Junto con otras colonias como el Centro Histórico y la Guerrero, la Roma fue una de las zonas de la ciudad más devastadas por el movimiento telúrico. En la memoria histórica de los habitantes de la Roma el terremoto significa sin duda una tragedia, pero también representa un momento extraordinario de solidaridad. Las clases bajas, medias y altas tuvieron que entregarse a la reconstrucción de las viviendas y la vida social en la colonia. Tras el terremoto de 1985, el movimiento y la resistencia de los damnificados fue determinante en la historia de la colonia Roma.

Según el testimonio de Alejandro Varas, habitante de la Roma, damnificado por el temblor, hubo tres momentos en la reacción tras el sismo: la emergencia de las primeras horas y días después de la catástrofe, de ayuda espontánea sin organización, muestras de humanismo por doquier, se trataba de rescatar vidas entre los escombros, las más posibles, a como diera lugar; una segunda etapa fue la de organización ante la pregunta ¿dónde vamos a vivir?; en una tercera etapa comenzó la reconstrucción material y espiritual de la colonia. Los sismos hermanaron a una comunidad que anteriormente no se conocía bien; se formó por primera vez un frente común y así nació la sociedad civil en la Roma. A partir de entonces, cambió la relación de los vecinos tanto con las autoridades como entre ellos, y surgieron nuevas formas de participación ciudadana frente al gobierno de la ciudad (cf. Varas, 2009).

Ha sido posible aprender importantes lecciones después del 85. Sabemos de sobra que las características del suelo hacen la zona de la Roma especialmente vulnerable a los movimientos telúricos, hundimientos, inundaciones, etc. De acuerdo con el Atlas de Riesgo de la Ciudad de México, la Delegación Cuauhtémoc, corazón de la ciudad, con tan solo cinco mil habitantes pero alrededor de cinco millones de visitantes o de población flotante diaria, alberga varios focos rojos y sitios de alto riesgo. En la colonia Roma están ubicados varios edificios en peligro de colapso, inundación o hundimiento. Cabe preguntarnos si actualmente la colonia Roma está preparada para resistir un siniestro de esta magnitud, si en la construcción de nuevos edificios se toman las suficientes medidas de seguridad y prevención de desastres. Si hoy 
volviera a temblar como aquella mañana del 19 de septiembre, ¿seríamos más o menos vulnerables?

El terremoto fue un verdadero parteaguas en la historia de la Ciudad de México y particularmente de la colonia Roma. Resulta irónico que lo que se cayó en esta zona fue, en su mayoría, lo edificado en la década de los sesenta y setenta, es decir, lo relativamente reciente en ese entonces, mientras que buena parte del patrimonio arquitectónico histórico se mantuvo en pie. Lo que ha acabado con esos edificios de principios del siglo XX ha sido la mano del hombre, en su mala interpretación de urbanización y la modernidad (cf. Tavares, 2009).

Los días después del temblor, el paisaje urbano de la ciudad era realmente dramático; a la vez, a partir de ese momento fue claro que si bien "habíamos perdido mucho, también conservábamos mucho... De alguna manera, todos conocíamos su existencia, pero después del 19 de septiembre, el patrimonio nacional dejó de ser una entelequia para convertirse en una ingente manifestación material de nuestra identidad...". Es así como a partir de este terrible momento de septiembre de 1985, "fuimos redescubriendo nuestro patrimonio, su importancia y la necesidad de rescatarlo, restaurarlo y conservarlo" (Fernández, 1990: 13-14).

\section{El valor patrimonial de la Roma}

Después del terremoto, que permanecerá enclavado en la identidad e historia de la Roma, la experiencia de la destrucción y la pérdida del patrimonio cobra matices peculiares. La sacudida del 85 ha servido para que algunos habitantes de la colonia, así como algunas autoridades, aprendan a valorar y proteger su patrimonio. De acuerdo con Tavares, la Roma reúne distintos valores patrimoniales: las innovaciones urbanísticas y la calidad del trazo urbano, el valor arquitectónico (más de mil inmuebles ejemplares que hay que conservar), además de un rico imaginario y cúmulo de representaciones que dan fundamento a la experiencia urbana colectiva (cf. Tavares, 2009).

¿Cómo se ha transformado la colonia Roma en los últimas décadas ¿Qué se ha perdido en el camino? ¿Qué queda todavía? ¿Es demasiado tarde para rescatar parte de este patrimonio? Actualmente no son únicamente desastres naturales los que amenazan a la Roma, sino sobre todo la mano del hombre. Varias casonas antiguas, que forman parte del patrimonio arquitectónico de la ciudad, están muy 
deterioradas o de plano abandonadas, como el triste caso del chalet estilo americano en la esquina de Insurgentes y Avenida Álvaro Obregón. Esta situación de descuido propicia que cuando una propiedad con un inmueble así cambia de manos, la primera alternativa que se presenta a los nuevos dueños es demoler lo que hubiera antes.

En este sentido, Guillermo Tovar y de Teresa hace un recuento de algunas de las muchas casas perdidas de la colonia Roma. La originalidad de su investigación radica en que utiliza la fotografía como testimonio de lo que esta colonia fue, sigue siendo y va dejando de ser. Se refiere concretamente a ocho espléndidas casonas que ya no existen, de las que solamente queda una serie de fotografías muy antiguas, tomadas por Guillermo Khalo, padre de Frida, para un catálogo de herrería regiomontana. Cabe mencionar que este tipo de herrería fina elaborada en los balcones, puertas y ventanas de las casonas, era una característica arquitectónica y estilística que distinguía a la Roma de otras colonias. La compañía que se había encargado de elaborar la herrería de muchas de estas casas, mostraba su trabajo en su catálogo comercial, que data de 1918. Tovar y de Teresa rescata este catálogo y lo utiliza como fuente visual para la investigación de lo que alguna vez fue la colonia Roma, en comparación con lo que es actualmente (cf. Tovar y de Teresa, 2009).

En este sentido, me parece relevante mencionar algunos ejemplos precisos de destrucción del patrimonio arquitectónico, citados tanto por Tovar y de Teresa (2009) como por Tavares (2009):

1) En la calle de Córdoba había una casa muy hermosa, un chalet tipo americano con un extenso jardín alrededor, coloquialmente llamada "la casa del trenecito" 8 porque cada año instalaban en el jardín una gran maqueta con un tren eléctrico miniatura, que todos los niños vecinos de la colonia iban a admirar. La casa se fue degradando, hasta que sus propietarios, la familia Lamm, decidieron venderla, se dice que con mucha visión de negocios, pero ocasionando una terrible pérdida arquitectónica e histórica para la colonia. La casa del trenecito finalmente se vendió, se demolió y actualmente en ese mismo terreno hay una gran torre de oficinas, con un banco Banamex en la planta baja, que ahora, dicho sea de paso, queda

\footnotetext{
${ }^{8}$ El arquitecto Fernando Abascal, antiguo habitante de la colonia, recuerda en su infancia la famosa Casa del Trenecito: "en el jardín de aquella casa había un trenecito montado alrededor de una gran maqueta, que era un espectáculo muy popular que todos los niños de la Roma admirábamos... Todo esto ha desaparecido por la especulación del suelo", reflexiona nostálgico este antiguo vecino de la colonia Roma, que añora también la ya desaparecida y prácticamente olvidada paletería Cadi, en el parque Río de Janeiro.
} 
enmarcada entre dos desarrollos inmobiliarios de DAKAB, compañía constructora estudiada en esta tesis. 2) En la esquina de Durango y Córdoba, donde hoy está el edificio de la Arquidiócesis, antes había una casa con un gran jardín en el que había garzas y pavorreales, que al interior tenía un elevador antiguo montado en una estructura con herrería majestuosa. 3) En la esquina de Álvaro Obregón y Córdoba, a finales de los 80 , se destruyó una casa que era una verdadera joya y en su lugar se construyó un edificio de departamentos, seguramente muy moderno en ese entonces, pero que hoy día luce bastante deteriorado. 4) Otro caso indignante es el del antiguo cine Balmori, sobre la Avenida Álvaro Obregón, entre Orizaba y Jalapa, que además de ser sala cinematográfica, era un centro cultural muy activo. Este inmueble fue igualmente demolido para construir en su lugar otra "moderna" torre de oficinas. 5) Una más de las casas perdidas de la Roma: en la esquina de Tabasco y Orizaba hay una casa de 1926, que hoy en día está en proceso de demolición. 6) Otro caso lamentable en la misma calle de Córdoba es la desaparición de una casa muy singular, entre las calles de Puebla y Avenida Chapultepec, en donde hoy está una universidad privada (cf. Tovar y de Teresa, 2009, Tavares, 2009).

Como éstos, hay varios casos alarmantes de devaluación del patrimonio. En estos nuevos edificios que reemplazan verdaderas joyas del pasado, hay una pobreza de recursos arquitectónicos que representa, más allá de la nostalgia personal, una triste pérdida del patrimonio edificado. "No es que queramos que la ciudad no se transforme", afirma Tovar y de Teresa, "pero sí que se transforme para bien, que no se empobrezca el patrimonio sin imaginación, por pura practicidad" (Tovar y de Teresa, 2009). Estas comparaciones que presenta, apoyadas en el registro fotográfico del antes y el después de la transformación de un espacio urbano particular, nos dan una buena idea del lamentable daño del que ha sido objeto la colonia Roma.

Si consideramos que hay una correspondencia entre los espacios y las formas físicas, por un lado, y las formas sociales y los comportamientos de los sujetos que habitan tales espacios, por el otro, es claro que con la destrucción del patrimonio arquitectónico, como con la demolición de viejos edificios con valor histórico, no sólo se pierden los inmuebles mismos, sino que con ellos desaparecen viejas formas de usar el espacio y habitar la ciudad. 


\section{Los cines perdidos de la Roma}

El cineasta Carlos González Morantes (2009) hace un recuento de los cines perdidos de la colonia Roma y señala que el nacimiento del cine coincide aproximadamente con el nacimiento de esta colonia. En 1895 se realiza la primera exhibición pública de las cintas de los hermanos Lumière en París. Muy poco después, el cine llega a México; se organiza en Chapultepec la primera proyección de estas mismas cintas. En sus orígenes, el cine en México tuvo una gran acogida gracias al amor porfiriano por la cultura francesa.

Desde su nacimiento, la colonia Roma se caracterizó por ser un espacio privilegiado para la cultura y los espectáculos —quizás por su familiaridad con el mundo circense-, sobre todo para la exhibición cinematográfica. Además, tal como sucedió con la arquitectura, la Roma siempre ha acogido influencias, tendencias, estilos y gustos del extranjero, lo que le imprime un carácter cosmopolita y vanguardista en el imaginario colectivo, que conserva cierta vigencia en la época actual.

González Morantes hace un recuento de los cines desaparecidos de la Roma, presentando algunos datos sobre casos muy reveladores:

En la esquina de Mérida y Guanajuato se encontraba el Cine Royal, con 1400 butacas, hoy hay ahí una sucursal de la empresa OmniLife. En el Cine Balmori, sobre Álvaro Obregón, había 1800 butacas, al igual que en el Cine Roma, ubicado en la esquina de Coahuila y Tonalá... El Cine Morelia estaba en la calle del mismo nombre, con una capacidad para 2 mil espectadores; hoy en su lugar hay un conjunto de vivienda de interés social... El Cine Estadio, uno de los más grandes, estaba sobre Coahuila, entre Yucatán y Jalapa, con 3 mil asientos, más tarde se convertiría en el Teatro Silvia Pinal, y hoy es una iglesia evangélica en cuya marquesina se lee "Pare de Sufrir". El Cine Vanguardias se encontraba en Frontera y Álvaro Obregón, hoy lo reemplazan unas oficinas y un centro deportivo. El Cine Frontera fue uno de los primeros en subdividir sus grandes salas en varias más pequeñas, esto fue en los setenta, después de tan visionaria remodelación, se cayó en el terremoto (González Morantes, 2009).

Estos antiguos cines de barrio estaban equipados con pantallas de cientos de metros cuadrados, enormes telones y grandes escalinatas alfombradas para acceder a la sala, entre otra parafernalia de fantasía "para hacer más suave el tránsito del sueño a la realidad", como afirma González Morantes. En la cartelera de estos recintos figuraba principalmente, ayer como hoy, el cine americano. Entre los años 
70 y los 80 inevitablemente se fueron imponiendo los multicinemas con varias salas. Después la televisión y el video se convertirían en el principal rival de las salas cinematográficas. (cf. González Morantes, 2009).

Definitivamente el consumo del cine ha cambiado, se ha tornado una experiencia menos colectiva y sobre todo menos masiva; hoy es una práctica más privada y claustrofílica. Hoy día, en 2010, podemos encontrar complejos de varias salas cinematográficas únicamente dentro de los centros comerciales alrededor de la zona. Hay un par de videoclubes y varias tiendas de venta o renta de películas, y en las banquetas de casi cualquier cuadra podemos encontrar múltiples vendedores semifijos o ambulantes de películas pirata. En el espacio de la colonia Roma es posible rastrear estas transformaciones en la cultura audiovisual; en sus transfiguraciones y devenir histórico se manifiestan y quedan huellas de estas y otras tendencias de consumo cultural.

\section{Imaginario y representaciones de la Roma}

Manuel Perló Cohen (2009) entreteje los discursos del urbanismo con el de las artes, utilizando la literatura como fuente de investigación y de inspiración para entender la colonia Roma y la ciudad en general. La Roma ha sido un referente importantes para varios escritores. Célebres cronistas, novelistas, ensayistas, poetas han tomado a la Roma como punto de referencia o espacio de inspiración para obras como: Ensayo de un crimen, Las batallas en el desierto, La región más transparente, El vampiro de la colonia Roma, Navaja, Ojerosa y pintada, así como en las crónicas de José Joaquín Blanco. Perló identifica seis rasgos distintivos de la colonia Roma que aparecen reflejados en una serie de obras literarias de distintas épocas y autores. A través de la literatura, la colonia Roma aparece perfilada de las siguientes maneras:

\section{Espacio de poder}

Desde la primera frase de La sombra del caudillo de Martín Luis Guzmán (1929), aparece un automóvil Cadillac que recorre las calles de la Roma, donde vivía la élite política, incluidos presidentes, generales y grandes personajes revolucionarios. La Roma aparece como lugar donde se tomaban determinaciones trascendentes para el país o se fraguaban conspiraciones (cf. Perló, 2009). 
Lugar de paso

Tanto en La región más transparente de Carlos Fuentes (1969) como en Ojerosa y pintada de Agustín Yánez (1960), la Roma representa un lugar de tránsito, de circulación; ya no es centro de atención, aparece intermitente y circunstancialmente. Aunque es una referencia obligada, ya no es el sitio principal ni el destino final; es base y conexión de tranvías, trolebuses y camiones; toda la red de transporte público pasaba por la Roma. Con la paulatina descentralización de las oficinas y los comercios hacia fuera del Centro Histórico, la colonia Roma se convierte en una especie de subcentro de la ciudad, un núcleo urbano independiente y funcional, una nueva centralidad en la que todos los oficios están representados... hay de todo en la Roma (cf. Perló, 2009).

\section{Sede de la rebeldía}

En varias novelas de los años cincuentas y sesentas la colonia Roma aparece habitada por pandillas, como "Los fortachones" que se enfrentan a pedradas con sus rivales de la colonia Doctores. Así, la colonia aparece como territorio de la juventud incomprendida, en el que proliferan las tribus urbanas, las bandas y grupos de rock (cf. Perló, 2009). Mucho de esto perdura en la actualidad. Cabe añadir además que posteriormente la colonia sería sede del Partido Comunista y más tarde de las oficinas del PRD capitalino, lo que la marca como una colonia identificada con la izquierda y la oposición política.

\section{Espejo de la otredad}

La Roma ha sido zona que tradicionalmente ha acogido a lo diferente, lo clandestino, lo oculto; que ha albergado a refugiados políticos de otros países, a minorías, extraños y extranjeros. La novela El vampiro de la colonia Roma de Luis Zapata (1979) expone claramente este aspecto. La narrativa se compone a partir de los testimonios de un homosexual alcohólico que se prostituye y vive en la colonia, la cual aparece como un sitio de burdeles, cantinas, baños públicos, hoteles de paso, etc. (cf. Perló, 2009). Dentro de esta categoría, hay que agregar que en la novela Naked Lunch de William S. Burroughs (1959), el personaje William Lee (alterego del propio Burroughs) le dispara a su mujer en la cabeza con una pistola, imitando el acto de Guillermo Tell, en un departamento de la Roma, sobre Avenida Monterrey, 
casi esquina con Álvaro Obregón. Cabe destacar que este hecho sucedió en realidad y el propio Burroughs mató a su mujer en la Roma (por lo que pasaría algunos meses en Lecumberri). Por otra parte, Jack Keoruac en su novela Tristessa (1960), también autobiográfica, se emborracha bebiendo whisky en un bar de la colonia Roma, cerca del Cine México. Estas anécdotas colocan a la colonia como sede de la contracultura norteamericana y guarida de beatniks y junkies en su paso por esta ciudad.

\section{Territorio entrañable de la nostalgia}

Claramente, en Las batallas en el desierto de José Emilio Pacheco (1981), la colonia Roma es el escenario querido de vivencias que se atesoran y se desvanecen. Este relato describe magistralmente la Ciudad de México en los años del Alemanismo (cf. Perló, 2009). Quisiera citar un pasaje de esta obra que hace referencia precisamente a las calles estudiadas en esta investigación, enfatizando su valor patrimonial tanto para la memoria individual como para la historia colectiva:

Caminé por Tabasco, di vuelta en Córdoba para llegar a mi casa en Zacatecas. Los faroles plateados daban muy poca luz. Ciudad en penumbra, misteriosa colonia Roma de entonces... Miré la avenida Álvaro Obregón y me dije: Voy a guardar intacto el recuerdo de este instante porque todo lo que existe ahora mismo nunca volverá a ser igual (Pacheco, 1981).

\section{Espacio amenazado}

En Navaja de Fernando Curiel (1991), la colonia aparece como lugar en peligro de destrucción; esta obra ofrece un retrato de la zona devastada después de sismos (del temblor en 1957, pero sobre todo del terremoto de 1985) y la ubica como un sitio permanentemente vulnerable, en riesgo constante; es descrita una colonia marcada por el fango en el subsuelo, por el lago debajo de sus calles y edificios (cf. Perló, 2009).

EI Dr. Perló termina su presentación lamentando que en los últimos años ya no se ha escrito tanto en torno a la colonia Roma.

\section{Los habitantes de la Roma, ayer y hoy}

Cabe mencionar que, geográficamente hablando, desde los primeros tiempos esta zona gozaba de "uno de los mejores climas del mundo... perfecto para la curación de enfermedades... aguas delgadas y sabrosas, oxígeno generado por la gran 
cantidad de árboles...", cualidades que hicieron que la aristocracia capitalina construyera en esta zona sus casas de campo, villas y palacetes de lujo, alejados de los miasmas de la ciudad" (Porras, 2007: 5).

En 1910, la Revolución detuvo en cierta medida por unos años el impulso constructivo del Porfiriato. Más adelante, la nueva clase dirigente revolucionaria habitaría la colonia. En las primeras décadas, la Roma fue habitada por las clases altas, la clase política poderosa de la sociedad urbana de la capital mexicana; se convirtió en una zona con una ubicación estratégica para el desarrollo de la Ciudad de México porque conecta el cuadrante del bosque de Chapultepec con el Zócalo. Sobre la antes llamada Avenida Jalisco estaba la casa donde vivió el general Álvaro Obregón hasta el momento de su asesinato, tras lo cual esta avenida adquirió su nombre (cf. Mendoza, 2009).

Durante las primeras dos décadas del siglo XX vivía en la Roma lo mejor de la sociedad, personajes históricos, como Ramón López Velarde, el padre Miguel Agustín Pro, Andrea Palma, Adolfo Prieto y Leonora Carrington. Estos rumbos eran sin duda un punto de referencia para viajeros y extranjeros que descubrieron la belleza de la colonia, que muchos consideraban "un rincón de Europa en México".

Ya a finales de los años cuarentas y durante los cincuentas comienzan a emigrar las familias ricas hacia otras colonias más nuevas y modernas como Polanco, o hacia zonas más retiradas del centro, como San Ángel o Coyoacán, al sur de la ciudad, para vivir en casonas tipo hacienda de estilo colonial mexicano. Así, con el paso de los años, la colonia Roma fue perdiendo su glamour (cf. Tavares, 2009).

Actualmente, a los viejos pobladores de clase media de la colonia Roma se han sumado nuevos habitantes, principalmente población joven, soltera o nuevos matrimonios con pocos hijos o sin ellos, además de artistas y trabajadores independientes que tienen sus estudios o talleres en la colonia.

\section{La Roma en la actualidad}

Durante la década de los 90 , en un espíritu de renovación después del terremoto, comenzó a fraguarse el resurgimiento cultural de la Roma. No es raro que a periodos de desastre sigan etapas de renacimiento del espíritu humano a través del arte y la cultura. Así, se abrieron en la Roma galerías de arte y museos; los lugares donde se habían colapsado edificios durante el temblor fueron reforestados y 
conservados como áreas verdes. La avenida Álvaro Obregón se ha convertido en un intento de corredor cultural. La calle de Orizaba, así como la de Colima, comienzan a albergar cada vez más restaurantes, tiendas, espacios consumo cultural y vida nocturna.

Calles como Tabasco y Colima se mantienen más o menos bien conservadas y alcanzan a recordar el viejo esplendor de la colonia; son vías ideales para dar caminatas agradables a la sombra de los árboles en las banquetas y camellones, actividad predilecta de la aristocracia porfiriana que aún practican los actuales romanos. Callecitas casi secretas, como Flora, o algunos tramos de Tabasco, conservan todavía su antiguo encanto (cf. Tavares, 2009).

Entre las tendencias y condiciones actuales, ha habido un estancamiento en el crecimiento de la población, aunado a un incremento en la producción habitacional y a una sobreabundancia en la oferta de vivienda disponible. También se ha dado un claro cambio en el perfil sociocultural de los habitantes, que se manifiesta en una particular forma de gentrificación o aburguesamiento de la colonia. Pero al mismo tiempo, la colonia Roma sigue presentando señas de alta vulnerabilidad en cuanto a hundimientos, inundaciones y sismos. En este sentido, es una caja de resonancia en la que se pueden estudiar los efectos de algunos de los problemas más importantes que también afectan al resto de la ciudad.

Hoy por hoy, la colonia Roma es una amalgama: tiendas de alto diseño, galerías de arte contemporáneo y restaurantes de primera clase se encuentran con vagabundos, niños de la calle, indigentes, cuidacoches, incontables puestos de comida callejera, etc. En una breve caminata se pueden encontrar condiciones de vivienda sumamente precarias, inmuebles deteriorados y abandonados, manifestaciones del mundo urbano popular, pobreza, marginalidad, informalidad (sobre todo mientras más se acerca uno a la avenida Cuauhtémoc y, por ende, a la colonia Doctores), pero también hallamos, codo con codo, burbujas de buena vida y tranquilidad, esferas habitacionales con una alta calidad de vida, edificios inteligentes, lofts modernos, casas antiguas cuidadosamente mantenidas y preservadas, así como numerosos edificios nuevos tipo estándar, "de medio pelo", como los estudiados en esta tesis. Transitar por las calles de la colonia Roma es, definitivamente, una experiencia ecléctica, acaso posmoderna y, a veces, surrealista. 
Como parte del decreto del Bando dos y el repoblamiento del centro, a partir de 2005 hubo en la colonia Roma un verdadero boom inmobiliario que actualmente continúa siendo palpable. Incluso sobre la avenida Álvaro Obregón se construyen edificios sin mayor preocupación por acercarse aunque sea un poco a la majestuosidad y buen gusto de antes. De acuerdo con el recuento de Édgar Tavares, unos pocos años antes del 2005 era imposible conseguir un crédito hipotecario y el correspondiente permiso para construir o reconstruir algún inmueble en la colonia Roma, pero a partir del Bando dos se desata la especulación del suelo y comienza a reconfigurarse este singular espacio metropolitano. Ahora hay cientos de proyectos inmobiliarios, que representan una serie de problemas y retos para la colonia; en ocasiones causan lesiones en los edificios colindantes, y en general su integración al entorno deja mucho que desear. No se adaptan o armonizan con el estilo arquitectónico tradicional o local, sino que tratan de imponer su nuevo estilo (cf. Tavares, 2009).

Jorge Legorreta y René Coulomb coinciden en que actualmente en la Roma hay una creciente privatización de los espacios públicos y apuntan que la tendencia es hacia la terciarización del barrio; ha habido un giro cada vez mayor hacia el sector de los servicios, que sustituyen las viviendas, bancos, oficinas, pero también un aumento en el uso de suelo comercial, tiendas, cafés, restaurantes, etc. El reto sería lograr equilibrar los distintos usos de suelo (cf. Coulomb, 2009).

La situación es compleja porque existen muy diversas experiencias de la colonia Roma y distintos actores con diferentes visiones, muchas veces contradictorias, sobre el rumbo que debería tomar su desarrollo. Pero también es preocupante que haya una creciente atomización y segregación de la población, lo cual afecta seriamente la posibilidad de la participación ciudadana (cf. Legorreta, 2009).

\section{Fotografía aérea y análisis de las transformaciones de la ciudad}

"En México las fotografías aéreas hechas por profesionales y con fines utilitarios y científicos comenzaron a circular en el segundo lustro de los años veinte... pronto se convirtieron en instrumento de trabajo utilizado por ingenieros, topógrafos, arqueólogos, geógrafos y urbanistas". Estas vistas de la ciudad "a vuelo de pájaro" permiten la fácil visualización de un lugar, entender la retícula de su trazo urbano, las manzanas, las calles, su alineamiento y su anchura (Escudero, 2005). 
Hay compañías que se dedican a retratar sistemática y periódicamente a la ciudad desde el cielo. Sus acervos contienen imágenes aéreas de la ciudad desde hace varias décadas hasta hoy en día. Esté género fotográfico, también conocido como aerofoto, es producto de una mirada desde las alturas, abarcante, panorámica, desde la perspectiva del "ojo de Dios". Una mirada macroscópica capaz de "abarcar con la vista el todo construido y el paisaje", que permite integrar (en una mirada global) los fragmentos de la experiencia adquirida a ras del terreno, "nos brinda una imagen más clara y más grande que nos permite ver mejor la ciudad":

Su utilidad es extraordinaria porque permite formarse una idea exacta y concreta de la clase de construcciones y el valor de éstas, de la manera como están distribuidos sus parques y jardines, del alineamiento de las avenidas y calles, de la topografía del terreno, la relación precisa entre unos elementos de la ciudad y otros..." (Antúnez, 1928, citado por Escudero, 2005).

La experiencia de mirar una fotografía aérea nos recuerda el relato de Michel de Certeau (1984) en el que reflexiona sobre la experiencia de mirar la ciudad de Nueva York desde las alturas del piso 110 de las ya desaparecidas Torres Gemelas en Manhattan. Entre otras intuiciones significativas, de Certeau se pregunta: " ¿A qué erótica del conocimiento pertenece el éxtasis de leer tal cosmos? ¿Cuál es la fuente del placer de mirar la totalidad como si fuéramos un voyeur?" (de Certeau, 1984: 92). Estas impresiones a su vez nos remiten a una observación de Néstor García Canclini en torno a la ilusión de una visión omnisciente, o los "simulacros de totalización", como los que se construyen a través del "helicóptero que sobrevuela la ciudad y ofrece cada mañana, a través de la pantalla televisiva y las voces radiales, el simulacro de una megalópolis vista en conjunto..." (García Canclini, 2007: 93). 


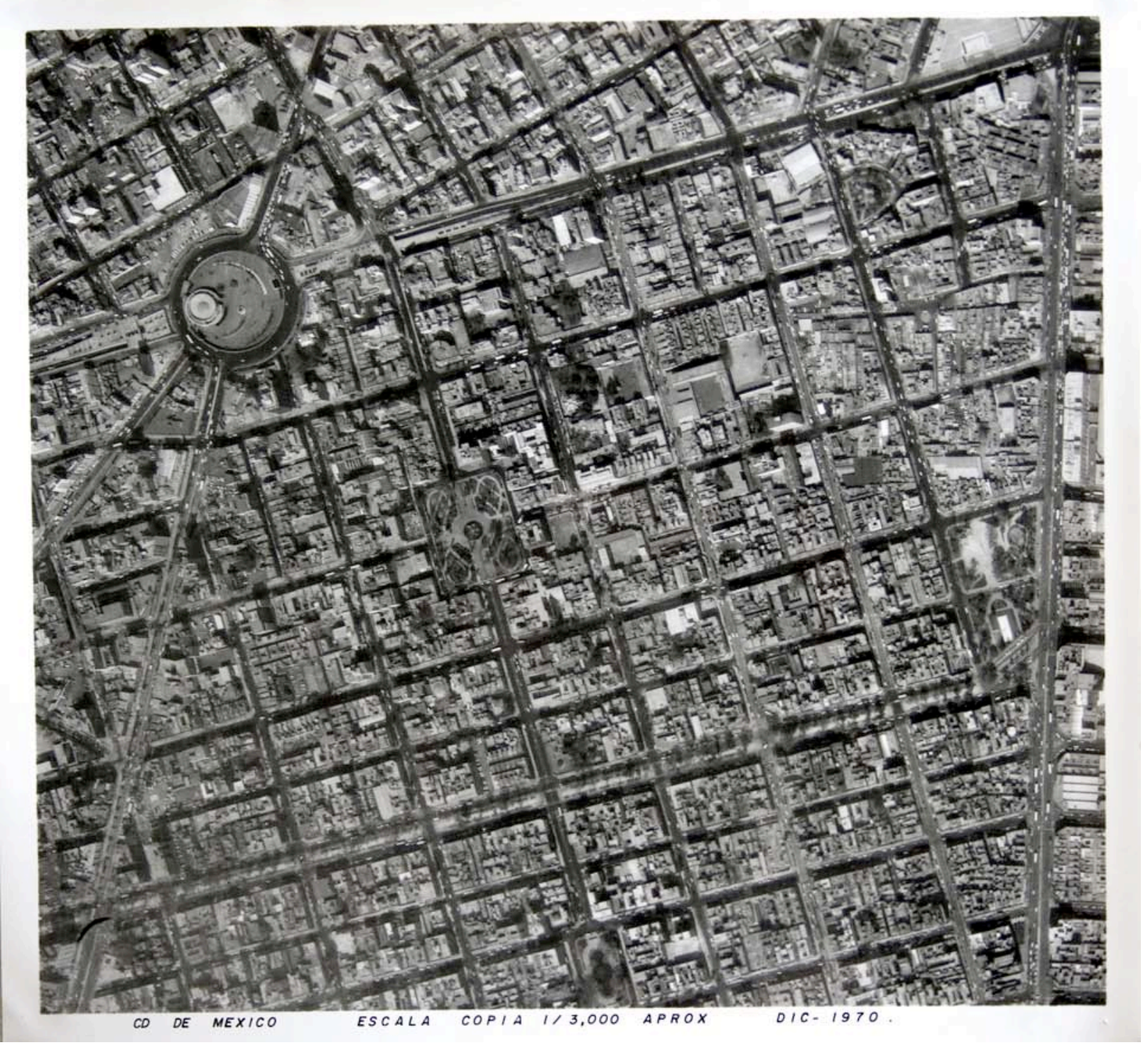

Fotografía aérea de la colonia Roma en 1970.

Fuente: Aerofoto S.A. de C.V. 


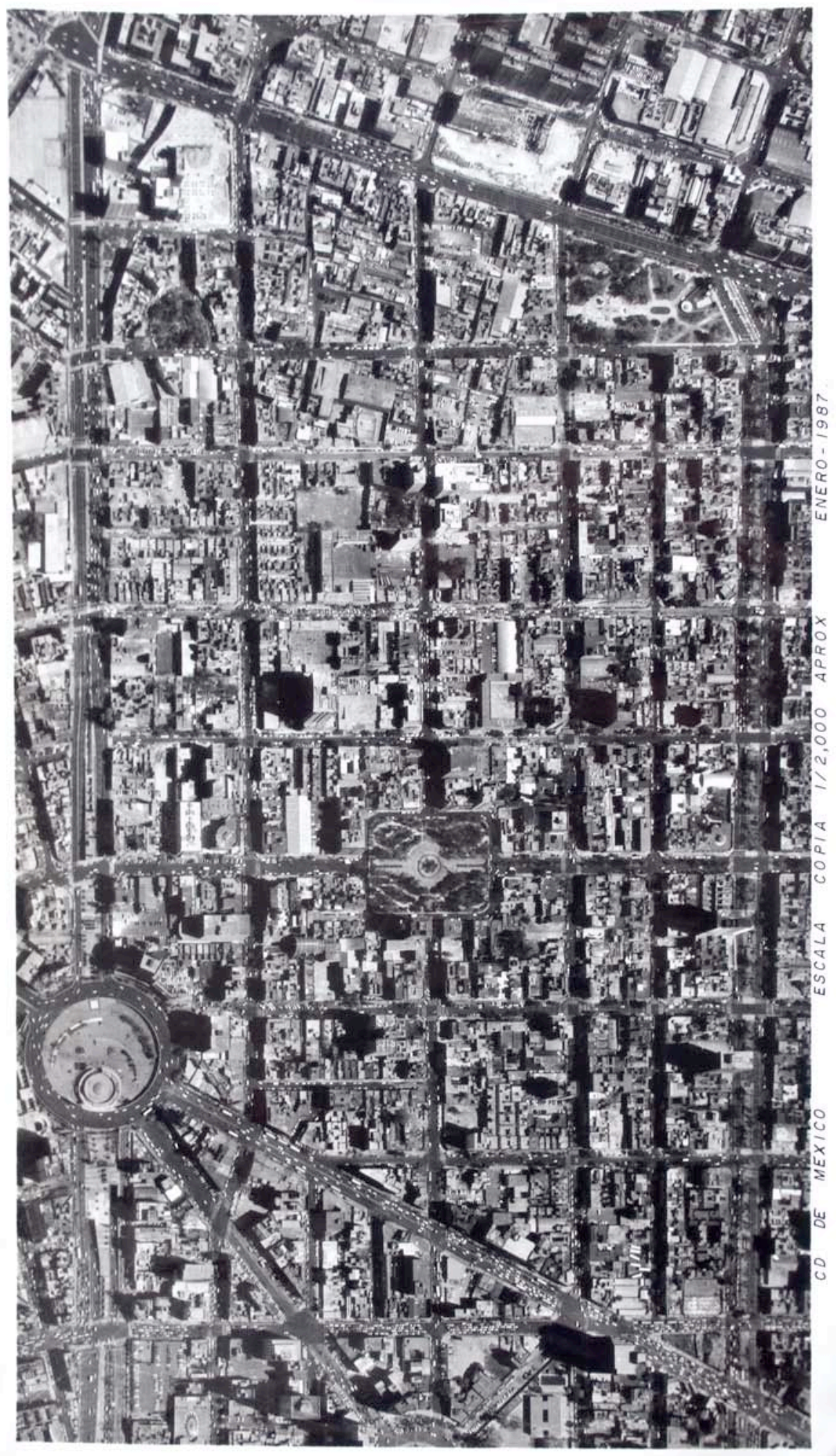

Fotografía aérea de la colonia Roma en 1987. Fuente: Aerofoto S.A. de C.V. 


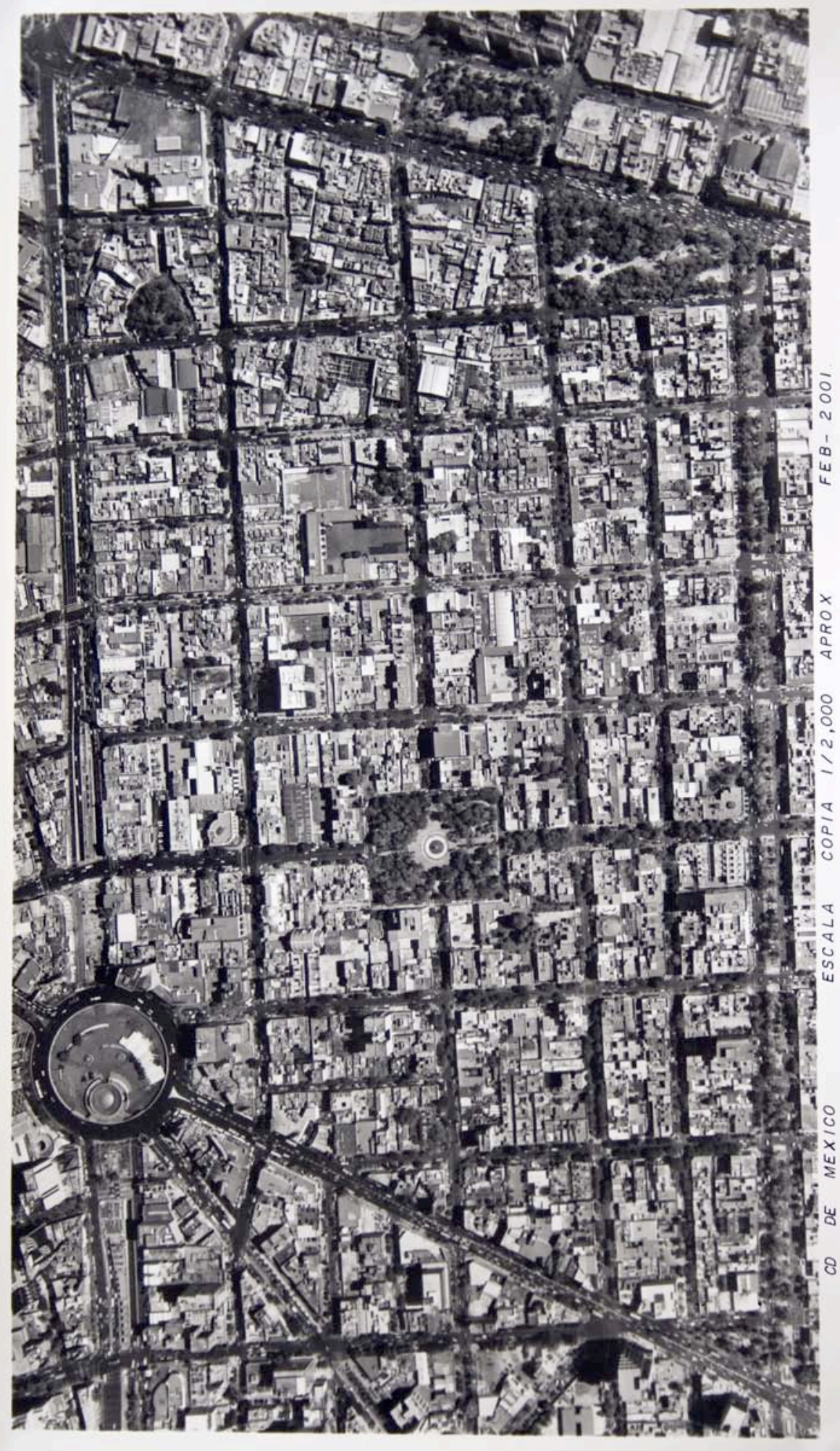

Fotografía aérea de la colonia Roma en 2001.

Fuente: Aerofoto S.A. de C.V. 


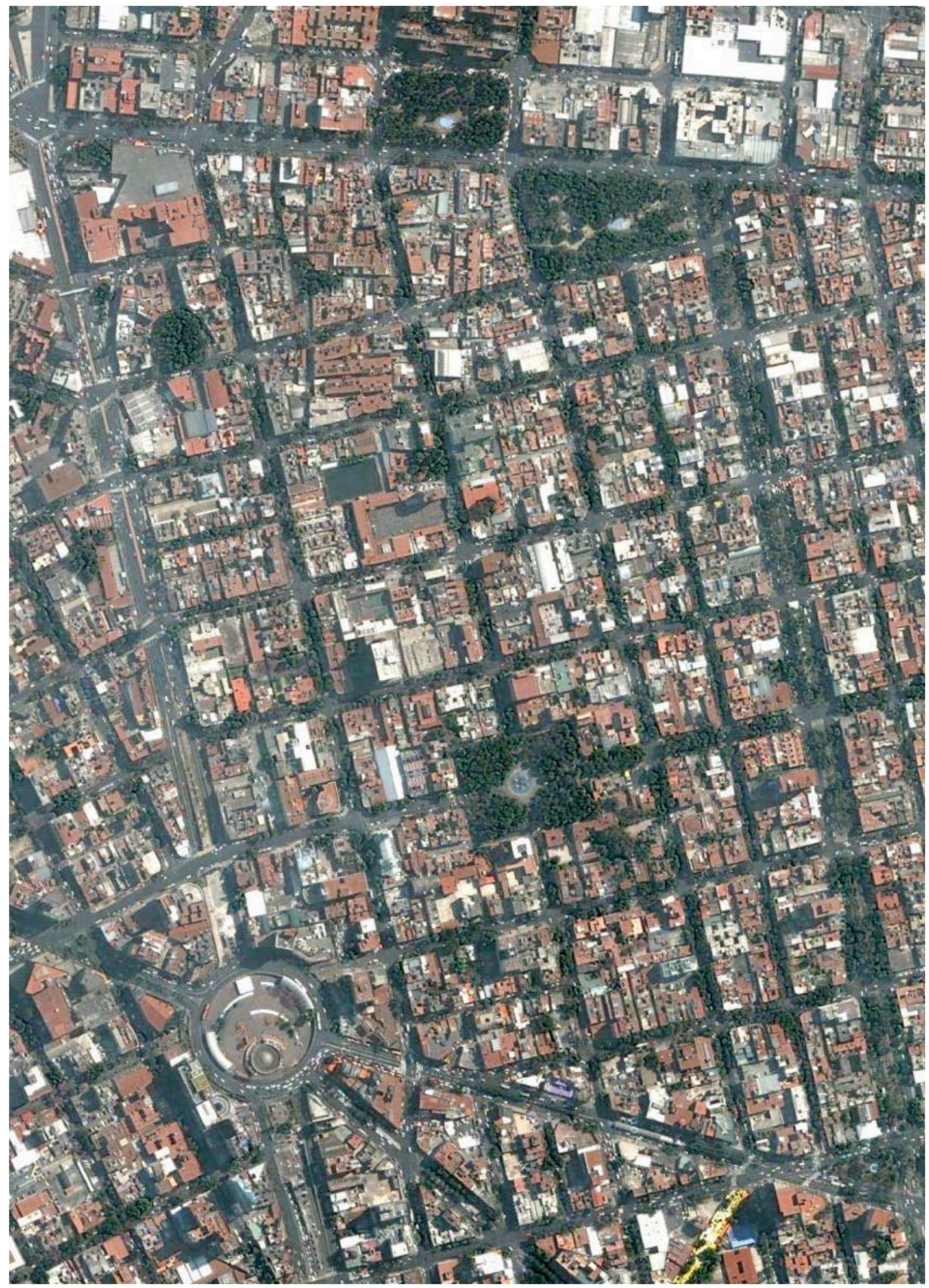

Colonia Roma, D.F., 2010, fuente: Google Earth. 
Interpretación de las fotos aéreas

En la presente investigación, emplearemos la aerofoto para analizar las transformaciones que ha sufrido nuestra zona de estudio, en el corazón de la colonia Roma, durante las últimas cuatro décadas. Pretendo comparar imágenes aéreas de esta zona de la colonia Roma, captadas en distintos momentos: 1970, 1987, 2001 y 2010. En una sesión de trabajo con Lourdes Roca, investigadora del Instituto Mora, analizamos cuidadosamente estas fotografías aéreas presentadas a continuación, enfocándonos en las transformaciones y continuidades que pueden observarse en nuestra zona de estudio a lo largo de las últimas cuatro décadas.

Para empezar, es necesario identificar y demarcar el terreno de interés; en este caso nos enfocamos en el polígono delimitado por las avenidas Chapultepec al norte, Avenida Álvaro Obregón al sur, Avenida Cuauhtémoc al este y Avenida Insurgentes al oeste. Después hay que establecer algunos puntos de referencia que sirvan como anclas al momento de leer la imagen. En nuestro caso, los lugares clave que nos pueden ayudar a notar ciertos elementos de cambio, contraste y permanencia son principalmente los parques, plazas y jardines del barrio; en primer lugar, la plaza Río de Janeiro, la Glorieta de los Insurgentes y el parque Alexander Pushkin.

Con el paso del tiempo ha cambiado considerablemente la apariencia de la plaza Río de Janeiro, pero más que un cambio de traza, ha habido un significativo aumento de la vegetación. Más arbolada cada vez, los caminitos que aparecen claramente trazados en 1970, están ahí en las siguientes imágenes e incluso en la actualidad, pero se esconden bajo las densas copas de los árboles. Entre 1987 y 2001 parece evidente que se sustituyó una fuente común y corriente por la réplica de la escultura de El David de Miguel Ángel que está en el centro de la plaza hasta la actualidad.

Un factor digno de mencionar es el incremento de árboles en la zona; ha habido un importante proceso de reforestación que hace a la Ciudad de México, a pesar del caos urbano que impera en ella, una de las ciudades más arboladas del país. Es notable cómo con los años las calles y las plazas de la Roma se han ido llenando de árboles, que con el paso del tiempo han crecido considerablemente. De acuerdo con las observaciones de Lourdes Roca, de los años 30 a los 70 hubo un periodo de deforestación de la ciudad, que se empezó a revertir de los años 70 en adelante. 
En 1970 pueden distinguirse en la zona de estudio muy pocos edificios que sobrepasen la altura promedio de las casas heredadas del Porfiriato; sólo se distinguen unos cuatro o cinco edificios altos como máximo, mientras que para 1987 pueden contarse varios inmuebles más de más de cinco o seis plantas, tendencia que se incrementó un poco hacia 2001, pero casi nada hacia el 2010, ya que desde hace varios años hay una reglamentación vigente según la cual en la colonia no se pueden construir torres de más de cuatro niveles.

En relación con nuestros casos de estudio, cabe mencionar que la escuela secundaria femenil que colinda con el edificio de Córdoba, es un referente permanente en todas las épocas retratadas, hasta la actualidad. La escuela fue un firme testigo de la transformación que aconteció a su alrededor. La Roma, desde los años 40 ó 50, ha sido una zona muy poblada de escuelas, un área muy vinculada con el sector educativo, con mucha vida estudiantil, como nos lo recuerda José Emilio Pacheco en Las batallas en el desierto. Cabe destacar que la gran cantidad de escuelas que había entonces en el cuadrante, se mantiene o incuso ha incrementado en la actualidad; la intensa vida estudiantil sigue siendo un sello distintivo de la colonia Roma.

Otros elementos del paisaje urbano apreciables desde las aturas son las calles y avenidas, y por consiguiente el tipo y la cantidad de tráfico que circula a través de ellas. Entre una y otra imagen es notable el incremento de automóviles circulando o estacionados en las calles del barrio. En cuanto al transporte público, en los años 70 todavía conviven los trolebuses con los camiones, pero después a los primeros ya no los volveremos a encontrar. Un ejemplo de cambio en el trazo urbano son los remates de las esquinas alrededor del parque Río de Janeiro, que se han ido perdiendo con los años; también se han modificado los pasos peatonales, que se van reduciendo cada vez más.

Tal vez podrían ubicarse alguno de los ya desaparecidos cines de barrio, como los que menciona González Morantes (2009), algunos todavía existentes en los años 70. Siguiendo este mismo procedimiento, podríamos rastrear el paradero de los casos concretos de inmuebles referidos en las memorias y testimonios de los vecinos e historiadores especialistas en la colonia Roma. Entre estos casos, están el del edificio de la Arquidiócesis y el de la torre de oficinas arriba del Banamex. En este último caso, en 1970 todavía se distingue la antigua casa arbolada, el famoso y memorable 
jardín del trenecito, mientras que en 1987 ya no existe más, y en su lugar se levanta una torre de oficinas de unos diez pisos.

De 1970 a 1987 hubo grandes cambios en el paisaje urbano de la Roma causados por el temblor de septiembre del 85 . Un caso específico que rinde testimonio del cambio drástico que sufrió la colonia Roma con el terremoto, son los multifamiliares Juárez, construidos por Mario Pani. Entre los edificios que se vinieron abajo con el terremoto, en la frontera de nuestra zona de estudio, al otro lado de la avenida Cuauhtémoc, frente al parque Alexander Pushkin, en 1970 había una gran construcción habitacional, que en 1987 quedó reducida a un terreno inhóspito de tierra, y más tarde se convertiría en el Jardín Chávez, un arbolado parque con una fuente en el centro. Otro edificio de altura considerable que desapareció entre 1970 y 1987, muy probablemente afectado por el sismo del 85, estaba ubicado cerca del cruce de las calles Durango y Tonalá. ¿Cuántos edificios más se cayeron en esta zona? 


\section{Mapas de obras en el cuadrante estudiado}

Siguiendo con la visión macro, presentaré una serie de mapas que muestran la cantidad de obras que proliferaron en esta zona en el lapso de unos meses, en 2008. Primero me enfocaré en el cuadrante formado por Av. Chapultepec, Av. Cuauhtémoc, Antonio M. Anza y las avenidas Yucatán, Monterrey e Insurgentes Sur. La calle de Córdoba atraviesa este cuadrante por el centro, de norte a sur.

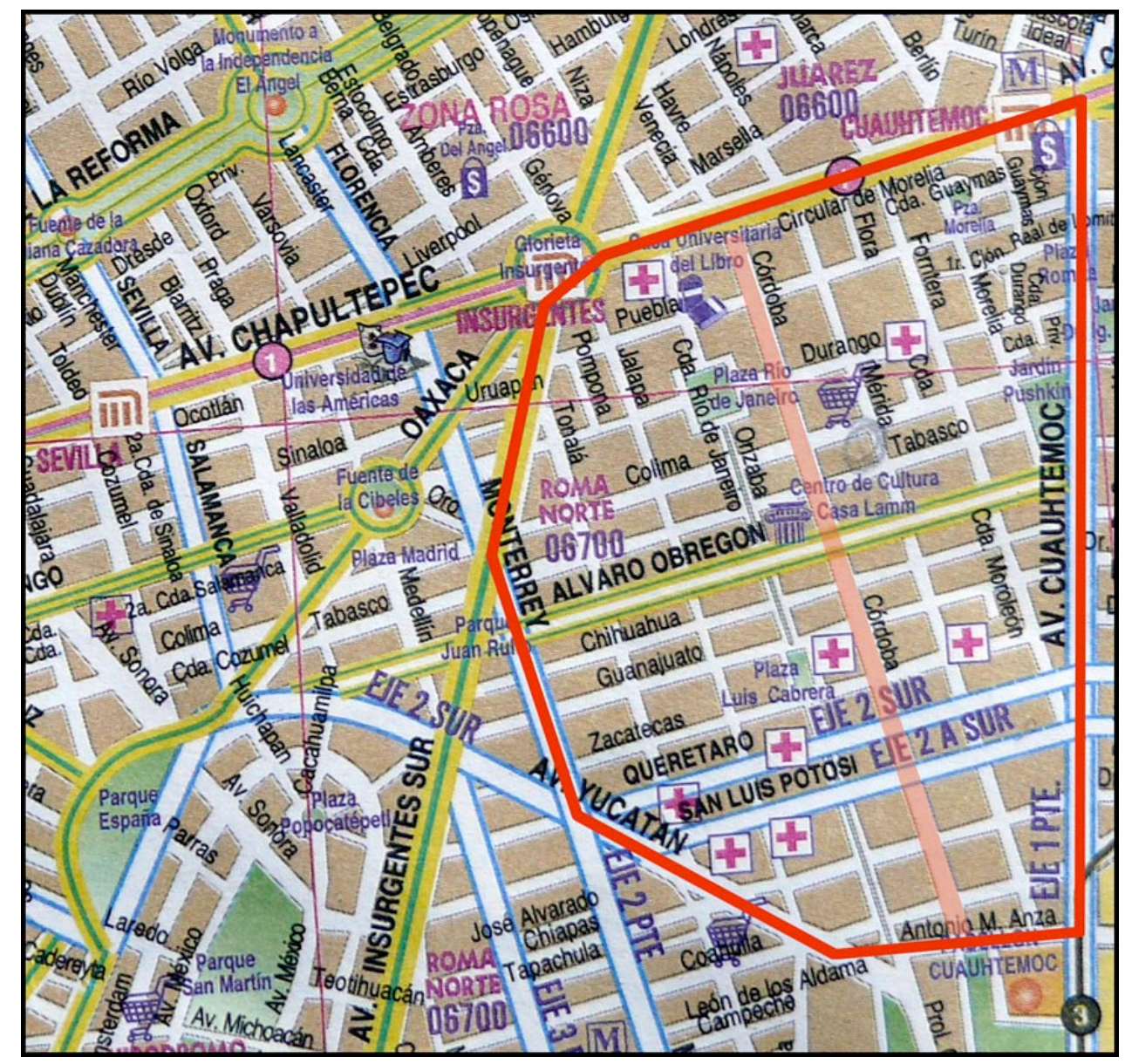

A lo largo de sus trece cuadras, desde Avenida Chapultepec hasta la calle Antonio M. Anza, sobre la calle de Córdoba hay trece edificios de departamentos nuevos (construidos en los últimos tres años) o aún en construcción, cantidad equivalente a un edificio nuevo por cuadra. Las dos obras estudiadas en la presente tesis se encuentran entre estas obras señaladas. 


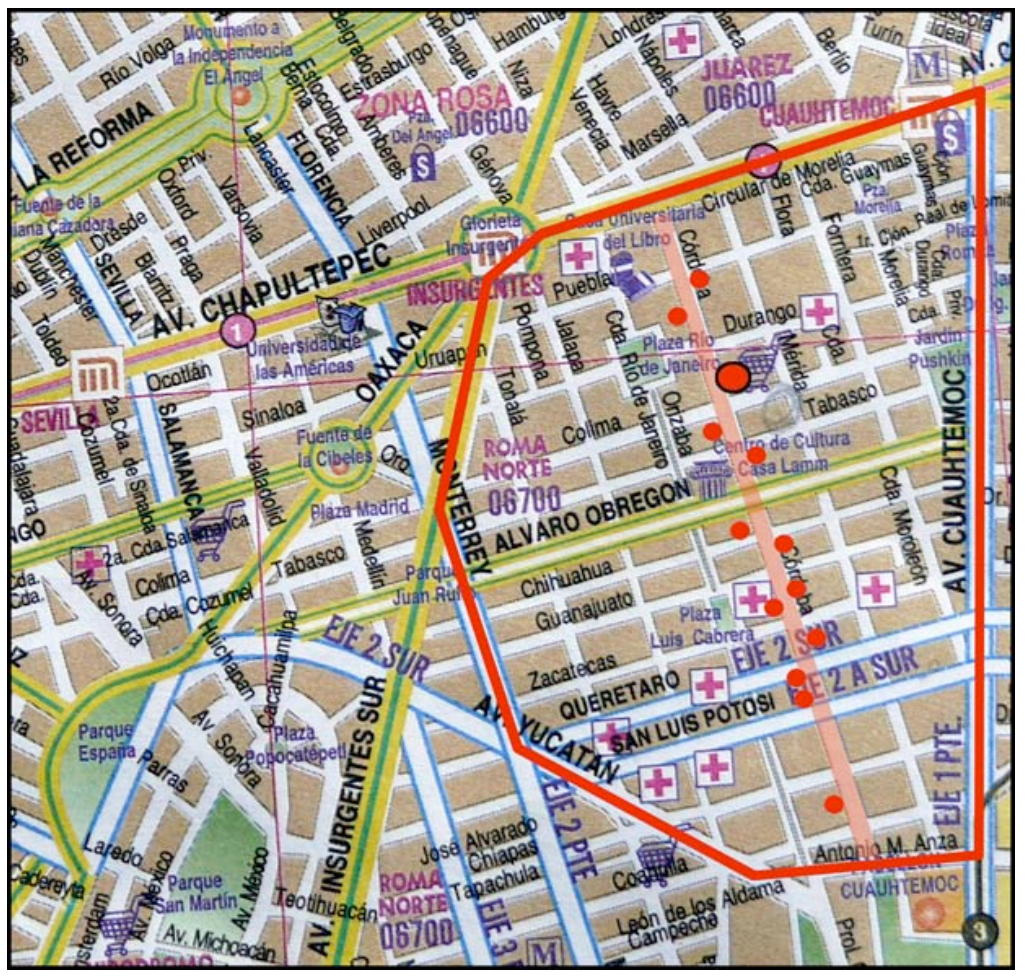

Y si nos enfocamos sólo en la mitad norte de este polígono, cortando por Álvaro Obregón, encontramos un total de veintiséis nuevos edificios de departamentos en este cuadrante que conforma nuestra principal zona de interés.

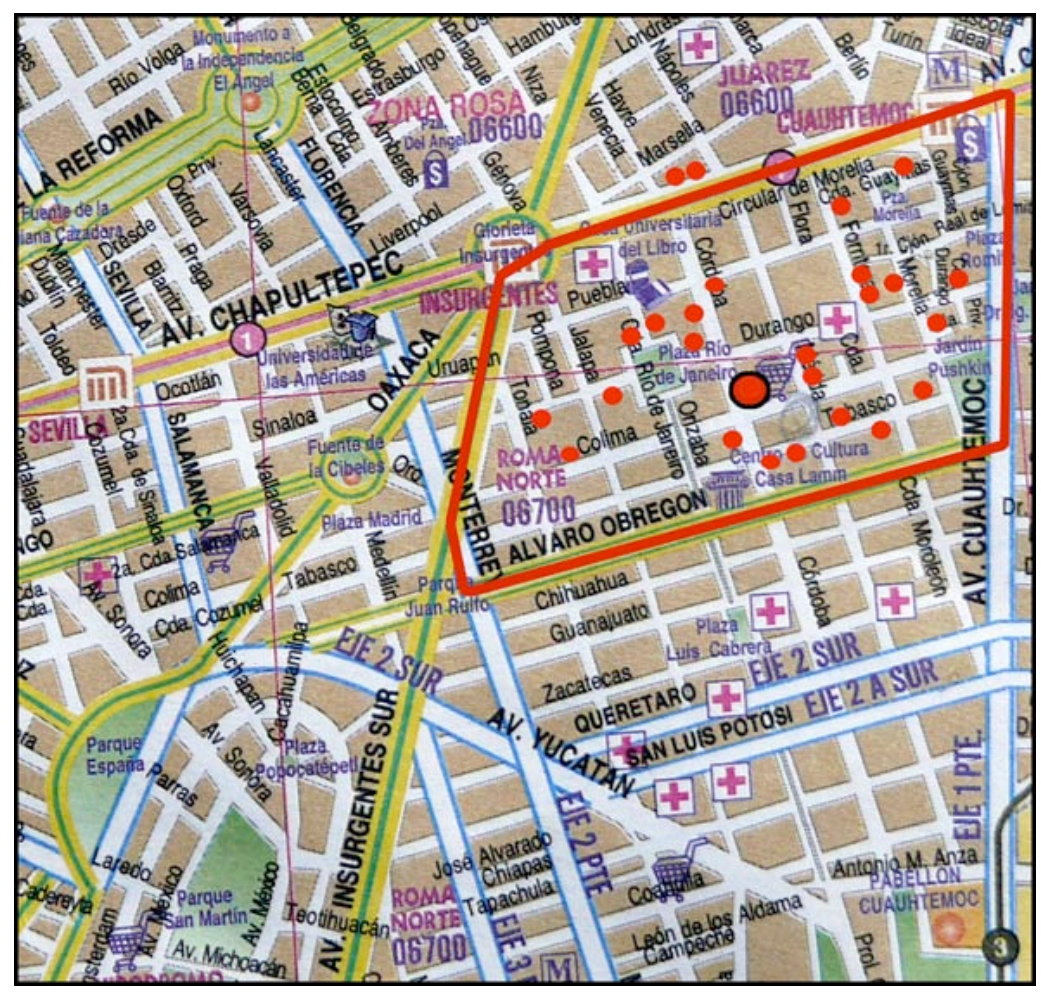


Estos números reflejan claramente el boom constructivo que vive la colonia Roma, al igual que muchas otras colonias pertenecientes a las cuatro delegaciones centrales del D.F.. Lo más interesante desde la perspectiva antropológica es que cuando estos edificios estén terminados y habitados, la densidad poblacional aumentará significativamente; así, estas nuevas viviendas que ahora se construyen, generarán considerables cambios sociales y culturales en el futuro próximo.

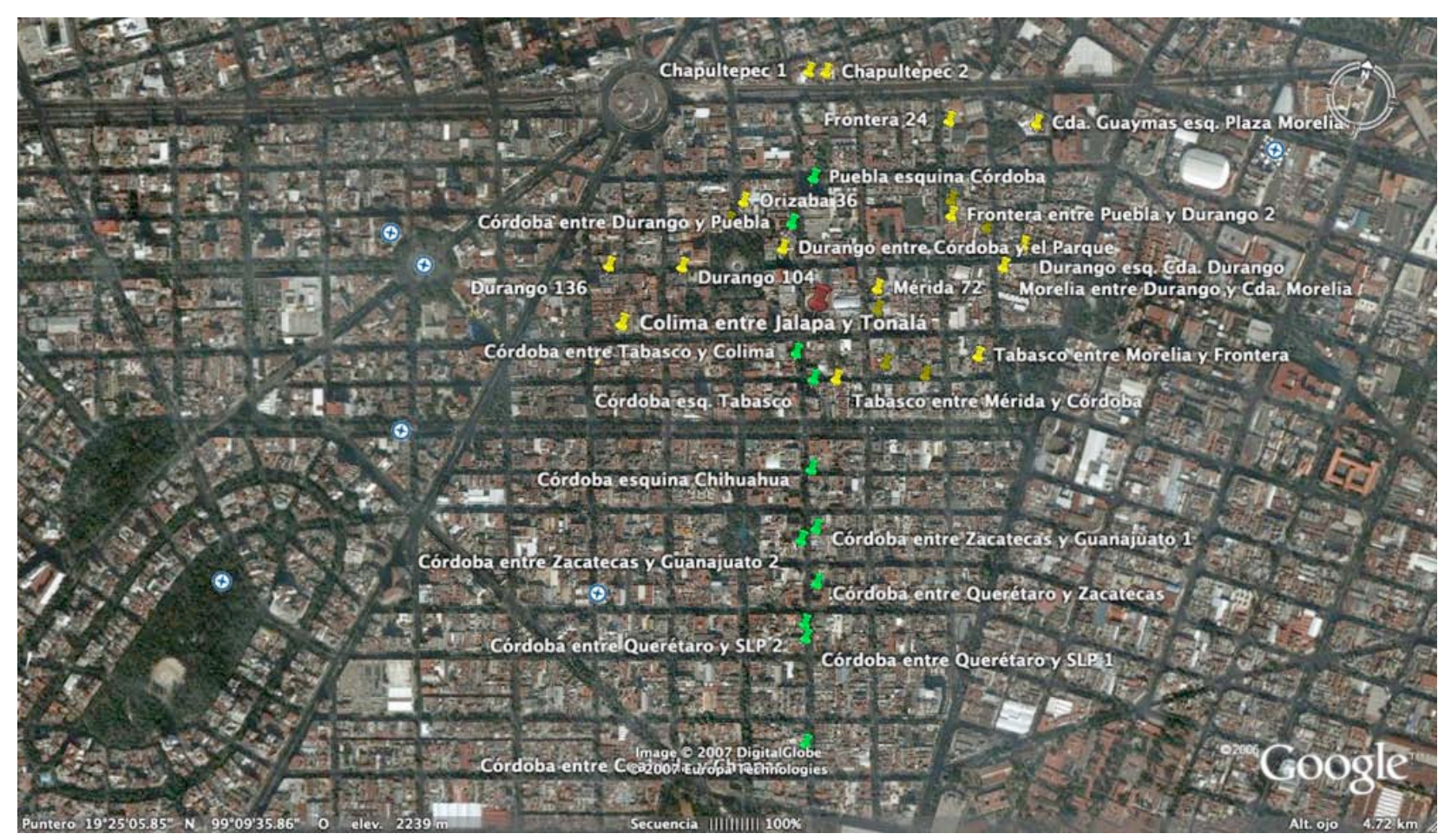

Observaciones en torno al mapeo de obras

Un dato relevante es que desde que elaboré el primer mapa de las nuevas construcciones en la zona, constantemente tuve que actualizarlo; frecuentemente encontraba alguna obra en el cuadrante que agregar al mapa. Por doquier aparecían nuevas construcciones similares a las estudiados en esta tesis. A continuación cito tres casos que ya no aparecen contemplados en el mapa arriba presentado.

1) Hay una nueva construcción de un edificio de viviendas en Colima 175, entre Orizaba y Córdoba. Esta obra empezó el 19 de junio de 2008, según dice en el permiso de construcción tipo $B$, que vence hasta 2010. La propaganda de la compañía constructora anuncia "24 departamentos exclusivos" en una "zona 
catalogada", de "102 y 112 m", con "2 ó 3 recámaras", "pisos de duela y terrazas de teka", "dos cajones de estacionamiento por departamento" y "roof garden"... "Te ofrecemos lo mejor de la colonia Roma", dice su slogan.

2) Hay otro edificio en construcción en la esquina de Córdoba y Tabasco, donde al parecer trabajan a marchas forzadas, con muchos obreros trabajando a un ritmo mucho más acelerado que en otras obras. Le pido información sobre el edificio a un trabajador que está parado afuera. Será un edificio de 16 departamentos en cuatro plantas, y la construcción estará lista para mediados de este año (2008), me dice.

3) Sobre Álvaro Obregón, entre Córdoba y Mérida, descubro otro terreno en el que están terminando de demoler un inmueble para inmediatamente empezar a construir un nuevo edificio de tres plantas con doce departamentos, según me informa un trabajador desde el techo.

\section{Vistas panorámicas de la Roma}

Desde la azotea del edificio construido en la calle de Córdoba, y más aún desde la torre donde está colocado el tinaco, la vista de los edificios de alrededor es bastante privilegiada. Edificios construidos hace un par de décadas conviven junto con otros mucho más modernos, con caras de espejos y formas irregulares, así como con casas relativamente antiguas, tendederos, tinacos Rotoplás, antenas parabólicas, tanques de gas, anuncios espectaculares, etc. Desde cierto ángulo sobresale el remate de la torre del "Edificio de las brujas", precisamente la parte que correspondería al sombrero de la bruja. Desde la planta de arriba, entre los castillos de varilla, sobresale en el fondo la punta de la Iglesia de la Sagrada Familia, en la esquina de Orizaba y Puebla, un icono de la colonia Roma. El edificio verde de la escuela, junto con otro más alto que está inmediatamente atrás, enmarcan el paisaje urbano desde la cima de este nuevo edificio.

Curiosamente, a unos cien metros de distancia, más allá de la azotea del edificio que está justo enfrente, ya sobresale otra obra: es la que está sobre la calle de Colima, entre Orizaba y Córdoba. Se ven varios trabajadores moviéndose entre castillos de varillas, como si fuera un reflejo de lo que sucede donde estamos parados. Como si hubiera un gran espejo en el fondo del paisaje urbano que nos devuelve nuestra propia imagen. 
Desde la azotea de la obra de Puebla hay muy buena vista de la cuadra de enfrente: en contraesquina hay un edificio con fachada de cantera que seguramente tendrá cerca de 100 años. La altura a la que ha llegado el edificio donde estoy permite apreciar el panorama elevado en el que se alcanza a distinguir a lo lejos la Torre Latinoamericana, algunos edificios también en construcción, como el de Reforma 222, anuncios espectaculares, la M de McDonald's y en un primer plano casonas antiguas y arboladas típicas de la Roma norte. Me percato de que el skyline de la Ciudad de México está delineado en gran parte por la figura de los tinacos Rotoplás, las jaulas de azotea y las antenas de televisión.

El panorama urbano resultante puede leerse como un palimpsesto hecho de parches sucesivos, estéticamente se asemeja a un collage de inmuebles de distintas épocas y estilos. La historia arquitectónica y constructiva propia de la colonia Roma, es un buen ejemplo de lo que Juan Villoro (2005) llama "nuestra aniquiladora forma de mezclar culturas", que ha caracterizado al desarrollo urbano de la ciudad en la última parte del siglo XX.

\section{Presentación general de los casos estudiados}

Como parte de la labor etnográfica que sustenta la presente investigación, abordé dos distintos casos de obras de construcción de edificios de departamentos en la colonia Roma. A continuación presentaré a grandes rasgos las características generales de dichas obras. Cabe mencionar que una de ellas, la obra ubicada en la calle de Córdoba \#74 (en adelante referida simplemente como la obra de Córdoba) constituyó mi principal terreno de estudio, puesto que fue mi proyecto original y mi interés primordial. Sin embargo, por circunstancias que más adelante explicaré, eventualmente me sentí atraído a otra obra con características similares, a unas cuadras de distancia, en la calle de Puebla \#108, en la esquina con Córdoba (en adelante referida simplemente como la obra de Puebla), perteneciente a la misma compañía constructora, llamada DAKAB.

\section{La obra de Córdoba}

En el número 74 de la calle de Córdoba, en el tramo comprendido entre las calles de Durango y Colima, en la colonia Roma Norte, Delegación Cuauhtémoc, Ciudad de 
México, me encontré con la inminente construcción de un edificio de departamentos. De acuerdo con la información que se podía leer en un letrero afuera del terreno todavía vacío, se trataba de "un desarrollo más de Grupo Inmobiliario DAKAB SA", que ofrecía, desde esos primeros momentos, información sobre la preventa de departamentos vía telefónica o en el sitio web de la empresa: www.dakab.com.mx.

Cabe destacar que el terreno en el que se construiría el nuevo edificio funcionaba desde hacía varios años como estacionamiento. El piso era de grava y en las paredes estaban pintados los números que marcaban cada uno de los cajones. Según el mismo cartel promocional, que anunciaba las características generales de la construcción, se trataría de un edificio de cuatro plantas con once "exclusivos" departamentos. Se ofrecían diferentes tipos de departamentos, a elección del cliente: de 1 ó 2 plantas y de diversas medidas: $83 \mathrm{~m}^{2}, 87 \mathrm{~m}^{2}, 105 \mathrm{~m}^{2}$, con vista a la calle o al jardín, con 2 ó 3 recámaras, con 1 ó 2 cajones de estacionamiento. Todos los departamenteos contarían con cocina y baños totalmente acabados, terrazas privadas, vigilancia las $24 \mathrm{hrs}$, elevador y roof garden. Los precios oscilaban entre un millón y medio de pesos $(\$ 1,490,000)$ y $\$ 2,700,000$. La obra comenzó a mediados de noviembre de 2006 y el proyecto de construcción estaba previsto que duraría diez meses.

Según la descripción que ofrecía la misma compañía en su sitio web, este nuevo desarrollo inmobiliario:

Se encuentra ubicado en el corazón de la colonia Roma, a una cuadra de la Plaza Río de Janeiro. Modernos y funcionales departamentos... Todo lo que usted busca para vivir la vida como se lo merece... Córdoba \#74 es un edificio de formas simples y elegantes, que juegan con volúmenes para crear así su identidad. Las líneas sencillas y sofisticadas permiten que estos departamentos sean atemporales. Su diversidad de espacios genera distintas atmósferas de convivencia que invitan a disfrutar de todo el inmueble (www.dakab.com.mx).

\section{La obra de Puebla}

A principios de febrero de 2007, después de tres meses de trabajo de campo en la obra de Córdoba, Antonio Bobadilla, el supervisor en jefe de la misma, me informó que DAKAB pronto comenzaría un nuevo desarrollo muy cerca de ahí, en la esquina de las calles de Puebla y Córdoba, a dos cuadras de la obra de Córdoba. Según me contó en aquella ocasión, se trata de un terreno considerablemente más grande, así 
que construirán dos torres de cuatro pisos, con 15 departamentos cada una, o sea, un total de treinta nuevas viviendas. Bobadilla calcula que ya empezarán a construir pronto, a fines de marzo o principios de abril, a más tardar.

De acuerdo con la información proporcionada por la propia empresa DAKAB en su página electrónica:

El conjunto residencial está constituido por dos torres $A$ y $B$, cuyos amplios departamentos de 2 y 3 recámaras, servicio de elevador, terraza y jardines interiores, dan origen a un espacio actual, confortable y asimismo de excelente ubicación. La exclusividad que resguardan los departamentos le ofrecen a sus residentes la seguridad, privacidad y tranquilidad para una excelencia de vida plena. Nos preocupamos por la armonía, el confort y el diseño para lograr el reflejo de estilo y clase que definen el buen vivir.

Un par de semanas más tarde, el maestro de obra me comentó que probablemente la próxima semana comenzarían a llevar trabajadores al nuevo lote de Puebla, para desmantelar unas estructuras de metal que había originalmente y que aún permanecían en aquel terreno. Según me dijo, posiblemente emplearían a algunos de los mismos trabajadores que ya laboraban en la obra de Córdoba, además mano de obra nueva, contratada especialmente para este nuevo desarrollo.

"La gran ventaja que tenemos con respecto a la mano de obra es que las dos obras van a estar bien cerca, de manera que los trabajadores pueden ir y venir de una a otra según los vayamos necesitando", concluyó el maestro Nicolás.

A los pocos días, pasé caminando frente al terreno de Puebla y observé que ya habían colocado láminas metálicas sobre una pared de madera que delimita el terreno, así como sobre la puerta de entrada que fabricaron los carpinteros, ganándole unos cuantos centímetros a la banqueta. Ese día encontré abierta la puerta del terreno y me metí a explorar con curiosidad. El terreno era rectangular, plano, considerablemente más extenso que el de Córdoba, por lo menos unas tres veces más amplio, calculé... Para mi sorpresa, a principios de marzo de 2007, mucho antes de lo que esperaba por lo que me habían anunciado, empezaron a trabajar en la obra de Puebla.

\section{Trayectoria de "DAKAB Grupo Inmobiliario"}

Un aspecto relevante para comprender el auge constructivo en la Ciudad de México a partir de la primera década del siglo XXI es la emergencia de numerosas empresas 
constructoras privadas, responsables en buena medida del boom inmobiliario. Estas compañías constructoras invierten y realizan la mayor parte de estos desarrollos inmobiliarios, con ayuda del gobierno local, a través de créditos hipotecarios, facilidades, beneficios. Son estas además las grandes beneficiarias de las ganancias económicas derivadas de este negocio multimillonario. La existencia y evolución de estas empresas es un indicador de que la industria de la construcción constituye un motor que impulsa la economía nacional, y sugiere que la transformación de la ciudad sigue una lógica de mercado.

Sin hacer un examen detallado de la cantidad ni de la naturaleza de estas empresas, ni de sus formas de operación, sino solamente ateniéndome a la información empírica obtenida a lo largo de mi periodo etnográfico, a continuación presentaré y reflexionaré sobre el caso de la empresa constructora DAKAB, su origen y trayectoria.

Para comenzar, quisiera hacer una revisión del discurso con el que la empresa $D A K A B$ se presenta en su página web. Con música ambiental de fondo, estilo lounge, que busca transmitir una sensación de relajamiento, comodidad y sofisticación, se lee la siguiente información:

DAKAB Grupo Inmobiliario construye y promueve desarrollos inmobiliarios integrales e innovadores, basados en la modernidad y vanguardia, con la finalidad de ofrecer espacios habitacionales que cubran las necesidades y mejoren la calidad de vida de nuestros clientes... Nuestra principal inspiración son nuestros clientes, gracias a ellos tenemos la capacidad y la motivación para diseñar espacios habitacionales e inmuebles pensando siempre en su completa satisfacción... DAKAB es un joven y creciente grupo inmobiliario dedicado a construir espacios originales, amplios y de creciente plusvalía. Creamos modernas y funcionales residencias con la finalidad de que disfruten el mayor número de personas, al precio más conveniente. Nuestra amplia experiencia y un profundo conocimiento del sector inmobiliario nos han permitido crear DAKAB Grupo Inmobiliario. Comenzamos operaciones en septiembre del 2006, creando un nuevo concepto de bienes inmuebles, en donde no solo se piensa en la construcción, sino en los espacios y en los momentos, en el ideal de vivir en perfecta armonía y en un entorno lleno de seguridad y vanguardia. Trabajamos todos los días en el desarrollo de una mejor calidad de vida para las personas. Hacemos un especial énfasis en el desarrollo urbano aportando a la transición armónica de las colonias donde se ubican nuestros proyectos, de tal forma que trasciendan en el tiempo y marcar así el inicio de una nueva era. 
Vale la pena subrayar algunos puntos que salen a relucir a partir de esta información. En primer lugar, el tono comercial y la imagen según la cual la empresa hace todo por el cliente, pensando únicamente en su beneficio, sin mencionar en ningún momento la conveniencia que el negocio representa para los inversionistas. El tono del mensaje, que en primera instancia podría parecer personalizado, resulta ser completamente impersonal, de cualquiera para cualquiera.

Algunos datos me parecen importantes. Primero, que se trata de un “joven y creciente grupo inmobiliario", recientemente creado, pero que, no obstante, tiene un "profundo conocimiento del sector inmobiliario". Esto podría parecer contradictorio; sin embargo es factible, ya que, como se verá más adelante, esta empresa no surgió de la nada, no empezó de cero, sino que fue impulsada y respaldada por otra empresa inmobiliaria de mucho mayor envergadura y experiencia, como se explicará más adelante. En este sentido, llama la atención que una empresa emergente tenga sus oficinas en una zona tan exclusiva y costosa de la ciudad, como las Lomas de Chapultepec.

Hay tres conceptos o valores en los que insiste el discurso de esta empresa: amplitud, calidad de vida y plusvalía, pero los tres son bastante relativos y cuestionables. En primer lugar, no parece que un departamento de $83 \mathrm{~m}^{2}$ se caracterice precisamente por su amplitud; posiblemente lo sea para una familia de clase baja que vive en una vecindad, pero definitivamente no lo es para el sector de la población que podría acceder a estos departamentos. En cuanto a la calidad de vida, esta noción igualmente depende de los trasfondos y aspiraciones de cada quien; no obstante, como se argumentará más adelante, este tipo de edificios "exclusivos" promueven el aislamiento más que la convivencia entre sus habitantes y con los vecinos de la colonia, la que cada vez tiene más problemas de tráfico, agua, basura, y que es altamente vulnerable a los sismos e inundaciones, de modo que el edificio está lejos de corresponder con el ideal de calidad de vida que se intenta proyectar. Por estos mismos motivos y otros que tienen que ver con el rápido deterioro de los materiales utilizados en la construcción de este tipo de edificios, tampoco me parece que la plusvalía de estos departamentos sea tan atractiva como se plantea, y menos aún considerando la enorme competencia y la sobreoferta que hay actualmente en la zona. 
Pero quisiera hacer hincapié sobre todo en lo que se dice acerca del desarrollo urbano y su supuesta aportación a una "transición armónica" de las colonias donde se ubican sus proyectos. Cabe preguntarnos si en DAKAB tienen realmente una noción profesional, seria y responsable del desarrollo urbano que resultaría más conveniente para cada colonia. ¿A qué se refieren con transición armónica, entre qué y qué facetas o estadios de las colonias? ¿Qué características vislumbran para esa nueva era que pretenden iniciar? ¿Qué es lo que pretenden dejar atrás y hacia dónde apuntan exactamente sus desarrollos inmobiliarios, además del negocio y la ganancia económica?

Me parece que este afán de ruptura con el pasado, la pretensión de marcar un época y crear distinciones al interior de una colonia como la Roma, contradice el ideal de desarrollo urbano según el cual distintos estilos deberían poder convivir armónicamente. El discurso de la empresa denota un afán por imponer un nuevo estilo, ignorar lo preexistente, olvidar el patrimonio arquitectónico anterior y el valor histórico de esta colonia. Además, me parece que su estilo arquitectónico, identificado por algunos conocedores del tema como "arquitectura chatarra", con materiales y diseños prefabricados, acabados toscos, lejos de trascender en el tiempo y representar digna y orgullosamente a una época, dentro de pocos años pasará de moda; los edificios de esta época se deteriorarán aceleradamente y pasarán a ser vestigios de una época en la que la lógica económica imperó sobre los valores del desarrollo urbano, la calidad de vida y el patrimonio cultural y arquitectónico.

Ahora bien, en cuanto a la trayectoria de DAKAB, es importante destacar que la obra de Córdoba, cuyo desarrollo registré de principio a fin, era tan solo la segunda construcción que esta empresa realizaba en su breve historia. El primer proyecto de construcción con el que esta empresa había comenzado estuvo ubicado en la calle Patricio Sanz \#1924, en la Colonia del Valle. Los departamentos de este primer desarrollo tienen más o menos las mismas características, medidas y apariencia que los de la obra de Córdoba, lo que significa que siguieron casi la misma fórmula en ambos casos, y también en los desarrollos posteriores.

El tercer proyecto que esta compañía emprendió fue la obra de Puebla \#108, también en la colonia Roma, construcción parcialmente registrada como parte de esta investigación. $Y$ al poco tiempo de haber comenzado esta tercera obra, me 
enteré, gracias a los trabajadores, del comienzo de otro desarrollo inmobiliario más de esta misma empresa, esta vez ubicado en la calle Sánchez Azcona \#1611, en la Colonia del Valle. Al finalizar la obra de Puebla, supe que DAKAB comenzaba otra construcción más en la colonia Roma, nuevamente en la calle de Córdoba \#48, entre Durango y Puebla, a muy pocos metros de la obra de Puebla.

En fechas posteriores a la terminación de mi trabajo de campo, revisando la página web de la empresa, supe que iniciaron un nuevo desarrollo inmobiliario en la calle Guadarrama \#7, en las Lomas de Chapultepec. El edificio que ahí se construye parece ser de más lujo que los anteriores proyectos de DAKAB, más pretencioso todavía. Por otro lado, además de estos edificios en la Ciudad de México, DAKAB ha iniciado otro proyecto en Ensenada, Baja California, de perfil más vacacional, con unos 70 departamentos. Con esto DAKAB sumaba cinco desarrollos en las colonias Roma y del Valle en menos de dos años, además de estos otros desarrollos fuera de la zona. Esto representa indudablemente un crecimiento bastante considerable para una empresa constructora que recién despegaba, lo cual es revelador de las infraestructura y buen manejo de la empresa, por un lado, y por el otro del contexto apropiado en esta zona de la ciudad, donde las condiciones fueron por demás propicias para que este crecimiento fuera posible.

Además de esta información que la misma empresa proporciona públicamente, contrastada con mis propias impresiones a partir del trabajo etnográfico, me parece fundamental hablar de la trayectoria y la naturaleza de la empresa DAKAB desde la perspectiva de algunos de sus trabajadores de confianza, que han vivido de cerca y han participado en este desarrollo. Su percepción es importante ya que constituye una visión desde dentro, más personal y mejor informada que la mía, y más realista que el discurso con el que la empresa se promociona. De hecho, más que interesarme por rastrear la real y verdadera historia de DAKAB, me interesan las perspectivas y los puntos de vista, e incluso el imaginario de los trabajadores sobre sus proveedores de empleo, su percepción de la desigualdad social.

Silvano, uno de los maestros encragados de la obra, me habla de cómo surgió $D A K A B$. Menciona que se trata de una filial de un corporativo mucho más grande, Grupo DANHOS, que tiene muchas obras de todas las escalas por todo el país. Dice que "después de ICA, la constructora más grande en México desde siempre, ésta es la cuarta o sexta constructora más importante". Según Silvano, esta gran empresa, 
DANHOS, pertenece a una familia muy adinerada y su origen se remonta tres generaciones atrás. En otra ocasión, un trabajador conocido como El Gato, se refiere al Grupo DANHOS como una constructora enorme, un gran corporativo de dueños "judíos hinchados de billete", que también son dueños de las tiendas de ropa Óptima.

Braulio, el maestro electricista, en una conversación informal y espontánea, me cuenta que lleva mucho tiempo trabajando en casi todas las construcciones de edificios y centros comerciales que ha hecho el Grupo DANHOS. Son responsables de grandes edificios en zonas residenciales lujosas, como Bosques de las Lomas, Polanco y Santa Fe, y también han construido torres de oficinas, como una en Insurgentes Sur y Periférico, junto a Villa Olímpica, que le renta a la empresa Elektra para albergar sus oficinas. Son dueños proporcionales de varias construcciones grandes, famosas y emblemáticas. En esos casos, no venden los espacios sino que los rentan para oficinas, $y$ de ahí obtienen grandes ganancias. Asimismo, DANHOS ha construido centros comerciales como Parque Delta, en la esquina de Cuauhtémoc y Viaducto Miguel Alemán, donde antes estaba el parque de béisbol del Seguro Social. Ahora, en 2008, está construyendo la Torre Reforma 222, que se ve al fondo de la calle desde la obra de Córdoba; se trata de un complejo inmobiliario que incluye un centro comercial en los primeros pisos, departamentos y oficinas en el resto del gran edificio. Me cuenta Braulio el electricista que el "arqui" también ha construido edificios de departamentos de interés social en Villa Coapa y en Satélite. Él ha trabajado en todas estas construcciones haciendo toda la instalación eléctrica $y$ de gas.

Braulio me confirma que DAKAB se trata de una ramificación de Grupo DANHOS. Según me explica, DAKAB está a cargo del hijo del arquitecto, quien acaba de comenzar su propia empresa, pero con todo el apoyo y la infraestructura del padre. Por su parte, El Gato me cuenta una versión parecida: que DAKAB se creó cuando uno de los dueños de Grupo DANHOS heredó en vida a su hijo: "le dijo: tú ya te titulaste de arquitecto; toma 100 millones de dólares para que empieces tu empresa, si los pierdes, te las arreglas tú solo como puedas, no te voy a dar nada más". Entonces el hijo se movió, buscó socios e invirtieron en varios terrenos en la del Valle, la Roma y así arrancaron. "En un año han crecido como espuma y todo el dinero que han ganado lo siguen reinvirtiendo en nuevos proyectos", de acuerdo 
con el relato del Gato. Comentamos sobre las enormes desigualdades en cuanto a oportunidades en el arranque de la vida, "lo injusto es que unos empiezan de cero y otros con 100 millones de dólares en la bolsa... así quién no la arma", insiste. Pero también dice que está conciente de lo importante que son los estudios para salir adelante en la vida; "si yo hubiera sido bueno para la escuela, otro gallo hubiera cantado", a lo que le contesto que, tristemente, hoy en día ni siquiera los estudios garantizan tener un buen trabajo.

\section{Comercialización del espacio}

A continuación reflexionaré sobre las nuevas formas de comercialización del espacio urbano. Retomaré las ideas de algunos autores que han interpretado de manera crítica las transformaciones recientes del espacio urbano y la lógica detrás de estos cambios. Pero sobre todo echaré mano de mi propia experiencia etnográfica con respecto al marketing y la publicidad inmobiliaria en los casos estudiados.

En su artículo "Cultura global a la venta: vivienda, imágenes sociales y marketing en Santa Fe, Ciudad de México" (2009), María Moreno Carranco se concentra en el desarrollo urbano de la zona de Santa Fe, que tiene características muy singulares. No obstante, destaca algunos aspectos que pueden aplicarse de manera general a muchos nuevos desarrollos habitacionales; reflexiona sobre el mercado inmobiliario, la publicidad que utilizan, la segregación social que fomentan y los imaginarios de la globalización en los que se fundan. Cabe destacar en principio que la publicidad y la mercadotecnia han alcanzado nuevos niveles de importancia. "El análisis de los discursos de la mercadotecnia, en imágenes y en palabras, ilustra sobre los elementos tangibles e intangibles considerados como valiosos por los potenciales residentes de los nuevos desarrollos habitacionales" (Moreno, 2009: 208).

Algunas de las formas, quizás las más evidentes, de apropiación y uso del espacio urbano son la privatización, compraventa y especulación del suelo urbano. En este apartado reflexionaré sobre las estrategias mercantiles de la empresa constructora DAKAB. Pretendo describir los modos de venta, comercialización y mercantilización del espacio urbano que llevan a cabo empresas constructoras privadas, a través de los cuales se apropian, construyen, fraccionan y luego venden por partes la ciudad en forma de viviendas. Las estrategias comerciales de DAKAB son representativas de 
las que emplean este tipo de compañías inmobiliarias. El patrón parece ser básicamente el mismo. Nuevamente, quisiera advertir al lector que no encontrará aquí un estudio de mercadotecnia, ni estadísticas comparativas, ni un análisis minucioso del mercado inmobiliario en la colonia Roma ${ }^{9}$. Simple y sencillamente me limitaré a relatar algunos fenómenos, prácticas y acontecimientos atestiguados y registrados durante mi trabajo de campo, que tienen que ver de una u otra manera con el aspecto mercantil, comercial o publicitario relacionado con el mundo de la construcción de nuevos edificios de departamentos.

\section{Ataque al imaginario}

En primer lugar, hay que tomar en cuenta que, como todas las campañas publicitarias, la mercadotecnia empleada por DAKAB busca conquistar el imaginario de los clientes potenciales. Más que promocionar los bajos costos o las conveniencias prácticas del negocio que ofrecen, sus mensajes están claramente dirigidos al mundo abstracto de las ideas y deseos de los posibles compradores, intentando transmitirles una imagen que se asemeje al lugar de sus sueños y aspiraciones. Estos discursos publicitarios están dirigidos a "un nicho muy específico de mercado, el de las clases medias y altas, que son fácilmente seducidas con estilos de vida asociados a los de países desarrollados" (Moreno, 2009: 210).

En este sentido, llama la atención el lema mismo de la empresa DAKAB: "Construyendo recuerdos". Otra noción a la que recurren comúnmente estas empresas inmobiliarias para promocionar sus viviendas es la de patrimonio. Le dicen a la gente que al adquirir un departamento estarán conformando un patrominio para su familia. Es interesante el uso de la noción de patrimonio por parte de las empresas constructoras, refiriéndose a un capital material y económico, sinónimo de seguridad social, que poco tiene que ver con la noción antropológica de patrimonio cultural, histórico o artístico de la humanidad.

Llama la atención el contraste entre el estado prematuro de la obra y la imagen comercial del producto acabado que venden, y sobre todo, resulta irónico el contraste entre las dinámicas sociales que se suscitan al interior de la obra y la proyección imaginaria de cómo será la vida en estos departamentos. No cabe duda

\footnotetext{
${ }^{9}$ Un estudio de este tipo, sobre la dinámica inmobiliaria habitacional en la Colonia Roma, puede encontrarse en la tesis de Maestría en Estudios Urbanos del COLMEX, de Adrián Benítez Ortega (2008).
} 
de que en estas primeras etapas realmente lo que se vende es una imagen, una fantasía, una ilusión del habitar, una modalidad imaginaria del habitar.

En este sentido, resultan especialmente significativas las imágenes con las que la empresa $D A K A B$, al igual que casi la mayoría de las compañías constructoras con este mismo perfil, ilustran sus discursos publicitarios. Por fuera del terreno hay varias vallas publicitarias con fotos impresas - ampliadas a gran escala- de familias bonitas y felices habitando los departamentos, sobre un fondo naranja, color identitario de la empresa. En todos los casos, representan familias "modelo" habitando felizmente sus departamentos, padres jóvenes conviviendo con sus hijos pequeños, todos rubios y de ojos claros, siempre sonrientes en sus acogedores hogares, acompañados de tecnología moderna.

En las fotos comerciales que se utilizan, los espacios que ofertan son lo de menos, y más bien muestran en primer plano a gente de tez blanca y rubia, profesionistas, adultos, alegres, compartiendo los espacios con su familia, utilizando aparatos de tecnología moderna, como celulares y laptops. En muchos casos presentan familias sonrientes con bebés recién nacidos jugando en la sala o en una habitación. Estas imágenes publicitarias, al igual que las descritas por Moreno, "muestran parejas felices, mujeres bellas y niños saludables quienes llevan a cabo actividades recreativas... todas las personas fotografiadas tienen la piel clara $y$, a menudo, el cabello rubio. Los niños son especialmente rubios, como si el vivir en estos lugares garantizara lo "güerito" a las próximas generaciones" (Moreno, 2009: 215).

Estas imágenes ayudan a ver a qué público están dirigidos estos departamentos, 0 al menos sirven para saber qué aspiran en la vida los posibles compradores de estos inmuebles, y cuáles son sus necesidades y demandas principales: cajones de estacionamiento techado, seguridad, espacio para reuniones sociales, etc. Los valores dominantes son el confort, el lujo, la exclusividad, la privacidad. La idea de exclusividad y distinción se hace patente casi en cada mensaje; entre líneas se puede leer que esto no es para cualquiera, pero puede ser para ti. En sus mensajes utilizan el lenguaje mercantil importado del boom inmobiliario de Estados Unidos: show room, roof garden, penthouse, lobby, etc.; incluso, en su afán de acercarse al primer mundo angloparlante, en ocasiones cometen el error de usar la palabra "apartamentos" en vez de departamentos. Todo lo anterior es una expresión del mundo del 'querer ser' en materia del habitar. No hay que olvidar que en DAKAB 
pretenden estar construyendo recuerdos, es decir, se venden sueños a futuro; los departamentos, en realidad, son lo de menos. "Según las mismas campañas publicitarias, lo que se está comprando es mucho más que metros cuadrados, se está comprando un nuevo concepto de vida" (Moreno, 2009: 211).

No se venden tanto los espacios, los materiales, el diseño, los servicios, sino más bien el imaginario, la fantasía, el sueño, la apariencia, el simulacro de una mejor calidad de vida, que conlleva un mayor prestigio y distinción social. "La vivienda se deja de vender primordialmente como espacio para habitar y se convierte en un significante de la pertenencia a una clase social cosmopolita, sofisticada y privilegiada" (Moreno, 2009: 208).

Moreno llama la atención sobre "el papel de la publicidad en la creación de la ciudad contemporánea", sobre "cómo la globalización es imaginada y reproducida en el entorno urbano por medio de la mercadotecnia del mercado inmobiliario" (Moreno, 2009: 207). En su publicidad, "los desarrolladores inmobiliarios explotan sistemáticamente imaginarios relacionados con lo global... la globalización puede ser imaginada, construida y explotada a través del mercado inmobiliario... Lo global aparece como signo de estatus... como soporte de la mercadotecnia". En este sentido, insiste Moreno en que debemos cuestionar "el papel de las narrativas mercadológicas en la creación de la ciudad y de la sociedad contemporáneas" (Moreno, 2009: 218).

\section{Estrategias de mercado}

Desde antes de que comenzara propiamente la obra y durante las primeras etapas de la construcción, en el exterior del terreno se colocaron letreros promocionales que anunciaban la preventa de los departamentos. Desconozco si además tenían algún otro centro de venta, pero al parecer el sistema predominante es el de la preventa in situ. A partir de los primeros días de la construcción, dentro del terreno había una cámper o remolque promocional de DAKAB habilitada como oficina, en donde se daban informes sobre la preventa de los departamentos.

Dentro del remolque-oficina había varias maquetas que mostraban tanto el edificio por fuera como los departamentos por dentro. De acuerdo con la maqueta, los acabados exteriores serían en tono blanco o grisáceo, con cristales opacos en los ventanales de las terrazas y tubos de aluminio como barandales. Al parecer, 
aplicarán el mismo estilo prácticamente calcado de múltiples desarrollos recientes en la zona. A juzgar por la maqueta, parece que por dentro los acabados serán de madera y el color predominante será el blanco. Existe la posibilidad de adaptar la distribución de los departamentos al gusto y necesidades del cliente: si así lo solicita, se pueden habilitar, por ejemplo, un estudio o un segundo piso.

Después de unos cuantos días, el remolque pasó a estar estacionado afuera del terreno, sobre la calle, ocupando lo equivalente a dos lugares de estacionamiento frente a la obra. También hay anuncios publicitarios afuera del terreno. Sobre el techo de la entrada colocaron dos letreros luminosos que brillan y resaltan en la oscuridad de la noche.

Como parte de las estrategias de promoción, un trabajador estaba enrollando cientos de pendones de plástico que anunciaban la venta de departamentos. A cada uno le ponía un alambre de cada lado, para así poder amarrarlos a los postes o árboles de las cuadras aledañas. Luego los hacía rollito y los amontonaba en un rincón del terreno. Un buen día, todos los postes y árboles de la colonia Roma amanecieron tapizados de pendones de plástico que anunciaban la preventa de estos departamentos de DAKAB en Córdoba \#74. Además, por toda la cuadra donde se encuentra la obra de Córdoba, hay banderines promocionales de plástico colgados de poste a poste que atraviesan la calle por todo lo alto.

En general, por toda la Roma, así como en otras colonias que conforman las cuatro delegaciones centrales del Distrito Federal (sobre todo en la Condesa, Polanco, del Valle, Narvarte, Escandón, Nápoles, etc., aunque cada vez esta tendencia se extiende más hacia otras partes del D.F.) los afiches y pendones de plástico tapizan cada árbol y poste anunciando departamentos, casi como en época de propaganda electoral. Esto es parte de la estética del boom constructivo e inmobiliario. Las empresas tapizan la ciudad anunciando sus productos inmobiliarios y divulgan por todos los medios posibles mensajes publicitarios ofreciendo sus nuevas viviendas en la ciudad.

La barda de madera que delimita la obra ahora fue forrada con metal, para ponerle algún anuncio publicitario. Días después me percataría de que las láminas se utilizaron para instalar vallas publicitarias que anunciaban los departamentos de $D A K A B$, de color naranja en el fondo, con la imagen de un árbol y un dibujo figurativo o realista del edificio ya terminado. 
En la obra de Puebla, desde antes de empezar a construir, colocaron grandes mantas publicitarias cubriendo las bardas que rodean el terreno, anunciando los futuros departamentos. Las mantas enlistan las características de los departamentos y hacen referencia a los tres desarrollos de vivienda que DAKAB construye (Patricio Sanz, Córdoba y Puebla), además de poner su dirección de Internet (www.dakab.com.mx) para mayor información. La nueva oficina de ventas en la obra de Puebla pasó por un proceso de renovación: se instalaron persianas y teléfonos, se compraron nuevos muebles de oficina, se le dio una manita de pintura y se hicieron otros arreglos.

En este nuevo desarrollo, parece que antes que nada van a construir una oficina de ventas en la mera esquina. Mientras tanto, afuera en plena calle hay una mesa con sombrilla y dos sillas, junto a una maqueta que muestra cómo serán los departamentos. En la obra de Puebla poco a poco se fue consolidando la oficina de ventas. Dos pintores pintan el techo con brochas $y$ rodillos. Las maquetas permanecen bien cubiertas con plásticos para que no les vaya a caer pintura. Las sacan a la calle y las sacuden para habilitarlas y que queden presentables.

Cabe señalar que para cada uno de sus desarrollos la empresa ha diseñado un logotipo especial que contiene el nombre y el número de la calle donde se ubica el edificio. Estos logotipos se utilizan como imagen de propaganda durante toda la etapa de construcción, y eventualmente se esculpen en metal para convertirse en el número oficial que lucirá en la entrada del edificio una vez terminado.

En el segundo piso de la obra de Córdoba, el ventanal de uno de los departamentos que da a la calle está cubierto por una lona publicitaria amarilla que cuelga y cubre dos pisos para abajo, promocionando créditos hipotecarios de Bancomer para comprar estos departamentos.

En el primer departamento están las maquetas del edificio y una mesita con el muestrario de los tipos de piso. Cabe mencionar que, en cuanto a los acabados, los departamentos se personalizan al gusto del cliente, quien escoge los colores y tonos de los baños y la cocina, el estilo de muebles de baño, etc. Los estilos van de los más clásicos a los más modernos.

Afuera de la obra de Puebla, cubriendo gran parte del edificio, hay una nueva manta que dice: "Gracias a su preferencia, últimos departamentos", junto a una 
ilustración del edificio ya terminado. Más o menos por las mismas fechas montaron una escalinata de madera pintada de blanco para acceder al departamento de muestra directamente desde la calle sin tener que pasar por la entrada de la obra ni ver a los trabajadores en acción. Las maquetas fueron llevadas a este departamento.

Con el paso del tiempo, fue interesante notar cómo inevitablemente todo este material propagandístico paulatinamente fue cayendo en olvido, sufrió deterioros o se le fueron dando otros usos distintos al original publicitario. Las maquetas cada vez lucieron más descuidadas. El nuevo velador me informa que los letreros luminosos que están en la calle ya no sirven, dice que "ya ni se prenden esas porquerías". La manta que cubre las bardas de la esquina anunciando el sitio web de DAKAB, ya fue también lienzo para graffitis, los teléfonos que aparecían originalmente han sido borrados, cubriéndolos con cachos de tela blanca. En un momento dado, hubo miles de afiches y pendones de plástico que sobraron, amontonados en el suelo haciéndose viejos.

El letrero de "Próximamente preventa", que fue lo que en primera instancia me atrajo a la obra de Córdoba, después fue arrumbado en el sótano entre los desperdicios de madera y demás basura. La lámina publicitaria con la imagen caricaturizada del edificio terminado, con un auto deportivo rojo entrando al estacionamiento y una mujer en minifalda que se pasea por la entrada, hacia el final de la obra fue abandonada de cabeza en un rincón. Un graffitidorado que fue pintado sobre la lámina, parece como si hubiera sido pintado sobre la ventana misma de uno de los departamentos. Progresivamente, las maquetas, lonas, vallas y todo el material promocional de las obras, fue quedando arrinconado, empolvado, hasta quedar completamente obsoleto y olvidado. Sin lugar a dudas, todo por servir se acaba.

\section{Los agentes de ventas}

Desde que comencé a interesarme por la obra de Córdoba, conocí a la señora encargada de ventas, una mujer muy seria de unos 45 años, vestida con traje sastre, a quien me acerqué con algunas preguntas sobre los costos de los departamentos. Como ya me había visto antes platicando con los trabajadores, con un poco de desconfianza me contestó que no tenía los datos a la mano pero que si le dejaba mi 
correo electrónico, prefería enviarme la información por email, cosa que hizo en los siguientes días.

Esta agente de ventas fue uno de mis primeros contactos en la obra. Con ella ocurrieron dos incidentes dignos de destacar: primero, que sospechando mal de mí, no me quería proporcionar el nombre completo del arquitecto Canela para dirigirle la carta de presentación de la UAM; después, cuando ya tenía dicha carta, se la dejé a ella pidiéndole que se la entregara al arquitecto la próxima vez que lo viera, por lo cual Antonio Bobadilla me regañaría, aclarándome que la parte de ventas y la parte de la construcción son ámbitos completamente distintos. Al poco tiempo esta señora sería reemplazada por otros agentes de ventas. Por lo visto los agentes de ventas también mantienen gran movilidad.

En una visita al interior del módulo de ventas encuentro a dos señores vestidos de traje, cada uno con su computadora personal. Mientras uno de ellos, más joven que el otro, habla casi a gritos por su teléfono celular, riendo a carcajadas, entrando y saliendo del remolque, aprovecho para preguntarle al mayor de ellos, flaco, de lentes, cómo van las ventas, si se ha vendido algo. Amablemente me contesta que sí, que ya casi todo está vendido; sólo le quedan cuatro departamentos de los once; es decir, que se han vendido siete en tan solo los primeros tres o cuatro meses de la construcción, a lo mejor incluso desde antes de que se iniciara. Como a las 5 p.m. veo a los dos agentes de ventas saliendo de la oficina listos para partir, una hora antes que los trabajadores de la construcción.

El señor de ventas llega casi siempre a media mañana. Deja su coche verde estacionado afuera de la obra, frente al remolque. Un trabajador le ayuda a abrir la puerta y bajar la rampa del remolque. En las siguientes semanas, el señor flaco de lentes permanecería solitario en el remolque o módulo de ventas, sin atender a nadie, ya que casi nunca había clientes interesados. A veces aprovecha para cortarse las uñas. Un día este agente de ventas se asomó a la obra buscando a Silvano, para que le mandara a algún muchacho a ayudarlo a subir la rampa de acceso al remolque, para cerrarlo y poder irse. Yo justo iba pasando por ahí y le ayudé a gritarle a Silvano, pero no nos escuchó. Así que más bien le pregunté si le bastaría con mi ayuda; me dice que sí y entonces salgo a ayudarlo. Entre los dos cargamos y subimos la rampa en una acción coordinada: "iuna... dos... tres!". "No está muy pesada, pero para uno solo sí está más complicado", me dice agradeciendo la 
ayuda. En adelante se mostraría muy amable conmigo. Aprovecho para preguntarle cómo van las ventas y me contesta que la verdad está flojo en esos días y no se ha vendido nada. Me informa que siguen quedando disponibles los mismos cuatro departamentos de hace varias semanas.

Un día, mientras él no estaba, llegó una pareja joven a pedir informes sobre los departamentos, pero no había nadie en el módulo para atenderlos... Otro día, el señor de ventas me informa que ya sólo falta vender tres departamentos, ya que muy recientemente se vendió uno más.

En la obra de Puebla, desde el principio de las labores, o incluso unos días antes de que arrancaran, había una agente de ventas lista para interceptar y atender a cualquier persona curiosa o interesada por los futuros departamentos. Se trataba de una señorita relativamente joven y muy amable. Con la cabellera teñida de rubio y las raíces negras, con una risa nerviosa incontrolable que hace evidentes los brackets que cubren sus dientes. De vez en cuando esta vendedora sale del módulo de ventas improvisado para fumarse un cigarro Marlboro.

En el módulo también había otro señor encargado de las ventas. De traje, pelo chino y escaso, pintado de negro, se presenta conmigo, su nombre es Eduardo Purgón. Sentado en una mesa de plástico, hablando por teléfono, siempre de traje y a veces con lentes obscuros, tomándose una Coca-Cola, el señor Purgón espera la llegada de clientes potenciales para mostrarles las maquetas de los edificios $y$ departamentos. A cada rato se para y pasea por la banqueta, fumando cigarrillos con gran fruición. El tinte negro hace que el cabello azabache le brille notoriamente bajo el rayo del sol.

Es curiosa esta pareja de agentes de ventas, ambos fumadores empedernidos, ambos con el pelo pintado de un tono evidentemente artificial. En plena calle, sobre la banqueta, colocan una mesa con cuatro sillas de plástico, protegida del sol por una sombrilla azul. Es el puesto de ventas temporal con el que prácticamente bloquean el paso a los peatones en su intento por atrapar clientes potenciales. Cabe mencionar que por lo general los sábados y domingos no trabajan los albañiles, sin embargo, para los agentes de ventas los fines de semana son los días más activos e importantes, ya que es cuando más gente pasea por las calles con el tiempo suficiente para detenerse a mirar con calma las maquetas y los departamentos. 
A la hora de la salida de los estudiantes de las "prepas" y universidades que hay en los alrededores de la obra, unos chavos con uniforme se detienen a mirar las maquetas exhibidas en la calle; "sí mira, puede ser tu patrimonio, dile a tu jefe que te herede en vida", le dice uno al otro en tono de broma. Otras dos personas estudian la maqueta con sumo cuidado e interés.

Tras la remodelación de la oficina de ventas, comento con los vendedores que su espacio laboral está quedando de lujo. La vendedora con el pelo oxigenado, coqueta y risueña, concuerda conmigo. Eduardo "Lalo" Purgón me dice que ahora sólo falta arreglar las maquetas, que se dañaron un poco con el sol.

Varios días después, Lalo Purgón también cubre las ventas en el edificio de Córdoba. Vestido elegantemente de traje, le va a dar un tour por el edificio a un señor interesado. Comienza por mostrarle lo que llama la sala de espera, le explica que es para que esperen las visitas mientras baja el residente, por si no quiere recibirlas en su casa, a menos de que le dé instrucción al guardia de que los deje ingresar hasta su departamento. El cliente potencial, de traje, lo escucha y lo mira atento, impresionado seguramente por sus lentes y su pelo rizado pintado de negro. Terminando el paseo, le pregunto cómo le fue, si el cliente mordió el anzuelo. Me contesta que al parece no y me comenta que todavía quedan tres departamentos por venderse. "El penthouse te está esperando, por si te animas", me dice con una sonrisa.

Otros personajes que me gustaría mencionar en este apartado son los presuntos inversionistas del proyecto, un grupo de señores de traje que apenas visitan la obra muy de vez en cuando y siempre se retiran muy pronto. Otro día llega un grupo de señores de traje, que estacionan su coche de lujo en la entrada del terreno y bajan a echarle un rápido vistazo. A uno de ellos ya lo había visto antes, a los otros dos más jóvenes, no. Me imagino que han de ser socios inversionistas. Sin involucrarse ni un ápice con la obra ni con los trabajadores, se comunican únicamente con la agente de ventas.

\section{Albañiles, comercialización del espacio y reproducción de la desigualdad} Un día que no había nadie que diera informes en el módulo de ventas, una señora interesada en los departamentos se asoma al terreno preguntando por los agentes. Las bromas de los albañiles no se hicieron esperar: "Los que venden no están, ipero 
aquí está la caja! „Pásele a pagar! ¡O si quiere déjenos su carro como adelanto!". Ante las carcajadas generalizadas de los trabajadores, la señora se dio la media vuelta y se alejó de la obra.

Cuando los albañiles pasan por delante de las imágenes publicitarias de DAKAB, se suscita una imagen curiosa y un tanto irónica: los personajes representados en las fotos, las familias blancas, rubias, limpias, sonrientes, contrastan con la presencia de los trabajadores morenos, chaparros, sucios, desaliñados, aunque igual de sonrientes que los modelos.

Entre risas y carcajadas, me cuenta el maestro Javier la anécdota de que un señor mayor, bastante humilde, fue a preguntar los precios de los departamentos a la oficina de ventas, creyendo que se trataba de departamentos de interés social, "y cuando le dieron los precios al ruco, casi se muere de un infarto". Esta anécdota es reveladora de la percepción de un maestro de obras de las desigualdades y las diferencias sociales en el seno de la construcción y venta de nuevas viviendas. Además, también resulta significativo el hecho de que alguien haya confundido el estilo de un edificio que pretende ser para gente de clase media alta, con una vivienda de interés social.

Un par de conversaciones con un trabajador conocido como El Gato fueron muy ilustrativas de la percepción que tienen los albañiles acerca de las disparidades económicas que se manifiestan en el mundo de la construcción y la industria inmobiliaria. Un día, hacia el final de la obra de Córdoba, estaba El Gato afuera del edificio disponiéndose a montar una nueva lona publicitaria que le acababan de entregar en el remolque de ventas...

- ¿¿Y eso?", le pregunto.

- "Nueva imagen, va a ir en lugar de las láminas naranjas".

- "Pero si todavía están buenas".

- "Sí, pero esos cabrones ya no saben ni en qué gastarse el dinero".

- “¿Y cómo van las ventas?", le pregunto al Gato.

- "Quedan un departamento y el Penthouse; el puro PH vale como tres millones. Hazme favor, con esa lana se podría construir una buena casita para cada uno de los albañiles que estamos trabajando aquí".

Otro día le menciono al Gato que vi al arquitecto saliendo del banco; "seguro que con los puros millones", bromea. Según El Gato, por cada edificio que construyen, obtienen alrededor de 20 millones de ganancia, "ya libres de paja". Me comenta 
que DAKAB empezó hace no mucho más de un año, y ya van por el quinto desarrollo inmobiliario. "O sea que por lo menos ya son 20 millones, por cinco obras, dan 100 millones que se embolsan en su primer año de vida", calcula El Gato.

\section{El proceso constructivo en las obras de Córdoba y Puebla}

El proceso constructivo general está subdividido o fragmentado en diversos subprocesos especializados. Las tareas y las especialidades se distribuyen entre una red de trabajadores de producción; cada etapa o fase del proceso se encomienda a distintos intermediarios, pequeñas empresas o maestros subcontratistas, lo cual da lugar a una administración fragmentada por oficios. Todos los grupos entran en ritmos discontinuos. Si bien hay secuencias de eventos en la construcción de vivienda que no se pueden alterar, hay varios procesos que se pueden desarrollar de manera simultánea, mientras otros procesos requieren coordinación con trabajadores de diversos oficios (cf. Bueno, 1994: 98, 101).

Por su parte, para entender la organización laboral en la obra, Priscilla Connolly propone dividir las labores en: "procesos de transformación" y "ensamblaje de componentes prefabricados". Los primeros tienen que ver con el empleo de los materiales más elementales: cemento, varilla, madera, etc. La segunda labor tiene que ver con las instalaciones y colocación de plomería, electricidad, así como una parte de los acabados (cf. Connolly, 1988: 211). De acuerdo con Carmen Bueno, la explicación de Priscilla Connolly apunta a la noción de fragmentación: “lo predominante en la construcción de vivienda ha sido la fragmentación del proceso general en diversos subprocesos independientes uno del otro. En cada uno de ellos se hace uso de prácticas artesanales, en las que un trabajador o una cuadrilla de trabajadores realiza cada una de las fases del proceso, de principio a fin... La empresa constructora delega la responsabilidad de la organización del trabajo a los maestros contratistas..." (Bueno, 1994: 19).

Siguiendo nuevamente a Carmen Bueno "el proceso laboral se caracteriza por tener varios subprocesos que entran y salen del sitio de construcción en diversos tiempos, según el avance de la obra... El proceso de albañilería es central, a lo largo de este hay otros procesos que se intercalan" (Bueno, 1994: 100). Los trabajadores se organizan en grupos llamados cuadrillas, que varían en número y grado de 
especialización". Esta autora se refiere a una estimación según la cual un $80 \%$ del proceso total de construcción de vivienda "está en manos de los albañiles" y el resto queda a cargo de cuadrillas de plomeros, electricistas, herreros, carpinteros, yeseros, colocadores de pisos, etc. (Bueno, 1994: 98).

Otra forma de abordar el proceso constructivo sería distinguir a grandes rasgos entre la etapa de la obra negra y la fase de los acabados. Con una gran capacidad de síntesis y buena narrativa, Carmen Bueno relata en dos o tres páginas la totalidad del proceso constructivo en la fase de la obra negra: desde consultar los planos, limpiar y trazar el terreno, hacer una bodega que sea a la vez albergue para el velador, abrir la cepa... después entran los fierreros, colocan los cimientos, instalan los castillos y alzan las columnas, la cuota de trabajadores va aumentando, se levantan los muros, entran y salen los carpinteros que ponen la cimbra, se coloca el piso, disminuye la cantidad de mano de obra requerida, termina la obra negra y empiezan los acabados... (cf. Bueno, 1994: 98-102). Con este mismo espíritu, tanto etnográfico como narrativo, en lo que sigue describiré y reflexionaré sobre los procesos constructivos en las dos obras que estudié, pero con más detalle y detenimiento. Otra diferencia importante es que en este recuento, además de mi propia experiencia, intento incorporar las voces de los diversos actores involucrados en este proceso de transformación.

Muchas veces los cambios en el espacio urbano nos sorprenden y nos dan la impresión de que sucedieron muy rápidamente, de un día para otro. Me parece que esa sensación de extrañamiento radica sobre todo en la experiencia de un observador ajeno al proceso constructivo. Basta seguir de cerca un proceso para hacernos concientes de todos los pormenores y la infinidad de eventos y acciones que acontecen. Entonces nos damos cuenta del verdadero transcurso del tiempo y se vuelve pertinente la noción de proceso. Mientras más cercanos o familiares nos volvemos con alguna obra, menos nos parece que aparece súbitamente como por generación espontánea. Todo depende de la perspectiva del observador.

Debo advertir nuevamente que este recuento no se hace desde la perspectiva técnica arquitectónica, sino desde mi propio punto de vista como etnógrafo y fotógrafo. Para hablar de cómo cambiaron los espacios es indispensable partir de cómo cambiaron para mí, cómo se transformó mi experiencia de ellos, mi percepción, mi sentir con respecto a ellos. Pretendo narrar también cómo cambiaban 
las dinámicas entre los trabajadores en distintos momentos en un mismo espacio, cómo había formas diferentes de utilizar los espacios, que van cobrando distintos significados y connotaciones. Me interesa especialmente cómo cambia el espacio en términos de iluminación, humedad, olores, sonidos y otros factores sensoriales, pero también en cuanto a los personajes que lo habitan y la acción social que en él se realiza.

Incluso los modos de referirse a un mismo espacio sufren cambios a lo largo del proceso. Es interesante notar que uso varios nombres distintos para referirme al lugar de investigación: "el terreno", "la obra", "el edificio", "los departamentos". Estos cambios semánticos son reveladores de cómo conforme se va transformando el espacio, algo cambia en nuestra manera de percibirlo, nombrarlo y habitarlo. Muchos de estos cambios son pequeños, sobre todo cuando uno trata de dar cuenta de ellos minuciosamente, pero se van acumulando y de repente hay un salto que ya no es cuantitativo, sino cualitativo. En el caso particular de la obra de Córdoba, el estacionamiento pasa a ser un terreno vacío, que a su vez se convierte en un sitio de construcción, y la obra poco a poco se convierte en edificio, y más adelante se van diferenciando los espacios, cada departamento, los espacios comunes, el estacionamiento, el hueco del elevador, la azotea, los baños, cocina, etc.

Me interesa mucho la percepción e interpretación de los propios trabajadores acerca del progreso de la obra, del avance y el ritmo que lleva la construcción. Recojo varios de sus testimonios y recuentos de lo que han hecho y lo que les falta por hacer, sus cálculos de cuánto tiempo tomará cada cosa, sus estimaciones de cuándo estará terminada la obra, etc., sin importar que muchas veces estén equivocados 0 caigan en contradicciones.

\section{El proceso constructivo en la obra de Córdoba}

A continuación me propongo relatar la transformación radical que sufrió un espacio urbano particular, en el transcurso de un año y tres meses, desde el comienzo de la obra en noviembre de 2006, hasta la culminación del proyecto en febrero de 2008. Intentaré describir y comentar a grandes rasgos algunas de las etapas y momentos más significativos del proceso constructivo, desde que se trataba de un terreno llano hasta que se convirtió paulatinamente en un edificio de departamentos. Algunas de las fases importantes de este proceso constructivo son, por ejemplo: la excavación, 
los cimientos, el colado, el trabajo con el fierro, con la madera, el levantamiento de muros, la instalación eléctrica, la de gas, los acabados, etc. Asimismo, algunos espacios de cuya construcción, reconstrucción o transformación daré cuenta son: el gran hoyo de tierra, el sótano-estacionamiento, los espacios interiores, la fachada y las ventanas, las escaleras y el elevador, las distintas plantas y niveles, el roof garden, el jardín trasero, etc.

Antes de que comenzara la obra, en noviembre de 2006, había un terreno perfectamente plano, limpio y rectangular, de unos 15 X 30 metros, aproximadamente. Solamente hay un árbol bastante grande en una de las esquinas del terreno. El piso está cubierto de arcilla roja, las paredes son blancas y con pintura azul están marcados los números de los cajones del estacionamiento que solía funcionar en este lote. Hay dos pequeñas habitaciones, como casetas de vigilancia, junto a la puerta de entrada, una de cada lado. Dentro del terreno hay un remolque estacionado con la imagen y los datos de la empresa constructora.

\section{Preparativos}

Uno de los primeros datos que deduzco al ver las maquetas que estaban dentro del remolque, es que el estacionamiento será semisubterráneo, por lo que seguramente tendrán que excavar bastante antes de empezar a construir.

La obra empezará muy pronto y según los planes tardará unos diez meses, "pero puede que un poco más", me anticipa uno de los encargados de la obra, Antonio Bobadilla. Silvano, uno de los maestros, me informa que lo primero que tienen que hacer es un "tapiado" para proteger a los peatones que pasen por la banqueta, para que no les vaya a caer nada proveniente de la obra. Otra de las primeras labores será construir un cuartito de madera que sirva de bodega y a la vez habitación para que duerma el velador. Esto lo harán justo en la esquina donde está el árbol. Patricio, uno de los primeros trabajadores que conozco y con quien establezco contacto, me explica que los dos cuartos que por ahora hay en la entrada del terreno, pronto serán demolidos. Días después, la bodega de madera que hacen en el fondo del terreno, junto al árbol, está un poco más avanzada que en días anteriores, pero sigue a medio construir, porque según me explica Nicolás, sólo en los ratos libres le dedican trabajo a ese cuartito; mientras, el velador duerme en uno de los cuartitos. 


\section{Excavación}

Una máquina excavadora marca Caterpillar remueve y acarrea tierra y escombro con una gran pala y su brazo mecánico. Tras la acción de la máquina, el suelo queda con las entrañas abiertas, un hoyo comienza a extenderse a lo ancho y profundo del terreno; tierra, lodo, piedras, raices y gusanos van quedando al descubierto. La superficie antes plana se vuelve agreste nuevamente. El terreno, ya en franca intervención, se siente más hostil, más difícil de transitar, más salvaje e inhabitable.

Los maestros Nicolás y Silvano comentan sobre lo efectiva que resulta esa máquina. Según me informan, el proceso de excavación les llevará muy pocos días. "A este ritmo, en unos 3 ó 4 días acabamos", me dicen. Bobadilla, por su parte, calcula, muy seguro de sí mismo, que en 2 ó 3 días terminarán la excavación. Pero los maestros, más realistas que el encargado, me explican: "todavía hay que excavar un poco más, hasta dos metros de profundidad aproximadamente, y a ese mismo nivel habrá que emparejar todo el terreno"; incluso será necesario excavar hasta la mera orilla, porque hay que volver a cimentar todos los bordes y rehacer los límites... "eso se dice fácil pero toma su tiempo". Me llama la atención la imposibilidad de hacer un pronóstico más exacto. Además, la labor puede complicarse ya que están encontrando cimientos de una casa que había previamente en el terreno, antes del estacionamiento. Me señalan grandes piezas de concreto entre los cerros de tierra excavada. Incluso, me señala el maestro Nicolás que ahí más abajo se puede ver el piso de la casa que estaba antes. Debajo de esta ciudad hay otras enterradas, nuestro espacio urbano es un palimpsesto con varias capas de sentido, sobre todo hacia abajo en el subsuelo.

Unos cuantos días después, todo el resto del terreno ya había sido excavado. Me pareció que habían avanzado rapidísimo. Silvano me dice que ya está prácticamente acabada la excavación de la primera parte del terreno y lo que falta lo harán a mano, porque si no la máquina podría dañar las estructuras de los muros de los inmuebles de junto.

Varias semanas más adelante, contratan otra vez una máquina excavadora para quitar y llevarse toda la tierra que falta de la parte de adelante del terreno. Desde ayer viernes empezó a trabajar la máquina excavadora con su operador y un supervisor. A pesar de que hoy es sábado, la máquina excavadora trabaja en la 
obra; ayer se hicieron cuatro viajes del camión cargado de escombros hasta el tiradero, pero "hoy nomás dio tiempo de tres", me dice el chofer.

\section{Demolición}

El cuartito que queda en pie al frente del terreno pronto también lo demolerán. A veces me sorprende mucho el hecho de que una construcción requiera tanta destrucción. Los restos de la antigua pared del cuartito que un día antes estaban demoliendo, ya fueron removidos totalmente. A los pocos días, ya están demoliendo el otro cuartito de enfrente, del lado izquierdo del terreno. Ahora que ya no existe ninguno de los cuartitos de adelante, el terreno se ve más amplio.

\section{El hoyo}

A partir de la excavación, hubo una presencia ineludible en el terreno, un imponente agujero en lugar del piso plano que antes había, un gran boquete enmedio del suelo al que me referiré de ahora en adelante como "el hoyo". La presencia del hoyo es tan imponente que sólo queda un angosto pasillo de menos de medio metro para caminar alrededor del terreno.

Le pregunto a Raúl, otro trabajador que conzco desde los primeros días de la obra, sobre la profundidad total del hoyo. "Son más de dos metros, como dos treinta, o es más güero, pérame tantito... para ser exactos, son 2.88". El piso de hoyo está lleno de lodo y las paredes son de tierra, lo cual le da al lugar un aspecto húmedo, sucio, oscuro y frío. Mirando transversalmente las paredes de tierra del hoyo se distinguen las diferentes capas del subsuelo por sus distintos colores. Se notan los arañazos de la pala mecánica.

Varios hilos atraviesan el terreno de lado a lado, marcando un nivel como referencia para que la profundidad del hoyo fuera pareja. Estos hilos blancos se sostienen amarrados en clavos retorcidos, puestos sobre trozos de madera que a su vez están clavados a la pared, casi a la altura del piso.

El maestro Nicolás me comunica que ya mero empiezan a cimentar, ahora que ya llegó la varilla. Posiblemente la próxima semana comience esta fase fundamental en toda construcción. "Mientras, en estos dos o tres días vamos a seguir limpiando el hoyo, hasta llegar a nivel cero", me cuenta Nicolás. 
Con el paso de las semanas, el hoyo ha continuado creciendo conforme siguen sacándole tierra y lodo. Del lado izquierdo ya removieron toda la tierra que formaba el pasillo por donde se podía transitar a lo largo del terreno. Del otro lado apenas comienzan a desmoronar la tierra manualmente con palas y picos. Tiempo después, la actividad predominante sigue siendo excavar el escombro y lodo desde el hoyo hacia el frente del terreno. En la entrada hay un gran cerro de escombro y lodo que han seguido sacando del hoyo y no se llevan aún. Sigue lleno de agua el hoyo al frente del terreno. Los trabajadores portan botas para andar por el charco que hay aún en el hoyo. Otros cuantos trabajadores excavan la tierra y sacan el lodo a cubetazos. Parte de lo que sacan es llevado con carretillas a la parte de atrás de la obra, para rellenar lo que será el jardín trasero, reciclando la misma tierra.

\section{Cimientos}

Dos estructuras formadas por múltiples varillas anudadas entre sí, llamadas trabes, atraviesan transversalmente el hoyo, por enmedio del terreno; éste es el principio de los cimientos. Me informa Nicolás que ayer lunes empezaron esta nueva etapa de la cimentación "y espero que se apuren mucho los fierreros, para terminar rápido con las varillas y empezar pronto a colar algunas estructuras la próxima semana".

Es contundente el avance logrado en los últimas semanas. Cuando quitan la madera de la cimbra, quedan al descubierto los cimientos ya colados, un sólido fundamento para una torre de departamentos de cuatro niveles.

\section{Fierro}

Los llamados fierreros se dedican al armado de trabes y columnas con varillas. Ahora están terminando de construir la cuarta trabe que atraviesa el terreno de lado a lado en la base del hoyo. Los "fierreros" comienzan a armar incluso una quinta trabe transversal, cada vez más pegada hacia la puerta. Además, cuatro castillos hechos con varillas muy gruesas se elevan un par de metros hacia arriba, rematando con las puntas dobladas. La estructura de los cimientos es ahora una complicada cuadrícula formada por trabes y castillos, hechos con múltiples y diferentes varillas, nudos y estribos... Por otro lado, un par de albañiles preparan las varillas para las nuevas trabes que formarán los cimientos de la parte de adelante del edificio... 
Otro cambio considerable es una cuadrícula de varilla delgada que se teje por todo el piso, casi pegada al ras del suelo.

\section{Madera}

En esta etapa de la llamada obra negra, el trabajo con la madera se refiere sobre todo a la cimbra. "Una vez acabado el trabajo de fierro, viene la madera", me dice clara y esquemáticamente Silvano. Acaba de llegar un nuevo equipo de carpinteros que están haciendo la cimbra, con la que se recubre el fierro antes de colar los cimientos, o sea, de vaciarle el cemento. Los carpinteros se desplazan hacia el hoyo, caminan sobre las trabes, calculando medidas para recubrir con madera la varilla, y para hacer también una especie de templete temporal. Unos días después se notó un avance importante: la estructura de varillas ya está casi totalmente revestida con tablones, vigas y barrotes de madera.

\section{Tabique y cemento}

Asimismo, comenzó la labor de levantar muros. Primero fue un muro de tabique gris en el extremo del terreno, bardeando la pared del fondo del hoyo, pegado a la primera trabe. Un trabajador estaba encargado de pegar los taquiques uno a uno con cemento, parado sobre un andamio de madera que fabricaron los carpinteros. Por varios días más, sigue la labor de construcción de este muro de tabique, que le da a la obra un toque más rasposo, seco y gris. En días posteriores el muro de tabique ya está bastante avanzado, cubriendo casi toda la pared de tierra del hoyo.

Han levantado varios muros de tabique que delimitan y delinean los departamentos, con castillos de varilla $y$ estribos cada par de metros aproximadamente. En los muros laterales hay bloques de unicel forrados con cuadrículas de alambre y varillas. Meses más tarde, la edificación de muros de ladrillo hace que la entrada de la obra luzca bien diferente, con más cara de inmueble, con espacios trazados y divididos.

\section{El colado}

La fase del colado, que se refiere a verter el cemento (o "mezcla", cuando está en estado líquido espeso), ya está a punto de comenzar del lado izquierdo del terreno. Silvano me dice que lo harán al día siguiente muy temprano por la mañana. Como a 
las 7 a.m. va a llegar "la olla" (el camión-revolvedora) con la mezcla lista para colar la pared del fondo del terreno. Los carpinteros fabricaron una estructura de madera, que llaman "tina", para recibir la mezcla directo de la olla y ahí contenerla en lo que se va ocupando. En otra ocasión me encuentro con el camión-revolvedora estacionado afuera del terreno. Tiene conectada una tubería de metal que conduce la mezcla desde la olla hasta su destino, impulsada por una bomba. "Cuando es mucha la mezcla se usan las pipas, cuando es poca se pone en una tina y transporta con cubetas o carretillas", me explica Antonio Bobadilla. A cada olla le caben unos 7 metros cúbicos de mezcla, calcula. El lado del terreno recién colado está tapado con un toldo de plástico negro, Rufino me dice que es por si llueve, ya que si le cae agua el cemento se pone feo y malo, y ésa parte ya la dejaron bien pulida y lista.

\section{El sótano-estacionamiento}

Abajo, en el sótano, estará el estacionamiento. Es el primer espacio interior que queda esbozado tras el colado de los cimientos y la preparación para el colado de la primera losa. Está medio nivel hacia abajo, es decir, que es semisubterráneo. Desde el nivel de la calle, para bajar al estacionamiento habrá que descender medio nivel por una rampa, y para llegar desde ahí al lobby y a la primera planta del edificio habrá que subir medio nivel por unas escaleras.

El nivel de la construcción que será la planta inferior, ahora está techado por vigas y maderas sostenidas por cabezales, formando una especie de sótano. Puede decirse que hasta abajo ya existe un sótano, invadido por los pilotes y cabezales de madera que sostienen la estructura de arriba que pronto será colada. Por primera vez un espacio techado, oscuro, húmedo; el sonido viaja diferente, hay eco. Como ya hay una parte techada y cubierta, se puede decir que ya existe un adentro y un afuera, atmósferas diferenciadas en el espacio habitado.

Una vez colado, se puede apreciar que el estacionamiento será de dimensiones muy reducidas, contempla tan sólo el espacio mínimo suficiente para que los coches -de preferencia pequeños- puedan maniobrar. La altura del techo está justamente calculada para usar el menor espacio posible; una camioneta apenas cabrá, casi pegando con el techo.

Por ahora, el sótano, que después será el estacionamiento, funciona como depósito de grava y arena. El sótano es por ahora un espacio lúgubre, lleno de 
moscas, oscuro, alumbrado solamente con una lámpara de halógeno, mojado, frío, Ileno de basura y desperdicios de todo tipo de material.

En la entrada están colando y a la vez aplanando la rampa de acceso al estacionamiento. Abajo y adentro unos cuantos trabajadores están pintando de color gris cemento las paredes del sótano, casi del mismo tono que el concreto. Aunque casi no cambia de color, con la pintura (marca Comex) este espacio se ve un poco más limpio. Aun así, el estacionamiento sigue siendo un sitio lúgubre, frío, húmedo y oscuro, lleno de escombro y material amontonado. Los pintores se tienen que iluminar con lámparas fluorescentes para poder ver lo que hacen. Una tubería de PVC recorre todo el techo del estacionamiento.

Algunos trabajadores están limpiando con picos y palas la basura y el escombro del sótano-estacionamiento, sacándolo en carretillas para luego depositarlo en la parte de atrás de un camión. Al poco tiempo, el sótano-estacionamiento ya quedó prácticamente limpio de todos los escombros que cayeron ahí desde todos los pisos por el hoyo del elevador. Ya está presentable, iluminado por las lámparas de halógeno ya instaladas, ya casi todo pintado de gris claro, color cemento. De hecho, ya hay un par de coches estacionados ahí, me imagino que del mismo arquitecto Canela, a quien veo a lo lejos.

En el sótano hay varios coches estacionados, pero también hay todavía varios materiales almacenados: rejas, plástico, sacos de pegamento, palas, etc. Los registros de luz y los cables enmarañados sobresalen al bajar la rampa. Hay algunos hoyos en el piso que dejan ver los huecos bajo el piso del estacionamiento; recuerdo la cuadrícula de trabes que forma los cimientos del edificio y los huecos cuadrados que quedaron entre ellas. Uno de estos huecos subterráneos lo recubren con azulejo, supongo que para usarlo como cisterna... El estacionamiento ya esta pintado de blanco y listo, pero todavía hay carpinteros que trabajan ahí, fabricando clósets, muebles de baño y cocina.

Niveles

El día del colado de la primera planta, la losa que ya está lista para colarse consta de una cuadrícula de varillas, trabes, castillos, columnas y cimbra, todo bien preparado para recibir la mezcla. Efectivamente, como dijo Silvano, en dos días se iba a ver un poco diferente el panorama general de la obra; una vez colada, se ve 
mejor definida la cuadrícula en la parte de enfrente del hoyo. Sobresalen de la losa apenas colada de la primera planta algunos castillos y muros de ladrillo. También arriba, en la parte ya colada, se notan avances en los castillos de varilla que van creciendo en altura.

Preparan el terreno para el colado de la segunda losa, para edificar la segunda planta. Todo está lleno de madera y fierro, formando un entramado de cimbra, trabes. Ya hay piso en la parte de enfrente, colaron esa parte justo hace un par de días, ahora están listos para empezar a edificar un nivel más para arriba. En el segundo piso, en plena construcción, están armando ya las trabes horizontales, que contribuirán a soportar los muros, el techo y los demás pisos que siguen hacia arriba.

Noto que la entrada está mucho más obscura que de costumbre, a causa de una estructura de madera que anticipa y prepara el colado de la losa de la planta de arriba, techando el acceso. En el fondo del terreno, la parte de atrás va más adelantada, ya hay estructuras que sobresalen de la segunda planta, como el cubo del elevador, cuyas paredes ya están lisas y coladas, y hay otros muros que se están haciendo de ladrillo.

Viendo la altura a la que nos encontramos en comparación con el edificio de enfrente, reflexiono que, en un abrir y cerrar de ojos, se han construido varios metros hacia arriba, ya hay dos pisos de departamentos y un estacionamiento. EI patio de la escuela ya se puede mirar hacia abajo sobre la barda que dividía los dos lotes. De igual manera, el edificio de junto ya se puede mirar en paralelo casi desde su misma altura máxima. En realidad, me doy cuenta, sólo faltan dos losas más para terminar toda la obra negra.

En la obra de Córdoba un nutrido grupo de trabajadores se dedican a colar varias partes de un nuevo nivel de la obra. Trabajan ya casi a la altura de la azotea del edificio de enfrente. La mayoría de los trabajadores está concentrada en la última planta, la única que falta para terminar la obra negra. Están ya a la altura de las grandes ramas del árbol, casi a la altura del último piso de la escuela de junto. Comento con El Gato el paisaje que se mira desde las nuevas alturas de la obra. Las viviendas atrás del edificio quedan chaparras. La escuela ya se mira hacia abajo, sus tres plantas ahora quedaron más bajas que el nuevo nivel más alto del nuevo edificio. 
Elevador y escaleras

Sobre una mesita me encuentro varios planos de la obra, los reviso de reojo sin lograr entender casi nada. Lo único que me queda claro es que al centro de la estructura, las varillas gruesas que sobresalen varios metros, formarán las paredes del hoyo del elevador. Semanas más adelante, avanzaron en el colado del elevador. Tras el colado de la primera planta, se nota claramente bien delimitado lo que será el cubo del elevador. Acaban de colar un nivel más arriba el hueco para el elevador. Esta acción resulta muy ilustrativa del proceso de colado de los muros de carga, firmemente fundamentados con gruesas varillas, que se forran de madera para verter y contener la mezcla.

Ya avanzada la obra, un cambio novedoso para mí es que ya existen las escaleras para subir al primer piso. Hoy mismo hace rato fueron coladas. Ya están casi secas, pero aún tienen los moldes de madera que contuvieron la mezcla dándole forma a los escalones. Están tan frescos que pusieron tablas de madera sobre ellos para que no vayan a quedar marcadas las huellas de algún descuidado o travieso. Pero aún así, hay un vaivén constante de trabajadores que las circulan por ellas con plena confianza. Las escaleras facilitan mucho el acceso al piso de arriba, ya que antes había que trepar los peldaños de un escalera de madera improvisada. Después de tanto tiempo batallando con rampas y escaleras improvisadas para subir y bajar, las escaleras ahora constituyen una ruta transitable para subir material desde la entrada a los pisos de arriba.

El conducto del elevador ha servido como tiradero de cascajo de arriba hasta el sótano. Las paredes del cubo del elevador lucen completamente sucias, toscas, abandonadas. En las escaleras de entrada todavía falta mucho trabajo de acabados por hacer. El hoyo del elevador por un tiempo estuvo tapiado con madera, aun así sigue reuniendo los desperdicios y basura de todos los pisos.

El área de las escaleras ya fue provista de vidrios opacos como esmerilados, que permiten el paso de la luz pero sin transparencia. En la planta baja, los carpinteros siguen recubriendo con madera los lados de la escalera de la entrada, que según me dicen será entintada de un tono chocolate oscuro. Dos chavos trabajan los acabados de la madera alrededor del elevador, me confirman que en el lobby de cada piso 
casi todo será de madera color chocolate. En las escaleras y los espacios comunes ya hay instaladas lamparitas pequeñas color metálico.

El cubo del elevador ya está limpio y libre. Sólo falta montar el elevador y todo el mecanismo. Dos trabajadores están instalando el elevador, montando las puertas y los marcos. Me explican en qué consiste su labor. Instalan una estructura metálica que son los rieles del elevador. Adentro del cubo del elevador suspendieron un andamio improvisado con unas tablas de madera, que les sirve para apoyar sus herramientas y apoyarse ellos mismos. El cubo del elevador es un lugar curioso. Fue de lo primero que se empezaba a distinguir en las primeras etapas de construcción de este edificio, sin embargo, es algo que permanecerá completamente oculto e inaccesible. Una parte escondida del edificio que siempre permanecerá sin aplanados, en bruto, a oscuras.

En el lobby del primer piso, la puerta y los marcos del elevador ya están prácticamente instalados; sólo faltaría retirar la película protectora de la superficie de metal, ideada para que no se raye antes de tiempo. No así en el segundo piso, donde apenas están armando los marcos del elevador.

\section{Instalaciones}

Antes del colado de una nueva planta, ya están montadas por todo el piso las tuberías para la instalación de gas y de electricidad, una serie de tubos metálicos dorados para el gas y otros de plástico anaranjados para la electricidad. Hay algunos cables de colores saliendo de los hoyos de las lámparas, enchufes y apagadores. Otro día presencié cómo se realiza la instalación eléctrica y de televisión. El electricista me enseña los planos que forman la instalación eléctrica, me explica varias cosas en el plano, pero la verdad no entiendo gran cosa. Parece que la instalación eléctrica se está haciendo en dirección contraria que la mayoría de las cosas, empezando de arriba hacia abajo.

Junto al elevador corre paralelo un ducto por donde pasan cables naranjas de la instalación eléctrica y las instalaciones para la TV, el interfón, etc. Las tuberías blancas aún son visibles en los techos de los baños.

En la caseta de vigilancia del edificio ya casi terminado, el maestro electricista instala una caja gris de registro de luz con varios cables de colores; es la correspondiente a todos los espacios comunes del edificio, desde la caseta de 
vigilancia, los pasillos, vestíbulos, el roof garden y el sótano. Afuera, un par de trabajadores de Telmex instalan un poste para las nuevas líneas que requerirá el edificio.

\section{Espacios interiores}

Los espacios interiores del edificio ya se sienten como espacios separados, acaso más privados. Algunos tienen ya su ambiente propio, en parte conformado por su orientación, sus dimensiones, la luz particular que entra por la ventana, pero también y sobre todo por el uso y la apropiación temporal que hacen los trabajadores de estas habitaciones por ahora desprovistas y precarias. Comienzan a amueblarlas con mesitas improvisadas y ponen clavos en la pared a manera de perchero.

A estas alturas ya se intuye fácilmente la forma de los departamentos, sus áreas comunes, las recámaras y los baños, así como el vestíbulo alrededor del elevador. Hay dos departamentos de doble planta, con tapanco, uno abarca los dos primeros pisos, y el otro departamento de doble altura abarca los pisos tercero y cuarto. El departamento en el primer piso, que será de dos plantas, ya está casi listo; se nota la forma de las escaleras que subirán al segundo piso.

Llegan algunos muebles de cocina y otros para las recámaras, además de vidrios y puertas. Algunos departamentos ya tienen piso y están casi listos, sólo esperando los muebles y otros detalles de acabados, como apagadores, enchufes, zoclos, etc. Por ahora los números asignados a cada uno de los departamentos están escritos con pluma en la pared, arriba del hueco donde irá el timbre: 201, 203, 301.

Una mirada al cubo del edificio deja ver cómo lucirá este patio interior, un espacio aéreo y sonoro compartido, uno de los puntos de mayor contacto con los vecinos, donde los olores y los ruidos de los demás departamentos podrán entremezclarse. A pesar de los acabados de medio lujo, en este espacio se puede ver lo cercanos que están unos departamentos de otros, casi como en cualquier edificio de interés social.

En el cuarto piso está el Penthouse, un departamento con un gran espacio, todavía sin yeso y menos acabado, pero muy amplio; ocupa el espacio de dos departamentos. Tiene un angosto pero extenso balcón. Aún falta instalar los vidrios que forman parte del barandal de aluminio. Mientras abajo ya está todo listo y 
como envuelto para regalo, aquí todavía hay muchas cosas en proceso. En este departamento hubo además una modificación casi de última hora, que obligó a romper una pared que incluso ya estaba recubierta de un material llamado porcelanite, para abrir una puerta y ampliar un área de servicio.

En la entrada veo que las paredes laterales que forman la rampa de bajada al estacionamiento están ya recubiertas de aquel material llamado pléiser, o algo así. Justo enfrente y arriba de la rampa, están armando la caseta de vigilancia con cristal opaco verdoso semirreflejante, con una ventana de aluminio con vista directa a la puerta de entrada. La casetita es de dos metros por uno y medio, con puerta corrediza y recubierta con pisos de porcelanite.

\section{Los acabados}

Pato me dice que la próxima semana ya vendrá un equipo de mujeres a hacer la limpieza general de la obra para poder empezar con los acabados. Javier me cuenta que ya tienen que limpiar toda el área, empezando de abajo hacia arriba, porque ahí vienen ya los equipos de yeseros, a partir de la próxima semana entrarán cuatro parejas de yeseros. A mediados de junio empiezan los acabados en una parte del edificio. El cambio más notable al entrar en el edificio es que ya empezaron a aplanar las paredes con yeso. Lo que antes era una pared de ladrillos ahora luce como una superficie más domesticada, más amable, más acogedora, más habitable, acaso más civilizada. Tras el alisado, sólo quedan los pequeños huecos para los apagadores y enchufes eléctricos. La apariencia de la obra negra cambia significativamente con el aplanado, deja de ser obra negra y la sensación del espacio es diferente.

El yesero acaba de aplanar las paredes de un cuarto y ahora está enfocado en el techo. Va dejando las paredes completamente lisas. El terminado de las puertas y ventanas es tosco todavía, porque falta que se monten los marcos de las puertas. Aun así, la sensación de un espacio con paredes ya alisadas con yeso es muy distinta a la de un espacio con tabiques a la vista.

En el departamento de la planta baja ya están instaladas las puertas de madera, las ventanas de aluminio y la cocina. Hay varios vidrieros colocando ventanas $y$ barandales por todos los pisos del edificio. En el departamento de arriba, que es doblemente grande, están en pleno proceso de montar las ventanas. Los marcos de 
aluminio y los vidrios permanecen recargados en la pared, sobre unos palos de madera.

Buena parte de los pisos ya están instalados con piezas cuadradas de cerámica color crema brillante, que francamente no me parece de buen gusto; se ven más corrientes que comunes, en contraste con la imagen de lujo y el toque de exclusividad que vendieron a los compradores. Casi todas las escaleras están ya cubiertas de piso y las paredes pintadas de blanco, incluso.

En el departamento de muestra, en el primer piso, el que ya tiene puerta de entada y por lo tanto se puede cerrar, hay varios obreros trabajando en los acabados. Ya se le instalaron los muebles de cocina y piso laminado, imitación parqué de madera oscura. Dos carpinteros entintan y barnizan los marcos y las puertas de entrada de los departamentos. Les pregunto si todas las puertas serán de ese color, café oscuro, casi negro, me dice que sí, que se llama chocolate y me comentan que está de moda. Otros trabajadores están instalando la escalera de madera para subir a la segunda planta del departamento, puliendo y barnizando la madera.

El departamento del fondo a la derecha, en el primer piso, es el que primero se ha ido desarrollando, acabando y amueblando. Una mesa, sillas y lámparas permanecen en bolsas de plástico. Los lavabos, escusados y muebles de baño están guardados todavía en grandes cajas de cartón apiladas. Ya están instalados los apagadores y enchufes, parece que sólo falta colocar el piso. Dos trabajadores entintan de negro la madera de la escalera que sube al segundo nivel del departamento. La escalera combina con un mueble de repisas negras ya empotrado en la pared. Otro departamento alberga a un grupo de carpinteros dedicados a entintar las puertas y marcos de todo el edificio, color madera chocolate, con manijas de metal plateado. Me dice un yesero que la semana entrante termina ya la labor del yeso en la obra de Córdoba. En el último departamento todavía hay otro yesero acabando unos últimos detalles del techo y los huecos de los enchufes y apagadores.

En general, a pesar de que falta colocar algunos pisos, ya hay algunos departamentos prácticamente listos, incluso con luz en las lámparas de los baños. Algunos departamentos ya tienen muebles, camas, burós, muebles de baño, clósets. 
Están colocando puertas de aluminio y vidrio opaco en el vestíbulo de cada piso para cubrir los registros y tuberías.

Adentro de los departamentos de los pisos superiores se trabaja sobre todo en la carpintería, fabricando puertas, ventanas y escaleras. En casi todos los departamentos las puertas de madera son oscuras, barnizadas color chocolate. Pero hay uno o dos en los que no, porque en realidad los departamentos se personalizan al gusto del cliente, quien escoge los colores y tonos de los baños y la cocina, el estilos de muebles, unos más clásicos y más modernos, etc.

En otro departamento, ya están fabricando la cocina, los cajones, una barra y la tarja de fregadero. Me sorprende ver también algunos muebles: mesas, sillas, sillones, lámparas, aún sin desempacar. Me pregunto si en algunos casos venderán los departamentos amueblados o si estos muebles ya pertenecen a uno de los nuevos dueños.

En otro departamento, los pintores pintan el techo de blanco con un rodillo largo. Algunos baños están todavía sin terminar, apenas se les está colocando el piso. Un chavo con el pantalón completamente roto está cortando y pegando ordenadamente las piezas de la futura regadera. Veo que un departamento que todavía no tiene piso llevará duela de madera, que está amontonada, amarrada en paquetes.

Las puertas de entrada a los departamentos ya tienen pegados los números color plateado. Un extintor espera ser colgado en su respectivo sitio. Los acabados de las escaleras centrales del edificio fueron mejorados colocando un zoclo de plástico gris, a manera de guardapolvo. En casi todos los pisos, en los vestíbulos, ya está terminado el revestimiento de paredes y puertas del elevador, triunfa el tono de madera color chocolate, de moda en este tipo de edificios porque se le asocia con tipos de madera muy fina y oscura, y supuestamente transmite una sensación de elegancia y clase, y cumple muy bien con las aspiraciones y pretensiones sociales de los clientes potenciales.

Roof garden

En el último piso, en lo que sería la azotea, se encuentra este espacio pretenciosamente llamado roof garden, aunque no ni sea un área verde y a veces no tenga ni una solo planta. 
Unos pocos trabajadores levantan algunas paredes para construir los baños del roof garden, que consiste en una terraza en la azotea con una barra. Hasta arriba, el roof garden ya está mejor definido, parece que habrá un espacio techado saliendo del elevador y las escaleras, con puertas corredizas hacia el resto del espacio abierto, sólo con una bardita alrededor. Ya están colando las últimas trabes de los baños y aplanando una bardita. Un trabajador empieza a colocar los mosaicos en las paredes del baño de la azotea.

En la azotea están echando el piso firme. Al cuarto de baño de la azotea todavía le siguen colocando el piso y las paredes de azulejo Interceramic. En la parte de atrás del roof garden el suelo está cubierto con unos rollos de aislante rojo, tipo tartán, imagino que será impermeabilizante. Veo que una parte de la azotea estará techada por una estructura de fierro y un lámina a manera de tragaluz, pero esto está en proceso.

Ya empezaron a pintar de blanco las paredes del roof garden. El piso rojizo está Ileno de huellas blancas. También comenzaron a poner piso de cerámica sobre la capa roja de impermeabilizante. Veo que montaron una escalera de fierro empotrada en la pared de los baños, para subir a los tanques de gas y a los tinacos. Me trepo a la parte más alta del edificio, arriba de los baños del roof garden, donde hay dos grandes tanques de gas y los tinacos marca Rotoplás. La vista de la ciudad desde aquí es bastante imponente.

En la azotea, sobre la bardas que marcan el perímetro del edificio, instalaron una malla metálica recubierta con tiras de plástico plateado para impedir la visibilidad y para tapar los tinacos. Sólo falta montar el barandal de aluminio que da a la calle. Ya hay puertas de aluminio desde el lobby del elevador y escaleras, hacia los dos lados de la azotea. Del otro lado de la azotea tres trabajadores están levantando un murete para hacer una barra.

El roof garden ya va cobrando más forma. La barrita ya está casi terminada, sólo falta pintarla. Están armando un techo de aluminio que protegerá del sol en una parte de esta área a cielo abierto. Un chavo se dedica a pintar de blanco la escalera de mano pegada a la pared, para trepar hasta donde están los tinacos. Dentro de los vestidores ya están los muebles de baño, espejo, wc, lavabo, estante, etc. Y ya están colocados los apagadores y enchufes eléctricos. 
En la azotea se está colocando el barandal de aluminio que impide la caída al vacío desde la cumbre del edificio. Pero todavía falta montar los vidrios opacos que completan el barandal. Sin embargo, en la parte de la azotea que da hacia atrás del edificio, ya está bien terminado el barandal. Acá arriba ya está pintado todo de blanco, hasta la escalera y las estructuras de fierro que formarán el techo. La barra ya está recubierta del mismo material que el piso, tipo Porcelanite. Ya sólo falta colocar el piso en un lado y pegar azulejos en las paredes de los baños y vestidores. pero se puede decir que ya está casi terminado, aunque ahora está inundado por agua de lluvia.

\section{La fachada}

Desde afuera se ven dos trabajadores que están montando una estructura de tubos de aluminio para eventualmente recubrir la cara del edificio con láminas de este material llamado "pléiser", que tiene apariencia de cemento blanco, pero más suave y liso. Varios trabajadores que se asoman, prácticamente colgándose desde la azotea, están armando una estructura de aluminio para recubrir la fachada del edificio con este material blanco.

Todas las ventanas de los departamentos del último piso faltan de ser instaladas, excepto una que da a la calle. De frente, desde el otro lado de la acera, el edificio luce prácticamente terminado, a no ser por los acabados y la fachada del primer piso, donde todavía se ven puertas provisionales y ventanas tapiadas con madera, $y$ el cemento no ha sido aplanado ni pintado.

En los balcones de los departamentos de los pisos de arriba, que dan al jardín trasero, empiezan a colocar los barandales con tubos redondos de aluminio que enmarcarán algún tipo de vidrio. Por la parte de atrás el edificio luce prácticamente terminado, su cara posterior está casi lista, salvo algunos detalles. Por cierto, el mismo material pléiser también recubre la fachada trasera.

En la obra de Córdoba las banquetas ya se ven bien trazadas y la rampa de acceso bien hecha. Fueron trabajadores del Gobierno del Distrito Federal a hacer esta labor entre el espacio público y el nuevo edificio. En la entrada al edificio parece que habrá un techo formado por un domo de acrílico montado sobre una estructura de fierro. Aún está en proceso de fabricación, ya montaron una 
estructura de fierro y ahora la están pintando de gris. Falta instalar el material del domo.

En la entrada del edificio de Córdoba ya instalaron la puerta de entrada para las personas, es de vidrio. Para evitar accidentes y que alguien se estrelle con la puerta casi invisible, le pusieron una cruz de masking tape.

Los acabados en la planta baja, de madera oscura, color chocolate, que recubre el exterior del primer departamento frente a la caseta de vigilancia, a primera vista parecen más finos y elegantes que otros lugares del edificio. Me pregunto si así lucirán todos los pisos, recubiertos de madera, o solamente este primero por ser la recepción. Es la imagen de entrada del edificio y muchas veces la primera impresión y la apariencia son lo más importante para la gente.

Retrato el edificio de Córdoba desde la acera de enfrente, ya prácticamente terminado, con sus balcones de cristal y tubos de aluminio, unas pocas plantas en uno de los departamentos de abajo, una mesa de trabajo aún en el departamento de hasta arriba. Estas vistas están enmarcadas por los cables que cuelgan de un poste frente al edificio. Un par de coches lujosos están estacionados en la puerta de entrada.

Entre los últimos detalles que se han hecho en el edificio de Córdoba, están colocar el logotipo del edificio a manera de número exterior en un material metálico brillante, esmerilar unas rayas horizontales en la puerta de vidrio de entrada, para evitar que alguien pueda chocar con ella, instalar el timbre-interfón para comunicación con el guardia; terminaron el techito afuera de la puerta hecho con fierro pintado de gris y vidrio opaco. Las ventanas del edificio ya terminado reflejan los árboles, postes y edificios que hay enfrente.

\section{El final de la obra}

El arquitecto me informa que ya pronto entregarán los primeros departamentos a sus nuevos dueños. El pintor me confirma que en verdad ya van a entregar los primeros departamentos: "el arqui quiere que acabe de pintar todo esto para el jueves, porque parece que el viernes ya tiene que estar listo el edificio para entregar".

Unos pocos trabajadores arreglan detalles en los departamentos ya prácticamente terminados. Los departamentos de abajo ya están prácticamente 
listos, aún faltan varios detalles, pero todos menores. Los vestíbulos de cada piso también lucen casi terminados.

Las paredes y techo de uno de los departamentos que tienen dos pisos, ya está pintado color amarillo limón y las escaleras para subir al segundo nivel son de madera y también están terminadas. Este departamento ya está terminado y vendido. En el piso hay un arreglo de flores y muestrarios de materiales de decoración, como si el departamento fuera un regalo para alguien. El piso de madera aparente, ventanas de aluminio, apagadores, muebles y accesorios de baño, espejos, etcétera; todo está ya en su lugar.

En la obra de Córdoba ya terminada, finalmente aparecieron cortinas, muebles y plantas en los balcones, entre otros signos de estar habitada por sus nuevos dueños.

Testimonios sobre el desarrollo general de la obra

Les digo a los trabajadores que a mi parecer está avanzando muy rápido la obra, pero ellos dicen que no, o que por lo menos su patrón no opina lo mismo, que a cada rato les dice que parece que trabajan en cámara lenta. Señalan que una vez colada esa parte que falta de la primera losa, sigue el otro lado, "y después lo demás ya sube como espuma".

Me dice Raúl que todavía falta mucho para colar la losa de la segunda planta. "Apenas están en el armado de las trabes de varilla, trabajo con el fierro, luego viene la cimbra, que es el trabajo con la madera, y después ya viene el colado, el trabajo con el cemento. Le digo que falta todavía una gran chamba, por lo menos la próxima semana entera se nos va en las trabes que faltan".

Me encuentro a Silvano y hablamos sobre cómo se procedió: partiendo el terreno casi por la mitad (la mitad exacta hubiera sido el elevador), primero desarrolló la parte de atrás, y ahora están enfocados en la de enfrente, que todavía tiene que emparejarse; de ahí en adelante, para arriba, será más fácil, sólo hay que ir haciendo los departamentos, pero se hace uno y los demás pisos se copian y se levantan más rápido. Yo estaré listo para entregar en octubre", asegura Silvano. "¿Así tan rápido?", le pregunto. Me responde haciendo un recuento del camino por recorrer: "Sí, yo voy a terminar antes de tiempo, el único problema es la parte de enfrente del terreno, lo de atrás ya está fácil, sólo es hacer lo mismo una y otra vez, pero enfrente todavía hay que hacer toda la cimentación. 
Silvano siguió explicándome que ahora las labores van a estar concentradas en la parte de adelante, para que se empareje con la de atrás, que ya está lista para crecer rápidamente, una vez que han sido edificados los cimientos. Es importante que se avance en la parte de enfrente, que es el acceso y la presentación de la obra, dice Silvano. El plan de la semana, me explica Silvano, es avanzar en la estructuras de varilla de la cimentación de abajo y terminar bien la demarcación del terreno del lado que falta.

"Sólo falta la última losa de hasta arriba", me dice Pato; calcula que van a finalizar la obra en unas tres o cuatro semanas. Supongo que se refiere a la obra negra, que es la parte que les corresponde a ellos, los albañiles. Para los acabados me imagino que falta más tiempo. "Un mes o dos meses más para acabar", me dice alguien más, pero todos parecen tener una idea diferente, y sin duda en esta materia todo el mundo es libre de opinar.

Los números de los cajones del antiguo estacionamiento permanecen pintados en las paredes en medio de la transformación radical de todo lo que antes les daba sentido y ahora los ha vuelto caducos y anacrónicos. Durante la primera parte de la obra, los números de los cajones del antiguo estacionamiento permanecen pintados en la pared, son las marcas distintivas de lo que solía ser el terreno, como signos identitarios del lugar, su seña particular. A partir de abril del 2007, los números de los antiguos cajones de estacionamiento apenas se alcanzan a ver, las paredes laterales del edificio sobrepasan su altura y los van dejando olvidados, enterrados, pero aunque nadie los vea ni recuerde, ahí seguirán pues nadie se tomó la molestia de despintarlos, hubiera sido ocioso, tan solo se les construyó encima.

Silvano, parado a la orilla del hoyo, contempla satisfecho los resultados logrados por los trabajadores que comanda; prendiendo un cigarro, admira la labor terminada de los cimientos de una nueva torre de departamentos, realizada en apenas unas cuantas semanas a un ritmo vertiginoso. "Ahora lo que sigue es la vigueta y bovedilla", me dice, "el trabajo nunca se termina del todo, tan solo son etapas que se van superando". Me explica que la semana que entra viene nuevamente la máquina para excavar la otra parte del terreno.

Antonio Bobadilla me expresa que aún no hay que cantar victoria, según él "todavía nos falta un resto más que unas pocas semanas para terminar. El departamento de muestra ya quedó, pero a todo lo demás todavía le falta un 
chingo". Días después, más optimista, Antonio Bobadilla, quien literalmente lleva puesta una camiseta de $D A K A B$, se muestra amable conmigo y comentamos brevemente sobre el estado de la obra. Me dice que ya están terminando, en tiempo todavía, según los planes, no ha habido mayores imprevistos, han avanzado bien en esta obra. "Aunque faltan muchos detalles, ya estamos en la última etapa, lo duro es que cuando parece que ya está casi todo listo, aparecen nuevos detallitos y todavía hay mucho por hacer, además los acabados son sutiles pero toman tiempo, son caros y requieren mucho trabajo".

Me cuenta El Gato que parece que el 10 de noviembre se entrega el primer departamento del edificio. El maestro encargado, simpático y amable, me comparte su impresión de que entre más se acerca el final, más parece que se tarda y hace más lento el proceso, siguen y siguen apareciendo detalles, pendientes e imprevistos. El edificio de Córdoba ya está casi terminado, pero aún se puede decir que sigue en obra.

¿En qué momento "la obra" se convirtió en "el edificio" ? Hace meses que este lugar dejó de ser un terreno y ciertamente ya tampoco es una obra, ahora se ha convertido propiamente en un edificio de departamentos, y además, a estas alturas, cada departamento tiene dueño.

\section{El proceso constructivo en la obra de Puebla}

A continuación haré una breve recapitulación del proceso constructivo de la obra de Puebla (a dos cuadras de la obra de Córdoba), más o menos en los mismos términos en que describí el desarrollo de la obra de Córdoba. Esta fue una obra de mayor escala en la que la compañía y los trabajadores demostraron más agilidad y rapidez en el proceso constructivo. La obra de Puebla consistió en un proceso más o menos con las mismas etapas y pasos que se siguieron en la obra de Córdoba. Por esto, ahorraré al lector los detalles de los procesos que se hayan repetido en ambas obras, y más bien pondré el énfasis en algunas coincidencias y regularidades significativas, así como en las diferencias, variaciones y situaciones particulares de esta nueva obra, como por ejemplo su clausura temporal en un par de ocasiones, el asalto del que fue víctima, entre otros acontecimientos.

Hay que aclarar que no concluí de documentar la totalidad del proyecto de Puebla, sino que sólo la registré en la medida en que coincidió y coexistió con la obra 
de Córdoba, que era mi referencia principal de un ciclo constructivo completo. En este sentido, es importante mencionar el dilema metodológico al que me enfrenté cuando comenzó a construirse la obra de Puebla y una gran parte de los trabajadores que conocía se fueron a trabajar a esta nueva obra de DAKAB. En un primer momento, no sabía si debía quedarme exclusivamente en el espacio de Córdoba, dándole prioridad al espacio sobre los actores, o si debía seguir a los trabajadores, actores móviles, a donde fueran, en este caso a la obra de Puebla. Finalmente decidí hacer ambas cosas, centrarme en la obra de Córdoba como estudio de caso principal, pero también seguir la pista de los trabajadores en la obra de Puebla, ya que estaba tan cerca y accesible. Por otra parte, uno de los factores que más me interesaba documentar en esta nueva obra, era la presencia o ausencia de los mismos trabajadores que había conocido en la obra de Córdoba, para tener datos que permitieran reflexionar sobre su movilidad laboral.

\section{Crónicas de otra metamorfosis}

A lo largo de esta segunda inmersión etnográfica muchas veces tuve la ingenua impresión de que esta otra obra se desarrollaba más fácil y rápidamente, quizás debido a la experiencia adquirida en la obra de Córdoba. Tal vez esta obra no fue más sencilla de construir para ellos, pero sí fue más clara y comprensible para mí, y por lo tanto más fácil de documentar. Ahora me parece más claro lo que están haciendo, para qué lo hacen y lo que vendrá después. Lo que sí representó una ventaja para ellos fue tener otra obra en la misma zona, por varias razones, como el conocimiento previo en términos de permisos y trámites burocráticos con la delegación, además de la posibilidad de préstamos de trabajadores y materiales entre estas dos obras de DAKAB.

A principios de mayo de 2007, en la obra de Puebla había un gran hoyo que formaron las máquinas tras varios días de excavación. Nuevamente brotó agua del subsuelo que inunda la base del hoyo. La extensión de este hoyo es evidentemente mucho mayor que el de Córdoba, sin duda esta obra será de una dimensión mucho mayor. $Y$ eso que aquí todavía no terminan de excavar completamente el terreno para hacer todos los cimientos. Aún siguen desmantelando partes de una estructura anterior hecha con barrotes de metal. Al otro lado del terreno todavía hay una 
franja de tierra a la altura de la calle, pegada a las viejas casas vecinas, donde hay un cuartito que funciona por ahora como bodega y habitación del velador.

Quedo sorprendido por el gran avance en la obra desde la última vez que fui, hace apenas unos días. Ya comienzan a formar las trabes para edificar los cimientos con gruesas varillas. Un grupo de unos veinte albañiles y fierreros, casi todos desconocidos para mí, trabaja bajo las instrucciones de Silvano. Casi toda la superficie del hoyo excavado está cuadriculada con trabes y castillos de varilla. Incluso la cimbra está también casi lista, forrando el acero para recibir el primer colado. Los cimientos ya están casi listos para colar el primer tramo del hoyo. A Édgar ya también lo transfirieron de la obra de Córdoba a la de Puebla. Otros diez trabajadores hacen las labores con el fierro y la madera en los cimientos al fondo del hoyo.

\section{Clausura de la obra}

A un mes exactamente de haber comenzado, la obra de Puebla fue clausurada desde el $1^{\circ}$ de junio de 2007, como a las 11 a.m. Hay sellos pegados en las puertas y por todo el exterior, en las vallas publicitarias y sobre las fotos de las familias bonitas. Versiones van y vienen: dice Antonio Bobadilla que fue por una cuestión de multas no pagadas, broncas de la oficina, que ellos esperaban saber cuándo y cuánto había que pagarle a la delegación, y en eso llegaron directamente a poner los sellos sin previo aviso, pero afirma que "en un par de días tienen que venir a retirar los sellos y liberar la obra".

Durante la primera mitad del mes de junio ha seguido clausurada la obra de Puebla. Sólo está la camioneta verde del maestro Nicolás estacionada afuera del terreno. Los sellos en los diferentes accesos aún impiden simbólicamente la entrada. Silvano me comenta que se suponía que hoy reabrirían la obra de Puebla, pero ya no sucedió, así que a ver si mañana. "Dos semanas ya es mucho", comenta molesto, "así se pierde todo el buen ritmo que llevábamos". Me platica que él es uno de los principales afectados, porque en lugar de ganar sueldo de maestro, regresó a la obra de Córdoba para ganar sueldo de oficial, aunque al menos no se quedó sin chamba, como seguramente le ocurrió a otros.

La obra de Puebla sigue cerrada, han pasado ya casi dos semanas desde su clausura. Cada día me dicen que ahora sí ya está a punto de reabrirse, pero la 
situación no ha cambiado. Con más de dos semanas de inactividad en la obra de Puebla, ¿qué estarán haciendo mientras tanto todos los trabajadores que estaban contratados ahí? ¿Cómo le harán para juntar la cuota de mano de obra necesaria una vez que reabran la obra?

\section{Reapertura}

En el terreno de Puebla hay ya una máquina rompiendo el piso y excavando, señal de que se ha levantado la clausura de la obra, que duró bastante más tiempo de lo esperado, unos 20 días. Veo por ahí a Antonio Bobadilla muy ocupado, caminando de un lado para otro. Me interpongo en su camino para saludarlo. ¡Enhorabuena, por fin reabrieron la obra!, le digo. Me cuenta que quitaron los sellos y reiniciaron oficialmente ayer, 19 de junio, por la tarde.

Adentro veo a Silvano vestido de camisa azul y gorra roja, lo saludo. Luce desconcertado, da instrucciones a unos cuantos trabajadores. Hablo con él y me dice que lo cogió por sorpresa el reinicio tan abrupto de la obra, que apenas ayer le avisaron, y hoy ya le mandaron la máquina, y que casi no cuenta con trabajadores disponibles en ese momento.

En la parte del terreno en que va más avanzada la obra, incluso ya con algunas columnas alzadas, están el maestro carpintero Calderón y otros dos o tres ayudantes sacando y marcando niveles con un sistema de hilos y pesas. Algunas partes del hoyo ya han sido cimentadas. Otros siguen desmantelando y moviendo marcos y vidrios de un lado al otro del terreno. Hay una tina (un cuadrilátero formado por cuatro paredes de madera) preparada para recibir mezcla, parece que se quedó armada y lista desde antes de que clausuraran la obra.

Hay dos puertas de acceso, ambas provisionales de madera, con hoyos en cada hoja para cerrarlas amarrándolas con una cadena y un candado. La parte de adelante del terreno es un verdadero desastre, entre bodega y basurero, con piezas, materiales y herramientas amontonadas, desechos, lodo, agua estancada, el baño y la toma de agua. Arrumbados en las orillas del terreno de Puebla hay un tanque de gas, un archivero de alguna antigua oficina, lonas, cascos, mangueras, alicatas para cortar vigas, etc. Una buena parte del piso está cubierto por miles de pedazos de vidrio roto. Hay muchos materiales y escombros todavía amontonados en el terreno, cerros de metal y aluminio, barras verdes con hoyitos y otras estructuras de 
metal arrumbadas junto con madera mojada de la cimbra. Junto a la casetita de entrada la basura tiene que ser contenida con tablones de madera, apuntalados con tablitas, formando un pasillo.

En la obra de Puebla me encuentro al Gato, al Pato y al Vela, nos saludamos con gusto y me dicen que llegaron aquí a esta obra desde el lunes. Hay todo un pelotón trabajando aquí, calculo que unos cincuenta trabajadores, unos nuevos y otros traídos de Córdoba. Veo entre otros al Pelón, Édgar, Paul, al Apache, que estaban anudando varillas, formando castillos con alambres. Otros empezaban a levantar muretes de tabique.

Comento con Paul que ahora voy entendiendo un poco mejor el proceso de construcción, ya reconozco momentos y etapas. Bromea diciéndome que "siempre es la misma gata nomás que revolcada y ahora bien acelerada", en alusión a que últimamente han avanzado muy aprisa. En la obra de Puebla se trabaja mucho más intensivamente y van muy avanzados. Hay todo un pelotón de trabajadores redoblando esfuerzos. Un número considerable de carpinteros y fierreros preparan una gran área para colar. Un puente improvisado atraviesa de una torre a otra, sobre una montaña de madera desechada. El cuarto de baño es una casetita de madera minúscula junto a la entrada.

En la obra de Puebla, por algunas partes del terreno ya están construyendo la segunda losa. Hay fierreros y carpinteros por todos lados. Me cuenta Calderón que las escaleras redondas que van del estacionamiento al primer piso van a tener una estructura de fierro previamente armada, no se cuelan de cemento, entonces no está tan trabajosa la cimbra ahí en esa parte. Tiempo después, las escaleras redondas ya están en uso y son de gran utilidad, se forma un vaivén de trabajadores que circulan a través de ellas.

Desde la banqueta ya se aprecian tres niveles que sobrepasan la barda exterior con las fotos publicitarias de DAKAB, mismas que ya han sido utilizadas como lienzo para múltiples graffitis y tags. Hay varias puertas por donde acceder a la obra. Siguen ahí los dos puentes asombrosamente improvisados y precarios, hechos con madera y lámina, que conectan las dos torres de departamentos. La planta que va más avanzada parece un cascarón compuesto de madera, ladrillos, varillas y tubos de plástico. 
Las labores continúan a todo vapor. Las escaleras para acceder al primer nivel en la torre de la derecha fueron recientemente coladas, ya se pueden usar pero todavía no les quitan la cimbra de madera que contuvo la mezcla. Dos chavos yeseros que conozco desde la obra de Córdoba ahora están en la de Puebla empezando a aplanar las paredes del primer departamento de la primera planta. Las ventanas y puertas de aluminio del área de servicio, con vidrio opaco, ya están perfectamente montadas. Parece que los patrones quieren tener el primer departamento de muestra cuanto antes.

En general, ya están trabajando en los acabados de la torre uno, la de la mera esquina; están montando el material de la fachada, llamado "pléiser" o algún nombre parecido, montando las puertas, aplicando el yeso, etc. En la torre dos, no tan avanzada como la uno, la obra negra ya está prácticamente terminada. Ya hasta están pintando el estacionamiento.

El edificio de Puebla se siguió construyendo a un ritmo acelerado, hasta que al menos desde fuera se veía completamente terminado como a mediados del año 2008. Se recubrió toda la fachada, pusieron la puerta de entada de cristal con su techo, el número, la caseta de vigilancia, etc.

Un día, semanas después de esto, cuando incluso me parecía que algún departamento ya estaba habitado, noté que había sellos de clausura sobre los vidrios y las puertas de entrada. Me pareció muy extraño que clausuraran un edificio cuando la obra prácticamente ya había concluido. Esta vez los sellos de clausura permanecieron por varias semanas, o tal vez meses, más tiempo incluso que la clausura anterior.

\section{Asalto a la obra}

Me entero de una noticia impactante. En las primeras horas del primero de enero se efectuó un robo a mano armada en la obra de Puebla, se robaron todos los materiales y herramientas, además de los sueldos de los trabajadores que se encontraban en el sitio de construcción. Todo esto me lo cuenta el maestro electricista primero, y me lo confirma Silvano después. Ambos me narran que justo en las horas en las que "todo mundo está papando moscas", celebrando el año nuevo, los ladrones aprovecharon para asaltar la obra: con pistolas encañonaron y amarraron al vigilante $y$ a los pocos trabajadores que había en ese momento en la 
obra; entraron con una camioneta, misma que cargaron con toda calma, hasta dejar vacías tanto la bodega de la obra como los bolsillo de los trabajadores, que acababan de cobrar su sueldo navideño.

\section{Comparación entre las dos obras}

Sería interesante analizar más y mejor las diferencias importantes entre las dos obras. Sobre todo los conflictos y accidentes en la obra de Puebla. En buena medida lo que cambió en el registro de uno y otro proceso fue mi experiencia. En Córdoba describí minuciosamente todo el proceso. En Puebla no quise repetir la misma descripción de procesos, me fijé más bien en lo extraordinario, lo diferente, lo particular. Pero más allá de esto, hay cuestiones estructurales que vale la pena señalar, factores que influyeron en el desarrollo de cada una de las obras. Por ejemplo, la clausura en la obra de Puebla responde a cuestiones jurídicas y políticas. La inundación remite a las condiciones materiales del subsuelo, compartido entre las dos obras, y el asalto a la obra de Puebla tiene que ver con circunstancias de orden social.

En términos generales, me parece que DAKAB hizo una mayor inversión en publicidad y en la imagen pública de la empresa, conforme fueron avanzando las obras. Resulta interesante plantear la pregunta de si conforme tuvieron mayor éxito comercial fueron invirtiendo más en publicidad, o viceversa, si entre más invirtieron en publicidad tuvieron mayor éxito comercial. El caso es que en la obra de Puebla, a diferencia de la de Córdoba, estuvieron más interesados en la apariencia y la promoción. Utilizaron mantas publicitarias cada vez más grandes para anunciar la preventa de sus departamentos, sin escatimar en gastos. Se apuraron mucho con la oficina de ventas y el departamento de muestra, además de concentrar muchos esfuerzos en la parte exterior del edificio. Definitivamente, invirtieron más en las fotos de las vallas publicitarias del exterior. Quizás todo esto se deba a que por ser una esquina más transitada, menos escondida, les interesaba hacer mucha publicidad abierta a quien sea que pase por ahí. También tiene que ver con que son bastantes más departamentos que vender en este caso, así como con el hecho de que ahora eran más departamentos que vender, y por ello una mayor inversión que recuperar, un negocio más arriesgado, que acaso ameritaba más habilidad mercadotécnica. 
Me parece que los departamentos de Puebla son más amplios que los del edificio de Córdoba 74. En este desarrollo hay unos cuantos departamentos con una vista bastante privilegiada, sobre todo los que están en la esquina o los que tienen vista al jardín de Banamex, cosa que no sucede en el edificio de Córdoba. Pero en términos de apariencia y calidad, ambos desarrollos son prácticamente iguales. Esto se nota sobre todo en los acabados; las puertas y marcos son también de madera color chocolate, igual que en el edificio de Córdoba.

A pesar de las diferencias que hubo entre estos dos desarrollos inmobiliarios de la empresa DAKAB, hubo factores comunes a las dos obras, como las condiciones del subsuelo, las condiciones laborales de la mano de obra, las fases del proceso constructivo, las acciones de los trabajadores, los materiales y herramientas que se emplean, etc. A continuación revisaremos algunas de estas características comunes a las dos obras estudiadas.

\section{Agua y lodo sin fin: las condiciones del subsuelo}

Uno de los acontecimientos imprevistos que afectó significativamente el desarrollo de las dos obras fue la gran cantidad de agua que brotó del subselo a partir de la excavación. Esta agua, que en contacto con la tierra se tornaba lodo espeso, se entrometió y trastornó los planes y el progreso de construcción de ambas obras, tanto la de Córoba como la de Puebla. Se invirtieron meses en sacar toda esa agua, a veces con ayuda de la pala mecánica, pero en las últimas etapas a mano. Pelotones de albañiles paleando lodo hacia afuera del hoyo, cadenas humanas transportando las cubetas llenas de lodo hacia afuera del terreno, viajes y viajes de camión hacia los tiraderos de escombro a las orillas de la ciudad, eran escenas comunes en ambas obras.

En la colonia Roma siempre ha habido una relación difícil entre la vivienda y las condiciones del subsuelo. El suelo fangoso es una condición que, desde que se decidió desecar el lago sobre el que se asentaba la Ciudad de México-Tenochtitlán, ha implicado retos para los habitantes. Aquí se manifiesta un enfrentamiento entre el hombre y el entorno, una determinante espacial que desde siempre se hace patente. Fernando Márquez Anaya, otro antiguo habitante de la colonia, rememora varias anécdotas de su infancia en la Roma. Recuerda que era incómodo dormir, porque había tanta agua en la zona, un suelo muy húmedo y fangoso, en el que 
proliferaban los mosquitos. Vivía en una privada en la calle de Puebla, donde a causa del hundimiento de la ciudad, una vez se rompió un desagüe que inundó los sótanos de las casas, incluyendo la suya. Se pudrió la madera de los pisos. Rememora que fue muy sonado el caso de un vecino suyo, en cuya casa una noche de fiesta se rompió el piso de madera y de golpe todos los invitados cayeron hasta el sótano. Hoy en día, en las obras estudiadas, hubo que lidiar con un gran charco de agua y lodo que dificultó la construcción. Además, los albañiles que pernoctaban en la obra, particularmente Pato, también hicieron referencia a los zancudos que no los dejaban dormir en las noches, tal como lo recuerdan los habitantes de hace décadas.

Al inicio de la obra de Córdoba, un electricista de pelo largo y chino, tipo Alex Lora, estaba poniendo una instalación eléctrica provisional, sobre todo para montar una bomba para sacar el agua que ha surgido del fondo del hoyo. Un trabajador con botas de hule recoge y enrolla una larga manguera a través de la cual pretenden bombear el agua lodoza. Cuando se da la instrucción, alguien prende y apaga la bomba con el switch en la caja de fusibles, junto a la entrada del terreno, entonces la bomba hace que la manguera, toda picada, se convierta en una fuente que emana numerosos chorros de agua a presión por todos los agujeros que tiene. "iPetróleo, somos ricos!", grita alguien de broma.

Una señora que va pasando, quien se dice vecina de la cuadra, al encontrar abierta la puerta de la obra, se mete, se acerca a los trabajadores y les dice: "¿saben por qué está lleno de agua?, por esa tubería (y apunta a una coladera en el centro de la calle); estuvo rota por más de diez años, y a mi casa siempre se me metía agua; como está abajo del nivel del piso, se me inundaba, y yo hablaba y hablaba a la delegación pero nada que me hacían caso, años y años insistí; incluso tuve que hacer un arreglo, subir el piso y hacer una bardita, para que no se me metiera tanta agua; hasta que finalmente me oyeron y vinieron a arreglarla hace unos años, abrieron el piso, excavaron y taparon la fuga... a lo mejor ahora se volvió a romper la tubería y por eso se les está inundando tanto el terreno".

"¿Cómo está, Raúl?", saludo. "Aquí nomás, mire, como cerdos, metidos en el lodo... no, como cree, si es lo más hermoso y delicioso que hay", me contesta chapoteando con sus botas de hule como niño chiquito. "Y lo mejor es que va a seguir saliendo más y más, es interminable este lodo", me dice actuando como desquiciado. Le pregunto de dónde cree que viene tanta agua. Me dice que "la 
tierra sigue llorando agua sin parar, sobre todo por los lados, es por la misma profundidad del hoyo". La bomba saca y saca agua, pero ésta sigue y sigue brotando del subsuelo; "no para y no va a parar de salir, es como un manantial allá abajo", recalca Raúl. Pienso en lago de Tenochtitlán sobre el que está edificada la Ciudad de México. ¿Será esa misma agua la que permanece en el subsuelo, tan sólo a tres o cuatro metros de profundidad? Ahora entiendo por qué es tan vulnerable ante los terremotos la colonia Roma, por lo inestable del subsuelo, el manto acuífero está a flor de piel.

Les pregunto a Silvano y a Leonel si el agua permanecerá ahí debajo de la obra, de dónde viene y a dónde irá a parar. Me dicen que "solita se sale después al meter el concreto". Sin embargo, un par de semanas más tarde, Silvano confiesa que el agua ha sido un verdadero problema, más de lo que esperaba, que es lo que ha hecho más lento todo el proceso.

Más adelante en el calendario, el hoyo aún está inundado. El lodo que siguen sacando se reúne en varios montones en la entrada del terreno, cada vez más seco y condensado. También comenzaron a demoler uno de los cuartos de la entrada, ya tiraron un muro y ahora ese espacio se usa como depósito de más cerros de lodo. Rufino también opina que "por lo que no se avanza bien es por el lodo; lo hace todo más difícil y tardado; vamos bien pero falta mucho por hacer; mire nomás, falta retirar toda la tierra de la parte de adelante".

Abajo, el hoyo sigue siendo una gran alberca de lodo y agua estancada. La actividad más cotidiana es palear lodo hacia afuera del hoyo. Un grupo de trabajadores está sacando agua a cubetazas de "el jacuzzi", como le dicen de cariño al hoyo lleno de agua estancada. Irónicamente, las cubetas que ahí llenan de agua, las van a vaciar a otro hoyo del otro lado del terreno.

Todavía a principios de marzo sigue lleno de agua el nuevo hoyo al frente del terreno. Todo es lodo, cerros de lodo que se despeñan hacia el hoyo. A finales de marzo del 2007 todavía hay agua en el fondo del hoyo, los fierreros andan con sus botas de hule. Unos trabajadores sacan lodo y escombro a cubetadas, sacando agua recogida con las palas, lo último que queda del agua, esperan todos. ¿De dónde viene esa agua? ¿A dónde se irá? ¿Seguirá ahí debajo del edificio ya terminado?

El agua estancada, emanada del subsuelo, por fin está a punto de desaparecer de la obra", dice Nicolás, "ha sido una presencia necia contra la que hubo que luchar 
durante toda la primera fase de esta obra, desde el principio de la excavación. A partir de mañana nos podemos olvidar de ella". Después de cinco meses de obra parece que por fin están terminando de sacar el lodo, finalmente están acabando de excavar y limpiar bien todo el terreno. "Ya parecía una eternidad, como que no iba a terminar nunca, para mí se convirtió como en una pesadilla", confiesa Silvano.

También en la obra de Puebla en el fondo del hoyo hay una buena cantidad de agua estancada, casi tanta como en la obra de Córdoba. Otra vez hay un problema de agua que sale del subsuelo en el hoyo del terreno, igual o más grave que en el terreno de Córdoba, porque aquí se excavó más profundo ya que va a ser un edificio más grande y alto. Un charco de agua estancada verde con plancton inunda el piso del terreno, sobre todo la parte de atrás. Un par de trabajadores remueven lodo de un lado para otro, cerca de la puerta, donde un camión pasará a recogerlo. La carretilla con lodo va y viene por un puente improvisado de madera. Al agua del subsuelo se le añade el agua de las fuertes trombas que han caído últimamente sobre la Ciudad de México. Por todo el piso hay agua, está todo inundado por las recientes lluvias. El piso del sótano permanece inundado. Hay un tambo lleno de agua que sigue recibiendo y derramando más liquido sin que nadie se percate. Noto que por donde está el tambo de agua hay goteras que atraviesan el techo desde el piso de arriba.

\section{Las lecciones del terremoto}

¿Cómo construir mejor en una zona tan sísmica? De acuerdo con Roberto Meli (2009), desde 1985 se han realizado muchos estudios técnicos y ha aumentado la resistencia de las construcciones, según los reglamentos de 1986 y 1987 . Hoy día hay mucho más conocimiento que entonces, pero también ha ido decayendo el interés por el tema y la investigación técnica al respecto, además de que hace falta una verificación efectiva de los inmuebles vulnerables y de alto riesgo.

El suelo de la colonia Roma, de acuerdo con Eduardo Reynoso, especialista en sismología, hace que la Roma esté asociada a riesgo sísmico mayor en la Ciudad de México. La nuestra es la única ciudad en el mundo con tales condiciones de subsuelo, al ser una ciudad construida sobre lo que antes era un lago. Hernán Cortés tomó la decisión de destruir Tenochtitlán, desecar el lago y construir una nueva ciudad, capital de la Nueva España. Pero el lago aún está ahí abajo, situación única que la 
hace particularmente peligrosa. En los terremotos, los llamados efectos de sitio son mucho mayores aquí debido a los suelos arenosos, cavernas, barrancas. Hay edificios enteros construidos sobre subsuelos de arcilla o sobre una capa de lodo de 20 ó 30 metros. Otro problema particular de los sismos en la Ciudad de México es su larga duración, y las reverberaciones que esto provoca (Reynoso, 2009). Como bien señala Juan Villoro, "la mañana del 19 de septiembre de 1985, la Ciudad de México fue un lago; las ondas sísmicas se desplazaron como olas" (Villoro, 2005).

A propósito de las condiciones del subsuelo y las precauciones para la construcción, quisiera referirme a ciertos testimonios, sobre todo de Silvano, sobre las medidas de seguridad y la forma de construir edificios tras la amarga experiencia del terremoto de 1985, que afectó especialmente a la colonia Roma.

Hablamos sobre lo fatal que fue el terremoto de 1985, particularmente en la colonia Roma. Me cuenta la anécdota de que él estaba trabajando en una obra en el centro, tiempo después del 85, cuando tembló y todos salieron corriendo; él no se dio cuenta hasta que le cayeron unas piedras encima, sin embargo pensó que le estaban aventando piedras, así que volteó enojado para ver quién era, pero no encontró a nadie, porque todos habían corrido hasta la avenida.

Le pregunto a Silvano por las medidas de seguridad que toman frente a la posibilidad de sismos, que pueden afectar particularmente esa zona de la ciudad. Silvano opina que desde el terremoto de 1985 "hemos aprendido la lección", que ahora un edificio se construye contemplando la posibilidad de un sismo. "Antes se ponían menos cimientos, ahora se busca que la estructura no se fracture, todas las columnas van apoyadas en el cruce de trabes y hay algunos muros, los de la base, que son muros de sismo, bastante más gruesos de lo normal, que no sólo soportan el peso, sino que impiden que se fracture el eje con el movimiento.

Todo eso es labor de calculistas (saber el peso de los materiales y el peso total de la obra), de los topógrafos (conocer las condiciones del subsuelo) y de los estructuristas. "Aunque a veces fallan", apunta Silvano, "como en la obra que está en la esquina de Orizaba y el Parque Río de Janeiro, que ya se les hundió un buen cacho la construcción, según me enteré por unos trabajadores que venían de allá".

A propósito de estructuras, dice Silvano: "lo primero que calculas antes de construir son los niveles de los inmuebles con los que colinda, lo haces colgando tus niveles, con plomos o botes de cemento colgando de un hilo". Me revela algo que a 
la mejor podría traerle problemas al edificio de Córdoba 74: la escuela con la que colinda está inclinada y se inclinará cada vez más hacia el otro lado, y esa presión en el subsuelo puede afectar al nuevo edificio. Con respecto al edificio de la escuela, me dice que se ve que le dieron una reforzada después del temblor del 85, a juzgar por el aspecto de un muro, pero que la intervención no sirve de nada porque sólo le metieron una columna pero sin base, "sin chancla", entonces es como si no tuviera nada.

Platico con Pato acerca del temblor que hubo hace pocos días. Me dice que sí se sintió, estaban ahí dormidos en la obra cuando se empezó a mover, sonó la chicharra de la escuela y hubo un apagón. Me dice que, según él, esos edificios como el que construyen no se caen con un terremoto, sí se mueven y se siente feo, pero aguantan sin problemas. También platico con Israel, el nuevo velador, sobre este mismo temblor reciente, me dice que sí lo sintieron, crujió todo y ladraron los perros que cuidan de noche la escuela, se movieron todas las chamarras que estaban colgadas. Pero me dice que como él nació en 1987 y no vivió el terremoto del 85, no sabe lo que es temerle a los terremotos en carne propia.

\section{Racionalidad e informalidad en la obra}

En este apartado quisiera seguir con la caracterización de la obra como un espacio en construcción y, como tal, un lugar marcado por las contradicciones y tensiones entre distintas fuerzas. Ya nos preguntábamos antes si la obra debe leerse como un espacio público o privado, si el trabajo en la construcción se trata de un empleo formal o informal, si los albañiles constituyen un gremio, una subcultura, si conforman siquiera un grupo estable, o si sería más apropiado considerarlos una multiplicidad de actores cuya unión es incierta, pero que sin embargo se mueven y son arrastrados por las mismas corrientes. Todas estas interrogantes son relevantes en este momento, porque vamos a tratar un tema que remite a la intrínseca ambigüedad de la obra y que la hace un espacio singular, relevante para comprender el desarrollo urbano y la reproducción de cultura en las ciudades contemporáneas.

En la obra está, por un lado, todo lo que se refiere a la planeación, los cálculos, la idea abstracta del proyecto, las estimaciones, los trámites formales, la legalidad, lo formal, lo institucionalizado, las reglas de cómo deberían ser las cosas y sus 
respectivas autoridades; y del otro lado están los factores inesperados, imprevistos, accidentales, que tienen que ver con la idiosincrasia de los trabajadores, con el mundo real, la cultura popular, la vida cotidiana, llena de retrasos, informalidad y todo lo que sucede extraoficialmente, corrupción, negligencia, etc. Es decir, las dinámicas y relaciones propias de una obra se caracterizan porque oscilan entre lo permitido, lo legal e institucional, y por otro lado todo lo marginal, transgresor, anárquico, popular, espontáneo, accidental. Para identificar estos dos polos, inspirado en las categorías analíticas propuestas por Ángela Giglia (2009), los Ilamaré: lo informal y lo racional. El espacio en construcción, la obra, está marcada por una intrínseca ambigüedad o dialéctica entre racionalidad e informalidad. La obra es, así, un laboratorio ideal para ver cómo es que pueden coexistir estos dos mundos y funcionar estas dos lógicas en un mismo espacio urbano. Patrones que se complementan, se implican y se necesitan unos a otros.

En lo que sigue, proporcionaré varios ejemplos de situaciones en las que me parece que se manifiesta un choque o un contraste, o quizás un diálogo, una retroalimentación o incluso un equilibrio, unas veces armónico otras veces más caótico, entre estos dos polos de lo informal y lo racional.

Autoridades, reglas y corrupción

Un camión que se había ido de la obra cargado de escombro hace apenas unos momentos, regresa casi inmediatamente. Antonio Bobadilla va a averiguar por qué y yo voy tras él. Resulta que un policía estaba molestando a los choferes de los camiones porque estaban obstruyendo la banqueta. También señalaba que el remolque estaba bloqueando permanentemente dos lugares de estacionamiento.

El policía argumentaba que se tenía que poner estricto porque ya se venía la hora del tráfico y la salida de la escuela que está junto. Decía que no iba a permitir ninguna obstrucción ni ocupación de lugares. Parecía como si estuviera defendiendo sus lugares, por los que quizás recibe propinas de los coches que ahí se estacionan. Me pareció obvio que se estaba poniendo exigente para que eventualmente le ofrecieran una mordida, y entonces sí dejarlos hacer lo que quisieran. Pero cuando Bobadilla dio la intrucción de que los camiones se acomodaran bien adentro del terreno, cosa que fue hecha en el acto, al poli no le quedó más que retirarse. Me comentó Bobadilla que "los tiras nada más andan 
viendo por dónde joder y cómo chingar, no dejan trabajar... y los choferes ya luego luego andaban insinuando que una coperacha pa los polis, pero siempre es mejor tratar de hacer las cosas bien desde el principio, porque si no, luego se malacostumbran los policías y andan pide y pide". El chofer se une a la plática y comenta que hace rato una patrulla lo había detenido sobre Insurgentes "por llevar la carga copeteada y mal tapada", y que había tenido que "aflojar una feria".

Sobre la acción de colgar los pendones promocionales del proyecto inmobiliario en todos los postes y árboles del barrio, un trabajador me dice: "luego también hay broncas con los policías, dicen que no puedes colgarlos sin permiso, sólo quieren bajarte una feria para luego dejarte poner lo que quieras, por eso a veces mejor los cuelgan en la noche y así no hay que pagarle a nadie".

Le pregunto a Silvano sobre los permisos de construcción en la zona y me dice que parece que ahora sí los están dando fácil, sin problemas, para edificios de hasta cuatro pisos.

Un día, el Arquitecto Canela discute acaloradamente con otro señor; cuando paso junto a ellos, lo escucho decir: "Pero cómo cree, por favor, mire, ahí están las tapas", y señalaban algo adentro del terreno. Me doy cuenta de que se trata de un inspector de la Delegación, buscando alguna irregularidad o problema para amenazar con clausurar la obra. Más tarde el arquitecto aún está con el inspector de la Delegación, sobre la rampa de acceso al módulo de ventas, hablando en un tono bastante más cordial, como si ya hubieran arreglado los problemas. Después los pierdo de vista y cuando le pregunto a Raúl por el arquitecto, me contesta: "yo creo que se lo llevaron a un restaurante o cantina, ¿no ve que vino el inspector?, parece que hubo bronca, pero todo se resuelve con una comidita y un par de tragos, así es siempre". Este testimonio es revelador de cómo funciona el trato de la obra con la delegación, o por lo menos de la percepción de un trabajador al respecto.

Hay que recordar que la intervención más significativa de las autoridades en estas obras de DAKAB fue sin duda la clausura temporal, en un par de ocasiones, de la obra de Puebla. A partir de esta clausura, en la obra de Córdoba hubo un imperativo: todos lo que entraran debían portar casco, incluidos los visitantes, como la señorita de las gelatinas y yo. "Son las nuevas medidas de seguridad para que no vayan a clausurar aquí también", me dice Javier. Entonces me asignan un casco, 
Javier manda al velador a que lo traiga de la bodega. Israel va y viene con un casco nuevo, empacado en bolsa. Me parece evidente que esta medida y sobre todo el carácter obligatorio que se le imprime ahora, no responde a cuestiones de seguridad laboral, sino más bien a un requisito institucional oficial para evitar problemas con las autoridades delegacionales.

Afuera en la obra de Córdoba el maestro carpintero Calderón realiza ajustes al tapiado que delimita la obra y la separa de la calle, para no invadir ni un centímetro de banqueta más de lo permitido. Están tomando las máximas precauciones para evitar sanciones, ya que los inspectores los han estado rondando con mucha frecuencia últimamente. Alguien me dice que el reglamento indica una multa de 15 a 20 mil pesos si algún trabajador no porta casco de seguridad, por no tener extintores, por invadir la banqueta u obstruir la circulación en la calle, entre otras posibles faltas administrativas.

\section{Accidentes}

Estaba terminando de repartir las fotos entre los trabajadores, cuando Paul mueve una varilla gruesa doblada por la punta que sin querer derriba una piedra de la pared del hoyo y causa un leve deslave que agarra desprevenido a uno de los albañiles que estaba dentro del hoyo levantando la pared de tabique. Varias piedras, unas medianas y otras de tamaño considerable, cayeron junto a él y por poco lo golpean en la cabeza. Entre "aguas" y risas le recomiendan a Paul que mejor se pase del otro lado de la trabe, porque "luego sale más caro el caldo que las albóndigas y los madrazos nadie te los quita".

Dos obreros pasan cargando unas vigas que casi le pegan en la cabeza a Pato, lo esquivan por centímetros. Otro día, casi ocurre un accidente cuando Rufino tiró sin querer unas varillas y casi le caen a otro albañil en la cabeza; todos se ríen de lo cerca que estuvo. De pronto, la grúa deja caer accidentalmente un gran trozo de concreto desde varios metros de altura. Ese bloque pudo haber matado o lesionado seriamente a alguien. Por suerte no había nadie parado ahí, de no haber sido así hubiera ocurrido una desgracia. El Gordo está descargando varillas muy gruesas de la parte de atrás de un camión, el velador le ayuda. Tienen que coordinarse para cargarlas al hombro entre los dos, lo hacen atrabancadamente, entre risas, 
"echando desmadre", hasta que finalmente se les caen las varillas a medio camino, entorpeciendo por un rato el tránsito dentro de la obra.

Errores, descuidos, imprevistos y cambio de planes

Para ejemplificar la precisión profesional de la construcción en otros países, en contraste con la idiosincrasia del trabajador mexicano, Silvano hace referencia a la construcción del túnel submarino que conecta Inglaterra con Francia. Me cuenta que lo hicieron entre los dos países, lo diseñaron juntos y empezaron a construirlo cada quién partiendo de su orilla, y cuando se encontraron a la mitad, los dos extremos embonaron con gran precisión, el cálculo fue casi perfecto, fallaron por una minucia, menos de un milímetro, "ni sé cómo se llama esa medida tan pequeña... Yo digo que fue exacto, pero ellos decían que no, por perfeccionistas; en cambio aquí aunque falle el cálculo por 2 ó 3 centímetros, decimos: ahí así ya lo dejamos".

Escucho que unos fierreros tienen algún problema con el ancho de una trabe, que no les quedó bien, como debía quedar, justo de 34 centímetros, erraron por un centímetro y medio o dos, sin embargo, luego de consultarlo con los maestros, consideran que la falla era insignificante y que la trabe estaba suficientemente bien armada, tan sólo habrá que hacer los ajustes necesarios en otras partes, para compensar esta imperfección.

Por otra parte, para los maestros es muy difícil calcular de antemano la cantidad exacta de materiales y de albañiles que necesitarán en la obra, ya que "esta labor presenta continuas fluctuaciones en la demanda de trabajo y materia prima. En una semana se pueden requerir cuatro trabajadores y a la siguiente contratar 25 o más. En la albañilería, las estructuras de trabajo se conforman y disuelven debido al avance de la obra" (Bueno, 1994: 99). Esto recuerda sin duda el planteamiento de Bruno Latour (2005), enmarcado en la teoría del actor-red, según el cual, como veremos más adelante, resulta inapropiado hablar de grupos y mejor habría que entender las dinámicas grupales como un proceso constante de formación $y$ desintegración de grupos, sobre todo entre sujetos tan móviles como los albañiles.

Sería imposible pensar en un plan maestro que pudiera prever con precisión todo lo que acontecerá en una obra. Los costos y tiempos de entrega varían considerablemente a lo largo del proceso. A pesar de los esfuerzos por controlar 
rigurosamente el proceso constructivo, "los constructores se quejan de que en la práctica existen contingencias innumerables que alteran los procedimientos...", por lo tanto, como sugiere Carmen Bueno, "al análisis de lo técnico habría que incorporar factores sociales" (Bueno, 1994: 20).

Le pregunto a Édgar cómo van, si están ya listos para colar mañana, miércoles, pero me dice que parece que no va a ser sino hasta el viernes. "¿Y eso?", pregunto; "pues quién sabe, ya ves que no se ponen de acuerdo los jefes", contesta. Me explica Pato que van atrasados y todavía falta mucho para poder colar, porque aún no les han llevado las varillas para la base que va pegada al piso, "desde cuándo está hecho el pedido, pero nomás no llega". Declara Rufino que no pudieron terminar de sacar toda la tierra el día de hoy, todavía falta bastante por excavar, o sea que el cálculo del ingeniero falló, se quedó corto. La máquina excavadora tendrá que ser contratada por otros días más, por lo menos el lunes y el martes, de acuerdo con la estimación del Rufles.

Le pregunto a Silvano por qué se retrasó el colado; me dice "quién sabe, tal vez algún problema allá arriba, porque yo estoy listo para recibir el cemento mañana", hablando como si él fuera la obra, en primera persona. Le pregunto si será por el dinero. "No, dinero nunca les falta, más bien les sobra; si tienen como veinte obras en la ciudad, además de que ya se vendieron casi todos los departamentos de este edificio... Pero como quiera que sea, tampoco ha llegado todavía la madera, también falta eso, que llegue más madera, todavía sigo esperándola"... Sólo han colado la parte de atrás, porque todavía no les han llevado el croquis de la de adelante y entonces no saben cómo va. "Primero Dios, la próxima semana vamos a estar colando la parte de adelante", declara Javier.

Los carretilleros empiezan a hacer estimaciones de cuánta mezcla falta por allá arriba y cuánta queda por acá, y junto con los que la remueven, calculan y comentan que va a faltar mezcla, lo cual llega a oídos de Silvano y a los míos de paso. Es entonces cuando Silvano salta para ir a verificar. Me dice un poco asombrado que esa ya fue la segunda olla, hubo una primera de tres y medio metros cúbicos y esta de cuatro, y ni así alcanzó, entonces asume que va a haber que pedir otra olla de mezcla más, para lo cual tendrá que pedir autorización a Nicolás y éste a su vez reportarlo a Bobadilla. 
Hablando de los problemas que se pueden suscitar en torno a una construcción, Silvano me cuenta de una obra en la que trabajó donde todo estaba mal: "había peleas, el material era insuficiente, el maestro no contaba ni revisaba nada porque pesaba como 180 kilos y apenas se podía mover, entonces nadie hacía lo que tenía que hacer, y luego la corrupción era tal, que mejor preferí salirme... Encuentras cada cosa... esto fue a principios de los 90, con una empresa constructora en el estado de Guanajuato".

En la entrada está un trabajador rompiendo un muro con un gran taladro eléctrico modelo GSH27. Es evidente que está corrigiendo algún error o mal cálculo, parece que colaron una columna que no tendría que ir ahi, y ahora hay que demolerla e incluso seguetear las gruesas varillas que salen del piso.

Javier y El Gato, revisando los planos, les dan instrucciones al Gordo y al velador para que modifiquen un muro al interior de un departamento, donde ahora va a haber una escalera en lugar del muro previsto originalmente, para el cual ya habían hecho una castillo de varilla. Me imagino que este cambio tiene que ver con la decisión de algún comprador de que su departamento sea de dos plantas. Para empezar a hacer esta modificación, primero tienen que cortar el castillo de varillas, lo cual se dice fácil, pero les daría a estos dos albañiles varias horas de trabajo, esfuerzo, aprendizaje, conversación y risas. Un par de días después, en este mismo departamento ya está casi listo el punto que estuvieron modificando el velador y El Gordo; se nota la forma de las escaleras y se nota claramente el cambio que hicieron, una variación no contemplada en el proyecto original.

La tina donde remueven la mezcla parece que comienza a fallar, se le están abriendo las paredes por un extremo. El arquitecto se muestra simpático con los trabajadores, creo que por primera y única vez que me haya tocado presenciar. Bromea diciéndoles que les apuesta su "raya" a que la tina se acaba de abrir antes de que termine el día. Dos trabajadores, Jorge e Israel, le siguen la corriente, entre risas le aseguran que "con un parche aquí y una reforzadita por allá, esa tina aguanta porque aguanta".

Un vidrio de los de la escalera ya presenta una cuarteadora. En un área de las paredes noto que el yeso se ha caído, ¿estará mal puesto, por qué duró tan poco tiempo? Alguien trapea el piso de las escaleras y el agua derramada se filtra y cuela al piso de abajo, haciendo una gotera que escurre y salpica los vidrios. Algunas 
paredes del cubo de la escalera en pisos superiores están sucias, percudidas, de tanto que se ha prolongado la obra después de que fueron pintadas; también deja ver lo tosco de los acabados en estas áreas comunes. Las escaleras entre piso y piso me parece que están inacabadas, no sé si piensen ponerles algún tipo de barandal, porque así como están pueden resultar muy inseguras. Visito unos departamentos en los que las paredes parecen estar manchadas por la humedad.

"No creo que acaben para el viernes, ¿o sí?", le pregunto a un trabajador, que aparentemente no sabía que para esa fecha deberían terminar todo. Lo cual refleja por un lado que no se han tomado muy en serio lo de la fecha límite y por otro que no hay una comunicación plena entre los trabajadores y sus superiores.

Un tramo de la malla metálica que montaron sobre las bardas para dividir el espacio del roof garden, fue derribada por los fuertes vientos durante la noche. La arrancó de la barda. Muy probablemente todavía no estaba bien puesta, o lo estaba sólo provisionalmente. O quizás lo mejor sería buscar otra alternativa.

Definitivamente, dos de los mayores imprevistos que ocurrieron en la obra de Puebla fueron, por un lado, la clausura de la obra en dos ocasiones: la primera fue por casi por un mes, muy al principio de la obra, y la segunda fue por más tiempo, casi al final del proceso constructivo, y por otro lado, el robo a mano armada en las primeras horas del primero de enero en el que se robaron todos los materiales y herramientas, además de los sueldos de los trabajadores que se encontraban en el sitio de construcción.

Trampas y relajamiento de la norma

El maestro Silvano y Antonio Bobadilla salen y anuncian a los trabajadores que volverán en un momento. La labor de los trabajadores se relaja notablemente, bajan el ritmo o disminuyen el esfuerzo en el momento de la ausencia de los jefes.

Un trabajador de la compañía que provee la mezcla, apenas llegó el camión, se acostó y se quedó dormido en una pequeña jardinera junto a la banqueta, mientras sus compañeros trabajaron arduamente armando pipas y tuberías para bombear la mezcla hacia adentro de la obra.

En plena hora de trabajo, al fondo del terreno está Rufino, El Rufles, haciéndose güey, sin trabajar, ejerciendo la más pura flojera, evitando el rayo del sol debajo de un techo improvisado con plástico negro. Ahí se estuvo unos buenos 15 ó 20 
minutos. Al verme pasar, me dice: "vente a platicar para acá, güero, para amenizar el descansito".

Charlando con El Gato en la entrada de la obra, le pregunto por qué nunca usa casco; me contesta que no le gusta, porque "estorba, incomoda, luego cuando lo usas mucho tiempo hasta te duele la cabeza, raspa y te da comezón", por eso él sólo usa gorra, "eso sí, el casco lo traigo siempre a la mano, y nomás cuando veo que llega el arquitecto me lo pongo de volón". Por todos lados hay cascos en desuso, que en realidad deberían portar, colgando de las varillas o de un clavo en la pared. Pero eso sí, los dejan siempre cerca por si hay algún tipo de supervisión.

De lejos escucho que Furcio le pregunta al Rufles cómo hacerle con eso de las varillas. Rufles le dice que ya le dijo a su amigo, y que él les puede ayudar con la camioneta. Me parece que se referían a sacar material de la obra para venderlo o usarlo en otra construcción, probablemente en alguna de sus casas de autoconstrucción. Se preguntaban cómo sacarlas de la obra en la noche sin que el velador se diera cuenta. Rufles se mostraba confiado de poder hacerlo sin bronca.

El nuevo velador, un señor mayor de barba y huaraches, con franca pinta de alcohólico, está checando las mochilas a los trabajadores que se van yendo, para evitar el robo de herramienta. Comentan que El Rufles la semana pasada traía una lámpara en la mochila y por eso lo regresaron.

Le pregunto a Silvano por varios trabajadores que no veo y me dice que "por ser lunes muchos no vinieron a trabajar, es muy común, el lunes es el día que más faltan los albañiles, por eso se dice que se toman su San Lunes", me explica Silvano. Según Carmen Bueno (1994), el famoso San Lunes es muy importante porque es el día para buscar nuevas posibilidades de un mejor empleo, representa una oportunidad para hacer ajustes laborales. Otros, como El Pelón, simplemente reconocen que el lunes, después de descansar el fin de semana, es el día que más flojera les da ir a trabajar.

Confiesa Silvano que el proyecto de construcción original sólo sirve para tramitar los permisos en la Delegación, pero luego casi siempre sufre modificaciones sobre la marcha. "Con respecto a estos cambios, la práctica usual es proceder poco a poco sin avisar ni pedir permiso. "Si intentas ser derecho y hacer todo legal, te topas con la pinche burocracia y sale mucho peor, más caro y tardado. Es mejor irte por la libre y ya si te cachan entonces sí ves cómo lo resuelves". 
Un chavo me muestra cómo están precariamente conectados a la electricidad los aparatos que se están usando en el departamento. Las clavijas de un taladro, una máquina cortadora de aluminio y por supuesto una radio, no estaban propiamente conectadas a una toma de corriente eléctrica, sino anudadas o colgadas de un cable pelado por la punta, haciendo un auténtico diablito. Más allá de quién pague esa cuenta de la electricidad que se utiliza durante la obra, está la cuestión de la seguridad, la posibilidad de generar un corto circuito, incluso un incendio, o que se les descompongan los aparatos.

\section{Interacción obra / entorno}

De acuerdo con el planteamiento de Ángela Giglia, en el estudio de las formas de habitar un lugar, de los modos particulares en los que se vinculan los seres humanos con el espacio habitable, es importante contemplar las relaciones e interacciones que estos mismos sujetos establecen no sólo con la vivienda, sino también con el espacio de sus alrededores, que suele denominarse como vecindario o espacio de proximidad (cf. Giglia, 2009). También es interesante ver las relaciones que se tejen entre los sujetos que trabajan y habitan la obra y los sujetos que se mueven por los lugares cercanos, así como tratar de entender cómo se relacionan distintos lugares entre sí por medio de los sujetos que transitan a través de ellos (cf. Signorelli, 2008).

En sintonía con estas ideas, en este apartado comentaré algunos ejemplos de los encuentros y desencuentros que se suscitaron entre la obra y su entorno inmediato en la colonia Roma. Estos contactos e interrelaciones se dieron en muy distintos niveles. Se refieren, en primera instancia, a la relación de la nueva construcción con el espacio físico y material colindante, con los inmuebles de junto, también a la fachada y al aspecto general de la obra, a su interfase o puntos de contacto con el mundo exterior, con la calles y banquetas. Este diálogo o retroalimentación también sucede en el plano de lo simbólico, en la escala de valores, los imaginarios, las creencias, y todo lo que define las concepciones del adentro y el afuera, de nosotros y de los otros, etc. Aunque serán abordados con mayor profundidad en el capítulo sobre la mano de obra, aquí también consideraremos brevemente a los actores que animan la obra, los albañiles y los trabajadores de la construcción, y los vínculos que establecen con los vecinos y otros actores ajenos a la obra, como los vendedores ambulantes y los peatones, sobre todo los de sexo femenino. 


\section{Los alrededores}

Empezaré por describir el entorno en el que está enclavada la obra de Córdoba. Los puntos de referencia que rodean la obra de Córdoba \#74 son, en primer lugar, pared con pared, la Escuela Secundaria Pública (Femenil) No. 18 de la S.E.P. "Soledad Anaya Solórzano", en el número 68 de la calle Córdoba. En el otro costado hay un edificio que en su planta baja alberga un local de venta de ropa, videojuegos y chácharas, como si fuera una venta de garage permanente. Con respecto a las dos aceras de la cuadra en la que se encuentra la obra, enfrente hay varias casas y edificios antiguos con fachada de piedra, gárgolas y esculturas. Una de ellas es la sede de la revista Artes de México. También en esa cuadra, en la esquina de Córdoba y Durango, está el Auditorio Cardenal Miguel Darío Miranda, de la Curia Arquidiócesis Primada de México, A.C. En la esquina de Córdoba y Colima hay una tienda de diseño, arte y decoración, recientemente abierta, debajo de un edificio de nueve pisos. También hay una óptica médica, una tienda club de boy scouts y una papelería en la esquina de Córdoba y Durango. Son tradicionales en esa acera el carrito de frutas y verduras que preparan con sal, limón y salsa casera, un puesto de tortas que sólo se pone por las mañanas, además de las múltiples vendimias que se instalan brevemente durante la salida de la escuela.

Doña Margarita y la pandilla de gatos

Afuera del terreno de Córdoba suele haber montoncitos de comida, alpiste, granos de maíz, migajas de pan para alimentar a la fauna de pajaros. (Esta práctica muy común en la colonia Roma; mi vecina en la calle de Mérida saca todos los días los restos de su comida y los vierte en los arbustos frente al edificio, lo cual me parece un gesto muy amable con los animales pero contribuye significativamente al aspecto sucio e insalubre que tiene el barrio.)

Un día, casi al inicio de la obra, encontré a una anciana muy mayor, de unos 70 u 80 años, calculo, arrodillada frente a la puerta del terreno, depositando trozos de comida y pequeños recipientes con leche por debajo de la puerta. A pesar de su avanzada edad y de la prominente joroba en su espalda, la señora, tirada en el piso, se esforzaba por empujar lo más adentro posible varios trastecitos con leche. Mientras sacaba y guardaba con las manos temblorosas estos alimentos de una 
bolsa de plástico negra, le pregunté para quién era la comida; ella me respondió amablemente que para un grupo de gatos que viven en el terreno, a los que desde hace mucho tiempo ella les ha llevado de comer, "sólo que ahora ya van a empezar a construir y está cerrada la puerta", me dice.

Me despido de ella y me voy pensando que a pesar de que el lote ha estado sin construir y sin habitar, es hogar de una pandilla de gatos, que se mantienen ahí gracias al apoyo de algunas personas, que juntas hacían al terreno parte de un microentorno urbano, un lugar habitado en cierta forma, con significados asociados, depositario de cierta memoria. Todo esto evidentemente se transformará radicalmente a partir de que comience la nueva construcción, acaso desaparecerá, acaso se conservará, cambiando para adaptarse.

Aparece la misma anciana que había visto días antes, con los dedos atrofiados y los brazos le temblaban, cargando dos bolsas de plástico, una en cada mano. Encogida por la edad, con una prominente joroba, con el pelo blanco, corto, y un rostro dulce, sorprendida por el avance de la excavación, se acerca a preguntarle a Silvano si todavía podría pasar a dejar el alimento para los gatos. Al escuchar el sí, la señora entra y se dirige a donde están sus trastes vacíos, lo cual, según ella, es señal de que los gatos siguen habitando el terreno por las noches. Los trastes están llenos de lodo, ella se agacha con trabajo y los ve manchados, se angustia, se pregunta en voz alta que dónde estará la llave de agua. Yo me ofrezco para ir a lavarlos, y me pide además que le llene la botella de agua. Cruzo al otro lado del terreno hasta la llave de agua. Lavo y lleno los trastes, regreso con la señora, que se llama doña Margarita Arellano, quien me cuenta que desde hace diez años que se da a la tarea de alimentar a los pajaritos y animales callejeros de la cuadra. Desde hace unos tres años pone diariamente comida en las banquetas, jardineras $y$ adentro de ese terreno, donde asegura que un grupos de gatos se refugian y comen por las noches, ya que los trastes que les deja siempre amanecen vacíos. Dice que hace como tres meses vio a través de la puerta unos gatitos recién nacidos con su mamá, que son los que ahora están comiendo, pero quién sabe hasta cuándo podrán seguir yendo ahí, porque eventualmente la obra los desplazará. Pero dice doña Margarita con admirable determinación que de todos modos ella seguirá yendo todos los días, a la misma hora (5 p.m.), a dejar dos recipientes de agua, tres de leche y una charola con croquetas; afirma que lo hará hasta que vea que ya no 
se comen la comida, sólo entonces abandonará su misión. Mientras sirve los trastes, encorvada hacia el frente sin doblar las rodillas ni levantarse un segundo, agradece la ayuda y la compañía que le brindé; dice que ella no hubiera podido ir sola hasta la llave del agua, y murmura insistentemente: "que Dios lo bendiga, joven". Cuando termina su labor, nos despedimos y ella se retira. Veo que conoce a la señora de ventas y al maestro; también se despide de ellos.

Otro día, más adelante, vi llegar a la señora Margarita, igual que la ocasión anterior, en punto de las 5 p.m., vestida con su falda gris y el suéter negro de siempre, cargando bolsas de plástico cargadas de alimento para los gatos, cada vez quedando más pequeña frente al imponente avance de la obra, indefensa y perpleja, pero sonriente y amable. Encomendada a Dios, doña Margarita continúa llevando leche, agua y croquetas para el grupo de gatos que regresan cada noche a pesar de la violenta intervención y de la transformación del espacio. Todavía amanecen vacíos los trastes, las charolas blancas de unicel y las latitas redondas. Pero ahora la señora ya no puede pasar ella misma a la obra. Tiene que encomendarle la labor a alguien más. En esta ocasión llega gritando suavemente el nombre de Mauricio. Después de un momento de observarla desde lejos, me le acerco y la saludo. Me dice que ahora le tiene que pedir a un trabajador que lleve la comida hasta la orilla del terreno: "a veces el que me ayuda es Mauricio"; "¿y cuál es Mauricio?", le pregunto; "no, pues desde aquí no alcanzo a distinguirlo, pero ahorita aparece, si no le digo al otro señor, para no interrumpir".

Me alejo de la señora y me voy al otro lado del terreno. Todos los trabajadores se encontraban chambeando dentro del hoyo. Al pasar, me doy cuenta de la burla generalizada que se traen los trabajadores en torno a la anciana. "Te habla tu abuelita, dice que vayas por la comida", se decían entre ellos. Y nadie iba ni le hacía caso a la viejita jorobada, para no convertirse en el blanco de las burlas. Finalmente, Raúl se acomide para ayudarle a la señora; le acerca los platos para que los llene de comida con sus manos temblorosas, y los lleva de nuevo a la orilla del terreno. La burla ahora es que Raúl, al ser un señor también mayor, "seguro se quiere coger a la ñora". De lejos veo a la señora despidiéndose y agradeciéndole efusivamente a Raúl.

Cuando les llevo a regalar sus fotos, la imagen de "la abuelita de los gatos" provoca risa generalizada y algunos comentarios sarcásticos entre los trabajadores. 
Dicen que en la foto parece que la anciana está echando ojitos a Raúl. Me confirman que hasta la fecha (11 de diciembre de 2006), todavía sigue yendo a dejar la comida. Voy hacia el fondo, noto que nuevamente los trastes de comida para gato están llenos de agua, leche y croquetas.

Tiempo después, casi cinco meses después de comenzada la obra, llega la viejita que le da de comer a los gatos, le pregunto si todavía van los gatos, si todavía les lleva comida y aún se la comen. Dice que sí les lleva comida todos los días, pero que ahora tiene que ir más tarde, después de que se haya ido el jefe, clandestinamente, porque ya no le gusta que vaya. Lleva un bolillo que desmenuza y vierte sobre el camellón para que se lo coman los pajaritos. Le confirmo que ya no hay moros en la costa, y va obstinada al terreno cargando con sus manos temblorosas las bolsas de comida.

Los trabajadores me confirman que todavía hay una pandilla de gatos que frecuentan el terreno, que seguido los ven por ahí. O sea que la viejita que les deja alimento está en lo cierto. Al respecto, Pato dice: "me cae que esos condenados gatos están mejor alimentados que nosotros; yo por eso le digo a la abuelita que mejor nos traiga de comer a nosotros. Apuesto que esos gatos no se comerían lo que nosotros comemos, prefieren sus piscas o siscas o wiskas". Termina Pato agregando: "Yo es lo que no entiendo y le pregunto a la señora: ¿qué caso tiene andar dejando comida por aquí y por allá, si ni son suyos esos gatos?".

A mediados de mayo, tras seis meses de construcción, debajo del remolque promocional de $D A K A B$, estacionado afuera del terreno, descubro que la anciana doña Margarita aún deja comida para la pandilla de gatos. En la noche vuelvo a pasar frente a la obra y veo un par de gatos comiendo leche y croquetas debajo del remolque. Por fin conozco a los beneficiarios de las atenciones diarias de doña Margarita y veo que tiene razón sobre la persistencia de las pandillas en el terreno y su efectiva relación con ellas. Ahora no alimenta a los gatos dentro del terreno, les deja la comida ahí cerca en la banqueta, afuera de la obra, debajo de la estación de ventas. Ha tenido que adaptarse a los pormenores de la obra, a los cambios que impone, pero a fin de cuentas sigue cumpliendo su misión, sigue la tradición resistiendo los embates transformadores de la construcción moderna. Veo pasar a la señora Margarita por afuera de la obra de Córdoba. Se detiene a mirar de arriba a abajo el edificio casi terminado. Esta señora y sobre todo su relación con los gatos, 
antes y después del nuevo edificio, es un caso revelador de la persistencia de la vida tradicional del barrio ante las formas modernas de urbanización.

\section{Colindancias y traslape de espacios}

En cuanto a las medidas de seguridad que toman antes de comenzar la obra, Silvano me informa que el "tapiado" que harán es para proteger a los peatones que pasen, "sobre todo por los niños", me dice, señalando hacia la escuela vecina. Se levantará un cerco de seguridad para delimitar la obra de la banqueta, de la calle, del entorno, pero como en todas las fronteras, hay un continuo intercambio $y$ circulación de personas y elementos de un lado a otro de la valla.

Ya está prácticamente terminada la excavación pero lo que falta lo harán a mano, porque si no la máquina excavadora podría dañar las estructuras de los muros de los inmuebles de junto. Le pregunto a Édgar para qué ocupan el unicel. Me dice que a veces lo meten entre las paredes limítrofes, para que no se recarguen en los muros del inmueble de junto, para evitar daños colaterales en los inmuebles colindantes.

Rufino lava la banqueta, talla la acera con una escoba y agua que emana de la manguera azul, conectada a la bomba que saca el agua del terreno; es decir, que tanta agua que sale del subsuelo, sirve por lo menos para lavar la banqueta. En el centro del terreno, debajo de una de las entradas, hay dos trabajadores que van a hacer algún arreglo en un gran tubo que sale del subsuelo; supongo que es el desagüe de todo el edificio, que se conecta con la tubería de la calle; parece que le van a hacer un murete de tabique alrededor.

Desde la planta más alta de la obra son posibles nuevas vistas de otros edificios en el entorno urbano. Retrato a una señora tendiendo ropa en el edificio de enfrente. En el edificio de junto hay un señor a la vista. Veo que la rama más alta del árbol de atrás da a la azotea del edificio viejo de junto, y prácticamente se recarga sobre las jaulas y tendederos.

El edificio de junto parece ser de oficinas. La altura de sus primeros pisos ha sido alcanzada por la obra. La gente trabajando en las oficinas queda a la vista. ¿Se sentirán invadidos, expuestos al ser observados por los albañiles? Desde la ventana del departamento de hasta arriba que da hacia atrás, se mira la azotea del edificio 
de enfrente, donde una señora lava y tiende ropa. Los edificios de junto a la obra han tenido que convivir con la obra por diez meses ya.

También Silvano me comenta sobre el retraso y la cantidad de hombres que hubo que contratar por el hecho de tener que sacar toda esa tierra a mano, por la precaria condición de la casa de junto: "esa pinche casa se está derrumbando, ya está bien hundida hacia acá, si no la tiramos nosotros se va a caer sola". La intensa actividad en la obra contrasta con el ritmo lento y pausado de una señora mayor que justo en ese momento baja lentamente de la azotea de esa casa vieja de junto.

Hay un contraste significativo entre el edificio que se construye en la obra de Puebla y las casas de junto. Distintas arquitecturas, épocas y coyunturas han dado lugar a edificios muy diferentes, pero separados por tan solo unos centímetros, quedando entre estos dos inmuebles un limbo angosto, una separación necesaria pero que nunca nadie ve, un rincón olvidado e insignificante de la ciudad.

Conflictos con los vecinos

Afuera en la calle hay una gran nube de polvo que se mete y se impregna en los ojos, nariz y boca de los peatones. Al salir del terreno me cruzo con un grupo de monjas que pasaban por ahí, una usaba un cubrebocas; alcancé a escucharlas comentar que esperaban que el polvo de la obra no fuera demasiado molesto y que no llegara hasta donde viven.

Desde la colindancia trasera de la obra se puede ver el patio del edificio de atrás. A esta altura, dos de sus departamentos están separados de la obra por tan solo una pared. Le pregunto a Rufino si no se han quejado los vecinos; responde: "claro que sí, el de este departamento sale a gritarnos por la ventana casi todas las mañanas, como a las 7 u 8, cuando empezamos a trabajar, a decirnos que no demos martillazos, que no hagamos tanto ruido. Yo le digo: usted puede dormir porque tiene dinero, pero yo que no tengo, debo trabajar desde temprano".

Me percato de que hay una discusión acalorada entre un grupo de antropólogos adscritos a la Coordinación Nacional del INAH, que está justo enfrente de la obra, y el arquitecto Canela. El motivo de la querella entre antropólogos y constructores es que en el terreno de Puebla se cortaron unos árboles muy grandes que había, para dar paso al nuevo edificio. Finalmente, llegaron los ecoguardias de la Secretaría del Medio Ambiente y pusieron a todos los implicados a llenar una serie de 
documentos. El arquitecto Canela está histérico, regaña a alguien que se le acerca a preguntarle algo: "iqué no ves la situación!". Mientras, platico con el policía de la entrada del INAH; me dice que parece que ya no se puede hacer nada porque parece que los constructores tenían permiso para tirarlos. "Lo triste es que llevaban muchos años ahí y estaban bien bonitos esos árboles", se lamenta el poli.

Invasión o apropiación de la vía pública

La cámper promocional estacionada afuera del terreno, sobre la calle, ocupa permanentemente lo equivalente a dos lugares de estacionamiento frente a la obra. Además de todos los lugares disponibles que se cancelan con la clausura del estacionamiento, bloquearon otros dos lugares de estacionamiento por el tiempo que duró la obra. Esto representa una pérdida de espacio muy significativa en una colonia con tantos problemas de tráfico y falta de opciones de estacionamiento.

La barda de madera que delimita la obra se come una pequeña parte de la banqueta, le gana unos cuantos centímetros de terreno. En el terreno de Puebla, uno de los carpinteros de la otra obra, Calderón, está haciendo la valla que rodea el terreno de madera, recubierta con lámina metálica, comiéndose por lo menos medio metro de banqueta.

Un coche se estaciona en la calle a un lado de la puerta de la obra. Bobadilla corre a decirle que mejor no se estacione ahí porque van a estar entrando $y$ saliendo camiones; que si deja ahí su carro es bajo su propio riesgo. Finalmente el conductor del coche opta por retirarse, claramente molesto.

Llega un camión de carga azul, el chofer se baja, se asoma y pregunta dónde se estaciona para cargar el camión. Afuera de la obra ponen botes y diablitos de madera para apartar lugar de estacionamiento a los camiones, en coordinación con el franelero local, un señor mayor.

Un día llegó un camión lleno de madera, cargado de tablones y polines para la obra. Como era justo la hora pico del tráfico, fue muy complicado que encontrara dónde estacionarse; tuvo que dar varias vueltas a la cuadra hasta que por fin movieron un coche y el camión pudo aparcarse de reversa, ante los claxonazos histéricos de los conductores. 
Dos trabajadores muy jóvenes estaban barriendo y limpiando la banqueta, donde permanecía posada la mano de la pala mecánica de la máquina, obstruyendo el paso... Un camión de carga azul está estacionado de reversa en la puerta del terreno, bloqueando la banqueta. En otra ocasión, al llegar al terreno veo el mismo camión azul de otras veces estacionado de cola hacia la puerta del terreno, de nuevo bloqueando la banqueta.

Afuera de la obra de Córdoba hay una intensa actividad. Un camión cargado de bloques de unicel deja un pedido en la obra. Los ladrillos siguen amontonados afuera del terreno. Adentro están colando y en la mera puerta de entrada construyeron una alberca en la que están removiendo la mezcla. No se pude entrar ni salir del terreno. La única comunicación es a través de la barda, por donde entran los cubos llenos de mezcla y regresan los que ya están vacíos, escalando la montaña de ladrillos. Los trabajadores formaron más que una cadena humana, un circuito de doble sentido que conecta el adentro y el afuera de la obra. La banqueta pasa a formar parte del espacio laboral de la obra.

El día anterior llegó una montaña de ladrillos que fue descargada afuera, depositada simplemente ahí en la banqueta. Un trabajador carga cubetas con ladrillos y los mete a la obra bajando por la rampa. Días después, en la banqueta todavía hay un montón de ladrillos y un trabajador trepado en él, pasándolos al otro lado de la barda, hacia adentro de la obra. A la obra de Córdoba llegó un nuevo cargamento de ladrillos, nuevamente desembarcó en la banqueta afuera de la obra. Tres peones, dos ya mayores y uno más joven, por fin están terminando de meter a la obra todos los tabiques que llevaban varios días apilados afuera en la banqueta. Los avientan desde la banqueta hasta arriba de la barda, y de ahí hasta el primer piso.

En la calle mojada sigue estacionado el remolque con el módulo de ventas de $D A K A B ;$ ya lleva más de seis meses aparcado ahí, privatizando un lugar público, y parece que continuará ahí mientras dure la obra. Además, afuera de la obra de Puebla está Paul, expectante, apartando lugar para que se estacione el camión con la olla, que debe estar a punto de llegar. En la calle de Puebla hay un tráfico tremendo ocasionado por los camiones que entran, salen y se estacionan afuera de la obra. 
Los camiones entran y salen del terreno, deteniendo por algunos minutos cada vez el tráfico de por sí pesado de la calle de Puebla. Bobadilla supervisa los movimientos, da la orden para que corten el tráfico. Afuera se forma una fila de camiones en la calle. Se improvisa un sistema de apartado de espacios para estacionar los camiones con barreras hechas con la madera de la cimbra. Se crea un pequeño caos vial en la calle de Puebla. Una patrulla llama la atención a los encargados de la obra que están afuera.

Entre cuatro trabajadores mueven una mesa de trabajo hacia el extremo opuesto del terreno, sacándola por la calle, obstruyendo la banqueta llena de gente. Tropezando, riendo, descansando cada tantos pasos, completamente desorganizados, entre dificultades y peripecias, los trabajadores que mueven la mesa estorban el paso de los transeúntes. Golpean un arbolito, bloquean el paso de una señora con sus hijos pequeños, quien se queja entre dientes, para sus adentros.

\section{La escuela}

La hora de la salida de la escuela se puede predecir por la presencia de numerosas madres esperando a sus hijas y de múltiples puestos, carritos y vendedores de papas, frutas, dulces, etc., esperando a que suene la chicharra que indica la hora de la salida. Suena la chicharra e instantes después se genera un intenso movimiento en la calle. La secundaria, al parecer, es de puras mujeres. A la hora de la salida todas comen chatarras, por lo que Rufino les grita: "no coman porquerías, chaparritas, o si no se me van a poner todas gordas". Poco después salen a la banqueta más albañiles que van terminando de comer y se unen al barullo en el exterior.

A la música de la radio que forma el sonido ambiental en la obra, de pronto se le encima la voz de la directora de la secundaria que está junto, hablándoles a las chavas por un altavoz, conminándolas a formarse y dándoles mensajes. En otra ocasión, por algún motivo que no alcanzo a escuchar ni a comprender, la directora regaña fuertemente a todos los alumnos reunidos en el patio, gritándoles a través de un altavoz.

Las alumnas del turno vespertino cantan, como todos los lunes, el Himno Nacional Mexicano y el Himno a la Bandera, acompañados por una grabación con la pista musical. Más tarde, practican para la ceremonia de honores a la bandera, con la escolta, la trompeta y la tarola. 
En plena descarga de un camión lleno de madera, las niñas de la escuela de junto seguían pasando, corriendo y jugando alrededor del material y los trabajadores. En un momento, dado, en la obra pusieron un parapeto para que no caigan cosas a la escuela de junto, como medida de seguridad.

Un buen día, la escuela dejó de ser verde, todos los balcones fueron pintados de azul, ahora los uniformes de las colegialas combinan con los balcones. También están pintando de azul las bardas de afuera de la escuela secundaria. Ahora dos trabajadores trabajan en la fachada sobre un andamio. En el mismo edificio de la escuela otros dos trabajadores cambian algunas ventanas y tiran vidrios desde la azotea que caen en la banqueta, vidrios viejos de las ventilas de los salones. Me parece increíble que tan sólo le gritan a los peatones para advertirles que no pasen por ahí, en lugar de tomar medidas de precaución más estrictas. ¿Habrán aprovechado que de por sí había una obra junto para hacer esta renovación de la escuela?

La escuela, en pleno recreo, parece convivir con naturalidad y sin mayor conflicto con la obra. Se suceden y traslapan escenas de la escuela vecina con escenas de la obra de construcción de este nuevo edificio de viviendas. Cabe mencionar que algunos de estos departamentos tendrán vista directa al patio central de la secundaria.

\section{Agentes externos}

Hablaré de algunos actores ajenos a la obra que, sin embargo, interactúan directa o indirectamente con la obra y sus personajes.

Una modalidad de interacción entre la obra y el entorno de la colonia Roma se da a través de los vendedores ambulantes que ofrecen sus productos, generalmente distintos tipos de comida, de obra en obra. Son actores ajenos y periféricos a la obra pero que se vinculan con los trabajadores, acuden al autoempleo informal como estrategia de supervivencia.

Llega un vendedor preguntando por el maestro; habla con Silvano, le muestra un folleto, le ofrece servicio de reparación y mantenimiento de todo tipo de maquinaria de construcción, ofrecen que ellos pasan a recogerla, la reparan y se la regresan a la obra. 
Llega el chavo de la bici con canasta que ya había visto un día antes. Les lleva comida a los trabajadores desde un negocio de comida corrida, una cocina económica situada en Mérida y Zacatecas. Descubrieron la conveniencia de repartir comidas a las obras de la zona, y están haciendo su agosto. Venden la comida, que incluye agua, tortillas, arroz y un guisado, por 22 pesos. Alimentar a tantos trabajadores es buen negocio. Además de esta obra, dan servicio a la de la esquina de Córdoba y Tabasco, a una en San Luis Potosí y a otra en Álvaro Obregón, "y no abarcamos más porque no podemos, no nos damos abasto; a nosotros sí nos conviene que ahorita haya tantas construcciones". Les dejan la comida en platos de plástico que más tarde recogen. Les dan la comida a crédito y les cobran lo de toda la semana los viernes, cuando a ellos les pagan la raya. Sin embargo, me dice el chavo que la mayoría de los trabajadores lleva su propia comida, porque eso les sale más barato. Es interesante notar el impacto económico y los efectos colaterales que tiene el boom constructivo en una colonia determinada.

Presencia albañil en la colonia Roma A media mañana me encuentro a Paul saliendo del Oxxo, en la esquina de Mérida y Colima, a un par de cuadras de la obra de Córdoba. Había comprando varios refrescos y jugos de diferentes sabores. El carpintero malhumorado también cruza la calle de Mérida con bolsas de comida que acaba de comprar en algún puesto callejero. Caminando por las calles de la Roma rondaban varios grupos de albañiles, muchos iban rumbo al Sumesa, al Oxxo u otras tiendas a comprar su comida o sus bebidas.

Unos diez minutos antes de la una de la tarde, por las calles de la Roma pasa un trabajador con un paquete de tortillas envueltas en papel estraza, una botella de Coca-Cola tamaño familiar y vasos desechables. Una noche, uno de los yeseros cenaba tacos de suadero en la calle a dos cuadras de la obra.

Afuera de la obra Nicolás platica con el cuidacoches de la cuadra. Édgar sale del terreno con un garrafón vacío, me dice que va al súper a rellenarlo. Un poco más tarde me lo encuentro afuera del Sumesa, en la misma cuadra de la obra, hablando en el teléfono público, con el garrafón aún vacío a su lado.

A partir del inicio de la obra de Puebla se entretejieron nuevas relaciones a lo largo de las cuadras que separan estas dos obras de edificios de departamentos de 
$D A K A B$. Se establecieron comunicaciones de todo tipo a través de la vía pública, un constante vaivén de hombres y la circulación de materiales y herramientas, irrumpiendo en la vida cotidiana de la cuadra. Por ejemplo, un día al andar por la calle de Córdoba me cruzo sucesivamente con varios trabajadores: primero con Eliseo, luego con Rufino y El Gordo, que van entre los coches empujando carretillas cargadas de mezcla entre una obra y otra, sorteando el tráfico. En este sentido, resulta simpática la anécdota: cuando Silvano le pidió a Jacobo, alias Furcio, que llevara cierta herramienta "a Puebla", Furcio, siempre distraído e ingenuo, creyó por un momento que lo estaban mandando hasta el estado de Puebla; cuando preguntó si le pagarían el camión y cuántos días tendría que estar por allá, todos se burlaron de él a carcajadas: "isi serás güey, la calle de Puebla está aquí a una cuadra!".

Parece haber canales de comunicación, un incipiente flujo de información de boca en boca entre los trabajadores de distintas obras en la zona. Como cuando me cuenta Silvano acerca de la obra que está en la esquina de Orizaba y la plaza Río de Janeiro, que ya se les hundió un buen cacho la construcción, "según me enteré por unos trabajadores que venían de allá". Pero a pesar del movimiento de los albañiles por las calles de la Roma, me llama la atención que, en realidad, su relación con el resto de la red social es escasa, superficial, o meramente pragmática. Salvo los intercambios comerciales más elementales, los albañiles parecen no integrarse con las comunidades que rodean las obras donde trabajan.

\section{El caso de un árbol}

\section{La jacaranda de Córdoba}

Este apartado es un recuento del paradero del único árbol que había en el terreno de Córdoba, a lo largo del proceso constructivo. Este árbol es como un testigo mudo de la transformación que aconteció a su alrededor, es probablemente la víctima más directamente afectada por el desarrollo de la obra y por el nuevo edificio. Este árbol funciona como una metáfora de las contradicciones y conflictos que pueden presentarse en el mundo de la construcción, del choque entre la naturaleza y el impulso urbanizador. Hay formas de habitar y urbanizar respetuosas del ambiente y otras simplemente se imponen a toda costa y borran las características del entorno en el que se insertan. 
Se trata de un árbol, me parece que una jacaranda, en la esquina trasera izquierda del terreno, que según el capataz, permanecerá intacto en el pequeño jardín que habrá atrás del edificio. Pero por lo pronto, van a construir junto al árbol un cuartito que sirva de bodega y casa del velador. Justo a un lado del árbol comienza el gran hoyo excavado que se extiende poco a poco al resto del terreno.

A los pocos días, un par de trabajadores de la empresa Higiene y Salud Ambiental, subcontratada por $D A K A B$, dedicada a la fumigación y control de plagas, trabajan sobre el árbol, quitándole del tronco larvas, capullos de oruga, mariposa y otras plagas. Ambos bien equipados, uno de ellos se trepa al árbol amarrado con varias sogas y un arnés, mientras el otro le pasa las herramientas y le saca fotos desde abajo. Recojo y veo los capullos ya deshabitados que están removiendo, medio traslúcidos pero con destellos color naranja, negro y amarillo.

Una vecina se detuvo espontáneamente frente a la obra, cuando apenas comenzaban las labores, para dirigirse a los maestros y encargados que estaban reunidos cerca de la entrada del terreno. "Lo que sí les voy a encargar mucho es mi arbolito, pobrecito, yo soy protectora de los árboles de aquí. A éste (señala hacia el fondo del terreno) desde que se vendió este lote hace años, nadie viene a regarlo y estaba todo triste y descuidado". Le responde Antonio Bobadilla: "Por supuesto, señora, despreocúpese, ése árbol es muy importante para nuestro proyecto, no le va a pasar nada". Una vez que le dijeron justo lo que ella quería escuchar, la vecina siguió su camino.

Después de meses de progreso en la obra, se percatan de que una rama del árbol interfiere con el crecimiento del edificio; "estorba la colocación del ventanal del balcón, así que vamos a tener que mocharla", me cuenta Édgar, "ni modo que dejen un hoyo en la pared y se meta la rama adentro del departamento, aunque bueno, así se ahorrarían tener que comprar arbolito de Navidad... ¿sí o no?", agrega riendo. Observo quizás por última vez la frondosa rama de la jacaranda que obstaculiza el avance de la construcción. En pocos días el muro que están levantando llegará a la altura de la rama y será inevitable que la corten. A pesar de la promesa de que el árbol quedaría intacto, su mutilación es inminente.

Tal como se veía venir, ya le cortaron un par de gruesas ramas al árbol, porque interferían con los crecientes muros del edificio. Con sus extremidades cortadas de tajo, el árbol luce mutilado, incompleto, cual Venus de Milo. La leña que queda tras 
la poda del árbol con motosierra, es recogida y llevada hasta un camión. Gran parte de esta madera, los restos de una rama gruesa y frondosa, cayeron del lado de la escuela vecina. Un par de trabajadores entran y salen de la escuela con carretillas cargadas de leña para depositarla en el mismo camión. Después de un rato, el camión parte ya cargado de leña.

Desde la ventana del departamento de hasta arriba, que da hacia el patio de atrás, se ven claramente las puntas cortadas de las ramas del árbol. Me parece una vista triste como para tenerla frente a la ventana de una habitación. Además, el árbol poco a poco va quedando apresado entre paredes que formarán un minúsculo patio trasero a su alrededor.

En el jardín trasero se han sembrado varias plantas, enredaderas, bambú y flores alrededor del árbol. Se construyó una cerca circular con ladrillo alrededor y la base del árbol quedó hundida medio metro más abajo que el resto del jardín. El patio trasero hoy está vació y en calma, no hay ningún trabajador, sólo está el árbol solitario. Entre el árbol y la pared amontonaron una pila de bloques de unicel. El pobre árbol luce cada día más acorralado, y sobre todo aislado, hasta atrás del edificio.

Después, se darían cuenta de que las ramas ya cortadas del árbol también interfieren con el barandal de aluminio de los departamentos de la segunda planta, pero por lo menos parece que esta vez sí serán respetadas. El barandal será cortado especialmente a la medida para sacarle la vuelta a la rama. A la mera hora esta rama del árbol resulta ser un obstáculo para los alumineros, que instalan el barandal con muchos trabajos.

Al fondo del terreno, en el jardín ya dividido, siguen instalando la reja que demarca y separa este patio de los cuatro edificios que lo rodean. Hacen un hoyo en la reja para dejar pasar otra rama del árbol hacia la azotea de la casa vecina. Se va a hacer una separación en el patio trasero para dividir en dos el ya de por sí minúsculo jardín. El ya de por sí minúsculo jardín ahora resulta que será una microárea verde, casi simbólica, como un aparador de tienda departamental. El árbol quedará de un lado, pero la rama pasará al otro lado. Tomo fotos del árbol ahora atrapado entre edificios, en realidad retrato el tronco mutilado, lo único que queda de la grandiosa jacaranda que era antes. 
Los árboles en la obra de Puebla

Silvano me confirma que va a ser necesario cortar los árboles que están en el terreno de la obra de Puebla, lo cual seguramente causará problemas con la delegación y los vecinos. La regla es, según me cuenta, que por cada árbol que se corte, se donen o se siembren treinta más. Hay que hacer un trámite con la delegación y ellos mismos vienen a cortarlos. Unos días después de esto, tendría lugar la confrontación ya relatada entre los antropólogos de la Coordinación del INAH y los encargados de la obra de Puebla.

\section{Epílogo: el final es un nuevo comienzo}

Unos día antes de terminar el ciclo de trabajo de campo, el maestro Javier me dio la primera noticia de que la misma compañía DAKAB posiblemente empezaría otra construcción muy cerca de las dos obras que ya tenía en la Roma. De hecho, este nuevo proyecto estaría ubicado en la misma manzana que la obra de Puebla, a dos lotes de distancia, en el número 48 de la calle de Córdoba, entre Durango y Puebla, en un terreno en el que hasta ese momento casualmente también había un estacionamiento. Dice Javier que todavía no es seguro, pero parece que pronto se sabrá, y agrega: "primero Dios, esperemos que sí se haga, para tener chamba asegurada al menos por un rato más".

Por otra parte, Ángel, El Pelón, me cuenta que oyó que el arquitecto ya está empezando a trabajar en los planos para el nuevo proyecto, que va a ser ahí, a la vuelta de la esquina. Parece que van construir dos torres más de departamentos donde está el estacionamiento, junto al Banamex, justo enfrente de la sede y la librería del INAH.

Días más adelante, Silvano me confirma lo que ya me habían anticipado extraoficialmente. DAKAB está en negociaciones para comprar el terreno de un viejo estacionamiento sobre la calle de Córdoba, en la misma manzana, a escasos metros de la obra de Puebla, y a unos cuantos pasos más sobre la misma acera de su primer desarrollo en la Roma, Córdoba 74. Parece que sólo falta el finiquito y el permiso para empezar a demoler el viejo estacionamiento. Según Silvano, este proyecto será igual o más grande que el proyecto hermano y vecino de Puebla, que a su vez ya es bastante más grande que el de Córdoba 74. 
Mientras tanto, ya empiezan a usar como bodega un espacio adyacente al estacionamiento, que parece que antes era algún conjunto de locales comerciales, con arcos de adobe en la entrada y el techo pintado de morado, cerrados con una cortina metálica toda graffiteada que sin duda llevaba algunos años sin abrirse. Ahora guardan ahí madera desechada de la cimbra de otras obras, algunas herramientas y las maquetas ya obsoletas de los edificios y de los departamentos de Puebla, seguramente casi todos vendidos a estas alturas. Una carretilla va y viene entre la obra de Puebla y esta nueva propiedad de DAKAB.

La nueva construcción en el estacionamiento sobre Córdoba ha comenzado a principios del 2009. El antiguo estacionamiento ya es historia, no existe más. El viejo remolque promocional que en un principio estaba en Córdoba 74, ahora invade una porción de calle afuera de esta nueva obra. Algunas veces he visto a Antonio Bobadilla afuera del terreno junto a la oficina de ventas.

Con este nuevo proyecto, la empresa DAKAB construye un total de tres desarrollos inmobiliarios en dos cuadras sobre una misma calle (casualmente, en dos de estos casos construyen sobre lotes que antes eran estacionamientos). Así, con estos tres proyectos, DAKAB se posiciona como uno de los mayores proveedores de vivienda en esta zona de la colonia Roma. No sólo sigue sumando nuevos proyectos a su trayectoria, sino que cada vez van siendo más grandes en cuanto a dimensión e inversión y, por tanto, con mayores ganancias. Este proceso nos recuerda a los fraccionadores de la colonia Roma hace más o menos cien años, a principios del siglo $X X$, cuando se fundó la colonia y unas cuantas familias ricas se hicieron de grandes porciones de tierra, que luego fraccionaron y revendieron, amasando grandes fortunas. Ahora, un siglo más tarde, vuelve a ocurrir un proceso similar de acaparamiento, especulación y comercialización del espacio urbano, en otro contexto histórico y con características muy diferentes, sin duda, pero no dejan de sorprender las recurrencias o continuidades de ciertos fenómenos.

Paradójicamente, todo vuelve a comenzar. El final parece ser, en realidad, el inicio de un nuevo ciclo, el principio de otro proceso. La transformación del espacio urbano parece permanente, interminable. Me queda claro que como investigadores, lo único que podemos hacer es recortar arbitrariamente y abordar por partes estos procesos, para entenderlos mejor en toda su complejidad. 


\section{Transformación del espacio: economía, política y cultura}

Sin duda, para comprender mejor los obras estudiadas en la colonia Roma, conviene considerar algunas tendencias económicas, políticas y sociales, presentes en un nivel macro o incluso a escala global, que inciden directa o indirectamente en el ámbito de la construcción de vivienda. Circunstancias como las recesiones económicas, el otorgamiento de créditos para la construcción por parte de instituciones financieras, la voracidad de las empresas constructoras privadas, las acciones u omisiones de los gobiernos, sus programas y políticas públicas en torno al desarrollo urbano, todo esto bajo la lógica neoliberal, tiene claras repercusiones sobre la edificación habitacional en la Ciudad de México.

Desde la perspectiva antropológica, resulta interesante estudiar cómo estos factores estructurales se entretejen con la cultura y el imaginario de la gente involucrada en la transformación del espacio, como por ejemplo en lo que respecta a las ideas y valores en torno a la globalización, el bienestar y las aspiraciones sociales. En lo que sigue intento esbozar algunos de estos rasgos de la economía y la política, que mezclados con diversas formas culturales y configuraciones sociales, se reflejan en los casos estudiados.

\section{El poder y la lógica detrás del cambio urbano}

Una posible lectura de las transformaciones del espacio urbano es la que plantea David Harvey, geógrafo marxista inglés, quien estudia la relación entre espacio y poder, y más particularmente, "cómo la lógica capitalista se refleja en la configuración del espacio urbano" (Harvey, 1989, 12). A Harvey le interesa cómo los procesos sociales producen formas espaciales, y más concretamente, cómo la economía capitalista produce y reconfigura el espacio urbano de las ciudades.

En una entrevista para el periódico El Pais ${ }^{10}$, David Harvey enfatiza la relación actual entre el capital y el territorio. Afirma que la producción del espacio es un aspecto central de la economía capitalista. Destaca el importante papel que el desarrollo urbanístico ha jugado en las dinámicas de acumulación de capital, y explica que a ello se debe el desaforado proceso urbanizador y constructivo que se vive actualmente. "Ahora mismo hay un auge de la construcción en todo el mundo. Hay

${ }^{10}$ Realizada por Iria Candela, publicada el 8 de septiembre del 2007. 
un desarrollo urbanístico excesivo, lo cual acarrea todo tipo de problemas ecológicos, políticos y económicos".

Harvey no piensa que cada lugar sea único o singular, sino al contrario, argumenta que en el sistema mundial capitalista los lugares aparentemente diferentes están vinculados dentro de un marco económico común. Debajo de las variadas formas de expresión en la arquitectura o en el consumo, por ejemplo, subyacen las mismas lógicas del capitalismo (Castree, 2004: 182).

\section{Gentrificación}

Resulta pertinente preguntarse si el proceso de renovación urbana y boom constructivo por el que atraviesan actualmente colonias como la Roma, la Condesa o el mismo Centro Histórico de la Ciudad de México, puede entenderse como un proceso de "gentrificación".

El término inglés gentrification (que proviene de gentry, que se refiere a la nobleza, burguesía, aristocracia o buena familia) fue acuñado a mediados de los años 60, para referirse al influjo de gente rica o de clase alta en los barrios viejos y deteriorados de la ciudades británicas, reciclando o remodelando inmuebles para darles un nuevo uso habitacional, desplazando a los anteriores habitantes, por lo general trabajadores y obreros pobres, de clase baja. Con el tiempo, el término se generalizó y se ha aplicado a los procesos de renovación y reconstrucción de zonas deterioradas de la ciudad, acompañados e impulsados por una nueva población pudiente que instaura nuevos patrones habitacionales y comerciales en la zona.

Este concepto, para el cual ni siquiera existe un consenso en cuanto a su traducción al español, ha sido utilizado desde la década de los 70, principalmente en Estados Unidos, para describir el proceso de elitización y renovación de los centros de las ciudades, que habían entrado en un proceso de decadencia y degradación, física y social. Algunos ejemplos importantes de gentrificación en Estados Unidos han sido el caso del Distrito de Height-Ashbury en San Francisco, el del centro y noroeste de la ciudad de Washington DC, así como el caso de la Calle 14 en Manhattan, NY.

Por un lado, es claro que este proceso de gentrificación urbana revitaliza las zonas deterioradas de las ciudades. Pero su contraparte, el desplazamiento de los antiguos 
pobladores pobres, representa también un problema mayúsculo. Esta circunstancia despertó un intenso debate en Estados Unidos. Los críticos propusieron imponer límites estrictos al proceso de renovación, pero el sector privado del mercado inmobiliario, muy influyente en la política, ha defendido a capa y espada sus intereses inmediatos. Hasta la fecha, no es muy claro el impacto de la gentrificación en el desarrollo integral de las ciudades, porque, además, al parecer estos procesos no responden a una tendencia constante, sino que suelen manifestarse por oleadas (cf. Nelson, 1988).

El caso de Estados Unidos puede servir como referencia, pero las ciudades norteamericanas han tenido un desarrollo tan distinto al de las mexicanas y latinoamericanas, que habría que tomar con mucho cuidado las comparaciones. En todo caso, habría que estudiar cuidadosamente los procesos de gentrificación en las metrópolis latinoamericanas, y particularmente el caso de la capital mexicana, con todos sus rasgos particulares. Lo importante es que la gentrificación produce nuevos espacios urbanos, los cuales traen consigo nuevas configuraciones residenciales y nuevas formas de cultura urbana. Así entendida, la gentrificación es un fenómeno que se ha extendido a varios países, pero en cada lugar el proceso adquiere características singulares según las condiciones locales. Valdría la pena situar este estudio de caso en el debate latinoamericano sobre la gentrificación, muy socorrido en Brasil y Argentina (ver Adrián Gorelik $(1998,2004)$ para el caso de Buenos Aires), pero no así en México. Recientemente se discuten algunas casos, como el del Centro Histórico de la Ciudad de México, que parecen sugerir que más allá de la problemática de la elitización y el desplazamiento, en determinadas circunstancias estos procesos de "gentrificación" pueden impulsar una verdadera regeneración de lo popular.

\section{Producción inmobiliaria en tiempos de globalización}

En la siguiente reflexión retomo algunas ideas de la conferencia "Enclaves de la globalización: expresiones de un discurso civilizatorio" 11 de Margarita Pérez Negrete (2009). Muy cercano al artículo de María Moreno (2009) en cuanto al terreno

\footnotetext{
${ }^{11}$ Este trabajo es producto de la investigación doctoral de Pérez Negrete, fue presentado en el marco del seminario: La construcción social de los espacios urbanos y regionales, organizado por la Dra. Claudia

Zamorano en el CIESAS, en mayo de 2009.
} 
abordado y al enfoque adoptado, esta autora también se centra en Santa Fe, en la Ciudad de México, como un enclave global.

De acuerdo con Pérez Negrete, el desarrollo urbano es causa y efecto de un proyecto político neoliberal impulsado por el sector privado, que ha regido en los planes de desarrollo urbano de la Ciudad de México. La producción del espacio y la transformación de la ciudad, señala la autora, han estado regidas por el poder de la economía y la especulación del suelo, que han generado un boom inmobiliario que beneficia ampliamente al sector privado de construcción de viviendas. Es decir, no se trata de una transformación regida por el caos, la anarquía o la falta de planificación, sino por las reglas muy claras de la economía y la política (cf. Pérez Negrete, 2009).

Siguiendo la argumentación esta autora, el sector privado y las empresas inmobiliarias, con el apoyo y la aprobación de las autoridades gubernamentales, sin importar de qué partido provengan, han estado al frente del desarrollo habitacional y la planeación urbana de la Ciudad de México, sobre todo en los últimos diez años. Han sido ellos los responsables del actual paisaje urbano, de la construcción y reproducción de un orden socio-espacial determinado; no ha sido una planeación participativa, sino impositiva. Siguiendo una lógica neoliberal, el gobierno se ha desentendido de la labor de diseñar una ciudad que sea más inclusiva, con un uso y acceso más equitativo por parte de todos los sectores de la población (cf. Pérez Negrete, 2009). Ha dejado en manos de la inversión privada el diseño y la planeación de la ciudad, y por consiguiente el destino de la cultura urbana.

"Este tipo de vivienda y el marketing que la acompaña no son exclusivos de la Ciudad de México, por el contrario, parecen ser una tendencia a nivel mundial". Dada la "internacionalización del mercado inmobiliario", las empresas constructoras importan casi literalmente "conceptos residenciales y modelos arquitectónicos totalmente nuevos para México", producen un tipo de "arquitectura cada vez más genérica" e impersonal que algunos llaman de "estilo internacional" (Moreno, 2009: $206,215,217)$.

\section{Nuevas configuraciones espaciales, segregación social y cultura urbana}

La noción de seguridad y la idea de exclusividad son fundamentales en los nuevos desarrollos: 
Como consecuencia directa de los discursos sobre la conveniencia, la seguridad y la exclusividad a través de comunidades homogéneas, los nuevos desarrollos de vivienda promueven la segregación, construyen al Otro como peligroso y abandonan el espacio público... se trata de eliminar incluso ese mínimo nivel de interacción con la ciudad... a nivel de arquitectura y planeación, se está construyendo segregación e intolerancia (Moreno, 2009: 218).

Pérez Negrete, por su parte, plantea que las convenciones arquitectónicas que predominan en los nuevos edificios los convierten en células introvertidas, separadas del mundo exterior y los espacios públicos, que perciben como hostiles e inseguros. Estos nuevos edificios autocontenidos no fomentan la coexistencia ni la interacción social, y así se va perdiendo el encuentro con la gente. Esta lógica olvida que los espacios comunes y públicos son los lugares de encuentro con lo distinto y de confrontación con los otros. En el fondo, el tan preciado discurso de la exclusividad con el que se venden los nuevos edificios de vivienda, genera y reproduce segregación y autosegregación simbólica y morfológica, así como el aislamiento de los habitantes de la ciudad (cf. Pérez Negrete, 2009).

En la última década los desarrolladores inmobiliarios comenzaron a producir un nuevo tipo de vivienda de acuerdo con un modelo habitacional que se ha denominado comunidades cerradas. En un principio, este término se refería principalmente a condominios horizontales, pero cada vez más se ajusta y se puede aplicar a "edificios habitacionales (de forma individual o en grupos) que ofrecen casi todo lo que la gente pueda necesitar para minimizar al máximo la necesidad de salir a la calle" (Moreno, 2009: 211-212).

Es interesante preguntarse si los edificios de departamentos como los estudiados en esta tesis podrían considerarse como comunidades cerradas, y en qué medida. Incluso cabría preguntarnos si estos edificios de departamentos dan lugar a comunidades en sentido estricto, o si conforman llanamente la suma de múltiples individualidades aisladas. Resulta sugerente esta analogía, sin embargo hay que recordar que aunque los edificios de DAKAB en la Roma siguen más o menos el mismo esquema que los desarrollos en Santa $\mathrm{Fe}$, son de una escala mucho menor y están dirigidos a una clase más media que alta, pero con firmes aspiraciones de ascenso social. 
Pero lo grave y peligroso, como señala Moreno, es que "no sólo está cambiando la estética, sino que nuevos conceptos de vivienda están modificando tanto la forma de vivir como su relación con la ciudad" (Moreno, 2009: 210). María Moreno nos invita a poner atención en los rasgos de las nuevas construcciones en la ciudad, "tanto a nivel funcional como estético", ya que tienen "un impacto no sólo en el urbanismo y en la arquitectura sino también en la conceptualización del espacio y sus usos" (Moreno, 2009: p. 207). Desde esta misma perspectiva crítica, conciente de que el cambio en las formas físicas está vinculado con el cambio en las formas sociales, en su artículo "Imaginarios urbanos, espacio público y ciudad en América Latina", Florencia Quesada plantea que:

La segregación residencial sigue en incremento y se ha acentuado el proceso con una creciente polarización del espacio urbano... el enclaustramiento es cada vez más común... La segregación espacial plantea una transformación importante en los usos tradicionales del espacio público en la ciudad. No sólo las élites se segregan cada día más, sino también otros grupos sociales medios y populares siguen un patrón similar (Quesada: 2006).

En muchas de las grandes ciudades latinoamericanas, el encierro es la norma: ahora se vive en casa enrejada, en barrio vigilado; se han debilitado la vida colectiva de los barrios y los lazos de solidaridad. Estas nuevas actitudes, producto de las transfiguraciones urbanas, significan un cambio cultural y social de gran trascendencia en la ciudad, han modificado las formas de vivir, percibir e imaginar la metrópoli. El modelo de aislamiento ha erosionado el sentido de comunidad en los barrios residenciales. Estas prácticas y formas de vida fomentan el individualismo y el sedentarismo (cf. Quesada: 2006).

Estas ideas nos remiten a los planteamientos de Sennett sobre cómo la nuevas formas urbanas producen experiencias sociales cada vez menos diversas y heterogéneas, y así se transforman las culturas del habitar. De acuerdo con este autor, las nuevas formas de cultura urbana y los nuevos estilos de vida en las grandes ciudades " han eclipsado algo de la esencia de la vida urbana: su diversidad y posibilidades de experiencia complejas..." (Sennett, 1990: xi-xii). Sennett argumenta que las culturas modernas sufren de una división entre el adentro y el afuera, se trata de una escisión entre la experiencia subjetiva, interior y la experiencia del mundo físico, exterior, una fractura entre uno y la ciudad, entre yo y el espacio 
urbano. En la sociedad contemporánea somos presas de un profundo miedo a la exposición, al encuentro o confrontación pública con los otros ciudadanos. "Algo característico de la construcción de ciudades en la actualidad, es separar con muros las diferencias entre la gente, asumiendo que estas diferencias pueden ser mutuamente amenazantes, más que mutuamente estimulantes" (Sennett, 1990: xii). El resultado de estas barreras entre la vida interior y la vida exterior, es un conjunto de espacios urbanos neutrales que buscan evitar, en la medida de lo posible, la amenaza del contacto social.

De acuerdo con Sennett, en las megalópolis como la Ciudad de México, la vida urbana tiende cada vez más a prescindir de nuevas y desconocidas relaciones sociales, y produce un rechazo a las experiencias diversificantes ( $c f$. Sennett, 1975: 101). Este proceso conlleva la simplificación, empobrecimiento, estereotipificación de los patrones de comportamiento y las formas sociales, así como la falta de contactos interculturales al interior de las grandes urbes, que en años más recientes se ha incrementado sensiblemente.

Los planificadores crean las condiciones urbanas que "promueven la abstención o retraimiento de la participación social" (Sennett, 1975: 104). Los desarrolladores, las empresas inmobiliarias privadas deben asumir la responsabilidad de sus actos en una sociedad histórica e impredecible (y compleja), y no en un mundo soñado de armonía y orden predeterminado... No deben planear conjuntos urbanos en abstracto, sino estudiar concretamente cada parte de la ciudad y las características de la población destinataria de las viviendas que construyen.

"Lo que hace falta es que ocurra un cambio... con el fin de crear nuevas formas de complejidad y nuevas formas de experiencias diversas" (Sennett, 1975: 100). Una buena planificación urbana debe ayudar a los habitantes a liberarse de la modalidad de retraerse ante las experiencias nuevas y desconocidas. (cf. Sennett, 1975: 118119). Sennett enfatiza el valor de observar la diversidad en la calle, de la exposición ante el mundo. Necesitamos ver las diferencias en la gente no como algo amenazante, sino como visiones necesarias. De acuerdo con Sennett, estas experiencias de interacción con la ciudad y con la demás gente son necesarias para que seamos capaces de lidiar con y aprender de la complejidad social, tanto a nivel individual como colectivo. Entonces, un problema urbano contemporáneo que es esencial enfrentar es cómo reencontrarnos con lo público, con el mundo exterior, 
LA CONSTRUCCIÓN DEL HABITAR

cómo revivir la realidad del afuera como una dimensión fundamental de la experiencia humana (cf. Sennett, 1990: xiii). 


\section{Capítulo III \\ MATERIALES Y HERRAMIENTAS \\ La vida social de los objetos en la obra}

\section{La dimensión material de la construcción}

Este capítulo reúne aquellas crónicas etnográficas en las que los materiales, herramientas y objetos involucrados en una obra de construcción adquieren un papel predominante. Desde un principio me pareció claro que estos relatos merecían un tratamiento especial, por lo significativo de algunas reflexiones derivadas de esta dimensión material de la construcción. Entonces surgió la cuestión de si este tratamiento formaría parte del capítulo sobre la transformación del espacio (ya que sin materiales y herramientas no habría dicha transformación) o si pertenecería al capítulo sobre la mano de obra (ya que son los trabajadores quienes utilizan y le dan sentido a estos materiales y herramientas). En realidad, esta temática está igualmente relacionada con ambos capítulos, pero al mismo tiempo no se agota completamente en ninguno.

Considerados por separado, los materiales tienen mucho que ver con el proceso constructivo que transforma el espacio y las herramientas con las acciones y técnicas de los trabajadores, pero juntos conforman una dimensión especial que vale la pena abordar de forma particular. Los materiales y herramientas conforman en realidad un tercer elemento indispensable para la construcción del habitar, constituyen la materia prima y los instrumentos de trabajo necesarios para que la mano de obra pueda intervenir y transformar el espacio. Por lo tanto, decidí asignarle a esta dimensión material un capítulo aparte, que a su vez se plantea como un puente entre los otros dos, o quizá sea más apropiada la metáfora de una rampa de madera ingeniosamente improvisada, compuesta por pequeños relatos y observaciones etnográficas, que permite el tránsito entre los dos capítulos centrales de esta tesis.

Sería interesante reflexionar sobre cómo ha evolucionado el uso de herramientas y materiales en la construcción y cómo se han desarrollado las técnicas constructivas; sin embargo, hay que reconocer que algunas de las acciones e intervenciones más elementales permanecen prácticamente iguales desde hace cientos de años, como por ejemplo, clavar con un martillo, cargar y transportar materiales, amarrar 
objetos, armar estructuras, demoler con un mazo, mezclar y acarrear con la pala, etc.

Los materiales para la construcción, como su nombre bien lo dice, constituyen las condiciones materiales para que exista el mundo físico, palpable y concreto, que nos rodea. Algunos materiales que se usaron en la obra son muy nuevos, aleaciones químicas y productos de la ingeniería industrial moderna (como el material con el que recubren la fachada); pero es muy interesante notar que todavía hoy se utilizan los elementos más básicos (como agua, tierra, piedra, grava, arena, etc.).

El tema de las herramientas ha sido fundamental en las teorías sobre la evolución del ser humano, la cultura y la sociedad. El surgimiento del Homo habilis está marcado por el uso herramientas entre nuestros ancestros. Se considera que hubo un salto cualitativo fundamental a partir de que los antropoides fueron capaces de construir sus propias herramientas y fabricar instrumentos como medios para conseguir otros fines. Aparece entonces una clase especial de objetos, las herramientas o instrumentos, que no tienen un valor por sí mismos, sino que su importancia radica en que sirven para conseguir otros propósitos. Este carácter de mediación de las herramientas y materiales es importante y más adelante lo retomaremos cuando se discuta, siguiendo las ideas de Bruno Latour (2005), sobre los objetos como actores y mediadores, con agencia propia y un peso específico en las redes sociales que se tejen a su alrededor.

Es importante destacar que además de la mera materialidad de los objetos, en este apartado pretendo dar cuenta de los significado que se les otorgan y algunos sentidos asociados con ellos. Los objetos se convierten en símbolos de otras cosas, representan valores, por ejemplo, en el ámbito laboral, denotan rangos y categorías. Me interesa particularmente lo que algunos autores, como Arjun Appadurai (1986) han llamado la vida social de los objetos. De acuerdo con este autor, los objetos, como las personas, tienen una vida social; adquieren un valor específico en tanto circulan en diferentes ambientes culturales y momentos históricos. Por lo tanto, propone Appadurai, hay que seguir a las cosas mismas, desentrañar sus significados, que están inscritos en sus formas, usos y trayectorias; sugiere practicar una biografía cultural o una historia social de los objetos y las cosas (cf. Appadurai, 1986: 3-34). Con esto en mente, pretendo argumentar que los objetos, sobre todo los materiales y herramientas, tienen una vida social muy preponderante en el mundo de la 
construcción y pueden ser considerados como un tipo particular de actores en la obra.

\section{La importancia de los objetos}

De acuerdo con Bruno Latour (2005), a lo largo de más de cien años de explicación social los objetos materiales han sido excluidos de la existencia colectiva en la que participamos los seres humanos. En este mismo sentido, Richard Sennett (2009) argumenta que muchas veces, cuando se trata el tema de la cultura material, los objetos analizados no se consideran "dignos de consideración por sí mismos", se les estudia como "reflejo de normas sociales, intereses económicos o convicciones religiosas; pero se prescinde de la cosa en sí misma" (Sennett, 2009: 19). Sennett mantiene la firme convicción de que vale la pena estudiar con cuidado nuestra conexión con los objetos físicos que creamos y que nos rodean.

Uno de los principales postulados de la teoría del actor-red (TAR) se refiere a la importancia de los objetos en la vida social. Latour sostiene que es necesario "aceptar a estas entidades no humanas como actores completos y desarrollados" con un peso significativo en las redes sociales que establecemos con ellos. Para lograr una verdadera recomposición de lo social, no podemos prescindir de los objetos, que juegan un rol muy importante para mantener vivo lo social. Los lazos no pueden mantenerse ni menos aún perdurar en el tiempo sin la ayuda de las cosas que nos rodean, que desempeñan acciones y por tanto poseen una verdadera agencia ( $c f$. Latour, 2005: 69-71).

Cabe mencionar que la TAR tuvo su origen en estudios de filosofía, sociología e historia de la ciencia y la tecnología; surgió precisamente cuando los objetos de la ciencia, como los instrumentos, inventos, muestras, partículas, sustancias y laboratorios, se volvieron compatibles con lo social y se incluyeron en el análisis social de la producción científica y tecnológica (cf. Latour, 2005: 36). Así, un rasgo distintivo de la TAR es "el rol crucial que le otorga a los elementos no humanos"; los considera verdaderos actores y no sólo portadores de una proyección simbólica, ni objetos de una causalidad naturalista" (Latour, 2005: 10).

Para la teoría social tradicional la acción está limitada a priori a lo que los humanos hacemos intencional y significativamente. A los objetos materiales se les ha vedado el acceso al dominio de la acción social; es decir, un martillo o un cuchillo 
existen en el dominio de la causalidad material, son parte de un haz de relaciones de causa y efecto, pero no han tenido cabida en el terreno de las relaciones sociales. Desde Durkheim, los objetos y las cosas que conforman el mundo material son "la materia sobre la que actúan las fuerzas sociales, pero por sí mismos no emanan ninguna energía social. El ámbito humano aparece como el único factor activo" (Durkheim, 1966: 113, citado por Latour, 2005: 73).

En contraposición, desde el punto de vista de la antropología de las asociaciones, cualquier objeto que modifique el estado de las cosas, marcando una diferencia, es un actor. Las cosas participan a su manera en las cadenas de acción, quizás no tengan iniciativa propia, pero de alguna manera influyen en la acción, pueden "autorizar, permitir, impulsar, brindar, posibilitar, sugerir, influenciar, bloquear..." hacer posible o imposible una acción (Latour, 2005: 72). La teoría de las asociaciones parte de la convicción de que las acciones humanas y las acciones de los objetos están constantemente vinculadas. La acción colectiva es posible gracias a que recoge diferentes tipos de fuerzas que se entretejen, entre ellas las acciones de los objetos no humanos. "Cualquier línea de acción humana puede enredarse con la acción de los objetos" (Latour, 2005: 75).

Resulta significativo que Latour utilice en varias ocasiones ejemplos provenientes del mundo de la construcción. Ilustra la idea de las interacciones entre las personas y los objetos señalando que "la inercia social y la fuerza de la gravedad no parecen estar conectadas, pero no obstante lo están cuando un grupo de trabajadores construye una pared de ladrillos... el grito que ordena a un trabajador pegar un ladrillo más, la conexión química del cemento con el agua, la fuerza de una polea que actúa sobre una cuerda con el jalón de una mano", son factores que están íntimamente conectados (Latour, 2005: 75).

La continuidad de una línea de acción rara vez consiste exclusivamente de conexiones entre humanos, casi siempre se compone de lazos entre humanos y objetos. Por ejemplo, señala Latour que "pastor, perro, ovejas y alambre de púas establecen un vínculo social y forman una misma línea de acción" (Latour, 2005: 77). Entonces, la antropología de las asociaciones se dedicaría al rastreo de conexiones entre actores, incluyendo a los objetos no humanos. Se trata de eliminar la asimetría a priori entre la acción humana intencional y el mundo material de las relaciones causales. Debemos tomar en cuenta a los objetos no humanos a la par de las 
acciones intencionales humanas, pero sin dejar de reconocer al mismo tiempo su fundamental inconmensurabilidad (cf. Latour, 2005: 75-78).

En lo que se refiere a la acción, insiste Latour en que resulta absurda la dicotomía entre objeto y sujeto. Los objetos tienen sus propios 'modos de acción', como la fuerza ejercida por un ladrillo sobre otro, el giro de una rueda sobre su propio eje, el equilibrio de una palanca sobre una masa determinada. En las ciencias sociales nunca se habla propiamente de la acción de los objetos, pero se les puede sentir por todas partes y en cada momento. Viven en los márgenes de lo social, hacen gran parte del trabajo de mantener activas las redes sociales, sin recibir crédito por ello. "Es hora de practicar una sociología orientada hacia los objetos", declara Bruno Latour (2005: 73).

Los objetos materiales transportan sus efectos silenciosamente, permanecen mudos y aparentemente dejan de ser actores, pasan a ser invisibles. Los objetos tienden a desvanecerse en el trasfondo, desaparecen más entre más familiares son para nosotros, muy rápidamente son dados por hecho. "Una vez construida, una pared de ladrillo no emite ni una palabra sobre sí misma o su función en relación con el mundo a su alrededor". Pero esto no significa que deje de actuar, sino que su modo de acción deja de estar conectado evidentemente con el resto de los vínculos sociales. Los lazos que establecen los objetos entre sí o con otro tipo de actores son sólo momentáneos y a veces prácticamente imperceptibles. Por eso a los objetos hay que captarlos al vuelo, al momento de su acción o de su creación, hay que hacer lo posible por hacerlos hablar, revelar su complejidad interna, confesar lo que hacen a los otros - humanos o no humanos - hacer. Definitivamente, los objetos deben entrar en los recuentos etnográficos (Latour, 2005: 78).

Latour menciona algunas situaciones en las que los objetos se tornan particularmente visibles y recomienda acudir a ellas para empezar a cambiar nuestra manera de concebirlos y restablecer su rol protagónico. En primer lugar, están las innovaciones técnicas y tecnológicas que suceden generalmente en el taller del artesano, el laboratorio del científico, el departamento de diseño industrial o una obra de construcción. En estos sitios los objetos tienen una vida claramente múltiple y compleja. Aquí los objetos se mantienen visibles por más tiempo. Otra buena ocasión la ofrecen los accidentes, colapsos, crisis o averías: cuando los objetos que un instante antes parecían silenciosos, automáticos y desprovistos de agencia, 
de pronto se tornan mediadores completamente desarrollados. Los objetos pueden cambiar rápida y radicalmente su modo de acción, y gracias a estas transformaciones nos dan la oportunidad de ver y sentir lo que pueden pesar en las redes sociales. Por último, irónicamente, cuando lo objetos han desaparecido, adquieren mayor visibilidad; uno no sabe lo que tiene hasta que lo pierde, dice el dicho; aunque casi siempre es posible traerlos de vuelta a la luz recurriendo a archivos, memorias, museos, colecciones o recuentos históricos (cf. Latour, 2005: 8081).

Lo anterior es relevante ya que de una u otra forma, estas situaciones se presentan en la obra, que puede entenderse como una especie de taller o fábrica en la que los objetos e instrumentos juegan un rol esencial, donde constantemente hay innovación, producción y creación material; un lugar donde ocurren accidentes que tienen que ver con los "caprichos" de los objetos, y donde con facilidad también ocurre que los objetos, en este caso los inmuebles, se pierden o desaparecen, con la consiguiente merma patrimonial. Todo lo anterior convierte la obra en un lugar idóneo para observar la importancia de los objetos, los materiales y las herramientas en la vida social.

\section{Materia prima}

\section{Las propiedades de la materia}

Les pregunto a los trabajadores como cuánto tiempo tarda en secar la mezcla una vez vertida durante el colado y me contestan que más o menos en tres horas ya está macizo, que si le dejaran de mover, en una media hora se empieza a poner dura, pero en secar bien, bien, bien, demora unos tres días. Édgar me explica que además se le puede echar un acelerador a la mezcla para que se seque más rápido. Este es un claro ejemplo de cómo los materiales imponen tiempos y marcan ritmos de trabajo, y de cómo el ingenio humano interviene para optimizar estos procesos laborales.

La tina fue barnizada con "grasa", una mezcla de solventes revueltos en una cubeta, untada en las paredes de la tina con una brocha improvisada con un palo y un papel, para que la mezcla que se depositará ahí desde la olla no se quede pegada en la madera... Embarran los tablones de madera con un líquido parecido a 
la brea, en preparación para colocar la cimbra y contener la mezcla... Pasan unos chavos cargando cubetas con algún líquido extraño, lechoso, espeso, con olor muy fuerte; le pregunto al Gato qué es y me cuenta cuidadosamente que es para pegar concreto, que se pone en las juntas del concreto, y agrega que es un material bastante caro.

Al frente los carpinteros siguen armando la cimbra, clavando y amarrando tablones, forrando de madera las estructuras de varilla hechas por los fierreros. La madera contiene y da forma a la mezcla que se vierte entre $y$ alrededor de las varillas, para que cuando se seque quede una estructura rígida de acero rodeada por una masa consolidada y firme de cemento... Paul me dice que colaron el viernes y la cimbra de madera se quedó todo el fin de semana con la mezcla, por eso les está costando tanto trabajo quitar la madera, se quedó demasiado tiempo pegada, ahora hay que arrancarla. Entre un entramado de varillas batallan con tubos $y$ cuñas para zafar la cimbra pegada al colado.

En la azotea un trabajador pule las orillas de unas láminas de un material que se llama algo así como pléiser, tipo tablarroca, suave y grisáceo, que al parecer será colocado en toda la fachada del edificio. Al pulirlo con una máquina que tiene un disco de lija que gira, este material desprende un fino polvo. El trabajador se protege el rostro con dos camisetas amarradas alrededor de la cara... Dos trabajadores siguen cortando y puliendo dicho material en la azotea, con los edificios y espectaculares de la Roma como telón de fondo. Siempre lo hacen en la azotea porque es mejor hacerlo al aire libre, por la cantidad de fino polvo que se desprende. Cuando terminan de cortar las piezas, las bañan con un líquido, con ayuda de una brocha y una cubeta, para protegerlas de la intemperie. Una grabadora anexa a la mesa de trabajo, protegida con una bolsa de plástico para que no se llene de polvo, les hace más amena la chamba.

En efecto, este material color cemento recubrirá toda la fachada y la cara posterior del edificio. Será lo primero que se verá desde la calle, su acabado externo, su presentación, su rostro. Previamente en la fachada habían colocado una estructura de aluminio en hileras a todo lo ancho $y$ alto del edificio. Luego colocarían las placas de este material, ajustándolas al aluminio con un clavos y tornillos, pero en donde no hay una superficie suficientemente firme, lo pegan con silicón... 


\section{Los materiales como parte del paisaje}

Adentro de la obra, cerca de la entrada, un camión despositó una carga de tabique gris. Había cerros de material en la entrada del terreno, mucha grava y arena. También hay montones de madera, tablones y vigas. Los cerros de materiales que han ido llegando al terreno, hacen que la obra parezca una gran bodega al aire libre. Las varillas descargadas el día anterior fueron depositadas en la entrada a lo ancho del terreno, acostadas transversalmente. Por tanto, hay que caminar sobre ellas para pasar a cualquier parte de la obra, lo cual complica el tránsito y se presta fácilmente al tropezón. Es necesario convivir con los materiales depositados por todas partes, que transforman el espacio en un camino lleno de trampas y obstáculos.

Grandes montones de madera, tablas, vigas y demás materiales permanecían almacenados en el terreno. Hay varias herramientas botadas por todas partes, un nivel, un bote con clavos, varias escaleras apiladas, una cubeta de brea, etc. Hay montones de madera utilizada en cimbras pasadas, arrumbados en los rincones. EI tránsito hacia adentro de la obra sigue siendo difícil. Ahora hay un cerro de grava impidiendo la entrada. Dos trabajadores están paleando el material, poniéndolo en cubetas y poco a poco subiéndolo al piso de arriba de la obra. En la entrada de la rampa hay un cerro de arena que hay que trepar para entrar a la obra. Cientos de varillas que recientemente depositó un camión están almacenadas a lo largo de la rampa que bajará al sótano.

Sobresalen del cemento ya firme los castillos de varilla que detendrán los pisos que vienen para arriba, así como varios tuberías de cobre y mangueras de plástico naranja, de las instalaciones de gas y eléctrica, respectivamente... En un patio interior se han ido amontonando desordenadamente los restos de la cimbra... El maestro electricista resguarda las lámparas de halógeno para iluminar el estacionamiento, la parte más oscura del edificio, que están amontonadas en los departamentos de abajo... En algunos recovecos hay material guardado. Las Ilantas de repuesto del remolque de ventas están guardadas en un cuartito del edificio... "es que si no se las vuelan", me dice el señor con cigarro en la boca. 
Los muros interiores son aplanados con yeso marca Las Peñitas, hay sacos de este material por doquier... Llega el material Porcelanite para el piso en losetas de $60 \times 60 \mathrm{~cm}$. Unos cuantos trabajadores van y vienen de afuera hacia adentro de la obra, cargando al hombro estos paquetes de la marca Interceramic. Por otros rincones del edificio hay más bultos de material acumulado... En el centro de la obra, entre las dos torres, hay un montón de basura que crece y crece conforme le van echando más basura y escombros desde todos los pisos de las dos torres. Suben y bajan cubetas cargadas de escombro amarradas con un alambre.

\section{Instrumentos de trabajo}

\section{Infraestructrura laboral}

Carmen Bueno (1994) señala la importancia la infraestructura material y los instrumentos que utilizan los trabajadores en el proceso de edificación habitacional. Prácticamente en toda obra de construcción de vivienda, el proceso comienza con la construcción de "una bodega provisional que sirve no sólo para almacenar el material que se va a utilizar exclusivamente en esa obra, sino que sirve de vivienda temporal para aquellos que provienen de zonas rurales, que no tienen otro lugar donde permanecer durante su estancia en la ciudad". Menciona también que "otra parte de la infraestructura fabril para este tipo de obra se compone de estructuras (andenes, andamios, mesas de trabajo), generalmente de madera, que se arman y se ajustan a las necesidades de la obra" (Bueno, 1994: 95).

Es importante destacar un objeto que tiene un importancia particular en la obra, al que me referiré como "mesa de trabajo de madera". Una de las primeras tareas que tienen los albañiles al iniciar una obra es construir unas mesas improvisadas con tablones y vigas de madera. Sobre estas mesas se desarrollan numerosas actividades: en ella trabajan los fierreros que fabrican estribos, los carpinteros que cortan y miden tablas, etc. Se convierten en referentes espaciales dentro de la obra, a los que se asocia la presencia de algunos trabajadores: "está allá abajo, en la mesa con el Pato". A su alrededor se generan dinámicas de reunión de grupo, a veces los albañiles conviven en silencio mientras trabajan o escuchan la radio, pero casi siempre platican y socializan mucho. Muchas veces se usan también, desde luego, 
como mesas para comer. Estas mesas de trabajo de madera tienen una presencia protagónica en varias historias que ocurren en la obra.

Tres trabajadores doblan y cortan varillas y alambres sobre una mesa de trabajo de madera. Tienen a su alrededor más material del que podrían terminar de trabajar en una semana laboral sin descanso alguno, me parece... Un grupo de carpinteros que se dedican a los acabados utilizan una mesa para desplegar sus herramientas y equipo, una sierra eléctrica y otros instrumentos más sofisticados... Cada quien construye su propia mesa de trabajo de madera de acuerdo a sus necesidades... En otra sección del sótano, iluminado con una luz incandescente, hay varias mesas de trabajo, unas son simples tablas sobre tambos y otras son más firmes... Un carpintero corta y une trozos de madera con martillo, clavos y una sierra montada en la misma mesa. Tiene una imponente caja de herramientas a su lado... Me llaman la atención los curiosos banquitos que usan los yeseros para alisar paredes, un palo largo sostenido por dos burritos en forma de " $A$ " en la orillas.

En el cubo central del edificio hay un andamio azul, con el que han aplanado y pintarán la cara exterior del edificio... Dos trabajadores jóvenes, que están sentados sobre un andamio que parece bastante firme, sostenido con un cable de metal de gran calibre; hacen agujeros con un taladro en la parte de afuera del edificio... Otro andamio, esta vez improvisado con madera reciclada, le sirve a otra pareja de trabajadores para caminar por fuera del cuarto, a la altura del segundo piso.

\section{Maquinaria y grandes herramientas mecánicas}

Bueno señala que "el uso de maquinaria (que es bastante reducido) tiene ciertas variantes en las distintas fases del proceso". En el proceso de excavación, "lo más probable es que el constructor subcontrate esa parte del proceso a una empresa que cuenta con maquinaria y trabajadores especializados para nivelar la superficie" (Bueno, 1994: 95).

En la obra de Córdoba me toca ver la excavación del terreno con una máquina marca Caterpillar modelo 320BL, que tiene un potente brazo mecánico. La pala mecánica excava y luego deposita la carga de tierra y lodo en un camión de volteo, que al llenarse parte hacia el tiradero de escombro. La máquina tiene una banda mecánica en vez de llantas y una cabina que gira junto con el brazo mecánico. Unos días después, la máquina excavadora se ha ido. Seguramente esta maquinaria 
pesada se alquila por día y debido al elevado costo que representa, se debe optimizar su uso lo más posible. La primera fase de la excavación de este terreno duró apenas unos tres o cuatro días.

Nuevamente hay una gran máquina excavadora, esta vez roja, estacionada en la entrada del terreno; descansa su brazo mecánico en el hoyo que acaba de cavar... En la obra de Puebla, una máquina excavadora Caterpillar 320C avanza haciendo más grande el hoyo y haciendo más agua. Comento con Silvano lo rápida que va la excavación, "es que es muy buena esa máquina", me explica. La parte de arriba, la cabina y el brazo mecánico, giran velozmente en relación con la base, que son dos rollos metálicos que se mueven como pies de una oruga mecánica. Dos trabajadores en el fondo del hoyo palean y remueven lodo de un lado para otro, como acomodándolo o amontonándolo para que el brazo mecánico lo recoja más fácilmente. La escala humana hace más evidente el gran poder que tiene la máquina en contraste con la fuerza del hombre.

Otro momento en el que se echa mano de maquinaria especializada es durante el proceso de colado, que requiere "máquinas para revolver la mezcla y transportes especiales para acarrear y mezclar el cemento" (Bueno, 1994: 95). En este caso la empresa constructora también subcontrata a una empresa que además de proveer el cemento hasta donde esté la obra, cuenta con el personal especializado y la maquinaria indispensable (camiones, pipas, tuberías, revolvedoras, etc.) para hacer llegar la mezcla hasta donde lo pida el cliente.

Llega a la obra otro camión de CEMEX con más mezcla; es la segunda olla que les llevan ese día. El mismo chofer es también el operador de la olla y va con él otro ayudante. Según me informa Silvano la carga de mezcla que les dejarán en esta ocasión será de 31/2 metros cúbicos; aunque en realidad la olla tiene más capacidad que eso. En ambos casos estudiados, la empresa proveedora de cemento fue CEMEX.

\section{Instrumentos manuales}

Fuera de esta maquinaria, todo lo demás se lleva a cabo con instrumentos manuales. En general hay dos tipos de herramientas, las producidas industrialmente y las de fabricación casera. Entre las primeras podemos mencionar las siguientes: 
cinceles, serrotes, martillos, niveles, carretillas, para los albañilería general; brocha, cubeta, estopa para los pintores; cuchara, cuñas, maceta, llana, tirolesas, para los yeseros; los colocadores usan pegamento, tina y pulidora, remachadoras y taladros, además de desarmadores, pinzas y sopletes para los plomeros y electricistas... (Bueno, 1994: 95-96).

Los fierreros amarran los estribos a las gruesas varillas que forman las trabes con unos alambritos casi insignificantes, que sin embargo mantienen unida la columna vertebral del edificio. Estos amarres los llevan a cabo con la ayuda de una herramienta muy común que parece un clavo enorme con la punta chueca, que sirve para doblar y anudar el alambre.

En el proceso de armar la cimbra, a las tablas les hacen un par de hoyos con una herramienta especial llamada tirabuzón, que da vueltas, para que les entre el alambrón que las sostiene pegadas a las varillas, según me explica el velador, quien está haciendo los hoyos... Los yeseros trabajan con un instrumento que semeja una espátula, con una especie de manija por un lado.

Les pregunto cómo funciona el instrumento llamado "tiralíneas" y me lo explican: es un hilo guardado en una cajita, que cuando se desenrolla sale manchado de un polvo rojizo, y después de tensarlo sobre el suelo formando una línea recta, se jala y rebota contra el piso, dejando marcada una línea. Pero cuando me hacían la demostración, el hilo se rompió y tuvieron que hacer toda una maniobra más complicada para repararlo, mientras fumaban un cigarro.

\section{Herramientas autofabricadas y objetos multiusos}

En la mesa de trabajo de madera un señor amable, bastante mayor que los demás albañiles, fabrica botes para cargar mezcla, usando grandes latas de metal a las que les quita la tapa y les clava una agarradera de madera. Éste es un caso ejemplar de herramientas hechas por los propios trabajadores, reutilizando objetos que originalmente tenían otra finalidad. Me interesa particularmente cómo los albañiles usan ciertas cosas de un modo diferente a su función originalmente prevista. En muchos casos los albañiles se fabrican las propias herramientas de trabajo, con gran ingenio, reciclando materiales de desecho, recuperando partes o residuos de distintos instrumentos, lo cual ahorra dinero al constructor.

El tema de las herramientas que fabrican los mismos trabajadores y el de los objetos que reutilizan para otra función, tiene mucho que ver con uno de los puntos 
más importantes que pretendo resaltar, el del ingenio y la precariedad como aspectos fundamentales del habitar en la obra. En muchas ocasiones, pude presenciar expresiones de la más pura sabiduría popular, de tecnología verdaderamente arcaica y de uso de los instrumentos más rudimentarios, para dar una solución práctica y efectiva ante una situación marcada por los imprevistos, la precariedad, la informalidad y la escasez de recursos. Además, hay algunos objetos e instrumentos que se conservan de una obra a otra, se mueven junto con los albañiles, su ciclo de vida útil trasciende la duración de un proceso constructivo.

La herramienta que llaman segueta, una especie de serrucho de fabricación casera que usan para cortar varillas no muy gruesas, también la fabrican ellos mismos. Consta de una varilla retorcida que forma un arco, que sujeta una navaja, que va empotrada en las puntas y es intercambiable cuando se desgaste... Pato está haciendo un arco nuevo, doblando una varilla en forma precisa pero irregular $y$ limándole las orillas para después insertarle una nueva navaja.

Un señor lleva todo el día haciendo estribos en la mesa de trabajo de madera en el fondo. Los estribos son las piezas rectangulares hechas de varilla doblada en cuatro segmentos, con las puntas dobladas hacia dentro, que rodean o abrazan las grandes trabes. Los estribos se fabrican a mano, uno por uno, en la mesa de trabajo de madera (ver descripción de acciones y técnicas más adelante).

La estructura de madera que sostiene la nueva rampa de acceso a la obra, que apenas ayer por la mañana no existía, hoy parece que todo el mundo la da por hecho, como un objeto más en la obra; sin embargo, me consta que su edificación estuvo llena de detalles e historias en las que ahora nadie parece reparar, al ir y venir sobre ella. También me sorprende que esta estructura de madera finalmente es un artefacto efímero, un instrumento desechable; una vez que termine su función esta rampa será desmontada y olvidada, sólo reciclarán los polines para cimbrar.

Pato sube a la siguiente planta trepando por el castillo de varillas cuyas puntas se enchuecan sensiblemente cada vez que lo usan como escalera... Para sacar un nivel tiran una plomada, una pesa hecha en esta ocasión con medio bote de jugo marca Bébere relleno de cemento, que cuelga de un hilo... A veces se usa el mango del martillo para anudar el alambrón y apretar bien el nudo que ata la madera con el acero; un trabajador sentado al borde de la parte más alta del edificio amarra y 
anuda alambres con ayuda del mango de su martillo, para fijar la cimbra a los castillos de varilla.

Polo, el exvelador gordito de bigote, me hace una demostración de cómo se usa un instrumento, un aro hecho con una varilla doblada en forma circular, que se coloca alrededor de la cintura y se sujeta con un gancho, para detenerse y tener más estabilidad en las alturas, quedando firmemente afianzado. La varilla circular es revestida con un tubo de plástico naranja, como el de la instalación de la luz, para hacerlo más cómodo.

Los montones de material de construcción constantemente sirven de mobiliario para los albañiles, los sacos de cemento se apilan de distintas maneras para formar mesas, sillas, burós, etc. Los ladrillos apilados sostienen vasos de unicel con restos de café y botellas de refresco. Édgar, notablemente crudo, está echado leyendo periódico sobre unos bultos de cemento estratégicamente acomodados para formar un cómodo aposento.

Después de haber vertido la mezcla para colar la losa del siguiente nivel, unos cuantos trabajadores la apisonan con un trozo de madera clavado a una varilla, una herramienta bastante rudimentaria de su propia fabricación. Después van a pulir más finamente el piso con sus cucharas de forma triangular. Todos portan necesariamente botas de hule. Un trabajador se tiene que trepar en una cubeta volteada para alcanzar mejor la altura de la barda en que está taladrando... Una mesa de trabajo de madera tiene un techo improvisado con unicel y alambres, para proteger del sol a tres fierreros que hacen estribos...

Un señor que hace un aplanado fino mantiene la mezcla en una charola improvisada con varios trozos de madera. Junto a él tiene un bote de refresco partido a la mitad con agua para salpicar y humedecer la mezcla de vez en cuando... En la azotea hay un par de tubos de cobre muy largos extendidos en el suelo, para la instalación de gas. Están recién pintados de amarillo, por lo que ingeniosamente los han suspendido sobre maderitas y botellas de Coca-Cola para que no manchen el piso mientras se seca la pintura... Una trabajadora quita manchas y gotas de cemento en el piso con una espátula ingeniosamente montada sobre un palo de escoba, que hace que ella no se tenga que agachar.

Es curiosa la noción que tienen de lo provisionales y temporales que son las cosas en el entorno de la obra. Por ejemplo, cuando necesitan hacer un cálculo, una suma 
u otra operación matemática, sin ningún reparo cogen un lápiz, voltean a la pared más cercana y ahí la escriben. Con que algo les funcione inmediatamente para resolver un problema que se les presenta, están satisfechos. Al fin que esa pared pronto pasará por alguna intervención o transformación, y entonces el graffiti será lo de menos...

\section{Otros objetos especiales}

Hay dos tipos más de objetos que no quisiera dejar de mencionar. Por un lado, la cámara fotográfica en el trabajo de campo, que podría considerarse como un objeto-actor. Como vimos anteriormente, la cámara tuvo un valor social especial al constituirse como referente principal en la relación que sostuve con los albañiles; hizo a los trabajadores actuar de cierta manera e hizo que me relacionara con ellos de una forma particular. Sin duda, la cámara tiene agencia, a veces permite que sucedan ciertas acciones, provoca, fomenta, interroga, pero otras veces estorba, incomoda e impide que sucedan otras cosas. Por otro lado, los objetos personales y pertenencias de los trabajadores son también elementos siempre presentes en todas las obras. Sus montoncitos de ropa, bolsas de plástico, mochilas, petacas, pares de zapatos, etcétera, acomodados en los rincones por todo el piso, son objetos sumamente significativos ya que a través de estos objetos los albañiles se apropian del espacio, lo conquistan poco a poco y lo habitan transitoriamente (como veremos más adelante en el capítulo V: "Habitar la obra").

\section{La vida social de los objetos}

Pato y Paul se van a cortar varillas al frente del terreno con una alicata gigante que hay que operar entre dos: uno coloca la varilla mientras el otro baja la palanca, recargando todo su peso en ella hasta que truena la varilla. Los objetos o herramientas moldean tipos de relaciones sociales entre los trabajadores, muchas veces exigen cooperación y su empleo requiere acciones coordinadas, alrededor de ellas se forman equipos de trabajo, grupos y vínculos sociales casi siempre efímeros.

En otra ocasión, un señor cortaba varillas con una pinza gigante más nueva que la que había visto antes. Esta es una herramienta curiosa, una parte parece fabricada industrialmente, pero está montada sobre una base de madera de 
fabricación casera. Le pregunté por qué tenían una nueva herramienta, y me enseñó que en la otra se había roto la pieza que sostiene la cuchilla a la tabla, "por poner tanta fuerza al hacer palanca, no aguantó". No cabe duda que todo por servir se acaba; las herramientas tienen un tiempo de vida limitado y más aún las que son sometidas a tratos rudos. Y cuando una herramienta falla o se descompone le impone al trabajador la condición infanqueable de repararla o adquirir una nueva.

Mientras descargaban varillas de un camión, en una acción coordinada, los trabajadores batallaban para acomodarlas transversalmente adentro del terreno: uno de los trabajadores grita que la varilla "quiere" más para allá, refiriéndose a que necesitan empujar o jalar más la varilla hacia uno u otro lado para que embone en un hueco del terreno. Debido a que el ajuste requerido se manifiesta en la varilla, éste se puede leer en ella; esta forma lingüística le devuelve a las varillas su agencia y reconoce su carácter de actores sociales. Me llama mucho la atención este modo de hablar, que le atribuye a los objetos una cierta voluntad y les adjudica algún grado de intencionalidad, otorgándoles poder de acción y una vida social. Esta expresión podría entenderse como una forma de insinuar que la varilla tuviera alma o vida propia, lo cual nos podría recordar por un lado el pensamiento mágico, pero por otro lado nos remite a planteamientos sobre la vida social de los objetos de Arjun Appadurai (1986), así como a la teoría del actor-red expuesta por Bruno Latour (2005), y más en un contexto como el de una obra de construcción, en el que los materiales y herramientas juegan un papel tan decisivo.

Silvano me comenta que se ha elevado mucho el precio del acero, y por lo tanto de la varilla, se rumora que por culpa del mercado chino. Saca de la bolsa de su camisa una serie de papelitos y tarjetas; en la parte de atrás de una tarjeta de negocios había apuntado una lista de materiales y costos. Me muestra que de cuatro toneladas de varilla habían sido $35 \mathrm{mil} \mathrm{y} \mathrm{cacho} \mathrm{de} \mathrm{pesos,} \mathrm{o} \mathrm{sea} \mathrm{-} \mathrm{saca} \mathrm{su}$ calculadora y divide-: casi a 9 mil pesos la tonelada de acero. Siguiendo con las cuentas, Silvano concluye que "de un par de años a la fecha el acero ha subido de 4 mil a 9 mil pesos, o sea que más del 100\% ha incrementado su precio." Supongo que el costo de los materiales puede influir en otras esferas; los cambios bruscos en el precio de los materiales pueden afectar la economía de una obra, al grado de provocar mermas en el sueldo de los trabajadores. 
Paul y El Pelón están cargando en la camioneta del maestro Nicolás las puertas de la estructura anterior que desmontan en el terreno de Puebla. Muchas veces, sobre todo en los trabajos de demolición y desmantelamiento, los trabajadores tienen oportunidad de aprovechar los materiales que en la obra se desechan, sobre todo quienes tienen la posibilidad de transportarlos y almacenarlos... Le pregunto a Paul si esa madera que usan para cimbrar la vuelven a aprovechar para otros colados, en esa o en otras obra. Me dice que a veces sí y a veces no, "dependiendo de la obra, en ocasiones quedan muy pandeadas y ya no sirven, también depende de la compañía y del maestro, muchas veces acaban muy cacareadas y van derechito al escombro"... Silvano me dice que con las lluvias se daña mucho la madera; el triplay se despega y ya no sirve bien, pero hay veces que sí se puede aprovechar. Me comenta Paul que está muy alto el precio de la madera, por eso siempre que se puede la intenta volver a utilizar, así es como ha logrado ir construyendo su propia casa. En la obra de Puebla, por otra parte, hay varias rampas hechas con material de desecho aprovechado, reciclado, reutilizado. Asimismo, muchos fierros de los que había antes en el terreno, los usan para construir puentes provisionales para pasar de una torre a otra.

En suma, todas estas trabes, columnas, castillos, estribos, cimientos cimbrados y colados, conductos, escaleras de madera, polines, cerros de ladrillos, montones de arena, torres de unicel, andamios colgantes, sacos de cemento o yeso, tambos llenos de agua, etc. son elementos indispensables, conforman las condiciones materiales y los instrumentos necesarios para la transformación del espacio en la construcción de edificios habitacionales, y como tales, son actores protagónicos que forman parte de la vida social de la obra.

\section{El valor simbólico de los objetos en la obra}

Por otra parte, hay que considerar que los objetos expresan también relaciones de poder, simbolizan jerarquías sociales, a veces refuerzan la desigualdad, conducen el poder social, objetivan inequidades, etc. No obstante, en los estudios sociales normalmente se les reduce a meros depositarios neutros o pantallas en blanco sobre los que se proyecta la capacidad simbólica humana. Pero es necesario reconocer que el valor simbólico de los objetos no sólo depende de su vínculo con las personas, sino que tiene que ver también con las propiedades intrínsecas de las cosas mismas. 
Una cruz en la entrada adornada con flores ya secas, moños y listones azules permanece en la entrada del terreno desde la comida del día de los albañiles, el 3 de mayo. Sería interesante analizar la vinculación de los trabajadores con el arquetipo de la cruz. El día de los albañiles es el día de la Santa Cruz; una de las marcas más populares de cemento es Cruz Azul; el equipo de fútbol del mismo nombre también es conocido como el equipo de los albañiles. ¿Se trata de la cruz cristiana?, ¿qué otros valores condensa?, ¿qué tanto está presente en las prácticas y creencias religiosas de las albañiles?, ¿realmente constituye un referente en su identidad gremial? Tiempo después, encuentro la Santa Cruz arrumbada en un rincón del sótano, a punto de formar parte del cerro de escombro, antes había sido perchero en la habitación de los yeseros.

El casco es un objeto muy interesante que tiene diversos usos y capas de significado. Por un lado, en el uso del casco los trabajadores expresan algo de su actitud o de su personalidad. Desafían a la autoridad si no lo usan, o lo usan con estilo, hacia atrás o sobre otra gorra. El Gordo y El Pelón se lo quitan porque ya tienen cierta confianza con Silvano y se atreven a dejarlo recargado en las trabes de varillas mientras trabajan. Pero además, el color y tipo de casco tienen que ver con el rango del trabajador. Los colores metálicos, principalmente el azul y el plateado, indican mayor jerarquía que los colores opacos de plástico. Los metálicos los portan los maestros y oficiales, por ejemplo Pato, Silvano, Javier, el carpintero Calderón y el señor del cigarro en la boca, mientras que el resto de los peones y ayudantes usan cascos de plástico normales.

\section{Herramienta, conocimiento técnico y jerarquía social}

Como señala Carmen Bueno, la herramienta es signo de estatus y marca jerarquías entre los trabajadores. Para demostrar su nivel de conocimiento, los oficiales tienen que portar la herramienta manual que utilizan según su oficio. Un oficial de albañilería debe portar martillo, nivel, cincel y flexómetro. Un oficial plomero debe cargar siempre desarmador, llaves y soplete. A los oficiales carpinteros se les pide segueta, flexómetro, martillo y otras herramientas. "El simple hecho de que un trabajador llegue a la obra con instrumentos más sofisticados, le otorga cierto prestigio entre los demás trabajadores... Las herramientas se convierten en una 
especie de título que acredita su conocimiento en la labor a ejecutar..." (Bueno, 1994: 96).

Por ejemplo, algo que distingue a los carpinteros es que usan cinturones de cuero de los que cuelgan bolsos especiales para portar sus herramientas y materiales, sobre todo cargan el martillo y puñados de clavos. Para ser reconocido como carpintero y contratado en una obra como tal, es indispensable contar con este equipo.

Una de las habilidades que distingue a los trabajadores de alto rango es la capacidad de leer e interpretar planos, lo cual requiere estudios o bien mucha experiencia e inteligencia. Hay un juego de planos sobre una tabla, sostenidos con un clip. Ante mi total incompetencia para interpretarlos, me pregunto cuántos y quiénes de todos estos trabajadores están capacitados para leer y entender esta representación bidimensional y luego materializarla en un edificio... Silvano revisa los planos y papeles sentado en su escritorio improvisado, en una esquina junto al vestidor-bodega de madera... Otro día llega Antonio Bobadilla junto con Nicolás y Silvano, observan todo y revisan unos planos... En otra ocasión, en la banqueta Javier y el maestro electricista revisan cuidadosamente un juego de planos. En eso Ilega el arquitecto Canela y se une a la discusión sobre los planos... El Gato y el Pato revisan los planos y supervisan algunas medidas sobre el piso con ayuda de una cinta métrica, antes de que otro trabajador empiece a levantar un muro. Su manejo de los planos me hace ver que tienen un cargo alto en la estructura laboral.

Las herramientas que posee un trabajador son fundamentales para determinar su rango laboral al momento de su reclutamiento en algún nuevo sitio de construcción. Pero no se trata solamente de poseer la herramienta, sino de tener la habilidad práctica para usarla. Una de las habilidades de los trabajadores que más me llaman la atención es la forma en que manejan la cinta métrica, cómo la estiran y la recogen con gran precisión y rapidez. Por la forma y la destreza con que un trabajador maneja su flexómetro, se puede deducir su experiencia y rango. Esta observación es un claro ejemplo del rol crucial que juegan no sólo las herramientas, sino otros instrumentos, objetos y materiales, en las redes sociales que se tejen alrededor de la obra. Las herramientas y los materiales en el mundo de la construcción tienen una vida social sumamente activa, son actores sociales, tienen agencia, aunque no sean seres humanos. 


\section{Redes, metáforas y alegorías}

Me llama mucho la atención la aparente fragilidad de los nuditos de alambre con los que atan las varillas unas con otras, para armar los castillos y trabes que conforman los cimientos, que a su vez sostienen a todo el edificio. A pesar de su pequeñez y de la facilidad con que los hacen los fierreros, estos amarres aseguran las conexiones que contribuyen significativamente a la solidez y consistencia de todo un edificio. Son una buena metáfora de la fragilidad del vínculo social, de la inestabilidad de las relaciones y nexos personales o grupales, de lo contingente que resulta lo colectivo, de cómo las redes dependen de amarres simples y microvínculos para seguir existiendo, pero no obstante existen contundentemente. Como dice Bruno Latour, lo social debe ser procurado, ejercido y mantenido, armado y rearmado lazo por lazo, porque si no desaparecería (cf. Latour, 2005: 37). Esta es una metáfora particularmente apropiada para un contexto laboral como el de los albañiles, caracterizado por su movilidad, lazos efímeros, inestables, pasajeros, inciertos.

Otra imagen reveladora es la de los puentes improvisados que parece que se sostienen de milagro, y sin embargo soportan pesos considerables. Asimismo, sorprende ver techos enteros sostenidos por pilotes $y$ trabes cortados muy inexactamente, pero que con una calzadita en la parte de abajo con un pedazo de cartón o un retazo de madera, cumplen su función de sostén, si no es que de pilar fundamental. Da la impresión de que toda una estructura, un sistema, una constelación de actores y relaciones puede estar sostenida solamente de un clavo. Esta imagen del equilibrio milagroso, refleja por un lado la precariedad, informalidad e inestabilidad que impera en la obra, pero por otro lado expresa el ingenio, habilidad y racionalidad con la que siempre salen adelante. Estas nociones me parecen muy importantes para entender el comportamiento de los actores y la dinámica de las redes que conforman la sociedad y la cultura urbana contemporánea.

Un objeto que tiene una importancia particular en la obra son los andamios. Los hay de diferentes tipos, desde los más improvisados con maderas, palos y tubos, que se arman por módulos de abajo hacia arriba para alcanzar una altura determinada, hasta los de fierro fabricados industrialmente, que cuelgan de cables de acero 
desde la azotea. Los andamios son parte de la infraestructura elemental en una obra. Su función es peculiar porque no sirven para intervenir directamente en el terreno, sino que sólo facilitan dicha intervención. Se me ocurre que la noción de andamio podría resultar muy adecuada para la antropología. Tal vez permitiría entender mejor ciertas configuraciones sociales, haciendo énfasis en su carácter operativo, provisional, flexible, frágil e inestable; a diferencia de la tan socorrida noción de estructura, que remite a configuraciones rígidas, pesadas, inmutables y anquilosadas. De esta manera, en vez de hablar de estructuras sociales, tal vez deberíamos referirnos a los andamiajes socioculturales que conforman el mundo. Ahora bien, también habría que reconocer los límites de esta metáfora: el andamio es después de todo un accesorio, una especie de herramienta, y no puede considerarse como un lugar en sí mismo, sino sólo como un apéndice o un anexo, de modo que no es no es exactamente equivalente ni comparable con la estructura, por lo que esta metáfora, aunque sugerente, tendría un uso restringido.

Antes del colado, el piso está formado por una cuadrícula de varillas de distinto calibre, atravesada por tuberías de cobre para la instalación de gas y mangueras naranjas de plástico grueso para la instalación eléctrica, que a su vez se entretejen sobre tramos de madera separados por bloques de unicel. Las varillas al cruzarse se amarran con nudos de alambre. Las conexiones entre los tubos de cobre son una especie de nodos que los redirigen hacia otras conexiones. Sobre esto se comienza a formar un laberinto de paredes y muros de ladrillo, divididos por castillos de varilla. La disposición de cada material en esta red tiene su propia lógica y orden en el espacio, sin embargo en varios puntos esta maraña de materiales se cruzan y enredan caóticamente. Todo esto forma una compleja red en la que se entrecruzan distintos materiales y el trabajo de muchos trabajadores de diversos oficios, que nos remite a la heterogeneidad de las redes sociales.

La telaraña de varillas que atraviesa el espacio visual en todas direcciones, permite hacer un ejercicio de percepción para entender cómo la configuración de las líneas y sus conexiones depende de la perspectiva que adopte el sujeto en relación con ellas. Con una pequeña variación de ángulo se crean para el observador nuevas conexiones en el campo visual y desaparecen otras tantas. Dependiendo del punto de vista que se adopte frente al atiborramiento de líneas y ejes que forman las varillas, aparecen cruces e intersecciones, puntos de 
concentración y áreas casi desiertas. Esta metáfora visual puede ser útil para entender cómo se configuran las redes sociales a partir de la perspectiva subjetiva de cada actor...

Enseguida, algunos trabajadores atraviesan el campo visual de vez en cuando. A contraluz, el contorno de su silueta con casco, guantes y martillo, no deja duda de su oficio, pero sus rasgos individuales y su personalidad particular permanecen borrados, oscuros, desconocidos. Trepan por los castillos de varillas como una araña transita por su telaraña. 


\section{Capítulo IV \\ MANO DE OBRA \\ Albañiles y trabajadores de la construcción}

\section{Los sujetos de esta investigación}

Este capítulo, junto con "La transformación del espacio", contienen la mayor parte del corpus etnográfico sobre el que se construye esta investigación. Además de documentar la transformación material y simbólica del espacio, a través de la labor etnográfica logré acercarme a diferentes actores involucrados en el mundo de la construcción: albañiles, peones, maestros, arquitectos, ingenieros, entre otros trabajadores y personajes vinculados de una u otra manera con las obras estudiadas. Me refiero genéricamente como "mano de obra" a todos estos trabajadores involucrados directamente en la construcción de vivienda, responsables materialmente de la transformación del espacio y el paisaje urbano. Estos sujetos son los actores protagonistas de este capítulo, en su conjunto conforman el elemento humano, que es el segundo componente fundamental de la construcción del habitar.

Uno de los principales intereses de esta investigación ha sido conocer de cerca la cultura particular de los trabajadores de la construcción, especialmente la de los que conforman el estrato más bajo, conocidos comúnmente como peones o simplemente albañiles. Ellos son los personajes imprescindibles en cada obra, la construyen ni más ni menos, la animan y la viven más de cerca que los demás. La figura del albañil está presente y atraviesa toda la problemática de la construcción; el peón, o la fuerza bruta que representa, es el común denominador en casi cualquier tipo de entorno constructivo.

Por otra parte, los albañiles son personajes emblemáticos que forman parte esencial de la cultura popular mexicana. En este sentido, el presente trabajo se identifica con el interés de Ricardo Pérez Montfort (2008) en torno a la historia las cotidianidades, la cultura popular y los imaginarios en México. A lo largo de su trayectoria, este autor se ha dedicado a rescatar y documentar lo particular y lo singular de las prácticas y costumbres más mundanas y ordinarias que hay en nuestra historia, "aspectos que comúnmente son excluidos de las versiones históricas oficiales y académicas... voces silenciadas por las historias generales y las versiones 
simplificadas de los fenómenos históricos de nuestro país" (Pérez Montfort, 2008: 12). La única diferencia es que en este estudio en vez de remontarnos hacia atrás en la historia, nos enfocamos primordialmente en la realidad presente. Más que hacer una historia de la vida cotidiana, aquí se trata de hacer una etnología de la vida cotidiana y del mundo popular, que en lugar de acudir a fuentes históricas, se basa en la información proveniente de la observación participativa, directa y en la experiencia de primera mano.

Sin duda, los albañiles son portadores de una gran riqueza cultural que se manifiesta de diversas formas, como se verá más adelante, pero sobre todo es admirable su ingenio y sus estrategias para domesticar, transformar y habitar el espacio de la obra. Sin embargo, a pesar de su importancia, estos trabajadores muchas veces pasan inadvertidos; suele reconocerse la labor de los arquitectos, pero los albañiles son prácticamente anónimos, a pesar de que representan una condición material de posibilidad en cualquier construcción. No debemos olvidar que son los hacedores directos de buena parte del mundo material que nos rodea. Andrés Ruiz, redactor de La Jornada, escribió en 2004 sobre la invisibilidad de los trabajadores de la construcción el siguiente texto inédito:

Como hormigas, abejas, arañas, así de pequeños se ven en las alturas o al pie de gigantescas máquinas o construcciones que, sin embargo, esos diminutos y al parecer incansables seres manejan o construyen. Son las anónimas manos que levantan las maravillas de nuestros días, los milagros urbanos, los prodigios de la ingeniería. Al final de la obra desaparecen, comúnmente no disfrutan lo que levantan, sus nombres son ignorados en las ceremonias grandilocuentes de sus empleadores, pero sin ellos todo es quimera, porque ellos son los constructores de sueños, los hacedores de utopías.

Los albañiles son personajes marginales que conforman los estratos más bajos de la escala social; aunque han sido poco estudiados y permanecen bastante desconocidos, son víctimas de múltiples prejuicios culturales. Por otro lado, su situación socioeconómica es muy representativa del tipo de problemas que enfrentan los trabajadores en otras formas de empleo, subempleo o trabajo informal. Ante condiciones como la falta de vivienda, la precariedad e inestabilidad laboral, la incipiente educación, los problemas de salud, etc., presentan estrategias de supervivencia como la movilidad constante, la migración temporal, el recurso a la informalidad y el desarrollo de un gran ingenio popular. 
Por todo esto, desde un principio fue mi intención otorgarle a los trabajadores de la construcción, y en especial a los albañiles, un lugar central en esta investigación. Pretendo cuestionar, confirmar o desmitificar los prejuicios comunes con respecto a los albañiles. Intento ir más allá de las etiquetas, superando los estereotipos y generalizaciones en torno a ellos, para elaborar un retrato más fidedigno que les dé rostro y voz, que les otorgue la importancia que merecen y reivindique, en alguna medida, su dignidad. Mi estrategia etnográfica consistió en involucrarme con distintos grupos de trabajadores en las dos obras estudiadas, propiciando una interacción que me permitió observar y documentar desde dentro su labor cotidiana y sus expresiones culturales. Me interesa el punto de vista de estos trabajadores porque ellos tienen la mirada más directa y a ras de tierra del mundo de la construcción.

Para dar cuenta de esta dimensión humana, seleccionaré de mi diario de campo y acervo fotográfico todos los relatos, crónicas e imágenes relacionadas con estas personas particulares, de carne y hueso, con nombre y apellido, con quienes me encontré a lo largo de mi trabajo de campo. Con ellos realicé algunas entrevistas y tuve muchas conversaciones casuales, a través de las cuales reuní los testimonios que presento a lo largo de este capítulo y que me parecen significativos para comprender el rol de estos personajes y el sentido que ellos mismos le dan a sus acciones dentro de este complejo sistema de prácticas y relaciones. Recogiendo la diversidad de sus puntos de vista, trataré de construir un relato polifónico acerca de los obreros de la construcción desde diversos ángulos, considerando sus distintas formas de inserción y participación. Por otro lado, resulta importante poner el acento no sólo en los nodos de la red, no únicamente en los actores, sino también y sobre todo en las relaciones, diálogos, intercambios, encuentros y desencuentros entre ellos, perceptibles a través de los rastros, las huellas, los hilos imaginarios que van tejiendo al transitar por la obra (cf. Latour, 2005).

Un rasgo que caracteriza a los trabajadores de la construcción es que nunca tienen un sitio de trabajo fijo, su entorno laboral es siempre cambiante, precisamente porque está en construcción. Deben adaptarse temporalmente a un espacio, aportar su fuerza para transformarlo y finalmente abandonarlo para moverse a otro sitio y volver a empezar. Otros aspectos significativos sobre la mano de obra que abordaré en este apartado tienen que ver con sus condiciones laborales 
y las relaciones entre los distintos oficios. Me interesaba observar, por ejemplo, las jerarquías y división del trabajo, su relación particular con los medios de producción, su grado de organización, los conflictos de intereses entre ellos, así como el grado de seguridad social con el que cuentan —o más bien del que carecen-al realizar un trabajo que suele ser de alto riesgo.

En este recuento trataré de esbozar a grandes rasgos algunas historias de vida de estos albañiles, intentaré trazar su perfil biográfico, poniendo atención en datos como su procedencia, situación familiar, trayectoria laboral, la percepción que tienen de su oficio, del mundo de la construcción, sus perspectivas y aspiraciones, etc. También quisiera señalar algunos usos y costumbres distintivos de su cultura y vida cotidiana: vestimenta, comida, tiempo libre, humor, lenguaje, apodos, su relación con los medios de comunicación, con el sexo opuesto, entre otros. Haré además una descripción detallada de algunas de las acciones y técnicas más importantes en las que consiste su trabajo.

Pero más allá de estas cualidades superficiales que los definen, existen otros elementos que me interesa destacar sobre los albañiles y los trabajadores de la construcción. Me refiero a factores como la gran movilidad que presentan en sus vidas y en sus trayectorias laborales, la asombrosa adaptabilidad o flexibilidad ante cualquier circunstancia por precaria que resulte, así como el hecho de que son depositarios de un gran ingenio y saber popular. En este sentido, este capítulo busca contribuir teórica y etnográficamente al conocimiento de esta población y su cultura particular. Creo que el carácter fragmentario e impresionista de este collage de crónicas y microrrelatos etnográficos puede ser un estilo apropiado para representar este tipo de realidades y cruces interculturales cambiantes, dinámicos, procesuales, complejos, frágiles y ambiguos.

\section{Actores en el mundo de la construcción}

Una pregunta interesante que hay que hacernos es cómo referirnos a los protagonistas de esta investigación, si es apropiado denominarlos genéricamente como albañiles o trabajadores de la construcción, mano de obra o fuerza de trabajo. Términos como objeto de estudio o informante tienen cierta carga que quiero evitar en esta investigación. Prefiero los matices que tienen palabras como actores, sujetos 
o personajes, aunque también muchas veces a lo largo de estos relatos los llamo simplemente por su nombre o apodo, o bien según su rango u oficio.

En este punto podríamos retomar la reflexión de Amalia Signorelli (2008) sobre la noción de sujeto, subrayando su complejidad en el mundo contemporáneo. Para empezar, dice que podemos pensar en sujetos individuales o sujetos colectivos, lo cual introduce ya cierto grado de dificultad. Además, los sujetos sociales que nos interesan, los albañiles, se caracterizan por su alto grado de movilidad. Esta movilidad no es para nada nueva, ciertamente, pero su incremento e intensificación la hacen por demás significativa en nuestros días. Los trabajadores de la construcción se ubican y establecen anclas en más de un lugar geográfico. Más que la permanencia de estos actores sujetos en un lugar fijo, lo común en este gremio es el tránsito, los flujos, los desplazamientos, los intercambios entre un lugar y otro. Los sujetos de nuestra investigación son sujetos multilocalizados, multisituados, se mueven entre distintos lugares físicos, pero también transitan por diferentes localizaciones imaginarias o virtuales. En el mundo de la construcción, como se describe en el apartado referente a la movilidad, nos enfrentamos a un incesante vaivén de trabajadores que transitan entre distintos ámbitos, y esta movilidad puede adquirir diversos rostros en el contexto de una obra. Así, el panorama urbano contemporáneo en general, y particularmente el espacio en construcción, está dominado por múltiples cruces de trayectorias subjetivas, encuentros y desencuentros interculturales.

Pero más allá de la terminología empleada, una cuestión fundamental que quisiera señalar en este apartado es el rol central que se le otorga a los actores como parte de la recomposición de lo social que propone la teoría del actor-red (TAR), expuesta por Bruno Latour (2005). En resumidas cuentas, de acuerdo con esta perspectiva, la misión del investigador social consiste en seguir a los actores a donde sea que nos conduzcan; hay que rastrear y dar cuenta de las conexiones y asociaciones que conforman su mundo, involucrarnos entre sus redes de interacciones.

Por otra parte, a los actores no hay que tratar de encajarlos de antemano en categorías prefabricadas, sino hay que hacer caso de las formas en que ellos mismos ordenan y definen lo social. No es el trabajo del científico social explicar lo social de antemano, esta labor debe ser dejada en manos de los actores mismos. La tarea de 
definir y ordenar lo social debe dejarse a los actores mismos o por lo menos compartirla con ellos en algún grado. En lugar de tratar de disciplinar a los actores y hacerlos encajar en nuestras categorías científicas, habría que dejarlos desplegar sus propios mundos y dar cuenta de ello (cf. Latour, 2005). Por tanto, la visión y la interpretación de la realidad cambiará dependiendo del actor con el que se interactúe en la obra. Es distinto seguir y rastrear al ayudante, al oficial, al maestro o al arquitecto; sus actividades y perspectivas dentro de la obra son muy diferentes. Su vinculación con la construcción es diferente, sus problemáticas laborales y personales varían bastante. De entre todas estas perspectivas ¿cuál es más importante tomar en cuenta?, ¿se les debe tomar en cuenta a todas?

\section{Formación y desintegración de grupos}

Otro punto medular en la TAR es la idea de que "no hay grupos, sólo un constante proceso de formación y desintegración de grupos". Es muy común que los antropólogos se apresuren a establecer una unidad de análisis desde antes de comenzar sus investigaciones. ¿Qué tipo de unidad o agrupamiento es más adecuado para comenzar una investigación social: individuos, organizaciones, colectivos, clases, gremios, rangos, o redes sociales? Siguiendo a Latour, no vale la pena definir de antemano categorías y criterios de agrupamiento, ni aferrarse a ellos incondicionalmente en el transcurso de una investigación. No hay un único grupo relevante para el análisis de lo social. Toda limitación a priori será arbitraria. Los lazos sociales o formas de pertenencia a un grupo son siempre cambiantes, frágiles, inciertos, controvertidos y en constante negociación. Así, para dar cuenta de ellos, es indispensable "seguir a los actores y rastrear las huellas que quedan tras su actividad de formación y desintegración de grupos (cf. Latour, 2005: 29). En otras palabras, "ahora debemos tomar en cuenta muchas más cartografías contradictorias de lo social" (Latour, 2005: 34).

Para la TAR, "los grupos siempre tienen que hacerse y rehacerse de nuevo... no hay ningún grupo que pueda sostener su existencia sin la debida labor de mantenimiento" (Latour, 2005: 37). Esto nos remite irremediablemente a la fragilidad del vínculo social: si no se procuran los vínculos se pierde el agrupamiento, desaparece lo social, su existencia jamás está garantizada de una vez y para siempre. Las lazos grupales tienen cierta dificultad para extenderse en el tiempo y 
en el espacio, no existe ninguna inercia o fuerza social que los mantenga unidos; deben ser inventados y reinventados, negociados y renegociados incesantemente. El mundo social tiene una aspecto provisional, inestable y caótico. Los lazos sociales no son tan durables ni sólidos como se piensa tradicionalmente (cf. Latour, 2005: 67).

Lo anterior es particularmente apropiado para describir una configuración social como la de los albañiles y los trabajadores de la construcción. Quizás pueda hablarse de un gremio que comparte características culturales, condiciones laborales, técnicas y conocimientos similares, más que de grupos propiamente dichos. Hay cuadrillas de yeseros, equipos de carpinteros, o grupos de confianza alrededor de un maestro contratista, pero estas agrupaciones también son efímeras, frágiles, flexibles, y se desintegran o se reforman constantemente. Podría pensarse que el sindicato podría conformar una forma de agrupación bien institucionalizada, pero como se verá en el aparatado dedicado a las condiciones laborales de los obreros, el sindicato no tiene una presencia efectiva como una agrupación estable y definida que proteja los intereses reales de los trabajadores de la construcción.

\section{Cultura urbana y orden laboral}

Al abordar el tema de los albañiles y trabajadores de la construcción, resulta indispensable revisar algunas categorías básicas, como la noción misma de trabajo o cultura laboral, con las que la antropología ha reflexionado sobre esta dimensión de la realidad. Para esto fue necesario revisar bibliografía sobre antropología del trabajo, formas de organización y cultura laboral.

Con esto en mente, retomo y discuto el texto: "Lo imaginario como articulador de los órdenes laboral y urbano" de Raúl Nieto Calleja (1998). Este trabajo explora las intersecciones entre dos ejes temáticos fundamentales en esta investigación: el orden urbano y el orden laboral. En otras palabras, Nieto se enfoca en "las complejas relaciones de complementariedad, de oposición y superposición" que existen entre el habitar y el trabajar en un contexto urbano como el de la Ciudad de México" (Nieto, 1998: 121).

Nieto se pregunta ¿de qué manera específica se articulan el trabajar y el habitar en la experiencia urbana?, ¿qué consecuencias sociales tiene esta articulación? Partiendo de la doble naturaleza de los fenómenos sociales y culturales (como 
prácticas o acciones concretas, físicas o materiales, por un lado, y como sentidos, valores y significados abstractos, simbólicos o imaginarios, por el otro) este autor propone mirar los cruces entre la dimensión laboral y otros ámbitos de la existencia humana, en el contexto de las ciudades contemporáneas (cf. Nieto, 1998: 121-122).

\section{La noción de trabajo, una definición antropológica}

Nieto se cuestiona radicalmente qué es el trabajo. Explica que el término proviene del latín laborare, que quería decir específicamente "labrar", pero en español derivó en el verbo "laborar", con el sentido más amplio y genérico de "trabajar". Retomando a Marshall Sahlins, Nieto afirma que el trabajo es una actividad humana fundamental que juega "un papel central en la estructuración del resto de las prácticas sociales y procesos culturales". El mundo del trabajo siempre ha dictado sus propios tiempos y espacios, imponiéndolos a otras esferas de la vida. De acuerdo con este autor, en la época contemporánea, a pesar de los cambios radicales que se han dado en el orden mundial en las últimas décadas, "los seres humanos siguen constituyendo su ser social a través de relaciones sociales en y con el mundo laboral" (Nieto, 1998: 122).

La noción de trabajo se ha construido como concepto teórico por infinidad de autores, de los cuales, Nieto retoma brevemente "la problematización que de tal concepto hizo Marx en El Capital (1872-1875)", donde se explica "cómo ha sido importante el trabajo en los procesos de hominización", y por lo tanto "es concebido como elemento portador de la esencia humana" (Nieto, 1998: 122). Ahora bien, la contraparte del trabajo es el ocio, el tiempo libre, el lugar ajeno al trabajo, pero que sin embargo "se construye de cara, en oposición y complementariamente a éste... ¿Dónde termina el trabajo y empieza el ocio?". En muchas ocasiones, "el ocio no empieza donde termina el trabajo", ni viceversa, sino que estos campos tienden a traslaparse (Nieto, 1998: 122-124). Hay que señalar que la frontera entre el tiempo libre y el trabajo, entre ocio y el negocio, nunca es absolutamente clara y definida, es más bien porosa y flexible.

Podemos plantear que existe una íntima conexión entre ambas dimensiones de la existencia y que entre ellas se teje una red de significados que da sentido a la vida individual y permite integrar al sujeto a una dimensión familiar, grupal y social mayor... (Nieto, 1998: 125). 
En el caso de los albañiles y los trabajadores de la construcción esto es muy claro. Por ejemplo, incluso en los momentos más intensos de trabajo físico, siempre hay cabida para alguna distracción o una pequeña pausa para el ocio, para tararear una canción de la radio, para un chiste, una gelatina o un taco de ojo. Pero además, al habitar y trabajar en el mismo lugar, que es el caso de muchos de ellos, el orden laboral de los albañiles está íntimamente entreverado con su experiencia urbana particular, su experiencia del trabajo está marcada por su habitar en la obra. Para ellos, la única diferencia se da en cuanto a la temporalidad, trabajan de día y descansan de noche, pero el espacio es el mismo. La gente con la que conviven y socializan cotidianamente en su tiempo libre, son sus mismos compañeros de trabajo.

\section{La dimensión simbólica del trabajo y el imaginario urbano}

Cuando pensamos en la noción de trabajo lo primero que nos viene a la mente es algún tipo de actividad física, una acción palpable que produce algún cambio material en el entorno. El trabajo de los albañiles puede plantearse como ejemplo paradigmático de trabajo físico, que implica una intervención directa sobre el espacio urbano para transformarlo. No obstante, no hay que ignorar un componente esencial del trabajo que casi siempre permanece invisible u oculto. Así, Nieto pone el acento en "la constitución simbólica del orden social del trabajo... en el proceso cultural de la construcción social del trabajo" (Nieto, 1998: 123-124).

No sobra reiterar el papel central que juega el trabajo en nuestra sociedad como estructurador de la dimensión simbólica y gran organizador de la praxis social... El trabajo, además de acción, de práctica social, de conducta, es representación, significación, construcción de sentido (Nieto, 1998: 123-124).

De igual manera, cuando pensamos en la ciudad, casi siempre evocamos su materialidad, la calle, los inmuebles, etc. Pero el orden urbano y la ciudad también presentan una dualidad entre su ser material y su dimensión simbólica. Vale la pena insistir, siguiendo a Nieto, en la importancia de la dimensión imaginaria de la ciudad:

El imaginario urbano constituye una dimensión por medio de la cual los distintos habitantes de una ciudad representan, significan y dan sentido a sus distintas prácticas cotidianas en el acto de habitar, constituye una dimensión en la que se 
establecen distintas identidades pero -y esto es muy importante- también se reconocen diferencias (Nieto, 1998: 125).

\section{Orden laboral y experiencias urbanas}

La vida y la dinámica en las ciudades está íntimamente vinculada con el orden social y simbólico del trabajo; el orden urbano sigue en buena medida los tiempos y los espacios establecidos por el trabajo. Esto resulta evidente si pensamos, por ejemplo, que la hora pico del tráfico coincide con las horas de entrada y salida de las oficinas, que los horarios y rutas del transporte público contemplan las zonas y los tiempos marcados por el trabajo, o que existen áreas de la ciudad desarrolladas especialmente para concentrar fábricas, oficinas o negocios. Puede decirse que "la ciudad es construida social y simbólicamente por el trabajo", es decir, la lógica que rige la dimensión laboral "moldea y configura la experiencia de habitar la ciudad" (Nieto, 1998: 127).

Ahora bien, hay que señalar que desde el punto de vista laboral, la ciudad representa un gran abanico de experiencias posibles: "no existe una sola forma de experiencia laboral" (Nieto, 1998: 128). El sentido que cada individuo le otorga al trabajo varía considerablemente de acuerdo con diferentes factores socioculturales. Por consiguiente, desde la perspectiva de la antropología habría que dar cuenta de la gran heterogeneidad de la experiencia subjetiva del mundo laboral.

El trabajo puede ser objeto de adicción o de repulsión, de pasión o tedio, puede proporcionar estatus o distinción o bien ser fuente de estigma social, puede ser motivo de orgullo y riqueza, o de escarnio y pobreza; puede investir de honor, dignidad y honradez o bien ser la fuente de vergüenza, deshonor o vileza (Nieto, 1998: 126).

En lo que sigue de este capítulo intentaré mostrar más precisamente cómo se entretejen los órdenes laboral y urbano, cómo se articulan sus dimensiones simbólicas y materiales, desde la experiencia particular de los trabajadores de la construcción, en el contexto de un par de obras de edificación de vivienda en la ciudad central. 


\section{Edificación de vivienda y trabajadores de la construcción}

Ahora quisiera revisar algunos estudios más concretos sobre el mundo de la construcción o la edificación de vivienda, ya ubicados plenamente en el contexto mexicano. Intentaré esbozar el contexto histórico, político, económico y las coyunturas actuales que nos ayuden a entender la situación actual de la mano de obra, concretamente de los albañiles, las relaciones de trabajo que establecen, sus condiciones laborales, la estructura y división del trabajo, sus usos y costumbres, su cultura cotidiana y finalmente su forma particular de relacionarse con el espacio, por el hecho de trabajar y habitar en la obra.

Hay que llamar la atención sobre la escasez de estudios académicos —desde cualquier disciplina o enfoque- acerca de los trabajadores y en general sobre el mundo de la construcción, tanto en la Ciudad de México como en el contexto nacional. Particularmente, existen sólo unas cuantas investigaciones antropológicas sobre la industria de la construcción que contemplen el mundo y la cultura de los albañiles. Los planteamientos de los pocos autores que se han ocupado del tema, como Dimitri Germidis (1974), Priscilla Connolly (1988), Carmen Bueno (1994) y Ana Luisa Liguori (1992) serán comentados a continuación.

\section{Investigaciones en torno a la construcción habitacional}

El estudio de Priscilla Connolly (1988) elabora un balance bastante completo del mundo de la construcción de vivienda en la Ciudad de México, articulando una visión macro, de conjunto, que considera factores estructurales, pero sin perder la relatividad de los distintos casos particulares, ni ignorar la complejidad o la riqueza cultural de cada caso constructivo. El trabajo de Connolly se adentra en un ámbito fundamental de los procesos habitacionales que sin embargo ha sido muy poco explorado. "Ni los investigadores $\mathrm{ni}$ los políticos, con algunas excepciones importantes, se han introducido en el aspecto más básico de la producción habitacional: la construcción o la edificación habitacional... El proceso de producción en sí y las relaciones de trabajo se han dejado en una especie de "caja negra" (Connolly, 1988: 183). Por tanto, la autora emprende una revisión minuciosa de los

procesos laborales y los diferentes actores que participan en las obras de construcción habitacional. Así, este estudio establece una referencia fundamental con la cual dialogar, comparar y contrastar los datos empíricos de la presente 
investigación. Será interesante confirmar la vigencia y, en su caso, notar la transformación de algunos aspectos que destaca Connolly, más de veinte años después de que apareció publicado este artículo.

Por otra parte, quizás el trabajo más cercano a la investigación que aquí se presenta, en cuanto al tema, el terreno de estudio y el enfoque, sea Flor de andamio: Los oficios de la construcción de vivienda en la Ciudad de México, de la antropóloga mexicana Carmen Bueno (1994). El estudio de esta autora parte de una interrogante sobre la eficacia productiva de la edificación de vivienda y se pregunta a qué se debe "la persistencia de una organización laboral basada en oficios" en este ramo, que se muestra arcaico, atrasado y aparentemente improductivo". A través de esta investigación podemos aproximarnos a factores como "la dinámica de la industria de la construcción", "la configuración de la mano de obra... la manera de organizarse... el patrón de movilidad ocupacional de los trabajadores de la construcción", entre otras aportaciones importantes que nos interesa recuperar en este capítulo (Bueno, 1994: 11).

Cabe mencionar que a diferencia de Connolly y Bueno, quienes hablan de la "industria de la construcción", término que le imprime una clara connotación económica a sus estudios, creo que para esta investigación sería más apropiado usar el término "mundo de la construcción" o "mundos de la construcción" ${ }^{12}$. Los mundos de la construcción contemplan mucho más que la actividad económica e industrial, se refieren a todo lo relacionado material y simbólicamente con esta actividad. Entre los temas que abordaré al respecto, cabe destacar: la perspectiva de las empresas constructoras, las prácticas e imaginarios de los actores involucrados, las relaciones sociales entre ellos, las condiciones laborales de los albañiles, sus usos y costumbres, acciones y técnicas, la transmisión de conocimientos, así como los diferentes discursos existentes sobre el mundo de la construcción, incluyendo novelas, películas y desde luego los estudios antropológicos al respecto.

De acuerdo con Connolly, los primeros estudios sobre la construcción de vivienda buscaban en primer lugar establecer leyes, encontrar relaciones generales y características intrínsecas en el fenómeno de la construcción habitacional. El más fundamental de estos principios se refiere al "carácter físico de la construcción", al

\footnotetext{
${ }^{12}$ Esta fórmula se ha aplicado a otras esferas, por ejemplo Howard Becker (1982) la empleó para hablar de los mundos del arte. El sentido que tiene para este autor la noción de "mundo", es bastante cercano a lo que pretendo abordar en esta investigación en relación con el ámbito de la construcción.
} 
vínculo indisociable "entre la construcción y la tierra", a la "necesidad de ocupar un terreno", al "carácter inmóvil de la construcción" (Connolly, 1988: 187). En este mismo sentido, Carmen Bueno señala que a diferencia de otras industrias en las que la planta laboral es fija y el producto es móvil, en la construcción sucede a la inversa, la planta productiva tiene que ser necesariamente móvil, mientras el producto permanece fijo en el lugar donde se edifica. Por lo tanto, "en cada obra se tiene que montar una "nueva fábrica" donde se entrelazan diversos procesos de trabajo" (Bueno, 1994: 47). En otras palabras, podría decirse, en tono de broma, que literalmente "se construyen casas a domicilio". No obstante, Connolly argumenta acertadamente que la industria de la construcción no es para nada homogénea, por lo que más allá de buscar leyes generales no debemos olvidarnos de estudiar, los atributos particulares de cada caso, "lo social e históricamente específico" en cada región, país o época (Connolly, 1988: 188).

\section{La industria de la construcción en México}

A partir del artículo de Connolly y el libro de Bueno podemos aproximarnos a las características generales de la industria de la construcción en México, lo cual resulta un marco elemental para comprender los casos abordados en esta investigación, que podemos ubicar dentro del sector privado de la industria de la construcción de vivienda, en la zona central de la Ciudad de México, en la primera década del siglo XXI.

Carmen Bueno hace una anotación importante en relación con el volumen de construcciones en la capital mexicana. En comparación con otras ciudades importantes del país, la Ciudad de México "duplica e incluso triplica la producción de los espacios construidos respecto a las metrópolis de Guadalajara y Monterrey". Por su parte, Leonard Martens (1982) señala que la capital mexicana absorbe casi la cuarta parte de la demanda constructiva del país (citado por Bueno, 1994: 18).

Connolly propone un esquema de clasificación que distingue la noción de construcción llamada "formal" de la "informal" y de la "autoconstrucción" (Connolly, 1988: 185). De acuerdo con sus parámetros, el sector formal estaría conformado por "el conjunto de empresas constructoras registradas en la Cámara Nacional de Industria de la Construcción (CNIC)". El sector informal "está constituido por una amplia diversidad de formas de producción, organizadas por maestros 
albañiles, especialistas... arquitectos, pequeñas compañías constructoras, etc.", que no necesariamente reportan sus actividades a la CNIC. Finalmente, el sector de la llamada autoconstrucción se refiere a los procesos constructivos no mercantiles, que en muchos casos incluso emplean "mano de obra aportada sin retribución por los mismos usuarios" (Connolly, 1988: 190). Llama la atención que según datos de la CNIC presentados por Connolly (1988), en 1987 el sector formal se encargaba solamente del $42 \%$ de las obras a nivel nacional, esto implica entonces que el $58 \%$ de las construcciones se llevaron acabo de manera extraoficial o eran desarrollos de autoconstrucción popular, ajenos a la industria construcción como institución oficial.

Para abordar el mundo de la construcción de vivienda en la capital mexicana, Carmen Bueno también plantea como eje de análisis la dicotomía entre lo formal y lo informal. Me parece interesante su planteamiento, que sigue el de otros autores, según el cual, en principio, se podría identificar la noción de informal con el concepto "tradicional" y el sector formal como análogo a lo "moderno". De acuerdo con Bueno y otros autores, y en sintonía con los resultados arrojados por mi propia investigación de campo, se puede afirmar que "la industria de la construcción es una actividad en la que se puede observar la concurrencia del sector formal y el informal" (Bueno, 1994: 13). En la edificación habitacional acontece una suerte de articulación simbiótica entre ambos sectores; en la organización productiva de una obra coexisten rasgos modernos y tecnologías avanzadas, con formas de organización laboral antiguas y tradicionales. La obra se torna escenario para "la interacción de esferas productivas típicas del capitalismo, con aquellas que se consideran resabios de formas organizativas no capitalistas" (Bueno, 1994: 21).

Resulta interesante comparar estos criterios con la distinción que hace Ángela Giglia (2009) entre la lógica racionalista y la lógica informal en la producción habitacional de la ciudad, esquemas ciertamente parecidos, pero basados en parámetros analíticos distintos. El esquema de Connolly se basa en criterios de tipo legal y económico, Bueno se refiere a una cuestión evolutiva, de desarrollo o atraso, a lo moderno y lo tradicional, mientras que el modelo de Giglia se enfoca más bien en cuestiones de orden cultural y cognitivo, se trata de distintas lógicas socioespaciales. Considerando estas vertientes, pienso que las obras estudiadas en este trabajo no podrían ubicarse claramente dentro de ninguna de estas categorías, más bien se sitúan en la fronteras porosas entre lo formal y lo informal, lo mercantil y lo 
no mercantil, entre la inversión privada y las políticas públicas, entre lo moderno y lo arcaico, entre lo planificado y lo improvisado, e incluso entre la vivienda popular y los nuevos desarrollos de lujo, por mencionar algunos criterios clasificatorios posibles.

Coexisten en México muchas formas de organización de la construcción. Cualquier intento de clasificar estas formas bajo criterios únicos y parciales enfrenta serias dificultades. Los diversos arreglos de agentes, procesos técnicos y tipos de propiedad se traslapan, se sobreponen y se complementan... no hay líneas de demarcación claras e inequívocas entre una y otra forma o sector de la construcción... En toda obra de construcción se manifiesta una mezcolanza de relaciones de producción... (Connolly, 1988: 189).

\section{Economía e industria de la construcción}

Uno de los méritos del trabajo de Bueno (1994) es que realiza un análisis minucioso del comportamiento económico de la industria de la construcción. De igual manera, Connolly (1988) estudia detalladamente la industria de la construcción a través de la estadística nacional, recurriendo a algunos indicadores económicos. Ambas autoras presentan datos y cifras que aunque se alejan del espíritu primordial de esta investigación, resultan reveladores para contemplar el cuadro completo en el que se inserta este estudio de caso.

En primer lugar, Connolly señala que la industria de la construcción en México ha tenido un desarrollo singular, distinto al de otro tipo de industrias; su "alta tasa de crecimiento es excepcional. Su producto casi se ha duplicado por década durante los últimos cincuenta años". Por lo tanto, "ha pasado a ocupar un papel importante en la economía nacional: contribuye en aproximadamente $6 \%$ al producto interno bruto", según datos de finales de la década de los 80 (Connolly, 1988: 193). Lo que me parece impresionante es que estos datos contemplan únicamente al sector formal de la industria de la construcción, que en esa misma época no representaba ni la mitad del total de la actividad constructiva. "Otro rasgo significativo de la construcción mexicana es que es uno de los únicos sectores de la economía que está casi totalmente en manos de mexicanos" (Connolly, 1988: 197); a diferencia de la industria manufacturera y el turismo, entre otras industrias en las que interviene de manera muy importante el capital extranjero.

Por ello, "se ha considerado la construcción como un sector rector de la economía" (Connolly, 1988: 193). En periodos de crisis económica en el país, la industria de la 
construcción ha jugado un rol determinante en la reactivación de la economía. Es por eso que en diferentes momentos de la historia, las políticas y acciones gubernamentales han estado enfocadas a impulsar y favorecer la construcción en cualquiera de sus ramos. Pero, como señala Bueno, "la industria de la construcción se caracteriza por mantenerse en continua fluctuación... opera como una caja de resonancia de la economía... las perturbaciones cíclicas y coyunturales son reflejo de las situación económica del país y de las políticas públicas...". Es importante situar esta discusión en el contexto más amplio de "la continua inestabilidad" de la economía nacional y de la industria de la construcción, "que experimenta oscilaciones muy grandes de auge y depresión" (Bueno, 1994: 37).

\section{La edificación habitacional frente a otros tipos de construcción}

El artículo de Connolly aborda las especificidades de la construcción habitacional, haciendo énfasis en el desarrollo diferenciado de la edificación de vivienda (cf. Connolly, 1988: 185). Este sector de la industria "suele tener características y una dinámica de cambio muy diferentes a las manifiestas en otros rubros de la construcción... El sector de la construcción habitacional no necesariamente tiene el mismo comportamiento que el conjunto del ramo" (Connolly, 1988: 188).

La construcción de vivienda ocupa un lugar preponderante dentro del total de construcciones en la ciudad. A finales de los setenta y principios de los ochenta, del total de la inversión en construcción, entre el $44 \%$ y el $58 \%$, era para edificación de vivienda. En el caso de la inversión privada, es mucho más claro el predominio de la construcción habitacional, que representa entre el $80 \%$ y el $85 \%$ de la inversión total. Sin embargo, calcular exactamente el peso, la dimensión o el desarrollo de la edificación de vivienda en la Ciudad de México resulta sumamente difícil porque, como estiman varios autores, más de la mitad de la producción en este rubro se realiza de manera informal, por lo que es prácticamente imposible de cuantificar (cf. Connolly, 1988; Bueno, 1994).

\section{Modernización tecnológica vs. sobreoferta de mano de obra (barata)}

En países como el nuestro hay tanta oferta de mano de obra que necesita empleo, que su costo es bastante bajo para las empresas constructoras, de manera que a veces parece que es más barato contratar varios albañiles por una semana, que 
alquilar una grúa mecánica que haga la misma tarea seguramente en menos tiempo. Hay una tensión entre la aplicación de nuevas herramientas y tecnologías en la industria de la construcción, y la necesidad de generar empleos, aunque sea mal remunerados, para una gran población desempleada o subempleada, que carece de capacitación.

Existe una gran reserva de mano de obra que rebasa las fronteras metropolitanas y echa mano de los trabajadores disponibles en comunidades campesinas próximas a la gran urbe... La constante disponibilidad de mano de obra se debe a que, a través del tiempo, la tradición y la información han creado puentes fortalecidos por experiencias pasadas de individuos de la misma comunidad o del mismo barrio urbano, que han consolidado los canales de flujo continuo de mano de obra (Bueno, 1994: 50, 149).

En relación con esto, Connolly (1988) destaca la "falta de un mayor desarrollo técnico en los procesos productivos" y le extraña que no se hayan introducido en México "técnicas más mecanizadas" en la edificación de vivienda (Connolly, 1988: 198). Esta autora previó que esta situación prevalecería sin alteraciones significativas mientras haya abundante oferta de fuerza de trabajo, una masa de jóvenes migrantes empobrecidos en busca de cualquier tipo de empleo o subempleo, a cambio del salario mínimo. Todo parece indicar que a mayor oferta de mano de obra, menor necesidad de introducir cambios importantes en la tecnología empleada (cf. Bueno, 1994: 17). Como lo dice claramente un ingeniero citado por Bueno: "tenemos un fuerte exceso de mano de obra que debemos aprovechar si queremos ser productivos" (Bueno, 1994, p. 39).

Mientras exista una masa de campesinos empobrecidos, dispuestos a incorporarse al trabajo de la construcción, desamparados y desprotegidos por las organizaciones sindicales, difícilmente puede haber aumentos significativos de productividad en esta rama (Connolly, 1988: 216).

Carmen Bueno insiste en que "el vasto soporte de recursos humanos dispuestos a emplearse en un mercado tan fluctuante" es un factor determinante para entender el mundo de la construcción y las condiciones laborales de los trabajadores, así como la permanencia de formas de construcción basadas en el trabajo intensivo y la contratación de abundante mano de obra (Bueno, 1994: 15). No obstante, "las actividades intensivas en mano de obra no son atrasadas o pasadas de moda", sino 
que son la estrategia que le ha permitido a la industria de la construcción sobrevivir en un entorno económico incierto y siempre cambiante. "La respuesta más eficaz ha sido mantener una vasta flexibilidad de demanda y expulsión de mano de obra, que sustituye las innovaciones tecnológicas" (Bueno, 1994: 52).

\section{Composición de la mano de obra}

En cuanto a la composición de la mano de obra, hay que partir de las diversas especialidades que integran la industria de la construcción, hay una gran estratificación y diversificación de trabajadores. Además de éstos, hay que considerar muchos otros factores, entre ellos la región de la que proviene la mano de obra... sus orígenes y trayectorias laborales ayudan a entender su transitoriedad o permanencia en el espacio de trabajo" (Bueno, 1994: 26).

Hay un claro contraste entre el tipo de trabajadores de la obra negra, el trabajo de albañilería, y los del proceso de los acabados. Los albañiles hacen el trabajo sucio y pesado, mientras los trabajadores que "hacen lucir" el producto terminado, en algunos testimonios aparecen referidos como los "vedettes" o relacionados con el "glamour" de la obra. Los primeros, los albañiles, representan el oficio más marginal, los que menos ganan; los segundos, los decoradores, están entre los trabajadores mejor pagados de toda la cadena laboral, acaso porque su trabajo es lo primero que ve el cliente. Son fácilmente reconocibles los trabajadores de uno y otro ramo, primero que nada por su vestimenta, su forma de hablar, etc. En muchas ocasiones estos dos tipos de trabajadores coinciden en la obra cuando se traslapan sus respectivos procesos laborales, dando pie a un encuentro intercultural interesante.

Otra observación de Connolly que resulta muy pertinente para entender los casos estudiados, es que desde hace tiempo en las obras de edificación de vivienda, "la mano de obra campesina parece sustituirse por jóvenes de origen urbano, muchas veces primogénitos que se ven obligados a contribuir al sustento familiar y consideran el trabajo en la obra como una solución temporal a una necesidad económica apremiante" (Connolly, 1988: 215). Otras veces, como se ilustra en esta etnografía, esta nueva clase de albañiles está conformada por jóvenes de diversos orígenes que residen en el corazón de la urbe y a su corta edad ya son padres de familia y tienen la responsabilidad de mantener a su mujer y hasta dos o tres hijos. 
El caso de Ángel, alias El Pelón, así como el de sus varios primos y cuñados, es buen ejemplo de este tipo de fuerza de trabajo que hoy en día se encuentra en las obras de construcción de vivienda cada vez en mayor número. Al respecto, Bueno también señala que "hay una cuota importante de trabajadores que son residentes de la gran metrópoli y que han encontrado en la construcción mejores oportunidades de trabajo que en otros sectores marginales de la estructura de empleo urbano" (Bueno, 1994: 152).

\section{Balance de los estudios sobre la construcción en México}

Algunas cuestiones anotadas por Connolly y Bueno siguen vigentes en la actualidad, otras han comenzado a modificarse poco a poco en los últimos años. De acuerdo con Carmen Bueno, Dimitri Germidis (1974) fue uno de los primeros investigadores en preocuparse por la situación de la construcción de vivienda, las condiciones laborales de los trabajadores de la construcción, las relaciones laborales injustas, la persistencia del sistema de oficios y la importancia de personajes intermediarios como los maestros contratistas. Otro estudio realizado por Leonard Martens (1982) daría cuenta de que no se habían experimentado modificaciones sustantivas en los sistemas constructivos en nuestra ciudad. Priscilla Connolly (1988) proporcionaría elementos para esbozar una continuidad en este sentido y Carmen Bueno (1994) daría cuenta nuevamente de la persistencia de esta mismas circunstancias. Hasta la fecha, en 2010, más de 35 años después del primer estudio de Germidis, la presente investigación documenta que las circunstancias siguen permaneciendo prácticamente iguales en estos rubros. Sigue persistiendo el sistema de oficios con la misma importancia de los agentes intermediarios, los maestros contratistas, y las condiciones laborales de los albañiles y peones rasos continúa siendo lamentable y degradante.

En mi opinión, las principales contribuciones de Carmen Bueno son su descripción etnográfica de la estructura o red laboral, del proceso constructivo y las relaciones de trabajo en el mundo de la construcción habitacional en la Ciudad de México, así como su interés en la movilidad y las trayectorias laborales erráticas de los trabajadores de la construcción; además del acierto de destacar la figura del maestro de obras como el pivote o la pieza clave que hace que todo lo demás sea 
posible y funcione relativamente bien, y no como un personaje parasitario que entorpece la productividad de la industria, y del que sería deseable prescindir.

Me parece que las diferencias más evidentes entre los estudios de Connolly y Bueno aquí discutidos, por un lado, y la presente investigación por el otro, se refieren principalmente a un enfoque teórico metodológico distinto, que lleva a construir objetos de estudio diferentes, y también al estilo general de la presentación de los resultados. Me parece que podemos entender estas diferencias como expresión de un cambio de paradigmas en los estudios sociales sobre la ciudad que se dio a finales del siglo XX. A partir de la década de los 90 emergen nuevas formas de entender la ciudad, como respuesta a lo que autores como Duhau (1992) y Zamorano (2007) identifican como la crisis de las corrientes y escueles marxistas estructuralistas en la investigación urbana.

En esencia, los nuevos estudios de los fenómenos urbanos desde principios de los 90 se empezaron a preguntar "cómo suceden las cosas antes que decretar cómo deben ser; ya no se trató de reducir el significado de los procesos urbanos a su función en la reproducción de la urbanización capitalista, sino de interpretar su desarrollo y sus cambios en cuanto procesos multidimensionales" (Duhau, 1992, citado en Zamorano, 2007: 167). Tanto Bueno como Connolly, al igual que otros autores que en su momento se encargaron del tema, se preocupaban por la cuestión de cómo modificar la organización laboral para mejor la productividad de la industria de la construcción en México; tema que, confieso, en ningún momento cruzó por mi mente durante el trabajo de campo, en el que me dedicaba más bien a documentar creativamente escenas significativas e imágenes reveladoras que hablaran principalmente de la relación entre los albañiles y la obra. Sin embargo, aunque el foco de la presente investigación está puesto en el habitar en la obra por parte de los albañiles, en un plano más filosófico que económico, es importante revisar los problemas y los enfoques que han adoptado las investigaciones anteriores sobre el tema de la construcción.

Asimismo, otro aspecto importante de este giro teórico-práctico en los estudios sociales sobre la ciudad, ha sido el relativo abandono de la idea de estructuras subyacentes y la asimilación de conceptos como redes y actores sociales para entender el mundo contemporáneo. Como bien señala Duhau, "se asumió que las prácticas sociales no son el producto de las estructuras, sino que la realidad social 
está estructurada en tanto y en cuanto los actores sociales, a través de la acción, reproducen prácticas y relaciones sociales... Así entendido, "el proceso de urbanización se visualiza ahora como el resultado de la intervención y las prácticas de una multiplicidad de agentes" (Duhau, 1992, citado en Zamorano, 2007: 167).

Esta nueva corriente de pensamiento y debate sobre redes sociales, de larga tradición en la antropología social anglosajona, fue introducida por primera vez en México por Larissa Lomnitz (1975) en su libro Cómo sobreviven los marginados. Sin embargo, por varios años estas ideas no fueron bien recibidas en nuestro país; se les criticaba su carácter apolítico y antiestructural. Hubo que esperar hasta los años 90 para que estas ideas fueran recuperadas y reapropiadas, al grado de que ahora estas nuevas concepciones se han instalado en nuestra manera de pensar el universo sociocultural. Es fácil darnos cuenta de que estas ideas coinciden en buena medida con los planteamientos de la teoría del actor-red presentada por Bruno Latour (2005) que sirve muy bien a esta investigación para esclarecer la complejidad de las redes que se tejen en torno a la construcción y el papel de todos los actores que las conforman.

En entrevista con Carmen Bueno en abril de 2010, a más de 15 años de haber realizado su estudio, le pregunté qué cosas cree que han cambiado y cuáles siguen igual, cómo emprendería un proyecto de esta naturaleza hoy en día o cómo han cambiado las formas de hacer antropología. A grandes rasgos, su respuesta coincide con algunas de las apreciaciones críticas aquí planteadas, en el sentido de que haría un análisis más micro sobre las trayectorias de los trabajadores, un análisis más cualitativo y no tan cuantitativo, conduciría su investigación más en términos de redes que de estructuras, y consideraría en buena medida las nuevas formas e imaginarios de la globalización en el sector inmobiliario. Trataría de usar más imágenes como parte de su proceso de investigación y análisis. Pero ante todo, señala que el campo de la construcción y los trabajadores sigue permaneciendo bastante ignorado y poco explorado desde la antropología. Sea cual fuera el enfoque que se adopte, hacen mucha falta más investigaciones sobre este sector, desde cualquiera de las posibles perspectivas o especialidades de la antropología.

\section{Vocación etnográfica}

En buen parte de su trabajo, Carmen Bueno se inclina más por la metodología cuantitativa para abordar el problema de la mano de obra. Recurre a la aplicación 
de cuestionarios para elaborar estadísticas sobre distintos aspectos, su composición, el porcentaje de hombres y mujeres, sus edades, nivel de escolaridad, su estado civil, sus trayectorias laborales, su origen y procedencia, lugares de residencia, etc. A pesar de lo serio y sistemático que es este trabajo, me parece que el análisis cuantitativo es menos revelador, vívido y significativo, que una buena descripción etnográfica, como la que Bueno sin duda demuestra que realizó, pero a la que en mi opinión no le dio suficiente espacio en su libro.

Sin embargo, una de las similitudes importante entre el trabajo de Bueno y la presente investigación es su vocación etnográfica, que brinda datos empíricos de primera mano como base para el análisis posterior. Con respecto a esta estrategia de observación micro en la obra, Bueno argumenta: “El análisis a nivel micro... el contacto directo con la realidad, permite detectar procesos que ni los economistas ni los ingenieros han podido observar..." (Bueno, 1994: 27). La etnografía que realizó esta autora es un gran ejemplo de cómo la narrativa etnográfica es capaz de transmitir, muchas veces mejor que las estadísticas y las explicaciones teóricas, los ambientes y aspectos de la compleja realidad sociocultural.

Algunos testimonios memorables presentados por esta autora, como el de un maestro que declara sentir nostalgia cada vez que terminaba una casa: "cada obra es como una hija, la ves nacer, crecer, desarrollarse y cuando llega a la madurez se va para pertenecerle a otro" (Bueno, 1994: 57-68), son fruto de esta vocación etnográfica y su capacidad de transmitir la experiencia de estar ahí en la obra, conviviendo con los trabajadores. Aunque los factores estructurales, tanto los históricos y geográficos como los económicos y políticos, son importantes para hacer una antropología de la obra, no hay que olvidar que el hacer antropología en la obra, es decir, la práctica y la experiencia etnográfica, constituyen una parte sustancial del proceso integral de investigación antropológica.

\section{Los albañiles en el cine y la literatura}

Me gustaría destacar otras aproximaciones a estos personajes, que han surgido desde otro tipo de registros, como el literario y el cinematográfico, entre los que destacan la novela Los albañiles de Vicente Leñero y su posterior adaptación cinematográfica dirigida por Jorge Fons, así como el documental En el hoyo de Juan Carlos Rulfo. 
En el hoyo (México, 2006), documental de Juan Carlos Rulfo, adoptando sin pretenderlo algunos rasgos y principios del documental etnográfico contemporáneo, es un retrato íntimo de los personajes involucrados en la construcción del Segundo Piso del Periférico, pero es además un documento que registra la gran transformación actual de la ciudad. Rulfo nos permiten aprehender de manera vívida fragmentos de nuestra ciudad en pleno proceso de hiperurbanización.

Además de su indudable valor estético, este documental posee una gran riqueza etnográfica. Encontramos el ojo de la cámara al ras del pavimento o metido en el hoyo, como un albañil más. La cámara está compenetrada con la situación de los personajes que retrata. En el hoyo consiste, en buena medida, en una serie de conversaciones entre los personajes principales y el realizador detrás de la cámara. Con una narrativa ingeniosa escuchamos historias que se van entrecruzando, testimonios y confesiones de los trabajadores sobre su trabajo y la vida en general.

Los procesos laborales son registrados con lujo de detalle y la textura de los materiales es examinada minuciosamente. Hay un seguimiento cercano de varias operaciones técnicas (como el manejo de taladros, la operación de grúas y el uso de otras herramientas) así como del trabajo duro que requiere mucha fuerza bruta e implica un gran desgaste físico. Pero sobre todo, el filme captura la peculiar dinámica de relajo entre los trabajadores, hace énfasis en lo lúdico, en el albur, en los toqueteos. Se fija con especial atención en su lenguaje, los apodos que se ponen y los piropos que lanzan.

El documental contiene una colección de momentos de la vida cotidiana de los trabajadores dentro y fuera de la obra, escenas de la comida, la siesta, el juego de naipes y los momentos de descanso. Hay momentos festivos y significativos en la vida de los trabajadores. También aparecen varios accidentes y acontecimientos inesperados. Se registran con gran atención algunos detalles y rasgos culturales de los trabajadores: la ropa que usan, la música que escuchan, las canciones que cantan, las historietas que leen. En su peculiar uso de los teléfonos celulares y en ciertas referencias a los programas de televisión que ven, se pone de manifiesto la presencia cotidiana de los medios masivos de comunicación en sus vidas.

En el hoyo brinda un retrato íntimo y con gran detalle etnográfico de la cultura de los trabajadores de la construcción y sus modos de apropiarse y relacionarse con la ciudad. Escucha atentamente todo lo que dicen y sobre todo cómo lo dicen. Presenta 
perfiles de vida de personajes entrañables, expresando muy bien su carácter y personalidad. En este documental somos transportados a los pueblos de origen de los trabajadores, estos momentos muestran cómo lo rural y lo urbano se funden en la vida de los obreros de la construcción, personajes multiculturales con identidades híbridas.

De acuerdo con Néstor García Canclini, este documental podría verse como una etnografía de las prácticas de supervivencia y disfrute de los trabajadores, que da cuenta de la complejidad de la vida cotidiana y de las interacciones de los actores. Uno de sus más grandes aciertos, aunque quizás involuntario, es que pone de manifiesto el hecho de que:

Las ciudades se hacen también para viajar, sobre todo las grandes ciudades..., para viajar a ellas, desde ellas y a través de ellas. Parte del paisaje de la ciudad son las avenidas, las autopistas, etc. El viaje, en cierto modo, es una síntesis y una vía de acceso a la vida en la ciudad.... ¿Por qué digo que la película de Rulfo trae novedades? Por una parte, encuentro que mira la ciudad desde el viaje, y el viaje desde el trabajo, desde la vida cotidiana de quienes construyen la ciudad, desde quienes trabajan en la construcción de la posibilidad de viajar (García Canclini, 2006).

En el hoyo es, a mi parecer, un documental etnográfico ejemplar que muestra la vivencia del realizador de convivir directamente con los actores urbanos. Tiene el mérito de combinar un doble enfoque sobre la ciudad: por un lado ensaya una visión macro, amplia, general del panorama urbano (que alcanza su momento cumbre al final de la película con la toma aérea de seis minutos que recorre de principio a fin la obra del Segundo Piso), y por otro, mantiene una visión micro, íntima, cercana, de los personajes urbanos (sus rostros, sus manos, sus historias). El documental captura y expresa el nuevo orden urbano, que conserva, no obstante, su carácter caótico, tradicional y humano. Es una representación de la modernización de la ciudad, con un profundo significado antropológico. El documental de Rulfo nos transporta a las entrañas de la ciudad y la cultura urbana en pleno proceso de construcción. Es un testimonio de cómo le está cambiando el rostro a la Ciudad de México en los primeros años del siglo XXI.

Sin embargo, cabe marcar la diferencia de intención e interés teórico entre el documental de Juan Carlos Rulfo y la presente investigación. Para empezar, como han señalado varios autores, y como he podido constatar en mi propia experiencia 
etnográfica, la edificación de vivienda es un sector completamente distinto al de las obras públicas de infraestructura urbana, como la construcción del Segundo Piso del Periférico. A grandes rasgos los perfiles de los trabajadores de uno y otro tipo de obras pueden llegar a ser similares, mas sus condiciones laborales pueden variar considerablemente, sobre todo en cuanto al trato que establecen con la empresa constructora, que es completamente distinto en ambos casos. Pero creo que la principal diferencia está en el interés teórico que esta investigación tiene sobre la cultura del habitar de los albañiles, desde una perspectiva antropológica.

Por otra parte, la novela Los albañiles (1963) de Vicente Leñero es en mi opinión una obra maestra de la literatura mexicana de la segunda mitad del siglo XX. Es en realidad un thriller policiaco que gira en torno al asesinato del velador de una obra de construcción. La trama es claramente una historia ficticia, pero el contexto en el que se desarrolla por momentos pareciera estar descrito como si fuera una crónica de no ficción, con un gran valor documental. Narrativamente hablando, es una obra bastante compleja y original, en parte porque el manejo del tiempo no es lineal sino que hay brincos hacia delante y hacia atrás en la historia. Pero sobre todo porque los hechos están contados desde las diferentes perspectivas de los actores de la obra, mientras rinden su testimonio ante los investigadores de la policía que intentan resolver el crimen. Cada personaje interrogado cuenta su versión de los hechos, pero sale a la luz no sólo su interpretación del asesinato, sino su visión de la obra en general. Así, Leñero nos hace adoptar el punto de vista del maestro, del ayudante, del arquitecto, del velador, entre otros trabajadores de la obra, presuntos sospechosos del asesinato.

Cabe mencionar que esta novela fue llevada a la pantalla grande por Jorge Fons en 1976, resultando en una adaptación bastante afortunada, en gran parte porque el guión y la adaptación corrieron a cargo del propio Vicente Leñero, con grandes actuaciones de Ignacio López Tarso, Resortes, Katy Jurado, entre otros. Con gran destreza narrativa y una descripción muy minuciosa, tanto en la novela como en la película, se recrea hasta el más mínimo detalle de cada escena; Leñero retrata nítidamente el ambiente general de la obra y varios aspectos de la cultura popular de los trabajadores. En la novela aparecen retratadas varias situaciones que ocurren comúnmente en las obras, como el robo de materiales, albures, bromas y toqueteos sexuales entre los trabajadores, la iniciación sexual de los ayudantes por parte de los 
oficiales que los "apadrinan", el velador y otros trabajadores que hacen de la obra su hogar, momentos de convivencia como la comida en la obra, el choque cultural entre el ingeniero y los trabajadores, la inconformidad de los trabajadores por tener que pagar una cuota al sindicato que ni les ayuda en nada, el maestro que les "pellizca" o "muerde" el sueldo a los obreros al momento de pagar la raya, la relación que tienen con las mujeres y el peculiar imaginario que tienen al respecto, etc. En una memorable escena de la película, don Jesús, el velador (representado por Ignacio López Tarso), dice:

A mí me gusta ir viendo crecer las obras, desde que son un mugroso terreno, lleno de basura y de miados de perro, luego se limpia y se arregla, como se arregla una novia para que le hagamos un hijo, y se lo hacemos, como de que no. Las obras son como los hijos. Por eso a mi me gusta trabajar en esto de la construcción, y más me gustaría si las obras no terminaran nunca, cuando el edificio está así, creciendo, es de usted y mío y de todos, se le ve nuestro sudor, nuestro trabajo y hasta nuestra sangre, pero luego ya terminado pus ya es de otra gente que ni ha visto ir creciendo el hijo y que no pueden quererlo como nosotros, que le hemos ido dando nuestra vida pedazo a pedazo.

Un fragmento del libro resulta especialmente relevante, ya que nos remite directamente al tema de la vida social de los objetos, tal como vimos en el capítulo anterior, así como a la relación íntima que guardan los albañiles con la obra:

...don Jesús le dice a Isidro:

- Las cosas sienten; ¿sabías eso? Cuando serruchas una tabla es igual que cuando le arrancas una rama a un árbol. Igual que si le quiebras la pata a un perro; como si te troncharan un dedo.

- ¡Voy!... ¿por qué?

-Porque así es. Nomás ponte a pensar y verás. ¿A poco no le tienes cariño al edificio?... Yo hasta me pongo a hablar con él. Y vieras, Isidro, me oye el cabrón. Hasta me contesta. No con palabras así como las de nosotros, sino con ruidos y rechinidos y una bola de modos que tiene para platicar: ahí están los olores. Cuando huelo mucho a yeso es que me está diciendo que hace frío.... Las cosas tienen vida, Isidro; lo sé desde cuando era como tú...

Es de suponerse que Leñero tuvo que haber conocido de primera mano el ambiente de una obra durante el tiempo suficiente para empaparse de tal manera en la cultura popular de los albañiles y ser capaz de elaborar un retrato tan minucioso y pormenorizado de este mundo. 
Por último quisiera destacar un trabajo fotográfico muy relevante en torno a los obreros de la construcción en la Ciudad de México; me refiero al ensayo visual titulado Obra negra del fotodocumentalista mexicano Ulises Castellanos (1998).

Sin lugar a dudas, leer esta novela de Leñero, así como ver la película de Fons o el documental de Juan Carlos Rulfo, así como mirar las imágenes de Ulises Castellanos, nos acerca y nos ayuda a entender el mundo de la construcción y la vida cotidiana de los trabajadores en la obra. Además del valor de sus contenidos, que nos permiten asomarnos al mundo de los albañiles y los trabajadores de la construcción, las obras comentadas son ejemplos de cómo el cine, la literatura y el arte pueden aportar considerablemente al conocimiento antropológico de una realidad determinada, pero también de cómo los métodos y técnicas de investigación etnográfica pueden contribuir y enriquecer significativamente la creación literaria y artística en general. En este sentido, propongo considerar al cine y a la literatura - tanto la ficción como el documental-como medios efectivos para la etnografía, y como fuentes valiosas para la investigación antropológica, en tanto formas de representación de las culturas.

\section{Oficios, perfiles de vida y relaciones laborales}

\section{La red de actores involucrados}

En lo que sigue intentaré hacer un esbozo general de las redes que vinculan a los diferentes actores y oficios que entran en juego en la construcción de un edificio de departamentos. Relataré algunas experiencias y reflexiones en torno a la cultura y dinámica laboral que se genera alrededor de una obra, describiendo las acciones que se llevan a cabo, las responsabilidades, jerarquías y especializaciones, la división social del trabajo, etc. Me interesan las diferencias y desigualdades de distinta índole que se producen y reproducen en el ámbito de la construcción, así como la percepción que un actor tiene de otro o del sistema en general. Trataré de abordar, en unos casos con mayor profundidad, y en otros solamente como un esbozo, la cadena de actores que estuvieron involucrados en la transformación de este espacio urbano particular, desde los clientes potenciales, cuyos sueños y aspiraciones son el objetivo de los inversionistas, pasando por la empresa constructora, el arquitecto, los maestros de obras, los oficiales, hasta llegar al eslabón más bajo, los albañiles, 
peones y trabajadores rasos, también conocidos simplemente como ayudantes. En este último grupo es en el que más me concentro a lo largo de esta investigación.

Desde luego, no pretendo explicar la estructura social ni descifrar la cultura laboral de todas las obras de construcción de vivienda en la Ciudad de México, tan sólo quisiera relatar desde mi punto de vista cómo operaban los casos concretos en los que me adentré. En este mismo sentido, tampoco sé si haya encontrado en estas obras a los albañiles típicos o al trabajador modelo, así que tampoco pretendo hablar sobre los albañiles como una categoría abstracta y genérica, sino que describiré $\mathrm{y}$ en todo momento me referiré puntualmente a los personajes particulares que conocí y a las labores que desempeñaban.

Por otra parte, resulta casi imposible separar el carácter y la historia de una persona determinada de los rasgos que le confiere su oficio. ¿Hasta dónde llega la personalidad de alguien y dónde comienza su carácter de carpintero, por ejemplo, o qué tanto el oficio de yesero le imprime algo a la personalidad de una persona? Ante la imposibilidad de una respuesta sencilla a esta cuestión, en la mayoría de los casos he optado por presentar juntos los datos referentes a los distintos oficios y los datos personales de los personajes que desempeñan tales oficios, sus historias o perfiles de vida, su trayectoria, procedencia, situación familiar, etc. Pero en otros casos, debido a que no me involucré tanto con todos los actores, hablaré de los oficios de forma general, sin referirme a las personas específicas que los desempeñan, como en el caso de los profesionistas especializados, como los fierreros, alumineros, yeseros, etc.

A continuación presento una lista comentada de buena parte de los actores que conocí alrededor de las obras durante mi trabajo de campo. En principio, los ordeno por rango, de arriba a abajo en la jerarquía laboral. Además, los separo en tres categorías: altos mandos, oficios intermedios y oficios más bajos. Esta disposición de la información puede parecer demasiado esquemática, pero tiene la finalidad de exponer con claridad un unvierso complejo en el que las disposiciones de los actores y sus vínculos se recomponen y se reinventan constantemente. No quisiera dar la impresión de que los actores se acomodan ordenadamente formando una cadena vertical y estática. En realidad, más que una cadena, se trata de una red en la que las posiciones se intercambian todo el tiempo, los actores se mueven, van y vienen, y los lazos entre ellos se transforman a cada momento, con cada movimiento. La línea 
que divide un rango de otro no es clara sino difusa; por ejemplo, el trabajador más bajo de los altos mandos es muy parecido y tiene casi las mismas condiciones laborales que el más alto de los rangos medios; las diferencias son graduales y siempre cambiantes, de manera que los cortes que aquí hago son arbitrarios pero espero que resulten útiles en términos de claridad.

\section{Las empresas constructoras privadas}

En cuanto a las empresas constructoras de vivienda, Bueno y Connolly hacen varias observaciones muy pertinentes para entender el caso de DAKAB, la compañía en la que nos centramos en esta investigación. Para empezar, de acuerdo con la descripción de Bueno, "en la cúspide de la estructura laboral se encuentran las empresas constructoras o profesionistas libres, generalmente arquitectos o ingenieros, cuya labor radica en conseguir inversionistas, financiamientos o créditos para llevar acabo el proyecto... buscar y comprar los terrenos, conseguir clientes, tramitar los permisos y pagos de impuestos ante las autoridades, llevar la parte administrativa y burocrática de la construcción, además de ser los responsables del diseño y la ejecución de la obra" (Bueno, 1994: 98).

Por su parte, afirma Connolly que "hay una constante proliferación de empresas de tamaño reducido. Muchas veces, por cierto, éstas son creadas como filiales en propiedad de firmas más grandes". Cabe señalar que la anterior descripción encaja a la perfección con las circunstancias de la empresa constructora DAKAB. Esta autora afirma que "existe una gran diversidad de tipos de empresas que se diferencian entre sí no sólo por su tamaño y especialización, sino también por sus formas de trabajo y desarrollo tecnológico... Pocas firmas se dedican exclusivamente a la construcción habitacional", casi todas combinan este rubro con otro tipo de proyectos constructivos (Connolly, 1988: 209-210).

Por lo que respecta a nuestros estudios de caso, "las empresas especializadas en la edificación tienden a ser medianas y chicas, y aplican procesos de trabajo muy poco mecanizados, organizados de manera tradicional... En el caso de las empresas especializadas en la construcción habitacional, su tamaño promedio es aún más reducido...". Connolly hace referencia a una tendencia que parecería vigente en nuestros días y quizás sería aplicable al caso de DAKAB: "el fenómeno de la 
generación espontánea -y a veces efímera- de nuevas empresas constructoras, no sólo de vivienda sino también de otros tipos de obra" (Connolly, 1988: 209).

En el caso de las obras estudiadas, el Arquitecto Canela, además de ser el responsable del diseño de los edificios, era socio inversionista de la compañía DAKAB, por lo tanto su presencia en la obra representaba a su vez la de la presencia de la empresa constructora en la obra.

Por lo general el Arquitecto Canela visita la obra temprano en las mañanas, como a las 8 u 8:30 am; nada más va un ratito y no todos los días. Un día por fin veo que llega el arquitecto Canela, vestido con camisa negra, pantalón café, zapatos negros, lentes obscuros. Se pone a tomar fotos y video de la obra con su celular. Más adelante, como a los 15 ó 20 min de haber llegado, se retira el Arq. Canela.

Siempre bien vestido, de tez blanca, de unos 50 años aproximadamente; sus ojos claros forman un gesto que denota presión y estrés. Su ropa es fina pero él luce desaliñado, despeinado, luce como recién levantado... El arqui estaba sentado en la mesa de la esquina, hablando por teléfono... Más tarde está discutiendo con un grupo de trabajadores de alto rango... Le pregunto a un trabajador cada cuánto visita el arquitecto la obra, a lo que responde que "casi siempre viene a diario, por ejemplo, ahorita aquí anda, mira, ahí está su coche estacionado afuera en la puerta". No se queda toda la jornada ni trabaja a la par de todos los obreros, pero cotidianamente hace acto de presencia y supervisa las labores.

Me encuentro al arquitecto hablando por teléfono, con el dispositivo llamado "manos libres" en la oreja. Está rodeado de otros trabajadores y encargados de la obra. Pienso en pedirle una cita para hacerle una entrevista, pero a pesar de que lo saludo de mano, no alcanzamos a cruzar ni una palabra, ni siquiera me voltea a ver, al parecer está muy ocupado y poco dispuesto a atenderme... Saludo al arquitecto Canela que está adentro de la obra sentado en uno de los departamentos siempre con un accesorio inalámbrico en la oreja; esta vez me contesta el saludo amablemente.

\section{Altos mandos}

El primer día que entré al terreno me encontré con un grupo de trabajadores, al parecer de alto rango, que estudiaban un juego de planos y discutían algunos puntos alrededor de una mesa blanca de plástico... Entre estos trabajadores 
estaban quienes en adelante conocería como Antonio Bobadilla, mano derecha del arquitecto, Nicolás, el maestro contratista, y Silvano, el maestro encargado de llevar la obra.

\section{Antonio Bobadilla: ingeniero residente}

En algunos casos, por ejemplo cuando una empresa constructora tiene varias obras a la vez, como en el caso de DAKAB, suele haber un ingeniero residente que se encarga de vigilar el avance general de la obra, además de lidiar y negociar con los maestros contratistas. En el caso de las obras de Córdoba y Puebla estudiadas en esta investigación, ésa labor la desempeñaba Antonio Bobadilla, quien cumplía las labores de administrador y supervisor de las obras.

Al otro lado del hoyo aparece Antonio Bobadilla, quien va directamente a regañar a los fumigadores por no haberle avisado antes de empezar a trabajar. Voy hacia donde está él, bien vestido, con actitud de "manda más", rayando en la prepotencia. No cabe duda de la autoridad de Bobadilla; va de un lado a otro repartiendo instrucciones en un tono fuerte. Otro día, Antonio Bobadilla permanece recargado en un coche al otro lado de la calle... Más adelante, Antonio Bobadilla supervisa la acción del colado con pipas cruzado de brazos afuera del terreno; revisa múltiples papeles, al parecer notas y facturas.

Permanezco con Bobadilla un rato recargados en la pared de la entrada. Entre largos momentos de silencio, contemplando la vida cotidiana en la calle Córdoba al atardecer, de vez en cuando le hago alguna pregunta, como "¿cuántos viajes han hecho los camiones hoy?", pero no me sabe responder porque sólo estuvo un rato en la mañana y luego se fue. Siempre me contesta reacio y escueto. Al menos hoy no está tan sangrón, sólo indiferente.

Antonio Bobadilla le pregunta a alguno de los yeseros a dónde mandar a traer el yeso sin que cobren el flete. Antonio Bobadilla me dice que a él también le toca coordinar a todos los contratistas para los acabados. Poco después veo a Antonio Bobadilla, con la ropa de siempre, algo más gruñón que de costumbre, contestando dos celulares a la vez, observando las acciones desde la orilla del terreno.

Saludo a Antonio Bobadilla, medio malencarado, serio, casi gruñón, con su misma ropa de siempre, la de trabajo. "Ya llegó la varilla", le digo; asiente sin responder, frunciendo el bigote y las cejas. 
Encuentro a Bobadilla en la entrada, muy serio, lo saludo y no me responde nada, no dice ni una palabra, brinca dudoso y torpe los obstáculos formados por cerros de escombro y lodo para entrar al terreno. Antonio Bobadilla estaba en la obra de Córdoba por la mañana y me lo encuentro otra vez en la de Puebla hacia el mediodía. Supervisa los movimientos y me mira desconfiado, serio, se nota que no me quiere, ni a mí ni a nadie de ahí. Veo por ahí a Antonio Bobadilla muy ocupado, caminando apurado de un lado para otro. Me interpongo en su camino para saludarlo, pero él más bien parece que me evita y se va.

Nicolás: maestro contratista o maestro de obra Uno de los niveles más altos en la estructura laboral, con quien tratan las empresas constructoras y el arquitecto, lo ocupan los maestros de obra o maestros contratistas, responsables de todos los procesos de albañilería, encargados de reclutar la mano de obra, además de vigilar el desarrollo de la construcción de principio a fin (Bueno, 1994: 96).

El maestro es el enlace necesario entre el capital y los trabajadores... En cada uno de los oficios se convierte en la cabeza de la estructura laboral... tiene la facultad de decisión sobre la manera práctica de hacer las cosas, tienen autoridad y responsabilidad casi exclusiva sobre el proceso de producción... además del control que detenta sobre la mano de obra (Bueno, 1994: 148).

Otros autores destacan que "los maestros de obra adquieren gran poder... organizan el trabajo, tienen facultades para despedir a los trabajadores... ellos son quienes pagan los salarios... El maestro contratista jamás trabaja en la obra: eso lo rebajaría y le restaría poder ante sus subalternos; pero debe saber de todo, por si alguno de sus trabajadores hace algo mal, corregirlo y exigirle que lo repare" (Liguori-González, 1992: 40).

De acuerdo con Carmen Bueno, Dimitri Germidis (1974) argumentaba que sería recomendable eliminar la figura de los maestros contratistas en el proceso de producción de vivienda, ya que en su opinión tenían una función parasitaria y daban pie a muchos de los abusos cometidos en contra de los trabajadores (cf. Bueno, 1994: 15). No obstante, hay que señalar que "la importancia del contratista en la construcción de vivienda, al igual que el maestro de obras, está en que permite hacer frente a las fluctuaciones del mercado de trabajo"; su habilidad consiste en 
ingeniárselas para "mantener continuidad en la intermitencia" en cuanto a la administración de la mano de obra (Bueno, 1994: 112). La figura del maestro de obra es particularmente compleja e interesante. Es un personaje emblemático de la obra, la bisagra que hace que todo funcione, una pieza clave, mediador entre distintas instancias y dimensiones en el mundo de la construcción. Como sugiere Carmen Bueno:

Los maestros, al ser el enlace obligado entre el constructor y la cuota de trabajadores, en su rol de coordinadores, se identifican con las demandas del constructor, a la vez que procura el beneficio de los trabajadores. Los maestros se convierten en intermediarios entre estos dos grupos sociales (Bueno, 1994: 99).

El maestro de obra es el verdadero orquestador, realiza la obra maestra de ensamblar y articular diversas perspectivas y encausar distintas acciones para logar un fin común, la vivienda terminada. Representan un puente de comunicación entre la empresa y el resto de la red laboral. Son sujetos interculturales que están en contacto con grupos de trabajadores de distintos orígenes, gente de distintos oficios, edades, etc. Tienen que proporcionar soluciones prácticas ante cualquier eventualidad, son maestros de la improvisación, poseen la mayor cuota de ingenio popular posible, además de la habilidad de ejercer formas de autoridad firme pero suave, dándose a respetar pero evitando confrontaciones. "Las constructoras no podrían edificar sin el servicio que ofrecen los contratistas... Los maestros contratistas mantienen un fuerte margen de maniobra, principalmente por el control sobre el reclutamiento y capacitación de los trabajadores" (Bueno, 1994: 102).

A este respecto, quisiera retomar la propuesta de Bruno Latour (2005) de considerar como mediadores, y no como intermediarios, a todos los actores involucrados en una cadena de acciones dentro del proceso constructivo. Esto es especialmente importante en el caso del maestro contratista, que tanto Carmen Bueno como Priscilla Connolly, presentan como un actor intermediario. Dice Latour que hay una "gran diferencia si los medios para producir lo social son considerados intermediarios o mediadores". Un intermediario es algo que transporta significado o fuerza sin transformación. "Los mediadores transforman, traducen, distorsionan y modifican el significado o los elementos que se supone deben transportar o trasladar. La especificidad de los mediadores tiene que tomarse en cuenta" todo el 
tiempo. "Pensar en términos de mediadores resulta más complejo, ya que cada uno puede conducirnos por direcciones muy diferentes" (Latour, 2005: 39).

En el caso de las obras estudiadas, el maestro de obras o contratista era el maestro Nicolás, alias el Barney. Un día lo veo trabajando con un pico rompiendo un muro limítrofe entre el terreno y la calle. Esta es una de las pocas veces que vería a un maestro de alto rango haciendo trabajo físico. Me parece un buen gesto de parte de Nicolás, un acto solidario con sus trabajadores que reafirma su liderazgo. No obstante, otro día el maestro Nicolás camina de lado a lado por un costado del terreno, bien atento a las labores de los peones, daba instrucciones desde arriba, sin meterse al hoyo ni ensuciarse las manos.

Me encuentro a Nicolás, que me acabo de enterar, gracias al Pelón, que le dicen el Barney "por chaparro, panzón y sonriente". El maestro Nico, da instrucciones a diestra y siniestra, comentamos el partido de ayer y me dice que él le va al Cruz Azul... Llega el maestro Nicolás, con una faja ajustada en el abdomen, le preguntan cómo sigue, dice que mejor, recuperándose de una caída que sufrió en su casa. Se retira Nicolás, sin despedirse, a resolver algún asunto afuera.

El maestro Nicolás y su segundo abordo, Silvano, observan y vigilan de cerca toda la acción de la máquina excavadora, ambos panzones, aunque el primero más que el segundo, y los dos más o menos bien vestidos. Me da la impresión de que se llevan bien y hacen un buen equipo. Más tarde, Silvano y Nicolás descansan en un cuartito.

\section{Silvano: "segundo"}

En ocasiones, este maestro de obra tiene un subalterno llamado "segundo", que auxilia al maestro en la coordinación general y la vigilancia directa del trabajo, siendo una especie de capataz (cf. Bueno, 1994: 96). Al respecto, otros autores señalan que "el contratista tiene una persona en quien deposita su confianza; éste lo representa en la obra y se encarga de vigilar y resolver los problemas cuando él no se encuentra" (Liguori-González, 1992: 40). En las obras estudiadas de DAKAB, es importante señalar la gran importancia que tenían los "segundos", particularmente Silvano en la obra de Córdoba. Debido a que el maestro Nicolás se hacía cargo de otras obras de esta misma compañía a la vez, el papel del segundo cobraba una relevancia especial en cuanto al trato con los trabajadores y la vigilancia general del 
desarrollo de la obra. En nuestro caso, este segundo abordo en la obra de Córdoba, así como en la de Puebla, fue Silvano.

Silvano me cuenta que él acaba de empezar a trabajar como supervisor de obra en esa empresa, antes ya había estado con ellos en otra obra, pero sólo como oficial. Siempre anda dando vueltas por el terreno supervisando todas las acciones, involucrado en la obra mucho más de cerca que Nicolás y por supuesto que Bobadilla. Silvano está por ahí revisando cosas, agachado, trepando, contando el material. Algunas veces le rinde cuentas directamente al arquitecto.

Me platica Silvano que la responsabilidad de "llevar la obra" es mucha: "estoy a cargo de que todo esté en orden con el material, de los pagos, de si los trabajadores piden préstamos y pagos por adelantado, de reportar el avance de la obra, de llevar las listas de asistencia... todo eso hay que supervisarlo bien bien". También me habla de todo lo que podría salir mal si él no hiciera bien su trabajo, así como las trampas que sería posible hacer desde su puesto: "comunmente puede haber robos de material, que se retenga el dinero para jinetearlo, que se les pellizque el sueldo a los obreros, que no se reporte el material que sobra o que se haga trampa con cada kilo de concreto".

Silvano constantemente aparece caminando por fuera de la obra, supervisando el perímetro. "Yo estoy listo para recibir el cemento mañana", me dice Silvano, hablando en primera persona, como si él fuera la obra. Esto revela la responsabilidad que debe asumir el maestro encargado de una obra, dando la cara por ella hasta el grado de convertirse retóricamente en ella.

Silvano nuevamente está supervisando las labores, pero apartado del lodazal, vistiendo una camisa de la Compañía de Luz y Fuerza del Centro y un sombrero blanco tipo safari. Siempre que veo a Silvano, nos saludamos con gusto recíproco. Pasando a temas más personales, me platica que Édgar, El Gordo (a quien conoceremos más adelante) es su yerno; está casado con una de sus hijas y le han dado varios nietos. Silvano tuvo cuatro hijas en su primer matrimonio, pero su esposa falleció durante el último parto, cuando las otras niñas estaban muy chicas todavía, lo cual fue muy duro de enfrentar. Luego se volvió a casar y tuvo dos varones "que todavía están morritos".

Silvano me informa que ahora está a cargo de la obra de Puebla. Más tarde sería uno de los principales afectados por su clausura temporal... Silvano, sin bigote, 
rejuvenece un poco. No acepta el cigarro que le ofrezco porque todavía no ha almorzado, "y como que con la panza vacía no se antoja tanto echar humo".

\section{Javier: "segundo"}

El maestro Javier es el nuevo encargado de la obra de Córdoba, a partir de que comenzó la obra de Puebla y Silvano se fue para allá. Javier es un señor grandote de bigote, panzón y cachetón, con una gorra color azul claro, de unos 40 años aproximadamente. Me presento con él, quien a partir de ese momento me llamaría siempre por mi nombre, aunque a veces también me llamaría güero, como todos los demás.

Le pregunto al maestro Javier el número de departamentos que se construirán en la obra de Puebla, pero no sabe cuántos exactamente, dice que acaba de llegar y apenas mañana le van a llevar los planos. Una vez con los planos en la mano, estudiará y analizará el caso para ver cuántos fierreros tiene que llevar, cuántos carpinteros, etc. Curiosamente, se refiere a los trabajadores como si fueran sus hombres, como si tuviera un ejército de albañiles a su disposición. Esta actitud me remite al hecho de que cada maestro es el encargado de reclutar y proveer la mano de obra. Muchas veces tienen su equipo de personas de confianza con quienes trabaja de entrada, pero según las necesidades de cada obra particular, va reclutando más o menos trabajadores entre quienes buscan trabajo de obra en obra, generalmente los lunes.

Javier tiene dos hijos. Uno de ellos tiene metido en la cabeza que quiere ser astrónomo. Él le dice que "nel", que está loco, que dónde va a trabajar y cuánto va a ganar. Hablamos sobre los distintos oficios, los pros y contras de algunos, los más cotizados, los más remunerados, sobre la vocación, aptitudes y el gusto de cada quien por distintas actividades y trabajos. Le insisto que debería apoyar a su hijo en sus ganas de ser astrónomo. Comentamos algunos principios básicos de la física, la astronomía, sobre el sistema solar, los planetas, las estrellas, los cometas, la gravedad, etc. Lo intento convencer de que eso que su hijo quiere ser es interesantísimo. Hay que saber mucha física y matemáticas primero, luego se va especializando. Le digo que el campo de trabajo es la universidad, la investigación, puede dar clases, escribir libros. "¿Pero cuántos años tiene que estudiar para eso... y en todo ese tiempo no va a trabajar y cómo lo vamos a mantener todos esos años... 
quién le va a tener que comprar su pinche telescopio?", replica Javier. Si es buen estudiante el gobierno le podría dar una beca, contesto mordiéndome la lengua, sabiendo lo difícil que ha de ser salir adelante para un niño rural de padre albañil. Le insisto que al menos mientras pueda no desanime a su chavo a estudiar lo que le hace tanta ilusión.

La plática con Javier deriva en que muchas veces las apariencias engañan y es difícil conocer a las personas, "luego gente que se ve como nosotros, sencilla, con ropa normal, saca los billetotes y deja sorprendida a los demás. Pero también está el caso contrario, la gente que usa ropa y joyas para apantallar, y a lo mejor hasta trae su carro nuevo, cuando en realidad son pobres y su casa es un pinche jacal".

Según Eliseo, Javier es el más "rélax" de los maestros de obras que han pasado por la obra: "es más alivianado y más cábula que Silvano y que Maximino"... Hace chistes y burlas hacia el velador. Édgar, El Gordo, las celebra y lo secunda. Pero también me tocó ver al maestro Javier dando órdenes enérgicas por aquí y por allá; manda, regaña y delega, ostentando su autoridad, pero sin perder el sentido del humor.

\section{Rango intermedio}

En este rango intermedio ubico a los oficiales, los jefes de cada oficio, que instruyen y dan órdenes a sus ayudantes, y ganan considerablemente más que ellos. El oficial, quien a través de la práctica ha tenido un conocimiento integral del oficio, goza de cierto estatus dentro de la organización laboral. Es responsable de organizar a su grupo de trabajo y llevar a acabo tareas concretas, por ejemplo levantar un muro, armar una columna o una trabe. Además, en la medida de lo posible, cumple la función de capacitar a los peones (cf. Bueno, 1994: 96). En las construcciones abordadas en esta investigación, Pato, Gato, Édgar, Paul y Calderón fueron algunos de los oficiales que mejor pude conocer.

\section{Patricio, alias Pato: maestro oficial}

Pato fue el primer trabajador que conocí desde el principio de la obra de Córdoba y sería uno de los pocos que permanecieron en las obras de DAKAB de principio a fin. En adelante, se convertiría en uno de los actores principales en la historia de esta obra y sin duda es uno de los personajes más importantes en esta investigación. 
Cuando me acerqué a él la primera vez estaba haciendo labores de carpintería, clavando y midiendo tablas en el fondo del terreno, casi terminando su jornada laboral. Sostengo con él una amena plática sobre su experiencia de trabajo de 27 años; sobre su procedencia, cerca de Atlacomulco, Estado de México y el horario de trabajo, de lunes a viernes de 7 am a 5 pm, que le permite ir a su casa los fines de semana, para dedicarse a otras labores y estar con su familia.

Me dice que en la obra no hace tanto frío como por su casa, donde amanece todo blanco con una capa de hielo. Sobre todo padece el frío cuando se tiene que venir en autobús a las 4:30 am todos los lunes, para llegar a la obra a las 7 am y empezar la semana laboral. Se viene junto con otros compañeros que también trabajan con él y viven por allá, por ahora son unos cinco en total, de los cuales tres trabajan en las mismas obras de DAKAB.

Otro día, Pato trabaja armando una columna de varilla sobre una barda de ladrillo. Me parece una imagen muy poderosa porque, a mi parecer, refleja y condensa muchos rasgos de la personalidad e identidad cultural del Pato: responsable, humilde, honesto, sencillo, afectuoso, luchador, flaco pero correoso, hábil. Su camiseta de Santana con un calendario azteca y su gorra con alguna leyenda en inglés, aportan lo suyo a esta escena. Después lo encuentro supervisando el trabajo que hicieron otros, checando que las medidas estén bien, cotejándolas con los planos. Aunque es discreto, callado y de bajo perfil, Pato es sin duda uno de los hombres de más confianza, peso, autoridad y responsabilidad en la obra.

Al primero que veo después de varios días de no ir a la obra es a Pato, quien me recibe alegre con los brazos extendidos. Después del abrazo, me saluda de mano con doble apretón. En ese momento Pato medía distancias y extensiones de varilla con su cinta métrica, inspeccionando que el trabajo de los demás esté bien hecho; definitivamente es un hombre de confianza para el maestro... Pato, quien viste una camiseta del PAN, se pasea por las rampas y supervisa la acción del colado mientras fuma un cigarrillo. Camina lentamente sobre las trabes de varillas, como checando que todo esté bien hecho a cada centímetro. Más adelante, Nicolás Ilama a Pato al segundo piso para revisar con él la instalación que hicieron los plomeros.

De pronto empieza a llover fuerte y muchos nos refugiamos debajo de un árbol que nace de la escuela de junto, cuyas ramas llegan justo al nivel donde estamos 
parados. La lluvia amainó muy pronto, pero la pausa se prolongó un poco más de lo necesario, hasta que sin decir nada, el Pato se puso a trabajar otra vez, dando el ejemplo a todos los demás, maestros y ayudantes. Pato hizo varias maniobras solo en el piso mojado, arrastrando y acomodando varillas, hasta que poco a poco todos los demás fueron volviendo a sus puestos de trabajo.

\section{El Gato: maestro oficial}

Lo conocí por primera vez cuando al retratarlo haciendo cuentas con un lápiz bicolor sobre la pared. Con el pelo rubio y ojos claros, todo un "güero de rancho", como se dice él mismo, El Gato se convertiría en uno de mis mejores amigos en la obra... Vive adelante de Toluca, cerca de Atlacomulco, es del mismo Pueblo que Patricio, o sea que forma parte del "grupo Atlacomulco" de la obra. El Gato, con su cinturón de herramientas, pantalón arremangado de una pierna, tenis sin calcetín, me cuenta que ha trabajado en varias obras, en distintos lugares de la República, como Cancún, San Luis Potosí, en el Estado de México, etc.

El Gato me habla sobre su particular sentido de la responsabilidad. "A mí me gusta ser responsable y cumplido en todo lo que me comprometo. Por ejemplo, a mí no me conviene regresar hasta mi casa este fin porque vamos a trabajar el sábado, pero me voy a ir, porque quiero ver a mis hijos, pero también quiero estar allá porque tengo partido de fútbol el domingo y no le voy a quedar mal a mi equipo, no soy como otros escuincles que se van con la novia en vez de ir al partido"... El Gato me dice: "no güero, aunque siga lloviendo hay que seguir chambeando, si no, no hay paga". El Gato tiene una noción muy aguda y quizás un tanto exagerada de las injusticias laborales de las que son víctimas. Siento que en mí encuentra un confidente, aliado o cómplice para expresarlas; probablemente soy una de las pocas personas que lo escucha con atención y se interesa por su situación.

El Gato está supervisando y dirigiendo las acciones, sin casco, con gorra, camiseta amarilla sin mangas y su chamarra de mezclilla. Al rato, antes de que acabara a jornada laboral, veo salir de la obra al Gato bien vestido y bañado después de bañarse, se va caminando por la calle cargando una petaca. Me extraña que siendo martes se retire así a media jornada; "al fin que es patrón", me comenta en voz baja alguien que también lo ve irse. 
La plática con El Gato gira en torno a los arquitectos, la gran responsabilidad que tienen, el estrés y lo difícil que ha de ser aguantar tanta presión. Según El Gato, de todos los actores involucrados en la construcción, ellos son quienes más dinero ganan, se hinchan de billete; pero también la tienen más difícil, se vuelven locos por el estrés, no pueden atender a su familia, se arriesgan económicamente... Los que están más arriba, como el encargado de obra, si algo queda mal, lo tiene que pagar. "Si la cagas, tú la pagas". Por eso, dice El Gato, "es mejor ser un simple trabajador sin tanta responsabilidad". Parafraseando al Gato, los inversionistas y empresarios, como el arquitecto Canela, se meten en muchos líos de dinero, préstamos, deudas, hipotecas, créditos, etc. y si por algo no sale bien el negocio, pueden acabar en la cárcel o muchos hasta terminan en el manicomio.

Parece que El Gato y Javier tienen la autoridad de decidir qué trabajadores continúan en la obra y a cuáles despiden. Me cuentan que tuvieron que despedir al Gordo y a Paul: "tarde o temprano pasó lo que tenía que pasar, tuvieron que rodar sus cabezas, para que no rodara la nuestra". Parte de su labor como oficiales es vigilar que los otros trabajadores cumplan su labor: "imagínate güero, si viene Nicolás en cualquier momento y los ve de holgazanes, va a pensar que nosotros no hacemos bien nuestro trabajo de supervisar; así es la cosa como capataz, cuando identificas un elemento que no funciona, si no lo corres a tiempo, te pueden correr a ti; y como dice el dicho: de que lloren en mi casa a que lloren en la tuya, mejor que lloren en la tuya".

\section{Paul: oficial fierrero}

En la mesa de trabajo de madera están el Pato y otro trabajador joven, fuerte, listo y amable, al que todos le dicen Paul, aunque su nombre verdadero es Fernando. El día anterior Paul manejaba muy hábilmente las varillas, hacía cálculos y sacaba medidas. Hoy está fabricando estribos con un ánimo muy alegre, cantaba y decía chistes para todos. Paul luce una camisa verde, gorra roja y recientemente se dejó el bigote, muy catrín, siempre bien arreglado, evocando acaso la figura mítica de Pedro Infante.

Platico con Paul sobre su casa en Iztapalapa, que levantó él mismo, en un largo proceso de autoconstrucción. Es en realidad la casa de él y de su hermano; la construyeron juntos. Me dice que es muy sencilla pero que sí se han dado algunos 
gustos, como por ejemplo un lavabo con forma de pavorreal que vio en una casa de lujo donde trabajó (que al parecer era de Eugenio Derbéz), y como le gustó tanto lo quiso poner igualito en su casa. También tienen un espejo con luz por dentro que copiaron de otra construcción. Me cuenta Paul que lo más caro al construir una casa tú mismo, es comprar la varilla y después los acabados; la madera no es tanto problema, sí está bastante cara también, pero lo bueno es que luego la consiguen usada de otras obras.

En la obra de Puebla, Paul, sin camisa, bañándose al final de la jornada, me comenta que están avanzando muy rápido con el armado de las primeras trabes. Me dice orgulloso que ahora en esta obra él es el encargado de los fierreros, o sea que entre una y otra obra ascendió de puesto, de ayudante a oficial. Mientras se viste con una camisa amarilla elegante y su gorra roja, me cuenta que está contento porque han avanzado muy bien y se siente muy seguro en su nuevo puesto, está orgulloso de su desempeño.

\section{Édgar, alias El Gordo: oficial fierrero}

Édgar es el yerno de Silvano, grande, fortachón, vive hasta Cuautepec, Estado de México, más allá del Reclusorio Norte. Me dice que hace más de dos horas de trayecto entre su casa y la obra, una hora hasta La Raza y luego toma el metrobús hasta la colonia Roma; "está de volón", agrega; presume que siempre llega muy puntual a la obra en las mañanas. Esto me hace pensar en lo relativa que puede ser la concepción del tiempo de los trayectos y desplazamientos en la ciudad.

El Gordo trabaja con una máquina que parece un gran taladro, rompiendo cachos del piso donde está parado. Le pregunto si está dura la labor con el taladro, me dice que al principio sí está pesada, pero que pronto se acostumbra uno. Sigue trabajando sin camiseta, con su chaleco rojo, enseñando un tatuaje en el brazo derecho. Numerosos collares, escapularios y amuletos le cuelgan del cuello y la muñeca, entre ellos uno de la Santa Muerte. La carne de los brazos y el vientre le tiemblan con la vibración del taladro, que hace un gran ruido al activarse.

Saludo a Édgar, quien me recibe gustoso: "qué milagro, valedor". Inmediatamente me cuenta que está "bien crudo". Desde el viernes agarró "la peda" en la obra, y de ahí ya se quedó "con sed" así que se la siguió todo el sábado chupando latas de Tequi-mix, ayer domingo, "entre pedo y crudo" estuvo todo el 
día viendo las películas de Los Piratas del Caribe en la televisión. El Gordo aprovecha nuestra plática para descansar un rato, luce muy desgastado. Mientras él descansa, se amontonan los ladrillos que el velador le sigue pasando. Me cuenta que no juega fútbol porque de niño se rompió el tobillo y ya nunca quedó bien. Pero aunque no juega, le gusta ver los partidos en la TV y le va al equipo del Cruz Azul. Luego practicó box por varios años y dice que pelea muy bien, me cuenta que un día, hace no mucho tiempo, "le rompí la nariz bien chingón a un cabrón que andaba molestando a mi sobrino, eso le pasa por culero".

Me acerco a platicar con Édgar, que inserta estribos alrededor de una trabe, con su gorra roja, el chaleco de siempre y cola de caballo salida de la gorra. Lo noto callado y apagado. Me cuenta que en su casa, allá en Cuautepec, todo va bien, todo tranquilo. Tiene dos hijas, una ya va en el $3^{\circ}$ año de la escuela y la otra apenas va a entrar a la escuela. Muy joven se inició en la paternidad, a los 17 tuvo su primera hija.

\section{Los oficios más bajos}

Como ya he mencionado, entre los actores que conocí a lo largo de esta investigación etnográfica, mi interés principal eran los trabajadores más bajos en la escala laboral, los albañiles, peones, ayudantes o chalanes. Este último estrato es el más numeroso, donde se ubica la mayor cantidad de los trabajadores de la construcción; estas masas de trabajadores que se dedican a los oficios más bajos conforman la base de la pirámide, el grueso de la fuerza laboral.

De acuerdo con Carmen Bueno, "en la base de la estructura están los aprendices, a los que se les denomina de muy diversas maneras: ayudantes, cabos, chalanes, peones". Forman la mayor parte de la fuerza laboral, son masas de "trabajadores no calificados" que "tienen un estatus marginal" en relación con los demás. Para ser contratados como peones de albañilería en una obra, "no requieren de ningún conocimiento en el oficio", requieren más de su fuerza bruta que de ninguna otra habilidad, buena disposición para aprender (Bueno, 1994: 97). Los albañiles son los trabajadores más subestimados entre los oficios de la construcción. Ellos mismos dicen: "nosotros somos los encargados de lo más negro de la obra. Nuestro trabajo es sucio, lo que luce está a cargo de los demás. Son los que le dan vista a nuestro esfuerzo" (Bueno, 1994: 100). En relación con la posición que ocupan en el nivel más 
bajo de la estructura laboral, afirma Carmen Bueno que "quienes han podido atravesar la barrera del trabajo de la albañilería, que es reconocido como el peor pagado dentro de la construcción, el más riesgoso, el más cansado y el más desprestigiado, harán todo lo posible por no regresar a ese oficio" (Bueno, 1994: 122).

Ángel, alias El Pelón: ayudante o peón de albañilería

Ángel es un chavo joven de unos 18 ó 19 años bastante listo y carismático, a veces se pasa de simpático, rayando en lo payaso. El Pelón es uno de los albañiles con los que más me relacionaría a lo largo de la obra. (Ver más adelante la crónica de cuando fuimos juntos al estadio de CU a ver a los Pumas). Ángel forma parte de una familia formada por varios primos y cuñados más o menos de la misma edad, que residen y trabajan en el Distrito Federal, vecinos incluso de la colonia Roma. Pero Ángel vive por ahora con su esposa y su bebé en un cuarto rentado por el Metro Martín Carrera.

Después de haberse bañado llega Ángel vestido con unas bermudas deportivas y bien peinado hacia atrás. Platicamos sobre varios temas. Primero sobre el enganche de diez mil pesos que tendría que dar para apartar un departamento de interés social, allá por donde vive, que aún no puede juntar. Luego me platica sobre el edificio en el que viven sus suegros y otros amigos y familiares, en la calle Guanajuato; también me cuenta más sobre su chamba alternativa como limpiaparabrisas en la calle Niza, en la Zona Rosa. Me cuenta que ese día, a la hora de comer, se había ido junto con sus cuñados a jugar fútbol a un parque, y me muestra orgulloso un herida en el vientre producto de la intensidad de juego; hablamos sobre fútbol, principalmente de los Pumas.

En la obra de Puebla, apenas abro la puerta y veo al Pelón con una camisa Polo verde, un gorro rojo y sobre él, el casco volteado hacia atrás. Antes de saludarme se mira la mano, ve que está sucia, se la pasa por el pantalón (que está igual o más sucio) y entonces sí me da un apretón de manos: "orita ando ocupado pero luego platicamos con calma, ¿sí o no?"... En la obra de Córdoba, Ángel aprende carpintería, vestido con camisa y el pelo relamido hacia atrás. Corta con un serrucho, clava, mide, usa martillo, cinta métrica, lápiz y varios clavos. Otro día EI Pelón está trabajando como fierrero, así va aprendiendo un poco de todo. 
De pronto aparece El Pelón, después de mucho tiempo de no verlo, con su sudadera roja de batalla, manchada de polvo, cemento y pintura, sin casco, con corte de pelo nuevo y arete en la oreja izquierda. Viene jalando un puñado de varillas de una recámara a otra, hacia donde está la tenaza cortadora. Lo noto un poco más regordete que antes. Se pone en cuclillas y junto con otro trabajador cortan varillas.

Chucho: ayudante o peón de albañilería

Mientras tomo unas fotos siento la presencia de alguien viendo sobre mi hombro la pantallita de la cámara; es otro de los cuñados de Ángel, no Eliseo, tampoco Israel, sino otro que ya había visto antes, casi siempre sonriente, de nariz prominente a la que se le inflan las fosas con cada gesto, con una cara muy expresiva que revela cierta inocencia. Lo saludo y le pregunto su nombre: "me llamo Jesús, pero todos me dicen Chucho", responde muy atento.

Chucho es chalán, pero me cuenta que poco a poco va aprendiendo distintas cosas, carpintero, fierro, yeso y -primero Dios- algún día, echándole ganas, podría ser maestro de obras y ganar más. Chucho es inquieto, sensible y tiene aspiraciones en la vida, quizás más que el resto de sus primos.

Tanto Chucho como su mujer tienen 19 años, ahorita ella está a punto de aliviarse de su segundo hijo, el primero tiene dos años, se llama Diego. Viven en la calle de Guanajuato, entre Jalapa y Orizaba, colonia Roma, en el mismo edificio color amarillo- que la suegra de Ángel y su primo el Tlacuache. Ahí comparten vivienda con sus suegros y otras dos cuñadas. Ese edificio alberga puras viviendas que hace algunos años asignó Andrés Manuel López Obrador, siendo Jefe de Gobierno del Distrito Federal, a gente de bajos recursos; Chucho dice orgulloso: "nos lo dio el Peje, porque sí fue casi como un regalo, el arreglo es que el precio total de cada departamento va a ser de ciento cincuenta mil pesos, que se pueden pagar hasta en treinta años.

Viven ahí unas ciento sesenta y cinco personas en ese edificio. Más adelante me enteraría gracias al Tlacuache que este edificio hace aproximadamente unos cinco años sufrió un incendio a casua de una paloma o un cohete que aventó algún irresponsable. Como las casas eran muy precarias, de lámina y madera, todo se prendió bien rápido. Afortunadamente no hubo pérdida de vidas humanas, todos 
se alcanzaron a salir a la calle, pero se murieron dos canarios de una señora, además de otras mascotas. Se perdieron todas las pertenencias y cosas materiales. Mientras se reconstruía el edificio, mandaron a los vecinos a vivir temporalmente a la colonia Doctores... Esta red familiar extensa de la que forman parte Ángel, Chucho, Israel, Eliseo, el Tlacuache, sus esposas, hijos, y demás primos, cuñados, suegros que viven en este edificio, es muy representativa de las de las nuevas formas de la pobreza urbana, como una versión actualizada de Los hijos de Sánchez de Oscar Lewis (1961).

Entre otras cosas, me platica Chucho sobre la posibilidad de migrar a los Estados Unidos, que ha estado considerando mucho últimamente (ver apartado sobre Movilidad). Después lo dejaría de ver por mucho tiempo, pensé que a lo mejor se había animado a cruzar la frontera, pero no; según me cuentan sus primos, Chucho se resignó a quedarse en México y se volvió evangélico, inducido por su mujer y la familia de su mujer.

Eliseo: ayudante o peón de albañilería

Eliseo es uno de los primos o cuñados del Pelón, siempre me saluda con una sonrisa tímida. Ángel, su cuñado Eliseo y otros primos suyos también le van a Pumas, lo cual crea un vínculo entre nosotros... Sostengo una larga plática con Eliseo, que viste un suéter rojo, mientras aventaba ladrillos uno por uno, nivel por nivel, tres pisos para arriba, a lo largo de una cadena humana. Me cuenta que tiene 23 años y dos hijas, una de seis y otra de tres años. Su mujer y sus niñas viven en Iztacalco, en un cuarto en el que paga mil pesos al mes de renta. Él vive en la Roma, en el edificio de la calle Guanajuato casi esquina con Jalapa que me comentaba El Pelón, donado por López Obrador. Dice que ha trabajado en casi todas las obras que están ahorita en la colonia Roma y también en la Condesa. Tiene la suerte de no tener que trasladarse. Tal vez al terminar de trabajar una temporada se va a ir a Villahermosa, con su primo, donde le ofrecen un mejor trabajo. Me cuenta todo esto hablando sin parar, sacando a relucir un vocabulario y un tono puros de barrio popular.

Tlacuache: peón de albañilería y bolero

Cuando conocí a este personaje me pidió que le sacara un retrato frente a una estructura de varillas. Este chavo eventualmente resultaría ser más familiar, 
conocido como el Tlacuache, otro más de los cuñados o primos del Pelón, que viven en la calle de Guanajuato... Semanas después platico con Chucho, le pregunto por su primo, el Tlacuache, a quien ya no he visto trabajar en la obra, y me dice que "anda por malos pasos, metido en drogas, loqueando, no hace caso, se la pasa afuera del edificio con una banda que siempre anda hasta la madre y regresa bien tarde a su casa".

El Tlacuache ahora trabaja de bolero afuera del banco BBVA, en la esquina de Córdoba y Durango, a media cuadra de la obra de Córdoba, con su bata azul marino espera clientes, bien abrigado con un gorrito que le cubre la cabeza durante esta ola de frío. También le regalo sus fotos. Me agradece mucho; a juzgar por la sonrisa que pone, parece que le gustan bastante.

Entre una y otra obra veo al Tlacuache afuera del banco, en su puesto de bolero. Pero esta vez me sorprende que tiene la pierna rota, "fractura de tibia y peroné", me aclara, porque lo atropelló una moto. Permanece inactivo pero presente en su puesto de bolero, sin poder caminar, cojo. Me dice que ya está mejor de su pie, pero que le dieron un año de reposo, sin embargo ahí está queriendo trabajar. Sigue con el pie malo, todavía no puede ni apoyarlo, se mueve cojeando, dando brincos con el otro pie.

El Tlacuache no está trabajando de bolero porque está en su pueblo, con su padre enfermo, al parecer ya sin remedio, "está cabrón que viva", me cuenta su primo Chucho. Al poco tiempo me cuenta El Pelón que el padre del Tlacuache se acaba de morir de alcoholismo. Él era originalmente el bolero de la esquina, pero desde que ya no pudo ir a trabajar le heredó el puesto al Tlacuache. Una semana después, me da gusto ver al Tlacuache sonriente con su playera y gorra de bolero, que ya puede caminar mejor con ayuda de una muleta.

Jacobo, alias Furcio: peón de albañilería y azulejero

Se llama Jacobo Parra pero todos le dicen Furcio, por su supuesto parecido con un personaje de animación que aparecía en la televisión. Vive por San Antonio Abad. Le calculo unos 25 ó 30 años, pero luce bastante desgastado. Habla lento, se le barre la voz, arrastra las palabras, como si tuviera cierto retraso mental, como si estuviera siempre en estados alterados de conciencia o afectado de por vida por las drogas ylo el alcohol, como si sus neuronas tardaran en conectarse, además de que 
es un poco bizco y a veces parece que sonríe involuntariamente. Pero está bien fuerte y correoso, con las manos callosas, fuertes y los dedos magullados... Es uno de los que son víctimas de más burlas por parte de los demás, es de los personajes mas chuscos, menos respetado, blanco de más bromas en la obra, y eso que sólo lleva como 2 ó 3 semanas trabajando ahí.

Me platica Furcio que no siempre trabaja de peón, a veces también se dedica a pegar azulejos, "porque sí se gana más, en una semana puedo sacar mucho más que mil pesos... una vez pegué en tres días como no sé cuántos metros cuadrados de azulejo y me gané diez mil pesos, con ese dinero hasta me compré un Nissan, un cochecito modelo 87, bien jodido pero que sí funcionaba... La carcacha me costó ocho mil y los otros dos mil los gasté en puras caguamas, que me tomé en unos cuantos días", relata y se ríe como buscando cómplices... Varias semanas después reaparece Furcio, que se había ido a pegar azulejos, pero me aclara que ya no le dicen Furcio, o por lo menos él ya les dijo a los demás que no le gusta ese apodo... Lo veo pasar por la obra distraído, con el casco ladeado, casi cayéndosele de la cabeza, cargando un cubo vacío con una mano y con la otra devorando una gelatina oscura sobre un pedazo de plástico.

Israel: velador y peón de albañilería Aparece Israel, el actual velador, alardeando y bromeando; dice de que se va ir de fiesta, "a cotorrear toda la noche", y no va a regresar sino hasta la mañana siguiente, a la hora de empezar a chambear. Insinúa que le va a pedir dinero prestado al Gato: "al fin que 600 pesos no son nada para ti", le dice. Cuando "el vela" se retira, El Gato me dice que se ve que el pobre chavo se siente como encerrado, ya que prácticamente vive en la obra y no sale de ahí, chambea de día y es el velador de noche... Israel, el actual velador, de pronto se integra a la acción, vistiendo un gorro de lana con orejeras tipo inca. Mientras pone estribos en los castillos de varilla, le pregunto si pudo irse a su casa durante el puente del día de muertos; dice que se quedó solo en la obra los tres días, con frío y muy aburrido.

Jorge: peón de albañilería y maleante Un día, a media obra, conozco a un trabajador nuevo, se llama Jorge, es hermano del maestro Javier. Después de comer me pide que lo siga a un espacio interno de la 
obra, donde habla sin parar durante unos cuarenta minutos, mientras se fuma un toque de marihuana forjado en papel estraza: "es de ley un despanzurre después del taco, ¿sí o no, güero?". Me cuenta historias de violencia, madrizas con judiciales, venganzas y traiciones pasionales, grandes "hazañas" del crimen organizado, asaltos, consumo y tráfico de drogas, etc. Continúa hablando sin parar contándome sus aventuras y anécdotas personales, a veces rayando en lo increíble, cual mitómano desatado, sin importarle que me acababa de conocer solamente unos minutos antes. En su charla habría material muy valioso para escribir una novela policíaca o un estudio sobre nuevas formas de criminalidad, violencia, corrupción y vida marginal en la ciudad. La presencia de Jorge en la obra fue muy fugaz, duró sólo unos cuantos días, máximo una semana. Supongo que habrá regresado a las andadas, tras una breve paso por la labor productiva en la obra.

\section{El hormiga atómica: peón de albañilería}

Es un nuevo trabajador que apareció hacia finales de la obra de Córdoba, y que acaba de migrar a la ciudad desde el estado de Veracruz. Es de muy baja estatura, tez morena y marcados rasgos indígenas. Todos lo apodan "hormiga atómica", tal vez por el contraste entre su baja estatura y su notable resistencia y fuerza física. Sube y baja con cubo cargado de tabiques al hombro, desde el sótano hasta la azotea, una y otra vez, incansablemente. El casco le queda grande, le baila en la cabeza, se lo acomoda hacia atrás para que le saque una foto, portando una camiseta con el conejo de Playboy. Cuando le pregunto cómo está, me contesta amablemente y con acento jarocho: "mientras haya chamba, todo está bien".

Serapio y Daniel: padre e hijo, oficial y ayudante respectivamente Encuentro a un trabajador mayor refinando el aplanado de una ventana. Tiene la cara, la ropa y las manos completamente salpicadas de cemento. Platico extensamente con él, me dice que se llama Serapio y llegó a trabajar a esta obra hace apenas dos semanas. Llegó preguntando por trabajo para él y su hijo a la obra de Puebla, y de ahí lo mandaron a la de Córdoba. Es originario del estado de Puebla; hace 27 años que trabaja en la construcción, sobre todo en los acabados. Ahora trabaja como oficial y gana mil seiscientos pesos a la semana. A los 11 años lo mandaron a la ciudad a trabajar, primero estuvo muchos años en una fábrica y 
luego se pasó a la construcción. Al principio no conocía a nadie ni tenía nada, así que se las tuvo que arreglar solo sin ayuda. Muy pronto se juntó y empezó a tener hijos, ahora tiene nueve. "En ese entonces no tenía yo la conciencia de planear ni la posibilidad de ahorrar", reflexiona.

Cerca de ese mismo espacio conozco a Daniel, hijo mayor de Serapio, que trabaja en coordinación con su padre, con un casco naranja, midiendo maderas $y$ quitándoles los clavos. Tiene 21 años, ya está casado y tiene un hijo, vive en Iztapalapa, en el mismo terreno que su papá, quien le dio chance de construirse un cuarto dentro de su mismo terreno. Además, el señor le enseñó a su hijo a trabajar en la construcción y poco a poco ha aprendido diversos oficios. A diferencia de su padre, quien empezó de cero, Daniel ha contado con el apoyo de su padre para salir adelante.

Constantino: peón de albañilería

Afuera, a media cuadra en la calle, me encuentro a un trabajador de la obra que se llama Constantino, proveniente del estado de Chiapas, acaba de llegar a trabajar a la ciudad hace sólo cuatro meses. Lo acaban de contratar como peón o ayudante. Por el momento se dedica a llevar material de una obra a otra con una carretilla. De edad difícil de calcular, entre los 25 y los 35 años, apenas habla español con un marcado acento de alguna lengua indígena. Por alguna razón lleva siempre trozos de papel en los oídos.

Martín: oficial a prueba

La única vez que vi a Martín, entablamos una agradable conversación, sentados en la última planta con los pies colgando del edificio. De camisa roja, pantalón de mezclilla y gorra azul, con voz tranquila, Martín me cuenta varias cosas sobre su vida y su historia personal. Es originario del estado de Hidalgo, tiene esposa y un hijo. Se vino a la ciudad terminando la secundaria, trabajó como chalán siete años y lleva unos cuatro años como oficial albañil. Llegó a la obra de Puebla buscando trabajo un martes, lo mandaron a hablar con Antonio Bobadilla, quien le hizo unas preguntas y lo remitió con el maestro Javier para que lo probara unos días a ver si de verdad era un buen oficial. 
Personaje anónimo: peón de albañilería

Éste es un trabajador sumamente tímido y reservado, siempre serio, callado y solitario, al grado de que me resultó prácticamente inaccesible, a pesar de que hice varios intentos de abordarlo. Casi siempre viste formal y luce muy limpio, de camisa bien abotonada y una gorra de los Yankies de Nueva York... Un día saludo de lejos al trabajador tímido mientras desayuna aislado sobre la mesa de trabajo de madera. Me responde con un sutil movimiento de la cabeza y un guiño apenas perceptible. Su presencia fue bastante prolongada en la obra, pero tan silenciosa que podría haber pasado inadvertida.

\section{Observaciones sobre distintos oficios}

En esta sección hablo brevemente sobre la labor de otros trabajadores o profesionistas involucrados con la obra, que conocí más superficialmente y no tuvieron un papel tan protagónico en esta investigación, pero que no obstante desempéñan oficios y tienen perspectivas de la construcción que me parecen dignos de mencionarse.

Operadores de maquinaria de excavación

La máquina excavadora la opera un gordito. Su jefe, evidentemente mejor vestido, supervisa cada maniobra desde lejos. Ambos me miran con desconfianza al darse cuenta de que les estoy tomando fotos. El operador de la máquina excavadora y su jefe se mantienen aparte del resto de los trabajadores. Es claro que no se conocen ni les interesa involucrarse con trabajadores de otro ramo, ni mucho menos con los de menor estatus. Esta misma situación se presenta con los trabajadores de la empresa CEMEX que distribuyen el cemento y operan el camión revolvedor de cemento.

\section{Velador}

Algunos de los veladores que pasarían por este puesto en las obras de DAKAB serían jóvenes inexpertos que además trabajan de albañiles durante la obra, y que en la mayoría de los casos durarían muy poco tiempo en el puesto y también en la obra... El velador ni siquiera se va a su casa los fines de semana. Por eso este puesto no lo toma cualquiera, lo suelen tomar los jóvenes desarraigados de sus núcleos familiares 
o señores mayores, gente que por una u otra razón encuentran ventajoso el hecho de vivir y trabajar en el mismo lugar. Hay un ir y venir más marcado en este puesto que en ningún otro; algunos duran dos o tres semanas, otros ni siquiera una.

Algunos dejan el puesto de velador pero continúan trabajando en la obra, como Rufino, pero otros dejan el puesto y desparecen de la obra, como aquel primer velador muy joven con arete en la ceja... En cuanto a si gana bien el velador de una obra, me dice El Gato que no tiene idea de cuánto sea el sobresueldo, pero que seguramente no es mucho, "después de todo es una chamba con la que el trabajador se beneficia, ya que se ahorra pagar renta en otro lugar", dice irónicamente El Gato.

\section{Chofer}

Con los ojos rojos y un gran rosario colgado al cuello, el chófer contó, con un acento y un vocabulario típicos de barrio popular chilango, que en el camino se le había ponchado una llanta y apenas alcanzó a llegar "al pinche talachas". Después de comer y de compartir otras anécdotas con los presentes, el chofer se fue a dormir una siesta al asiento del conductor. Cabe mencionar que a menudo el oficio de chofer en el mundo de la construcción también implica labores de peón, sobre todo palear materiales para cargar o descargar su camión.

\section{Fierreros}

Unos siete $u$ ocho fierreros comandados por Patricio construyen una complicada estructura de varillas. Miden y calculan con hilos, pesas y cintas métricas, y hacen marcas sobre las varillas con un lápiz color rojo. La operación más común es el amarre de las de varillas gruesas con alambres más delgados, con ayuda de una herramienta que es como un bastón corto de fierro con un pico en la punta.

\section{Soldador}

En el hoyo hay solamente un soldador solitario que continúa trabajando mientras los demás ya se preparaban para comer. Le pregunto a un grupo de comensales si el soldador no va a comer; "no, pues quién sabe... a lo mejor está a dieta", bromea el velador. Me explican que más bien ni lo conocen, que llegó aparte junto con su otro compañero, y la mera verdad no se llevan con él, por eso no comen juntos... Le 
pregunto a Pato si hay que soldar toda la estructura y me dice que no, "sólo las varillas del 12, y nada más en las juntas". Me advierte que tenga cuidado de no mirar fijamente a la chispa que desprende el soplete, porque daña la vista, "si te le quedas mirando mucho tiempo te puedes quedar ciego", por eso el soldador lleva puesta una careta. Este soldador parece ser un trabajador más independiente, contratado sólo por obra determinada, ya que al parecer no tiene relación con nadie más que con su ayudante.

\section{Carpinteros}

Estoy un rato con carpinteros que fabrican la plataforma de la base de cimentación, vestidos con trajes como de la Compañía de Luz y Fuerza, equipados con cinturones que detienen el equipo: clavos, martillo, cinta métrica, etc. Dentro de este grupo hay un par de señores mayores a los que se les ve mucha experiencia, que dirigen a otros más jóvenes que siguen sus instrucciones e imitan lo que hacen los maestros... Cortan tablas con serruchos, clavan con sus martillos, miden hábilmente con su cinta, arman pilotes, apuntalan aquí y allá, refuerzan y preparan los muros para recibir el techo. Todos con cinturones de cuero de los que cuelgan bolsos especiales para detener todas sus herramientas y puñados de clavos. Esto es lo que más caracteriza a los carpinteros.

Otro día algunos carpinteros trabajan en el sótano cortando madera, siempre apartados de los demás trabajadores... En lo sucesivo, los carpinteros continuarían armando estructuras de madera por su parte, casi siempre trabajando aislados del resto de los trabajadores. Parece que los carpinteros tienen un sentido de grupo más fuerte o una identidad gremial más marcada que el resto de los oficios de la construcción de vivienda.

\section{Estructuristas}

En relación con el trabajo de ingeniería que sustenta la construcción de un edificio, considerando que se construye en una zona especialmente vulnerable a los sismos, me dice Silvano que es labor de los estructuristas y calculistas saber el peso de los materiales y calcular el peso total de la obra; y de los topógrafos conocer las condiciones del subsuelo. Este tipo de trabajadores más especializados tienen una presencia fugaz en la obra, no se requiere su presencia todos los días, no se 
involucran ni pertenecen propiamente al grupo de trabajadores de la obra. Supongo que serán contratados aparte. Los que me tocó conocer eran jóvenes profesionistas o pasantes de alguna carrera técnica relacionada con la ingeniería.

\section{Calculistas}

Silvano me comenta que al día siguiente un calculista o un equipo de calculistas iría para supervisar todo lo construido hasta el momento. No sabe a qué hora, pero irán para revisar las medidas, para checar que todo vaya bien. Es como una prueba para él y los demás trabajadores. En efecto, un día después Silvano platica con dos hombres bien vestidos; imagino que pueden ser los calculistas que me habían dicho que iban a supervisar los avances.

\section{Topógrafos}

Por ahí andaban también dos topógrafos haciendo mediciones, ambos jóvenes $y$ buena onda. Me cuentan sobre su labor: "es importante checar los niveles para detectar posibles hundimientos que puedan afectar la obra o las casas vecinas, a las que se les puede llegar a levantar el suelo, a veces sólo unos milímetros pero otras veces bastante más". Su labor también tiene que ver con tomar las precauciones necesarias para mitigar movimientos del subsuelo en caso de sismo. El más joven de ellos, con peinado estilo mohicano con abundante gel, se muestra muy amistoso, sonríe mientras se trepa a una barda para medir un nivel.

\section{Yeseros}

A mediados de junio del 2007 aparecen por primera vez en la obra los yeseros. EI maestro Javier observa cuidadosamente y parece que aprueba de cerca el trabajo de los yeseros. "Ganan bien los yeseros, mucho mejor que los albañiles", me comenta Javier... En otro espacio, ya comienza a trabajar el yesero, de bigote, nariz aguileña, gorra hacia atrás, manchado de gotas de yeso en toda su camisa azul y sobre la cara. Me dice que sí ganan bien, pero comenta que "esta chamba a veces parece muy fácil pero sí que tiene mucha ciencia".

En un cuarto hay una junta de los yeseros, al parecer les pagan la raya, a la mayoría no los conozco, no me conocen, excepto uno, al que saludo amable. Un señor de pantalón de vestir y camisa parece ser el jefe, me mira desconfiado y 
comenta: "¿hasta aquí andan con las fotos?" De pronto, van todos al cuarto de enfrente y miden la extensión de una habitación, para calcular los metros cuadrados ya enyesados y determinar el pago exacto a uno de ellos. El jefe de los yeseros, un señor de camisa negra, y su hijo recorren todo el edificio, supervisando los muros ya trabajados por sus empleados.

\section{Carpinteros de acabados}

En el departamento de junto, dos carpinteros entintan y barnizan los marcos y las puertas de entrada de los departamentos. Me informan que ellos mismos están a cargo de las puertas de todos los departamentos. Son chavos jóvenes, amables, les digo que ya nos estaremos viendo por ahí. Hay un fuerte olor a solventes, pero no utilizan tapabocas ni alguna otra protección.

\section{Alumineros}

Se dedican a fabricar y colocar ventanas y barandales en las terrazas y balcones del edificio. En el segundo piso, dentro de uno de los departamentos, encuentro a un grupo de tres alumineros armando los marcos de los ventanales, sobre una mesa de trabajo de madera; entre dos empatan y encajan las esquinas. Estos trabajadores están considerablemente bien vestidos y limpios. Trabajan con taladro agujerando y uniendo partes, y cuando las terminan las van recargando sobre la pared. Les pregunto dónde irán esos marcos y me dicen que en los departamentos de arriba. EI departamento donde se encuentran ya tiene su ventanal listo, pero lo adoptaron como su lugar de trabajo; desde ahí construyen todos los ventanales y luego los van a colocar al departamento que toca. Empezaron con esta chamba hace tres o cuatro semanas y todavía seguirán un par más.

Un grupo de vidrieros está subiendo el material para armar un ventanal hasta el segundo piso. A uno de ellos lo apodan el "Drácula". Los vidrios que suben con cuerdas los 5 ó 6 vidrieros, van para los departamentos de atrás, los de adelante ya están instalados. Con ayuda de cuerdas elevan y jalan las hojas de vidrio ya enmarcadas con aluminio casi desde la rampa de entrada y hasta el segundo piso... El jefe de los alumineros revisa una ventana recién instalada por uno de ellos, que al parecer estaba mal puesta. Lo escucho quejarse: "pinches indios, además de 
huevones, pendejos, hasta que no se les caiga un ventanal encima y los mate, no van a aprender a hacer bien las cosas".

\section{Herreros}

Es importante no confundir a los fierreros con los herreros. Los primeros se dedican a la obra negra y los segundos entran en la parte de los acabados. En la mera entrada hay un herrero con su careta puesta, trepado sobre una escalera, soldando una estructura de fierro a manera de techo sobre la puerta de entrada al edificio. En cada una de las torres habrá unas escaleras circulares de fierro para subir y bajar al sótano-estacionamiento desde el primer piso. Por ahora, en una de las torres sólo se ve un hoyo perfectamente redondo en el piso... También veo que otros herreros están soldando rejas en las ventilas que dan al estacionamiento, a la altura de la banqueta... Ya están también montadas las escaleras redondas que bajan de la primera planta al sótano estacionamiento. Se nota que han tenido mucho trabajo de los herreros en los últimos días.

\section{Limpieza}

A partir de la mitad de la obra más o menos, empezó a aparecer de vez en cuando, una o dos veces por semana, una persona vestida con camiseta y gorra azul, barriendo y limpiando con agua la banqueta y la calle afuera de la obra... Más adelante, platico con una mujer que trapea el piso; comento con ella el hecho de que es una de las únicas mujeres trabajando en la obra; "hay otra señora también de limpieza", me indica... En el patio trasero, junto al árbol, me encuentro con una mujer que barre la basura con escoba y trapeador, deposita la basura en una cubeta. Me dice que lleva como dos semanas trabajando ahí, que su horario es más corto que el de los albañiles... La muchacha de la limpieza, a quien ya he saludado varias veces, me saluda con una sonrisa y aprovecho para retratarla recargada en la pared, con su paliacate blanco en la cabeza, lentes, guantes y el trapeador en la mano.

\section{Aprendizaje sobre la marcha}


En cuanto a la capacitación, Connolly señala que en la obra predomina lo que identifica como "capacitación tradicional", que se refiere a:

La adquisición de los conocimientos íntegros necesarios para la producción de la construcción o parte de ella... tales conocimientos se adquieren casi siempre en la obra: trabajando o "sobre la marcha"... El peón no calificado funge así como aprendiz; al trabajar recibe una capacitación a cargo de su maestro, lo que en cierta forma compensa o justifica su magro salario (Connolly, 1998: 212).

Con respecto a este interesante proceso de enseñanza-aprendizaje, o a la transmisión de conocimientos y saberes prácticos, Bueno señala que "las personas que concurren a este mercado de trabajo no requieren invertir tiempo ni dinero en cursar un programa formal. El adiestramiento se lleva a cabo en la práctica por especialistas en el oficio que ofrecen sus conocimientos en forma personal; por cada chalán-aprendiz hay un oficial-instructor" (Bueno, 1994: 97).

Paul me explica en términos coloquiales su interpretación de la teoría del soporte de las grandes estructuras, como la de un edificio, demostrando tener mucho conocimiento empírico que ha adquirido como autodidacta: "no estudiamos, pero sí aprendemos, y vamos entendiendo con la experiencia cómo hacer que se sostenga un edificio". Me parece que hay mucho que aprender de ellos, que son portadores de una gran sabiduría que algunos, como Paul, ostentan con orgullo.

Veo al Pato que está trabajando con un ayudante joven e inexperto, le pide que calcule y marque la cuarta parte de la medida que hay entre dos filas de varillas. El chalán se queda parado pensando un momento y luego confiesa que no sabe cómo hacerlo. Entonces Pato le enseña pacientemente, mide repetidas veces mientras le explica por qué se hace así y no de otro modo. Deberá aprender este tipo de cosas rápidamente si quiere prosperar en el oficio de la construcción. Saber matemáticas básicas y poder calcular medidas es parte de lo que necesita saber un peón para eventualmente ser oficial.

El Pelón, después de aprender un poco de carpintería como ayudante de Calderón, ahora está trabajando como fierrero con Édgar, y así va aprendiendo un poco de todo. Los albañiles son trabajadores versátiles, prácticos, multifuncionales. El conocimiento técnico de la ingeniería popular se transmite en la práctica, se aprende viendo a los otros hacerlo. Las figuras del ayudante y el oficial, la relación entre ellos de transmisión e intercambio de saberes, es el núcleo básico del proceso 
de enseñanza-aprendizaje en los oficios de la construcción. No hay escuelas ni cursos que preparen para la construcción, es a base de ensayo y error que se aprende.

Édgar, El Gordo, e Israel, el velador, se disponen a cortar un castillo de varillas para corregir un error de planeación en uno de los departamentos. Se ve claramente que por ahora el velador es el aprendiz. El Gordo le enseña cómo cortar las varillas, le dice cómo hacer fuerza en los brazos para que funcionen bien las alicatas, mientras detiene doblado el castillo de varillas para que no quede tan alto. Llega Pato y les ayuda, o más bien les demuestra cómo hacerlo. Así, el Pato se convierte ahora en el maestro y los otros dos en aprendices. Otro trabajador panzón de bigote que andaba por ahí los observa de reojo y pone atención a la lección de Pato, sin dejar de hacer lo suyo.

El Gato trepa por unas varillas hasta llegar a donde un par de trabajadores jóvenes recubren con madera las estructuras de varilla, para que eventualmente sean coladas y formen las paredes del hueco del elevador. El más joven escucha atento y respetuoso las instrucciones que le da El Gato. Siguiendo las indicaciones, aprietan las tablas con otros pedazos de madera, a su vez amarrados con alambres anudados.

Me encuentro a Braulio, el maestro electricista, el mismo que trabaja en la obra de Puebla. Nos saludamos amablemente mientras él recoge sus cosas para irse a comer, y enrolla cables de colores. Le pregunto que cómo aprendió su oficio y me contesta que trabajando desde chico; en su familia había varios electricistas y plomeros, así que viendo y haciendo fue adquiriendo técnica, conocimiento $y$ destreza. Así es la transmisión de conocimiento en este campo laboral. Como dice el dicho, "echando a perder se aprende".

Dice Martín que admira mucho a Silvano, al Pato y al Gato, porque tienen mucha experiencia en la construcción, años y años. Agradece que Javier lo ponga a prueba, lo presiona para que aprenda. "Cuántos tabiques se necesitan para levantar un muro de 2.20 por 3 metros y cuánta mezcla hay que preparar para pegar todos esos tabiques, ése es un de los cálculo que me enseñó a hacer el otro día".

Finalmente cabe señalar, siguiendo nuevamente a Carmen Bueno, que en este proceso de aprendizaje sobre la marcha, en esta peculiar forma de transmisión de conocimientos tácitos y corporales, no solamente se aprenden las técnicas laborales 
y el manejo de herramientas, sino que, como señala acertadamente Bueno, "la obra es el ámbito donde se aprenden las normas de la ocupación y el profesionalismo en el trabajo" (Bueno, 1994: 148).

\section{Oficio, cultura material y trabajo artesanal}

Las nociones de oficio, cultura material y trabajo artesanal resultan muy importantes para comprender el carácter y la perspectiva de los trabajadores de la construcción. De acuerdo con Carmen Bueno (1994) el oficio persiste como un componente básico en el proceso de producción. El oficio se refiere a un tipo de conocimiento práctico que representa para el trabajador un nivel de ingresos, un grado de aprendizaje, un tiempo y costo de formación, pero también se traduce en una marca de jerarquía profesional, estatus o distinción social (cf. Bueno, 1994: 22). En relación con la construcción de vivienda en la Ciudad de México dice Bueno que "el oficio es más que el mero aprendizaje de la manera de hacer las cosas, es saber cómo vender el conocimiento, cómo calcular el riesgo ante la incertidumbre, cómo responder al trabajo sin que exista ningún convenio formal que lo ampare, cómo mantener la improvisación con éxito..." (Bueno, 1994: 149).

Quisiera retomar algunas ideas planteadas en el libro más reciente de Richard Sennett, El artesano (2009), que gira en torno a la noción de artesanía, relacionada con el concepto de trabajo y cultura material. En particular, este ensayo puede echar luz sobre la albañilería y algunos oficios de la construcción tal como se desarrollan en la obra, como un tipo de trabajo manual artesanal. En sentido amplio, la actividad artesanal, según Sennett, se refiere a la habilidad de hacer las cosas bien, al impulso humano, básico, profundo y duradero, de realizar bien una tarea. La artesanía puede entenderse como un conjunto de maneras de utilizar herramientas, de organizar movimientos corporales y reflexionar acerca de los materiales; se refiere al conocimiento tácito y a las habilidades que se acumulan y se transmiten a través de la interacción social, que forman un auténtico saber corporal del que a veces no se tiene realmente conciencia (cf. Sennett, 2009: 17-28).

El mismo Sennett pone como ejemplo de labor artesanal el trabajo de albañilería. El trabajo de albañilería en la obra nos remite no solamente al trabajo físico del obrero, como fuerza laboral, bestia de carga, sino al ingenio artesanal del albañil "como productor que analiza, juzga y valora colectivamente su trabajo y las 
prácticas materiales" (Sennett, 2009: 17). Sennett se centra en la estrecha conexión que existe en el trabajo artesanal entre la mano y la cabeza, en el diálogo que se entabla entre las prácticas concretas y el pensamiento. Como el buen artesano, el albañil "debe aprender de las experiencias de adversidad, precariedad; la resistencia y la ambigüedad pueden ser experiencias instructivas... generan procesos imaginativos que nos capacitan para mejorar la producción de las cosas" (Sennett, 2009: 22).

En sentido filosófico, Sennett se pregunta: “¿qué nos enseña de nosotros mismos el proceso de producir cosas concretas? Los seres humanos, gracias a la cultura material, tenemos la capacidad de hacernos un lugar en el mundo" (Sennett, 2009: 26). En esta obra Sennett mantiene una visión más esperanzada y esperanzadora del trabajo en el ser humano. Construye una concepción humanista del trabajo que reivindica de la labor manual y las formas de trabajo tradicional, la técnica, la habilidad, la destreza manual, el ingenio. Dice que "sólo podemos lograr una vida material más humana si comprendemos mejor la producción de las cosas" (Sennett, 2009: 19-20). Podría decirse que esta investigación coincide con este profundo interés por la cultura material en el mundo de la construcción; en este sentido, constantemente intento describir y representar de diferentes maneras los objetos creados, el proceso de producción, las herramientas utilizadas, los materiales empleados, las técnicas y conocimientos que entran en juego, la experiencia del albañil en su carácter de artesano, su situación laboral, las relaciones y organización del trabajo, etc.

\section{Organización del trabajo e interacciones entre rangos y oficios}

Carmen Bueno señala que la estructura laboral en la industria de la edificación habitacional "requiere de una organización sin fronteras permanentes y con un alto grado de discontinuidad en la demanda de los trabajadores". Dice además que "entre más compleja sea la obra, mayor será la división del trabajo" (Bueno, 1994: 102). Las obras de la empresa DAKAB aquí estudiadas, podrían considerarse de dimensión pequeña o quizás mediana, de una complejidad considerable, con varios niveles y nodos entre los que se establecen diferentes tipos de interacciones y se entretejen diversos significados. En la edificación de vivienda opera una forma de organización laboral muy flexible, en la que "se articulan organizaciones englobadas 
en otras... El resultado es la formación de unidades productivas que se configuran y desvanecen según la demanda del momento... con esto se cancela cualquier posibilidad de una reglamentación laboral que se rija por convenios a largo plazo" (Bueno, 1994: 116, 147).

Volviendo a los planteamientos de Sennett, podemos decir que la organización laboral en la obra no debe entenderse como una estructura piramidal, sino como redes que se pueden desmontar o redefinir su estructura constantemente, en las que "tampoco están rígidamente definidas las tareas". Podría decirse que la obra "opera como una estructura de red flexible más que como una rígida estructura de mando en la cumbre" (Sennett, 2006: 22). Entonces, más que pensar la construcción de vivienda en términos de una estructura vertical rígida, sería más apropiado imaginarla en términos de actores y redes (cf. Latour, 2005), o parafraseando a Carmen Bueno, como "un engranaje de empresas englobadas en otras" o "un archipiélago de organizaciones productivas" 0 de "grupos de trabajo autorregulados" que son "responsables de alguna o varias partes de un proceso fragmentado" (Bueno, 1994: 148).

Es interesante el uso del término "mai", diminutivo derivado de la palabra "maestro". Los de menor rango le dicen "mai" a los de mayor rango, pero no al revés. De abajo para arriba todos son "mais". El término conlleva una cierta connotación de respeto... En una plática con Édgar sale a relucir el respeto que les tiene a "los mais" Silvano y a Nicolás por sus años de experiencia, y también porque le han hecho bastantes paros dándole chamba en varias ocasiones.

Platicando con Édgar, alias El Gordo, de pronto llegó el maestro Javier a arrearlo para que se pusiera a trabajar; lo mandó a hacer algo además de acomodar los ladrillos amontonados. Javier se portó amable y bromista con Édgar pero marcando claramente los límites de lo permitido y manifestando su autoridad... Un trabajador algo mayor y medio torpe tira accidentalmente el cable del teléfono que estaba sobre la mesita de ventas en la calle, y se viene abajo el aparato. Nicolás lo regaña con un tono fuerte y despectivo: "iCuidado con el teléfono, levántalo, ahora conéctalo!". El maestro Javier entra a hacerle el paro al trabajador mayor, conectando él mismo el cable del teléfono, ya que al viejo le hubiera tomado mucho tiempo atinarle... 
Silvano me habla de lo importante que es tener siempre alguien en quien apoyarte, una mano derecha en quien confiar:

Así como tú le 'segundeas' a alguien, alguien te va a estar echando la mano a ti. Por ejemplo, ahora en esta obra en los que me apoyo son Pato y Maximino, y a su vez, en este momento yo soy la mano derecha de Nicolás. A Nico le gusta que todo vaya ordenado, no que uno solo tenga que ir corriendo a todos lados, por eso divide $y$ reparte bien las responsabilidades, todo se hace bien organizado, por eso Nico confía en mí y Bobadilla confía en Nico... Y mira (me indica con el brazo, demostrando que todo está funcionando bien delante de nosotros). Cuando vienen los estructuristas, calculistas y topógrafos a checar que todo vaya bien, a lo mejor nos hacen una que otra observación, pero nada más.

Este testimonio es revelador de cómo funciona la estructura de organización laboral en el ámbito de la construcción de viviendas y edificios de departamentos, la división del trabajo por oficios, un sistema basado en la confianza que se desarrolla entre ayudante y oficial, maestro y segundo, el arquitecto y el encargado de obra, y así sucesivamente.

También resulta interesante destacar la interacción que se crea entre el aprendiz y el maestro, entre el ayudante y el oficial. La tarea fundamental del chalán consiste, por ejemplo, en "acercar al maistro todos los materiales que necesita para hacer su trabajo... acarrea los bultos de cemento, la grava, la arena y el agua, prepara la mezcla, acercar los tabiques... también hace tareas como barrer, limpiar y sacar cascajo. Además de cumplir con su trabajo, los peones, deben ofrecer al oficial servicios personales, como comprarle las tortillas o hacerle los mandados. Poco a poco, "el chalán puede atreverse a experimentar con la cuchara y pegar unos cuantos tabiques... El "maistro" suele alardear de haberle enseñado el oficio (Liguori-González, 1992: 42). Esta es una relación particularmente interesante porque a través de ella se transmite y reproduce el conocimiento práctico del oficio de la construcción.

\section{Acciones y técnicas}

En este apartado primero revisaremos algunos planteamientos teóricos en torno a la noción de acción desde la perspectiva de la teoría del actor-red (TAR), para 
después analizar las acciones y las técnicas que realizaban los trabajadores de la construcción en las obras estudiadas. Cortar, medir, amarrar, clavar, transportar, excavar, son algunas de las actividades más comunes que desarrollaban los personajes que animaron la obra. Con fines expositivos, planteo una distinción entre acciones individuales y acciones colectivas, que a su vez pueden ser simultáneas, sincronizadas o coordinadas.

\section{¿Qué cuenta como una acción?}

Los actores no podrían ser considerados como tales si no llevaran a cabo ciertas acciones, si no tuvieran la capacidad de generar un cambio en su entorno, y en nuestro caso, si no tuvieran la habilidad de transformar el espacio y hacerlo habitable. Es a través de la acción que los actores interactúan y se forman los vínculos sociales. Las acciones definen a los sujetos, condicionan sus formas de experiencia, les confieren una identidad, determinan los lazos que establecen con otros actores, humanos o no humanos. En el campo de la construcción la acción puede entenderse como la praxis o puesta en práctica de un oficio determinado.

La acción es un componente fundamental en la TAR, por lo tanto resulta pertinente retomar otra vez las ideas de Bruno Latour (2005) para reflexionar sobre lo que se considera como acción desde la perspectiva de la antropología de las asociaciones. Este autor llama la atención sobre "la naturaleza heterogénea de la acción", que nunca es simple, pura o directa. La acción casi siempre es intervenida o tomada por asalto por diversos actores o agencias mediadoras que se entrometen en el camino para transformarla, alterarla o modificarla. Así, Latour se pregunta: cuando actuamos, ¿quién más está actuando?; “¿Cuántos agentes más están presentes? ¿Por qué estamos sujetos a fuerzas que no son de nuestra propia factura?" (Latour, 2005: 42).

"La acción nunca es transparente, es más bien una especie de nudo o un conglomerado de varias agencias que deben ser desenredadas lentamente"; es necesario ampliar nuestra comprensión sobre el tipo de agencias involucradas en una cadena de acciones, "para dar cuenta de la complejidad, la diversidad y la heterogeneidad de la acción" (Latour, 2005: 44). La acción no es un asunto coherente, controlado, redondeado y con los bordes bien recortados. 
Inevitablemente la acción es intervenida, redistribuida, influenciada y traducida por múltiples agencias. Nunca sabemos con seguridad quién o qué es lo que nos lleva a actuar (cf. Latour, 2005: 46). Por eso, en vez de referirnos a una acción -en singular- de algún actor en particular, por lo general es más apropiado hablar de líneas o cadenas de acciones.

En la siguiente descripción de las acciones y técnicas que observé durante el trabajo de campo se entremezcla otro tipo de información relativa a diversos aspectos del mundo de la construcción. Aparecen por ejemplo referencias a la vestimenta, a los pasos del proceso constructivo, a las condiciones laborales, a los diferentes oficios, a la personalidad de los trabajadores, etc. También cabe mencionar que hubo algunas jornadas laborales que me parecieron particularmente intensas y agotadoras, con muchos trabajadores haciendo varias acciones al mismo tiempo. Otras sin embargo, eran mucho más relajadas, dependiendo de la etapa de la obra, además de otras circunstancias. Una vez más, mi propia experiencia y percepción de la obra y los trabajadores es la base ineludible sobre la que se construye este relato.

\section{Acciones individuales}

Fierro / Acero

Junto a la mesa de trabajo de madera, un peón bastante joven serrucha una gruesa varilla con una segueta. El método me parece muy ingenioso: la varilla se detiene enmedio de un par de clavos clavados en la mesa de madera, doblados a la medida y con la separación precisa para sostener firmemente la varilla. Además se necesita mucha fuerza y persistencia para completar esta labor, cortar una varilla de este calibre le lleva unos 15 o 20 minutos de esfuerzo constante a este peón, que desempeña su tarea sin descanzar más que entre una varilla y la que le sigue.

Hay un camión cargado de varillas afuera del terreno. Patricio, trepado sobre la carga, corta con segueta y pinzas los amarres que mantienen el material sujeto a la parte trasera del camión, para proceder a descargarlo... Más tarde, en el fondo del terreno, Pato golpea y retuerce manojos de alambre sobre la mesa de trabajo de madera.

La técnica de hacer estribos consiste en atorar la varilla en un agarrador que está fijo en la mesa, luego se inserta la varilla dentro de un tubo y se dobla con fuerza el 
tubo, doblándose así también la varilla. Esto se hace mecánicamente una vez que se ha estudiado bien la medida y el punto de flexión de las varillas, porque cada trabe es de una medida diferente y lleva estribos de distintos tamaños, según me explican. Bromeamos acerca de la gran cantidad de estribos que han hecho y los que les falta todavía por hacer, icientos o miles! "Pero esto no es nada", me dice Paul, "esta obra está leve, imagínate cuando se levanta un edificio de una cuadra entera".

Tres o cuatro trabajadores doblan las varillas más gruesas con una herramienta que consta de un tubo de fierro grande con un hoyo en la punta, como preparación para empezar a armar una gran trabe que será parte de los cimientos. Cuidadosamente miden la varilla con cinta métrica y marcan el punto de flexión con un lápiz bicolor, que antes mojan con la lengua para que la saliva lo humedezca y pinte mejor sobre la varilla. Insertan la punta de la varilla en el tubo, y entre dos o tres hacen palanca con fuerza sobre el tubo y así se doblan las varillas más gruesas.

Al frente del terreno hay dos grupos de trabajadores jóvenes, unos están cortando varillas gruesas, segueteándolas a mano. Entre dos, se tardan de 5 a 10 minutos en cortar cada una; es una labor cansada, coinciden ambos. El otro par de trabajadores corta las varillas más delgadas, de menor calibre, con una pinza enorme apoyada sobre el piso; uno de ellos marca la medida de la varilla usando como referencia un trozo ya cortado, acomoda la varilla en la pinza, y el otro simplemente apoya todo su peso sobre la palanca.

En el patio de atrás sigue la interminable labor de hacer estribos. El señor fumador con el cigarro siempre en la boca está constantemente en ello sobre una mesa de trabajo de madera. Se incorpora un muchacho joven regordete y entre los dos desempeñan la labor de doblar varillas para hacer estribos. Ángel, junto con otros fierreros, anudan unos estribos a los que llaman "cocoles", por su forma de rombo, usados para amarrar las columnas más fundamentales, como las de las esquinas del terreno. Un trabajador inserta anillos cuadrados en los castillos de varillas que ya sobrepasan la altura de la barda.

Sobre la mesa de trabajo de madera, portando unos guantes que lucen como nuevos, Ángel corta varillas medio gruesas, no de las más gruesas pero las que siguen. La técnica consiste en cortar cada una sólo hasta la mitad, y después colocando un palo de madera debajo del corte, se hace palanca entre dos personas 
para terminar de quebrar la varilla; pero esto no basta para separarla en dos partes, luego hay que dejarla caer con fuerza sobre el piso para que se separe completamente. Las puntas de la varilla quedan calientes por la fricción de la segueta, una mitad queda lisa y la otra rugosa. Le tomaba a Ángel como 15 ó 20 minutos cortar cada una; en la hora o más que estuve por ahí cortó unas cuatro. Pato pasa por ahí y le pregunta a Ángel si su arco necesita una segueta nueva, porque se gasta muy rápido con el uso intensivo: "dura sólo para cortar unas 3 ó 4 varillas y luego luego hay que cambiarla ", me aclara Ángel.

Después me acerqué a platicar con Furcio, quien segueteaba con sus manos callosas un puñado de alambres delgados con los que amarran y hacen nudos a las estructuras de varilla. Llevaba un buen rato dándole a la segueta sin que se viera mucho avance.

\section{Madera}

Uno de los carpinteros corta tablas con una sierra eléctrica, otro clava clavos en los cajones con un martillo, y el tercero corta tablones con un serrucho. Todos usan cuidadosamente una regla y lápiz bicolor para medir y marcar líneas como guía antes de proceder a cortar. Con tremenda habilidad clavan clavos en diagonal para mantener juntas dos piezas. Dan primero dos golpecitos sosteniendo el clavo con la otra mano, luego la quitan para dar otros dos o tres golpes fuertes y clavar bien el clavo hasta adentro sin detenerlo. Un carpintero malencarado hacía arreglos para poder cerrar la puerta de madera. Por otro lado, unos ceban los tablones, untándolos con grasa, para que no se les pegue el concreto.

Varios equipos de dos o tres trabajadores fijan los tablones de madera a las trabes de varilla usando alambrón y pinzas; primero le hacen hoyos a las tablas con una herramienta que tiene un pico que gira. Luego le clavan polines para que enmarquen la pieza de madera, que queda entonces rodeando o revistiendo el acero, para que contenga firmemente la mezcla que ahí se verterá, dándole forma a los cimientos... Ángel aprende carpintería, vestido con camisa y el pelo relamido hacia atrás. Fabrica las piezas de la cimbra, clavando barrotes para formar los marcos de las tablas. Corta con un serrucho, clava con martillo y varios clavos. Trabaja con cinta métrica, lápiz en la oreja y una escuadra. 
Los carpinteros fijan la cimbra que cubre una estructura de varilla, en preparación para recibir el colado, haciendo nudos y amarres en la madera con alambrón. Forran de madera las estructuras de varilla hechas por los fierreros, clavando y amarrando tablas y pilotes. La madera contiene y da forma a la mezcla que se vierte entre $y$ alrededor de las varillas, para que cuando se seque quede una estructura rígida de acero rodeada por una masa firme de cemento.

Un maestro carpintero con casco azul metálico orquesta a los otros tres que están a su alrededor. Uno embarra la madera con una especie de brea sobre la que se derramará la mezcla, para que no se quede pegada y se pueda separar bien del cemento una vez seco y firme. Otro carpintero que nunca había visto antes, trabaja suspendido sobre una viga que sobresale del primer piso hacia la banqueta. Clava piezas de madera para apuntalar la cimbra. Con la boca detiene un clavo y atora su lápiz bicolor detrás de la oreja, con ayuda de su gorra volteada.

\section{Cemento}

En lo alto de la tarima está El Gordo simpático, quien opera una manguera que vibra impulsada por un motor, la introduce en la mezcla recién vertida en la ranura que queda entre la madera y la barda existente. Me explica que la función de la manguera es que no quede floja la mezcla, para que se asiente bien hasta abajo $y$ no queden huecos ni grumos; es una sacudida para que baje bien la mezcla. Todo esto me lo dice a gritos porque el motor hace un ruido considerable. Pato con una cinta métrica mide la altura precisa a la que debe quedar la barda que están colando. Silvano sube también ahí arriba, supervisa y quita la mezcla que se le embarra a las varillas. Pato endereza bien las varillas de los castillos de una vez, porque después, cuando se seca la mezcla, ya resulta imposible.

\section{Acarreo / Transporte}

La piedra y el cascajo que van quedando tras la excavación son acarreados por dos trabajadores con cubetas que cargan al hombro, que suben por la escalera $y$ descargan para regresar después a cargar de nuevo la cubeta. Dos o tres cubetas van y vienen constantemente. Algunas piedras grandes las cargan al hombro sin cubeta. 
El chofer del camión azul, con el pelo relamido con abundante gel y patillas puntiagudas, palea los últimos escombros que quedaban en el sótano de la obra; anteriormente, otros trabajadores se los depositaron en la puerta del terreno, para que él los aviente a la parte de atrás de su camión de carga y se encargue de desaparecerlos de la obra. El chofer está sudando a cántaros pero sin siquiera despeinarse, las gotas que devienen chorros de sudor le hacen lo que el viento a Juárez a su look moderno.

Un trabajador vacía su cubeta de escombro en el cerro de basura que se ha creado hasta abajo en el cubo del elevador... Otros trabajadores suben costales de cemento al hombro por las escaleras que ya tienen piso... Unos cuantos trabajadores suben y bajan cargando cubos llenos de madera... Constantino está llevando de una obra a otra un rollo de malla de alambre en una carretilla. Dos trabajadores llevan pesadas rocas al hombro hasta donde están depositados los escombros en la entrada de la obra.

\section{Tabique}

A partir de cierta etapa de la obra, los trabajadores empiezan a levantar los muros de tabique que dividen los departamentos y crean espacios interiores. Pegan los tabiques con la mezcla que toman de una charola de madera improvisada, utilizando la herramienta que Ilaman cuchara... Pato y El Gato están midiendo, haciendo marcas y trazando líneas en el piso. Ahora que está recién colado hay que trazar primero marcas con lápiz, luego con el "tiralíneas" para luego levantar los muros. Van leyendo los planos, midiendo distancias con la cinta, haciendo cálculos y sumas, escribiendo sobre el piso. Revisan cuidadosamente los planos y las medidas que les quedan entre línea y línea.

Gran parte de la actividad laboral está concentrada en levantar muros de tabique. Pegan un ladrillo con otro con la mezcla de cemento que tienen preparada en su charola, utilizando la cuchara. Trabajan en ello un chavo siempre serio y con la camisa azul bien fajada, ordenado y sistemático y otro chavo que nunca había visto antes, con guantes, cinturón y un sombrero amplio. Otros dos ayudantes preparan y revuelven más mezcla en el piso, para depositarla en las charolas según la requieran... Otras veces se requiere romper el tabique y demoler paredes que habían sido levantadas. Eliseo está rompiendo una pared de concreto para abrir 
una ventana en un baño, golpea el concreto con un mazo pequeño, y a ratos cambia de herramientas para realizar esta labor. "Está bien duro, llevo desde ayer aquí dándole con el cincel y martillo", se queja.

Yeso / aplanado / acabados

Un par de yeseros trabajan con una sofisticada técnica para poner el yeso en sus grandes paletas. Uno de ellos, con la cara toda salpicada, pone más polvo en un recipiente, vaciándolo desde un saco de papel cartón y mezclándolo con agua. Usa una paleta para aplanar el techo y una diferente para otro tipo de superficies. Otro yesero está en la primera etapa del aplanado de otra pared, avienta el yeso más en bruto, toscamente, tiene una tina más grande con mucha mezcla lista. Utiliza una paleta más grande y avanza más rápido. No pulen nada con ninguna máquina, todo lo hacen a mano con sus paletas, también el techo, por incómodo que resulte. Se trepan en una tarima improvisada para alcanzar estas alturas... Un yesero detalla los huecos de los apagadores con mucho cuidado... Otro trabajador aislado, hace un resane fino con yeso, parado sobre un andamio que cuelga por afuera del cubo de la escalera.

\section{Colocación de pisos}

Unos trabajadores colocan y cortan a la medida las piezas cuadradas de piso que van sacando directamente de las cajas de Interceramic. Miden, hacen marcas, cortan, colocan y pegan... En un departamento están colocando pisos de azulejo, al verme entrar me previenen de no pisar las piezas todavía frescas. Me explica un azulejero que primero nivelan el piso con cemento para que quede todo parejo a la misma altura, luego pegan las piezas con ese pegamento especial llamado pegazulejos... En otro departamento hay un trabajador a punto de comenzar a colocar el piso, empezando por la terraza. En el piso está el cortador de losetas, su maletín y una botella de refresco vacía. Alrededor hay un tiradero de trozos rotos. Trabaja con una cuchara extendiendo el cemento para luego colocar y pegar las losetas. El trabajador se levanta, entra al departamento desde la terraza, caminando con cuidado para no dañar las losetas recién pegadas y empieza a limar los lados de una nueva pieza... Otro par de trabajadores desconocidos para mí colocan el piso de las escaleras de la entrada, son losetas de cerámica blanca. Un 
chavo bastante joven y flaco corta las piezas mientras otro las coloca cuidadosamente sobre el pegamento previamente esparcido sobre el piso, y con un buen apretón las pega.

\section{Instalaciones}

Varios hombres están haciendo ranuras en las paredes de tabique con cincel $y$ martillo para poder colocar la instalación eléctrica... Adentro de un baño me encuentro a un plomero ensamblando y soldando la tubería de cobre con un soplete alimentado por un tanque de gas. Además también está encargado de pegar los tubos blancos de PVC. Un plomero me muestra cómo se hace la soldadura... Otro más llega para soldar una tubería de cobre... Más adelante, un trabajador pinta de amarillo los tubos de cobre del gas en el cuarto de servicio de cada departamento... Un trabajador está metiendo tubos de plástico para la instalación eléctrica por el entramado de varilla y madera, antes de que se cuele el piso firme. Otro señor pega tubos de PVC para el drenaje, mientras que uno más inserta tubería de cobre entre el piso.

\section{Limpieza general}

Junto a la toma de agua me encuentro a Chucho y a otro albañil llenando cubos de agua para limpiar el excusado que usan los trabajadores. "Está lleno de cagada y huele a madres", se queja uno. "Pues tápate las narices y también para eso traes los guantes", le contesta Chucho en tono regañón... Una trabajadora de limpieza de pelo corto y gorra hacia atrás está barriendo y recogiendo basura y escombros. Después lava una jerga en el lavadero del cuarto de servicio, junto a la cocina de un departamento... Una chica de limpieza bastante joven quita gotas de cemento y manchas del piso con una espátula agachada en cuclillas. Varias mujeres prosiguen la labor de limpieza, limpian ventanas, barren y trapean los pisos.

\section{Otras acciones individuales}

Por todos lados hay acciones sucediendo: el Hormiga atómica sube ladrillos desde abajo con la cubeta al hombro, al llegar arriba los acomoda ordenadamente en una torre. Un trabajador levanta un muro de tabique, mientras otros preparan mezcla. El señor con el cigarro en la boca, como siempre, fabrica piezas de fierro en la mesa 
de trabajo junto con otro colega... Un trabajador que se ve bastante joven, callado y tímido, vestido al estilo moderno, llena un cubo de agua con una manguera junto a un tambo... Un trabajador con una camiseta enredada en la cabeza cubriéndole la cara está en el roof garden cortando y puliendo aquel material blanco tipo tablarroca sobre dos mesas de trabajo de madera, con una máquina que tiene un disco de lija que gira... Silvano anda muy ocupado, metido en todo, dando instrucciones por aquí y por allá. Paul, muy simpático, canta y dice chistes para todos. Un carpintero ya mayor es blanco de la burla general. Otro carpintero malencarado hace arreglos para poder cerrar la puerta de madera. Alguien corta bloques de unicel con un serrucho.

\section{Acciones colectivas}

Aquí me referiré a las acciones coordinadas o simultáneas, como las cadenas humanas, que requieren de la acción colectiva y provocan la interacción entre los trabajadores. Es interesante notar cierta contradicción entre la supervivencia de algunas de estas acciones colectivas, como por ejemplo el transporte de material a través de cadenas humanas, y el empleo de máquinas, herramientas sofisticadas y nueva tecnología constructiva, como una grúa capaz de mover de una sola vez un cerro de materiales de un lugar a otro en la obra. Como vimos anteriormente, esto tiene que ver con la sobreoferta de mano de obra y la persistencia de ciertos oficios y prácticas dentro del mundo de la construcción.

Agua, tierra y lodo

En una esquina un grupo de 3 ó 4 obreros mezclan grava con cemento y agua, usando sus palas para revolver la mezcla. Se organiza una acción en la que casi todos los obreros están involucrados, formando una cadena de varios eslabones para llevar botes de mezcla desde el rincón junto a la puerta de entrada, donde la preparan, hasta el otro extremo del hoyo, bajando por una escalera de madera, donde finalmente la vierten.

Unos cinco trabajadores remueven lodo y agua con palas dentro del gran hoyo, haciendo lo mismo que los dos días anteriores. Me da la impresión, tal vez ingenua, de que el esfuerzo que hacen los trabajadores para sacar el agua no rinde ningún 
fruto. Tratan de mover lodo de un lado para otro, sin que nada suceda aparentemente. Parece una tarea interminable, cual mito de Sísifo. Se ayudan con el pie, apoyando fuerte la bota de hule sobre la pala, para clavarla más y sacar más lodo, pero en el trayecto una buena parte del lodo vuelve a caer a su lugar de origen.

Tres jóvenes se dedican a sacar lodo del hoyo con cubetas y palas: uno palea y Ilena cubetas que los otros dos acarrean, van y vienen a través de una rampita escalonada que fue improvisada especialmente para esta labor, para ir a tirar el lodo a un cerro donde ya se ha acumulado. Un camión azul de carga llega al terreno y se estaciona de reversa. El chofer, su ayudante y un trabajador de la obra avientan el lodo que está en la entrada del terreno a la parte de atrás del camión.

El mismo camión azul de carga está estacionado en la puerta. Su chofer de siempre, relamido con gel, sudando a chorros, con la cara empapada, palea lodo y escombro hacia la parte de atrás del camión, aventándolo hacia arriba con gran fuerza por el costado. Los demás excavadores, distribuidos formando una cadena humana, van añadiéndole tierra al montón que el chofer lucha por disminuir con gran ímpetu y asombrosa resistencia física.

Con el lodo y escombro que excava la máquina se llena la parte de atrás de varios camiones, sobrepasando un poco su máxima capacidad, pero cada chofer se encarga de cubrir su carga con una lona, para evitar que se vaya cayendo y sobre todo para no tener problemas con las autoridades de tránsito durante el traslado hasta el vertedero de escombro.

En la parte de atrás de la obra de Puebla hay todo un pelotón de hombres trabajando simultáneamente, numerosos peones para mí desconocidos que forman una flotilla. Están paleando decididamente el lodo, casi todos usan casco. Excavan con palas el piso de tierra, lanzando el lodo que sacan hacia los montones donde se concentra para luego evacuarlo. La obra está en pleno bullicio y movimiento, se emplea una gran cantidad de esfuerzo colectivo para lograr un mismo objetivo, unos arriba, otros en medio y otros más abajo, todos sacando lodo. Vistos desde la altura del segundo piso, esta actividad genera una dinámica que me recuerda al movimiento de las hormigas alrededor de su hormiguero.

Colado colectivo 
El proceso de colado es necesariamente una acción colectiva, requiere siempre de más de una persona atendiendo alguna de sus fases. Esta vez hay una máquina intermedia entre la olla y la tubería, para filtrar e impulsar la mezcla. La tubería, elevada del piso sobre unos trozos de madera, conduce la mezcla a través de la rampa hasta la primera planta, en donde hay varios hombres metidos hasta las botas en la mezcla, comenzando a aplanarla y nivelarla con vigas de madera. Personal de CEMEX maneja tanto la máquina como la tubería, sus "codos" y extensiones. Varios hombres estaban aplanando el piso recién colado y removiendo el exceso de mezcla que le habían echado, poniéndola en cubetas y llevándola a formar parte del cerro de lodo en la entrada. Otros acarreaban las cubetas por la rampa, cargándolas al hombro. Después pasan al pulido de la mezcla. Continúa el vaivén de los cubos. La olla termina de descargar y se va. La máquina intermedia que surte la mezcla se queda estacionada ahí para ser lavada a manguerazos.

Un célula de albañiles con botas de hule trabajan en conjunto en el colado. Uno de ellos, con paliacate en la cabeza, se dedica a remover mezcla en el piso con una pala y verterla en las cubetas que le van llevando los otros trabajadores, que se la llevan hacia alguna otra parte de la obra. Cuando se termina la mezcla hay que preparar más, así que abren y vacían los sacos de papel que contienen el cemento en polvo, y lo mezclan con agua. Tras esta acción se levanta una gran nube de polvo blanco a su alrededor.

Raúl y Paul están colando un muro lateral, la barda del lado izquierdo del terreno, echando mezcla sobre y alrededor de las varillas, entre los tablones de madera, contra el muro que ya existe. Su labor consiste en vaciar cubetadas de mezcla a los lados de la pared. La mezcla es removida dentro de una "tina" improvisada al frente del terreno por dos trabajadores que están literalmente metidos en ella, portando botas de hule y sirviéndola con palas en las cubetas, que van y vienen cargadas al hombro por otros cuantos obreros, que a su vez se las llevan a Raúl y Paul.

A la entrada está ya vertida la mezcla para el colado de la barda del fondo del hoyo. Me dicen que la olla, el camión revolvedora, llegó desde bien temprano, a las 7 a.m. en punto. Dos trabajadores palean y remueven la mezcla; están metidos hasta los pies, con sus botas de hule, dentro de una especie de alberca delimitada con tablas de madera, donde fue depositada la mezcla. Desde ahí comienza un 
constante vaivén de cubetas de mezcla hasta el fondo del terreno, transportadas al hombro por unos cuantos obreros. Los dos que están dentro de la alberca les Ilenan las cubetas de mezcla con una pala, ellos las impulsan desde el piso hasta su hombro, bajan la rampa, atraviesan el hoyo hasta llegar a unas rampitas por donde suben y entregan las cubetas a otros trabajadores que las reciben parados sobre un andamio. A su vez, ellos vacían la cubetada de mezcla en la ranura donde se formará el muro de cemento y devuelven la cubeta vacía aventándola hacia abajo, para que el proceso vuelva a comenzar de nuevo, una y otra vez.

Al fondo del terreno, varios trabajadores están en pleno colado, unos manejando el motor y la manguera vibradora, otros dirigiendo el vaciado de la mezcla en los surcos, directo desde las carretillas... A través de un pasillo y varias rampas improvisadas con tablones de madera, carretillas con mezcla van y vienen, desde la tina improvisada al frente del terreno hasta el fondo de la pared derecha, donde finalmente la vierten. Pato, Édgar y Paul dirigen la gran manguera metálica que escupe mezcla hacia los huecos de la pared, rellenando el espacio libre entre varillas, madera y unicel, formando trabes, columnas y muros al lado derecho del terreno.

Tres trabajadores se aplican en el colado de la rampa para bajar al estacionamiento, le trazan rayas transversales para que funcionen como dispositivo antiderrapante. Hacen pequeños surcos en la mezcla todavía fresca, usando un palo que sujetan contra el piso y vierten la mezcla desde una cubeta, luego otro define más finamente las líneas con un instrumento especial para ello. Se ocupan de esta labor el nuevo maestro, Maximino, el albañil tímido y reservado, y otro peón más que no había visto jamás... Días después, otros tres trabajadores diferentes retoman el trabajo de marcar las rayitas de la rampa. Pato, Paul y el Vela los observan desde arriba y se burlan de ellos cuando parece que cometieron un error y se fueron chuecos al hacer los surcos.

Me saluda sonriente un albañil con la cara llena de gotas de cemento seco salpicado. Hoy colaron la última planta del edificio desde temprano... La olla con la mezcla para el colado está estacionada afuera de la obra. Junto a este camión hay cuatro trabajadores, cuyo trabajo al parecer viene incluido en el precio del servicio. Uno es el chofer y los otros ayudantes, todos están vestidos casi igual, de azul marino con casco blanco, y portan una faja de cuero alrededor de la cintura para 
cargar cosas pesadas. Hábilmente controlan la gran manguera que vierte mezcla, sus tubos y conexiones, que llaman "juntas"; dominan la tubería como si montaran una serpiente gigante. Cargan y botan, conectan y desconectan, ensamblan y reensamblan las piezas que forman la gigante anaconda metálica que escupe cemento dentro de la obra... Afuera están todavía los dos encargados de la olla, desconectando y lavando una tubería que subía hasta la última planta.

Mientras tanto, los trabajadores de la obra esparcen la mezcla con palas en el piso previamente cuadriculado con varillas. Israel, el velador, anda por ahí con la manguera vibradora, que introduce en la mezcla recién vertida. El ruido del motor del vibrador hace que las voces casi no se oigan y haya que gritar. Los trabajadores con botas están metidos en plena mezcla. Me dicen que hoy mismo harán el pulido: primero reciben la mezcla y la esparcen con palas, esperan que se asiente con el vibrador, la aplanan un poco más con un palo y finalmente hacen el pulido más fino.

Afuera hay una olla (siempre de CEMEX) que a través de una gran boa de hule segmentada y con anillos en las uniones, escupe mezcla hacia las ranuras formadas entre la madera y la varilla. Los empleados de CEMEX manejan la manguera, le quitan y ponen anillos, la dirigen, controlan el chorro. A veces modulan la salida de la mezcla con la mano enguantada, variando la presión, igual que se le hace a una manguera con el dedo. Andrés, con su casco metálico, con estampitas pegadas, remueve la mezcla una vez vertida. Terminan el colado y amontonan las tuberías en la banqueta.

\section{Diversas acciones colectivas}

Es un día de trabajo intenso, hay más trabajadores y muchas actividades diferentes sucediendo al mismo tiempo. Entre tres trabajadores transportan una larga y gruesa varilla a través del terreno, una tarea aparentemente simple pero que resulta sumamente complicada, sobre todo porque la realizan con mucha descoordinación, atravesándose inevitablemente en las labores de los otros, que a su paso hacen una pausa, se tienen que agachar tantito o de plano mejor se quitan.

El chofer del camión cargado de polines y tablones, junto con su ayudante fornido, se dieron a la tarea de descargar la madera. El chofer le pasaba al fortachón los polines, de 3 en 3 ó incluso de 4 en 4 , y él se los colocaba en el 
hombro sobre una protección de hule que se puso antes de empezar a cargar. Este tipo de transporte de materiales incluye el servicio de carga y descarga. Silvano les indicó amablemente que pusieran la carga amontonada afuera, sobre la banqueta.

En cuanto a la acción de meter varillas al terreno y acomodarlas, primero las meten inclinándolas hacia un lado y luego las empujan hasta la esquina, maniobrando difícilmente sobre todo con las más largas y gruesas, jugando con su mínima capacidad de flexión. Están en ello Paul, Pato, Maximino y Ángel. Antes de empezar la acción discuten brevemente cómo meterlas, consultan con Silvano, quien vigila la escena desde el segundo piso y por lo tanto tiene una mejor perspectiva del asunto, con su sombrero blanco que lo cubre del sol.

Arriba, varios trabajadores preparan una mezcla de materiales en un círculo en el piso. Un señor mayor revuelve el cemento con la pala, mientras Israel, vierte agua con una manguera. Se integra otro trabajador nuevo con otra pala y Silvano llega a supervisarlos un rato, se recarga en la pared y los observa. Llegan unos a descargar material en el círculo, hasta que se va haciendo una mezcla integrada.

Pato, asomado al jardín trasero desde el segundo piso, espera a que Silvano y EI Gato, que están un piso más arriba, lancen un hilo con una pesa. Pato revisa la colocación exacta con un nivel y hace marcas en el hilo con un lápiz bicolor. Cuando termina de medir, avisa con un grito y los de arriba sueltan el otro extremo del hilo, que Pato recoge y enreda.

Un grupo de vidrieros está subiendo el material necesario para armar un ventanal en el tercer piso. Entre 5 ó 6 de ellos suben las hojas de vidrio ya enmarcadas con aluminio amarradas con cuerdas; unos las impulsan desde abajo y otros las jalan desde arriba, pasando por un nivel intermedio, donde uno de ellos rectifica la dirección para asegurarse de que el frágil material no choque con nada.

En la rampa que baja al estacionamiento en medio de las dos torres, la acción consiste en subir cubetas de grava hasta la cima del edificio. Dos equipos de trabajadores hacen esto con ayuda de poleas y cuerdas. Amarran la cubeta en un extremo de la cuerda con un gancho en forma de ' $S$ ', jalan y se cuelgan del otro extremo de la cuerda para así elevar la cubeta. Arriba dos o tres trabajadores, parados sobre un andamio improvisado - una endeble plataforma de madera que sobresale del edificio-, completan la acción recibiendo las cubetas, vaciándolas y 
transportando con carretillas la grava hasta el lugar donde se va a ocupar. Otros trabajadores llenan las cubetas con palas desde unos grandes montones de grava.

Los trabajadores en la obra de Puebla se dedican a diversas actividades, unos están anudando varillas, otros poniendo la cimbra, recubriendo de madera el acero; más allá están levantando muros de ladrillos, haciendo estructuras con varillas, improvisando una alberca para la mezcla, aventando ladrillos de abajo a arriba. Se genera una conjunción de distintas actividades paralelas, aparentemente arbitrarias y cada una con una finalidad particular, no obstante, todas contribuyen a la construcción de un edificio y en este sentido están dirigidas a un mismo fin y son parte de un mismo plan racional.

\section{Cadenas humanas}

Entre las acciones colectivas observadas me parece interesante resaltar las cadenas humanas que muy comúnmente se formaban en la obra, por ejemplo para transportar material de un lugar a otro. Cada actor o cada albañil forma un eslabón de la cadena, que funciona como una metáfora de cómo se construyen los vínculos sociales y las redes, y cómo circulan los objetos a través de las mismas redes sociales.

La tarea que dispuso Silvano fue meter toda la madera hasta adentro del terreno. Nadie quería empezar, los trabajadores evadían la labor y se reían entre ellos por la gran flojera que les daba comenzar de nuevo la chamba después de comer. Hasta que llegó un trabajador panzón de bigote, Maximino; dio instrucciones $y$ organizó a todos para que armaran una cadena humana para ir pasando el material. Y así se hizo: fueron pasando vigas y tablas de mano en mano, a través del cerro de escombro, por el pasillo de madera, hasta bajar al nivel del hoyo, primero bastante desorganizados, pero después agarraron ritmo y se articularon bien todos los eslabones. Esta acción coordinada se realizó al ritmo de la música de los 80 y 90 que salía del radio a todo volumen. En un momento determinado, el cable de la grabadora, atravesado en el aire, estorbaba el paso de las tablas. Primero Silvano lo alzaba empujándolo con una escoba, hasta que Ángel, El Pelón, se trepó hábilmente en la puerta y lo amarró para que ya no se interpusiera en el paso de la madera. Pero nunca consideraron apagar el radio. 
Dos albañiles levantan un muro, colocan el cemento y los tabiques mientras otros tres peones les van llevando el material que ocupan, circulando por el angosto pasillo lateral que bordea el hoyo. Dos de ellos van y vienen con carretillas, pero el otro carga a mano los tabiques de 4 en 4 y transporta el cemento en cubetas... Los carpinteros se piden a gritos lo que van necesitando: "iun polín de 1.30!", y por allá otro lo mide con un flexómetro, lo marca apenas con un clavo, lo serrucha y se lo pasa al primero, aventándoselo un par de metros.

Llega a la obra un camión cargado de arena, misma que descarga levantando su parte trasera para dejarla caer sobre la banqueta, afuera del terreno. Los trabajadores empiezan a desplazarse hacia afuera para acarrear la arena hacia adentro del terreno, formando un desfile de carretillas que transitan de ida y vuelta sobre las rampas. Afuera, dos trabajadores, Pato y uno desconocido para mí, les cargan la carretilla de arena con palas; los otros van y avientan la arena hacia el sótano, donde se empieza a formar un cerro que aumenta paulatinamente con cada vuelta de carretilla. Entre los carretilleros están puros peones rasos.

Un camión con costales de cemento está estacionado en la entrada de la obra. Desde la parte de atrás del camión, los dos repartidores les acercan los costales a una serie de peones que se acomodan los costales en el hombro y los transportan uno por uno hasta el sótano... Otro camión cargado de bloques de unicel llega y se estaciona afuera del terreno. Eliseo, que desde antes estaba trepado sobre la montaña de ladrillos afuera del terreno, es el encargado de cachar los bloques de unicel que el chofer le avienta desde la parte de atrás del camión, y él a su vez se los avienta a otros trabajadores que los reciben y acomodan ya adentro de la obra.

A la obra de Córdoba llegó un nuevo cargamento de ladrillos que nuevamente descargó en la banqueta afuera de la obra. Eliseo, su primo y otros dos señores se encargan de hacerlos llegar hasta donde se necesitan en la tercera planta, donde se concentra la actividad de levantar muros. Eliseo los avienta desde la calle, a veces de uno en uno y a veces de tres en tres, a su primo en el segundo piso, quien los cacha y casi como van, con el mismo vuelo, prolonga su trayectoria hasta el tercer piso, donde un señor mayor los recibe y los va colocando en un montón. "Así no van a acabar nunca", les digo. "Sí avanzamos", me contesta Eliseo. "¿No sería más fácil ponerlos en una cubeta y jalarla con una cuerda y una polea?", pregunto. "Quién sabe, pero así nos dijeron que le hiciéramos", responde. 
Eliseo y otro cuñado están nuevamente involucrados en la operación de meter tabique a la obra desde la calle, aventándolos desde abajo y afuera hacia arriba y adentro. Esta vez la cadena humana consta de tres eslabones. El primo parado sobre el montón de ladrillos se agacha, los recoge y los avienta de uno en uno a Eliseo, que está parado sobre una tabla de madera volada. Él a su vez los lanza a otro trabajador en el mismo piso cerca de él, quien con un solo movimiento los recibe y los acomoda en un nuevo montón... Siguen aventándose ladrillos de afuera hacia adentro y hacia arriba. Parece una labor interminable; cuando están terminando con un montón, llega un camión y descarga otro.

\section{Condiciones laborales}

En este apartado se narran algunos acontecimientos relacionadas con las condiciones de trabajo bajo las cuales se desarrolló la labor de los albañiles en los casos de las obras estudiadas. A través de diversos relatos etnográficos se consideran cuestiones tales como las formas de reclutamiento, el contrato tácito que se establece entre las partes involucradas, la relación entre el contratista y el contratado, el trato personal que se genera, los horarios y días de trabajo, el manejo de los días de descanso obligatorio, la cuestión de los salarios de los trabajadores, el grado de seguridad social, el papel de la empresa constructora, del sindicato de trabajadores de la construcción, las medidas de seguridad en la obra, la presencia del trabajo infantil dentro de la obra y la dinámica que se genera en torno al pago de la raya, entre otras. Todos estos aspectos forman parte de la cultura laboral propia del mundo de la construcción, que tiene marcados tintes de informalidad e inestabilidad, en el que es común que ocurran injusticias, explotación, abusos, pero en el que también suceden otros aspectos más positivos dentro del mercado laboral de la construcción, como la transmisión personal del conocimiento.

Connolly denuncia "las pésimas condiciones laborales de sus procesos de producción" como un rasgo inherente a la industria de la construcción mexicana. "Los obreros de la construcción están entre los peor pagados", ganan sueldos y salarios irrisorios. Varios autores señalan a los obreros de la construcción como "los más desprotegidos por los sistemas de todos los trabajadores... Los riesgos de trabajo en la construcción son altísimos; la tasa de accidentes se ha calculado en 16 por cada 100 trabajadores" (Martens 1982, citado por Connolly, 1988: 200). 


\section{Reclutamiento de la mano de obra}

En cuanto al reclutamiento de la fuerza de trabajo, Connolly explica que el maestro de obra es el único responsable de llevar a cabo este proceso.

Existe una variedad de mecanismos para la incorporación del trabajador al proceso productivo. En muchos casos el trabajador en busca de empleo se dirige al maestro en la obra; en otros, el maestro se dirige a la central camionera u otros centros establecidos para reclutar mano de obra. Con frecuencia, cuando se presenta una relativa escasez de mano de obra, el maestro se dirige a su lugar de origen, generalmente una zona rural, para reclutar trabajadores entre sus paisanos, parientes y compadres (Connolly, 1988: 213).

Me platica Silvano cómo encuentran a los trabajadores. Me dice que actualmente hay mucha gente que quiere trabajar, que busca y necesita chamba, que nadie es imprescindible hoy en día, que siempre habrá alguien que lo sustituya. Abunda:

Si no es suficiente con los trabajadores que hay, uno se va a buscar a los mercados de trabajadores, en las centrales de autobuses, ahí se juntan los que buscan trabajo, y luego entre ellos también se pasan la voz y traen a sus primos. Uno los va viendo cómo trabajan, si aguantan o no, y así se van quedando, o ellos mismos se van cuando no rinden; a los que van empezando les cuesta trabajo aguantar, por eso luego vienen una o dos semanas y dejan de venir. Aquí pueden trabajar el día que quieran, un día sí y otro no, por eso el contrato es solamente verbal y se paga cada semana la raya, según los días que haya venido; día trabajado, día pagado.

El Gato me cuenta su perspectiva como maestro de obras. Dice que últimamente nunca ha sufrido por conseguir personal. "Siempre los lunes hay gente que pasa por las obras preguntando si hay trabajo, siempre hay gente que necesita chambear". Entre quienes buscan trabajo ya se sabe que en la Roma, la del Valle, la Condesa, el Centro y la Narvarte hay muchas posibilidades de empleo en la construcción de edificios. "Uno como contratista piensa que, por ejemplo, un lunes como a las 8:30 ó 9:00 de la mañana, si todavía no llegan tus mismos trabajadores de la semana anterior, fácilmente consigues otros que los reemplacen".

Eliseo me cuenta que ya tenía dos semanas sin ir a trabajar: "andaba de vago"; hasta ayer lunes fue a buscar chamba a la obra de Puebla pero no encontró lugar, "ya había un chingo de chalanes allá", me dice... Me cuenta El Pelón que cuando 
de plano no halla una obra en la que se pueda trabajar fácilmente, y cuando no quiere andar todo el tiempo de limpiaparabrisas, también se va los lunes tempranito en la mañana a las centrales camioneras, y ahí van los patrones a reclutar trabajadores eventuales.

Un día llegó un chavo a pedir trabajo, lo conduzco con Nicolás, "¿De qué buscas trabajo, hijo?". "De lo que sea, de ayudante", contesta. Nicolás lo manda a la otra obra, donde no llegaron suficientes chalanes... Otro día se apareció en la obra un chavo bien vestido a preguntarle a Javier "si hay jale", está buscando chamba para él y su primo, él como oficial de albañilería y su primo de ayudante. "Sí hay jale para ti y para tu primo", responde Javier, "pero vénganse mejor el 17 a la otra obra, allá en Córdoba y Puebla, allá vamos a necesitar mucha mano de obra". El chavo se va agradecido. Apenas se retira, los que estaban alrededor comentan algo burlándose de él.

\section{Contrato laboral}

En cuanto a las relaciones contractuales de trabajo en el mundo de la construcción, Carmen Bueno destaca que la contratación es semanal y a veces incluso por día, se establece un convenio sin ningún compromiso legal, se siguen un conjunto de normas consuetudinarias; los trabajadores son considerados asalariados eventuales. La lista de raya que lleva el maestro de obra es el único control directo sobre los trabajadores que hay en una obra (cf. Bueno, 1994: 105). Entre los albañiles y el maestro de obra se establece "una relación contractual con relativa autonomía y flexibilidad, a cambio de una gran inestabilidad en el empleo... Lo legal está ausente; la formalidad se suple por la palabra". Se crean "pautas de conducta aceptadas por la colectividad basadas en la costumbre, transmitidas por la experiencia de generaciones" (Bueno, 1994: 116).

¿Por qué a los trabajadores de la construcción les pagan cada semana y no por quincena o mensualmente, como en otros trabajos? Supongo que esta costumbre tiene que ver con la inestabilidad laboral que impera en el gremio; cada albañil es libre de decidir dónde trabaja cada semana y el compromiso laboral es menos fuerte con sus empleadores. ¿Pero a quién le conviene más esta inestabilidad? Por una parte, así no hay obligaciones por parte del contratista, ni prestaciones, ni 
antigüedad, ni aguinaldo, pero también es cierto que a los trabajadores les conviene contar su sueldo cada semana, al ser su único patrimonio económico en la vida.

En el resto de los subprocesos que integran el proceso constructivo, al igual que en la albañilería, los trabajadores subcontratados tampoco establecen ninguna relación formal de trabajo con el maestro ni con el constructor, sin embargo, en estos oficios especializados suelen formarse equipos más permanentes que en la albañilería, que en algunos casos se convierten en unidades laborales más complejas o microempresas familiares (cf. Bueno, 1994: 111).

El velador me dice que espera ser reemplazado este fin de semana, porque no quiere quedarse en la obra tres días y pasar ahí solo la Navidad. "Pero si no llegan a cubrirme mañana como a las 10 am, yo igual me voy", me dice. Esta anécdota es reveladora del grado mínimo de compromiso laboral en este rubro. De hecho, esa sería la última vez que ví a ese velador.

Pregunto a algunos trabajadores qué harán cuando terminen esta obra. Unos, como El Gato, dicen que parece que podrán seguir trabajando en la de Puebla. Édgar, El Gordo, ya está allá, por ejemplo. Otros dicen "quién sabe, ojalá que sí nos contraten en la obra de Puebla, pero es el patrón el que decide". Estos testimonios nos hablan de una inestabilidad, inseguridad, informalidad del empleo. Hay una gran fragilidad del contrato laboral, del compromiso entre contratante $y$ contratado. Viven en el aquí y el ahora, sin posibilidad de ahorro, de prestaciones ni de previsión para el futuro.

Los dos cuñados del Pelón me cuentan que se fueron a Querétaro a las fiestas del pueblo donde está el Tlacuache y se quedaron allá cuatro días. Faltaron dos días a su trabajo. Bromean con otros dos albañiles y se molestan entre ellos por desobligados, porque dejan de trabajar a la menor provocación. Me dicen que lo bueno es que hay suficiente chamba en la zona y hasta se pueden dar el lujo de trabajar en otra obra si acaso los corren de alguna.

\section{Trato personal}

"También es importante cómo se trata a los trabajadores en una obra. Sin estarlos explotando se tiene que poner cierta presión para que avancen y rindan todo el día, pero sin ser demasiado exigentes", agrega Silvano.

Les pregunto si tuvieron alguna comida por el primer colado o por el fin de año, como es tradición, y me contesta Raúl, encontrando un confidente con quien 
desahogarse: "No'mbre güero, aquí la tradición no les importa, se está perdiendo eso de la comida del primer colado, eso ya sólo se hace en la construcción de casas particulares, pero ahora con las compañías ya está desapareciendo, por codos y ambiciosos, no te regalan ni un vaso de agua, ni las gracias le dan a uno. Hasta la fiesta de la Santa Cruz, el 3 de mayo, se está perdiendo: antes ese día ni se trabajaba, se adornaba todo, la cruz, los patrones se ponían con las cervezas, el chupe, el chivo, los chescos, pero ahora ya casi no se hace nada de eso con estas compañías". La queja de Raúl va dirigida a las compañías constructoras que "quieren todo para sus bolsillos".

Silvano me informa que hubo un grupo de trabajadores que hoy salieron una hora antes, para compensarles una hora extra que se habían tenido que quedar descargando un camión con material que llegó más tarde de lo previsto. "La verdad es que no les puedo compensar con dinero, porque a mi no me dan nada para horas extras, pero por consideración los dejo irse una hora antes, para que vean que se les toma en cuenta; les damos ese trato para quedar bien", me dice Silvano.

Me entero de que la comida del día de la Santa Cruz la hicieron en la obra de Puebla, donde también me percaté de que pusieron una cruz en la entrada; ahí juntaron a los trabajadores de las cuatro obras de DAKAB. La comida estuvo buena, a decir del Gato: "ahora sí se discutió el Arquitecto, nos dieron barbacoa y la pasamos bien a gusto, por fin logramos cortarle una flor de su jardín". Pero me informa que ahora que sea el primer colado en la obra de Puebla ya ni de chiste va a haber otra comida.

Comento con El Gato que a mi parecer su trabajo está menospreciado. "Sin ustedes, los arquitectos por más estudios que tengan, no podrían materializar nada". "Así es, güero", me dice Gato, "pero en la realidad ni las gracias nos dan". "Lo que pasa es que no nos valoran. Pinches sueldos de pueblo que paga el arqui. Yo el otro día me le iba poner al brinco, llegó a regañarnos, todavía que nos paga una miseria quiere que hagamos todo a su modo, le iba yo a decir, pero ya me dijeron cálmate, no vale la pena. No aprecia lo que le costaría conseguir otros buenos trabajadores, si de pronto nos fuéramos todos él perdería mucho tiempo y dinero".

\section{Horario de trabajo}


Connolly señala que no hay ninguna regulación efectiva sobre la cantidad de horas diarias que un peón deberá trabajar para ganar su sueldo, a veces son jornadas de 8 horas, otras de 10 y en algunos casos trabajan hasta 12 horas al día (cf. Connolly, 1988: 215).

Antonio Bobadilla me comenta que el horario de trabajo es de 7 am a 6 pm, es decir, 11 horas en la obra, menos una que se toman para comer, de 1 a 2, en esta obra se trabaja 10 horas al día, en lugar de tener una jornada laboral de 8 horas diarias. Bobadilla me explica que se trabajan dos horas más cada día porque descansan todo el sábado... Me encuentro a Silvano y charlamos sobre lo pesada que llega a ser la jornada laboral, porque es más larga de lo normal. Pero me cuenta que muchos trabajadores prefieren trabajar una o dos horas más al día para poder descansar todo el sábado... Hubo días que los trabajaron hasta pasadas las 6:30 p.m.; me pregunto si esas fracciones extras de trabajo les serán remuneradas.

Un día a media mañana le pregunté a Silvano por Antonio Bobadilla y me dice que ya se fue a otra obra; el arquitecto no ha ido en lo que va del día y la señora de ventas tampoco ha llegado. Otro día Silvano me dice que Antonio Bobadilla hace rato estuvo por la obra pero se fue diciendo que más tarde regresaba, "aunque quién sabe", agrega Silvano, "porque a veces dice que sí vuelve y luego ya no regresa". Es evidente que existen distintos horarios de trabajo y condiciones laborales muy diferentes entre los distintos oficios y rangos. Ninguno de los altos mandos, ni el arquitecto, Antonio Bobadilla, Nicolás, ni la chica de ventas tienen que estar tan temprano y puntuales como los albañiles y el encargado de la obra, Silvano. En la cadena de trabajadores de la construcción, los albañiles y peones son menos dueños de su tiempo que otros actores, su misión es hacer lo que se les diga, cuando se les diga.

Me informan de un nuevo ajuste en el horario de trabajo durante el invierno, lo llaman "media y media" y quiere decir que solamente les dan media hora para comer pero salen media hora más temprano, por aquello de que en esta época del año oscurece más temprano, y a veces como a las 5 ya no hay luz suficiente para trabajar bien.

\section{Calendario laboral}


Hoy, seguramente por ser día festivo, 20 de noviembre, aniversario de la Revolución Mexicana, no había nadie en la obra y la puerta de acceso al terreno se encontraba cerrada. Al parecer se respetan los días de descanso obligatorio que marca la ley.

Me dicen unos trabajadores que parece que mañana van a colar, aunque sea sábado, van a trabajar para compensar un día de descanso obligatorio que perderán la próxima semana, por ser día de muertos. Pero no están muy seguros de esta información, porque apenas les avisaron; no saben si sólo trabajarán medio día o la jornada completa. Esta falta de información habla de unas condiciones laborales informales... Más tarde me confirman que trabajarán el próximo sábado todo el día completo, para compensar el Día de muertos, 2 de noviembre, que cae en viernes la próxima semana, que es día de descanso oficial.

Les pregunto si les van a dar el día libre, ya que al día siguiente será el día de la Virgen de Guadalupe. Me dicen que seguramente no, y si acaso se los dieran, se los descuentan de su sueldo. El 12 de diciembre llego a la obra a las 3 p.m. Aparte de la música del radio, la encuentro desierta. Entro por la puerta entreabierta y me hallo en el escenario vacío, sin actores que lo animen. Me desconcierto totalmente por unos momentos. Después recapacito que es día de la guadalupana y que seguramente no trabajaron. Voy al cuartito y me encuentro al velador $y$ a otro trabajador. Me informan que sólo trabajaron medio día, hasta la 1 p.m. Les pregunto si ellos no van a ir a La Villa y me responden que no porque ya se hizo muy tarde.

Calculamos en qué día van a caer las fechas feriadas y días festivos próximos, como el 24 de diciembre y el primero de enero. Casi todos van a caer en fin de semana o lunes. El velador dice que esos días se va a dar a la fuga para no quedarse solo ahí. De hecho, casi ni toca descanso este fin de año, porque tanto la Navidad como Año Nuevo caen en domingo, y sólo se les otorgará el lunes de puente. Éste es el último día de la semana de trabajo del año, el viernes antes de la Navidad que cae en domingo, así que será un fin de semana largo, porque tampoco se labora el lunes 25, o sea que descansan desde el sábado hasta el hasta el martes... En relación con los días que descansaron el fin de año, Raúl también me confiesa su descontento, ya que sólo descansaron dos días en total, el 25 de diciembre y el $1^{\circ}$ de enero, pero luego los tuvieron que reponer trabajando los sábados siguientes... 
Me dice Ángel que al parecer mañana (sábado) van a tener que ir a trabajar para reponer por adelantado el 21 de marzo, que es día de descanso oficial. Algunos trabajadores que viven lejos, como Pato y Rufino, deciden entonces quedarse a dormir en la obra, no tiene caso ir hasta su casa si tienen que estar ahí mañana. Algunos de los presentes no saben si empezarán a las 7 a.m. ni si trabajarán todo el día o sólo medio. Al día siguiente, Rufino sale del terreno y me confirma que trabajaron hoy (sábado), pero sólo medio día, hasta la 1 p.m. Después Édgar me cuenta que el sábado 17 de marzo sí trabajaron, para reponer el lunes, que fue feriado, de descanso obligatorio (en conmemoración del natalicio de Benito Juárez, el 21 de marzo). Dice Édgar que escuchó que en otras obras por ahí sí trabajaron.

Al momento de pagarles la raya, Silvano explicaba a los trabajadores cómo iba a ser el calendario de trabajo para la Semana Santa: la encomienda era trabajar corrido desde el lunes 26 de marzo hasta el miércoles 4 de abril, una semana y media sin descanso, trabajando sábado y domingo, para "reponer" por adelantado los días santos, de descanso oficial, el jueves 5 y viernes 6 de abril. Les avisaba que ése sábado, al día siguiente, no trabajaban pero que el próximo fin de semana sería completo, trabajarían sábado y domingo. Cuando Silvano les informa esto a los trabajadores, ellos no cuestionan, ni se quejan tantito, asumen y se dicen de acuerdo, aunque algunos parece que ni entienden el planteamiento.

En realidad, para un albañil no hay más días de descanso que los fines de semana, en algunos casos sólo los domingos; todas las fechas festivas alrededor del año las tienen que reponer sacrificando fines de semana. Cualquier día que no laboren tienen que compensarlo con trabajo los fines de semana, antes o después del "día de descanso". En el oficio de albañil no existe el concepto de vacaciones. Si quieren que se les pague su trabajo, tienen que desquitar completo su sueldo, trabajando la jornada y la semana entera, no se les regala ni perdona nada.

\section{Salarios}

Un punto de crucial importancia que destaca Connolly es el bajo precio de la fuerza de trabajo, en relación con los demás costos de producción y el precio final del producto. De acuerdo con esta autora:

Los salarios pagados a los obreros de la construcción ni siquiera son negociados entre las empresas y los trabajadores. El salario base en la industria de la 
construcción es el salario mínimo... El tipo de trabajador más numeroso en la construcción, el peón no calificado, percibe el salario mínimo... Los sueldos de los demás trabajadores, los semicalificados y los especialistas por oficio, siempre guardan una proporción constante con el salario mínimo. Como regla general, el trabajador calificado, el albañil oficial, por ejemplo, gana dos veces el sueldo del peón (Connolly, 1988: 215).

El hecho de que hasta la fecha el salario mínimo sea la medida para establecer el precio de la fuerza de trabajo en la construcción de vivienda, resulta tan alarmante como ridículo. Resulta evidente que el salario mínimo en México no alcanza para cubrir las necesidades elementales de trabajador para mantener a una familia.

Carmen Bueno indica que los ingresos que perciben los trabajadores de la construcción varían considerablemente de un oficio a otro. "La manera en que dichos salarios se cotizan no depende de la destreza o dificultad en el proceso, sino del reconocimiento social otorgado a cada oficio. Los salarios más baratos son percibidos por los trabajadores que desarrollan la actividad medular de la obra... La albañilería es el trabajo que exige mayor desgaste físico y el de mayor riesgo por las condiciones de trabajo tan improvisadas". Muchas labores que realizan los albañiles requieren gran destreza y precisión, no obstante, son los más desprestigiados y los menos remunerados (Bueno, 1994: 133-134).

Silvano me habla de los distintos puestos que hay y cuánto ganan: a la semana el promedio es de unos mil 800 pesos, pero depende de la categoría, el ayudante de albañil, el puesto más común, gana sólo mil a la semana.

Le pregunto a Rufino por qué ya no es velador; me responde que "porque está muy barato el sueldo, sólo son 700 pesos más a la semana por rifarte todas las noches alerta, y además se estaban perdiendo muchas cosas, luego me echaban la culpa y encima me descontaban una lana, así es que no conviene y menos aún por 700 pesos".

Cuando se decide que en la obra se trabajaría también el sábado, para obligar a que los trabajadores vayan, el pago de la raya se hace el sábado en vez del viernes, entonces si los trabajadores quieren cobrar tienen que resignarse a trabajar un día extra. Pero el mayor problema es que esto se implementaba casi siempre sin previo aviso. No se les comunicaba oficialmente a los trabajadores, tan solo confiaban en que se corriera la voz, que entre ellos se fueran comunicando la noticia, que los tomaba de sorpresa y cambiaba radicalmente sus planes de última momento, sobre 
todo a los que viven fuera de la Ciudad de México y sólo van a su casa los fines de semana.

Un viernes, me dice Raúl que Silvano y Nicolás prácticamente se dieron a la fuga sin pagarles, que sólo les avisaron que tienen que ir a trabajar mañana (sábado), para poder cobrar su sueldo. Los obligan a trabajar un día extra sin preguntarles nada, ni siquiera avisarles con anticipación. Rafael tuvo que pedir unos pesos prestados para poder regresar a su casa, porque ya no tenía nada y esperaba que le pagaran. El cobrador de la comida corrida se fue prácticamente en blanco porque los trabajadores no pudieron saldar sus cuentas de la semana. Poco a poco van llegando otros trabajadores a preguntar qué onda y no se muestran muy conformes con tener que trabajar el sábado tan inesperadamente, pero al fin y al cabo parece que se resignan. Dice Raúl, "sólo porque ahorita no hay dinero, a fuerza hay que venir mañana a cobrar, pero si no, yo sí los mandaba a volar".

Declara El Gato, haciendo gala de su conciencia política: "cada vez está más peleado el campo de la construcción, cada vez hay más cabrones que te pueden bajar la chamba. Es verdad que hay más obras, pero no más oportunidades. Como oficial, la neta gano lo mismo que hace cinco años; no suben los sueldos pero sí todo lo demás, el transporte, la comida... todo... iQué pedo con este pinche gobierno!".

Platicamos El Gato, el Pato y yo sobre el oficio de los yeseros y los sueldos de los trabajadores en general. Me dicen que los yeseros ganan más o menos 27 pesos por metro cuadrado. Les va mucho mejor que a los albañiles porque a ellos les pagan por levantar el muro y ya, mientras que a los yeseros les cuentan las dos caras del muro, además de los techos.

Saludo de lejos a Paul, quien está en el hoyo. Comento con Silvano que me parece muy buen trabajador ese Paul; me confirma que sí, que trabaja muy bien, que ha sido un buen capitán de los fierreros, pero lo malo es que lo ha sido sin el sueldo correspondiente, porque todavía no se lo autorizan los patrones. Ganaría $\$ 2,500$ pesos a la semana como capo. De acuerdo con Silvano, el trabajador que más lana se lleva es el administrador de obra, que gana a destajo, por volumen de operación, un porcentaje fijo por cada kilo o por cada metro de material que se utiliza. 
Un señor que es oficial considera que su hijo ya también podría ser contratado como oficial, sin embargo, en esta ocasión lo contrataron como ayudante y gana sólo mil pesos por semana, pero espera poder demostrar su habilidad y que los asciendan pronto. Me dice que en esta obra el sueldo está barato, no muy bien pagado, que creen que el problema no es el patrón, sino los maestros que muerden los sueldos de los trabajadores.

La obra puede entenderse como un microuniverso en el que se reproducen muchas de las relaciones desiguales y condiciones de injusticia y explotación económica y social en el mundo contemporáneo; una caja de resonancia en la que quien más trabajo físico realiza, es quien menos dinero obtiene por su esfuerzo, en cambio, los empleos mejor pagados en el campo de la construcción son para los actores que menos trabajo físico desempeñan. En un extremo está el albañil que desempeña trabajos muy pesados durante diez horas diarias y recibe un sueldo de mil pesos a la semana, y en el otro extremo están el inversionista, quienes se llevan la mayor tajada sin poner nunca un pie dentro de la obra.

\section{El pago de la raya}

Hoy es día de la raya, viernes, como a las dos de la tarde. En el cuartito subterráneo que hay en el estacionamiento, Javier, Nicolás y Silvano hacen cuentas con mucho dinero. Pato sube y baja las escaleras llamando trabajadores. Afuera del cuartito hay una mesita con papeles y planos que Silvano usa como base para pagar la raya. Sobre la mesa hay un paquete de cigarros Marlboro y un encendedor, que Silvano mandó comprar para fraccionar uno de los billetes y tener cambio para poder pagarles la cantidad exacta a los trabajadores. Los cigarros los deja como cortesía a la disposición de los trabajadores para que libremente agarren uno cuando van a cobrar.

Poco a poco llegaban con Silvano a cobrar, uno por uno, a veces algunos tenían que esperar su turno; él recordaba su nombre y apellido de memoria, buscaba su expediente en una pila de hojas y les pedía que firmaran un papel, entonces procedía a darles su dinero en efectivo. Algunos cogían un cigarro de la cajetilla colectiva. Tras firmar torpemente un papel, al momento en que Silvano les da su dinero a los trabajadores, no hay intercambio alguno de 'gracias' ni 'de nadas' de ninguna parte a la otra. Algunos ni cuentan el dinero, otros sí revisan sus billetes y 
se los guardan bien... Silvano siempre tiene que mandar a algún trabajador a comparar algo a la tienda (cigarros, agua, refrescos) para tener cambio y poder pagar exacto. Comenta sobre los sueldos que ganan: "mil los ayudantes, dos mil los oficiales, mil siete los carpinteros, mil seis los fierreros".

Silvano venía de pagarle su sueldo, "la raya", a un albañil que sólo había trabajado tres días esa semana. Al presenciar el trámite, recuerdo la frase "día trabajado, día pagado", como lema de la política laboral en la obra. Como casi todos los viernes, era día de paga para los trabajadores, además era una raya muy importante para ellos, la navideña. Me confirma Silvano que los trabajadores no reciben aguinaldo ni gratificación extra en esas fechas, ni tendrán siquiera una comida para celebrar el fin de año.

\section{Trabajo infantil}

Me llamaron la atención varios casos de menores de edad trabajando en las obras de construcción, entre otras razones porque es una evidencia del grado de informalidad laboral que impera en la obra, pero también porque permiten presenciar en su esencia más clara el proceso de transmisión del conocimiento práctico entre los jóvenes aprendices y los trabajadores más experimentados.

Cuando están anotando los datos, nombre y fecha de nacimiento, de los trabajadores nuevos para inscribirlos en el seguro social, llegan un par de trabajadores que al parecer son hermanos o parientes, uno es mucho mayor que el otro, que se ve casi como un niño. Cuando Silvano le pide su fecha de nacimiento, se dan cuenta de que no lo pueden enrolar por ser menor de edad, nació el 30 de abril de 1990, nació el día del niño y sigue siendo un niño, pero ya trabajando como adulto. Discuten el caso entre el hermano, Silvano y el enlistador. Noto que mi cercanía les estorba para negociar una solución, así que me hago a un lado por un rato. Al poco tiempo todos vuelven a trabajar y llega otro trabajador a enlistarse. Al parecer todo se arregló fácilmente, ya que en adelante vería a este joven trabajando cotidianamente en la obra. Así como él, conocería a varios trabajadores menores de edad, nacidos de 1990 en adelante.

Cerca de la puerta está Édgar con un taladro eléctrico rompiendo el poco concreto que queda del antiguo piso al frente del terreno. Junto a él está el 
trabajador joven de 16 años que tuvo problema para que lo registraran en el seguro social; mira atentamente a Édgar, como aprendiendo de él, fogueándose. Noto que es zurdo y me parece notar una cierta inexperiencia o torpeza en sus movimientos, a pesar del gran empeño y fuerza que le imprime a su labor. Se llama Abelardo, es el hermano menor de Norberto... Me llama la atención ver pasar a un albañil que es prácticamente un niño cargando cubetas llenas de arena al hombro. Le calculo unos catorce o quince años máximo.

\section{Medidas de seguridad}

Don Raúl es el único de los trabajadores que lleva puesto un casco. Pero en general, esta médida de seguridad, la más básica y elemental, no se sigue en la obra, o se sigue inconstantemente... Al poco tiempo de que se instaurara la regla estricta de portar casco obligatoriamente, varios trabajadores usan su caso de seguridad, pero otros portan solamente una cachucha en la cabeza, mientras sus cascos descansan colgados de la punta de una varilla.

Junto al tablero de la electricidad ahora hay un extintor, instalado sobre la reja que divide la obra con el jardín de junto. En el piso de hasta arriba, aún a cielo abierto, también hay un extintor con manchas de cemento colgado de una estructura vertical de varilla. Seguramente estos accesorios son parte de las medidas de seguridad que se tuvieron que implementar a partir de la clausura de la obra (relatada en el capítulo II: Transformación del espacio).

\section{Salud y seguro social}

En relación con las instituciones de salud y seguro social, Carmen Bueno comenta que:

El acceso a servicios de asistencia social es muy limitado. Los constructores por lo general dan de alta a los albañiles en el Seguro Social por ser un requisito formal vigilado por el gobierno durante las auditorias realizadas a las empresas. Para poder acceder al servicio, los trabajadores tienen que acudir a la clínica del Seguro donde fueron dados de alta para dar un aviso de trabajo y luego poderse tratar en caso de algún accidente... pero al no tener un trabajo permanente, mejor no se inscriben, porque además, tendría que pedir un permiso para faltar, lo que merma sus ingresos y limita la oportunidad de ser contratado nuevamente la siguiente semana (Bueno, 1994: 139). 
Una estimación interesante que plantea Bueno es que durante los años ochenta los trabajadores de la construcción representaban dos terceras partes del total del mercado laboral urbano en México, sin embargo, "no representan ni la décima parte del total de empleados inscritos en el IMSS" (Bueno, 1994: 139).

Le pregunto a un trabajador si no ha venido Pato, me informa que sí vino pero se acaba de ir, que sólo fue para avisar que está enfermo y se fue... Pato me confirma que estuvo enfermo un par de días la semana pasada, con fiebre y una fuerte infección en el estómago. El miércoles ni se pudo levantar, el viernes tuvo que venir a la obra a mostrar las recetas a los maestros, para demostrar que estuvo malo. Me dice que sí tomó medicinas y que ya se alivió. Cada día que no pudo ir a trabajar será descontado de su salario semanal... Silvano de pronto detiene su labor por una lesión en la espalda. Rufino sugería remedios tradicionales a Silvano para calmar el dolor.

Le pregunté a Ángel si alguna vez había tenido algún accidente en la obra y me contestó que gracias a Dios no, nada grave, salvo una vez que se clavó un clavo largo, de esos para concreto, en la planta del pie. Le atravesó el zapato y se le encajó tan profundo en el pie que por poco sale por arriba, me describe minuciosamente. Le dolió mucho y se tardó varios días en sanar, sin poder caminar bien. En esa obra no tenía seguro ni nada. Él tuvo que pagar las medicinas y los días que no pudo trabajar se los descontaron.

Uno de los carpinteros de edad mayor, como casi todos los que trabajan encima de los techos, se acerca a preguntarle a Silvano: "Oiga mai, nos vienen a decir que firmemos otra vez, ¿y eso para qué, si ya firmamos en la mañana?". "Hace rato fue para la asistencia, y ahora esto es para inscribirle en el Seguro Social", le contesta. Un hombre joven estaba registrando a los nuevos trabajadores para afiliarlos al IMSS de parte de la empresa. Contratado por la inmobiliaria, este chavo va a todas las obras de la empresa, para que todos los trabajadores estén cubiertos, "quién sabe, cualquier día puede suceder un accidente", me dice. El afiliador, con su papelería sujetada en una tabla para escribir y todo el equipo necesario, pedía los datos (nombre, puesto, fecha y lugar de nacimiento) a los trabajadores que hasta entonces no habían sido registrados. Casi todos los carpinteros tuvieron que registrarse, también un ayudante de albañil que acababa de empezar. A cada uno lo hacían firmar un documento y poner su huella digital junto a su firma. 
Me encuentro a Raúl y le pregunto dónde andaba el día anterior, que no lo vi por la obra. Me cuenta que tuvo que ir al Seguro porque le estaba doliendo mucho una lesión que tiene en la pierna. Hace unos dos años se cayó de unos cinco metros de altura en el trabajo; se rompió la tibia y el peroné porque intentó caer parado. Lo operaron y le pusieron un clavo que a veces le molesta. Hace unos días se torció el pie al descargar unas varillas del camión; se volvió a resentir la pierna y empezó a dolerle el clavo. Entonces fue al Seguro pero en vano porque no lo atendieron, sólo lo tuvieron esperando, que porque estaban mal sus datos que le tomaron los encargados de la compañía, por algún error cuando lo dieron de alta. Raúl dice, refiriéndose al IMSS: "no, ahí ni lo atienden a uno, sólo se va a perder el tiempo".

Llega a la obra el enlistador o empadronador del Seguro Social, saca su tabla y papeles. Con apoyo de Silvano, Ilaman a los trabajadores nuevos para que vengan a apuntar su nombre y sus datos. Hay un grupo de 6 ó 7 nuevos trabajadores, parece que son amigos entre ellos. Vienen del estado de Puebla. Les pregunta: "¿oficial o ayudante?", "albañil", responden. Les pide su número de Seguro Social, si es que tienen, para que sea más fácil el trámite. Pato le recuerda a Maximino que no se le olvide inscribir en el Seguro al chavo de las tortillas; antes de que se vaya le preguntan su nombre. Esta semana hay 39 trabajadores en la nómina, según el censo que hizo ayer el encargado del ISSTE, me dice Javier.

\section{Sindicato}

Carmen Bueno revisa una de las primeras investigaciones sobre la construcción de vivienda en México, a cargo de Dimitri Germidis (1974). Esta investigación estuvo centrada principalmente en la sindicalización de los trabajadores en la industria de la construcción. Este estudio concluye que el movimiento sindical de la construcción es por lo general débil, privado de la posibilidad de tener políticas propias (cf. Bueno, 1994: 15). Bueno explica la situación de los sindicatos en relación con los trabajadores de la construcción de la siguiente manera:

A pesar de que no hay un contrato formal entre los trabajadores y el constructor, éste tiene que afiliar a aquéllos a uno de los sindicatos de los trabajadores de la construcción... la supuesta organización gremial de los albañiles... Se trata de contratos colectivos de trabajo por obra determinada... no se registran personas de carne y hueso, sino que hace una estimación aproximada de la cantidad de trabajadores que paga directamente el constructor... Este contrato sindical se hace 
visible... a través de una placa rojinegra que se cuelga a la entrada de las obras (Bueno, 1994: 108).

En el techo de la caseta, en la entrada de la obra, hay un par de letreros: por un lado, la manifestación de obra y los datos específicos del permiso de construcción, escritos en negro sobre un tablero blanco; y arriba de este letrero hay otro más pequeño, rojo con negro, que anuncia que los trabajadores de esa obra pertenecen al sindicato de trabajadores de la construcción. En cuanto a la presencia del sindicato, diría sin reparos que su verdadera influencia en las condiciones laborales de los albañiles no pasa de ese minúsculo pedazo de cartón. En un año y medio de trabajo de campo nunca oí nada por parte de los trabajadores que refiriera al sindicato, como si prácticamente no existiera.

Silvano me dice que la relación con el sindicato no es igual que en una fábrica, donde está siempre presente; en cambio, en la construcción sólo está para fijar un sueldo establecido, y si a los trabajadores no les pagan menos de eso, no acuden a él. "Uno de cada mil ingenieros dan liquidación, prestaciones o aguinaldo a sus trabajadores", dice Silvano casi riendo. Por eso dizque existe el sindicato, pero también hay que pagarle una cuota, entonces casi todos se van mejor por la libre". Afuera está el letrero porque todos tienen que estar en cierta forma afiliados, pero para el desarrollo de la obra no es para nada importante la relación con el sindicato.

Cabe subrayar que la afiliación al sindicato y el contrato laboral se han convertido en un trámite burocrático que tienen que realizar los constructores, sin el cual no puede llevarse a cabo una obra, a pesar de que los derechos y obligaciones que establece jamás se cumplan en la realidad. Además, quisiera mencionar que durante mi trabajo de campo en las obras nunca me tocó ver a ningún inspector sindical, pero sí numerosas pruebas de infracciones al contrato laboral. "Los trabajadores no tienen conocimiento de su afiliación sindical... no conocen a sus representantes sindicales... no saben qué función cumple... lo confunden con su afiliación al Seguro Social..." o de plano tienen opiniones negativas sobre él, ya que "hace caso omiso de la vigilancia de las mínimas condiciones de seguridad y bienestar social de los trabajadores" (Bueno, 1994: 109).

Las circunstancias de abuso o explotación laboral están estrechamente vinculadas con otro punto que plantea acertadamente Connolly: "la ausencia casi total de 
militancia obrera y la escasa funcionalidad de los sindicatos del ramo" (Connolly, 1988: 214). La escasa participación política de los trabajadores de la construcción, su adormecimiento ideológico, enajenamiento y docilidad también tienen su correlato en el nulo rol del sindicato, que casi podría definirse como un sindicato fantasma.

Son varios los factores que contribuyen a la inexistente movilización de trabajadores de la construcción por sus derechos laborales. El hecho de que sea un trabajo segmentado e intermitente, inhibe las acciones colectivas en el ámbito urbano. A pesar de que sus condiciones laborales son deplorables, no existe registro de ningún movimiento real por la reivindicaciones, protestas, marchas, huelgas, acciones colectivas o medidas de presión. Hay una profunda atomización y desorganización de los trabajadores de la construcción.

\section{Movilidad}

Una de las características más importantes de los actores que conforman el mundo de la construcción es su gran movilidad. Para ilustrar este argumento, debo reconocer que antes de comenzar este trabajo de campo, tenía la ingenua idea de que al estar en una obra de principio a fin me involucraría con los albañiles que trabajarían en la obra también de principio a fin. Supuse que si permanecía con ellos a lo largo de todo el proceso constructivo, al final alcanzaría una gran familiaridad con ellos y serían unos "informantes" ideales. Ésta era mi inocente premisa, pero estaba muy equivocado. Nunca hubo un grupo fijo de albañiles que trabajara en la obra de principio a fin. Hubo más bien un constante vaivén de actores. Gracias a esta sorpresa, que al principio fue un tanto decepcionante, fue que más adelante me surgió el interés por observar la movilidad de los trabajadores de la construcción como uno de sus rasgos más singulares que definen su forma de ser.

Cabe aclarar que no me refiero a una movilidad vertical, hay muy pocas oportunidades de ascender de puesto, de escalar a un mejor oficio por méritos propios y tener un mejor salario. La movilidad a la que me refiero es más bien horizontal, pero además, parece ser una forma de transitar sin rumbo fijo, vagabunda, desorientada, consecuencia de los oficios temporales, que a su vez 
generan cruces efímeros, lazos sociales inestables, incertidumbre e informalidad laboral.

La movilidad de los trabajadores es resultado de múltiples factores. La primera razón es obvia y tiene que ver con la naturaleza de los oficios de la construcción, que deben hacerse in situ, a diferencia de otras culturas laborales que pueden desempeñar sus labores en un taller, una fábrica o una oficina, por ejemplo. En cambio, los albañiles necesariamente construyen inmuebles en el lugar donde los inmuebles van a permanecer, y por lo tanto deben desplazar su fuerza de trabajo hasta donde sean contratados. Para desarrollar su labor, los albañiles deben transportarse constantemente entre diversos sitios geográficos y adaptarse a las condiciones que cada lugar les impone.

Pero esta movilidad tiene que ver también con otras circunstancias que se presentan en la obra, que van desde los pequeños acontecimientos que forman parte de la atmósfera de informalidad, hasta factores que nos remiten a una escala macrosocial, como el boom constructivo y la proliferación de obras en la zona central de la ciudad. Hay una considerable cantidad de mano de obra que se emplea de manera semiinformal en el ramo de la construcción, una abundante población masculina, en su mayoría joven, que se traslada diariamente al D.F. desde los municipios aledaños en busca de oportunidades para ganarse la vida. Otro factor que contribuye a esta movilidad es la informalidad en el contrato laboral, las malas condiciones de trabajo, de seguridad social, la ausencia de un sindicato efectivo, los salarios mínimos, algunas injusticias y grandes desigualdades, falta de compromiso de las partes, etc. Estos son algunos de los factores que hacen que los albañiles no se arraiguen profundamente, ni por mucho tiempo, a una obra, sino que vayan transitando de un trabajo a otro.

Por todo lo anterior, podemos afirmar que la obra es un lugar idóneo para observar una multiplicidad de encuentros y desencuentros interculturales. La obra representa un nodo de una red más extensa; es un sitio donde confluyen momentáneamente las diversas trayectorias de múltiples actores. La obra es un punto donde la movilidad de los sujetos se hace especialmente evidente. Centrarnos en la obra es equivalente a tomar una foto en la que la cámara permanece fija por un momento, mientras que los sujetos que se mueven a través del cuadro aparecen borrosos, o más bien desaparecen como fantasmas, dejando un rastro que se 
desvanece rápidamente. Si dejamos la mirada fija en una obra, se nota el vaivén fugaz de los trabajadores, sus perfiles aparecen desdibujados o borrosos por su constante movimiento.

El reto etnográfico es cómo aproximarse a investigar y aprender de un conjunto de personas que no se quedan quietas en un mismo lugar, que no forman grupos estables, localizados, sino que se mueven y generan una constelación de redes distinta cada vez que se le mira. La teoría del actor-red, tal como la presenta Bruno Latour (2005), es muy propicia para entender este tipo de conformaciones sociales inestables, en movimiento, efímeras, improvisadas y espontáneas.

\section{Actores en movimiento}

Entre tanta movilidad y considerando el boom constructivo actual en la colonia Roma y en la ciudad central, cabe preguntarnos por la experiencia de los albañiles: ¿qué implica para ellos, en términos de sus condiciones laborales, que haya tantas construcciones, tantas oportunidades de trabajo? Más allá de las teorías macroeconómicas de la generación de empleo y de las leyes de la oferta y la demanda laboral, ¿cómo se traduce esto en ventajas o desventajas para sus vidas? Podemos suponer que en un contexto así, las relaciones que se establecen entre ellos muchas veces están marcadas por lo efímero, la fugacidad, los lazos utilitarios, enfocadas en el plano inmediato del aquí y el ahora. Pero hay que señalar que en este mismo contexto todavía se crean vínculos sólidos y fuertes, por ejemplo, entre miembros del mismo pueblo, parientes, colegas, que a veces forman grupos o integran equipos alrededor de un maestro contratista.

El problema de la movilidad de la mano de obra implica cierto desdibujamiento de los sujetos. Por tanto, la atención no está puesta totalmente en los actores individuales, sino en las interacciones entre ellos, en el rastro que dejan sus acciones y conexiones. Importa el tránsito, la circulación, el movimiento. Si tomamos como punto de referencia una sola obra de construcción, como hicimos en esta investigación, nos damos cuenta de que los trabajadores van y vienen, aparecen y desaparecen constantemente.

A través de una serie de encuestas y cuestionarios aplicados a numerosos trabajadores de la edificación de vivienda, Carmen Bueno analiza cuidadosamente "la articulación entre el trabajo y los patrones de movilidad ocupacional", así como 
"las alternativas de empleo a las que accede la mano de obra de la construcción". Esta autora estudia "las modificaciones en sus trayectorias de vida... los cambios importantes en sus carreras laborales... la movilidad entre los diversos oficios de la construcción... la dirección de dicha movilidad... el ascenso o descenso en la jerarquía profesional o en la posición ocupada... los cambios de giro... las ocupaciones alternas o simultáneas como actividades económicas complementarias... la discontinuidad en el trabajo", etc. (Bueno, 1994: 119).

Es importante recalcar que no hay un grupo permanente de trabajadores de principio a fin en una obra. Hay brigadas especializadas de diferentes oficios, que aparecen en distintas etapas de una obra y se mantienen circulando entre una y otra obra según se les requiera. Por ejemplo, Silvano señala el hecho de que algunos fierreros ya se fueron y ahora llegaron los carpinteros, y así según vaya avanzando el nivel de la obra. La misión del maestro contratista es ir consiguiendo a los hombres necesarios para cada etapa. Así, los únicos que acaso pueden permanecer durante toda la obra son el velador, el encargado de la obra, algunos oficiales, unos que otros albañiles y ayudantes de confianza; casi todos los demás forman una población más bien flotante y fluctuante.

En la mayoría de los casos, los albañiles no deciden el lugar donde trabajan físicamente, sino que su ubicación laboral depende de las decisiones y necesidades de un contratista. Cuando le pregunto a un trabajador si cree que permanecerá en esta obra de principio a fin, responde que quién sabe, que luego los mueven a cada rato de una obra a otra, que no es decisión de ellos en dónde trabajan. Trato de imaginarme el grado de incertidumbre que implica para los albañiles el hecho de no tener un espacio laboral fijo y localizado, y nunca sabe con seguridad qué le espera el día de mañana.

No deja de sorprenderme lo inestable que es el trabajo de albañil. Al ver tantas caras nuevas y no ver varias de las que esperaba ver, me doy cuenta de que los trabajadores van y vienen constantemente; de una semana a otra pierden su empleo o consiguen otro nuevo. Una obra dista mucho de ser un trabajo estable para los albañiles. Se trata de una población errante, por lo que en esta investigación más que concentrarse en un sujeto o grupo de sujetos, conviene más tratar de reconstruir las redes que van tejiendo a través de sus relaciones efímeras. Esta inestabilidad de los grupos de trabajadores de la construcción está 
directamente relacionada con su movilidad, que genera un incipiente compromiso laboral de ambas partes, por un lado falta de responsabilidad por parte de los contratistas y por otro escaso sentido del deber por parte de los peones asalariados. "Una parte importante de los trabajadores se mueve indistintamente entre los diversos oficios de la construcción, sobre todo aquellos que trabajan en la albañilería..." (Bueno, 1994: 130).

¿Cómo se modifican las interacciones entre ellos dada la fragilidad de los vínculos sociales en este medio? Hacia el final de la obra de Córdoba varios albañiles me piden que les tome una foto de grupo, "porque se está acabando esta obra y mañana quién sabe qué nos espera". Esta frase, aunque fue dicha muy a la ligera, me parece sumamente reveladora de la movilidad y la inestabilidad laboral de los albañiles.

Un dato curioso es que el puesto de velador fue sin duda el más transitorio de todos los empleos en la obra de Córdoba. A lo largo de un año y medio hubo más de diez personas distintas que desempeñaron esta labor. El primero que conocí fue un chavo joven con arete en la ceja. Al poco tiempo, Rufino me informa que ahora es él quien se está quedando en las noches en el puesto de velador, apenas desde el viernes pasado. "Antes estaba el otro chavo que acaba de irse, pero no le gustó, faltaba mucho y lo corrieron una vez que vinieron a revisar algo en la noche y él no estaba, había dejado sola la obra", me cuenta el Rufles. Después de que otros desfilaran por el puesto, le pregunto a Silvano por el último velador, porque ya no lo he visto; me dice que apenas ayer lo cambiaron por otro... Más adelante nuevamente cambiaría el velador. ¿Qué tendrá este puesto que nadie dura? ¿Será que el sueldo es muy poco o tendrá que ver con la experiencia y la responsabilidad de cuidar la obra de noche? Me encuentro a Israel, el nuevo velador, bastante joven, y le digo: a ver cuánto duras de velador porque nadie ha aguantado mucho. "Pues yo voy a romper el record", me dice y se ríe. En efecto, Israel, que en adelante pasaría a ser "el vela", fue uno de los que más tiempo permaneció en el puesto.

Debo decir que durante el periodo de observación etnográfica hubo algunas importantes excepciones que confirman la regla de la movilidad generalizada, como el caso de Pato, trabajador permanente, fiel y de confianza. Pato es uno de los pocos trabajadores que conozco desde el principio (de hecho el primero con el que platiqué y me presenté), que aún permanecen en la obra de Córdoba. Pato es sin 
duda uno de los hombres de más peso, autoridad y responsabilidad en la obra. Gato recuerda que también estuvieron juntos durante unos meses en la obra de Patricio Sanz y de ahí Pato ya se vino para acá a la Roma, de donde no se ha movido desde que llegó. A lo largo de un año y medio de trabajo de campo, los únicos dos que han permanecido, además de Pato, son los de más alto rango: Nico, Bobadilla, Silvano y el arquitecto Canela. Al parecer, entre más alto es el rango laboral que tiene un trabajador, menos movilidad presenta y más estable es su chamba. En contraparte, entre más bajas son las condiciones laborales, tiende a haber más inestabilidad, informalidad y por ende mayor movilidad.

Debido a estos vínculos de tan corto plazo, existen pocas posibilidades de ascender y superarse en este oficio. Carmen Bueno señala que en la industria de la construcción "la movilidad ascendente es un proceso muy a largo plazo, los oficiales que aspiran a ocupar una posición de maestros pasan por periodos de 10, 15 ó más años para lograr su objetivo" (Bueno, 1994: 72). Cabe mencionar que en el transcurso del trabajo de campo solamente encontré un par de casos excepcionales de movilidad vertical: Fernando, alias Paul, quien me dice orgulloso que ahora en esta obra él es el encargado de los fierreros, o sea que ascendió de puesto, parece que valoraron su buen trabajo y esfuerzo... Otro caso es el de Andrés, un ayudante en proceso de entrenamiento para ser oficial. Antes de que empiece a comer, platico con este trabajador joven, alto y fuerte, originario de Tabasco. Me cuenta que desde los 11 años vino a la ciudad a trabajar con su primo. Porta un casco metálico, así que le pregunto si es oficial y me dice que lo están entrenando para ello, que quieren que aprenda bien, entonces él se esfuerza mucho para superarse y aspirar a un buen puesto. Sin embargo, en los oficios de la construcción de vivienda una mejor o peor posición laboral, un mejor salario, siempre puede ser solamente algo temporal, provisional; nada les garantiza mantener su empleo incondicionalmente.

\section{Demanda variable de mano de obra}

"Los albañiles, como asalariados eventuales, entran en una dinámica de empleo intermitente que depende del avance de la obra" (Bueno, 1994: 108). Ciertamente, a las obras estudiadas constantemente llegaban oleadas de trabajadores de acuerdo con las necesidades de personal de cada etapa constructiva. La empresa o 
los maestros contratistas pueden ya sea contratar o bien prescindir de trabajadores conforme los vayan requiriendo en las distintas fases de la construcción. "Por la discontinuidad en el proceso mismo de la construcción, la posibilidad de mantener una estabilidad en el empleo con el mismo empleador es casi nula". La cantidad de trabajadores siempre es variable, unas veces hubo muy pocos y otras veces había un gran número. Todo el tiempo aparecían caras nuevas a la vez que otros trabajadores fueron desapareciendo. "El trabajador de la construcción tiene su propia lógica de permanencia y movilidad" (Bueno, 1994: 129).

Los trabajadores experimentan no solamente una movilidad horizontal dentro y fuera de la construcción, sino también muestran una elasticidad para cambiar de posición ocupacional dentro de la estructura laboral, ante las continuas fluctuaciones en la demanda de mano de obra... Al conocer uno o varios oficios tienen la opción de abrir sus oportunidades de trabajo... Se trata de una mano de obra funcionalmente flexible, lo que les permite hacer frente a la incertidumbre del espacio laboral (Bueno, 1994: 153).

Las siguientes anotaciones intentan dar cuenta de este desfile de trabajadores, del flujo incierto pero constante de mano de obra que pasó por las dos obras estudiadas. A menudo me preguntaba: ¿hasta cuándo se quedarán tales o cuales trabajadores en la obra? Es muy difícil de predecir, depende de múltiples factores. Los albañiles, por ejemplo, tienen cabida durante toda la obra negra, pero los fierreros sólo están hasta que se acaba el trabajo con las varillas, al igual que los carpinteros cuando termina la fase de la madera. En la etapa de los acabados entra una población muy distinta, empezando por los yeseros, los carpinteros que fabrican muebles y puertas, los plomeros, los colocadores de pisos y los encargados de otro tipo de acabados. Esta gente se organiza de modo muy diferente, por cuadrillas, se les paga por obra determinada, no por día, hay un jefe contratista que maneja a su gente y negocia con la empresa constructora.

Veo una buena cantidad de trabajadores en acción dentro del lodazal que hay en el hoyo, todos portando botas de hule, son unos catorce o quince en total. El afiliador del IMSS me informa que en total tenía doce trabajadores registrados, este día hubo una baja de cuatro trabajadores que faltaron y un alta de nueve trabajadores nuevos, que deben ser los ocho carpinteros y el despistado que se inscribió al último. 
Me parece que hay bastante más gente que en ocasiones anteriores; se lo comento a Nicolás y me lo confirma, cuento unos 30 trabajadores en un primer vistazo, la mayoría completamente desconocidos para mí. Pero algunos de los trabajadores que en este momento me eran desconocidos más adelante me serían más familiares, y viceversa, personajes que en esta etapa me parecían centrales, desaparecieron del panorama eventualmente.

Debido a la clausura de la obra de Puebla, sólo unos pocos trabajadores que ahí laboraban, unos diez, fueron acomodados provisionalmente en la obra de Córdoba, me informa Silvano; "pero los demás tuvieron que tomarse un descanso forzado, ni modo, si mientras pueden conseguirse otra chamba, bien por ellos, pero si no, habrá que esperar a que se reabra la obra". Después de dos semanas de inactividad en la obra de Puebla, me pregunto: ¿qué estarán haciendo todos los trabajadores que estaban contratados ahí? ¿Cómo le harán los contratistas para juntar la cuota de mano de obra necesaria, una vez que reabran la obra? Días más tarde, cuando finalmente se levantó la clausura, Silvano me dice que lo cogió por sorpresa el reinicio tan abrupto de la obra, que apenas ayer le avisaron y casi no cuenta con trabajadores disponibles en ese momento, pero confía que lo resolverá en los próximos días. Finalmente, el resto de esa semana hubo muy poca mano de obra en Puebla, en cambio, contrataron la máquina excavadora para terminar el hoyo en el último rincón del terreno. Pero Silvano espera que ya el lunes de la próxima semana Ileguen a trabajar todos los peones que estaban antes de la clausura. Una semana después, efectivamente había unos treinta y tantos obreros, casi cuarenta; contrataron más hombres para acabar con esta tarea de sacar el lodo lo más pronto posible.

Ahora hay muy pocos albañiles en la obra de Córdoba, unos 8 ó 10, más los yeseros y plomeros. Se rumora que próximamente, el 17 de agosto, los mandarán a todos a la obra de Puebla. La llegada del mobiliario para estos nuevos departamentos marca el inicio del desplazamiento de los albañiles fuera de la obra. En adelante permanecen algunos trabajadores de acabados, de instalaciones, de limpieza, pero el trabajo bruto general, no especializado, como el de los peones o ayudantes, ya no tiene más cabida en este lugar... Ya casi no conozco a nadie aquí en la obra de Córdoba, sólo reconozco al Hormiga atómica, uno de los únicos 
peones que siguen realizando diversas labores, sobre todo de limpieza profunda, en el edificio ya casi terminado.

Mientras tanto, en la obra de Puebla se percibe mucho barullo ya que hay una buena cantidad de trabajadores, calculo que unos 50 ó 60, una cantidad superior a la a que había visto en la obra de Córdoba, lo cual me hace percatarme de que la escala de esta otra obra es considerablemente mayor.

\section{Altas y permanencias}

Todo el tiempo había caras nuevas que aparecían y desaparecían, alrededor de un núcleo de trabajadores de mayor rango, que permanecieron casi todo el tiempo en la obra. Noto que en el techo hay un grupo de trabajadores nuevos, una brigada de unos nueve hombres que están cortando madera y clavando palos y tablas. En este pelotón había dos o tres trabajadores que ya había visto antes, más otro grupo recién llegado a la obra.

Un trabajador nuevo que no reconozco trabaja picando piedra cerca de la entrada, en cuclillas. Varias caras me resultan nuevas. Hay como veinte o más trabajadores en total, la mayoría de ellos recién llegados a la obra; me resultan desconocidos, aunque también cada vez más familiares en cuanto a su perfil general... Unos pocos trabajadores, todos jóvenes y desconocidos para mí, se encargan de los últimos detalles antes de cerrar la semana laboral.

Me entero de que en la obra de Córdoba hay un nuevo maestro encargado de supervisar la parte final de los acabados, es un señor mayor de nombre Marcos. Esta es su primera semana en el cargo, desde que a Javier lo mandaron a dirigir la obra de Puebla junto con Silvano. "Ahí vamos, apenas nos vamos ubicando, pero todo pinta bien", me dice cuando nos presentamos.

\section{Bajas y desapariciones}

Cuando le pregunto a Raúl si piensa que va a estar trabajando ahí durante toda la obra, me dice: "sí, si no me corren", en tono de broma. El señor Raúl fue un personaje con una presencia relativamente larga en la obra, pero que finalmente desaparecería repentinamente a medio proceso constructivo, como casi todos los demás. 
Viendo con ellos las fotos que les llevo de regalo, me dicen que tal trabajador ya no fue, que a unos fierreros ya los mandaron a otra obra, que otros cuantos trabajadores faltaron y quién sabe si van a regresar. Por ejemplo, nunca volví a ver ni al velador ni a los otros albañiles jóvenes de peinados estilizados. Es difícil notar las ausencias, muchos se van y ya no se habla más de ellos, no se les recuerda, la vida en la obra sigue, la chamba continúa.

Me extraña no ver al Pato en esta ocasión, tampoco encuentro a Raúl. Noto que los hermanos Norberto y Abelardo ya no están; desde ayer los busco para darles sus fotos, pero alguien me dice: "Uy, güero, ésos dos ya no vienen por acá". Hay muchos trabajadores que por ahora ya no veo en la obra, como a Furcio y los cuñados del Pelón, pero luego volverían a aparecer. Un señor me dice que su hijo ya no trabaja ahí en la obra, porque no le querían pagar sueldo de oficial y ya encontró otro lugar donde valoran más su experiencia, a pesar de que se vea muy joven.

Platico un rato con Paul; cuando le pregunto por los demás, me cuenta que al Pelón, al igual que al Rufles, "los mandaron a descansar", o sea que los corrieron. "Es que faltaban casi cada lunes, y en los últimos días ya ni habían venido". Uno de los cuñados de Ángel me explica su versión: "lo que pasa es que faltó el lunes y entonces dieron su chamba, ocuparon su lugar". Siento pena sobre todo por mi amigo Ángel, que acaba de perder su chamba, pero al mismo tiempo confío en que podrá conseguir otro trabajo de albañil fácil y pronto en alguna de las múltiples obras que hay en la colonia. Pero además, resiento el haber perdido a uno de los que consideraba personaje central de esta investigación.

En ninguna de las dos obras encontré a Édgar ni a Raúl. ¿Será que ya no trabajarán más con DAKAB? ¿Los volveré a ver? Me cuenta El Gato que despidieron a Édgar y a varios trabajadores más: "tuvieron que rodar sus cabezas, con todo el dolor de mi corazón, le tuvieron que llegar". Continúa El Gato: "es como en todo, güero, seas bolero, albañil o vende chicles, el que hace bien su trabajo se queda y hasta sobresale; $y$ el que no, tarde o temprano se va a la verga".

Me encuentro y saludo a Javier, que anda apurado para arriba y para abajo, le pregunto por su hermano y me dice que ya no va a ir a trabajar más, "me duró poco el gusto de ver trabajando a ese pinche vago, sólo estuvo una semana en la obra, se aburrió y ahora quién sabe en qué anda el cabrón". 


\section{Migración}

Otra vertiente de la movilidad en los trabajadores de la construcción es la migración, que se presenta en distintas modalidades. En primer lugar, está la migración temporal o permanente del campo a la ciudad, del interior de la República a la capital, en busca de mejores empleos. Pero también conocí casos de trabajadores que habían migrado ilegalmente hacia los Estados Unidos o tenían planes de hacerlo.

\section{Al otro lado}

Escucho que entre Chucho y Ángel se comunican una noticia: "que ya cruzó, habló desde Arizona". Me dice Chucho que se refieren a su primo de 14 años, quien se acaba de ir al otro lado. "¿Qué más queda, qué puede hacer uno?", me pregunta resignado. Me quedo mudo, sin respuesta. "Es que allá se gana la misma cantidad, pero en dólares, que valen diez veces más que los pesos", reflexiona Chucho. Entonces iniciamos una larga plática sobre la migración de mexicanos a E.U., sobre lo atractivo que resulta migrar, las dificultades y los peligros que implica. Me relata algunos pormenores de este fenómeno, desde su propia experiencia.

Me cuenta que se acaba de ir un familiar suyo de 14 años. No estaba haciendo nada aquí, andaba de vago y metido en las drogas, entonces mejor prefirieron él y su familia que se fuera para allá. Chucho argumenta que lo bueno es que en Estados Unidos ya tiene una red de contactos familiares, "el tío de su vieja ya vive allá hace muchos años, hasta está naturalizado, y ha mandado traer a sus parientes con un pollero de confianza, que sólo cobra si la persona llega bien hasta su destino".

Chucho ya intentó cruzar una vez, hace no mucho, justo antes de empezar a chambear en esta obra, pero lo arrestaron y lo regresaron: "Ya estaba del otro lado, bien adentro por Arizona; íbamos un grupo como de 25 personas con el mismo "guía", que era de Oaxaca, y de los otros, muchos venían de Guatemala y Honduras. Era de noche y de pronto nos encontró un helicóptero y nos echó la luz, intentamos escondernos abajo de un árbol, pero no hubo cómo, unos corrieron pero igual los agarraron; sólo cuatro que iban pegados con el guía se salvaron y pasaron, porque sí se pudieron esconder bien. De ahí nos llevaron a un centro de 
detención, donde tenían a muchos ilegales, tantos que ni se podían contar. Era un salón muy grande, lleno de gente, principalmente centroamericana".

Sigue relatándome que los trataron muy mal, pero que no obstante, a los mexicanos los trataron mejor que a los centroamericanos, "a ellos los llevaban a otra sección del centro de detención y de ahí ya no los volví a ver". A él lo regresaron en avión hasta el aeropuerto de la Ciudad de México, y a partir de ahí empezó a trabajar en esta obra. Me pregunta si yo sé cómo hacer los trámites para pasar a Estados Unidos legalmente. Le explico lo que sé y concluimos que estaría difícil lograrlo. Tiene la firme determinación de esperar un rato más, para luego intentar cruzar otra vez en junio o julio.

Migración temporal del campo a la ciudad (campesinos-albañiles)

Con respecto a la migración del campo a la ciudad para trabajar en la construcción, Carmen Bueno señala, siguiendo a Dimitri Germidis, que existen "dos tipos de flujo de mano de obra: uno es el de campesinos que abandonan sus tierras con la esperanza de instalarse de manea permanente en la ciudad, y otro, el flujo discontinuo y estacional de agricultores en busca de un ingreso complementario" (Germidis, 1974, citado por Bueno, 1994: 25).

Hoy en día, en efecto, aún es palpable la existencia de estos dos flujos; en las obras estudiadas conocí algunos trabajadores que vinieron hace años de otros estados y se instalaron a vivir en la periferia del D.F., pero sobre todo me encontré con la presencia de trabajadores inmigrantes de origen campesino que vienen a la ciudad intermitentemente, pero "no se desligan por completo de sus comunidades de procedencia". Es interesante observar en estos sujetos híbridos "la intersección entre dos sistemas socioeconómicos distintos: uno basado en el trabajo asalariado y otro sostenido por la producción agrícola doméstica, atado a la esfera campesina". Se ven orillados a retomar elementos de los dos mundos para lograr sobrevivir, por eso "tienen características distintivas y una dinámica propia" para enfrentar "un trabajo que presenta condiciones laborales de gran inestabilidad" (Bueno, 1994: 25). Conocí muchos casos de migrantes temporales que utilizaban la obra como albergue, para no gastar su salario en pasajes y no perder tanto tiempo en su transportación. "Muchos de ellos viven un proceso de trashumancia permanente, se mueven del 
campo a la ciudad y después, en el vasto territorio de la gran urbe, continúan su peregrinar de obra en obra" (Bueno, 1994: 79).

Cuando Bueno realizó su investigación hace más de diez años, casi tres cuartas partes de los albañiles tenían experiencia laboral previa en el campo, sembrando en la milpa; formaban parte de un "circuito migratorio de campesinos de la zona central de México, que van y vienen entre la Ciudad de México y sus pueblos originarios, principalmente en el Estado México, Hidalgo y Tlaxcala" (Bueno, 1994: 120). Hoy día parece que el área de influencia se ha extendido hacia otros estados; en las obras estudiadas también conocí trabajadores provenientes de Morelos, Puebla y Veracruz, entre otros estados.

Me quedé cerca del trabajador que entrevistaba a los albañiles para inscribirlos al IMSS, para poder escuchar algunos datos sobre los trabajadores. Casi todos provenían de Hidalgo, Puebla y el Estado de México; "los que son de más al norte se van más bien a Acapulco, porque allá está mejor pagada la mano de obra", me comenta el empadronador. Tiempo después casualmente me cuentan que Eliseo está chambeando en Acapulco, también en la construcción, pero que allá gana más $y$ entonces se fue a probar suerte a la playa.

Pato y El Gato forman parte del "grupo Atlacomulco", un conjunto de trabajadores originarios de un pueblo "adelantito de Toluca", cerca de Atlacomulco, en el Estado de México. Habitan en la obra durante toda la semana y regresan a su pueblos sólo los fines de semana. Se vienen junto con otros compañeros que también trabajan en la ciudad y viven por allá. $A$ veces coinciden en la misma obra, como ahora, pero a veces se dispersan en distintas zonas de la ciudad. Casi siempre, después de pasar el fin de semana en sus casas, todos los lunes se ven a las cuatro de la mañana. Comparten un taxi para salir de sus pueblos, así llegan a la carretera y de ahí toman un autobús hasta la estación de Observatorio, desde donde se mueven en metro o microbús hasta sus lugares de trabajo. O si alguno de ellos no sabe dónde trabajar, se puede quedar en Observatorio y ahí también es casi seguro que consiga trabajo, al menos como peón. Los viernes también intentan regresarse juntos a su pueblo para compartir los gastos del taxi que toman desde la carretera hasta sus casas.

Comento con El Gato que ahora por Atlacomulco hay muchas obras públicas de caminos y puentes; "sí, ha cambiado mucho por allá", me contesta. "¿Y por qué no 
te has quedado por allá si hay chamba más cerca de tu casa?", le pregunto. "Primero, porque allá está barato, no pagan bien la mano de obra. Además aquí ya conocen mi experiencia, tengo mejor puesto y gano mejor. $Y$ sobre todo, güero, yo nunca quise ser un albañil de pueblo... me he topado con albañiles que se quedan toda su vida en su pueblo y no saben más que hacer casitas cuadradas con techos de lámina, en cambio un edificio como éste nunca lo podrían hacer, yo por eso siempre busqué aprender más y superarme". Después de tan elocuente respuesta, alcanzo a imaginarme una diferencia que antes no concebía entre ser un albañil de pueblo o un albañil urbano, e identifico en El Gato el impulso de superación que seguramente trae a muchos jóvenes trabajadores rurales a trabajar a las grandes ciudades como la de México.

Escucho que un grupo de trabajadores que provienen del estado de Puebla hablan en lengua totonaca entre ellos. Cuando me les acerco cambian a un español con marcado acento indígena y me cuentan que llevan muchos años trabajando en la construcción en la ciudad. Uno mayor y el otro bastante más joven, quizás padre e hijo. El mayor me cuenta que trabajó muchos años en la cocina de un restaurante... El Hormiga atómica proviene del Estado de Veracruz. "¿Ya van terminando esta obra?", le pregunto. "Ya casi, poquito a poco", contesta. "¿Y acabando aquí se va a la obra de Puebla?", "yo creo sí, mientras haya chamba, está bien", responde con acento jarocho.

En este sentido, resulta pertinente mencionar algunos estudios sobre el tema de la migración temporal entre los trabajadores de la construcción, que se han realizado en México y otros países de Latinoamérica. La misma Carmen Bueno explora más a fondo este aspecto en su artículo: "Trabajadores indígenas en la construcción de vivienda en la Ciudad de México" (1992). El libro Albañiles campesinos: La migración temporal de los obreros de la construcción (1986) de Amalia Mauro, aborda este problemática para el caso de Quito, Ecuador. Asimismo, el libro Paraguayos, bolivianos y argentinos en la obra. Identidades étnico-nacionales entre los trabajadores de la construcción de Patricia Vargas (2005), hace lo propio para el caso de Buenos Aires, Argentina. En los tres casos, se enfatiza que la mano de obra migrante, también llamada "pendular", se ajusta perfectamente a las necesidades de la industria de la construcción por su carácter inmediato, intensivo, rotativo y no calificado. 
Definitivamente, la relación simbiótica entre la construcción y la agricultura de subsistencia es un punto muy interesante para analizar. Esta problemática guarda una estrecha conexión con el tema de "las migraciones temporales de la fuerza de trabajo". De acuerdo con un estudio citado por Connolly, en tres obras estudiadas, "entre el $60 \%$ y el $80 \%$ de los trabajadores provenían de zonas rurales de agricultura tradicional" (Connolly, 1988: 215). En el caso de las obras de DAKAB, el grupo de trabajadores que vive por Atlacomulco, caen perfectamente dentro de esta categoría de trabajadores que son obreros y campesinos a la vez, personajes tan rurales como urbanos.

\section{Tránsito entre obras}

Por un lado, "los albañiles... buscan las zonas en la ciudad donde se llevan a cabo varias obras a la vez y así brincar de un sitio de construcción a otro", o bien de un oficio a otro (Bueno, 1994: 106). Por ejemplo, me comenta Braulio, un trabajador mayor, que por ahora la zona central de la ciudad es donde más posibilidad de chamba hay, porque hay cientos de obras de construcción, y basta con caminar por las calles de la Roma, la Condesa o el Centro para encontrar obras y preguntar si hay jale: "casi siempre se puede encontrar chamba de albañil, aunque luego no tan bien pagada".

Por otro lado, Carmen Bueno menciona una situación que se aplica perfectamente al caso de las obras de la compañía DAKAB en la colonia Roma, esto es, que "la coordinación de subprocesos se facilitaba más porque la empresa constructora tenía varios proyectos a la vez en la misma zona, lo que daba cierta estabilidad en la demanda de trabajo" (Bueno, 1994: 101). Entre las obras de Córdoba y Puebla había un flujo constante de trabajadores que al terminar su propio proceso en una obra tenían posibilidades de comenzar en la siguiente.

Sin duda, un factor que incrementó la movilidad de los trabajadores en nuestros casos fue el hecho de que la misma compañía constructora comenzara otro proyecto a pocas cuadras de distancia. Así, empleaban trabajadores e intercambiaban herramientas y materiales entre una y otra obra indistintamente, según fuera necesario. Esta situación originó un constante tránsito de albañiles entre estas dos obras de DAKAB. 
Me encuentro con Javier en la obra de Puebla, me dice que ahora él está a cargo de esta obra, junto con Silvano. Veo al velador, también al carpintero Calderón, a Paul y a otros trabajadores que antes estaban en Córdoba y ahora están en la obra de Puebla. Según Silvano, Raúl también está en la obra de Puebla, junto con otros dos que también ya se fueron para allá. A Édgar ya también lo transfirieron de la obra de Córdoba a la de Puebla.

Veo con gusto que reaparecen varias caras conocidas de gente que hace tiempo no veía: reconozco a Édgar, a Israel, al otro exvelador gordito con bigote, a los dos cuñados del Pelón, a uno más que usa lentes, etc. Platicando con Javier, me entero de que la gente que estaba en la obra de Patricio Sanz ya se vino para acá, porque allá ya terminó la obra negra. "Ahora aquí los patrones ya quieren ir de volada para arriba, por eso metieron más gente y vamos a otro ritmo, el viernes colamos", señala de prisa Javier.

Me cuenta Silvano que aquí en la obra de Puebla ya que terminaron temprano el colado, que era la actividad principal del día, mandó a varios hombres a la obra de Córdoba. Más adelante, por la clausura de la obra de Puebla desde el vienes a mediodía, varios trabajadores se fueron a la obra de Córdoba, "para no desaprovecharlos y avanzar más de volada", dice Silvano. Una vez reabierta la obra de Puebla, nuevamente los trabajadores que van acabando aquí en la obra de Córdoba, me dice Bobadilla, se van yendo a la obra de Puebla, como ya se han ido varios. Me pregunto ¿de qué depende a quiénes dejan en una obra y a quiénes mandan a la otra? ¿Por qué Chucho y el Hormiga atómica, por ejemplo, no se han ido a la obra de Puebla, como casi todos los demás?

Los trabajadores que montan el elevador me cuentan que también trabajaron en la obra de DAKAB en la calle Patricio Sanz, ahora están en Córdoba, de ahí pasarán a la de Puebla, luego a la de Sánchez Azcona y de esta manera esperan mantenerse trabajando durante todo el año, "Parece que ahora sí puede haber chamba todo el año... primero Dios", dice uno de ellos. Su destino laboral está ligado —en buena medida y al menos por ahora- a la suerte financiera de la empresa constructora.

Silvano me cuenta algún chisme sobre otra obra que hay en la misma zona de la Roma, algo que le contaron unos trabajadores que venían de allá. Es muy interesante rastrear las redes y relaciones que se establecen entre las tantas obras que hay en la zona, a través del vaivén de los trabajadores, como Ángel, que ha 
transitado por varias obras. Los que han transitado entre diversos sitios constructivos cuentan sus historias y pormenores, comparten y comparan sus experiencias y trayectorias. Un trabajador que va de obra en obra lleva con él información, datos y experiencias sobre las obras anteriores.

Cuando un día llego a la obra de Puebla y casi no encuentro a nadie familiar, un trabajador me cuenta que a Javier, al Gato y a Pato, entre otros, ya los mandaron a trabajar a la otra nueva obra de DAKAB en la calle de Sánchez Azcona, colonia del Valle.

\section{Otras chambas}

También es común que los albañiles realicen otros trabajos esporádicos fuera de la construcción, como por ejemplo el pequeño comercio durante los fines de semana. El caso de Ángel es muy ilustrativo en este sentido, además de su trabajo en la obra entre semana, trabajaba de limpiaparabrisas en la Zona Rosa los fines de semana. De acuerdo con el estudio de Carmen Bueno, "como regla general, entre menor es el ingreso obtenido en la construcción, mayor el porcentaje de trabajadores que buscan ocupaciones fuera de la obra" (Bueno, 1994: 143).

La construcción brinda a la mano de obra la alternativa de moverse de manera selectiva entre oficios, además de que las habilidades constructivas se pueden utilizar para realizar otros trabajos por cuenta propia... La obra se convierte en el lugar donde se intercambia información que después se utiliza para obtener mayores ingresos (Bueno, 1994: 152, 145).

En muchos casos, el trabajo de albañil se alterna con otro tipo de empleos a lo largo de la trayectoria laboral de una persona: además de albañiles en otras obras, muchos de los personajes que conocí eran o habían sido también boleros, limpiaparabrisas, trabajadores en una feria, delincuentes, etc. De esta forma, las trayectorias profesionales de algunos de estos trabajadores de la construcción son un compendio de experiencias acumuladas en distintos ámbitos y oficios. Por ejemplo, Paul me platica que también ha trabajado en obras públicas y antes trabajaba de plomero en la comisión de agua, por un primo que lo metió, y ahí sí está más pesado, luego no se puede descansar, si hay una fuga a la hora que sea te ponen a excavar y a repararla. "¿Pero el pago era mejor?", le pregunto; "No, estaba igual o hasta menos", responde. 
Furcio me pregunta que cuándo le llevo su foto, me pide que sea pronto porque no sabe cuánto tiempo más va a trabajar en esa obra, "estoy aquí sólo de mientras", ya que tiene otra chamba de albañil pega azulejos donde le pagan más, en Interlomas, donde gana mínimo \$1,600 por semana, mientras que en Córdoba recibe sólo mil pesos. A la semana siguiente, Furcio, quien supuestamente se iba a pegar azulejos, continúa trabajando en esta obra, en contra de sus predicciones. Me platica que siempre no se fue, como me había dicho, pero que a lo mejor la próxima semana sí: "ojalá, porque se gana mucho más, en una semana puedo sacar mucho más que mil pesos". Varias semanas después reaparece Furcio y me cuenta que le fue bien pegando azulejos, que ganó hasta dos mil pesos por semana. Pero por el momento no había más chamba para él allá, así que decidió regresar otra vez a la obra de Córdoba.

Converso un rato con Silvano, quien me confiesa que tal vez dejará esta chamba porque le ofrecen otra mejor pagada: "por la economía, más que nada", me dice. Pero no es completamente seguro que salga ese otro trabajo. De hecho, está considerando la posibilidad de llevar las dos obras al mismo tiempo, una a distancia y la otra in situ; me cuenta que ya lo ha hecho así en otras ocasiones, entre Sinaloa y Acapulco: "dejo dos cabos y me la aviento por teléfono"... Más adelante, Silvano me platica que todavía no decide si seguirá chambeando aquí o se irá a la otra obra donde le ofrecieron trabajar en la construcción de una casa particular, que cree que le conviene más. Le pregunto a Édgar si también se iría con Silvano, su suegro, si es que se va a otra obra; me dice que "hay que andar con el 'mai' a donde nos lleve". Pero cuando le pregunto a Silvano si sabe algo de su otra oferta de trabajo y a quién se llevaría con él, contesta que no ha decidido nada aún, aunque supuestamente allá le multiplicarían el sueldo por tres, pero asegura que no se llevaría a nadie con él, porque Nicolás es un gran amigo suyo y no sería leal descompletarle su equipo de trabajadores aquí. "De todos modos yo conozco más gente por allá", afirma.

En la esquina de Córdoba y Durango veo al Tlacuache, que antes trabajaba en la obra. Me sorprende que ahora trabaja como bolero afuera del Bancomer. Eventualmente comento el punto con Ángel:

—“Vi al Tlacuache de bolero"

- "Sí, ahí anda el güey cubriendo a su jefe". 
- ¿¿Ah sí? ¿O sea que es temporal?"

- "Sí, no, bueno, quién sabe, es que su jefe está enfermo, está grave, es que antes le entraba muy duro al alcohol y está bien destrozado por dentro, unos días está bien, unos mal y otros peor".

- ¿YY tú sigues trabajando de limpiaparabrisas?"

- "Ya casi no he ido, es que está cabrón el operativo, te levantan por limpiar vidrios y no vale la pena.

Los casos del Tlacuache y El Pelón son buenos ejemplos de que la albañilería es un trabajo que para algunos es sólo transitorio, casi circunstancial, un recurso siempre disponible para muchos jóvenes que por su situación marginal y falta de otras oportunidades recurren al trabajo físico no calificado de la construcción como una opción casi siempre viable.

Me pide Ángel mi teléfono para poder localizarme, por si ya no trabaja en la obra la próxima semana, porque dice que hay rumores de que va a haber cambios y recortes en el personal, y él presiente que a él le podrían cortar la cabeza. Previendo eso, me cuenta que hace rato, a la hora de comer, ya pasó con el maestro de otra obra que está a una cuadra, también sobre Córdoba, entre Tabasco y Colima, para ver si ahí habría "jale", y le dijeron que sí. Cuando un poco más adelante desaparece Ángel, ninguno de sus parientes sabe a ciencia cierta dónde está trabajando El Pelón... Semanas después, el Tlacuache me dice que últimamente no ha visto mucho a sus primos y del Pelón me comenta que le dijeron que está trabajando en otra obra ahí cerca, en el mismo barrio, pero quién sabe dónde.

Por otro lado, Chucho me cuenta que casi siempre tiene más opciones de empleo bajo la manga, a las que suele recurrir. Por ejemplo, un tío suyo es contratista y con él, pegando azulejo, gana un poco más, "no mucho más, sólo unos 200 pesos extras a la semana, pero algo es algo"... Le pregunto por su cuñado, El Pelón, y me cuenta que hasta donde él sabe, la semana pasada trabajó en la obra grande del edificio que está en Reforma 222 (me señala el edificio blanco que se puede ver al final de la calle). Dice que allá le pagan más que aquí, \$1,300 pesos por trabajar en el quinto piso, pero que entre más arriba trabajes, te pagan más porque es más peligroso.

Tiempo después me llevo la sorpresa de encontrarme nuevamente a Ángel, EI Pelón, quien regresa a estas obras después de varios meses de trabajar en otros lados. Me cuenta que efectivamente trabajó en la obra del edificio que está ubicado en Reforma 222 y me platica sobre esa experiencia laboral: 
-Qué milagro.

-No pues sí, anduve chambeando aquí y allá.

- Me dijo Eliseo que andabas chambeando en la obra de Reforma. ¿Cómo te fue ahí?

-Bien.

- ¿Andabas muy alto?

- Nel, hasta abajo, arriba sí está más peligroso, pero pagan más.

- ¿A ti te pagaban bien?

-No me puedo quejar del sueldo, pagaban un poco mejor que aquí, andaba con los tablarroqueros. Pero allá estaba bien pesado, la jornada es de 8am a 10pm, demasiado cansado, entonces mejor vine para acá otra vez. Aquí el sueldo está más o menos, pero a veces me da flojera, me aburro y mejor me voy a buscar a otro lado.

También me cuenta que otra chamba en la que anduvo fue en la construcción de la nueva línea de tren suburbano por el Estado de México, una gran obra pública, pero dejó de estar bien y se regresó aquí. Habló con el maestro Nico ayer lunes como a las 8 de la mañana para pedirle chamba otra vez, y la consiguió. Comentamos que sus cuñados ya tampoco están trabajando aquí, Eliseo está en una obra por San Juan del Río, y otros de sus primos y cuñados están trabajando como limpiaparabrisas en el crucero de la calle Niza con Insurgentes, en la Zona Rosa.

Mientras El Gato serrucha un polín, Javier nos platica sobre su otra chamba: alternativamente, de vez en cuando es "feriero", trabaja en las ferias ambulantes que se montan y desmontan de pueblo en pueblo, de fiesta en fiesta.

- ¿Hace cuánto chambeas en eso?

- Cada que me aburro de la construcción. Se gana buena lana. Imagínate, a 15 pesos el boleto para cada juego, y se venden rollos de cientos de boletos. También ayudo a armar los juegos mecánicos. En mi barrio allá por Naucalpan esa feria se monta a mediados de agosto y dura todo el fin de semana.

Me cuenta largo y tendido sobre las ferias, con lujo de detalle: que el patrón deja que sus hijos se monten gratis, que por costumbre les ceden a los operadores las ganancias de la primera vuelta, etc. "La inversión se recupera en un año y es un buen negocio, pero luego también se aburre uno mucho porque una vez montado todo ya no hay nada que hacer, y entonces mejor me voy a jugar billar".

En la azotea un chavo solitario sigue colocando el piso. Llega el otro chavo joven y le pregunta por qué no fue a trabajar ayer, a lo que le contesta que porque los 
llamaron de urgencia al otro trabajo, le vuelve a preguntar que cuándo van a terminar de poner el piso, y contesta que el jueves supuestamente ya queda, pero que ahora se lo tiene que echar casi todo él solo porque sus demás compañeros se van a quedar en la otra chamba.

\section{Transformaciones y desigualdades en el mercado laboral urbano}

Richard Sennett aborda algunos aspectos de la esfera laboral que resultan relevantes para la presente investigación. Este autor propone algunas nociones y señala caminos para pensar los problemas contemporáneos referentes a la mano de obra y la cultura laboral. En La corrosión del carácter (2006) analiza las profundas transformaciones que han sufrido el orden laboral y la noción misma de trabajo bajo el régimen político y económico que denomina "nuevo capitalismo", que ha traído consigo "nuevas maneras de organizar el tiempo, y en especial el tiempo de trabajo" (Sennett, 2006: 20). Para reforzar este argumento, cabe señalar, de acuerdo con Raúl Nieto, que "el conjunto de relaciones establecidas entre el trabajo, la cultura, el orden social y urbano está cambiando" (Nieto, 1998: 124).

El análisis de Sennett de este nuevo ámbito laboral se puede aplicar en buena medida a las relaciones laborales en el mundo de la construcción; no obstante, es necesario aclarar que las razones que determinan estas circunstancias son completamente diferentes en el ámbito de la obra y en el ámbito de las nuevas formas de trabajo en el neocapitalismo que describe este autor. Las relaciones laborales a las que Sennett se refiere tienen que ver con las condiciones del mundo moderno, están marcadas por el mercado global y el uso de nuevas tecnologías. En contraste, en el caso de las relaciones laborales que existen en las obras de construcción de vivienda, su origen es más antiguo y sus causas son más bien culturales y sociales, y no tanto políticas y económicas (aunque evidentemente hay también factores de este tipo que influyen en ellas). Definitivamente una obra de construcción no es un ámbito laboral posmoderno como los que describe Sennett. Más bien al contrario, podría decirse que la construcción es, en buena medida, un ámbito de trabajo a la usanza tradicional. Pero una vez establecida esta divergencia fundamental, cabe destacar que hay paralelismos importantes entre estos dos ámbitos que vale la pena resaltar. 
Como hemos visto anteriormente, el trabajo es un elemento esencial en la conformación de la cultura y la personalidad, un componente clave en la constitución de la identidad individual y colectiva. Además, juega un papel fundamental en la estructuración del orden urbano, establece un orden espacio-temporal en la ciudad. De acuerdo con Sennett, ya prácticamente no existen las rutinas estables, las trayectorias laborales predecibles, la adhesión o la lealtad a una empresa, ni la estabilidad, seguridad o confianza en cuanto al contrato de trabajo y las condiciones laborales. Los trabajadores, como por ejemplo los obreros de la construcción, se enfrentan a un mercado laboral flexible, a empresas constructoras dinámicas, a reajustes y recortes periódicos e imprevisibles en la plantilla de trabajadores, a exigencias de movilidad absoluta. Se trata de un orden laboral marcado por la movilidad, el riesgo, la flexibilidad y la inmediatez. Para sobrevivir en este medio, los trabajadores deben ser "capaces de reinventarse a sí mismos sobre la marcha" (Sennett, 2006).

En este sentido, Sennett plantea que este tipo de contextos laborales "puede afectarnos profundamente, al atacar nuestras nociones de permanencia, confianza en los otros, integridad y compromiso" (Sennett, 2006). A Sennett le preocupan sobre todo los efectos que tienen estos comportamientos, prácticas y relaciones laborales en el carácter de los trabajadores, en su vida interior y moral, el impacto que tiene sobre su vida extralaboral, sobre el resto de sus relaciones personales, vida familiar, imaginario, emociones y salud mental. Se pregunta, por ejemplo: ¿cómo perseguir metas a largo plazo en un panorama laboral entregado al corto plazo? ¿cómo sostener la lealtad y el compromiso recíproco cuando las relaciones laborales están en continua desintegración o reorganización? (cf. Sennett, 2006: 10).

Resulta interesante reflexionar sobre las relaciones de trabajo y las condiciones laborales que encontramos al interior de la obra, a la luz de las ideas de Sennett. La mayoría de los trabajadores son multiusos y desempeñan casi cualquier labor que se requiera. Entre más versátil sea un peón, más se valora su trabajo. La carrera de los trabajadores es impredecible, pueden comenzar su trayectoria como peones o albañiles y terminar como carpinteros, fierreros o bien en otro ramo laboral del mercado de trabajo urbano completamente distinto. Además, es necesario tomar en cuenta la inestabilidad laboral: los pueden correr, recortar la plantilla laboral, clausurar la obra, o simplemente pueden terminar un proyecto sin tener otro en 
puerta. Los trabajadores presentan una movilidad constante, una transitoriedad entre obras, entre oficios, entre ramos de la construcción, entre distintos tipos de trabajos (como por ejemplo bolero, limpiaparabrisas $u$ operador de juegos mecánicos en una feria). La duración de una obra puede considerarse un proyecto de mediano o incluso a veces de largo plazo, pero en la inmensa mayoría de los casos la inserción o participación de los trabajadores en ella, su paso por la obra, es definitivamente de corto plazo. Solamente uno o dos trabajadores que conocí desde el principio, conservaron su trabajo durante todo el proceso constructivo, y cabe mencionar que éstos fueron algunos de los trabajadores de más alto rango. Los trabajadores de la construcción deben estar abiertos al cambio, deben asumir riesgos, tanto riesgos físicos dentro de la obra como tomar decisiones laborales riesgosas, como permanecer en una obra o buscar trabajar en otro lado.

Las condiciones laborales de los albañiles dependen cada vez menos de reglamentos y procedimientos formales. Se trata de un contrato verbal basado en la confianza y la flexibilidad. La trayectoria laboral de los trabajadores de la construcción no es fácil de reconstruir en términos lineales, su carrera no está compuesta por etapas sucesivas claramente definidas, marcadas por unos pocos oficios o puestos de trabajo. Van y vienen constantemente entre distintos empleos, muchas veces se van de una obra y regresan al cabo de unas semanas. Combinan varios trabajos al mismo tiempo, como El Pelón: albañil entre semana y limpiaparabrisas los sábados y domingos. Su identidad y experiencia laboral está formada por episodios y fragmentos.

En el mundo de la construcción, como dice Sennett, "la fuerza de trabajo es siempre contingente" (Sennett, 2006: 20). El entorno laboral de la obra es siempre impredecible, la experiencia de los trabajadores está marcada por la incertidumbre, por la sensación de estar siempre a la deriva, además de ser invisibles para las clases medias y altas. Los contratos - casi nunca oficiales, tan sólo verbales- son a corto plazo, circunstanciales, y el trabajo siempre es temporal. Para ser albañil se debe estar dispuesto a mudarse y cambiar de trabajo, y por lo tanto de hábitat, con suma frecuencia. Un trabajador de la construcción debe ser flexible, adaptable, amoldable. "La incertidumbre está integrada en las prácticas cotidianas y la inestabilidad es algo normal... La gente ha aceptado que la vida cambia de repente... y también que, para sobrevivir, hay que improvisar" (Sennett, 2006: 30). 
Bajo un régimen así, los obreros se tornan menos capaces de establecer lazos duraderos, ni entre ellos, ni con otros actores, ni con el espacio en el que trabajan y habitan. En ambientes de esta naturaleza, a Sennett le preocupa "el aspecto fugaz de la amistad y de la comunidad local" (Sennett, 2006: 19). En cuanto al compromiso y la lealtad, "el principio de "nada a largo plazo" corroe la confianza... En un plano más personal, se desgasta la disposición a establecer compromisos con los demás, imperan el desapego y la cooperación superficial" (Sennett, 2006: 22).

Finalmente, me parece importante destacar, siguiendo a Nieto, que junto con "los nuevos e hipermodernos contextos laborales", como los que describe Sennett, persisten lamentablemente "las formas más degradadas y precarias del trabajo y el subempleo... El orden urbano y el orden laboral -a la manera de dos ríos- son tributarios de un orden social que está fundado en la desigualdad y en la existencia de clases sociales". En este sentido, afirma Nieto que en los estudios sobre el mundo laboral y el ámbito urbano, es muy importante no confundir las diferencias culturales con las desigualdades sociales, que se agravan cada día más en la sociedad contemporánea, por lo que es urgente entender sus causas estructurales, tanto políticas como económicas, para poder pensar y buscar caminos alternativos (Nieto, 1998: 128).

\section{Usos y costumbres: ¿cultura albañil?}

En este apartado intentaré hacer un retrato hablado del perfil cultural de los albañiles y otros trabajadores de la construcción, describiendo diversos aspectos de su forma de ser, sus creencias, prácticas, formas de vestirse, de hablar, de trabajar, de relacionarse entre ellos y con extraños, etc. Todo esto lo recojo a través de la observación etnográfica a lo largo de un año y medio de convivencia con ellos en su entorno laboral, dentro del ámbito de su vida cotidiana.

Ante la movilidad que caracteriza y define el oficio de los albañiles, ¿cómo puede hablarse de gremio o de un grupo social, cuándo los sujetos que supuestamente lo conforman permanecen tan disgregados entre sí? A pesar de la inestabilidad que los caracteriza, en mi opinión los albañiles comparten una serie de experiencias que les confieren ciertos rasgos culturales en común, como por ejemplo: la música y las estaciones de radio que escuchan, la sabiduría práctica que implica su oficio, la 
preferencia por ciertos equipos de fútbol, el juego de naipes, el gusto por el material pornográfico, el hábito de fumar tabaco o marihuana, de beber y emborracharse, el consumo de ciertos medios masivos de comunicación, cientos de términos técnicos y vocablos de una rica e ingeniosa jerga popular, etc. Estos rasgos conforman un núcleo o matriz cultural de un sector de la fuerza de trabajo que se dedica a la construcción, y es a lo que me referiré como cultura albañil.

Me parece que en la cultura albañil —si es que podemos llamarla así1 expresan claramente ciertos rasgos característicos de la idiosincrasia de los sectores más populares de la población mexicana. En cuanto a su cultura laboral, en primer lugar cabe destacar su ingenio, creatividad, inventiva y capacidad para resolver problemas prácticos con los pocos recursos que tengan a la mano. Todas estas habilidades, que nacen de la condición de carencia y precariedad en la que viven y desarrollan su trabajo, se condensan en un gran acervo de sabiduría popular. Resulta interesante su forma de reproducción del conocimiento práctico relativo a su oficio. No queda más que aprender en la práctica, o como suele decirse: la práctica hace al maestro. Otros aspectos importantes de la cultura laboral de los trabajadores de la construcción tienen que ver con su alto grado de informalidad, que ha dado pie al estereotipo generalizado del albañil holgazán e irresponsable; ciertamente, en muchos casos son desobligados, faltan a menudo, trabajan desorganizadamente y hay muy poca regularidad en sus labores, en suma, mantienen un estilo informal de trabajo.

También considero relevante indagar en aspectos extralaborales, cuando están en sus ratos de descanso, de ocio, durante sus traslados, o en su entorno íntimo, en su vida privada, familiar. Así, observé con atención y a continuación describo algunos otros rasgos distintivos de su cultura y vida cotidiana, como su apego al lugar de origen, su hábitos alimenticios, su forma de hablar y usos del lenguaje, los apodos y albures, la música y las estaciones de radio que escuchan, los remedios populares a los que recurren, sus prácticas y creencias religiosas, su desafío al peligro y su afición al fútbol, además de la vestimenta que utilizan, su relación con la tecnología y los medios de comunicación, sus ideas e imaginarios entorno a la salud y la sexualidad, sus prácticas recreativas, juegos y uso del tiempo libre, sus dinámicas en ciertos

\footnotetext{
${ }^{13}$ Para una discusión seria sobre los usos del término cultura en combinación con otros conceptos, particularmente dentro de la antropología mexicana, sería pertinente remitirnos al libro La cultura adjetivada de Esteban Krotz (1993).
} 
momentos determinados como el fin de la jornada laboral o el descanso después de comer, además de otras impresiones, detalles y sutilezas aparentemente insignificantes que sin embargo, a mi parecer, sintetizan o expresan de manera vívida la vida diaria de los albañiles.

Definitivamente, los albañiles conforman un gremio muy peculiar con una gran riqueza cultural. Son, cada uno, sujetos multiculturales, multifacéticos, con varios rostros. Representan un estilo híbrido particular entre lo rural y lo urbano; son personajes complejos que encierran muchas de las contradicciones propias de un entorno multicultural como la Ciudad de México a principios del siglo XXI.

\section{Vestimenta}

El equipo de carpinteros usa una ropa parecida al uniforme de la Compañía de Luz y Fuerza: pantalón y camisa color café claro, botas negras de cuero, cascos blancos y un cinturón en el que cargan todas sus herramientas. El atuendo del resto de los trabajadores consta de ropa del diario convertida en ropa de trabajo a través del desgaste: las botas de hule "son de ley" en ciertas etapas de la obra, el pantalón metido dentro de las botas, camisa o camiseta, fajada o desfajada, siempre algo en la cabeza, ya sea una gorra, con la visera hacia adelante o hacia atrás, un paliacate o entre los más jóvenes es común que tengan peinados estilizados, con mechas decoloradas y en algunos casos usan piercings en la cara.

Me llaman la atención dos albañiles muy jóvenes, con peinados estilizados, cual personajes de dibujos animados japoneses, con picos en el cabello mantenidos gracias a una generosa cantidad de gel y las patillas en forma espiral. Sus pantalones de trabajo están rotos de todas partes... Dos peones muy jóvenes laboran vestidos con su ropa de trabajo pero sin perder el estilo, con peinados muy elaborados, tipo cholos. Uno de ellos destaca por su look moderno y un peircing amarillo fosforecente en la ceja. A esta pareja de albañiles en adelante los identificaría como "el que viste a la moda" y "el que porta un arete en la ceja".

El primo del Pelón está vestido de sudadera azul con capucha que tiene una leyenda en inglés. Trabaja trepado en un andamio junto con el otro cuñado de Ángel, que casi siempre usa ropa deportiva y en esta ocasión porta una camiseta del equipo de fútbol de Barcelona. Sus tenis y jeans deshilachados cuelgan por debajo del andamio. 
Dos jóvenes yeseros trabajan trepados sobre cubetas, con peinados modernos y pantalones holgados de batalla, toda su ropa está completamente manchada de blanco, con la cara y la manos también salpicadas de yeso y pintura. Uno de ellos porta un gran escapulario, abundantes pulseras metálicas y un imponente tatuaje de la Santa Muerte en el brazo.

Uno de los ayudantes porta un sombrerito típico de albañil sobre la cabeza, con forma de barquito de papel pero invertido, hecho a partir de un trozo de papel estraza o cartón arrancado de un saco de cemento. A pesar de que en el imaginario popular éste tipo de gorrito figura como un rasgo característico de la vestimenta de los albañiles, hoy en día ya no es común encontrarlo, ahora más bien todos usan cachuchas de béisbol o gorros de tela, sobre los cuales, a veces, portan también el casco.

Antonio Bobadilla viste una gruesa chamarra y guantes, bien protegido del frío invernal. No cabe duda de que en el estilo y el tipo de vestimenta se puede notar claramente la diferencia y la jerarquía de los distintos actores en la obra. Al día siguiente, Bobadilla usa la misma ropa que el día anterior.

Un par de trabajadores cortan piezas del material con el que recubrirán la fachada del edificio, con la cara cubierta con una camiseta enrollada en la cabeza, en vez de usar máscaras más apropiadas. Para protegerse del inclemente sol del mediodía, otro trabajador se cubre la cabeza amarrándose una camiseta alrededor de la gorra... Un chavo con estilo y actitud "emo" porta múltiples pulseras de tela de colores, entre ellas una del grupo mexicano de rock Zoé. En contraste con este estilo llamativo, junto a él un trabajador mayor viste de manera muy sobria, portando una camisa gris con el logotipo del G.D.F.

Un peón con un mechón teñido de güero que le cae sobre la mitad de la cara, anuda alambre en torno a unas varillas, cubriéndose del sol con una sudadera de gorrito. Israel, el actual velador, usa un gorrito tejido de lana con orejeras, estilo inca. Aprovecha el momento de descanso para amarrar las agujetas de sus botas... Un trabajador con el pelo engominado hacia atrás, estilizadas patillas con ramificaciones, vistiendo una camiseta blanca sin mangas, con varios escapularios que le cuelgan del cuello, completamente bañado en sudor, avienta tierra, lodo y escombros a la parte trasera de un camión de carga. 
El Gato está sin casco, con gorra, camiseta amarilla sin mangas y su chamarra de mezclilla... Édgar, El Gordo, peinado con cola de caballo que sobresale de su cachucha, después de guardar sus botas de hule en una bolsa de plástico, las avienta a un rincón de la bodega, comenta que no se las lleva a su casa porque apestan, "mejor que se queden aquí estas pinches botas hediondas"...

El Pato viste una sudadera marca Guess, de moda en los años 80. Me parece curioso que muchos albañiles usan ropa de marcas americanas o con leyendas en inglés, que seguramente adquieren en la fayuca o en mercados de ropa de segunda mano. También es común que vistan camisetas de antiguas campañas políticas, que en su momento tenían un sentido determinado, y que después se reciclan y sirven como ropa de trabajo, o de batalla, como le dicen ellos. Por ejemplo, el Pato anduvo varios días vistiendo una camiseta del PAN como su uniforme de trabajo. Cuando le pregunté si de verdad era simpatizante del Partido de Acción Nacional, me respondió que a él la política le da lo mismo, y que esa camiseta se la habían regalado a su esposa un día en Toluca, pero le quedó mejor a él.

Me gusta cómo los fierreros, al igual que los carpinteros, usan una bolsa de cuero que les cuelga por un costado, amarrada a su cinturón, en la que portan sus herramientas, para tenerlas siempre a la mano.

\section{Juegos y actividades recreativas}

Unos albañiles juegan fútbol usando el edificio en obras como terreno de juego. La pelota vuela y rebota en los cerros de materiales apilados en el piso, su trayectoria se desvía por culpa de la basura y se patina por los charcos. La cancha plagada de obstáculos no tiene límites definidos, donde caiga la bola se sigue jugando; la única portería está señalada con dos cubetas cerca de una esquina del oscuro sótano.

El Gato me platica que juega en la liga municipal de fútbol allá por donde vive, en Atlacomulco, Estado de México. Hay primera, segunda y tercera división; son más de 30 equipos en total. Él estaba en la primera división con el equipo de los Pumas, pero la temporada pasada descendieron y este año estuvieron a punto de regresar, pero fueron eliminados en semifinales.

Hasta abajo en el sótano, donde será el estacionamiento, hay dos grupos de trabajadores jugando baraja alrededor de un par de mesas improvisadas con una tabla de madera, sostenida sobre unos cuantos tabiques. Hacen sillas y mesas de lo 
que sea, se sientan sobre cubetas, en una viga o sobre un trozo de unicel. Entre ellos reconozco al Pelón, a Paul y a Andrés, entre otros trabajadores ya familiares. En este torneo de cartas subterráneo, instalado junto a un cerro de escombro y basura, se apuesta con monedas de uno o dos pesos y se fuman cigarros Delicados, ovalados, sin filtro.

Sobre la mesa cada quien tiene sus monedas, hay algunas hasta de cinco o diez pesos, aunque la apuesta máxima no suele pasar de dos pesos. A lo largo de la partida anotan el marcador rayando con un clavo la tabla que hace las veces de mesa. Arrojan las cartas sobre la madera con mucho ímpetu. Confieso no entender las reglas del juego, a pesar de que ya me lo intentó explicar El Pelón, pero sin mucho éxito, porque nos quedamos empantanados en la traducción cultural. Pasadas las dos de la tarde, llegando al final de su hora de descanso, reanudan sus labores poco a poco, resistiéndose a dejar el juego, picados, pidiendo revancha.

\section{Tecnología y medios de comunicación}

Podría pensarse que los albañiles, por su situación de pobreza, tienen poco contacto con los medios de comunicación y uso de la tecnología, pero en realidad sucede todo lo contrario. Los trabajadores de la construcción son grandes consumidores de radio y televisión, ya sea en la obra o en sus casas, mantienen estos aparatos prendidos a su alrededor la mayor parte del tiempo. Varios de ellos leen el periódico, sobre todo la prensa deportiva, así como historietas ilustradas del tipo del libro Vaquero. Además, recientemente muchos de ellos se han convertido también en usuarios de la telefonía celular.

El radio suena a todo volúmen desde la caseta de entrada. Hay una enorme grabadora sobre un bote de pintura volteado de cabeza, la clavija está conectada a un cable pelado por la punta. Una estación (106.5 FM) Ilena de música y anuncios todo el piso de arriba, anima la labor de los albañiles, que tararean la "música de los ochentas, noventas y más".

En la radio, que está cerca de ellos, hay un concurso al que todos los obreros, fieles radioescuchas, permanecen atentos. El locutor atiende llamadas de la gente que se comunica a la cabina para adivinar o cantar canciones de un determinado grupo. Conforme van ganando acumulan dinero, el doble cada vez; pero si pierden, pierden todo lo acumulado; pueden elegir retirarse del juego cuando quieran, sin 
embargo el locutor siempre los trata de convencer de que sigan adelante, arriesgándolo todo por un premio mayor. Cuando una participante gana 3,600 pesos, la atención se incrementa, se vuelve tensión y excitación entre los albañiles; comparto con ellos el momento y opinamos sobre si la concursante debería o no seguir adelante en el juego; finalmente la valiente señora ganó un refrigerador. "Sí se rifó la ñora, a poco no?", oigo que dice uno.

Un yesero está escribiendo mensajes de texto desde su celular. En general, hay varios trabajadores que usan celulares: por ejemplo, una vez El Gato se aparta de los demás para hablar con alguien y otra vez el timbre de un aparato sonaba insistentemente dentro de una mochila colgada en la pared... Rufino y Rafael tratan de componer un teléfono celular al que se le cayó la batería. Israel, el nuevo velador, y Polo, el gordito de bigote, juegan con sus celulares, comprando y recibiendo mensajes con fotos eróticas, como lo anuncian en la tele. Cuando lo logran se ríen mirando la pantalla nerviosos... El velador sigue con la atención enfocada en su celular, intentando cambiarle el sonido o arreglar algo que no alcanza a entender bien; trata de leer algo en inglés, como burlándose de sí mismo.

El Gato porta una camiseta de fútbol del América, equipo al que sigue y apoya desde que tiene uso de razón. Comento con él la goliza de 8-0 de Pumas contra Veracruz y el supuesto buen desempeño de la nueva generación recién salida de la cantera Americanista, entre otras noticias deportivas del momento. Hablamos sobre el reciente desastre ocurrido con las inundaciones en el estado de Tabasco. Me comenta que en un hotel muy cercano a donde estamos, en la colonia Roma, es donde golpearon a "Fabiruchis", un conductor de programas de chismes en la tele. Todo lo anterior revela el gran consumo de televisión que existe en los sectores de trabajadores pobres mexicanos. Me dice El Gato que él principalmente ve la tele los fines de semana con la familia, durante la semana escucha la radio en la obra.

Escucho de casualidad que un trabajador le dice a otro: "cálmate, ni que fueras Rodrigo Montalvo (refiriéndose al galán de una telenovela de Televisa muy popular en esta época). Me llama la atención lo pendientes que están los albañiles de las telenovelas y demás programas de la televisión mexicana. Tienen una cultura televisiva muy actualizada, son consumidores habituales del contenido de los medios masivos de comunicación, a pesar de que vivan en condiciones muy precarias, habitando en una obra negra a medio construir. 
A la hora de la salida, un trabajador lee el periódico deportivo Esto mientras espera a otro compañero; la noticia que retiene su atención habla de los éxitos recientes del equipo de fútbol de las Chivas, actuales campeones del fútbol mexicano... Durante el tiempo que visité las obras, El Pelón se convirtió en mi mejor informante deportivo, quien me ponía al tanto de los partidos de fútbol por venir, los días y horarios de los distintos estadios, las posiciones en la tabla de los equipos, etc. Decía que no se perdía el programa "Sólo De Fútbol", que se transmitía todos los días de 10.30 a 11.30 de lo noche por el canal 4 de Televisa.

\section{Comida y hábitos alimenticios}

Un día temprano por la mañana pregunta un trabajador: "¿ya pasó la muchacha del café?"; "sí, pero dijo que al rato regresaba", contesta otro. Como a las 9 a.m. pasa una chica que cada mañana les va a vender café, pan y tortas, empujando un carrito. Lleva uno o dos grandes termos con agua caliente, y aparte, en botes de plástico lleva el café, azúcar y leche en polvo. Todos hacen una pausa en sus labores para desayunar al frente del terreno, afuera en la banqueta. Los trabajadores se reúnen a su alrededor, le compran su desayuno y cotorrean con ella, como tratando de ligársela. La chica del café les sigue la corriente, pero siempre guardando su distancia. Catorce pesos es lo que casi todos gastan por un café, una torta ylo un pan dulce. "¿No gusta un café?", me ofrece Pato, "dicen que es bueno para el estrés", bromea.

Por las mañanas a veces hay un carrito de tamales aparcado fuera de la obra, que es atendido por un señor con un delantal de plástico. Rufino bromea con el tamalero, parece que ya se conocen... Adentro de la obra de Córdoba saludo a Eliseo, quien se está desayunando una torta de tamal... Más tarde entra a la obra un trabajador con un vaso de unicel con atole.

El encargado de la obra, Silvano, le dice a su colega y jefe, el maestro contratista Nicolás: "vamos a comer, si o no", "ah, ¿pos qué horas son?", contesta el otro. Veo mi reloj y me doy cuenta de que es la una en punto. Ellos lo confirman mirando el reloj en la pantalla de sus teléfonos celulares. Entonces Nicolás saca de su bolsillo unos billetes y se los da a un peón para que se vaya por el mandado... Unos minutos más tarde, Nicolás y Silvano ya estaban empezando a comer sus tacos de guisado, recién traídos por un chavo que antes cortaba varilla. Uno de los guisados 
era de salchicha en en salsa roja. Aparte tenían un buen tambache de tortillas y un galón de jugo de naranja Bonafina. Les deseo buen provecho y me contestan: "gracias, güero, ¿no gustas un taquito?".

Faltando veinte minutos para la una empezó la movilización entorno a la comida. "Ya vamos aproximándonos a la botana", me dice Silvano. Uno de los carpinteros nuevos le pregunta a Silvano si él manda a alguien por las tortillas de todos, o si cada quién va por las suyas, y en ese caso dónde está la tortillería. "Hay que mandar a dos de los muchachos, es aquí cerca, tres cuadras para abajo". Al poco rato fueron dos peones por las tortillas mientras los demás empezaron a sacar los guisados que habían traído de sus casas. Lo que siempre se compra fresco cada día son las tortillas y el jugo artificial de naranja o de uva, marca Amí o Bonafina, que compran por garrafa de galón.

De pronto, Silvano da la señal de que ya es hora de comer, gritando: "iA la comezón!". En esta ocasión cada grupo come por su lado. Los carpinteros, que trabajan aparte y no conocen a los demás, hacen su propio círculo; se quejan cuando les entregan sus tortillas porque son muy poquitas, a lo que el peón que fue por ellas les responde: "es que no es tortillería ahí donde fui, sólo venden toritillas sueltas y por eso están más caras"... Otro grupo de trabajadores, los que se quedan a dormir en la obra, se reunieron en el fondo del terreno y cooperaron entre ellos para comprar las bebidas que van a compartir. Sacan de varias bolsas de plástico sus trastes (tupperware) con guisados como mole verde, adobo, arroz, albóndigas. Socializan la comida; todos comen un poco de todo. Circulan los botellones de jugo de naranja y se sirven en un vaso desechable o en una botella de refresco de plástico cortada por la mitad. Previamente, todos habían tenido que esperar en fila para lavarse las manos en la llave de agua que está en la esquina del terreno. "Provechito", les digo al acercarme; "gracias, ¿no gusta?", responden ellos.

Cinco minutos antes de la una de la tarde, paso frente al supermercado Sumesa y veo un casco amarillo que sobresale de la fila de gente que espera para pagar. Reconozco a Raúl, el señor mayor que me cae bien, y lo espero a que salga. En la bolsa de plástico que le ayudo a cargar lleva un galón de jugo de manzana marca Ami. Me avisa que todavía tiene que parar en el puesto de tacos placeros de la esquina, donde tras una espera de algunos minutos, lo atienden para despacharle seis huevos cocidos y un bote de unicel con arroz rojo. Le pregunto si no va a 
comprar las tortillas ahí, me contesta que por las tortillas ya fue alguien más, allá adelante, por la calle Córdoba, "donde las dan más calientitas y más baratas, porque allá sí es tortillería".

Se acerca la hora de comer. "iA darle de tragar al tigre!", grita El Gato como si hablara por un altavoz. Este día hay trabajadores que se sientan solos y otros en parejas. Pero también están los que prefieren continuar sus labores de corrido y comer un poco más tarde. Algunos de los solitarios se entretienen con alguna lectura mientras comen... Un grupo de trabajadores conocidos están por lavarse las manos. Sigo a Raúl hasta el fondo del terreno, donde están reunidos Silvano, el velador, El Gordo y otro señor, entre otros; todos alrededor de la mesa de trabajo, sobre la que habían colocado un tablón de madera a manera de superficie para comer, sobre la que ya había un tambache de tortillas envueltas en papel y una bolsa de plástico, y unos cinco tupperwares con distintos guisados. Me ofrecen que le llegue a un taco, "¿de veras no gusta un taco?".

Llego estratégicamente a la 1 p.m. en punto, justo cuando distintos grupos de trabajadores estaban reuniéndose y organizándose para comer. Todos sacan sus tupperwares con diferentes guisados, los socializan y comparten entre todos. Destapan el tambache de tortillas y empiezan a comer, preparan los tacos siempre con doble tortilla... Mientras todos comen me siento junto a Patricio en una pila de tabiques. Se para a servirse otro taco y regressa sosteniéndolo entre sus manos. Sin ponerse de acuerdo, parece que se alternaran para cercarse a la mesa, agarrar un par de tortillas y ponerles un poco de alguno de los guisados. Al parecer, todos comparten la comida que llevan, por un lado para que haya más variedad y así de paso la cantidad total de comida se reparte y socializa entre quienes hayan aportado algo a la comida colectiva... Al otro lado del terreno comen otros tres trabajadores recargados sobre un tambo de Fester. El equipo de carpinteros come dentro del cuartito sobre el que trabajan.

Me encuentro a Paul saliendo del Oxxo en la esquina de Mérida y Colima, a un par de cuadras de la obra de Córdoba. Había comprando jugos y refrescos de diferentes sabores. Caminando de regreso hacia la obra nos encontramos al carpintero malencarado que también cruza la calle cargando bolsas con algo de comer que acaba de comprar en la calle... Afuera del terreno espera un muchacho que había llegado en una bicicleta con canasta un momento antes de la salida. Es el 
repartidor de la cocina económica que les lleva comidas corridas todos los días, y le pagan semanalmente, cada viernes. Bien vestido y peinado, les cobraba cierta cantidad de dinero a algunos trabajadores mientras iban saliendo del terreno.

Durante la hora de la comida me encuentro en el parque Río de Janeiro al Pelón y sus cuñados, con sus respectivas mujeres e hijos, que a veces suelen reunirse ahí para comer... En otra ocasión, dos señoras les llevaron la comida a los trabajadores. En la puerta de entrada improvisaron una mesa colocando una tabla sobre un tambo. Sacaron numerosos tuppers con guisados, tortillas, bolsas de plástico, platos de unicel, y todos se recargan alrededor para comer, incluidas las mismas señoras. Otro día, alrededor de la una, llegan las mismas señoras de hace unos días para alimentar a la tropa, esta vez llevando la comida en bolsas de plástico... Un trabajador llega a sentarse a la terraza, para comer mirando el movimiento de la calle. Poco después otros dos trabajadores ya se le habían unido y comían todos guisado de pollo con mole y tortillas. El guisado lo llevaron ellos, me cuentan que fue cocinado por una de sus hermanas, las tortillas las compraron en Sumesa... En la azotea me encuentro a un señor mayor con su hijo y otro trabajador más. Me ofrecen un "taco de albañil". Me siento con ellos y me preparo un taco con una sola tortilla (a diferencia de ellos que siempre lo hacen con dos), con un poco de arroz rojo y salsa muy sabrosa de un guisado al que ya no le queda nada de carne.

Entro a la obra junto con la vendedora de gelatinas, que llega todos los días cargando su charola y una cubeta llena de sus productos; además de gelatinas vende arroz con leche $y$ otras golosinas dulces. Nos encontramos al Gato, quien compra una gelatina y me invita una. El azúcar que contiene la gelatina me produce un golpe de energía, lo cual explica por qué tiene tanto éxito la venta de gelatinas a media mañana; los trabajadores necesitan una inyección extra de calorías para continuar con el duro trabajo y aguantar bien hasta la hora de la comida. No le pagan cada día, se ve que tienen línea de crédito y seguramente le pagan semanalmente. Además, el hecho de que sea una vendedora joven, hace más atractiva la transacción, ya que aprovechan para bromear y coquetear con ella, quien les sigue la corriente entre risas nerviosas; quién sabe qué tan inocente sea su actitud coqueta y nerviosa o qué tanto sea una estrategia conciente para vender más gelatinas... A los pocos días, otra vez me encuentro con la vendedora de gelatinas, pero ahora en la obra de Puebla, anotando en su cuaderno la lista de los 
adeudos. Parece que en estas obras está haciendo su agosto... La muchacha que vende gelatinas recorre toda la obra, piso por piso, con un casco puesto. Va vendiendo gelatinas prácticamente a todos los trabajadores que encuentra a su paso. Le va bastante bien en la venta, casi todos los trabajadores le compran al menos una gelatina. Me cuenta que visita como cinco obras y otros negocios cada mañana. Lleva tres o cuatro bandejas Ilenas de productos. Siempre se le acaban las gelatinas y todo lo que lleva. "Nunca regreso a mi casa con ni una sola gelatina", me dice sonriente $y$ orgullosa.

En el sótano, adentro de un cuarto me encuentro al Pato, al Gato y al velador, esperando a que El Gato les termine de cocinar un guisado que humea en un sartén sobre una parrilla eléctrica. Bromean diciendo que parecen niños viendo cómo su papá les prepara la comida. Todos reconocen que El Gato es muy buen cocinero, el mejor de todos los que están ahí, por eso siempre le encomiendan a él que cocine.

Últimamente, en la obra de Puebla un señor monta un puesto de guisados y agua dentro de la obra, donde casualmente estará ubicada la cocina de un departamento. Lleva platos y vasos desechables, unos ocho recipientes con diferentes guisados, un garrafón de agua de jamaica y un buen cargamento de tortillas. Con él también abren cuenta los trabajadores, los apunta en una lista y no pagan sino hasta al final de la semana, cuando reciben la raya. Sonriente y amable, el vendedor de comidas se ganó pronto la confianza de los trabajadores... Al poco tiempo, un día a la hora de la comida muchos albañiles bajan a comer con el señor de los guisados que se instala en la entrada. Se recargan viendo por la ventana que da a la calle. Un servicio de comida cuesta 22 pesos e incluye todos los vasos de agua de sabor que quieran tomarse.

\section{Momentos muertos y tiempo de descanso}

Patricio y Paul se toman un descanso de su labor aparentemente interminable de doblar varillas para formar estribos. Caminan al frente del terreno para recoger más varillas de las que están en la entrada y aprovechan el viaje para beber un poco de naranjada marca Bonafina que tienen en una garrafa. Les pregunto si van a estar todo el día haciendo estribos y me dicen que sí: "todo el día, toda la semana y seguramente hasta la próxima semana, porque todavía faltan un chingo de estribos por hacer", señala Paul. 
En la obra, a las 13:45 hrs., después de comer, los trabajadores están disfrutando de un momento de descanso; van terminando de comer y se dispersan; algunos estaban relajándose en sus últimos minutos de tiempo libre, muchos se duermen una siesta, otros juegan cartas o platican con sus compañeros... Raúl se mete a la bodega porque está más fresco, otro chavo se acuesta sobre las tablas de madera y se tapa del sol con una gorra... El maestro electricista, habiendo terminado de comer, aprovecha para leer el periódico con toda calma.

Este día hay pocos trabajadores, me parece que menos que en otras ocasiones. Además, nadie está realizando ningún trabajo muy intenso. Hay una especie de calma y relajamiento generalizado, quizá porque faltan escasos minutos para la hora de la comida. De hecho, un grupo de trabajadores, entre ellos Paul, esperan afuera del terreno, descansando y platicando tranquilamente. Más adentro del terreno hay un trabajador profundamente dormido, echándose una siesta así nomás sobre el piso.

De pronto en la obra parece haber momentos de placidez, un trabajador desenreda con toda calma un alambre con ayuda de sus pinzas, sentado en una confortable banca improvisada. La mesa de trabajo de madera en la que se fabrican estribos está abandonada por el momento... Por allá un trabajador se empina una botella de refresco de dos litros... De pronto empieza a llover y varios nos refugiamos debajo de un árbol. Se forma un momento íntimo de risas compartidas, bromeando con que los electricistas, que no pararon de trabajar, se iban a electrocutar. Al otro lado, pegado a la barda se resguardó solo el trabajador serio y callado. La lluvia amainó muy pronto, pero la pausa se prolongó un rato más de lo necesario, hasta que muy poco a poco y a duras penas todos fueron volviendo a sus puestos de trabajo.

Un grupo de trabajadores toman un descanso hasta arriba de la obra; sentados, acostados, durmiendo una siesta, tomando el sol. En un departamento hay una reunión de yeseros y trabajadoras de la limpieza en plena chorcha, preparándose para ir a comer, esperando y apurando a una de ellas que todavía no acaba de limpiar un ventanal... Al momento del descanso, después de la comida, un grupo de cuatro o cinco trabajadores están sentados muy cerca de la entrada de la obra, sobre un puñado de varillas, recargados en la pared de concreto, de la que sobresalen alambres y clavos. Este es el único resquicio de sol que pega en esa parte 
del terreno. Están sentados plácidamente, a veces alguno menciona algo, pero sobre todo impera un profundo silencio, mientras transcurre lentamente su tiempo de paz y relajamiento.

Hay varios trabajadores sentados sobre el borde del edificio; uno lee el periódico deportivo sentado sobre una carretilla vacía, con el pantalón roto y la rodilla cortada. Luego llega otro a platicarle de cerca... Otros tres están sentados de espaldas a un cerro de arena y otros materiales. Algunos aprovechan el descanso para enviar mensajes de texto desde su celular... El periódico cambia de manos y ahora es otro trabajador quien lo revisa minuciosamente.

En la sobremesa, Leonel prosigue su relato hasta que Silvano mira su reloj y se da cuenta de que ya mero son las dos, entonces dice: "ya casi es hora". Se levanta sin pensarlo dos veces, y al verlo, los demás trabajadores también se incorporan a sus puestos de trabajo y lentamente reinician sus labores. Leonel recoge todos los trastes que quedaron sobre la mesa en la que platicábamos, que deja de ser comedor para convertirse nuevamente en mesa de trabajo.

\section{Usos del lenguaje}

Algunos de los trabajadores, como Silvano y Pato, tienen un rico repertorio de frases para referirse a su labor cotidiana y al transcurso de los días en la obra. Cuando los saludo y les pregunto cómo van, siempre me responden algo diferente: "aquí andamos con este relajito", "dándole a este negocio", "en las mismas que ayer y que mañana", "persiguiendo la chuleta", "chambeándole, para variar", "aquí duro y dale, güero, no hay de otra", etc.

Entre los usos más destacables del lenguaje está su utilidad como vehículo principal para expresar el sentido del humor, sobre todo en cuanto a los apodos con los que se refieren a los demás y los ingeniosos albures que se dicen, con doble sentido y connotación sexual.

El albur es un juego de palabras de contenido sexual. Por lo general se establece como un reto verbal entre dos hombres, y se busca determinar quién penetra a quién. Es un juego de argucias y velocidad mental. El que se queda sin poder responder, pierde y es penetrado metafóricamente por el otro... La jerarquía que existe en el trabajo se extiende al ámbito del albur... Quienes se encuentran en una posición superior gozan de la libertad absoluta de alburear a sus subalternos. En 
cambo, éstos no tienen las mismas posibilidades de responder... (Liguori-González, 1992: 44).

Un grupo de trabajadores se burla de uno de los albañiles nuevos, "pobre chavo, se lo traen de bajada", me dice Silvano. Al parecer, justo en esos momentos le están acuñando el apodo de "el Azteca", que más adelante derivaría en "el Apache". Para complementar la broma, hacen ruidos con la boca como indios pieles rojas e imitan sus danzas y el sonido de tambores, causando una prolongada carcajada colectiva. El Apache porta una franela roja debajo de la gorra, tiene ojos rasgados y piel rojiza, es rellenito y habla con un acento simpático. Parece que la burla en él concentrada no le hiere tanto el orgullo, tampoco le agrada, pero la asume como algo inevitable.

El agente de ventas se asoma al terreno buscando a Silvano, que está trabajando en el piso de arriba, con el resto de los fierreros. Se forma una verdadera cadena de gritos y chiflidos para avisarle a Silvano que lo llaman, se va corriendo la voz y se reproducen los silbidos hasta que el mensaje llega a su destinatario, quien empieza a bajar corriendo hacia la entrada.

\section{Prácticas e imaginarios sexuales}

En relación con la cultura sexual de los trabajadores de la construcción, a continuación me referiré a un estudio sumamente relevante realizado por Miguel Ángel González Block y Ana Luisa Liguori (1992), en torno al SIDA entre los estratos socioeconómicos más bajos en México, en el que abordan el caso de los albañiles como una población especialmente vulnerable ante la propagación de este virus. De acuerdo con estos autores, una parte de los obreros y trabajadores de la construcción presentan algunos factores predisponentes al SIDA... Muchos albañiles son migrantes temporales que viven en la obra en condiciones de hacinamiento, en medio de relaciones laborales jerárquicas, dentro de una cultura machista mezclada con prácticas bisexuales (cf. Liguori-González, 1992: 37).

Para abordar este problema los autores aplicaron metodología y técnicas de investigación etnográfica, principalmente observación participante y algunas entrevistas a profundidad. "Se observaron con especial interés las manifestaciones físicas y verbales de la sexualidad", que reflejan a su vez "los valores y la conducta sexual, así como el papel de la bisexualidad en sus vidas" (Liguori-González, 1992: 
39). Entrando de lleno en el ambiente de la obra, los autores relatan que después de la hora de trabajo, la obra se convierte en un universo habitado por "albañiles y peones que vienen de provincia de manera temporal y que carecen de recursos. Después de las seis de la tarde, sobre todo los días de "raya", es común que muchos se queden a jugar naipes y a beber. En ocasiones invitan a mujeres o inclusive a homosexuales..." (Liguori-González, 1992: 38).

Por otra parte, se centran en la relación compleja y polisémica que se establece entre el oficial o "maistro" y el peón o "chalán". "Entre el oficial y el peón se establece una relación ambivalente. Por un lado es de protección y por el otro de sojuzgamiento; paternalismo y autoritarismo van de la mano" (Liguori-González, 1992: 42). Este tipo de relaciones laborales son propicias para que haya insultos, albures y juegos sexuales durante el trabajo.

El albur tiene su mayor expresión entre los "maistros" pero sobre todo de éstos hacia los peones... El oficial se la pasa diciendo frases de doble sentido como "pásamelas", "aflójame este lazo", "sácamela", "ahí te va", "agárramelo", etc. Hay un constante juego sexual entre los trabajadores de la obra... Por ejemplo, cuando un trabajador encuentra a otro distraído y agachado, se refriega contra él o le pica las nalgas... También es común que se toquen las nalgas unos a otros", lo que llaman "tortear", que opera más o menos bajo las mismas reglas jerárquicas que el albur (Liguori-González, 1992: 45).

Los trabajadores de la construcción "alardean constantemente de sus aventuras sexuales". Los autores hacen un estupendo registro de una serie de testimonios en los que relatan sobre sus conquistas, novias, infidelidades, prostitutas, travestis, experiencias homosexuales o bisexuales, con menores de edad o incluso violaciones (Liguori-González, 1992: 46). La interpretación de los autores apunta a que "la estructura laboral vertical y la dinámica interna en una obra se sostienen a partir de una violencia (simbólica) permanente, mediante la cual quien está en una posición jerárquica superior tiene que reafirmar su posición en forma constante". Argumentan que "la cultura sexual machista que comparten los trabajadores de la construcción es integrada en una especie de modelo práctico que permite organizar y controlar las relaciones informales de trabajo". Ocurre "una transposición de los roles sexuales a la lógica del trabajo", lo cual pone de manifiesto la gran importancia de la metáfora sexual para organizar el trabajo" en el entorno de una obra de construcción (Liguori-González, 1992: 50-51). 
Sin duda, sería muy interesante realizar un estudio cuidadoso sobre la cultura sexual de los albañiles y sus formas de asumir la masculinidad, considerando por ejemplo, sus roles de género, las relaciones que establecen con el sexo opuesto, el tema de la bisexualidad, así como sus imaginarios relacionados con la sexualidad en general. Cabe mencionar el tema de la bisexualidad entre los trabajadores de la construcción, que abordan muy bien Liguori y González. Este tipo de prácticas sexuales es común en situaciones en las que grandes grupos de hombres cohabitan y colaboran dentro de una estructura de poder (como en el ejército, las cárceles o las obras de construcción). Sería interesante investigar sobre estas formas alternativas de experimentar la masculinidad y su articulación con otras esferas de la vida y la cultura, sobre todo porque este tipo de población marginal y migrante, altamente propensa y vulnerable al contagio del SIDA. Pero lo más preocupante en esos casos, es que "estos hombres están expuestos a infectarse y llevar posteriormente a sus casas la enfermedad" (Liguori-González, 1992: 52).

Unos albañiles que leen el periódico se detienen con entusiasmo en una página donde aparece una chica semidesnuda a plana completa. Abren bien los ojos para mirarla mejor y suspiran tan agitadamente que hasta se les expanden las fosas nasales. Me muestran emocionados la foto para que entienda lo que les causa tal conmoción... Por otro lado, en la entrada del terreno me quedo platicando con unos trabajadores nuevos, mientras ven y circulan un librito pornográfico de bolsillo, una edición muy barata impresa en papel periódico, del mismo tipo que el libro Vaquero. Al principio pensé que se trataba de dibujos animados, pero después me fijé que se trataba de un fotocómic, una clase de imágenes pornográficas para el consumo de las clases más bajas y populares.

El Gordo opera una especie de manguera o tubo flexible que vibra impulsado por un motor portátil. Lo introduce entre la mezcla recién vertida, para que se asiente y llegue parejo hasta el fondo y a todos los rincones de la estructura que están colando.

- "Se mueve como si fuera un vibrador para que sientan chido las mujeres, ¿a poco no?, para que se les acomoden bien sus tripitas", dice Édgar entre risas.

- "Por eso te gusta tanto agarrarlo y no lo sueltas", le dice otro que va pasando, provocando carcajadas. 
Mientras construyen la barrita en el roof garden, tres trabajadores bromean: "aquí van a estar las chachas, unas bien buenotas, sirviendo copas en el bar"... El Gato me cuenta que los viernes llega bien fogoso a su casa con su mujer. Ella le dice, "¿por qué tienes tanta energía sexual si se supone que trabajas tan duro toda la semana?"; "pero yo le digo no importa, vieja, tú afloja porque vengo en mis meros jugos".

Un albañil me saluda sonriente mientras va saliendo del hoyo a encontrarse con su mujer, quien lo fue a visitar a la obra y lo espera muy perfumada en la puerta de entrada... En la entrada del terreno encuentro a Rufino, alias el Rufles, oficial fierrero y temporalmente velador de la obra de Córdoba. Mientras separaba varillas de un montón, les chiflaba y lanzaba piropos a todas las mujeres que pasaban por la calle, sin excepción alguna... El Gordo y el velador desde el segundo piso de la obra le dicen algo a una chica que pasa caminando por la banqueta, ella les responde con una evasiva, sin dejar de caminar; ellos la siguen con la mirada hasta que se da vuelta en la esquina. Bromean por su hazaña: "qué buena suerte tienen los que no se bañan", dice el velador... Dos trabajadores intercambian gritos de un lado al otro del terreno, apenas pueden entender lo que dice el otro: "sí, pero con tu hermana!", contesta uno para rematar la fallida comunicación.

Adentro de un departamento me encuentro con la chica joven de limpieza. Veo que Eliseo se asoma por la puerta del departamento. Me llama y me insinúa algo que me hace entender que le gusta la chica, coincido en que es linda y entonces siento que se crea cierta complicidad entre nosotros. Eliseo me dice: "pero tú chitón", porque me recuerda que vive con su mujer y tiene hijos. Me pide que retrate a la chica de la limpieza y luego le regale su foto. Luego se le acerca a la chica y comienza un sutil juego de cortejo entre ellos, o por lo menos de él hacia ella.

Sentado en la azote viendo hacia la calle, platico con Martín acerca de las muchachas que pasan por la calle, casi todas estudiantes jóvenes de la Universidad del Valle de México, que esta a la vuelta de la esquina. Humildemente, Martín me dice: "esas ni siquiera me gustan, prefiero una de mi misma clase, sin tantas pretensiones, porque si no, imagínate, luego no alcanza para mantenerlas. Quieren coche, cine, viajes y todo. Por eso, aunque algunas sí están bien buenas para echar un taco de ojo, yo mejor ni me fijo ni fantaseo mucho". 


\section{Estampas de la cultura albañil}

A continuación presento un collage de crónicas etnográficas que retratan diversos aspectos de la cultural albañil... impresiones, instantáneas, pequeños gestos y detalles, sutilezas de la cultura aparentemente insignificantes, que sin embargo me parece que sintetizan nítidamente la idiosincrasia y forma de ser de los albañiles.

Un trabajador proveniente de Hidalgo, cuando tuvo que dar sus datos para que lo registraran en el Seguro Social, no sabía su fecha exacta de nacimiento, sin embargo, traía copias de sus documentos oficiales, pero no sabía leer; entonces le ayudé a buscar sus datos y resultó que había nacido el 10 de mayo de 1982, "naciste el día de las madres y ni así te acuerdas de tu cumpleaños, cabrón", lo regaña de broma el empadronador. Esta anécdota ilustra el analfabetismo y el grado de ignorancia que presentan algunos albañiles.

Mientras varios trabajadores anudan varillas, uno de ellos canta canciones de desamor a medio pulmón, ostentando una buena voz; posiblemente lo hará para desahogar alguna pena, pero sobre todo canta para el deleite de sus compañeros que lo rodean, quienes cuando termina una canción, le piden otra, y así se la pasan un buen rato de la tarde, sumergidos en este tono melancólico, pero entretenidos a final de cuentas.

A pesar de su carácter generalmente apolítico, en algunas ocasiones escuché algunos comentarios y conversaciones interesantes al respecto, por ejemplo en torno al nuevo presidente Felipe Calderón, con quien "nos vamos a morir de hambre los que de por sí ya somos pobres", afirma un carpintero mayor de gestos duros y profundas grietas en el rostro.

A la hora de la salida, varios trabajadores comentan sobre los festejos y las borracheras que se van a a poner la noche del Año Nuevo: "los deberías de ver, güero, cuando se toman sus cubas se transforman gacho", me dice Édgar... Un albañil orina en un rincón del terreno, entre dos cerros de estribos.

En la mesa de trabajo de madera sigue la acción de fabricar estribos, las piezas que integran las complejas estructuras de varilla, que forman el esqueleto del edificio. Un señor que siempre tiene un cigarro en la boca, parece ser el principal encargado de esta importante tarea. En adelante, creo que este señor no se despegaría de la mesa de trabajo, al igual que no se despegaría el cigarro de la 
boca. Vale la pena mencionar que muchos de los trabajadores de la construcción fuman durante el trabajo y en los momentos de descanso; los cigarros Delicados sin filtro son muy populares entre los obreros y trabajadores de la construcción, sobre todo porque son más baratos que otras marcas. Otra razón práctica que puede explicar esta preferencia es que los Delicados, al ser ovalados, si lo dejan en una superficie plana mientras necesitan usar ambas manos, la forma ovalada evita que el cigarro ruede y se caiga. Pero parece que esto no le importa el señor con el cigarro en la boca, quien jamás suelta su cigarro, no se desprende de él ni por error, nunca se lo despega de los labios.

\section{Fin de la jornada laboral}

Dan las seis. De pronto, Silvano grita: "ivámonos muchachos, ya estuvo, ya es hora!". Los trabajadores empiezan a suspender sus distintas actividades y se preparan para marcharse. Unos se juntan en la bodega del fondo, se ponen otra ropa y zapatos que tienen guardada o colgada de un clavo, se cambian de pantalones, se ponen camisa y suéter, uno que otro saca de una bolsa de plástico sus zapatos de vestir. Dentro de la bodega se forma una chorcha enmedio del hacinamiento. Algunos van a la esquina donde está la llave de agua para darse un rápido baño, se cambian, encreman y peinan con ayuda de un espejito y se ponen desodorante. Unos descamisados muestran su gran panza al aire; un señor se encrema y se pone colonia con gran impetu. Varios pasan al baño improvisado para orinar antes de retirarse. Otros se alistan al frente del terreno. Los carpinteros se cambian aparte, sobre el techo del cuartito en la entrada del terreno. Comienzan a irse, se despiden, "adios mai, hasta mañana", se oye por todos lados. La tarde se hace noche y ya oscurece.

Se prenden los faroles de la calle. El velador comienza a meter los anuncios promocionales que durante el día permanecen en la banqueta. Prende los dos anuncios luminosos que están en el techo, abre bien la puerta para facilitar la salida de los trabajadores. Poco a poco van saliendo de la obra limpios y elegantes, con suéter, pantalón y zapatos. Se van caminando, cargando sus pertenencias en petacas o en bolsas de plástico. Los carpinteros se retiran todos juntos, "iapúrale güey!", le gritan a un rezagado. Varios trabajadores van saliendo del terreno, cargando sus cosas, sorteando obstáculos; "ya a descansar", me dicen. 
Paul estaba cambiándose, peinándose, poniéndose elegante, rociándose desodorante en aerosol que impregna el aire a su alrededor. De por sí Paul suele trabajar bastante bien vestido, con camisa verde a cuadros bien fajada, gorra roja para atrás y unos buenos jeans, pero es evidente su transformación al ponerse su ropa de no trabajo, su traje de civil, y no el uniforme de batalla. Pato, Raúl y Édgar salen de la obra bien aseados y peinados, con chamarras y ropa limpia, oliendo a jabón y desodorante.

Un día a la hora de la salida los trabajadores se empezaban a reunir y se preguntaban a qué hora y por dónde iban a poder salir, porque la salida estaba bloqueada por la alberca para la mezcla, que estaba en plena construcción. De vez en cuando se oían gritos y silbidos que indicaban que ya era hora. Pero los carpinteros seguían clavando clavos, midiendo y serruchando polines y barrotes. Entonces los trabajadores tienen que ingeniárselas y poco a poco empiezan a salir habilidosamente por una columna de varilla. Trepan cargando sus maletitas, bien peinados, antes de dar el último brinco hacia fuera, se despiden y se van.

Los viernes al final de la jornada, después de que los trabajadores recogen sus herramientas, limpian un poco su espacio de trabajo y guardan sus cosas, y después de que se lavan, se visten, se peinan y se alistan para irse, esperan a que les paguen la semana que han trabajado. Puede notarse el entusiasmo de los trabajadores cuando se acerca el fin de una semana entera de trabajo, cuando se acerca la hora de cobrar, el momento de la raya.

Unos pocos trabajadores se encargan de los últimos detalles antes de cerrar la semana laboral, sobre todo se ocupan de que la madera de la cimbra esté bien acomodada en montones junto a los rollos de malla de alambre. Otros trabajadores atraviesan el hoyo en fila hacia la oficina, me imagino que van a que les paguen la raya, como todos los viernes cuando se acerca el fin de la jornada. Poco a poco van quedando a un lado las herramientas y los materiales, los cascos colgados de un clavo en la pared; se quedarán ahí un par de días hasta que el lunes temprano regresen los trabajadores a ocuparlos nuevamente.

Me despido de todos, el Vela se despide de choque de mano y puño, saludo típico popular. El Gato se despide dándome la mano, girando la muñeca y haciendo un movimiento en dos tiempos. Les digo que nos vemos pronto, "cuando quieras, 
güero", me dice El Gato, "al fin que aquí vamos a estar todos los días hasta que terminemos la obra o hasta que la obra termine con nosotros, ¿verdad?".

\section{Epílogo: al estadio de C.U. con Ángel}

Lo que sigue es la crónica de un acercamiento especial, más allá de la obra, con un personaje que me parece bastante representativo del tipo de albañiles que conocí en las obras de DAKAB en la Roma. A continuación relato la ocasión en la que fui con El Pelón al estadio de CU para ver un partido de fútbol de los Pumas contra las Chivas.

Una de las primeras veces que coincidimos en la obra y tenemos oportunidad de platicar, Ángel, alias El Pelón me pregunta de qué universidad vengo; cuando le contesto que de la UAM, me dice:

- "Lástima, yo creí que venías de la UNAM y podías conseguir boletos para ir al estadio a ver a los Pumas".

- ¿A poco le vas a los Pumas?".

— "Pues sí, a cuál otro... ¿y tú?".

Cuando le digo que yo también le voy a los Pumas se crea cierta complicidad entre nosotros. Le prometo que si algún día puedo conseguir boletos lo invito a un partido en el estadio de CU; "el próximo domingo va a estar bueno, vamos contra las Chivas", me dice emocionado.

A los pocos días Ángel vino a saludarme y le informé que sí conseguí boletos para el partido de Pumas-Chivas el próximo domingo en CU. Con una sonrisa incontenible me pregunta si no estoy bromeando. Se mostró incrédulo cuando le confirmé que de verdad iríamos a ver el juego. Quedamos de vernos el domingo temprano, a las 10:30 a.m. afuera de la obra, para irnos juntos al estadio.

El domingo 11 de marzo de 2007 voy con Ángel al estadio. Cuando llego a la obra a las 10:30 a.m. él ya estaba esperándome sentado, con el cabello recién cortado y peinado con abundante gel, con su camiseta de Pumas bien puesta. Nos encaminamos sin demora hacia el Metrobús. En el camino me chismea que al parecer hace rato el velador no estaba en su puesto de trabajo cuando el señor flaco de ventas lo fue a buscar, así que, según Ángel, es muy probable que lo despidan. 
Me cuenta Ángel que su suegra vive muy cerca de la obra, en la colonia Roma, en un edificio en la calle de Guanajuato, casi esquina con Jalapa. Él, su mujer y su hijo viven por el metro Martín Carrera. Su esposa tiene 20 años, igual que él, y Christian, su hijo, tiene ya 2 años. Son una pareja joven con un bebé, que se las ve duras para ganarse la vida.

El Pelón nació en Papantla, Veracruz. En sus gestos me parece encontrar ciertos resabios de raza negra veracruzana, pero no sólo en cuanto a su fenotipo, sino algo cultural que quizá tiene que ver con su carácter alegre y simpático además de ser ágil y fuerte. Desde los 12 años se trasladó al D.F. en busca de trabajo. Su primer empleo fue en una fábrica de CONDUMEX. Después ha trabajado intermitentemente en varias obras de construcción por varias partes de la ciudad. Pero en los últimos años, desde que tuvo a su hijo, ha trabajado en la construcción de edificios en la colonia Roma. Le conviene trabajar en la Roma, o lo más cerca posible, porque su suegra les echa la mano cuidando al bebé mientras ambos trabajan. Ha estado en las obras de Zacatecas y Monterrey, Frontera y Tabasco, y en Córdoba y Guanajuato; en esta última dejó de trabajar porque la clausuraron y entonces tuvo que buscarse otra chamba. Así llegó a esta obra de Córdoba, gracias a la recomendación de su amigo el cuidacoches que se pone afuera del Banamex, quien intercedió por él ante Silvano.

En otras ocasiones ha conseguido trabajo junto con sus parientes, con su cuñado Eliseo y otros primos que ahora también están trabajando en la obra de Córdoba. Dice que quién sabe cuánto tiempo dure trabajando en esta obra; de hecho, nunca ha trabajado en una obra de principio a fin, sino que ha ido pasando de una a otra, y a veces vuelve a caer en una misma obra en repetidas ocasiones. Trabaja hasta que se cansa, se aburre o hasta que lo despiden.

También trabaja los sábados como limpiaparabrisas en la esquina de Niza e Insurgentes, en la Zona Rosa; "antes trabajaba en otra esquina, sobre Yucatán, pero quién sabe qué le paso a esa esquina, que de repente ya nadie te daba nada, en cambio en Niza sí te dan, porque como hay muchos restaurantes y bares por ahí, la gente pasa ya jaladona y aflojan el varo, luego que porque están celebrando". Me cuenta anécdotas de cuates suyos que han recibido hasta billetes de $\$ 500$ por una lavada de coche; a él lo máximo que le han dado es un billete de cien. 
Así, combina dos trabajos, uno semiformal, como albañil, y el otro completamente informal, como limpiaparabrisas. Tiene que buscar otras fuentes de empleo para completar su ingreso y poder mantener a su familia, porque con el sueldo de la obra no les alcanza. Con DAKAB gana alrededor de mil pesos a la semana. Lleva cuatro años trabajando en la construcción, pero a pesar de que ya sabe hacer varias cosas, sigue siendo simplemente ayudante. "Eso me pasa por no estudiar", me dice. Ahora lo que tendría que hacer, según él, es echarle ganas para aprender bien y especializarse en algún oficio, como carpintero, electricista o fierrero. Me cuenta que incluso los ayudantes de los carpinteros ganan más que otros ayudantes, y un carpintero que ya es oficial puede ganar hasta dos mil por semana.

Antes de subirnos al Metrobús, Ángel me cuenta que está tratando de juntar dinero para el enganche de un departamento de interés social, en un gran conjunto habitacional que están construyendo junto al Metro Martín Carrera. Piden diez mil pesos de enganche para apartarlo, que para Ángel es una cantidad muy difícil de ahorrar, equivalente a juntar su sueldo durante diez semanas sin gastarse nada, sin pagar renta, sin comer nada él ni su familia, o sin transportarse para ir a trabajar, lo cual resulta una ironía social desgarradora.

En el trayecto me platica que los domingos juega con un equipo en un torneo en cancha grande de tierra, lo invitaron apenas hace poco, entra casi siempre de refuerzo y ahí le prestan un uniforme. Además, seguido va a jugar fútbol al parque de enfrente del Hospital General, sobre Avenida Cuauhtémoc, con su cuñado Eliseo y otros primos. Me cuenta la anécdota de que una vez una pandilla de la colonia Doctores que iba pasando cuando ellos jugaban fútbol en el parque, les robó un balón de la UEFA Champions League que Eliseo había comprado con mucha ilusión, le había costado 800 pesos en Deportes Martí: "estaba bien chingón ese balón, entonces lo vieron los de la Doctores y dijeron venga para acá, y nosotros ya ni pusimos resistencia porque ellos eran varios y nosotros sólo tres".

Reconoce que él es bueno jugando, pero dice que Eliseo, su cuñado, es muy habilidoso y hace muy buenos quiebres. Casi todos sus cuñados y compañeros le van al equipo de la Máquina Cementera del Cruz Azul: "casi la mayoría en el trabajo de la construcción son del Azul". Él le va a Pumas porque "alguien que conocí de morrito me regaló una camiseta con el Puma bien grandote y chingón, y desde 
entonces le agarré gusto y cariño al equipo de la UNAM". Entre él y sus cuates hacen apuestas y retos de honor en torno al fútbol; me cuenta que varias veces ha terminado rapado, sin cejas, o con el pelo teñido de colores cuando los Pumas pierden contra el Cruz Azul o las Chivas.

Durante todo el trayecto el Metrobús iba abarrotado de gente vestida con camisetas y banderas de Pumas y Chivas. Finalmente llegamos al estadio y había una gran fila que cruzaba una gran explanada entera para poder ingresar. Debajo de un sol pleno que a Ángel no parecía afectarle en lo más mínimo, tuvimos tiempo de platicar varias cosas más. Me cuenta que su madre todavía vive en Veracruz y seguido va a visitarla; su padre falleció a causa del alcoholismo. Confiesa que su infancia fue muy dura, dejó de ir a la escuela en $4^{\circ}$ grado de primaria porque no tenía dinero para comprar zapatos, ni mucho menos para comprar libros, "porque mi papá se lo bebía todo y no nos dejaba nada, ese era el problema". Entonces dejó la escuela en Veracruz, se salió de su casa, se vino a la gran ciudad y se puso a trabajar.

Cuando El Pelón ve a los tipos que ponen maquillaje en la cara con el logotipo de los equipos, me dice que ésa es otra cosa que suele hacer para ganar una lana extra: poner maquillajes patrióticos el 15 de septiembre en el Zócalo. En eso, Ángel me señala y me dice el nombre de un reportero de Televisa Deportes, que justo se acerca a la fila para entrevistar aficionados de uno y otro equipo. Entrevistan a los de adelante de nosotros, seguidores de Chivas, y luego al ver a Ángel con la camiseta de los Pumas, apuntan la cámara hacia él y le preguntan: "¿qué son para ti las Chivas?", pero él enmudece y sólo dice: "no, pus no sé", así que el equipo de grabación se retira sin más. El Pelón me dice "chale, ora sí que me apendejé, me cae que hasta hubiera salido en La Jugada".

Entramos finalmente a la parte de abajo del estadio, ya bastante tarde, el partido había comenzado. Nos tocaron unos lugares malísimos, a ras de cancha, la reja no nos dejaba ver nada, sólo parados se podía ver algo, pero entonces todos los que estaban sentados atrás nos mentaban la madre y gritaban "iahí va el agua!". Nos tomamos un par de chelas cada uno durante el primer tiempo, que con mucho gusto yo le invité.

Al medio tiempo nos cambiamos de lugar a la parte de arriba junto con mi grupo de amigos que siempre van al estadio. De pronto, me dice: "Oye, quiero decirte 
algo, como te venía diciendo, yo ahorita ando bien corto de dinero; me gustaría invitarte una cerveza pero no traigo casi nada de lana, así que por favor discúlpame, me da pena venir de gorrón, pero prefiero decírtelo de frente y que no pienses que me hago güey". Le contesto que no se preocupe, que yo con mucho gusto le invito las cervezas y le digo que aprecio su sinceridad.

Al terminar el partido nos quedamos todavía un buen rato platicando adentro del estadio. Me confesó que antes era bien atascado con las drogas, le gustaban mucho la mota y la piedra, que andaba en las calles trabajando siempre hasta la madre y se gastaba todo su dinero en vicio. Pero cuando tuvo su hijo ya le bajó al consumo y empezó a trabajar más... "¿porque quién más va a ver por él, si no yo?".

Hablando de la obra de Córdoba, me dice que está contento trabajando ahí y que espera permanecer más tiempo. Le gusta la buena convivencia que hay entre todos, "siempre pasa que al principio no conoces a nadie, pero poco a poco vas conociendo y encontrando buena gente, algunos te ayudan y aprendes, otros ni te hablan. Lo bueno es que en este trabajo uno se puede divertir mucho". Me doy cuenta de que Ángel no conoce por su nombre a casi ninguno de sus compañeros trabajadores, sólo por sus apodos; para él, Édgar es El Gordo, Patricio es el Pato, Rufino es el Rufles, Nicolás es el Barney, Fernando es Paul, Israel es el Vela, etc.

Salimos del estadio, comentando el partido, que estuvo bueno a pesar de que terminó empatado 0-0. Nos separamos sobre Insurgentes ya que yo después voy para otro lado. Le presto mi tarjeta del Metrobús para que no tenga que gastar en su regreso. Se despide muy agradecido con un abrazo y quedamos de vernos al día siguiente en la obra.

Walter González, reportero de la página deportiva www.mediotiempo.com concluiría su nota diciendo: "Al final del duelo la cancha era un mar de abrazos. Jugadores de ambos equipos que han coincidido en los mismos planteles en torneos anteriores se saludaron y platicaron en un gesto ejemplar del fútbol. Ellos jugaron a tope, pero después tuvieron la gallardía de felicitar al rival, en esta ocasión no sintieron la necesidad de esconder el abrazo para el vestidor, lo mostraron abiertamente en la cancha y claro, esto se reflejó en los aficionados de ambos equipos que abandonaron el Olímpico de CU con una tranquilidad y alegría que ojalá se vuelva crónica". 


\section{Capítulo V \\ HABITAR LA OBRA \\ Culturas del habitar en el mundo de la construcción}

\section{La interacción sujeto-espacio}

El presente capítulo se plantea como un diálogo entre los capítulos anteriores. A grandes rasgos, la noción de habitar se refiere a la interacción entre los sujetos y el espacio, entre las personas y su entorno, entre actores y lugares. En esta investigación, el estudio de cómo habitan los albañiles la obra implica la integración entre la transformación del espacio y la mano de obra que realiza dicha transformación.

Para definir mejor la clase de vínculo que se establece entre sujetos y espacios, podríamos recurrir a distintos modelos teóricos y metáforas. Retomando la idea de la dialéctica hegeliana, sería posible considerar el habitar como la síntesis entre la transformación del espacio y la mano de obra. En términos más pragmatistas, podríamos decir que existe una interacción o transacción entre los sujetos y su entorno físico y social, basada en una idea compleja y rica de experiencia. Podríamos importar algunas ideas de la biología evolutiva para interpretar la relación albañilobra, sujeto-espacio, como un proceso de plasticidad mutua o de equilibrio reflexivo, que se plantea entre criatura y nicho o entre mente y mundo.

Es importante señalar que el habitar no es la mera suma del espacio y los sujetos, no es la simple conjunción de lugares y personas. El acto de habitar tiene propiedades nuevas que emergen de la relación entre sus componentes, que no se reducen a las propiedades de dichos componentes. Es decir, el producto de la interacción sujeto-espacio tiene propiedades que no están presentes en ninguno de los elementos involucrados por separado; es diferente a la suma de los elementos. EI habitar es algo más que la yuxtaposición de un sujeto y un lugar.

Es necesario entender el habitar como una actividad cultural básica. El acto de humanizar el espacio, junto con su contraparte, la naturaleza espacial de los sujetos, pueden considerarse como "el grado cero de la cultura" (De Martino, 1977, citado por Giglia, 2009: 228). La dimensión del habitar es de fundamental importancia, incluso una condición de posibilidad, para el desarrollo de otras esferas culturales. Por tanto, resulta indispensable el desarrollo de una antropología del espacio y del 
habitar, particularmente enfocada en la interacción entre los espacios urbanos y los ciudadanos en el contexto mexicano contemporáneo.

El sentido del habitar que me interesa enfatizar tiene mucho que ver con la "interiorización" del espacio por parte de un sujeto. Esta interiorización puede entenderse como la apropiación mental o aprehensión de un lugar determinado. Un ejemplo ilustrativo es el de una escalera difícil de transitar en una casa recién construida. En un principio los nuevos habitantes tendrán que tener cuidado cada vez que suban o bajen por dicha escalera, probablemente tropezarán un par de veces, pero poco a poco, conforme transiten por ella repetidamente, más fácil les parecerá. Se grabará en su mente una imagen del espacio que les permitirá dominarlo y transitar por él sin tener que reparar en cada movimiento. Gracias a esta generación de hábitos ocurre una suerte de incorporación del espacio, como si nuestro cuerpo se aprendiera los movimientos exactos para desplazarse por cierto lugar sin tener que prestar atención concientemente. Con el transcurso del tiempo, los habitantes de esta casa podrán subir y bajar la escalera con los ojos cerrados; la escalera se convierte así en un espacio habitado, humanizado.

En una plática impartida recientemente en la UAM-I, Amalia Signorelli (2008) abordó cabalmente el tema de la relación entre los sujetos y los lugares, que de acuerdo con ella es el núcleo central de la antropología del espacio y una problemática medular de la antropología urbana. Como punto de partida, establece que desde la perspectiva de la antropología del espacio, "el objeto de estudio no deben ser los sujetos por un lado y los lugares por el otro, sino las relaciones que se establecen entre éstos" (Signorelli, 2008).

Signorelli argumenta que sería equivocado pensar a los seres humanos como si no estuviesen ubicados o considerar a los sujetos aparte de los lugares, como si fueran entidades abstractas, deslocalizadas. También sería absurdo pensar en los lugares como meros espacios abstractos, vacíos o desprovistos de sentido humano. No existen seres humanos que no estén en algún lugar y tampoco existen lugares que no estén de alguna manera humanizados. Si un lugar no es al menos pensado por algún sujeto, no sería posible decir que ese lugar exista; de igual forma, si no podemos decir dónde se encuentra un sujeto, no podemos decir que ese sujeto exista en la realidad. La premisa básica es que "los sujetos son siempre sujetos localizados, y complementariamente, los lugares de la vida humana son siempre 
lugares subjetivados" (Signorelli, 2008). En sintonía con las ideas de esta autora, podríamos decir que el objeto de esta investigación son los sujetos localizados en relación con el espacio subjetivado, es decir, la interacción entre los albañiles y demás trabajadores de la construcción y el espacio en construcción que representa la obra.

Signorelli plantea las siguientes cuestiones fundamentales, de índole filosófica, en torno a la interacción entre sujetos y lugares, que considero relevante recuperar:

¿Hay un determinismo de los lugares hacia los sujetos? ¿Hay un determinismo de los sujetos hacia los lugares? ¿En qué medida y de qué modo los seres humanos condicionan los lugares? ¿En qué medida y de qué modo los lugares condicionan a los seres humanos?... Con ayuda de un poco de imaginación antropológica, podemos intentar pensar cómo sería distinta la presencia y la acción de los seres humanos si estuviera localizada en otro lugar y cómo sería diferente un lugar si en él hubiera otros seres humanos o ninguno (Signorelli, 2008).

Retomando estas preguntas para pensar el entorno metropolitano de la Ciudad de México, Ángela Giglia (2008) argumenta que existen nexos fundamentales entre las formas urbanas y las formas sociales, entre la organización del espacio y las prácticas urbanas, pero sería equivocado pensar el vínculo entre estas dimensiones como una relación mecánica o determinista.

En cuanto a las relaciones entre los sujetos y el entorno físico, Signorelli presenta algunos ejemplos de cómo las formas y propiedades de los lugares moldean las dinámicas y relaciones sociales entre los actores: la amplitud o estrechez, la forma y la distribución de las cosas, el calor o el frío, la luz o la oscuridad, lo seco o lo mojado, determinan muchas veces las acciones, actitudes, posturas y generan distinto tipo de interacciones entre los sujetos. De una u otra manera, la obra impone condiciones en los albañiles que afectan sus acciones y relaciones, como las condiciones del subsuelo lodoso o los imperativos del paisaje repleto de materiales. En buena medida las relaciones entre los seres humanos están condicionadas por los lugares que habitan o entre los que transitan. No es lo mismo la interacción social en la vivienda, dentro de un banco, en un hospital, en la cárcel o en un estadio de fútbol (cf. Signorelli, 2008). En este sentido, habría que decir que en una obra de construcción el tono de las relaciones sociales está marcado por el trabajo físico, masculino, que implica grandes esfuerzos, en condiciones materiales hostiles, pero a la vez se crea un 
ambiente relajado e informal, con muchos momentos muertos para descansar y socializar libremente, en el que predomina el buen humor en el ánimo general.

Por otra parte, los espacios se convierten en lugares a través de su relación con los sujetos. En nuestro caso, el espacio inicial era un estacionamiento, cuyo terreno se convirtió primero en obra, la cual atraviesa por varias etapas, más tarde en edificio y finalmente en los departamentos y el hogar de alguien, a través de la intervención directa de los trabajadores de la construcción que lo habitaron y transformaron progresivamente. También hay que señalar que un mismo espacio puede ir cobrando diferentes sentidos para distintos actores a lo largo de su proceso de construcción. Es importante señalar que las relaciones entre lugares y sujetos no son objetivas, sino que dependen de la experiencia subjetiva, tienen que ver con los recursos, la intención, la posición y el poder de cada actor para asumir o transformar sus circunstancias espaciales. Es claro que lejos, cerca, feo, peligroso, hostil, de lujo, precario, etc. son valoraciones de los sujetos, no propiedades objetivas de los lugares (cf. Signorelli, 2008).

\section{La observación etnográfica del habitar}

Una vez esbozada la complejidad teórica de la problemática, Signorelli se pregunta cómo investigar sobre esto en la práctica y con qué herramientas se puede abordar. Propone un esquema para identificar las relaciones entre sujetos y espacios. Para empezar, Signorelli plantea que existen distintos tipos de lugares (reales, imaginarios, virtuales, públicos, privados, híbridos) que se relacionan con una amplia gama de sujetos (individuales, colectivos, estáticos, móviles, multilocalizados); pero además, argumenta que estas relaciones pueden darse en varios niveles y sentidos: entre los sujetos y los lugares, entre distintos sujetos que se encuentran en un mismo lugar o entre diferentes lugares a través de los sujetos que transitan por ellos (cf. Signorelli, 2008).

De acuerdo con la metodología que plantea, para empezar hay que definir nuestro punto de vista; decidir si abordamos a los sujetos como sujetos colectivos o como un conjunto de sujetos individuales (cf. Signorelli, 2008). En el caso que nos atañe, me parece más apropiado considerar a los albañiles como un conjunto de sujetos individuales, y no como un sujeto colectivo, debido a que no conforman un grupo homogéneo ni sólidamente cohesionado, con un origen común ni propósitos 
compartidos. Si bien confluyen circunstancialmente en la obra y pertenecen ocasionalmente al mismo gremio, no se reconocen a sí mismos como parte de una misma comunidad cultural con una identidad bien definida.

Ensayando con los esquemas propuestos por Signorelli, aplicándolos a esta investigación, encontramos los siguientes formas de relación entre sujetos y lugares. En primer término, en la obra se establecen relaciones muy particulares entre los albañiles y el espacio físico, en proceso de transformación, en un doble sentido: realizan una intervención directa en el espacio para transformarlo, pero también mantienen una relación de habitación temporal.

También se establecen en la obra múltiples relaciones entre los diversos actores que ahí confluyen. Hay que destacar la heterogeneidad de los sujetos que interactúan en la obra. Se dan relaciones horizontales entre los mismos albañiles y relaciones verticales con otros eslabones de la cadena laboral: entre peones, oficiales, maestros, encargados de obra, arquitectos, inversionistas, agentes de ventas, etc. En la obra tienen cabida numerosas relaciones entre actores que practican distintos oficios, poseen diferentes rangos, provienen de diversos orígenes, trasfondos culturales, posiciones económicas, etc.

Por último, diversos lugares entran en contacto a través de los trabajadores que confluyen en la obra; se crean conexiones entre sus lugares de origen, pueblos, barrios, zonas de la ciudad, se entrecruzan mapas laborales de los lugares en los que han trabajado en el pasado. Asimismo, se forman nexos entre las diversas facetas de la obra, entre la obra como sitio laboral y la obra como lugar que habitan temporalmente. También habría que considerar los diálogos entre la obra como lugar real y su presencia como lugar imaginario, más o menos tangible a través de maquetas, fotos publicitarias, planos del edificio etc.

Más adelante retomaremos el análisis de Amalia Signorelli, después de presentar en el siguiente apartado una serie de crónicas etnográficas que ponen de relieve los vínculos y las dinámicas entre los albañiles y la obra, y pretenden esbozar algunos rasgos significativos de esta particular cultura del habitar. 


\section{Los albañiles y el espacio en construcción}

\section{Vivir y trabajar en la obra}

En la presente investigación, la idea de habitar la obra se refiere, en primera instancia, a la dinámica de los trabajadores que hacen de la obra también su vivienda, esto es, se apropian del espacio laboral para convertirlo también en su espacio habitacional. El velador sería la figura más representativa de esta forma de habitar, pero es importante subrayar que no es el único actor que vive y trabaja en la obra. Hubo en todo momento grupos de albañiles, migrantes temporales en su mayoría originarios de los estados y municipios alrededor de la ciudad, que solamente volvían a sus casas los fines de semana, y entre semana vivían en la obra. La obra era para todos ellos tanto vivienda como lugar de trabajo. De acuerdo con los resultados de la investigación de Carmen Bueno, "más de la mitad de los trabajadores en la fase de albañilería son inmigrantes temporales que utilizan la obra como vivienda" (Bueno, 1994: 107).

Pero en un segundo plano, habitar también quiere decir apropiación a través de la construcción; se refiere al uso, apropiación y transformación de un espacio en construcción por parte de los obreros. Parto del supuesto de que construir o intervenir sobre un terreno para edificar un inmueble, es ya una forma de habitar el espacio, de hacerlo habitable o de modificar su habitabilidad anterior.

A través del siguiente recuento, espero describir cómo conforme se va transformando el espacio de la obra, cambian las condiciones materiales y evolucionan los usos y las maneras de habitarlo. Pero paradójicamente, los trabajadores construyen $-\mathrm{y}$ al construir habitan - un espacio durante un tiempo, pero al final, cuando su esfuerzo culmina, deben retirarse, abandonar ese espacio y moverse a otro que nuevamente deberán domesticar o urbanizar.

"Por las noches nos quedamos a dormir en la obra varios que somos del mismo pueblo, por allá cerca de Atlacomulco, en el Estado de México", me cuenta Patricio. A Pato, como al grupo de albañiles de su pueblo ("el grupo Atlacomulco"), les conviene la opción de vivir y trabajar en la obra entre semana, para regresar a sus casas desde el viernes en la tarde hasta el lunes en la madrugada. "¿Entonces están contentos con esta chamba y con su horario de trabajo?", les pregunto a Pato y a Paul. Ambos asienten. "Sí, porque a algunos nos conviene más asi", dice Patricio, "a los que venimos de fuera, como yo, nos queda bien trabajar más horas cada día 
entre semana, a cambio de poder volver a nuestras casas el fin de semana completo... Si trabajáramos los sábados, como en otras obras, aunque fuera sólo medio día, no podríamos estar con la familia más que un día entero".

Pasadas las 6 p.m., una hora después de la salida de los trabajadores, me doy una vuelta por la obra. Ya estaba oscuro y la puerta estaba cerrada. La ventana del cuarto del velador está cubierta con plástico proveniente de los pendones promocionales que anuncian la venta de los departamentos. Hay luces prendidas en el cuartito y la radio transmite un juego de fútbol. A lo lejos, dentro de la obra, oigo varias voces, lo cual quiere decir que el velador no es el único que permanece en la obra fuera de las horas laborales. Me parece que son varios los trabajadores que pernoctan en el terreno, todos ellos trabajadores migrantes temporales provenientes de los estados cercanos a la ciudad.

Por la ventana descubierta del otro cuartito se puede ver una mesa de plástico, sillas con ropa colgada, cartones apilados, basura tirada en el piso, un par de botas de hule llenas de lodo, maletas deportivas colgadas de clavos en la pared, entre otras marcas y huellas de la apropiación y habitación del espacio en construcción por parte de los trabajadores. ¿Cuántos trabajadores vivirán ahí en la obra? ¿Cómo se acomodarán para dormir?

A la hora de la salida, el velador y otros tres trabajadores se reúnen cerca del cuartito de la entrada. Por ahora son únicamente ellos cuatro quienes se quedan a dormir en la obra, por lo tanto no se cambian ni se arreglan como los demás. En el cuartito donde guardan su ropa, herramientas y planos, tienen pósters de chicas desnudas pegados en la pared. Les pregunto qué tal pasan las noches ahí; dicen que bien, que no pasan mucho frío, pero "lo latoso son los zancudos; hay un chingo, por aquello del agua que hay todavía en el hoyo"... Tiempo después, cuando le pregunto al nuevo velador - un señor mayor, bastante flaco pero correoso-qué tal está el frío por las noches en la obra, me contesta - con un fuerte aliento alcohólico, la cara medio hinchada y la voz aguardentosa-: "el frío no hay pedo, lo malo son los pinches mosquitos".

Rufino, el actual velador, me dice que en el nuevo cuartito hasta atrás del terreno sí pasa un poco de frío y quisiera conseguirse un mejor colchón. Estaba mucho mejor dormir en el cuarto que había antes, pero ya lo demolieron... El velador me dice que los fines de semana, cuando los demás se van a su pueblo, la 
obra se queda muy solitaria y se siente bien raro, todo muy silencioso, no hay ruido en la escuela ni en la calle. Se va un momento y regresa al cuartito diciendo que ya le dio hambre otra vez, porque siempre a esa hora por la parte de atrás del terreno llega un olor a pan que irremediablemente le abre el apetito.

Paso de noche por la obra y me encuentro a Israel, el nuevo velador, quien me informa que además de él, esta semana se han quedado a dormir unos siete u ocho trabajadores. Mientras platicábamos llegó a la obra un señor mayor con un fuerte aliento alcohólico, vistiendo una camiseta amarilla con el logotipo del sol azteca del PRD; no me parece haberlo visto antes trabajando en la obra, quizás sea conocido de algún albañil o también podría ser uno de tantos vagabundos de la zona.

Al verme cargando dos mochilas, un trabajador me pregunta de broma si acaso me corrieron de mi casa. Me dice que ahí me pueden rentar un cuartito y me señala la guarida donde alguien duerme por las noches, un cajón tipo sarcófago improvisado con unicel, tablas de madera y un plástico negro; me asomo y detrás de unas cobijas veo un trabajador acostado, dormido plácidamente y roncando.

En un rincón apartado de la obra me encuentro al Gato que se está bañando a jicarazos con una cubeta, en calzones, parado sobre una tabla de madera. Lejos de sentirme un intruso transgrediendo un espacio íntimo, sentí confianza para quedarme por ahí actuando con naturalidad; comenté algo como: "qué tal el bañito", a lo que me respondió: "sí güero, es que si no se lava uno bien después del colado, la mezcla se queda bien pegada a la cara". Junto había un cuartito que en ese momento estaba abierto, a pesar de tener una puerta de madera equipada con candado y cadena. Supongo que se trata de "la habitación" del Gato, bastante bien equipada, iluminada provisionalmente con una de las lámparas que se usarán para el estacionamiento; cuenta con un colchón, almohada y varios sarapes. Sobre la cama lo espera su ropa limpia, pantalón y chamarra de mezclilla, cachucha y unos buenos tenis colgados de un clavo en la pared. La confianza, naturalidad y espontaneidad del momento me permitió tener una visión desde adentro del espacio íntimo de uno de los trabajadores que habitan la obra.

El sótano en la obra Córdoba, que eventualmente sería el estacionamiento del edificio, fue un lugar importante en términos de habitar la obra, fue uno de los primeros lugares resguardados donde pudieron vivir temporalmente los trabajadores... Los albañiles han improvisado casitas precarias y provisionales con 
madera, plástico y el material de desecho que encuentran a su alrededor; me recuerdan un poco a los hogares que elaboran algunos niños de la calle.

El sótano-estacionamiento, este nuevo espacio interior, oscuro y húmedo, ya ha sido ocupado o habitado temporalmente por los trabajadores. En la esquina, hicieron un cuartito con dos paredes de madera, el espacio de junto fue amueblado con una mesa y sillas de plástico, dos camas, un tendedero y varios percheros para colgar ropa y mochilas. En un rincón hay una mesa de madera que sirve como cocina. Sobre la mesa hay una parrilla eléctrica, ollas, latas de chiles, un garrafón de jugo de naranja artificial, aceite, sal y varias bolsas de Sumesa. La indispensable grabadora cuelga de la pared. La radio toca canciones que uno de los trabajadores tararea impetuosamente. Por todos lados pasan y se enmarañan los cables de la precaria instalación eléctrica; un foco parpadeante apenas ilumina el sitio.

Pato me platica que vivir en la obra no está tan mal. En las noches se queda en el sótano, ahí tiene su bodeguita. El único problema es que últimamente ha llovido mucho, "ahora con las lluvias lo malo es que se cuela el agua, el suelo se pone bien helado en la madrugada y sigue habiendo muchos zancudos que no dejan dormir en paz", agrega. Gato me confirma que ahora sí el frío está duro por las noches en la obra, que el viento se les cuela por las puertas de madera, hechas de cimbra reciclada que tiene grandes ranuras.

Me llama la atención el particular uso del espacio en este sótano, que igual sirve como depósito de basura, garage para bicicletas, habitación provisional y bodega para materiales; cobertores, maletas, instrumentos de cocina y restos de comida, conviven con cascos, cajas para los registros de luz apiladas en el piso y otros materiales ahí almacenados... Encuentro muebles improvisados, burós hechos de tabiques y restos de cimbra, la cama destendida sobre barrotes de madera, sartenes, botes de jugo, chamarras y mochilas colgadas por doquier y un garrafón de agua para que tome quien quiera. Un ejército disperso de moscas invade zumbando el espacio aéreo del cuarto.

En la segunda planta también hay algunos cuartos provisionalmente habitados por los trabajadores, bastante más en forma que los del sótano: unos tienen mesa, $T V$, estufa e incluso una pequeña caja fuerte. Igualmente, el cuarto donde se quedan cuatro yeseros provenientes de Tlaxcala, está equipado con TV, cama de madera, cobijas con dibujos de ositos, y está adornado con fotos de mujeres 
desnudas en la pared. Hay ropa tirada por todos lados y hasta usan la Santa Cruz como perchero. Incluso tiene una puerta improvisada que se puede cerrar con candado y cadena.

En el sótano de la obra de Puebla, que nuevamente es la parte más habitada, hay cuartos con literas, camas con mosquiteros, mesas con trastes y comida, ropa tirada en el piso... verdaderas habitaciones temporales más establecidas que las de la obra de Córdoba, tal vez porque será una obra de mayor duración. Hicieron dos cuartos de baño de madera temporales para los trabajadores, ingeniosamente edificados, elevados casi un metro del piso, por lo que fue necesario poner un tabicón a manera de escalón.

\section{Precariedad e ingenio popular}

Albert Camus decía que lo que cierra el paso obliga a abrir camino. En este apartado describo situaciones en que el acto de habitar la obra por parte de los albañiles destaca por su ingenio para resolver problemas prácticos e improvisar soluciones ante la precariedad de las condiciones - tanto materiales como sociales-que se les presentan. Este binomio de conceptos, ingenio y precariedad, ha resultado una categoría teórica importante a lo largo de esta tesis, para desentrañar los sentidos que tienen las acciones de los trabajadores, y constituye una característica esencial de su cultura, su idiosincrasia, y sus usos y costumbres en la vida cotidiana. Resulta útil aplicar la noción de precariedad-ingenio como herramienta conceptual para pensar las circunstancias de la obra en términos de una constante batalla por resolver problemas materiales, por superar las condiciones que impone el espacio, por domesticarlo con los pocos recursos que se tengan a la mano. Se trata de sobreponerse a la precariedad por medio del ingenio popular, más que de la ingeniería propiamente dicha, ligada a la ciencia y la tecnología. Buena parte de las relaciones entre la mano de obra y el espacio en construcción, pueden interpretarse como una interacción entre estos dos polos, ingenio y precariedad, que junto con los de racionalidad e informalidad, ocupan un lugar central en esta investigación.

En medio del aparente caos y la precariedad que imperan en la obra, el proceder de los albañiles es también una labor metódica y racional; prevén que tienen que hacer una cosa primero para después con ella hacer otra cosa más, actuando según un principio fundamental de la racionalidad práctica: lo primero es lo pimero. La 
experiencia de los maestros les permite prever los pasos del proceso constructivo y actuar siguiendo un orden, aunque esto no siempre sea tan evidente.

Resulta curioso el parecido fonético entre las palabras 'imprevisto' e 'improviso', que en el contexto de una obra tienen además una cercanía semántica, ya que ante lo imprevisto, siempre hay que improvisar algún tipo de respuesta o solución. Otros términos importantes en este sentido son 'ingenio' e 'ingeniería'. Ambas palabras provienen del latín ingenĭum, que según la Real Academia Española, entre sus acepciones comprende: "la facultad del hombre para discurrir o inventar con prontitud y facilidad", "intuición, entendimiento, facultades poéticas y creadoras", así como "la industria, maña y artificio de alguien para conseguir lo que desea". Todos estos sentidos están presentes tanto en el ingenio como en la ingeniería, pero quisiera marcar una distinción importante. Cuando utilizo el término ingeniería me refiero a la disciplina profesional, técnica, científica y tecnológica, de diseñar y construir estructuras inmuebles de diversos tipos. En contraste, utilizaré ingenio o ingenio popular, para referirme al conocimiento empírico, intuitivo, espontáneo, que solamente se transmite a través de la experiencia directa, y se aprende sobre la marcha, a base de ensayo y error, en una dinámica de imitación y capacitación entre aprendiz y maestro, entre ayudante y oficial.

Este ingenio o capacidad para resolver problemas prácticos con los pocos recursos que tienen a la mano, es parte fundamental del capital social de los albañiles. En toda obra o construcción se requieren ambas lógicas: por un lado la ingeniería, los cálculos, los planos, el diseño arquitectónico, las técnicas y medidas oficiales e institucionalizadas, en fin, todo lo relativo a la racionalidad, y por otra parte, igualmente indispensable es el ingenio, la sabiduría popular, el know how, la maña, las técnicas aprendidas en la práctica cotidiana o por imitación, junto con el conocimiento tácito, corporal, el desarrollo de habilidades y destrezas, que incluyen la fuerza bruta, la resistencia, los callos, entre otras adaptaciones físicas y corporales que desarrollan los trabajadores de la construcción. Así, en el contexto de una obra como las estudiadas en esta investigación, ingenio e ingeniería son formas distintas de emprender la transformación del espacio, que sin embargo van siempre de la mano y en todo momento forman un binomio, de modo que no podría haber la una sin la otra. 
Para entrar al terreno hay que zafar un cordón amarrado a un clavo, que detiene la puerta para mantenerla entreabierta. Subo al techo por una escalera de madera clavada a la pared... Más tarde salgo por la puerta del terreno, nuevamente desatorando y volviendo a atorar el mecate en el clavo que la mantiene entrecerrada.

La instalación eléctrica provisional que alimenta de energía todo lo que sucede en el fondo del sótano, está formada por una enredadera de cables pelados y unidos con masking tape a las clavijas de los aparatos, sin necesidad de enchufes normales... Una grabadora llena el ambiente de música trasmitida por radio, conectada a un enchufe de corriente eléctrica con una larga extensión color naranja, a través de un cable pelado y bifurcado por la punta... Para cocinar en la obra, los albañiles fabrican ingeniosas parrillas eléctricas, con resistencias colocadas sobre ladrillos con diminutos canales labrados, conectadas a la corriente eléctrica a través de un cable pelado por un extremo y metido en una clavija. La caja en la que estaba empacado un excusado sirve ahora como despensa en esta cocina improvisada.

Los yeseros hacen una tarima con un tablón de madera sostenido sobre dos cubetas volteadas, para alcanzar la parte alta del muro... Sobre la mesa de trabajo de madera, los trabajadores que ahí hacen estribos todo el día, improvisaron un techo de unicel sostenido con alambres desde un muro cercano, para resguardarse del sol...

Dos obreros jóvenes se disponen a meter al terreno un tonel lleno de impermeabilizante. El problema es que hay varios obstáculos interponiéndose en su camino. Primero intentan cargarlo, pero al constatar que pesa demasiado, deciden rodarlo y cuando es necesario, ponen dos polines para empujarlo y rodarlo por encima de los obstáculos que se les interpongan, como por ejemplo la tina para la mezcla recién construida.

En esta ocasión, el esfuerzo colectivo se concentra en la fabricación de una estructura de madera para que las carretillas y los hombres puedan circular hasta el fondo del terreno. Cuando llegué, apenas había un primer esqueleto de esta estructura pero en menos de una hora ya estaba casi lista. Los carpinteros son los más aplicados en esta labor, pero todos cooperan de una u otra forma. En un abrir y cerrar de ojos se ingenian un sistema de rampas y pasillos con tablas, polines, 
barrotes y restos de otras piezas de madera, que ellos nombran con términos técnicos populares, como punteros, madrinas, padrinos, cabezales, calzadores, etc. Todo parece muy espontáneo, la estructura se va armando como por azar, anárquicamente y sin un plan bien definido ni acordado previamente. No obstante, al final todas las partes se ajustan y el conjunto funciona perfectamente. Un pequeño defecto se puede arreglar localmente $y$ de hecho no afecta la integridad de la estructura general... Si uno se enfoca en los pequeños detalles que conforman una determinada estructura, observando cuidadosamente cada hoyo, cada clavo, cada alambre, de pronto nos vuelve a sorprender que tales aspectos tan minúsculos e inestables por sí solos, sean parte de algo mucho mayor y más complejo, que resulta completamente funcional.

La presencia y contribución del equipo de carpinteros dentro del hoyo es muy notoria. Una pareja de hombres mayores edificaron en un santiamén una plataforma suspendida sobre el hoyo, un entrepiso provisional para facilitar el paso de materiales entre arriba y abajo... Hay varios espacios con pilotes de madera de piso a techo, con amarres, terminales y cabezales ingeniosamente improvisados, unos con calzador, otros descuidados e incompletos, pero que sin embargo en conjunto terminan por funcionar bien... Los cabezales que descansan sobre un cerro de grava a veces quedan metidos a presión contra el suelo, otras veces hay que ajustarlos con calzadores para que queden bien firmes. Es impresionante que una estructura construida tan de prisa, espontáneamente, con errores corregidos al momento, improvisada de última hora, sea finalmente tan firme y efectiva.

Los espacios que están siendo techados son atravesados por pilotes verticales que detienen la estructura de madera y varilla que formará el suelo del piso de arriba. Me asombran la precariedad, el ingenio, la espontaneidad, la anarquía, con que se detienen tales pilotes, atorados, ajustados y apuntalados de mil maneras contra el piso y el techo. No hay uno que sea igual que otro. La solución depende del tamaño del trozo de madera del que partan. Se reutiliza madera de otras cimbras. Se necesita ingenio para prolongar o acortar un pilote hasta obtener la medida exacta necesaria. A veces hay que darle una buena calzada con una tablita de madera a un segmento que se siente endeble o tambaleante. Me llama la atención la gran estabilidad que se logra en conjunto, a pesar de que si nos fijamos en cada uno de los pilotes no parecen estables en absoluto. Supongo que los albañiles intuyen o 
saben por experiencia el grado de inestabilidad o inexactitud que puede soportar una estructura determinada.

Observo asombrado un tipo de andamio muy peculiar, improvisado con sólo siete piezas de madera clavadas entre sí y contra la pared... eso es todo lo que un albañil necesita para sostenerse y trabajar sobre un muro, a una altura que rebase su propia estatura.

En la obra de Puebla, a la altura del tercer piso, improvisaron un puente con tablas colocadas sobre tubos y láminas metálicas, que conecta las dos torres de la obra. Desde mi perspectiva este puente parece demasiado frágil e inestable como para aguantar, por ejemplo, a un trabajador con una carretilla llena de material. Hay un gran contraste entre las estructuras sólidas de las dos torres de departamentos y la aparente fragilidad del puente improvisado que las une. Sin embargo, curiosamente a este puente le han colocado barandales a los lados, con una sola varilla amarrada de lado a lado con alambres. Resulta casi irónica una medida de seguridad tan ínfima en medio de tanta precariedad, inestabilidad e improvisación.

En un momento dado la obra parece un laberinto donde todo es de madera: pasillos, techo, barandales, pilares, rampas, etc. Todo este andamiaje podría parecer sumamente inestable y sin embargo resulta completamente funcional, tomando en cuenta lo efímero e improvisado que es. Este es, sin duda, uno de los aspectos que me parecen más significativos de una obra, la relación entre la precariedad del entorno en plena transformacion y el ingenio popular de los albañiles para sobreponerse a ella, hacer posible la construcción e incluso hacer habitable el espacio de la obra.

\section{Imágenes y modalidades del habitar}

Amalia Signorelli propone que las relaciones sujeto-lugar pueden ser de diversos tipos, de los cuales me interesa retomar sobre todo dos: las que llama relaciones de asignación y las relaciones de apropiación. Estas categorías se refieren sobre todo, según entiendo, al poder de un sujeto para actuar ante las condiciones que le impone un espacio (cf. Signorelli, 2008). En consonancia con lo planteado por Signorelli, a través del análisis del acervo fotográfico generado como parte 
sustancial del trabajo etnográfico, encontré varias imágenes que remiten a la noción del habitar como punto de encuentro y diálogo constante entre lugares y sujetos. Las fotos del habitar reflejan los distintos modos de interacción entre la mano de obra y el espacio en transformación. En estas imágenes se pueden leer las diferentes modalidades de la relación entre las personas y los lugares; expresan cómo el hombre interviene, modifica, construye, se apropia y habita un lugar, y cómo ese entorno habitado representa a su vez condicionantes importantes para la actividad humana. Estos tipos de relaciones son lo que llamo modalidades del habitar y se aproximan mucho a las categorías propuestas por Signorelli (2008).

A continuación describiré estas modalidades del habitar basado principalmente en las fotografías etnográficas, pero también recuperando del diario de campo los relatos que se refieren a la interacción albañil-obra, persona-lugar, sujeto-entorno, señalando las coincidencias con el esquema planteado por Signorelli, pero agregando algunas observaciones críticas y nociones complementarias.

\section{Atrapados (asignación)}

Signorelli llama "relaciones de asignación" a las interacciones entre un sujeto individual o colectivo- y uno o más lugares de diversos tipos en las que el sujeto no cuenta con la capacidad, los recursos o el poder para modificar significativamente las características de tal lugar, ni las condiciones que éste le impone. Podemos hablar de relaciones de asignación (o quizás mejor de imposición) cuando un sujeto tiene poca o nula oportunidad de acción sobre el espacio; cuando se debe conformar o adaptar a él, en la medida de sus posibilidades; cuando un sujeto no puede elegir tiene que asumir o se debe resignar a algo que le es asignado o impuesto (cf. Signorelli, 2008).

Analizando las formas de habitar la obra a partir de mis fotos, identifico este primer tipo de relaciones en las imágenes en las cuales los albañiles dan la sensación de estar determinados o condicionados por el espacio; cuando los trabajadores parecen estar apresados o arrinconados, atrapados por los materiales o las estructuras que construyen, cuando aparentemente son atravesados por ellos o están metidos dentro, sin muchas perspectivas de modificar su situación.

Por supuesto, todo sujeto está sometido en alguna medida a procesos de asignación, a situaciones más allá de su control, a condicionantes de diversos tipos. Por ejemplo, resulta imposible cambiar ciertas condiciones que nos impone la ciudad 
donde vivimos, mas podemos adaptarnos a ellas. Pero esto es relativo y puede variar en cada caso particular. Estas nociones se refieren a circunstancias contingentes y a momentos particulares, que pueden cambiar de un momento a otro, o entre un actor y otro (cf. Signorelli, 2008).

El caso de los albañiles es muy curioso porque por un lado tienen la facultad, la misión, los recursos y las herramientas para actuar directamente sobre el espacio y modificarlo, son los agentes indispensables de la transformación del espacio, pero por otro, no lo hacen de acuerdo con sus intereses, sino siguiendo órdenes y realizando un proyecto elaborado por otros. Están ahí y hacen lo que hacen por asignación, una asignación que en este caso no es del espacio propiamente dicha, sino de su situación social. A final de cuentas, no tienen control sobre los lugares que contribuyen a construir, porque eventualmente, después de todo, deberán abandonar la obra, serán desplazados una vez que lleguen los habitantes legítimos.

\section{Integrados (apropiación)}

Otra variedad de la relación sujeto-espacio se refiere a las situaciones en las que el sujeto tiene la posibilidad de hacer algo sobre el espacio, cuando tiene el poder de actuar para modificar sus circunstancias espaciales. Signorelli denomina a esta segunda modalidad "relaciones de apropiación", verbo que remite a la acción de un sujeto activo, intencional, que en su actuar hace suya alguna cosa, bien u objeto. Es importante captar todos los matices de significado del término apropiación en relación con el espacio; por ejemplo: conquistar, ocupar, adaptar, transformar, construir, usar, transitar, etc. son formas importantes de apropiación (cf. Signorelli, 2008).

En una esquina del terreno los albañiles armaron un nuevo cuartito de baño improvisado con restos de madera, apenas tapado con un hule negro que cuelga del muro, detenido con dos clavos. A pesar de que no hay ningún tipo de instalación sanitaria, el hecho de ponerle un plástico para que los usuarios se cubran, simbólicamente lo convierte en un lugar privado. Este es un ejemplo del tipo de acciones que me interesa observar en esta investigación, aquellas operaciones que implican institucionalizar un lugar, designarlo para una función, marcar el territorio, nombrarlo o fundarlo, interiorizarlo, representarlo y dotarlo de un sentido compartido, vincularlo con la memoria colectiva, convertirlo en sitio de 
relaciones e intercambios, en suma, humanizarlo. Estas son precisamente las formas de apropiación de la obra, los modos particulares de habitar el espacio que me han interesado a lo largo de esta investigación.

En un recorrido por los espacios interiores del edificio en obra, me encuentro con un reducido apartado (que después seguramente será el medio baño de un departamento), por ahora convertido en un dormitorio improvisado y muy precario, que tiene a manera de cama una tabla de madera levantada sobre tabiques y un trozo de tela alfombrada como colchón, tapiado provisionalmente con un tablón de madera mal colocado... Junto había un baño provisional, delimitado con tablones de madera, que constaba de la taza de un WC sin tapa ni aposento y un cubo para depositar el papel... Justo donde serán los baños del roof garden y el tocador para las visitas durante los eventos sociales en la terraza, irónicamente ahora está el baño para los trabajadores, que consiste en un excusado sucio y sin tapa, un cubo de lata, un tambo de agua y un rollo de papel de estraza tirado en el piso mojado.

Definitivamente el espacio se siente cada vez más habitado, significado y apropiado por los albañiles; cada día es más claro que, al menos por ahora, en cierta forma, este lugar les pertenece.

Nuevamente en referencia al acervo de imágenes etnográficas, me parece que estas relaciones de apropiación se pueden identificar en las situaciones en las que los trabajadores parecen integrados a su entorno, fundidos con el lugar; cuando forman una unidad con él, cuando están enmarcados por el lugar y son parte del espacio que habitan. Vale la pena destacar nuevamente que las apropiación de los albañiles tiene mucha imaginación e ingenio, usan cosas y objetos para otras finalidades distintas a las que están originalmente destinados. Hacen su lugar de trabajo y su lugar de residencia con los pocos recursos que tienen a la mano. Ponen sus pertenencias, dejan huellas, basura, adornan, decoran, se envían mensajes, etc.

Pero es importante enfatizar que las situaciones de asignación y de apropiación no son absolutas. El estar atrapados implica que el espacio impone condiciones, que nos limita; en la integración el hombre supera las condiciones que le impone el espacio, se adapta. Pero esto nunca ocurre total e irreversiblemente. Entre la circunstancia de estar atrapados por el espacio, encerrados o arrinconados, y la situación de integración o adaptación a las condiciones que impone el espacio, hay una frontera difusa, permeable, que permite el paso constante entre un estado y 
otro. Estas dos modalidades pueden entenderse más bien como dos fases de un proceso, dos caras de una moneda que no deja de girar, o como un vaivén entre una y otra etapa de un mismo ciclo. El habitar es un proceso continuo, no una acción definitiva.

Además de estas dos modalidades básicas del habitar, que coinciden con la propuesta de Amalia Signorelli, encuentro en las imágenes y textos de mi experiencia etnográfica otras modalidades importantes en que los albañiles habitan la obra, otras formas de vinculación entre la mano de obra y el espacio en transformación, que planteo a continuación.

\section{Tránsito}

A mi juicio, otra forma de habitar el espacio es transitar por él. Los lugares están marcados por los movimientos y desplazamientos de los actores que circulan a través de ellos. La obra puede entenderse como lugar de tránsito en diversos sentidos, desde el nivel literal hasta el metafórico. Propongo interpretar la obra como un punto de encuentros y desencuentros interculturales. Es un sitio donde se hace manifiesta la movilidad laboral de la mano de obra (en forma de despidos y nuevas contrataciones, trabajos alternos o complementarios, informales o ambulantes, migraciones temporales, del campo a la ciudad, o hacia los Estados Unidos, etc.). Pero también hay que resaltar la gran habilidad que muestran los albañiles para transitar por el espacio físico de la obra, para armar y utilizar puentes, rampas y pasillos frágiles, estructuras inestables, o la manera en la que trepan por las columnas o castillos de varillas.

Desde arriba me concentro en la gran cantidad de caminos improvisados que se han fabricado por toda la obra: rampas, pasillos y atajos hechos específicamente para cada sitio, para optimizar el tránsito por el espacio; polines y tablones de madera sirven de puentes para cruzar charcos o atravesar desniveles; un sistema de pasillos, caminos y puentes improvisados y provisionales conectan un espacio con otro.

Para entrar al terreno, tras la última fase de la excavación, hay que trepar o descender por un castillo de varillas hacia donde trabajan la mayoría de los trabajadores. Me dicen que para mañana ya va a haber una rampa para que se pueda entrar bien, "porque así brincando está más complicado y lioso"... En efecto, 
al día siguiente estuvo lista una rápida y efectiva rampa de madera para unir estos espacios... El piso de arriba amaneció inundado por un fuerte aguacero nocturno. $A$ primera hora, los trabajadores colocaron una fila de tablas traslapadas, trazando un camino por toda la planta hasta las escaleras, para evitar que quienes suban se mojen los pies y ensucien el resto del edificio.

Para rematar las esquinas del hoyo, los trabajadores pusieron tres polines a manera de puente para cortar la esquina y pasar más fácilmente con las carretillas cargadas de material. Otra cosa que me llama mucho la atención por su gran practicidad es una rampa que utilizan para bajar y subir al hoyo desde la entrada, fabricada con varios tablones de madera unidos, sostenidos sobre pilotes de diferentes medidas, equipada con unos trozos de madera para apoyar los pies, a manera de huellas antiderrapantes, pero dejando libre un angosto corredor en el centro, para que rueden las llantas de las carretillas.

Tres carretilleros van y vienen tomando ágilmente las curvas y las rampas de la estructura de madera que ayer terminaron de armar. Pasan por un largo pasillo elevado, sostenido por cabezales con forma de "Y"... Silvano pasa hacia adentro del terreno brincando la tina de mezcla y caminando por el filo de sus paredes, cual equilibrista, comprobando la firmeza y estabilidad de esta estructura de madera improvisada, que parece endeble pero en realidad tiene suficiente resistencia.

En la obra de Puebla hay varias rampas y puentes fabricados aprovechando $y$ reutilizando el material de desecho. Para subir a la parte de arriba de la obra, a la planta recién colada, hay una rampa tendida que fue fabricada improvisadamente usando las barras de fierro que había en el terreno antes de la obra... Silvano construye un puente improvisado para trepar arriba del techo del cuartito que había en el terreno en un principio. Pone un pilote y lo detiene con unos tabiques y unos barrotes de fierro. Su estructura parece algo primitiva, demasiado rústica, pero después de todo le resulta suficientemente práctica para conseguir su objetivo. Cruza el puente haciendo equilibrio con mucha gracia e ingenio.

\section{Pertenencias, huellas y marcas}

Otra modalidad del habitar que encuentro al analizar las fotografías capturadas durante el trabajo de campo, son aquellas en las que el habitar ocurre a través de los objetos o pertenencias de los trabajadores. Así, llevan a cabo una forma de 
apropiación del espacio al acomodar en él sus objetos personales o herramientas de trabajo. Este es quizás el caso más claro de habitar en la vida cotidiana, de la acción de convertir un espacio en lugar, ya sea lugar de trabajo o sitio privado. Esto está estrechamente relacionado con la vida social y el valor simbólico de los objetos como actores que forman parte de las redes sociales-, tal como ha sido esbozado en el capítulo referente a los materiales y herramientas.

Desde el principio de la obra se dedicaron a la construcción de una bodega provisional de madera, misma que también sirve como guardarropa, donde los trabajadores dejan colgada su ropa buena mientras traen puesta la de batalla. Otros trabajadores dejan sus mochilas, camisas, botas y tenis guardados en una esquina de esta casetita temporal... Muchos dejan sus pertenencias agrupadas en el piso, contra la pared: tenis, bolsas con su almuerzo, mochilas, chamarras, etc. Otros ponen clavos en la pared y los utilizan como percheros en los que cuelgan cascos, zapatos, bolsas de plástico y petacas. Agrupar las cosas con las que uno cuenta es una forma básica de demarcar un territorio, tener una base, ocupar un lugar, habitar un espacio... Por todos lados los objetos personales de los trabajadores cuelgan de las paredes y en algunos cuartos de los futuros departamentos hay ya camas improvisadas en las que por ahora duermen los trabajadores. Un espejo de bolsillo, un cepillo y una pasta de dientes, guardados en una bolsa de plástico transparente, sobresalen de una petaca deportiva en un rincón de la estancia...

El cuartito de atrás, de madera, sin puertas, lo siguen usando de guardarropa y bodega. En el interior hay una pila de botas de hule y un despertador tirado en el suelo... El nuevo sótano está repleto de mochilas, prendas colgadas y envases de refresco tirados por todo el piso... Otras habitaciones de los futuros departamentos del edificio sirven como bodegas en las que se guardan carretillas, lonas, publicidad vieja, tubos de plástico naranja de distintos calibres para la instalación eléctrica y hasta un par de llantas de la cámper u oficina de ventas.

Hacia el final de la obra todavía hay múltiples huellas del habitar transitorio de los albañiles; de las paredes cuelgan las chamarras de los trabajadores que los protegieron en la fría mañana, pero que resultan innecesarias ahora al mediodía en que desempeñan una intensa actividad física bajo el sol... En el sótano encuentro una mesa con una grabadora y múltiples utensilios de cocina; en los baños del roof 
garden hay pilas de costales de material adhesivo para pegar azulejos, y sobre ellos, ropa y zapatos de mujer de las trabajadoras de la limpieza.

También podemos identificar y representar el habitar a través de las huellas o marcas que dejan los trabajadores en el espacio; tal vez la basura que dejan tras de sí sea el ejemplo más claro de las huellas del habitar de los albañiles en la obra. Me interesaba observar los rastros y registrar las huellas del habitar temporal, las marcas del uso del espacio de los albañiles.

Por todo el piso hay basura y desperdicios, así como manojos de banderitas de plástico color naranja que formaban parte del material de publicidad, arrumbados en un rincón... En el piso de la obra, debajo de la parte ya techada, pueden verse las huellas de un incipiente habitar por parte de los albañiles. Hay ropa vieja y basura tirada en algunas partes... El conducto del elevador ha servido como vertedero al que avientan la basura desde cualquier nivel, y esta cae y se acumula en el sótano/estacionamiento.

Durante la obra negra, mientras los albañiles viven y trabajan en la obra, las huellas del habitar son muy evidentes; sin embargo, a partir de la etapa de los acabados, estas huellas son cuidadosamente borradas. Las mujeres son las principales encargadas de limpiar el rastro del proceso constructivo y eliminar cualquier indicio de la presencia albañil en el edificio terminado. Cabe señalar que esta es una de las únicas formas de participación femenina directa en las labores de la construcción.

Otra faceta del habitar tiene que ver con el uso del espacio como medio de comunicación y expresión entre los trabajadores. Se envían mensajes a través del espacio de la obra, se escriben frases de toda índole en las paredes, desde instrucciones de trabajo, hasta mensajes lúdicos y obscenos. Cuando los albañiles se comunican o mandan recados a través de las superficies provisionales, están habitando la obra.

Sobre una pared está anotado con lápiz el teléfono celular de un tal Martín. Además hay varias inscripciones y mensajes escritos en los ventanales, así como información pintada sobre las paredes: "sí porcelanite blanco, recámaras no, baño sí". Un graffiti en las vallas publicitarias que anuncian los departamentos dice: "Mariel: te amo". Ciertos muros dentro de los departamentos están numerados con 
lápiz de color azul marino, como contando las superficies aún pendientes de pintar o enyesar: $16,17,18 \ldots$

Sobre algunas paredes hay pintas hechas presumiblemente por los mismos albañiles, como la que dice "Joel puto" $y$ en otro punto hay varios rayones cancelando otro mensaje... Otras pintas sobre las paredes indican cuentas y medidas, sumas, restas $y$ otras operaciones matemáticas... Hay múltiples inscripciones hechas a mano, presuntamente por los mismos trabajadores de la obra, con lápices bicolor (rojo y azul), sobre la madera de las puertas de entrada a la obra, mensajes escritos como: "si tienen huevos díganlo", "puto cara de perro", "tocayo ojete", además de algunos dibujos obscenos casi infantiles. ¿Se quita fácil, eventualmente se cubrirá con otra capa de material, o quién lo limpia?

Las láminas publicitarias naranjas de DAKAB han sido utilizadas como lienzo o soporte para inscribir en él diversas formas de arte y lenguaje urbano. La manta publicitaria de la obra de Puebla ha sido intervenida con plumón dorado, entre otras marcas de la ciudad en la obra.

\section{Nuevo mobiliario y desplazamiento hacia afuera de la obra}

En esta sección pretendo evocar el contraste que existe entre las formas de habitar la obra de los albañiles durante la construcción, y los estilos de vida de los futuros habitantes de los departamentos del nuevo edificio. Es importante recalcar que ambas culturas del habitar coinciden en un mismo espacio, pero en momentos diferentes (y ciertamente no en idénticas condiciones de construcción, organización, disposición, etc.), por lo que prácticamente no se traslapan en el tiempo, salvo quizás un poco en las últimas etapas de los acabados. Pero sobre todo hay que señalar que su relación con el espacio es completamente diferente. Por lo general, la llegada del nuevo mobiliario para los departamentos, los muebles de baño y cocina, marca el desplazamiento de los trabajadores hacia afuera de la obra; a partir de este momento casi todos los departamentos se cierran con llave y solamente el encargado de obra deja entrar a las cuadrillas asignadas a cada departamento.

Me llama la atención la gran diferencia visual que genera el hecho de que una superficie, como por ejemplo la cara de un muro, esté o no aplanada. Aunque en realidad la diferencia es una mínima capa de cemento o yeso, estéticamente cambia radicalmente la percepción sensorial de un lugar. Un sitio con paredes de tabique se 
siente más tosco, salvaje, agreste, en bruto. La textura de las paredes toscas, rugosas, grises, con cemento escurrido y tornillos salidos transmiten cierta sensación de precariedad o descuido. En cambio, una pared aplanada y alisada con yeso se percibe como un espacio civilizado, cómodo y habitable. Estos pequeños cambios materiales representan sin embargo una diferencia cualitativa importante en la interacción de los sujetos con un lugar, y constituyen un aspecto estético fundamental en la domesticación y la apropiación del espacio, en la construcción del habitar. Pero además, este revestimiento de acabados también es importante porque a partir de ése momento los albañiles se vuelven ajenos a dicho espacio.

La primera dueña de un departamento ya empezó a hacer su mudanza. Afuera de su departamento hay varias cajas apiladas, rotuladas como si hubieran sido enviadas por correo y con etiquetas escritas con plumón: "edredones", "sábanas nuevas", "cocina", etc. En el penthouse ya se encuentran apilados pero aún desarmados los anaqueles que formarán la cocina. Uno de los departamentos está siendo pintado de blanco; ya tiene colchón, cortinas y una maceta con una enredadera junto a la ventana, casi listo para ser ocupado.

En uno de los departamentos de arriba están terminando de instalar la cocina, los cajones y estantes son blancos, al igual que los mosaicos. Una serie de post-its pegados en la pared contienen instrucciones particulares y especificaciones para el instalador. Los clósets, puertas y chapas son de un estilo más clásico que los de otros departamentos, supuestamente más elegante o con gusto un tanto anticuado $y$ conservador. Los muebles de baño de este departamento, de madera color chocolate, también tienen decoración y acabados más clásicos que los demás departamentos.

Finalmente, en la obra de Córdoba una vez terminada aparecieron cortinas, muebles y algunas pocas plantas en los balcones, entre otros signos de estar habitada por sus nuevos dueños, que han desplazado sin siquiera saberlo a los trabajadores constructores, que fueron los primeros habitantes de estas nuevas viviendas.

\section{Hacia una antropología del habitar}

El artículo "Culturas del habitar y espacios urbanos" de Ángela Giglia (2009) es sin duda uno de los textos más relevantes sobre culturas del habitar en el espacio 
metropolitano mexicano contemporáneo, escrito desde una perspectiva antropológica. Asimismo, en el siguiente análisis retomo algunas ideas expuestas por esta misma autora en su libro conjunto con Emilio Duhau: Las reglas del desorden: formas de habitar la metrópoli (2008), que se perfila como un nuevo clásico de la antropología urbana mexicana. Los conceptos, argumentos y definiciones presentados en estos trabajos tienen una importancia especial para los estudios urbanos en general, y una aplicación particularmente interesante en el caso de esta investigación sobre la construcción del habitar y la relación entre los trabajadores de la construcción y el espacio en construcción que es la obra.

De acuerdo con Giglia, el estudio del habitar debe "ocupar un lugar de primer plano a la hora de construir una mirada antropológica sobre el espacio de la metrópoli". Con esto en mente, la autora se dispone a elaborar "una definición antropológica del habitar que nos permita entretejer un diálogo entre este concepto y el de cultura, con el objeto de proponer una definición de cultura del habitar que dé cuenta de la variedad de procesos culturales asociados a los distintos tipos de hábitat presentes en una gran metrópoli" (Giglia, 2009: 225).

\section{Aproximaciones a la cultura del habitar}

El artículo de Ángela Giglia (2009) ofrece una revisión clara y concisa de las ideas de algunos autores que se han ocupado del tema del habitar, como Radkowski (2002), De Martino (1977), Signorelli (2006) y Bourdieu (1995, 2002), entre otros. De este panorama conceptual retomaremos algunos puntos que son relevantes para esta investigación, pero sobre todo dialogaré con la propuesta de la propia autora, especialmente apropiada para pensar las culturas del habitar en el contexto contemporáneo de la Ciudad de México.

Como punto de partida, esta autora afirma que, "en un sentido amplio, el habitar se refiere a la relación de los seres humanos con su entorno, es decir, a los procesos de orientación, percepción, apropiación y significación del espacio..." (Giglia, 2009: 225). Asimismo, sostiene que "habitar es la experiencia de la metrópoli por la cual un espacio se convierte en un lugar, delimitado geográficamente, reconocible materialmente y provisto de significado compartido" (Giglia-Duhau, 2008: p. 22-23). El acto de habitar puede entenderse como la humanización de un espacio, como el acto de dotarlo de sentido humano, de proveerlo de memoria y significado. De 
acuerdo con Ángela Giglia, el habitar podría caracterizarse como "una de las actividades humanas más elementales y universales". Dichos procesos de vinculación con el entorno, ahonda Giglia, son posibles gracias a la cultura y están inevitablemente mediados por ella; así, "podemos empezar definiendo al habitar como la relación con el espacio mediada por la cultura" (Giglia, 2009: 225-226). "EI habitar es, en suma, un hecho cultural por excelencia. Habitar es producir el mundo en cuanto universo cultural" (Giglia, 2009: 228).

Para comprender mejor este sentido fundamental del habitar, dicen Giglia y Duhau, siguiendo a Radkowski (2002), que hay que distinguir en el habitar una parte instrumental y una dimensión simbólica: la relación de un sujeto con un lugar representa tanto amparo y protección con respecto al entorno, como la constitución de su presencia en el mundo. La dimensión simbólica del habitar "alude al establecimiento de una centralidad, aunque sea transitoria y cambiante, y a la constitución de un principio de orden", que le permite al sujeto ubicar su posición con respecto al entorno (Giglia, 2009: 227).

En este contexto, Giglia recupera también las ideas del antropólogo italiano Ernesto de Martino (1977), cuyo pensamiento nos remiten a la cuestión filosóficoantropológica de la presencia humana en el mundo ${ }^{14}$. Aunque de Martino nunca se interesó por el habitar como tal, su pensamiento ha servido como un ayuda o un apoyo para pensar el tema del habitar. Desde esta perspectiva, cercana al existencialismo, el habitar podría entenderse como una forma elemental de "estar en el mundo". Giglia señala que la noción de presencia en este autor no sólo se refiere a la simple ubicación física en un lugar, sino al "estar concientemente en el mundo", "saberse parte del tiempo y de la historia" y "establecer un horizonte de sentido". La concepción del habitar que se derivaría del pensamiento de de Martino, tendría que mantener una vinculación íntima con la esfera de la cultura y el espíritu humano, estaría basada en la conciencia de "estar presente en la historia mediante la cultura" (de Martino, 1977, citado por Giglia, 2009: 228).

Otra propuesta teórica relevante que retoma Giglia es la idea del "habitus socioespacial" elaborada por Pierre Bourdieu, que se refiere a "un conjunto de prácticas no reflexivas, más bien mecánicas o semiautomáticas", a una serie de saberes,

\footnotetext{
${ }^{14}$ Para una reflexión plenamente filosófica sobre la noción de habitar, desde un punto de vista metafísico, habría que revisar las ideas de M. Heidegger (1992) plasmadas en su texto: "Construir, habitar pensar".
} 
significados, gestos y usos casi inconcientes, por medio de los cuales "ordenamos el espacio en el que establecemos nuestra presencia", a la vez que nos relacionamos con otros sujetos cohabitantes del mismos espacio (Giglia, 2009: 228). Otra manera de entender este habitus es como una "subjetividad socializada" o un "saber con el cuerpo", gracias al cual podemos habitar el espacio (Bourdieu y Wacquant, 1995, citados por Giglia, 2009: 228). En relación con esto, Giglia señala que a través de la generalización o institucionalización de estos habitus, se crean ciertas normas de uso y comportamiento para cada lugar, mismas que los sujetos aprehenden e interiorizan, y que en su conjunto generan un orden socio-espacial. "Por cada lugar existen ciertas reglas de uso -más o menos flexibles- que normalmente son respetadas..." (Giglia, 2009: 229).

El habitus espacial me hace reconocer el orden que me rodea... y me pone en condición de actuar en sintonía con él... El habitus espacial es al mismo tiempo mi capacidad para leer el espacio y mi capacidad para actuar coherentemente con esa lectura. La noción de habitus como "cultura del habitar" nos recuerda que el espacio lo ordenamos, pero $-\mathrm{y}$ al mismo tiempo-que el espacio nos ordena. Podríamos decir que "nos pone en nuestro lugar", imponiéndonos ciertas reglas de uso que tienen que ver no sólo y no tanto con constricciones de tipo material, sino más bien de tipo social. El orden espacial, en cuanto producto cultural y social, atañe no sólo a las maneras de leer el entorno, sino a las formas de usarlo y darle significado, de transformarlo en algo propio y que tiene sentido para uno (Giglia, 2009: 229-230).

En suma, recuperando elementos de estos autores revisados, Giglia y Duhau definen el habitar como "un conjunto de prácticas y representaciones que permiten al sujeto colocarse dentro de un orden espacio-temporal y al mismo tiempo establecerlo. Es el proceso mediante el cual el sujeto se sitúa en el centro de unas coordenadas espacio-temporales, mediante su percepción y su relación con el entorno que lo rodea. Habitar la metrópoli alude por tanto al conjunto de prácticas y representaciones que hacen posible articular la presencia de los sujetos en el espacio urbano y su relación con otros sujetos" (Giglia-Duhau, 2008: 24).

Un argumento de Giglia resulta especialmente relevante para esta investigación. Señala que en un primer momento sería fácil asociar la noción de habitar con la de hábitat, entendiendo esta última "como sinónimo de vivienda o morada... techo o amparo, como un espacio que cumple una función defensiva y protección, un lugar donde sentirse resguardados de las intemperies y amenazas que pueden provenir 
del entorno..." (Giglia, 2009: 225). Sin embargo, destaca la autora, esta asociación de términos, a pesar de su cercanía etimológica, no resulta tan pertinente cuando nos enfrentamos con modalidades del habitar en las que los espacios no proveen una sensación de seguridad a los sujetos, "cuando las condiciones de la vivienda son muy precarias", cuando impera "una sensación de incertidumbre, inseguridad y riesgo" (Giglia, 2009: 226).

Numerosas experiencias metropolitanas muestran que es posible habitar un espacio sin sentirse amparado por él. Esto seguramente es así en buena parte de las viviendas de autoconstrucción, pero también lo es, sin duda, en el caso de los albañiles que habitan la obra. El espacio en construcción de la obra, en el que viven muchos albañiles mientras laboran en ella, se caracteriza por su precariedad y hostilidad, no les ofrece mayor resguardo ni seguridad. Puede decirse, por ejemplo, que los albañiles, al igual que algunos habitantes de las periferias autoconstruidas, "habitan intensamente el espacio en cuanto transforman poco a poco un territorio inicialmente inhabitable en algo (relativamente) doméstico" (Giglia, 2009: 226).

En este tenor, Giglia también señala otra distinción entre habitar y residir. Residir tiene que ver con las funciones propias de la reproducción social del orden doméstico (descansar, dormir, comer, guardar pertenencias). El habitar, en cambio, puede tener un sentido más amplio, profundo y abstracto. De esto se desprende que es posible habitar un lugar sin necesariamente residir en él. Los albañiles, por ejemplo, habitan las obras mas no residen en ellas. Sería más adecuado entonces, afirma Giglia, entender el habitar como "la producción colectiva de un entorno provisto de significado" (Giglia, 2009: 226).

Sin duda, el enfoque de Giglia (2009) brinda una sólida base conceptual para el estudio antropológico del habitar en el espacio metropolitano y su papel en la conformación de la culturas urbanas contemporáneas. Sin embargo, a mi juicio, hay un aspecto cuya importancia no queda suficientemente establecida; me refiero a la dimensión de la experiencia y la afectividad de los sujetos en relación con los espacios. El habitar puede entenderse también como una forma de experiencia, concebida ampliamente como interacción entre el sujeto y su entorno, en la cual los elementos de dicha interacción, por medio de ésta, se modifican mutuamente. Como toda experiencia, el habitar posee una rica y compleja dimensión subjetiva, posee una especial carga sensible, afectiva y moral. Considero fundamental considerar lo 
emotivo como un motor importante en la experiencia del habitar. La dimensión afectiva del habitar es un componente esencial en la conformación de la cultura urbana; en las investigaciones sobre la ciudad es necesario preguntarnos cómo los sujetos experimentan estética y afectivamente su relación con el espacio urbano, qué sentido le dan, individual y colectivamente.

En este sentido, me gustaría mencionar brevemente algunos trabajos que podrían servir como punto de partida en la exploración de la dimensión afectiva y la experiencia sensible de los fenómenos urbanos. En primer lugar, el geógrafo humano japonés Yi-Fu Tuan (1974) propone la noción de topofilia para referirse al "lazo afectivo entre las personas y el lugar o el ambiente circundante". Este término implica necesariamente que nuestra relación con el entorno y con el espacio no es natural, sino que está mediada por la cultura, y como tal, es diversa y relativa; por lo tanto, desde la perspectiva de la antropología del espacio y del habitar, habrá que indagar en las actitudes de los diferentes grupos humanos hacia el medio ambiente, sus valores, cosmovisiones, ideas, creencias, percepciones, así como el tono emocional y la disposición perceptiva que marcan nuestra interacción con el mundo en el que nos desenvolvemos (cf. Tuan, 1974: 8-13). Este mismo autor propone abordar las nociones de espacio y lugar desde la perspectiva de la experiencia (1977); plantea que espacio y lugar son componentes centrales en nuestra experiencia del mundo, le interesa explorar cómo la gente piensa y siente los lugares y los espacios, sus vivencias y formas de experiencia en relación con el entorno.

En el contexto de las investigaciones urbanas sobre ciudades mexicanas, quisiera mencionar un par de trabajos que adoptan la perspectiva de la afectividad y el significado en nuestra relación con el espacio urbano. El trabajo de Ernesto Licona (2007) sobre la ciudad de Puebla, titulado: Habitar y significar la ciudad, se interesa por "conocer las formas de habitar la ciudad, de percibirla, de representarla e imaginarla... los significados que sus habitantes construyen sobre el espacio urbano, la relación espacio-cultura, que implica tanto la conformación física como la configuración simbólica" de la ciudad (Licona, 2007: 15-16). También quisiera resaltar la aproximación de Patricia Ramírez Kuri y Miguel Ángel Aguilar (2006) sobre la afectividad, la memoria y el significado en el espacio urbano contemporáneo. Estos autores recuperan la importancia de la subjetividad en la configuración de la cultura urbana y retoman nociones como "apego", 
"pertenencia", "afectividad colectiva", "sensación compartida", y argumentan que todo el tiempo interactuamos con el espacio urbano como "lugar sensible", como "entramado de percepciones" y emociones culturalmente construidas, que conforma una dimensión de la realidad más allá del dominio del lenguaje y la razón (cf. Ramírez Kuri-Aguilar, 2006: 8-9).

\section{Culturas del habitar en el contexto de la Ciudad de México}

Ahora bien, para abordar concretamente el estudio del habitar en una metrópoli tan compleja como México, Giglia señala que "no se puede soslayar como punto de partida la profunda heterogeneidad de tipos de espacio habitable que la caracterizan" (Giglia, 2009: 224). En la capital mexicana "coexisten formas muy diferentes de habitar el espacio que remiten a su vez a distintas maneras de producir la vivienda, desde las más precarias y no planeadas, hasta las más planificadas y racionalistas..." (Giglia, 2009: 221).

Giglia hace una elocuente caracterización de los procesos habitacionales metropolitanos. Plantea que dentro de la amplia gama de modos de habitar y formas de relación entre seres humanos y espacios urbanos, podemos distinguir principalmente dos órdenes distintos, a los que se refiere como la ciudad informal y la ciudad racionalista: "las colonias populares autoconstruidas y los conjuntos habitacionales modernistas constituyen los ejemplos más extremos. La ciudad informal de las periferias autoconstruidas y las máquinas para habitar del más puro estilo funcionalista... constituyen dos respuestas muy distintas a un mismo proceso, representan dos tipos de hábitat... inspirados en lógicas y principios diametralmente opuestos..." (Giglia, 2009: 224). Entonces, la autora se propone abordar y comparar estos dos modos de habitar y producir el espacio urbano que, como veremos, resultan significativos para comprender la especificidad de la forma en que los albañiles habitan la obra.

De acuerdo con Giglia, el origen de la ciudad informal es el insólito crecimiento de la población urbana que tuvo lugar entre 1940 y 1970, debido principalmente a un proceso migratorio del campo a la ciudad. Los millones de nuevos pobladores evidentemente necesitaban viviendas y las fueron construyendo poco a poco, casas de muy pobre calidad, en asentamientos irregulares, sobre todo en las periferias, sin control alguno ni planificación urbana. Esta situación dio lugar a una enorme 
expansión de la ciudad, y es importante subrayar el impresionante hecho de que la mitad de la Ciudad de México ha sido producida por autoconstrucción, sin planificación, durante los últimos cincuenta años. "La ciudad informal resulta del llamado urbanismo progresivo, una forma de producir lo urbano en la que los protagonistas principales son los propios habitantes procedentes del campo: al llegar a la ciudad y no poder acceder a una vivienda ya construida, optan por edificarla ellos mismos poco a poco en terrenos no previamente urbanizados", de acuerdo con su propia lógica, que a veces tiene que ver más con el entorno rural que con el medio urbano (Giglia, 2009: 222).

Extrapolando está lógica informal al caso de una obra, los albañiles, actores protagónicos en la construcción, como hemos visto, son en muchos casos migrantes temporales provenientes de los estados aledaños al D.F., que generalmente viven en la obra y marcan el espacio con referentes vinculados a sus lugares de origen. En el caso de otros trabajadores que viven en las periferias de la ciudad, mucho de lo que se ve en una obra en cuanto a las acciones y técnicas de construcción, así como las dinámicas y formas de organización colectiva, tiene que ver con las formas aprendidas en el proceso de autoconstrucción en sus propios pueblos y barrios. La autoconstrucción funciona además como entrenamiento para la vida profesional. Gracias a la experiencia de participar en la construcción de su propia vivienda y el entorno urbano en sus colonias populares, las nuevas generaciones de pobladores de la ciudad se preparan para trabajar en los distintos oficios del mundo de la construcción. En este sentido, hay una estrecha similitud entre el habitar de una familia que paulatinamente autoconstruye su vivienda de manera informal y la cultura del habitar de los albañiles en la obra, igualmente ingeniosa, precaria y provisional, con hondas raíces rurales en el seno de un nuevo espacio urbano.

La ciudad racionalista, en cambio, ha sido producto de "importantes intervenciones institucionales en materia de vivienda social". A partir de los años 20 y 30 , célebres arquitectos crearon grandes edificios y conjuntos habitacionales que hoy son indudablemente iconos de nuestro paisaje urbano (como por ejemplo los Multifamiliares Miguel Alemán construidos por Mario Pani en 1949). Algunas décadas más adelante, "desde las instituciones de gobierno y desde la universidad pública no faltaron los intentos de resolver el problema de la vivienda mediante la planificación y la creación de un hábitat moderno y funcional, coherente con el 
impulso modernizador y racionalista... Se trataba de emplear los nuevos materiales y recursos técnicos en la producción de vivienda en serie según prototipos..." (Giglia, 2009: 223).

En este sentido, es claro que las nuevas construcciones de edificios de departamentos tienen también un aspecto netamente racionalista. Responden a las acciones para la renovación y el repoblamiento de la ciudad central implementados desde el gobierno local de la Ciudad de México, según los planes de desarrollo urbano y las políticas habitacionales vigentes. Por otro lado, son proyectos realizados por empresas privadas que forman parte de la economía formal, supuestamente dentro del marco legal, que conducen sus desarrollos de acuerdo con el diseño de arquitectos e ingenieros profesionales, siguiendo planos y proyectos que a su vez se someten a la supervisión por parte de las autoridades correspondientes. Además, este tipo de nuevas viviendas, como los edificios de departamentos estudiados en esta tesis, son construidos prácticamente en serie, aunque no a gran escala, pero sí siguiendo prototipos, que responden a las tendencias arquitectónicas imperantes y los estilos constructivos de moda en el momento.

Estas dos "modalidades del proceso de habitar" generan "procesos culturales distintos, basados en una relación diferente con el espacio habitable" (Giglia, 2009: 230-231). El resultado son culturas del habitar opuestas, que mantienen una relación distinta con respecto a la vivienda: una consiste en ir habitando la vivienda conforme se procede a su construcción, en el caso de la ciudad informal; la otra consiste en habitar una vivienda que fue construida en serie. En suma, afirma Giglia:

La ciudad racionalista, producida por la intervención pública, basada en las visiones de la arquitectura funcionalista moderna, y la ciudad informal, producida por el urbanismo popular, constituyen dos tipos de hábitat que no sólo responden a lógicas sociales de producción diferentes sino que se encuentran asociados a culturas del habitar distintas... que a su vez conllevan importantes diferencias en la forma de producir, significar y practicar la vivienda y el espacio de sus alrededores (Giglia, 2009: 224).

Ahora bien, es importante destacar que de cualquier forma que se produzca el espacio habitable, sea de manera racionalista o informal, siempre hay que atravesar por un proceso constructivo, más o menos extendido en el tiempo y traslapado con el proceso de habitar. La obra es un tipo de espacio presente casi en cualquier contexto de producción de la ciudad, e incluso en ámbitos no urbanos. El espacio, para ser 
transformado en lugar, pasa necesariamente por una fase de obra, por un tiempo y un espacio en el que no importa tanto lo que había antes ni lo que vendrá, sino que se encuentra en un estado liminal, intermedio, en transición, durante el cual no es plenamente ni racionalista ni informal.

Si tuviéramos forzosamente que clasificar el espacio en construcción dentro de una de estas dos categorías, ciudad informal o ciudad racionalista, quizás podríamos decir que las dinámicas que se suscitan al interior de la obra son más parecidas a las de la vivienda popular autoconstruida, que a las de los grandes conjuntos habitacionales. Muchas de las características de las viviendas y colonias populares parecen perfectamente aplicables al caso de una obra en construcción.

Aplicando a nuestro estudio algunas caracterizaciones de Giglia sobre las viviendas de autoconstrucción y las colonias populares, podríamos decir que: una obra es un "espacio complejo, poli-funcional y poli-significante", "se transforma en espacio habitable mediante el esfuerzo colectivo"; en un principio, las obras "se presentan como espacios vírgenes, no habitados...", donde "los límites entre lo propio y lo ajeno no están establecidos formalmente de manera precisa, sino que se van construyendo en el devenir cotidiano del proceso de domesticación del entorno"; una obra casi siempre "empieza desde el desorden, la incertidumbre y la confusión, en un estado de carencia y de precariedad"; la obra es producto de "lógicas a menudo azarosas, de esfuerzos individuales y colectivos de distintos actores... no siempre coordinados entre ellos", pero que sin embargo producen a final de cuentas un determinado orden socio-espacial (Giglia, 2009: 233-235). En este sentido, vale la pena señalar que lo informal -en este caso el trabajo de los albañiles - no es necesariamente sinónimo de improvisación, de precariedad o de caos, sino que esta informalidad laboral y habitacional responde a una racionalidad adecuada para su habitus o a su cultura albañil.

Para reforzar la analogía entre la experiencia de los albañiles que habitan la obra y la de los pobladores que autoconstruyen progresivamente su vivienda en colonias populares, nuevamente siguiendo a Giglia, podemos decir que:

...en este proceso, prolongado y forzosamente colectivo, se generan reglas comunes y compartidas acerca de los usos del espacio... Se trata de un proceso de domesticación porque implica familiarizarse con el espacio, empezar a nombrarlo, a usarlo y a hacerlo propio, modificarlo para conseguir ciertos efectos, transformarlo 
en algo útil, establecer desde allí una relación con otras personas y con otros espacios, en suma: transformar el espacio en un lugar (Giglia, 2009: 234).

No obstante, a pesar de que la forma de habitar la obra por parte de los albañiles podría equipararse con la forma de habitar una vivienda de autoconstrucción, quisiera llevar el análisis un paso más allá. En el caso de este estudio, podemos considerar que la parte racionalista - que son los planos de los ingenieros, los cálculos, los principios de la ingeniería, el diseño del espacio por construir, etc.- tiene una importancia preponderante que no debemos menospreciar. Por otra parte, en cuanto el edificio está terminado, las circunstancias habitacionales de los nuevos residentes son más parecidas a las de la ciudad racionalista.

Por lo tanto, creo que sería apropiado presentar el caso de los albañiles, de su relación con la obra, como una combinación peculiar de estas dos modalidades de habitar, la racional y la informal, con características de una y otra forma de producir el espacio urbano. La cultura del habitar propia del albañil es una mezcla interesante de estas dos modalidades de establecer un orden socio-espacial: por un lado, está marcada por la informalidad, la precariedad, lo provisional y el ingenio para domesticar improvisando, y por el otro, está enmarcada siempre en un proyecto racionalista, moderno, oficial, con el que tienen que dialogar. El resultado es un orden socio-espacial particular, una forma de mediación particular entre racionalidad e informalidad. En la obra se funden estas dos formas de habitar y producir orden urbano, que conforman las facetas más típicas del paisaje de la Ciudad de México. 



\section{REFLEXIONES FINALES La construcción del habitar y el habitar en construcción}

Para cerrar, presentaré una serie de reflexiones siguiendo más o menos el mismo orden temático de los capítulos que conforman esta tesis. De acuerdo con la metáfora planteada en la introducción, estas conclusiones serían equivalentes a la azotea o el roof garden del edificio terminado. Desde estas alturas es posible recapitular retrospectivamente las partes del edificio que ha sido necesario recorrer para llegar hasta este nivel: podemos recordar la fachada, la recepción, los cimientos, cada uno de los pisos y los conductos por los que transitamos de una plataforma a otra; pero también, esta planta superior funciona como un mirador desde el cual contemplar el panorama más amplio que nos rodea. Una vez en la cima del andamiaje, podemos vislumbrar nuevas problemáticas que se abren justo donde esta investigación termina.

En estas reflexiones finales recuperaré los temas más relevantes de esta investigación, atando cabos y señalando pendientes, examinando el estado de la cuestión, haciendo un balance crítico de los estudios existentes al respecto, resaltando las dudas y cuestionando las certezas que surgen a partir del material presentado, además de trazar otros problemas de investigación que se entrecruzan con el nuestro, pero que no se abordaron en este trabajo, más que acaso tangencialmente. Definitivamente, a lo largo del camino encontramos múltiples cuestiones que a pesar de su relevancia quedan abiertas para futuras investigaciones.

\section{Construcción, proceso y complejidad en el pensamiento antropológico}

Con respecto a la noción central de esta investigación, la noción de construcción, hay que señalar que se trata de un concepto fundamental para la antropología contemporánea, indispensable para comprender mejor la cultura y los procesos sociales en la actualidad. El fenómeno de la construcción nos enfrenta inevitablemente con la complejidad del mundo en general y de la experiencia humana en particular. Su consideración implica el reconocimiento de que $\mathrm{n}$ el mundo humano no hay nada dado de antemano, fijo y estable, sino que todo lo que sucede a nuestro alrededor ha llegado a ser como es a través de una serie de 
transformaciones, acciones y relaciones con otros elementos del entorno. Es decir, todo cuanto existe y ocurre en el mundo está conectado sincrónica y diacrónicamente con otros factores, y tales conexiones se modifican mutua y constantemente. Debemos asumir que el universo está en constante transformación, el cambio es la norma; la construcción no es una etapa sino un estado permanente.

Además del carácter interconectado y cambiante de la realidad, la noción de construcción nos remite también al concepto de proceso y a un enfoque procesal. Nos conduce a asumir que todo fenómeno o acontecimiento forma parte de procesos más amplios y a su vez está conformado por una serie de ciclos más pequeños. No hay hechos definitivos, cada fenómeno o acontecimiento implica el cierre de alguna etapa, pero a la vez se inauguran nuevos ciclos. Las fases de los procesos sociales no siempre mantienen un patrón determinado de cambio, sino que muchas veces se traslapan o se intercambian, se aceleran o se retrasan con ritmos variables. Ciertamente existe un cierto orden o lógica detrás de la sucesión de etapas y su dinámica interna, pero también hay que considerar que el azar interviene considerablemente; hay mucho de aleatorio y accidental en los procesos históricos y sociales, hay un alto grado de indeterminación e incertidumbre en su desarrollo.

Así, como antropólogos, siempre hay que tener en mente la nociones de construcción, proceso y complejidad para aproximarnos a la alteridad, para intentar entender y aprender de diversas culturas, grupos, regiones, épocas, ciudades, etc. En el transcurso de la historia y en el curso de la vida humana, en cualquier nivel de análisis, nada es estático, inmutable, absoluto o definitivo; todo parece ser más bien contingente, cambiante, pasajero, pero no necesariamente caótico. El mundo está en proceso de ser y dejar de ser, un cambio provoca otras transformaciones en cadena. Todo está en constante construcción y también destrucción: el mundo social, las culturas, los individuos, las comunidades, el espacio urbano, las ciudades contemporáneas, el conocimiento, la política, la economía, la ciencia y la tecnología, las religiones, las leyes, etc. Desde la época de los filósofos presocráticos, la idea heracliteana del devenir sigue teniendo vigencia y contundencia en la actualidad. 
¿Viejas y nuevas antropologías?

En cuanto a la combinación de perspectivas teórico-metodológicas que orientan esta investigación, podría decirse, en síntesis, que representa un intento por integrar la teoría del actor-red, la reflexividad y la experiencia estética como parte de la labor antropológica en el espacio urbano, a través del uso de medios audiovisuales y un estilo de registro etnográfico cercano a la crónica literaria. Otra característica de esta aproximación es que hemos optado deliberadamente por una mirada multifocal que nos ha permitido movernos entre diferentes niveles de análisis que se intersectan en la problemática abordada; hemos mantenido un constante vaivén entre lo micro y lo macro, lo particular y lo general, lo individual y lo colectivo, y entre el espacio específico de la obra y la ciudad en su conjunto.

En varios puntos de este trabajo he insistido en la importancia de la reflexividad para la antropología y las ciencias sociales, no como un estilo o tendencia dentro de las investigaciones recientes, sino como un control epistemológico indispensable en la producción de conocimiento. Al adoptar desde el principio una postura autorreflexiva, a lo largo de esta investigación me he permitido ensayar con distintos medios y recursos para hacer etnografía y generar conocimiento antropológico, siempre reflexionando sobre sus alcances y sus límites, sus condiciones y los resultados que han arrojado. Gracias al ejercicio de la reflexividad ha sido posible presentar y articular materiales diversos —crónicas etnográficas, diálogos con otros autores, reflexiones teóricas, referencias históricas y contextuales, imágenes fotográficas, aerofotos, mapas, retratos, etc.- para construir un discurso antropológico coherente e integral.

También he intentado rescatar el valor de la experiencia estética, así como de la dimensión sensorial y afectiva como fuentes legítimas de conocimiento, convicción que nos condujo a repensar constantemente el tema de la subjetividad, la objetividad y la intersubjetividad en relación con la investigación antropológica. Asimismo, en el transcurso de la investigación ensayamos con distintos lenguajes para hacer etnografía. Los medios audiovisuales fueron vehículos efectivos para captar, interpretar, representar y transmitir la parte sensible de la experiencia etnográfica. A pesar de que los resultados de esta etnografía visual no aparecen plasmados en la presente versión escrita, es claro que las imágenes conseguidas durante el trabajo de campo han dado pie a múltiples reflexiones y se articularon de 
diferentes formas con la antropología verbal aquí presentada. Eventualmente, este material visual será elaborado para construir algún producto audiovisual, como un desarrollo posterior de esta investigación.

A partir de las perspectivas adoptadas, cabe preguntarnos cómo han cambiado las formas de hacer antropología en años recientes. Hemos intentado practicar una antropología más libre y abierta, acaso más humanista, cualitativa y creativa, alejada de las estadísticas, cuestionarios, entrevistas formales y los estudios cuantitativos que han caracterizado a otras escuelas o corrientes antropológicas a lo largo del siglo XX e incluso en la actualidad. ¿Pero es verdaderamente nueva o innovadora esta clase de antropología que aquí adoptamos? ¿Qué ha cambiado y qué permanece en cuanto a las formas de hacer trabajo de campo, desde Malinowski en las islas Trobriand hasta el investigador urbano contemporáneo? Sin duda, hoy en día tenemos nuevos instrumentos, nuevas ideas, enfrentamos nuevos escenarios, nuevos problemas, con nuevas teorías y nuevos medios, pero a pesar de esto, a mi juicio, los antropólogos nos seguimos formulando las mismas preguntas por la identidad y la alteridad, la naturaleza y la cultura, el individuo y la sociedad, etc.

La antropología como forma de conocimiento se suele definir no tanto por su objeto de estudio y ni siquiera por sus formas de abordarlo, sino por la peculiar perspectiva que adopta y la pregunta que se hace sobre la realidad humana. Esta cuestión antropológica nace de la experiencia del contacto intercultural y del asombro que éste nos provoca; es la pregunta por la alteridad, el cuestionamiento acerca de la identidad y la diferencia frente a los otros, que asume la diferencia en la otredad pero también, al mismo tiempo, una similitud esencial en tanto seres humanos. Ante este cuestionamiento fundamental en la base de toda investigación antropológica, podemos concluir que a lo largo de esta investigación fue tan rico y necesario recurrir a nuevos enfoques para formularnos viejas preguntas, como desempolvar viejos conceptos para echar luz sobre nuevos escenarios y problemáticas.

Mirada crítica a la teoría del actor-red

A pesar de la elocuencia que demuestra Bruno Latour y de la gran pertinencia que tiene la teoría del actor-red para repensar algunos problemas de la sociedad y la 
cultura contemporánea $-\mathrm{y}$ concretamente para abordar el tema y los personajes de nuestra investigación-, es posible elaborar una reflexión crítica en torno a dicha teoría, que nos permita reconocer sus puntos débiles y sus límites explicativos. ¿Hasta dónde nos sirve la TAR para entender concretamente el mundo de la construcción? ¿Qué aristas quedan sin un tratamiento realmente convincente?

De acuerdo con Néstor García Canclini, la teoría del actor-red corre el riesgo de arrinconarse en la observación del fragmento: "un análisis particularista, sólo atento a la diversidad de escenas y a las variaciones de los actores, como practica Latour, no alcanza para entender las acumulaciones de poder y sentido que construyen los actores transnacionales e intermediáticos" (García Canclini, 2008). En sintonía con esta observación, me parece que el modelo del mundo como un gran laboratorio de actores-red, que concibe lo social simplistamente como una serie de interacciones cara a cara, no sirve para explicar, por ejemplo, las causas de la distribución desigual de la riqueza, que han sido una constante en la historia de las culturas y el desarrollo las ciudades. La dimensión política de la interacción social permanece fuera del alcance de los planteamientos de la antropología de las asociaciones. Cuando Latour se ocupa de los factores económicos y políticos, lo hace sólo de manera bastante marginal.

Latour reduce lo macrosocial a un tráfico entre sitios locales... descuidando la recomposición concentrada del poder en redes cada vez más poderosas gracias a la convergencia digital y la fusión de empresas. ¿Cómo entender las posibilidades de eficacia de cada actor y cada red si no trabajamos al mismo tiempo con las nuevas condiciones de producción y comunicación transnacional de la cultura? (García Canclini, 2008).

\section{Metamorfosis urbana: rupturas, continuidades y futuros posibles}

A pesar del enfoque sobre la transformación de los espacios urbanos, que fue ampliamente desarrollado en el capítulo II, el caso de la historia de la colonia Roma parece sugerirnos que es tan importante leerla desde la perspectiva de la permanencia como desde la del cambio. La actual ola constructiva puede interpretarse como parte de ciclos de más larga duración. En efecto, presenciamos la construcción de nuevos edificios, así como nuevas formas de comercializar el espacio, de construirlo y habitarlo; sin embargo, si vemos la problemática desde una óptica más amplia, vemos que en realidad está ocurriendo algo muy parecido a lo que 
sucedió hace cien años, tras la fundación de la colonia. Unos cuantos empresarios se encargan de fraccionar la colonia para comercializarla, fragmentándola en espacios habitacionales más rentables. Ciertamente ha cambiado el perfil de los habitantes, el tipo de viviendas, el entorno urbano, la densidad de población, entre otros muchos elementos, pero en el fondo, la situaciones que se han presentado a principios de los siglos XX y XXI son bastante semejantes y en cierto sentido parece como si la historia se repitiera.

Ha habido en la historia de la Roma varios momentos de transformación intensiva, oleadas constructivas que han respondido a la intención de sobreponerse a lo que había antes e imponer nuevos estilos de inmuebles. La regla general parece ser la falta de aprecio por los estilos arquitectónicos y las tendencias urbanísticas que nos han precedido. Hoy encontramos un nuevo tipo de inmuebles habitacionales, edificios de departamentos de un tipo bien definido, muy parecidos entre sí, que le imprimen una nueva fisonomía a la colonia. Encuentro ciertas recurrencias significativas en la historia de su desarrollo urbano. Si nos enfocamos en el mediano y largo plazo, es más fácil distinguir las continuidades y los verdaderos momentos de ruptura; se trata de un espacio urbano especialmente susceptible a la transformación abrupta y radical, que sin embargo mantiene ciertos elementos identitarios y características propias que parecen mantenerse ante las oleadas de cambio.

Por otro lado, es evidente la coexistencia de distintas arquitecturas en el espacio de una misma cuadra. En esta colonia conviven edificios porfirianos, muestras ejemplares de art nouveau y arquitectura gótica, con casonas estilo americano construidas en los años 40 y 50, y torres de oficinas con fachadas de cristal de los años 80 , así como con los nuevos y monótonos desarrollos habitacionales edificados en lo que va del siglo XXI. El resultado es una estética de parches, un collage urbano, un palimpsesto metropolitano; se trata de un paisaje fragmentario, producto de la superposición material y simbólica diferentes épocas, estilos, mentalidades y configuraciones sociales, en un mismo espacio.

La colonia Roma siempre ha estado sujeta a las modas y tendencias, ha sido rehén de las políticas de la clase gobernante, botín de guerra, manzana de la discordia y conejillo de Indias. Pero como reconoce Guadalupe Lozada, Coordinadora de Patrimonio Histórico, Artístico y Cultural del Gobierno del Distrito Federal, en la 
Roma, sobre todo en los últimos 50 años, "se perdió el estilo, imperó el mal gusto, no se logra nada de armonía y domina una idea de restauración mal entendida" (Lozada, 2009). Los recientes desarrollos inmobiliarios en la colonia permanecen indiferentes a los estilos anteriores; la arquitectura y el diseño de estos nuevos edificios muestra poca voluntad de dialogar o armonizar con los edificios que los rodean. Estos inmuebles no respetan ni mucho menos intentan integrarse al paisaje preexistente (cf. Pérez Negrete, 2009).

Sin duda, sería mucho más deseable rescatar y reciclar antiguos edificios históricos, aunque se encuentren muy deteriorados, en lugar de sustituir tajantemente estos inmuebles emblemáticos de una época, con gran valor arquitectónico, por edificios prácticamente hechos en serie, reproduciendo modelos y formas importadas, sin una identidad bien definida, con una pobreza de recursos, que a su vez representa un ahorro significativo en términos económicos para las empresas constructoras y por lo tanto hace más rentables los nuevos espacios.

Como muestra de que es posible rescatar espacios, hay que destacar algunos casos exitosos de un genuino reciclamiento urbano en la colonia Roma, casos de intervención de edificios históricos para renovarlos y revitalizarlos, conservando y aprovechando su valor patrimonial. El Edificio Balmori (sobre Orizaba, casi esquina con Álvaro Obregón), la Casa Lamm (sobre Av. Álvaro Obregón) y la Casa Universitaria del Libro (en la esquina de Orizaba y Puebla), son casos ilustres de restauración de inmuebles antiguos, iniciativas que han entendido que lo que le da valor a la colonia, e incluso plusvalía, es su patrimonio arquitectónico, su sentido histórico. Pero además, estos son casos ejemplares de reapropiación y revitalización del espacio urbano, al convertir estos lugares en centros culturales (en el caso de los últimos dos) o en un edificio que combina departamentos con oficinas de organizaciones culturales (en el caso del edificio Balmori). Casos como estos resultan esperanzadores, pero lamentablemente son excepcionales.

\section{Desarrollo urbano y construcción de vivienda}

Frente a las nuevas políticas de redensificación del área central de la ciudad, que han marcado la pauta del desarrollo urbano de la Ciudad de México en las últimas dos décadas, y que han dado pie a la intensa oleada constructiva en la colonia Roma, lo primero que salta a la vista es la multiplicación del número de viviendas. Por 
ejemplo, en uno de nuestros estudios de caso, donde antes había un estacionamiento ahora se construye una torre con 11 departamentos. Estas nuevas construcciones muestran una clara tendencia hacia la reducción de los espacios vitales y una mayor saturación del espacio urbano. En estos nuevos edificios se construyen viviendas cada vez de menores dimensiones, lo más pequeñas y compactas posibles.

En relación con la calidad de las nuevas construcciones, algunos especialistas llaman la atención sobre la alarmante obsolescencia de los inmuebles producidos recientemente, como parte de una transformación destructiva de la ciudad. De acuerdo con el urbanista Emilio Pradilla, la Ciudad de México es "víctima del modernismo destructivo de la inversión inmobiliaria"; la lógica de mercado que rige el desarrollo urbano la mantiene estancada en un constante proceso de degradación-obsolescencia-reconstrucción. "El uso creciente de la arquitectura chatarra -transitoria, de poca calidad y rápida obsolescencia-" hace que los espacios urbanos que se construyen actualmente tengan un ciclo de vida muy corto, "que los lleva al deterioro, al abandono o a la necesidad de una parcial reconstrucción" (Pradilla, 2005: 10). Este es uno de los factores que propician el constante proceso constructivo y reconstructivo que vemos sobre todo en la zona central de la ciudad.

Tomando en cuenta que los espacios físicos moldean las prácticas sociales, sin duda, con la reciente ola de edificación habitacional en la zona central de la Ciudad de México están surgiendo nuevas formas del habitar el espacio urbano. Vale la pena mencionar ciertos aspectos negativos que señalan algunos autores en este sentido. La homogeneización de la vivienda, junto con la insuficiencia de espacios públicos en la urbe, produce una creciente atomización y aislamiento. Este patrón de vivienda moderna se ha olvidado de diseñar espacios comunes o lugares de encuentro. En el diseño de los nuevos edificios de vivienda no se contemplan sitios para la reunión y convivencia de los vecinos, más allá de la azotea o roof garden que resulta poco acogedora. Estas nuevas configuraciones socio-espaciales apuntan a una mayor fragmentación de la experiencia colectiva, a la claustrofilia (la vida se circunscribe al interior de las casas), a cambios en la forma de convivir con los vecinos y hacer vida comunitaria, todo lo cual redunda en el deterioro de la solidaridad ciudadana. Por otra parte, la tendencia al hacinamiento que provoca la reducción y 
densificación de las viviendas genera una cercanía física obligada con los vecinos, sobre todo en términos de ruido y olores, lo que suele traducirse en desencuentros, conflictos y confrontaciones entre distintas lógicas de apropiación del espacio, entre las diferentes y desiguales formas del habitar (cf. Pradilla, Moreno, Pérez Negrete, Sennett, Nieto, Giglia, Duhau).

\section{La perspectiva de los habitantes y la planeación participativa}

Para cerrar la reflexión sobre el desarrollo urbano y la construcción de vivienda en la colonia Roma, cabe preguntarnos: en términos humanos: ¿qué consecuencias tienen estos cambios para la calidad de vida de los habitantes de la colonia Roma? ¿Cómo condicionan sus experiencias del habitar problemas como el tráfico, la falta de estacionamientos, la escasez de agua, la complicada recolección de basura, la vulnerabilidad frente a sismos, inundaciones o hundimientos?

Estas son algunas interrogantes que quedan pendientes a partir de este estudio, puesto que su tratamiento requeriría otra investigación aparte. Sin duda, hubiera sido pertinente explorar las nuevas formas de habitar que surgen en el seno de este tipo particular de viviendas. Resultaría revelador estudiar los usos de la construcción, las diferentes prácticas en los nuevos espacios, el comportamiento y la opinión de los nuevos residentes sobre los departamentos construidos; sería interesante conocer su experiencia, cómo viven en ellos, saber si cumplieron sus expectativas, cómo fue su experiencia de la compraventa, etc. Éste tipo de cuestiones relacionadas con la perspectiva de los nuevos habitantes, están sin duda emparentadas con la presente investigación, pero no las abordé plenamente debido a que mi interés estuvo centrado principalmente en las formas de habitar que presentan los albañiles en la obra.

De cualquier manera, considero importante plantear como una problemática significativa el punto de vista de los ciudadanos, la perspectiva de los nuevos y viejos habitantes en relación con la transformación urbana. Al respecto, podemos recuperar lo que han dicho varios autores sobre el tema. Se ha argumentado que la construcción intensiva de conjuntos habitacionales responde a un modelo segregativo de organización de la ciudad; se ha señalado que el modelo de creación de microcomunidades cerradas puede generar más fracturas que cohesión en la estructura urbana, ya que tiende a fomentar la diferenciación social y produce una 
mayor atomización de la población; con lo cual se promueve y reproduce la desigualdad social (cf. Pradilla, Moreno, Pérez Negrete, Sennett, Giglia, Duhau).

Para confirmar estos planteamientos habría que entrevistar a varios vecinos de los nuevos y viejos edificios de la Roma sobre estos temas, para indagar si en efecto su experiencia coincide con estos señalamientos. También sería relevante preguntarle a los antiguos habitantes cómo se vivía en la colonia hace diez, veinte o treinta años, su percepción de cómo ha cambiado y los problemas actuales que consideran que afectan a la colonia. Todo esto, repito, aunque resulta de gran interés, sería materia de otra investigación.

El desarrollo urbano de la Ciudad de México a lo largo del siglo XX estuvo marcado por la necesidad de resolver problemas urgentes, actuando reactivamente, sin planeación a futuro. En términos de vivienda, la acción de los gobiernos y especialistas se enfocaba en atender las demandas de la población que desbordaba el territorio urbano. No hubo la oportunidad de detenerse a imaginar y planificar qué tipo de ciudad era el más deseable. Por otra parte, las decisiones y acciones que han definido el perfil y la dinámica de la ciudad (podemos pensar en varios ejemplos: la prohibición de construir grandes fraccionamientos habitacionales en el D.F. en tiempos de Uruchurtu, la construcción de los ejes viales en la administración de Carlos Hank González, el decreto del Bando dos desde el gobierno de Cuauhtémoc Cárdenas, o más recientemente la construcción del Segundo Piso del Periférico durante el gobierno de López Obrador), se han tomado desde las altas esferas del gobierno, respondiendo tanto a la situación de emergencia ya señalada, como a distintas presiones e intereses políticos y económicos, pero sin considerar la perspectiva ni la opinión de los habitantes de las colonias en cuestión.

Varios autores han señalado la necesidad de revertir drásticamente esta forma de proceder. En primer lugar, habría que empezar a diseñar hoy la ciudad que queremos en el futuro, cambiando las cortas miras de la lógica de los negocios por una visión y una planeación más a largo plazo; y tomando en cuenta sobre todo la perspectiva de los ciudadanos que serán directamente afectados por las acciones e intervenciones en el espacio urbano. En otras palabras, hay que democratizar la toma de decisiones sobre la ciudad, primero informar y luego consultar la opinión de los vecinos, por medio de plebiscitos, consultas, asambleas de barrio o a través de 
representantes elegidos por la gente (cf. Coulomb, Legorreta, Benlliure, Ziccardi, Michel).

En el caso de la intensa edificación de nuevas viviendas en la Roma, sería indispensable contemplar la postura de los habitantes de la colonia en cuanto a la cantidad de viviendas que se construyen, así como sobre la calidad y el tipo de inmuebles que proliferan actualmente. ¿Qué tanto más quiere la gente que se redensifique su colonia, qué tanto más dicen los urbanistas que sería recomendable, en qué medida pesan las presiones mercantiles en las políticas de desarrollo urbano? Para la recuperación y promoción del patrimonio cultural de la colonia Roma sería indispensable la planeación participativa, involucrando a la población con las autoridades para pensar sobre el futuro del barrio, diseñando proyectos para que la ciudadanía se apropie el territorio y los espacios públicos.

En este sentido, hay que señalar como un signo esperanzador la existencia desde 1995 de una organización ciudadana que vela por el bienestar de la colonia Roma. Trabaja, por ejemplo, para gestionar que mejore el sistema de la recolección de basura y promueve que los vecinos adopten simbólicamente alguna parte del espacio público de la colonia, para que se hagan cargo de cuidarlo y mantenerlo limpio. Otro objetivo fundamental de este Movimiento Pro Dignificación de la Colonia Roma AC, encabezado por la señora Jaqueline Ducolomb, es lograr que la colonia sea declarada Zona de Monumentos Históricos, para que sea catalogada y protegida oficialmente por el INAH como patrimonio arquitectónico nacional. Esta organización civil es un ejemplo de movimiento en defensa de la ciudad, a través de un urbanismo micro, enfocado en el espacio local, de escala humana. "Ni las autoridades, ni los arquitectos, ni los diputados tienen la solución en su poder, la ciudadanía es la que debe rescatar el espacio público y cuidar la naturaleza en nuestra colonia Roma", dice enérgicamente la portavoz de esta organización.

\section{Antropología de la obra}

Ahora quisiera referirme a la originalidad de la obra como espacio en construcción, para redondear esta reflexión antropológica sobre el espacio y su transformación, que ha ocupado buena parte de esta investigación. La obra es quizás la expresión más evidente del proceso de urbanización; es un espacio sumamente adecuado para presenciar y registrar el tránsito del espacio al lugar, en sus varias modalidades 
culturales. La obra representa un caso privilegiado para observar cómo se transforma el espacio físico y sus correspondientes formas de habitarlo, y puede verse como la unidad mínima de análisis en el proceso de producción y reproducción de la ciudad. Se trata de un sitio que escapa a cualquier intento de clasificación espacial rígida y nos obliga a repensar las nociones con las que identificamos los diferentes tipos de espacios. Informalidad-racionalidad, público-privado, realimaginario, laboral-residencial, son binomios que no terminan de ajustarse bien al caso de una obra. Por ello, me pareció necesario realizar una etnografía del espacio en construcción, encauzada hacia una antropología del habitar en la obra.

En cuanto a las dos formas de producción del espacio urbano de la Ciudad de México que señala Giglia (2009) -la lógica racionalista y la lógica informal一, podemos decir que la obra es un sitio ideal para explorar la imbricación de lo formal con lo informal, de lo planificado con lo irracional, y para descubrir la interacción que se suscita entre distintas lógicas: la funcionalista impuesta por los arquitectos, urbanistas e ingenieros, que casi nunca se cumple cabalmente, y los esfuerzos azarosos y relativamente coordinados de los trabajadores, con su condición de precariedad y gran ingenio popular. Aunque cambiante y aparentemente caótica, la obra responde a reglas y disposiciones de diversa índole que forman un cierto orden, que es posible discernir. Pero también podría plantearse a la inversa: aunque aparentemente planeada y diseñada por arquitectos e ingenieros hasta los últimos detalles, la obra se mueve de hecho en un ajetreo cotidiano en el que en una importante medida impera la improvisación y el caos.

La obra es una forma sui generis de espacio habitable, en ella conviven formas de habitar y producir el espacio precarias y no planeadas, espontáneas, informales, anárquicas, desordenadas, pero que no obstante, suceden dentro de un proyecto planificado, funcionalista y racionalista, estructurado moderno y ordenado. Por ejemplo, la empresa DAKAB seguramente está inscrita formalmente en el registro de la Cámara Nacional de la Industria de la Construcción, mientras que algunas partes del proceso constructivo, como el reclutamiento de los trabajadores y la dinámica laboral al interior de la obra, son completamente informales. Es decir, la obra es un lugar de encuentro entre la ciudad informal y la ciudad racionalista; éstas se funden en ella, y en ella se traslapan, confrontan y conviven cotidianamente. Mientras el espacio se encuentra en construcción se crea un tipo de espacio híbrido 
entre ambas modalidades de hacer ciudad, donde se expresan las lógicas contradictorias detrás del aparente (des)orden urbano, y de esta articulación aparentemente milagrosa resulta un orden socio-espacial determinado y una forma particular de cultura urbana.

En la obra impera un orden socio-espacial impuesto en buena medida por las condiciones materiales particulares del espacio, por el difícil tránsito a través de ella, pero también un orden que tiene que ver con cuestiones de índole social, con la desigualdad que existe entre los rangos y las jerarquías de los trabajadores, con la marginalidad económica que les impide tener una calidad de vida digna, junto con la exclusión social e invisibilidad que los caracteriza ante el resto de la sociedad. El estudio de una obra nos permite observar de manera nítida la transformación del espacio y las dinámicas de la mano de obra, poniendo de manifiesto las interacciones que se establecen entre los sujetos y el lugar.

También en relación con la obra, hay que mencionar que es un espacio en el que resalta claramente la importancia de la cultura material en las redes sociales, un lugar donde resulta evidente que los materiales, las herramientas y otros objetos tienen una vida social, dando lugar a una peculiar relación hombre-objeto. En la obra esto es particularmente claro en el conocimiento sobre las propiedades de los materiales, su disposición en el espacio, el uso de los instrumentos por parte de algunos albañiles como si fueran una extensión de su propio cuerpo, en la autofabricación de herramientas y otros objetos multiusos. A lo largo de esta investigación he intentado enfatizar la importancia de considerar a los objetos como parte de los universos que estudiamos los antropólogos, sobre todo en lo que se refiere al valor simbólico de las cosas, su significado cultural y su rol social; sin los objetos no podríamos comprender el mundo.

\section{La interculturalidad en la construcción del habitar}

La obra, desde el punto de vista habitacional, tiene un doble significado, por un lado es el hogar actual de los albañiles que construyen el edificio, y por el otro es el futuro hogar de los dueños de los departamentos. El estudio de la construcción del habitar podría enfocarse en la experiencia de habitar la obra de los albañiles, que viven en ella y se la apropian durante el proceso constructivo, así como en la configuración de nuevas viviendas, que a su vez prefiguran formas de habitar la ciudad para los 
nuevos usuarios o dueños de estos departamentos. Como ya aclaramos antes, en esta investigación ensayamos principalmente la primera vertiente, pero es importante tener en cuanta la segunda como punto de referencia para contrastar el caso del habitar de los albañiles y observar los cruces interculturales entre estos mundos.

Parafraseando a Giglia, podemos decir que en la obra, a lo largo del proceso de construcción, "se expresa de manera elocuente la polifonía y la interculturalidad de una gran metrópoli" (Giglia, 2009: 236-237). En la producción habitacional casi siempre "existe en suma una distancia y una contraposición entre la visión del espacio y del habitar de quien diseña estas viviendas versus las expectativas, las necesidades y las prácticas de quienes los habitan" (Signorelli, 1989, citada por Giglia, 2009: 232-233). Podemos observar en la obra estas y otras fracturas e hibridaciones culturales entre los modelos, los ideales, los discursos y los imaginarios del habitar de las empresas constructoras, por un lado, y por el otro las prácticas reales y los usos concretos de los trabajadores de la construcción y los nuevos habitantes de estos edificios de departamentos.

En la obra es posible discernir la multiplicidad de significados que se suelen entretejer en torno a un espacio urbano en un momento determinado. Para los trabajadores es tan sólo un lugar de trabajo más; para los arquitectos y constructores significa una gran inversión, que esperan se traduzca en un negocio rentable, con el riesgo que conlleva; para los vecinos, la obra ha sido hasta ahora un infierno, por las diversas molestias que les ha ocasionado el ruido, el polvo y la presencia indiscreta de los albañiles; para el barrio representa un proyecto inmobiliario más; para la ciudad significa que habrá decenas de nuevas viviendas, en donde antes no había ninguna, con las repercusiones que esto implique a nivel macrosocial. En ella se manifiestan distintas formas de apropiación y uso del espacio: por parte de los albañiles, por parte de los clientes, por parte de los arquitectos, de los nuevos habitantes.

En este estudio se aprecia el contraste entre diferentes formas del habitar y de la apropiación del espacio, la enorme distancia entre el precario habitar de los albañiles y las formas imaginarias de la mercadotecnia con que se busca vender los departamentos, que proyectan el sueño del habitar moderno de una clase media con aspiraciones de alta. De aquí se deriva un argumento que resulta de 
fundamental importancia para esta tesis, a saber, que "el habitar puede ser estudiado como un proceso intercultural $-\mathrm{y}$ la vivienda como un objeto intercultural- mediante cuyo estudio podemos ver el contraste y las hibridaciones entre el orden impuesto y el orden producido por los habitantes" (Giglia, 2009: 232).

En suma, la obra es un lugar ideal para observar los cruces, interacciones y desigualdades sociales, así como la formación y desintegración de una serie de redes interculturales. Este haz de relaciones que se suscita dentro y alrededor de este lugar híbrido que es la obra, nos coloca inevitablemente en el terreno de la interculturalidad. Por ello, me parece importante poner el acento en la cuestión de los encuentros y desencuentros entre diversos actores, e intentar entender en qué términos dialogan sus perspectivas en la obra.

\section{La cultura del habitar de los albañiles en la obra}

En cuanto a los personajes centrales de esta investigación, los trabajadores de la construcción, habría que destacar que se trata de sujetos híbridos, complejos, multiculturales, mediadores entre los proyectos constructivos y su materialización, actores cuya importancia en la reconfiguración del entorno y el paisaje urbano hay que reconocer plenamente. Si vamos más allá de los prejuicios, estereotipos y estigmas socioculturales que los tachan de vulgares, informales, ignorantes, etc., podemos encontrar personas admirables, sumamente ingeniosos, con un valioso conocimiento práctico, portadores de saberes y destrezas, que realizan su oficio artesanalmente, con gran dignidad.

La informalidad y la movilidad que los caracteriza, así como su ingenio, pueden entenderse como estrategias de adaptación ante la naturaleza inestable del empleo en la construcción. El flujo variable pero constante de los trabajadores de la construcción nos conduce hacia una antropología de la movilidad, nos sugiere dejar de lado ideas como estructura, sistema o función, y nos invita a pensar lo social en términos de redes, rizomas, archipiélagos de asociaciones, encuentros y desencuentros, intersecciones, traslapes y otros tipos de conexiones flexibles, frágiles e inestables, tal como los andamiajes provisionales que fabrican los albañiles en la obra.

Ahora me referiré concretamente a la forma en que los albañiles habitan la obra, a su cultura del habitar. Las prácticas habitacionales de los trabajadores de la 
construcción comparten rasgos con otras formas de habitar el espacio urbano, pero al mismo tiempo tienen características muy particulares y significativas. "Podemos decir que estamos en presencia de cierta cultura del habitar cuando nos encontramos delante de un orden espacial específico, resultado de la imbricación entre formas del espacio y modos de habitarlo" (Giglia, 2009: 230).

Pero cabe preguntarnos: si el habitar es la relación entre sujetos y entorno, mediada por la cultura, ¿cómo es la cultura del habitar cuando por un lado los sujetos son móviles y por otro los espacios sufren una acelerada transformación? Es curiosa una cultura del habitar como la de los albañiles, que en buena parte se constituye a partir de una experiencia de desapego territorial; están acostumbrados a vivir en el presente inmediato; su horizonte geográfico es cambiante y adaptable a la medida de las circunstancias. ¿Se encariñan los albañiles con la obra? ¿Se crea alguna relación afectiva entre estos sujetos y el espacio? ¿O se trata más bien de un vínculo utilitario, funcional y exclusivamente laboral?

La forma de habitar la obra por parte de los albañiles se caracteriza también por la precariedad, por la adversidad y por las condiciones inhóspitas y hostiles que sin embargo superan con gran ingenio para adaptarse al espacio. Otro factor importante que marca su peculiar modo de habitar el espacio en construcción es la breve temporalidad, es un habitar efímero, de corto plazo; su presencia, sus formas de apropiarse, ordenar y dar sentido a la obra, así como las relaciones que establecen con otros trabajadores en este mismo entorno, están marcadas inevitablemente por su carácter transitorio y móvil. Su forma de habitar contiene una buena dosis de desarraigo con respecto al lugar que habitan, ya que siempre al terminar la obra serán desplazados.

Nos encontramos ante una dinámica habitacional marcada por una capacidad de adaptación extrema, en un contexto de tensión entre tradición y modernidad, donde nuevas técnicas y modalidades de producción se combinan con antiguos oficios, así como con materiales y herramientas ancestrales. El habitar de los albañiles, por contradictorio que parezca, podría caracterizarse como una apropiación de un espacio que en última instancia no les pertenece; no obstante, posee una enorme riqueza cultural, consta de habilidades, destrezas y saberes incorporados, tácitos, que se transmiten y reproducen en la práctica cotidiana, para hacer uso del espacio y transformarlo. 
Podemos trazar una analogía entre la interacción albañil-obra y la experiencia de habitar la Ciudad de México para muchos de sus habitantes. Estas formas de habitar el espacio son semejantes en cuanto implican el acto de habitar un lugar inhabitable, apropiarse de lo inhóspito, adaptarse y formar parte de ello, e incluso aprender a quererlo, en un intento continuo por domesticar un espacio hostil que constantemente impone retos y dificultades que hay que enfrentar con ingenio o resignación. La obra puede verse como metáfora de la ciudad y los albañiles como un caso ilustrativo de nuestras formas de interactuar con ella. Como una vez dijo Gonzalo Celorio: "la Ciudad de México es un lugar tan inhabitable como inevitable" 15 .

Así, este estudio sobre la cultura de los albañiles nos puede servir para pensar y entender la experiencia de habitar en la Ciudad de México. Con tantas obras inacabadas al mismo tiempo por toda la ciudad, los ciudadanos nos encontramos inmersos en un proceso inacabado, estamos cotidianamente en una situación liminal, en una larga y lenta transición entre unas estructuras que perecen y otras nuevas que las sustituyen. Nos encontramos en una suerte de reacomodo $\sin$ fin en la relación que mantenemos con nuestro hábitat. En este sentido, nuestra experiencia de la ciudad a menudo se parece a la experiencia de los albañiles. Estudiar las respuestas adaptativas a un medio tan cambiante, nos puede ilustrar sobre algunos aspectos importantes de la manera en que los capitalinos nos vinculamos con la ciudad y los espacios urbanos; este caso peculiar de interacción entre el hombre y el espacio pone de manifiesto el juego constante entre las condiciones que uno impone y las estrategias del otro para superarlas.

Pero hay que reconocer los límites de la metáfora y marcar las disparidades entre los casos planteados. A diferencia de los albañiles, el común de los ciudadanos no construye materialmente la ciudad, tampoco viven y trabajan en un mismo espacio y probablemente sus condiciones laborales no sean tan precarias, inestables y móviles como la de estos actores. Sin embargo, la semejanza radica en el ingenio que surge a partir de la precariedad, en las soluciones provisionales y los arreglos temporales ante las condiciones que dicta el espacio urbano, y en la creciente tolerancia y muchas veces sabia resignación frente a las adversidades de la ciudad. Otra similitud

\footnotetext{
${ }^{15}$ Juego de palabras pronunciado durante la presentación del libro de Vicente Quitarte: Elogio de la calle: Biografía literaria de la Ciudad de México, 1850-1992, Ediciones Cal y Arena, México, 2001.
} 
importante tiene que ver con la fragilidad de los vínculos sociales y la inestabilidad de las redes interculturales que configuran el tejido de la obra, así como el entramado urbano más amplio. Tal como la experiencia del habitar del albañil en la obra, las culturas del habitar capitalinas están en constante construcción.

La sorprendente habilidad que muestran los albañiles en su relación con un espacio en plena trasformación, es un buen caso para analizar las nuevas formas de habitar en el seno de la ciudad, ante un espacio urbano que constantemente se reinventa, que es mezcla de lo público y lo privado, lo formal y lo informal. Así como los albañiles se integran al entorno de la obra, los ciudadanos y habitantes de la ciudad también nos vamos sobreponiendo a las difíciles condiciones de vida que impone la ciudad, "les sacamos la vuelta". La obra es un crisol, una caja de resonancia, un microuniverso que nos puede servir de referencia para desentrañar otros fenómenos urbanos a una mayor escala; es un espacio privilegiado para observar y reflexionar sobre los procesos habitacionales, la transformación y el desarrollo en las megalópolis. La cultura e idiosincrasia de los albañiles nos puede proporcionar ciertas claves para desentrañar las nuevas formas que está cobrando la cultura urbana contemporánea, sus patrones y dinámicas, así como las redes sociales e interculturales que se entretejen alrededor de la obra y al interior la ciudad en su conjunto. 


\section{BIBLIOGRAFÍA Y FILMOGRAFÍA}

- AGUILAR MÉNDEZ, Fernando Antonio: La expansión territorial de las ciudades de México, UAM-X, México, 1992.

- APPADURAI, Arjun: The social life of things. Commodities in cultural perspective, Cambridge University Press, 1986.

- AUGÉ, Marc: Los no-lugares. Espacios del anonimato, Gedisa, Barcelona, 1992.

- ARCINIEGA Ávila, Hugo: Arquitectura como símbolo: el caso de Manuel Gorozpe, conferencia presentada en el marco del ciclo: "La Colonia Roma: orígenes, historia, identidad, perspectivas", organizado por la Universidad Nacional Autónoma de México, a través del Programa Universitario de Estudios Sobre la Ciudad y el Movimiento Pro Dignificación de la Colonia Roma AC, el 29 de enero de 2009

- BENÍTEZ Ortega, Adrián: Renovación urbana en áreas centrales. La dinámica inmobiliaria habitacional en la colonia Roma, 1997-2005, tesis de maestría en Estudios urbanos, COLMEX, 2008.

- BENLLIURE Bilbao, Pablo: "La expansión urbana. Reciclamiento o desbordamiento", en La Ciudad de México a debate, Jorge Legorreta (coordinador), UAMAzcapotzalco, 2007.

- BECKER, Howard: Art Worlds, University of California Press, Berkeley, 1982.

- BERGER, Peter L. / LUCKMANN, Thomas: La construcción social de la realidad, Amorrortu Editores, Buenos Aires, 1979.

- BOURDIEU, Pierre y WACQUANT, Löic (1995): Respuestas: por una antropología reflexiva, 1995, Editorial Grijalbo, México, 1995.

- BOURDIEU, Pierre: La miseria del mundo, Fondo de Cultura Económica, México, 2002.

- BOURDIEU, Pierre: El oficio de científico. Ciencia de la ciencia y reflexividad, Editorial Anagrama, Colección Argumentos, Barcelona, 2003.

- BUENO, Carmen: Flor de andamio. Los oficios de la construcción de vivienda en la Ciudad de México, CIESAS, México, 1994.

- BUENO, Carmen: Trabajadores indígenas en la construcción de vivienda de la Ciudad de México, (copia xerox) CIESAS, México, 1992.

- BURROUGHS, William: Naked Lunch (1959), Grove Press, N.Y., 2001.

- CASTREE, Noe: "David Harvey" en Key Thinkers on Space and Place, Phil Hubbard, Rob Kitchin and Gill Valentine (editors) Sage Publications, London, Los Angeles, Singapore, New Delhi, 2004. 
- CATALÁN Valdés, Rafael: Las nuevas políticas de vivienda. Una visión de la modernización de México, Fondo de Cultura Económica, México, 1993.

- CISNEROS Sosa, Armando: La ciudad que construimos. Registro de la expansión de la Ciudad de México (1920-1976), UAM-I, México, 1993.

- COLLIER, John and COLLIER, Malcolm: Visual Anthropology. Photography as a research method, University of New Mexico Press, Albuquerque, 1986.

- COULOMB, René: La recuperación de la colonia, conferencia presentada en el marco del ciclo: "La Colonia Roma: orígenes, historia, identidad, perspectivas", organizado por la Universidad Nacional Autónoma de México, a través del Programa Universitario de Estudios Sobre la Ciudad y el Movimiento Pro Dignificación de la Colonia Roma AC, el 29 de enero de 2009.

- CONNOLLY, Priscilla: "La industria de la construcción y relaciones de trabajo en la producción habitacional en México", en Procesos habitacionales en la Ciudad de México, Marco A. Michel (coord.), Cuadernos Universitarios 51, UAM-SEDUE, México, 1988.

- CONNOLlY, Priscilla: "La política habitacional después de los sismos", en Estudios Demográficos y Urbanos, vol. 2, num. 1, p. 101-120, COLMEX, México, 1987.

- CONNOLLY, Priscilla: El contratista de don Porfirio. Obras públicas, deuda y desarrollo desigual, Fondo de Cultura Económica, UAM-A, COLMICH, México, 1997.

- CORDERA, Rolando, RAMÍREZ Kuri, Patricia y ZICCARDI, Alicia (coords.): Pobreza, desigualdad y exclusión social en la ciudad del siglo XXI, UNAM-Siglo XXI Editores, México, 2008.

- CRUCES, Francisco: "Trabajar con historias urbanas: de la entrevista a la etnografía", conferencia impartida en la UAM-Iztapalapa, México, 2007.

- CUICUILCO, revista de la Escuela Nacional de Antropología e Historia, volumen 6, número 15: Antropología urbana y las ciudades contemporáneas, México, eneroabril, 1999.

- CURIEL, Fernando: Navaja, Ed. Premiá, Puebla, México, 1991.

- CURIEL Defossé, Fernando: Filología de la Roma, conferencia presentada en el marco del ciclo: "La Colonia Roma: orígenes, historia, identidad, perspectivas", organizado por la Universidad Nacional Autónoma de México, a través del Programa Universitario de Estudios Sobre la Ciudad y el Movimiento Pro Dignificación de la Colonia Roma AC, el 29 de enero de 2009.

- DE CERTEAU, Michel: The practice of everyday life, University of California Press, 1984. 
- DE MARTINO, Ernesto: La fine del mondo, Einaudi, Turín, 1977.

- DUCOLOMB, Jacqueline: La Colonia Roma en nuestros días, conferencia presentada en el marco del ciclo: "La Colonia Roma: orígenes, historia, identidad, perspectivas", organizado por la Universidad Nacional Autónoma de México, a través del Programa Universitario de Estudios Sobre la Ciudad y el Movimiento Pro Dignificación de la Colonia Roma AC, el 29 de enero de 2009.

- DUHAU, Emilio y GIGLIA, Ángela Las reglas del desorden. Habitar la metrópoli, UAM-I, Siglo XXI, México, 2008.

- DUHAU, Emilio: "Ciencias sociales y estudios urbanos: ¿adiós a los paradigmas?" en Sociológica, año 7, num. 18, UAM-Azcapotzalco, México, 1992.

- ESCUDERO, Alejandrina: "La fotografía aérea y la planificación de la Ciudad de México, 1927-1938", en Imagen e investigación social, Instituto Mora, México, 2005.

- FERNÁNDEZ, Martha: Ciudad rota: La Ciudad de México después del sismo, Instituto de Investigaciones Estéticas, UNAM, México, 1990.

- FIERRO Gossman, Rafael: Una casona de la Colonia Roma, Casa de Gobierno de Quintana Roo en el Distrito Federal, CONACULTA-INBA, México, 2002.

- FONTCUBERTA, Joan: El beso de Judas. Fotografía y verdad, Editorial Gustavo Gilli, Barcelona, 1997.

- FOUCAULT, Michel: "Los espacios otros", revista Architecture / Mouvement / Continuité, Francia, 1984. Tomada del sitio web:

(http://foucault.info/documents/heteroTopia/foucault.heteroTopia.en.html).

- FUENTES, Carlos: La región más transparente, Fondo de Cultura Económica, México, 1969.

- GARCÍA CANCLINI, Néstor (coordinador): De lo local a lo global. Perspectivas desde la antropología UAM- Iztapalapa, México, 1994.

- GARCÍA CANCLINI, Néstor: Consumidores y ciudadanos. Conflictos multiculturales de la globalización, Grijalbo, México, 1995.

- GARCÍA CANCLINI, Néstor (coordinador): Cultura y Comunicación en la Ciudad de México. UAM-I, Editorial Grijalbo, México, 1998.

- GARCÍA CANCLINI, Néstor (coordinador): Reabrir espacios públicos. Políticas culturales y ciudadanía, UAM-Plaza y Valdés, México, 2004.

- GARCÍA CANCLINI, Néstor (coordinador): La antropología urbana en México, CONACULTA, UAM, Fondo de Cultura Económica, México, 2005. 
- GARCÍA CANCLINI, Néstor: Comentario sobre el documental "En el hoyo" (texto inédito), participación en las "Segundas Jornadas de Antropología Visual", ENAH, 2006 (http://antropologiavisual.com.mx/muestra-mexicana/53-en-el-hoyo.html?start=1).

- GARCÍA CANCLINI, Néstor: "¿Qué son los imaginarios y cómo actúan en la ciudad?", (en diálogo con Alicia Lindón) en Revista Eure, vol. 32, num. 99, Pontificia Universidad Católica de Chile, pp. 89-99, 2007.

- GARCÍA CANCLINI, Néstor: "La reconstrucción de la teoría y el resurgimiento editorial", artículo publicado en Revista Ñ, suplemento cultural del diario Clarín, Argentina, 2008.

- GARDNER, Robert: The impulse to preserve. Reflections of a filmmaker, Other Press LLC, NY, 2006.

- GARDNER, Robert and OSTOR, Ákos: Making Forest of Bliss. Intention, Circumstance and Chance in Nonfiction Film, Harvard University Press, 2001.

- GARZA, Gustavo: "La evolución de la Ciudad de México en el siglo XX" en MICHEL, Marco A. (coord.): Procesos habitacionales en la Ciudad de México, UAM-SEDUE, México, 1998.

- GERMIDIS, Dimitri A.: El trabajo y las relaciones laborales en la industria mexicana de la construcción, COLMEX, 1974.

- GIGLIA, Ángela: Retos metodológicos para la antropología de la ciudad. La contribución de la antropología al estudio de las metrópolis multiculturales, ponencia presentada en el Seminario Internacional "A dónde va la antropología", organizado por el Departamento de Antropología de la UAM-I, del 22 al 24 de septiembre, México, 2004.

- GIGLIA, Ángela: Humanización del espacio y construcción de lo urbano en el oriente de la ZMCM. Repensar la metrópoli, UAM-I, México, 2005.

- GIGLIA, Ángela: "Metodología, conocimiento antropológico y reflexividad" notas del curso impartido en la Universidad Autónoma Metropolitana, unidad Iztapalapa, 2007.

- GIGLIA, Ángela: "Culturas del habitar y espacios urbanos" en Pensar lo contemporáneo: de la cultura situada a la convergencia tecnológica, Miguel Ángel Aguilar, Eduardo Nivón, María Ana Portal y Rosalía Winocur (coordinadores), Anthropos Editorial-UAM-I, Barcelona-México, 2009.

- GUILLIEM Arroyo, Salvador: Pasado precolombino de la colonia Roma, conferencia presentada en el marco del ciclo: "La Colonia Roma: orígenes, historia, identidad, perspectivas", organizado por la Universidad Nacional Autónoma de México, a través del Programa Universitario de Estudios Sobre la Ciudad y el Movimiento Pro Dignificación de la Colonia Roma AC, el 29 de enero de 2009. 
- GUZMÁN, Martín Luis: La sombra del caudillo (1929), Editorial Castalia, Madrid, 2002.

- GONZÁLEZ Morantes, Carlos: Los cines desaparecidos de la Roma, conferencia presentada en el marco del ciclo: "La Colonia Roma: orígenes, historia, identidad, perspectivas", organizado por la Universidad Nacional Autónoma de México, a través del Programa Universitario de Estudios Sobre la Ciudad y el Movimiento Pro Dignificación de la Colonia Roma AC, el 29 de enero de 2009.

- GORELIK, Adrián: La grilla y el parque. Espacio público y cultura urbana en Buenos Aires, 1887-1936, Universidad Nacional de Quilmes, 1998.

- GORELIK, Adrián: Miradas sobre Buenos Aires. Historia cultural y crítica urbana. Siglo XXI Editores, Buenos Aires, 2004.

- GRAU, Jordi: Antropología, cine y refracción: los textos filmicos como documentos etnográficos, Gazeta de Antropología, № 21, 2005 (http://www.ugr.es/ pwlac/G21_03Jorge_Grau_Rebollo.html).

- GRIMSHAW, Anna: The Ethnographer's Eye, Ways of Seeing in Modern Anthropology, Cambridge University Press, 2001.

- HACKING, Ian: The Social Construction of What? Harvard University Press, 1999.

- HALBWACHS, Maurice: Espacio y memoria colectiva, en Revista "Estudios sobre las Culturas Contemporáneas", Vol. III, Núm. 8-9, Centro Universitario de Investigaciones Sociales, Universidad de Colima, México, 1990.

- HARVEY, David: The Urban Experience, Johns Hopkins University Press, Baltimore, 1989.

- HARVEY, David: "En el espacio público ideal el conflicto es continuo ", entrevista para el periódico El País, por Iria Candela, publicada el 8 de septiembre de 2007.

- HEIDEGGER Martin: "Construir, habitar, pensar", en Conferencias y artículos, Ediciones del Serbal, España, 1994.

- HOWES, David (editor): The Empire of the Senses. The Sensual Culture Reader, Berg, 2005.

- KEROUAC, Jack: Tristessa (1960), Penguin Books, 1992.

- KRIEGER, Peter: Megalópolis, la modernización de la Ciudad de México en el siglo XX, U.N.A.M. - Instituto Goethe, México, 2006.

- KROTZ, Esteban: La cultura adjetivada: el concepto 'cultura' en la antropología mexicana actual a través de sus adjetivaciones, Ed. Universidad Autónoma Metropolitana-Iztapalapa, México, 1993. 
- LATHAM, Alan: "Edward Soja" en Key Thinkers on Space and Place, Phil Hubbard, Rob Kitchin and Gill Valentine (editors) Sage Publications, London, Los Angeles, Singapore, New Delhi, 2004.

- $\quad$ LATOUR, Bruno: Reassembling the Social. An Introduction to Actor-Network Theory, Oxford University Press, 2005.

- LATOUR, Bruno: We have never been modern, Harvard University Press, 1993.

- LEGORRETA, Jorge: El futuro patrimonial de la Colonia Roma, conferencia presentada en el marco del ciclo: "La Colonia Roma: orígenes, historia, identidad, perspectivas" , organizado por la Universidad Nacional Autónoma de México, a través del Programa Universitario de Estudios Sobre la Ciudad y el Movimiento Pro Dignificación de la Colonia Roma AC, el 29 de enero de 2009.

- LEGORRETA, Jorge (coordinador): La Ciudad de México a debate, UAMAzcapotzalco, México, 2007.

- LEÑERO, Vicente: Los albañiles (1961), Punto de Lectura, México, 2002.

- LEWIS, Oscar: Los hijos de Sánchez (1961), Editorial Grijalbo, México, 2000.

- LICONA Valencia, Ernesto: Habitar y significar la ciudad, UAM-CONACYT, México 2007.

- LIGUORI, Ana Luisa y GONZÁLEZ Block, Miguel Ángel: El SIDA en los estratos socioeconómicos de México, Instituto Nacional de Salud Pública, México, 1992.

- LOMNITZ, Larissa: Cómo sobreviven los marginados (1975), Siglo XXI editores, México, 1998.

- LOZADA León, Guadalupe: Cómo se transformó la Roma, conferencia presentada en el marco del ciclo: "La Colonia Roma: orígenes, historia, identidad, perspectivas" , organizado por la Universidad Nacional Autónoma de México, a través del Programa Universitario de Estudios Sobre la Ciudad y el Movimiento Pro Dignificación de la Colonia Roma AC, el 29 de enero de 2009.

- LYNCH, Kevin: La imagen de la ciudad, Editorial Gustavo Gilli, México, 1984.

- MACDOUGALL, David: Transcultural Cinema, Princeton University Press, New Jersey. 1998.

- MACDOUGALL, David: The Corporeal Image: Film, Ethnography and the Senses, Princeton University Press, 2006.

- MARKS, Laura U.: The Skin of the Film: Intercultural Cinema, Embodiment and the Senses, Duke University Press, 2000.

- MARTENS, Leonard: Algunas tendencias actuales en el mercado de trabajo de la construcción, 1982. 
- MAURO, Amalia: Albañiles campesinos. Migración temporal de los obreros de la construcción, Centro de Investigaciones CIUDAD, Quito, Ecuador, 1986.

- MEDINA, Cuauhtémoc: Ciudad espiral y otros placeres artificiales, texto curatorial sobre la exposición de Melanie Smith, Museo Universitario de Ciencias y Artes, UNAM, México, 2006.

- MELI, Roberto: Las lecciones del 85, conferencia presentada en el marco del ciclo: "La Colonia Roma: orígenes, historia, identidad, perspectivas", organizado por la Universidad Nacional Autónoma de México, a través del Programa Universitario de Estudios Sobre la Ciudad y el Movimiento Pro Dignificación de la Colonia Roma AC, el 29 de enero de 2009.

- MENDOZA Vargas, Héctor: Geografía, territorio y tiempo, conferencia presentada en el marco del ciclo: "La Colonia Roma: orígenes, historia, identidad, perspectivas", organizado por la Universidad Nacional Autónoma de México, a través del Programa Universitario de Estudios Sobre la Ciudad y el Movimiento Pro Dignificación de la Colonia Roma AC, el 29 de enero de 2009.

- MICHEL, Marco A. (coordinador): Procesos habitacionales en la Ciudad de México, UAM-SEDUE, México, 1998.

- MORENO Carranco, María: "Cultura global a la venta: vivienda, imágenes sociales y marketing en Santa Fe, Ciudad de México", en Pensar lo contemporáneo: de la cultura situada a la convergencia tecnológica, Miguel Ángel Aguilar, Eduardo Nivón, María Ana Portal y Rosalía Winocur (coordinadores), Anthropos Editorial, UAM-I, Barcelona-México, 2009.

- NELSON, Kathryn P.: Gentrification and Distressed Cities. An Assessment of Trends in Intrametropolitan Migration, The University of Wisconsin Press, 1988.

- NIETO Calleja, Raúl: Ciudad, cultura y clase obrera. Una aproximación antropológica, CONACULTA, México, 1997.

- NIETO Calleja, Raúl: "Lo imaginario como articulador de los órdenes laboral y urbano", en "Formas plurales de habitar y construir la ciudad", Revista Alteridades, año 8, num. 15, págs. 121-129, 1998.

- NIVÓN, Eduardo: Cultura urbana y movimientos sociales, UAM-I - CNCA, México, 1998.

- OLIVÉ, León (compilador): Ética y diversidad cultural, Fondo de Cultura Económica, México, 1993.

- PACHECO, José Emilio: Las batallas en el desierto, Editorial Era, México, 1981.

- PÉREZ Montfort, Ricardo: Cotidianidades, imaginarios y contextos: ensayos de historia y cultura en México, 1850-1950, Publicaciones de la Casa Chata, CIESAS, México, 2008. 
- PÉREZ Negrete, Margarita: “Enclaves de la globalización: expresiones de un discurso civilizatorio", conferencia presentada en el seminario: La construcción social de los espacios urbanos y regionales, organizado por la Dra. Claudia Zamorano en el CIESAS, México, mayo de 2009.

- PERLÓ Cohen, Manuel (coordinador): La modernización de las ciudades en México, IIS-UNAM, México, 1990.

- PERLÓ Cohen, Manuel: El urbanismo y las artes, conferencia presentada en el marco del ciclo: "La Colonia Roma: orígenes, historia, identidad, perspectivas", organizado por la Universidad Nacional Autónoma de México, a través del Programa Universitario de Estudios Sobre la Ciudad y el Movimiento Pro Dignificación de la Colonia Roma AC, el 29 de enero de 2009.

- PINK, Sarah: Doing Visual Ethnography. Images, Media and Representation in Research, Sage Publications, London, 2001.

- POLIT, Gabriela: "Antropología, literatura y narcotráfico", conferencia impartida en la UAM-Iztapalapa, México, 2007.

- PORRAS, Jeannette: "La Colonia Roma: una propuesta de lujo y modernidad" en la revista CULTURA URBANA, año 3, número 16, Colonia Roma: Claroscuros y fantasmas, UACM, México, 2007.

- PRADILLA COBOS, Emilio (compilador): Democracia y desarrollo urbano en la zona metropolitana de la Ciudad de México, Tomos 1-7, Editorial Antártica, México, 1990.

- PRADILLA COBOS, Emilio: Lo conocido, lo ignorado y lo que necesitamos investigar. Distrito Federal, zona metropolitana, ciudad región del centro, en "Andamios", Revista de investigación social, Dossier: La Ciudad de México, Colegio de Ciencias Sociales y Humanidades, Universidad Autónoma de la Ciudad de México, número 1, otoño-invierno 2004.

- PRADILLA COBOS, Emilio: Zona Metropolitana del Valle de México: megaciudad sin proyecto, texto inédito, 2005.

- QUESADA Avendaño, Florencia: "Imaginarios urbanos, espacio público y ciudad en América Latina" en Pensar Iberoamérica, Revista de Cultura de la Organización de Estados Iberoamericanos para la Educación, la Ciencia y la Cultura, número 8, abriljunio de 2006 (http://www.oei.es/pensariberoamerica/ric08a03.htm).

- QUIRARTE, Vicente: Elogio de la calle, biografía literaria de la Ciudad de México, Ediciones Cal y Arena, México, 2001.

- RADKOWSKI, Georges-Hubert de: Anthropologie de l'habiter. Vers le nomadisme, Presses Universitaires de France, París, 2002. 
- $\quad$ RAMÍREZ Kuri, Patricia y AGUILAR Díaz, Miguel A. (coords.): Pensar y habitar la ciudad. Afectividad, memoria y significado en el espacio urbano contemporáneo, Ed. Anthropos-UAM, México, 2006.

- REYNOSO Angulo, Eduardo: El suelo de la colonia Roma, conferencia presentada en el marco del ciclo: "La Colonia Roma: orígenes, historia, identidad, perspectivas" , organizado por la Universidad Nacional Autónoma de México, a través del Programa Universitario de Estudios Sobre la Ciudad y el Movimiento Pro Dignificación de la Colonia Roma AC, el 29 de enero de 2009.

- ROJAS Flores, Jorge y Gonzalo: La historia de los obreros de la construcción, Programa de Economía del Trabajo, Santiago de Chile, 1993.

- ROSALDO, Renato: Cultura y verdad. Nueva propuesta de análisis social. Ed. Grijalbo, México, 1989.

- ROSALDO, Renato: "La narrativa en la etnografía; verdades, mentiras y usos" conferencia impartida en la UAM-Iztapalapa, el 22 de enero de 2007.

- ROSIQUE CAÑAS, José Antonio: Centralismo y desconcentración en el desarrollo urbano de México: retrospectiva y prospectiva al siglo XXI, UAM-X, México, 1999.

- ROWE Colin y KOETTER, Fred: Collage City (1978), The MIT Press, Cambridge, London, 1993.

- RUSELL, Catherine: Experimental Ethnography. The Work of Film in the Age of Video, Duke University Press, 1999.

- SCHTEINGART, Martha: "Producción habitacional en la Zona Metropolitana de la Ciudad de México", en Espacio y vivienda en la Ciudad de México, COLMEX, I Asamblea de Representantes del Distrito Federal, México, 1991.

- SEARLE, John: The Construction of Social Reality, The Free Press, 1995.

- SENNETT, Richard: Vida urbana e identidad personal. Los usos del desorden, Ediciones Península, Barcelona, 1975.

- SENNETT, Richard: The conscience of the eye. The Design and Social Life of the Cities, Alfred A. Knopf, New York, 1990.

- SENNETT, Richard: La corrosión del carácter. Las consecuencias personales del trabajo en el nuevo capitalismo, Anagrama, México, 2006.

- SENNETT, Richard: El artesano, Anagrama, México, 2009.

- SIGNORELLI, Amalia: Conferencia inédita en español impartida en la UAMIztapalapa, en noviembre de 2008.

- SINGER, Paul: Economía política de la urbanización (1975), Siglo Veintiuno Editores, México, 1998. 
- SOJA, Edward: "La espacialidad de la vida social: hacia una reteorización transformativa", en D. Gregory y J. Urry, Social relations and spatial structures, MacMillan, Londres, 1985.

- SOJA, Edward: Post-modern Geographies: The Reassertion of Space in Critical Social Theory, Verso, London, 1993.

- SOJA, Edward: Thirdspace: Journeys to Los Angeles and Other Real-and-Imagined Places. Blackwell, Oxford, 1996.

- TAVARES López, Édgar: "The Roma Neighbourhood: A Glorious Past", en revista Voices of Mexico, UNAM-CISAN, México, num. 71, abril-junio, 2005.

- TAVARES, López, Édgar: Colonia Roma, Editorial Clío, México, 1998.

- TAVARES López, Édgar: La Colonia Roma en el tiempo, 1902-2009, conferencia presentada en el marco del ciclo: "La Colonia Roma: orígenes, historia, identidad, perspectivas" , organizado por la Universidad Nacional Autónoma de México, a través del Programa Universitario de Estudios Sobre la Ciudad y el Movimiento Pro Dignificación de la Colonia Roma AC, el 29 de enero de 2009.

- $\quad$ TOVAR Y DE TERESA, Guillermo: Las casas perdidas de la Roma, conferencia presentada en el marco del ciclo: "La Colonia Roma: orígenes, historia, identidad, perspectivas" , organizado por la Universidad Nacional Autónoma de México, a través del Programa Universitario de Estudios Sobre la Ciudad y el Movimiento Pro Dignificación de la Colonia Roma AC, el 29 de enero de 2009.

- TREJO, Luis Manuel: El problema de la vivienda en México, Fondo de Cultura Económica, México, 1974.

- TUAN, Yi-Fu: Topofilia. Un estudio de las percepciones, actitudes y valores sobre el entorno, Ed. Melusina, España, 1974.

- $\quad$ TUAN, Yi-Fu: Space and Place: The Perspective of Experience (1977), University of Minnesota Press, 2008.

- TURNER, Victor: On the Edge of the Bush. Anthropology as Experience, The University of Arizona Press, 1985.

- URQUIDI, Víctor L.: "La construcción de vivienda y el empleo en México", en Demografía y Economía, COLMEX, 1973.

- VALDEZ Ruiz, Enrique: Desarrollo urbano y modernidad en la colonia Roma, 19021955, tesis de maestría en Historia, Facultad de Filosofía y Letras, U.N.A.M., México, 2009.

- VARAS Orozco, Alejandro: La resistencia de los damnificados, conferencia presentada en el marco del ciclo: "La Colonia Roma: orígenes, historia, identidad, perspectivas" , organizado por la Universidad Nacional Autónoma de México, a 
través del Programa Universitario de Estudios Sobre la Ciudad y el Movimiento Pro Dignificación de la Colonia Roma AC, el 29 de enero de 2009.

- VARGAS, Patricia: Paraguayos, bolivianos y argentinos en la obra. Identidades étnico-nacionales entre los trabajadores de la construcción, Editorial Antropofagia, Argentina, 2005.

- VILLAVICENCIO, Judith: "Acción habitacional y vivienda popular. Una propuesta de programa", en Espacio y vivienda en la Ciudad de México, COLMEX, I Asamblea de Representantes del Distrito Federal, México, 1991.

- VILLORO, Juan: "El eterno retorno de la mujer barbuda", en Diario La Nación, domingo 21 de agosto de 2005.

- WARD, Peter M: México megaciudad: Desarrollo y política 1970-2002, Ed. Porrúa y El Colegio Mexiquense, 2004.

- YAÑEZ, Agustín: Ojerosa y pintada (1960), Editorial Joaquín Mortiz, México, 1967.

- ZAMORANO Villarreal, Claudia Carolina: "Vivienda y familia en medios urbanos. ¿Un contenedor y su contenido" en Sociológica, año 22, num. 65, UAMAzcapotzalco, México, 2007.

- ZAPATA, Luis: El vampiro de la colonia Roma, las aventuras, desventuras y sueños de Adonis García (1979), Ed. De bolsillo, México, 2004.

- ZICCARDI, Alicia: Las obras públicas de la Ciudad de México (1976-1982). Política urbana e industria de la construcción, IIS-UNAM, México, 1991.

- ZICCARDI, Alicia, DE GORTARI, Hira y HERNÁNDEZ, Regina (compiladores): Bibliografía de la Ciudad de México, Instituto Mora, IIS-UNAM, Departamento del Distrito Federal, Pórtico de la Ciudad de México, México, 1991.

- ZICCARDI, Alicia (coordinadora): Planeación participativa en el espacio local. Cinco programas parciales de desarrollo urbano en el Distrito Federal, IIS-UNAM, PUEC, México, 2003.

- ZIRIÓN Pérez, Antonio: Los hoyos negros urbanos: una mirada antropológica sobre el Cuadrante de la Soledad y la subcultura marginal de los barrios bajos en el Centro de la Ciudad de México, tesis de licenciatura en Etnología, ENAH, México, 2003.

- ZIRIÓN Pérez, Antonio: La construcción social de la construcción en la Ciudad de México: El caso de Rafael Checa \#18, tesina de maestría en Ciencias Antropológicas, UAM-I, México, 2006. 


\section{FILMOGRAFÍA PERTINENTE}

- 9 Star Hotel, documental de Ido Haar, Israel-Palestina, 2007.

- Aquí se construye, documental de Ignacio Agüero, Chile, 2000.

- Barán, película de ficción de Majid Majidi, Irán, 2001.

- En construcción, documental de José Luis Guerin, España, 2002.

- En el hoyo, documental de Juan Carlos Rulfo, México, 2006.

- La casa de mi abuela, documental de Adán Aliaga, España, 2005.

- Los Olvidados, película de ficción de Luis Buñuel, México, 1950.

- La colonia Roma, documental de Daniel G. Yubi, transmitido por Canal Once, producido por México Desconocido, México, 2005.

- Los albañiles, adaptación cinematográfica de Jorge Fons, basada en la novela de Vicente Leñero, México, 1976.

- Obra negra, serie fotográfica de Ulises Castellanos, México, 1998.

- The Architecture of Mud, documental de Caterina Borelli y Pamela Gerome, Yemen, 1999. 